RAFAEL LIMA SAKR

\title{
A CLÁUSULA DA NAÇÃO MAIS FAVORECIDA NA ORDEM ECONÔMICA INTERNACIONAL: UMA INVESTIGAÇÃO SOBRE O DISCURSO JURÍDICO DO ARTIGO I:1 DO GATT
}

Dissertação de Mestrado

Professor Orientador: Alberto do Amaral Júnior

UNIVERSIDADE DE SÃO PAULO

FACULDADE DE DIREITO

São Paulo

2010 


\author{
RAFAEL LIMA SAKR
}

\title{
A CLÁUSULA dA NAÇÃO MAIS FAVORECIDA NA ORDEM ECONÔMICA INTERNACIONAL: UMA INVESTIGAÇÃO SOBRE O DISCURSO JURÍDICO DO ARTIGO I:1 DO GATT
}

Dissertação apresentada à Faculdade de Direito da Universidade de São Paulo para obtenção de título de Mestre em Direito.

Área de Concentração: Direito Internacional

Prof. Orientador: Alberto do Amaral Júnior 


\section{Catalogação da Publicação \\ Serviço de Biblioteca e Documentação \\ Faculdade de Direito da Universidade de São Paulo}

Sakr, Rafael Lima

A cláusula da nação mais favorecida na ordem econômica internacional : uma investigação sobre o discurso jurídico do artigo I: 1 do GATT / Rafael Lima Sakr. - São Paulo : R. L. Sakr, 2010.

381 p. : il. ; $30 \mathrm{~cm}$.

Dissertação (Mestrado) - Faculdade de Direito da USP, 2010.

Orientador: Prof. Doutor Alberto do Amaral Júnior.

Notas de rodapé

Inclui bibliografia.

1. Cláusula da nação mais favorecida 2. Ordem econômica internacional 3. Organização Mundial do Comércio 4. Discriminação 5 GATT 5 Sistema multilateral de comércio I. Título. 


\section{FOLHA DE APROVAÇÃO}

NOME: SAKR, Rafael Lima.

TÍTULO: A cláusula da nação mais favorecida na ordem econômica internacional: uma investigação sobre o discurso jurídico do artigo I:1 do GATT

Dissertação apresentada à Faculdade de Direito da Universidade de São Paulo para obtenção de título de mestre em direito.

Aprovado em:

\section{BANCA EXAMINADORA}

Prof. Dr. Alberto do Amaral Júnior

Julgamento:

Prof. Dr.

Julgamento:

Prof. Dr.

Julgamento:
Instituição: Faculdade de Direito da Universidade de São Paulo

Assinatura:

Instituição:

Assinatura:

Instituição:

Assinatura: 
Em memória dos amados

Emile Sakr e Luiza Rodrigues Cavallaro, meus avós, saudades. 


\section{AGRADECIMENTOS}

Embora grande parte do tempo investido na preparação e redação de uma dissertação seja realizado em total isolamento, não é menos verdade que sem o contínuo intercâmbio de conhecimentos e experiências, que muito contribuíram para o aperfeiçoamento das ideias, o resultado final não teria o mesmo brilho. Em razão disso, gostaria de agradecer a todas as pessoas e instituições que me engrandeceram, ao longo desses anos. Dada a falta de veia poética, sintetizo minha dedicatória recorrendo à famosa expressão de Isaac Newton: se eu pude ver mais longe, foi por estar nos ombros de gigantes.

Ao Prof. Dr. Alberto do Amaral Júnior, mais uma vez agradeço não apenas pelos ensinamentos acadêmicos e pela orientação durante a elaboração deste trabalho, que foram essenciais para todo o desenvolvimento, como, além disso, pela disposição em manter um diálogo edificante sobre as veredas da vida, as quais sempre instigam um açodado aluno.

À SYLFF-USP (Ryoichi Sasakawa Young Leaders Fellowship Fund Program), especialmente aos Professores Doutores Carlos Roberto Azzoni, Adalberto Fischermann e João Grandino Rodas, e a Maria de Lourdes “Malu” Silva, pelo inestimável apoio e orientação no decorrer das apresentações dos relatórios parciais da dissertação, os quais serviram como um continuado processo de qualificação. Foi graças a uma bolsa, concedida pela Tokyo Foundation, que pude concluir a pesquisa realizada para a elaboração desta dissertação.

À Faculdade de Direito da USP, alunos e corpo docente, que há oito anos são responsáveis pela construção da minha vida acadêmica. Manifesto a minha particular gratidão a três professores que foram (e são) fundamentais para esse processo. Ao Prof. Dr. Celso Lafer, meu orientador na graduação e membro da banca de qualificação deste trabalho, agradeço por me ensinar, dentre todas as lições, o imprescindível valor do parar para pensar. Ao Prof. Dr. Tercio Sampaio Ferraz, meu professor nos cursos de graduação e pós-graduação, sou grato pelos ensinamentos, profundos na simplicidade, que permitem a seus alunos irem além do direito. Ao Prof. Dr. Umberto Celli Júnior, agradeço por me ensinar, desde a graduação, o valor da pesquisa acadêmica. Também agradeço de modo especial ao Prof. Dr. 
Fernando Dias Menezes Almeida, que integrou a banca de qualificação, reservando tempo para examinar e fornecer contribuições valiosas para o aprimoramento desta investigação.

Ao Prof. Dr. Gerd Willi Rothmann e ao Dr. Marcio Carneiro Sperling, os quais foram fundamentais para a construção da minha vida profissional. Precisão, clareza e objetividade, circundadas pelo rigor jurídico e pela solidariedade profissional, foram as mais importantes lições aprendidas nos anos de convívio.

Aos meus amigos e leitores críticos, Ana Carolina Cavalcanti de Albuquerque, Cristina Godoy Bernardo de Oliveira, Gabriela Bueno de Almeida Moraes, Henrique Bertolo Canarim, Leonardo David Quintiliano, Lucas Augusto Ponte Campos, Rafael Meira Silva, Vinicius Feliciano Tersi, agradeço o aprendizado pelo convívio, a leitura e os comentários a esta dissertação. Sou também grato a Roseli Aparecida da Costa, pela paciência, cuidado e dedicação durante a revisão dos manuscritos deste trabalho.

À minha família, que me acompanha nas diversas veredas da minha vida, agradeço ao apoio, paciência, incentivo e postura que nunca faltaram. Sem ela, nada teria sido possível.

São Paulo, 12 de janeiro de 2010. 
"Não há morte. O encontro de duas expansões, ou a expansão de duas formas, pode determinar a supressão de uma delas; mas, rigorosamente, não há morte, há vida, porque a supressão de uma é a condição da sobrevivência da outra, e a destruição não atinge o princípio universal $e$ comum. Daí o caráter conservador e benéfico da guerra. Supõe tu um campo de batatas e duas tribos famintas. As batatas apenas chegam para alimentar uma das tribos, que assim adquire forças para transpor a montanha e ir à outra vertente, onde há batatas em abundância; mas, se as duas tribos dividirem em paz as batatas do campo, não chegam a nutrir-se suficientemente $e$ morrem de inanição. A paz nesse caso, é a destruição; a guerra é a conservação. Uma das tribos extermina a outra e recolhe os despojos. Daí a alegria da vitória, os hinos, aclamações, recompensas públicas e todos os demais efeitos das ações bélicas. Se a guerra não fosse isso, tais demonstrações não chegariam a dar-se, pelo motivo real de que o homem só comemora e ama o que lhe é aprazível ou vantajoso, e pelo motivo racional de que nenhuma pessoa canoniza uma ação que virtualmente a destrói. Ao vencido, ódio ou compaixão; ao vencedor, as batatas."

Machado de Assis 


\section{RESUMO}

SAKR, Rafael Lima. A cláusula da nação mais favorecida na ordem econômica internacional: uma investigação sobre o discurso jurídico do artigo I:1 do GATT. 2010. 381 f. Dissertação (Mestrado) - Faculdade de Direito, Universidade de São Paulo, São Paulo, 2010.

Como produto da prática mercantil, a cláusula da nação mais favorecida (“CNMF”) é um fenômeno jurídico complexo. Enquanto sua estrutura variante não é passível de padronização, por se adaptar às necessidades da sociedade internacional em cada momento histórico, seu núcleo funcional permanece imutável. Na ordem econômica internacional, a descentralização do poder político provoca desconfianças nos agentes econômicos, resultando em um permanente estado de guarda e competitividade predatória. Para assegurar maior estabilidade às expectativas normativas, os Estados celebram tratados, a fim de alterar tais percepções, conferindo durabilidade às relações econômicas internacionais. Resultado da configuração contemporânea da governança econômica internacional, a Organização Mundial do Comércio (“OMC”) simboliza a consolidação das expectativas normativas dos atores internacionais em torno do sistema multilateral de comércio ("SMC”). A OMC tem a função de consolidar o SMC, garantindo a posição de autoridade para corrigir as numerosas lacunas e antinomias

jurídicas e reforçar a eficácia social, mediante a atuação de seu Órgão de Solução de Controvérsias (“OSC”). O SMC é um ordenamento jurídico, com lógica própria e princípios e regras específicos, que disciplina o mercado globalizado, cuja origem remonta à celebração do Acordo Geral sobre Tarifas e Comércio (“GATT”) em 1947. Prevista no artigo I:1 do GATT, a CNMF positiva o princípio da não discriminação, tendo por finalidade sistêmica desempenhar um papel dinâmico e integrado, ao: (i) assegurar transparência e dispersão de conhecimento; (ii) promover a cooperação internacional, a fim de eliminar ou reduzir, reciprocamente, as barreiras às trocas comerciais; (iii) vedar as práticas e instrumentos discriminatórios e protecionistas, tendo por função estender, automática, multilateral e incondicionalmente, as vantagens concedidas; e (iv) conservar as expectativas normativas, 
mediante a incorporação dos compromissos negociados ao SMC. Contudo, a proliferação de acordos preferenciais de comércio e de medidas protecionistas e discriminatórias pelos Estados-membros tem ameaçado o SMC de desautorização. Por recorrerem a exceções válidas à $\mathrm{CNMF}$, esses fenômenos permitem a formação de relações discriminatórias e protecionistas, o que impacta negativamente as expectativas normativas dos agentes econômicos, ameaçando a função unificadora de sentido da CNMF, cujo resultado é a erosão da ideia de livre-mercado mundial. As reiteradas quebras de expectativas implicam problemas de coesão e eficácia normativa ao SMC, os quais são denominados desafios sistêmicos. Com efeito, o SMC sofre um processo de desestruturação, causado pela tensionada interação das dimensões ideacional e fática. Isso exige um controle de legalidade e de licitude dos atos jurídicos e das práticas dos Estados-membros. Em face desses desafios sistêmicos, a dissertação verifica se o artigo I:1 permanece como regra determinante para a decidibilidade do OSC. Para responder adequadamente, empregam-se os métodos analítico, hermenêutico e argumentativo, com um enfoque essencialmente dogmático, dentro de um ângulo crítico zetético. Ao fim da investigação, constata-se que a CNMF vem se consolidando como regra determinante para a construção do discurso jurídico-decisório pelo OSC. A confirmação jurisprudencial da imperatividade e da eficácia normativa do artigo I:1 reverbera reflexamente sobre os desafios sistêmicos, tendo o poderoso efeito de simbolizar a preferibilidade da incidência da CNMF sobre as relações econômicas internacionais.

Palavras-chave: 1. Cláusula da nação mais favorecida. 2. Ordem econômica internacional. 3. Organização Mundial do Comércio. 4. Discriminação. 5. GATT. 6. Sistema multilateral de comércio. 


\begin{abstract}
SAKR, Rafael Lima. The most-favored-nation clause in the international economic order: an inquiry into the legal discourse of Article I:1 of GATT. 2010. 381 p. Dissertation (Masters) Faculty of Law, University of São Paulo, São Paulo, 2010.
\end{abstract}

As a product of commercial practice, the most-favored-nation clause ("MFN") is a complex legal phenomenon. While its variable structure is not subject to standardization, since it adapts to the needs of international society in each historical moment, its functional core remains unchanged. In the international economic order, the decentralization of political power leads to distrust of the economic agents, resulting in a permanent state of awareness and predatory competition. To ensure greater stability to the normative expectations, States enter into treaties in order to change such perceptions, providing durability to international economic relations. Result of the contemporary configuration of international economic governance, the World Trade Organization ("WTO") symbolizes the consolidation of the normative expectations of international actors around the multilateral trading system ("MTS"). The WTO has the mission of consolidating the MTS, ensuring a position of authority to correct the many shortcomings and antinomies of law and strengthen the social effectiveness through its Dispute Settlement Body ("DSB"). The MTS is a legal system, with its own logic and specific principles and rules, which regulates the globalized market, and has its origins in the General Agreement on Tariffs and Trade ("GATT") in 1947. Set forth in Article I:1 of the GATT, the MFN establishes the principle of non-discrimination and has the systemic purpose of playing an integrated and dynamic role as it: (i) ensures transparency and dissemination of knowledge, (ii) promotes international cooperation, by eliminating or reducing reciprocal barriers to trade, (iii) deters discriminatory and protectionist practices and instruments, being its function to extend, automatically, multilaterally and unconditionally, the benefits provided, and (iv) maintains the normative expectations, through the incorporation of negotiated concessions to the MTS. However, the proliferation of preferential trade agreements and protectionist and 
discriminatory measures by the member states has threatened the MTS of disempowerment. By resorting to MFN's valid exceptions, these phenomena allow the formation of discriminatory and protectionist relationships, which negatively impacts the normative expectations of economic agents, and threatening the harmonizing function of MFN; the result of which is the erosion of the global free market idea. Repeated breaches of expectations result in problems of cohesion and normative effectiveness of the MTS, which are called systemic challenges. Indeed, the MTS undergoes a process of disintegration, caused by the tensioned interaction of ideational and factual dimensions. This requires a control of legality and legitimacy of legal acts and practices of the member States. Given these systemic challenges, the dissertation verifies if Article I:1 remains the rule for determining the decidability of the DSB. In order to properly answer that, analytical, hermeneutic and argumentative methods are employed, with a primarily dogmatic focus, within a zetetic critical angle. By the end of the investigation, it's stated that the MFN is becoming the consolidated rule for determining the construction of the legal and decision making discourse of the DSB. The confirmation from case law of the imperative nature and of the normative effectiveness of Article I:1 reverberates reflexively on the systemic challenges, having the powerful effect of symbolizing the desirability of MFN impact on international economic relations.

Keywords: 1. Most-Favored-Nation Clause. 2. International Economic Order. 3. World Trade Organization. 3. Discrimination. 4. GATT. 5. Multilateral Trading System. 


\section{ABREVIATURAS E SIGLAS}

Acordo Constitutivo da Organização Mundial do Comércio - Acordo OMC

Acordo de Livre-Comércio da América do Norte - Nafta

Acordo sobre Aspectos dos Direitos de Propriedade Intelectual Relacionados ao Comércio TRIPS

Acordo sobre a Implementação do Artigo VI - Acordo Antidumping

Acordo sobre a Implementação do Artigo XXIV - Entendimento XXIV

Acordo sobre Regras de Origem - ARO

Acordo sobre Subsídios e Medidas Compensatórias - Acordo SCM

Acordo Geral sobre o Comércio de Serviços - GATS

Acordo Geral sobre Tarifas e Comércio - GATT

Acordos preferenciais de comércio - APC

Áreas de livre-comércio - ALC

Artigos sobre Responsabilidade do Estado da Comissão de Direito Internacional - ARE

Associação de Nações do Sudeste Asiático - ASEAN

Associação Europeia de Livre Comércio - EFTA

Associação Latino-Americana de Integração - ALADI

Associação Latino-Americana de Livre-Comércio - ALALC

Banco Internacional para a Reconstrução e o Desenvolvimento - BIRD

Comitê de Acordos Regionais de Comércio - CARC

Cláusula da nação mais favorecida - CNMF

Comissão Econômica para a América Latina e o Caribe - Cepal

Comissão de Direito Internacional da Organização das Nações Unidas - CDI

Comissão Econômica para a América Latina e Caribe - Cepal

Comunidade Econômica Europeia - CEE ou EEC

Comunidades Europeias - CE

Conferência das Nações Unidas para o Comércio e Desenvolvimento - Unctad 
Conselho de Assistência Econômica Mútua - Comecon

Conselho Geral da OMC - CG

Conselho sobre o Comércio de Bens - CCB

Convenção de Viena sobre o Direito dos Tratados - CVDT

Corte Internacional de Justiça - ICJ

Entendimento sobre a Interpretação do Artigo XXIV do GATT - Entendimento XXIV

Entendimento sobre as Regras e Procedimentos que Governam a Solução de Controvérsias ESC

Fundo Monetário Internacional - FMI

Industrialização por Substituição de Importações - ISI

Institut de Droit Internacional - IDI

Liga das Nações - LdN

Mecanismo de Transparência para os Acordos Regionais de Comércio - Mecanismo de Transparência

Mercado Comum do Sul - Mercosul

Órgão de Solução de Controvérsias - OSC

Órgão Permanente de Apelação do Órgão de Solução de Controvérsias - OPA

Organização das Nações Unidas - ONU

Organização dos Países Exportadores de Petróleo - Opep

Organização Internacional do Comércio - OIC

Organização Mundial do Comércio - OMC

Países do grupo Ásia, Caribe e Pacífico - ACP

Países menos desenvolvidos - PMD

Regras de Procedimento para Encontros do Comitê de Acordos Regionais de Comércio RPECARC

Sistema geral de preferências - SGP

Sistema multilateral de comércio - SMC

Tratamento especial e diferenciado - S\&D

Tratamento da nação mais favorecida - TNMF

União Europeia - UE

Uniões aduaneiras - UA 


\section{SUMÁRIO}

INTRODUÇÃO

\section{SEÇÃO I \\ A CLÁUSULA DA NAÇÃO MAIS FAVORECIDA NA ORDEM ECONÔMICA INTERNACIONAL}

1.1. O CONCEITO DE ORDEM ECONÔMICA INTERNACIONAL .25

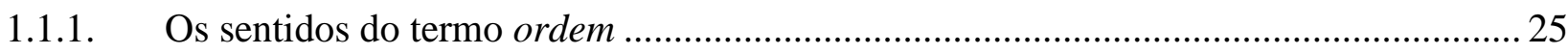

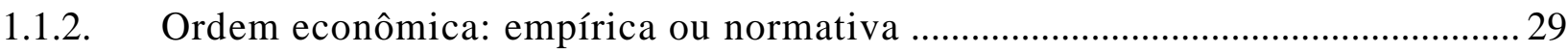

1.1.3. Ordem econômica na vida internacional ...................................................................... 31

1.1.4. Subordens: comportamental, axiológica e institucional-legal ....................................... 33

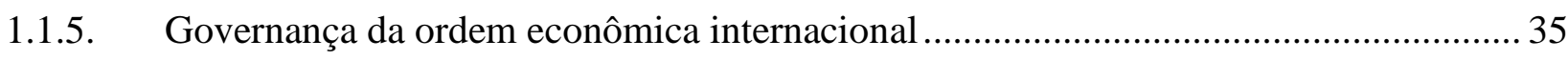

1.1.6. O ponto de partida: a cláusula da nação mais favorecida e a ordem econômica

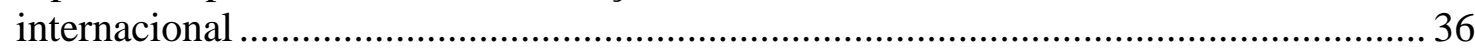

1.2. ORDEM ECONÔMICA INTERNACIONAL LIBERAL ………………….......... 42

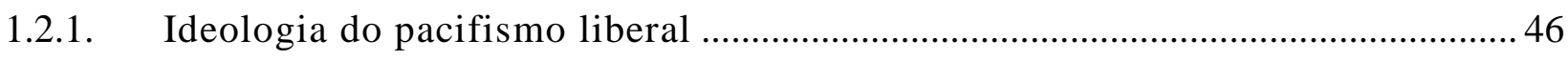

1.2.2. Estado Liberal e o direito internacional de coexistência .......................................55

1.2.3. A Era do Livre-comércio britânico: a consolidação da supremacia da cláusula da nação mais favorecida nos tratados bilaterais de comércio .............59

1.3. A ORDEM ECONÔMICA INTERNACIONAL FRAGMENTADA ……….......... 67

1.3.1. Neoliberalismo, Socialismo e Desenvolvimentismo: os conflitos de

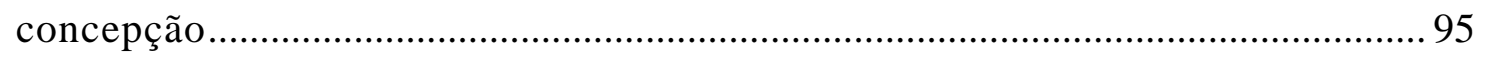

1.3.2. Estado Intervencionista e o direito internacional de cooperação ........................ 109

1.3.3. A Era do Livre-comércio estadunidense: o GATT e a construção multilateral da cláusula da nação mais favorecida ............................................................................ 114

1.4. ORDEM ECONÔMICA INTERNACIONAL CONTEMPORÂNEA ……..........131

1.4.1. A Era do Livre-comércio globalizado: os desafios sistêmicos e a institucionalização da cláusula da nação mais favorecida na OMC. 


\section{SEÇÃO II \\ A CLÁUSULA DA NAÇÃO MAIS FAVORECIDA NO SISTEMA MULTILATERAL DE COMÉRCIO}

2.1. CONCEITO DE SISTEMA INTERNACIONAL DE COMÉRCIO ..................... 170

2.2. A OMC COMO SISTEMA MULTILATERAL DE COMÉRCIO ............................. 176

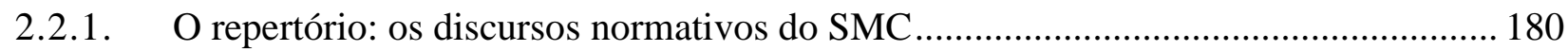

2.2.2. Regras de estrutura: a interpretação do SMC ........................................................... 182

2.3. REINTRODUZINDO OS DESAFIOS SISTÊMICOS À LUZ DO ARTIGO

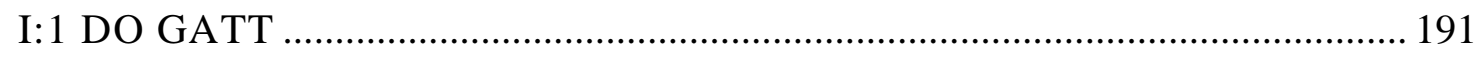

\section{SEÇÃO III \\ O DISCURSO JURÍDICO-CONVENCIONAL DA CLÁUSULA DA NAÇÃO MAIS FAVORECIDA}

3.1. O DISCURSO JURÍDICO-CONVENCIONAL DO ARTIGO I:1 DO GATT ............ 198

3.2. O CONCEITO DE CLÁUSULA DA NAÇÃO MAIS FAVORECIDA ....................... 201

3.3. POSITIVAÇÃO NO SISTEMA MULTILATERAL DE COMÉRCIO......................... 209

3.4. ESTRUTURA NORMATIVA: PACTUADA, INCONDICIONADA E

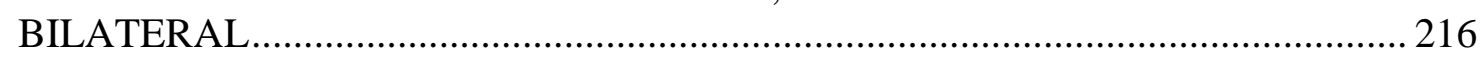

3.4.1. Fonte do direito: tratado e declaração unilateral de vontade .........................................2 216

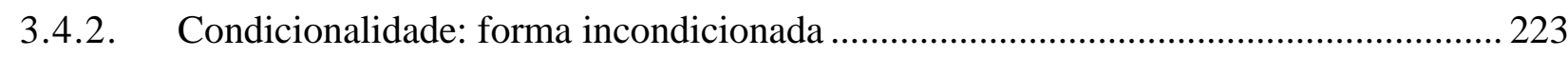

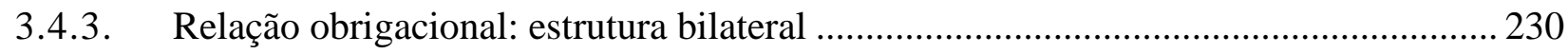

3.5. FUNCIONALIDADE: TRATAMENTO DA NAÇÃO MAIS FAVORECIDA ......... 240

3.5.1. Conceito de tratamento da nação mais favorecida....................................................... 242

3.5.2. O tratamento da nação mais favorecida do artigo I:1 do GATT ………………......... 244

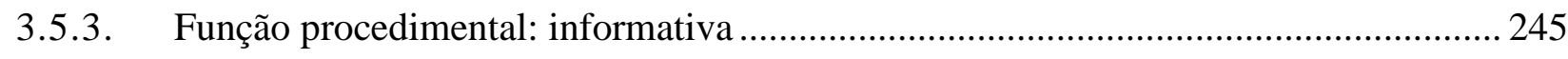

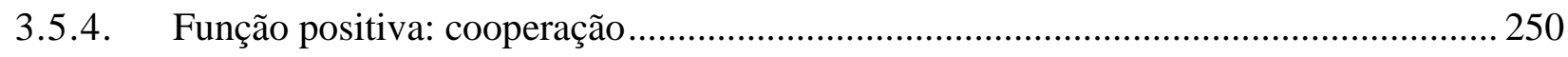

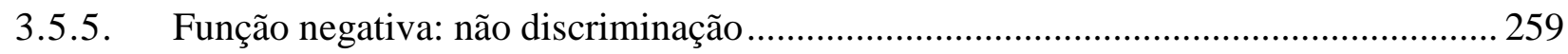

3.5.6. Função estabilizadora: aquisição e acumulação de vantagens........................................ 264 


\section{SEÇÃO IV \\ O DISCURSO JURÍDICO-DECISÓRIO DA CLÁUSULA DA NAÇÃO MAIS FAVORECIDA}

4.1. O DISCURSO JURÍDICO-DECISÓRIO DO ARTIGO I:1 ....................................... 271

4.2. ANÁLISE DOS TERMOS LINGUÍSTICOS DO ARTIGO I:1 DO GATT .................2273

4.3. RELAÇÕES SISTÊMICO-NORMATIVAS DO ARTIGO I:1 DO GATT ………...... 295

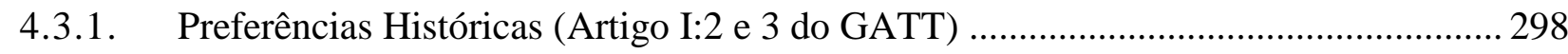

4.3.2. Restrições Quantitativas (Artigos XI e XII do GATT) ................................................. 300

4.3.3. Antidumping e medidas compensatórias (Artigo VI do GATT) .......................................303

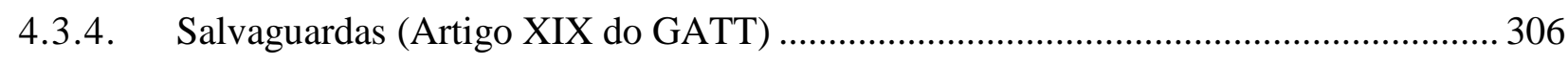

4.3.5. Suspensão de concessões e outras obrigações (Artigo XXIII do GATT) ....................... 308

4.3.6. Acordos Preferenciais de Comércio (Artigo XXIV do GATT) .................................... 310

4.3.7. Suspensão de obrigações (Artigo XXV:5 do GATT e IX:3 e 4 do Acordo OMC) ...... 331

4.3.8. Tratamento Especial e Diferenciado (Parte IV do GATT e Cláusula de Habilitação) 333

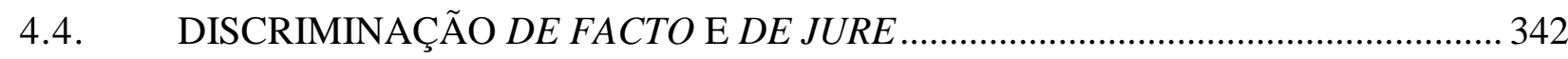

CONCLUSÃO

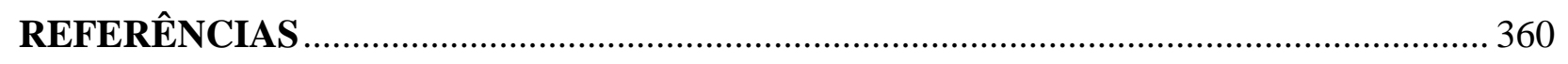




\section{INTRODUÇÃO}

Não há dúvida, é o fim da história! A derrocada da ideologia socialista e a submissão do pensamento desenvolvimentista consagram a retumbante vitória do capitalismo neoliberal. A abertura das economias nacionais não encontra antecedente histórico. O comércio internacional e o fluxo de investimentos atingiram níveis sem precedentes, implicando uma integração econômica jamais presenciada. A emergente sociedade em rede exige que todos os agentes econômicos pensem de forma global sobre cada decisão a ser tomada. Em razão das novas tecnologias, o intercâmbio econômico e cultural atinge a sociedade velozmente, formando uma rede quase homogênea, na qual as fronteiras nacionais são cada vez mais irrelevantes. A consolidação da sociedade global cosmopolita conduz ao eclipse do Estadonação e à ascensão do mercado como centro organizador da vida social. A globalização é um processo tão inevitável quanto irreversível. Após décadas de integração econômica internacional, os centros econômicos mundiais apregoam livremente que o sistema capitalista global é uma ordem natural das coisas. ${ }^{1}$

A irônica exclamação de triunfo incontestável guarda grande semelhança com os discursos que impregnavam o cenário do século XIX para o XX. A integração econômica internacional, por meio do livre-comércio, era encarada como uma verdade absoluta e inexorável. Sob a regência da Grã-Bretanha, as relações econômicas internacionais eram orientadas pelos princípios liberais positivados nos tratados comerciais, os quais formavam uma rede interligada pela cláusula da nação mais favorecida (“CNMF”). Todavia, a Primeira e Segunda Guerras Mundiais destruíram as estruturas da ordem econômica internacional liberal. A globalização revelou-se, assim, um modelo construído e não um fato naturalístico e imutável. $^{2}$

Nos 70 anos subsequentes a 1914, a integração econômica global era objeto de estudo de teóricos e historiadores, pois a economia mundial era fragmentada em três ordens parciais

\footnotetext{
${ }^{1}$ FUKUYAMA, Francis. Fim da história e o último homem. Trad. Aulyde Rodrigues. Rio de Janeiro: Rocco, 1992. EVANS, Peter. The eclipse of the State? Reflections on Stateness in an Era of Globalization. World Politics, [s.1.], v. 50, n. 1, 1997, p. 62-65.

${ }^{2}$ FRIEDEN, Jeffry A. Capitalismo Global: a história econômica e política do século XX. Trad. Vivian Mannheimer. Rio de Janeiro: Zahar, 2008, p. 13-14.
} 
de cooperação econômica, fruto das relações de poder e da prevalência de certas ideologias. Sob a sombra da Guerra Fria, a sociedade internacional era fracionada em torno de polaridades definidas, que originaram as ordens neoliberal, socialista e desenvolvimentista, fundadas numa diversidade heterogênea de sistemas normativos, axiológicos e jurídicos, que redundavam em conflitos de concepção acerca da forma de organizar a economia mundial. ${ }^{3}$

Somente com o fim das polaridades definidas, devido ao colapso do socialismo e ao predomínio do capitalismo neoliberal, diluíram-se os conflitos de concepção, tornando possível globalizar as estruturas da ordem parcial neoliberal, por meio do processo de integração econômica. Como há 100 anos, a interligação da economia internacional incita discursos sobre sua determinista imutabilidade, fruto de uma ordem natural imanente. No entanto, a globalização de aspiração neoliberal continua a depender das escolhas dos agentes econômicos, em especial dos Estados, na medida em que expressa um dos processos sintéticos da interação dinâmica entre as estruturas comportamental, axiológica e institucional-legal da ordem econômica internacional contemporânea. ${ }^{4}$

Produto da atual configuração da governança econômica internacional, a Organização Mundial do Comércio (“OMC”) simboliza a consolidação das expectativas normativas dos atores econômicos internacionais em torno do sistema multilateral de comércio ("SMC"). Inserida, justamente, no movimento de intensificação e integração das relações econômicas internacionais, a constituição da OMC contribui para: (i) o aumento da confiabilidade dos Estados; (ii) a passagem de um sistema normativo orientado pelo poder para um ordenado pelo direito; (iii) o adensamento de juridicidade, por meio do desenvolvimento do mecanismo de solução de controvérsias; e (iv) a transferência de competências ratione materiae para organismos internacionais. Com efeito, o aprofundamento institucional conferiu à OMC a função de consolidar o sistema multilateral de comércio, garantindo a posição de autoridade para corrigir as numerosas lacunas e antinomias jurídicas, bem como reforçar a eficácia normativa, mediante a atuação de seu Órgão de Solução de Controvérsias (“OSC”). ${ }^{5}$

O sistema multilateral de comércio é um ordenamento jurídico, com lógica própria e princípios e regras específicos, que ordena e disciplina as relações econômicas internacionais

\footnotetext{
${ }^{3}$ LAFER, Celso. A OMC e a regulação do comércio internacional: uma visão brasileira. São Paulo: Forense, 1998, p. 20-21.

${ }^{4}$ FRIEDEN, 2008, p. 14-15.

${ }^{5}$ FARIA, José Eduardo. O direito na economia globalizada. São Paulo: Malheiros, p. 151. LAFER, 1998, p. 2324.
} 
no mercado globalizado, cuja origem remonta à celebração do Acordo Geral sobre Tarifas e Comércio (“GATT") em 1947. À época, para consolidar a estrutura institucional-legal da ordem parcial neoliberal, os atores internacionais acordaram em organizar o comércio com base na cláusula da nação mais favorecida, pois sua forma flexível e adaptativa, em conjunto com suas múltiplas funções, permitiria ordenar o SMC, segundo os princípios neoliberais. Em sua estrutura normativa mais simples, a CNMF dispõe acerca da obrigação do Estadopromissor de tratar o Estado-beneficiário, em bases não inferiores ao tratamento concedido, ou que irá ser concedido, a um terceiro Estado mais favorecido, em razão de um tratado colateral. ${ }^{6}$

Prevista no artigo I:1 do GATT, a cláusula da nação mais favorecida tem por objetivo positivar o valor da liberdade, entendida como não discriminação, na condição de princípio teleológico do sistema multilateral de comércio. Não limitada à mera imputação de comandos prescritivo-obrigacionais, a CNMF tem por escopo desempenhar um papel dinâmico nas etapas sucessivas e integradas do SMC: (i) assegurar transparência e dispersão de informações às relações econômicas internacionais; (ii) promover a cooperação internacional, a fim de eliminar ou reduzir, reciprocamente, os entraves às trocas comerciais; (iii) estender automática, multilateral e incondicionalmente obrigações, vantagens e benefícios outorgados pelos Membros; e (iv) estabilizar as expectativas pela incorporação das concessões negociadas ao SMC, na forma de listas de compromisso vinculantes. Nas palavras do Consultative Board da OMC:

at the heart of the GATT was the principle of non-discrimination, characterized by the most-favoured-nation (MFN) clause and the national treatment provisions principally embodied in Article I. The MFN clause was regarded as the central organizing rule of the GATT, and the world trading system of rules it constituted. ${ }^{7}$

Contudo, o sistema multilateral de comércio vem sofrendo com ameaças de desautorização de suas regras e princípios nucleares, em razão do fenômeno do spaghetti bowl, que consiste na proliferação de acordos preferenciais de comércio (“APC"), e da adoção de uma sorte de medidas protecionistas e discriminatórias pelos Estados-membros. Esses dois

\footnotetext{
${ }^{6}$ AMARAL JR., Alberto do. A solução de controvérsias na OMC e a aplicação do direito internacional público. Tese apresentada ao concurso para provimento do cargo de Professor Titular, junto ao Departamento de Direito Internacional da USP, 2006, p. 113. SCHWARZENBERGER, Georg. The fundamental principles of international law. Recueil des Cours, Leiden, v. 87, n. 1, 1955, p. 138.

${ }^{7}$ LAFER, Celso. O GATT, a cláusula da nação mais favorecida e a América Latina. Revista de Direito Mercantil, Industrial, Econômico e Financeiro, São Paulo, v. 10, n. 3, p. 41-56, 1971, p. 46.
} 
movimentos, ao recorrerem a exceções válidas ao tratamento da nação mais favorecida, estabelecem relações comerciais em bases protetivo-discriminatórias. Os defensores dos APC justificam que seus objetivos são aprofundar o processo de liberalização comercial e promover a globalização econômica, os quais são interrompidos pela falta de consenso das rodadas multilaterais de negociação comercial. Por sua vez, o discurso do novo protecionismo assevera que as medidas contingenciais de comércio permitem relaxar certas obrigações, a fim de manter a estabilidade do SMC, facilitar a cooperação econômica, administrar o processo de liberalização, compensar a celebração de acordos mais profundos de integração e fomentar o desenvolvimento econômico setorial. No plano jurídico, ambos fundamentam a validade desses instrumentos de preferência e de restrição comercial em regras do próprio SMC que permitem calibrar as obrigações nele previstas.

Ocorre, entretanto, que as análises empíricas demonstram que a participação de Estados nos acordos preferenciais de comércio e a utilização de medidas protecionistas têm modificado suas atuações, ao ficarem mais hesitantes e menos cooperativos nas negociações multilaterais. Devido ao substancial impacto nas expectativas dos agentes econômicos, esses fenômenos ameaçam a função unificadora de sentido da cláusula da nação mais favorecida, cujo resultado é a erosão da ideia de livre-mercado mundial. Assim, as reiteradas quebras de expectativas pelo comportamento dos agentes econômicos internacionais implicam problemas de coesão e eficácia normativa do sistema multilateral de comércio, os quais são denominados desafios sistêmicos. ${ }^{8}$

Com efeito, o sistema multilateral de comércio sofre um processo de desestruturação, causado pela interação das dimensões ideacional e fática. Na perspectiva comportamental, a difusão de APC e de medidas contingenciais conduz ao aumento do comportamento discriminatório nas relações econômicas internacionais, o que é nocivo para um mercado em processo de globalização. No plano axiológico, a crescente tendência à valorização do protecionismo e da discriminação, dentro de uma lógica de fragmentação e aprofundamento econômicos, atenta contra os valores constitutivos da OMC.

Essa tensão fático-axiológica incide sobre o sistema multilateral de comércio, exigindo um controle de legalidade e de licitude dos acordos preferenciais de comércio e das medidas

\footnotetext{
${ }^{8}$ SUTHERLAND, Peter et al. The Future of the WTO - Addressing institutional challenges in the new millennium. Genebra: WTO, 2004. Relatório apresentado pelo Conselho Consultivo ao Diretor-Geral Supachai Panitchpakdi, p. 19-27.
} 
protecionistas. O controle de estruturas é realizado pela verificação da adequação formal dos APC e das medidas contingenciais às condições previstas no SMC. O controle de condutas consiste no exame do respeito aos deveres materiais pelos Estados-membros.

Diante disso, coloca-se a presente questão-problema: à luz da proliferação dos acordos preferenciais de comércio e das medidas protecionistas, que implicam desafios sistêmicos ao sistema multilateral de comércio, e a erosão da não discriminação nas relações econômicas comerciais, é a cláusula da nação mais favorecida a regra determinante para os controles de estruturas e de condutas exercidos pelo Órgão de Solução de Controvérsias?

A resposta à questão-problema exige a compreensão do fenômeno jurídico da cláusula da nação mais favorecida em suas múltiplas dimensões, na medida em que, por desempenhar o papel de lex generalis do sistema multilateral de comércio, questioná-la implica reflexamente indagar os próprios fundamentos jurídicos da ordem econômica internacional contemporânea. A problemática ganha relevo, pois a própria concepção de mercado global, no qual as relações econômicas internacionais transacionam, livres de discriminação e protecionismo, está intrinsecamente vinculada à legitimidade e eficácia social do tratamento da nação mais favorecida.

Desse modo, um exame jurídico-analítico não seria suficiente para construir uma resposta adequada, razão pela qual um leque de recursos será utilizado. Partindo da classificação proposta por Tercio Sampaio Ferraz Júnior, a presente dissertação emprega os métodos de investigação analítico, hermenêutico e argumentativo, com um enfoque essencialmente dogmático, dentro de um ângulo crítico zetético. ${ }^{9}$

$\mathrm{Na}$ Seção I, a zetética jurídica desempenha uma função importante, pois visa examinar as regularidades empíricas das relações econômicas internacionais, em termos de realização das expectativas normativas, bem como analisar a interação entre poder, verdade e direito em três períodos históricos de estabilização estrutural da ordem econômica internacional. Isso permite determinar os fatores histórico-axiológicos que conduziram a cláusula da nação mais favorecida à posição de norma ordenadora do sistema multilateral de comércio, bem como verificar os desafios que a ela encerram. Em razão disso, o conceito de ordem econômica internacional é analisado criticamente e modelado para servir como instrumento de exame

\footnotetext{
${ }^{9}$ FERRAZ JR., Tercio Sampaio. Introdução ao estudo do direito: técnica, decisão, dominação. $3^{\text {a }}$ ed. São Paulo: Atlas, 2001, p. 42-52.
} 
analítico-dogmático do relacionamento dos agentes econômicos internacionais. A primeira Seção termina com a verificação dos impactos dos desafios sistêmicos sobre o sistema multilateral de comércio e os respectivos reflexos sobre a cláusula da nação mais favorecida. ${ }^{10}$

Sob uma perspectiva zetética, a Seção II apresenta um exame analítico do conceito de sistema multilateral de comércio, o qual não é constituído dogmaticamente, mas é por ela regulado. Investigam-se as relações e elementos estruturais da noção de sistema internacional de comércio, do qual o termo sistema multilateral de comércio é espécie. A relevância de determinar a noção de sistema GATT/OMC reside no emprego desse instrumento para examinar as decisões dos intérpretes da OMC acerca da cláusula da nação mais favorecida em face dos desafios sistêmicos.

A partir do conceito de sistema multilateral de comércio, a Seção III realiza um exame analítico e hermenêutico da cláusula da nação mais favorecida positivada no artigo I:1 do GATT, tendo por objetivo determinar seus elementos, bem como os respectivos critérios de interpretação. A investigação trata precisamente dos elementos histórico-conceituais, estruturais e funcionais da CNMF. O objetivo é expor todas as multifacetadas características do discurso jurídico-convencional, permitindo ao intérprete clareza no momento da decisão.

Por fim, a Seção IV investigará criticamente as decisões proferidas pelo Órgão de Solução de Controvérsias sobre o artigo I:1 do GATT. Sob a perspectiva da dogmática hermenêutica e argumentativa, o objetivo é verificar casualmente se, ante os desafios sistêmicos, a cláusula da nação mais favorecida é a regra determinante para os controles de licitude e de legalidade. Em face disso, será possível endereçar uma resposta jurídica à questão-problema.

\footnotetext{
${ }^{10}$ FOUCAULT, Michel. Em defesa da sociedade: curso no Collège de France (1975-1976). Trad. Maria Galvão. São Paulo: Martins Fontes, 1999, p. 27-30.
} 


\section{SEÇÃO I}

\section{A CLÁUSULA DA NAÇÃO MAIS FAVORECIDA NA ORDEM ECONÔMICA INTERNACIONAL}


A Seção I tem por objetivo examinar as regularidades empíricas das relações econômicas internacionais, em termos de realização das expectativas normativas, bem como analisar a interação entre poder, verdade e direito no contexto da ordem econômica internacional. Com isso, será possível determinar os fatores histórico-axiológicos que propiciaram a criação, desenvolvimento institucional e ascensão da cláusula da nação mais favorecida à posição de norma ordenadora do sistema multilateral de comércio, bem como verificar os desafios sistêmicos que a ele encerram.

Para isso, o conceito de ordem econômica internacional é analisado criticamente e modelado para servir como instrumento de exame analítico-dogmático do relacionamento dos agentes econômicos internacionais. Nesse particular, verifica-se o impacto da cláusula da nação mais favorecida sobre as relações econômicas internacionais em três diferentes períodos, os quais foram escolhidos por duas razões. Primeiro, a intensa utilização do instituto implicou modificações em sua estrutura e funcionalidade, responsáveis por adequá-lo às transformações socioeconômicas. Segundo, o papel central da CNMF na formulação de políticas comerciais, tendo por consequência ser a principal norma organizadora dos fluxos comerciais em tais períodos.

Finalmente, a Seção I termina com a análise da ordem econômica internacional contemporânea, na qual globalização, regionalismo e protecionismo têm interagido, segundo lógicas próprias, podendo ser colidentes ou complementares. Esses movimentos estruturais são responsáveis por reiteradas quebras de expectativas normativas, resultando na formação dos desafios sistêmicos. A contestação da legitimidade e redução da eficácia da cláusula da nação mais favorecida incidem diretamente sobre o sistema multilateral de comércio, tendo por efeito desestruturá-lo. 


\subsection{O CONCEITO DE ORDEM ECONÔMICA INTERNACIONAL}

O estudo da ordem econômica internacional impõe definir os termos conformadores do próprio conceito. Por isso a necessidade de examinar, preliminarmente, o significado de ordem, para, em seguida, considerá-la em termos de instrumento analítico-dogmático, hábil para investigar a vida econômica internacional nos três períodos mais relevantes de operação da cláusula da nação mais favorecida.

A abordagem examinará os elementos estruturais conformadores da ordem, bem como os arranjos organizacionais formulados para conduzir as relações econômicas internacionais, para a consecução de certos fins. Com isso, enfocar-se-ão as manifestações da CNMF na ordens econômicas internacional-liberal, fragmentada-neoliberal e contemporânea.

\subsubsection{Os sentidos do termo ordem}

O termo de conceito ordem encerra uma pluralidade de sentidos que devem ser esclarecidos de antemão, a fim de evitar problemas de compreensão. A expressão ordem, cuja

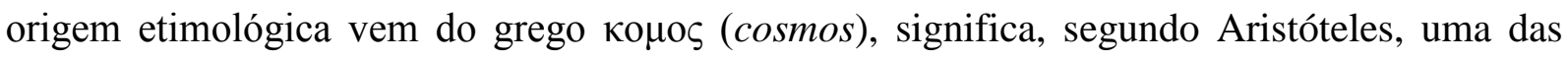
formas ou classes da medida. A ordem deve ser entendida como uma disposição de elementos, em sentido ontológico e não só como conformidade especial de coisas entre si. ${ }^{11}$

Seguindo a tradição aristotélica, Santo Agostinho e São Tomás de Aquino concebem a ordem como uma determinada relação recíproca entre elementos. Nesse particular, Santo Agostinho afirma que a ordem é um dos atributos que permitem a bondade aos criados de Deus, o qual criou as coisas segundo forma, medida e ordem perfeitas e ontologicamente hierarquizadas. Nesse sentido, para Santo Agostinho só existe ordem com relação aos

\footnotetext{
${ }^{11}$ ARISTÓTELES. Metafísica (Livro I e II). Trad. Vincenzo Coceo. São Paulo: Abril, 1984, p. 11-15. MORA, José Ferrater. Dicionário de Filosofia. Tomo III (K-P). São Paulo: Loyola, 2001, p. 2162.
} 
objetivos traçados por Deus. Apesar de não conceber sempre com o mesmo significado, São T. Aquino, também pressupondo uma hierarquia ontológica, define ordem como a disposição de uma pluralidade de elementos, de acordo com a anterioridade e a posteridade em virtude de um princípio, Deus. ${ }^{12}$

Na modernidade inicia-se um oscilante processo de desontologização e quantificação do conceito de ordem, o qual é convertido numa disposição geométrica e numérica, de modo a acentuar as questões do conhecimento diante das questões sobre a realidade. Enquanto no conceito medieval Deus é tomado como único referencial para determinar a justa adequação, no conceito moderno, ordem se refere a uma relação de realidades entre si. Representante da transição, Gottfried W. Leibniz tinha por objetivo unir o pensamento medieval ao moderno. Por um lado, defende a compreensão de um mundo ontologicamente hierarquizado, no qual há um princípio que determina a localização correta das coisas; por outro, não reduz tudo à noção ontológica de ordem, de modo a compreendê-la não apenas como hierarquia, mas também como uma série.

Nesse contexto, G. Leibniz explica que o extraordinário é extraordinário somente em relação a alguma ordem particular. Isso porque, quanto à ordem universal, tudo é perfeitamente harmônico, visto que nada acontece fora de regra, como também não se saberia sequer imaginar algo semelhante. Todavia, quando uma regra é muito complexa, o que lhe pertence passa por irregular. Assim, qualquer que fosse o modo como Deus tivesse criado o mundo, este teria sido sempre regular e teria uma ordem. Daí o conceito de ordem designar simplesmente a possibilidade de expressar com uma regra, geral e constante, uma relação qualquer entre dois ou mais elementos quaisquer. Com isso, há a passagem da ideia de ordem sobrenatural à de regularidade e uniformidade da natureza. ${ }^{13}$

O rompimento definitivo vem com Immanuel Kant, na medida em que vincula a questão sobre o ser à boa-ação, ao investigar objetos sensíveis e inteligíveis segundo uma dupla metafísica: da natureza e dos costumes. A noção ontológica de ordem, concebida a partir da adoção de um ser supremo como a causa única e totalmente suficiente, é contestada pela crítica kantiana. A ordem natural passa a ser identificada apenas com a ideia de regularidade

\footnotetext{
${ }^{12}$ AQUINO, Tomás de. O Ente e a Essência. Os Pensadores: Tomás de Aquino. Trad. Luiz João Baraúna. São Paulo: Nova Cultural, 2000, p. 39-45. AQUINO, Tomás de. Súmula contra os gentios. Os Pensadores: Tomás de Aquino. Trad. Luiz João Baraúna. São Paulo: Nova Cultural, 2000b, p. 155-160. MORA, 2001, p. 2162-2163.

${ }^{13}$ MORA, 2001, p. 2163-2165.
} 
dos fenômenos naturais. Isso conduz à impossibilidade de admitir um ente superior como objeto empírico, mas tão somente como objeto de entendimento, visto que a razão impõe considerar a conexão dos elementos do mundo conforme princípios de uma unidade sistemática completa, ordenada por uma causa formal, pressuposta e universal. Fundada sobre o princípio a priori, supremo e único da autonomia da vontade, a ordem moral é uma totalidade resultante da ligação sistemática, por meio de leis comuns, tanto de diversos seres racionais enquanto fins em si, como também dos próprios fins que cada ser racional se imponha. $^{14}$

A compreensão da ideia de ordem está, porém, incompleta, pois depende da verificação da noção de desordem. A ordem é uma unidade conveniente do múltiplo, em razão de uma finalidade conhecida. O fator cognoscitivo é responsável pela conveniência. A desordem é também uma ordem, mas uma ordem que não se quer. Em verdade, não existe uma desordem, pois esta é apenas uma ordem com a qual não se concorda. Assim, a desordem, que é composta de duas ordens, uma objetiva e, outra, subjetiva, não pode ser ausência de ordem, mas é presença de ordem, por consequência, a desordem é ordem. ${ }^{15}$

A ideia de ordem consiste, em síntese, em certo conjunto de relações entre elementos, as quais podem ser expressas por regras uniformes. A partir dessa noção particular, é possível distinguir três sentidos específicos de ordem: (i) ordem serial; (ii) ordem total; e (iii) ordem gradual.

Na concepção de ordem serial, os elementos possuem uma relação de anterioridade e posterioridade. Aristóteles observa ser necessário reconhecer nessa relação o princípio do movimento, por meio do qual é possível determinar a proximidade dos elementos com o princípio. Daí ser admissível estabelecer sequencias em relação ao espaço e tempo, bem como em relação à potencialidade e à disponibilidade dos elementos. O próprio conhecimento de um elemento implica conhecer a respectiva causa formal. Com efeito, a noção aristotélica identifica a ordem serial à ordem causal, admitindo-se, portanto, a existência de um princípio e

\footnotetext{
${ }^{14}$ KANT, Immanuel. Crítica da Razão Pura. Os Pensadores: Immanuel Kant. Trad. Valério Rohden e Udo Moosburger. São Paulo: Nova Cultural, 2000, p. 172-183; 415-416. KANT, Immanuel. Fundamentação da Metafísica dos Costumes. Trad. Paulo Quintela. Lisboa: Edições 70, 1997, p. 92-95.

${ }^{15}$ TELLES JÚNIOR, Goffredo da Silva. $O$ direito quântico: ensaio sobre o fundamento da ordem jurídica. $5^{\mathrm{a}}$ ed. São Paulo: Max Limonad, 1980, p. 240-245.
} 
uma finalidade para uma série sempre finita de causalidade. Isto é, reconhece-se que a causa subsiste sem o efeito, mas o efeito não pode subsistir sem a causa. ${ }^{16}$

Santo Agostinho e I. Kant também reconhecem na ordem a noção de causalidade serial. Santo Agostinho lança um desafio condicional, no qual incita a todos a demonstrar que alguma coisa pode acontecer sem causa, sob pena de serem obrigados a acreditar, como ele, que nada acontece sem certa ordem de causas. A noção agostiniana identifica, portanto, a concepção de ordem com a de causalidade. ${ }^{17}$

Em Immanuel Kant, a ordem serial é regra pressuposta à ordem temporal, pois:

o que em geral precede um acontecimento deverá incluir a condição de uma regra, segundo a qual este acontecimento sucede sempre e de maneira necessária; mas, inversamente, não posso voltar para trás, partindo do acontecimento, e determinar (pela apreensão) o que precede. Porque nenhum fenômeno retorna de um momento seguinte ao precedente, embora se relacione com um momento qualquer antecedente; de um tempo dado, pelo contrário, há uma progressão necessária para um tempo posterior determinado. Por isso, visto existir algo que sucede, preciso necessariamente referi-lo a algo diverso em geral que precede e ao qual segundo uma regra, isto é, necessariamente, de modo que enquanto condicionado o evento remete seguramente a uma condição qualquer, esta contudo determinando o acontecimento.

Por isso, o princípio da relação causal na sucessão dos fenômenos vale também antes de todos os objetos da experiência (sob as condições de sucessão), pois ele mesmo é o fundamento da possibilidade de uma tal experiência.

[...] assim como o tempo contém a condição sensível a priori da possibilidade de uma progressão contínua daquilo que existe àquilo que segue, mediante a unidade da percepção, o entendimento é a condição a priori da possibilidade de uma determinação contínua de todas as posições para os fenômenos neste tempo, através da série de causas e efeitos, cujas primeiras acarretam inevitavelmente a existência dos seus segundos e desse modo, tornam válido para todos o tempo (universalmente), por conseguinte objetivamente, o conhecimento empírico das relações de tempo. ${ }^{18}$

Em sua segunda acepção, ordem é identificada como totalidade, ou seja, ordem total é a modalidade de disposição recíproca dos objetos de um todo. Aristóteles aponta que ordem total pode se referir ao lugar, à potência ou à forma. Disso se infere que se a ordem serial é essencialmente ordem causal, a ordem total é essencialmente ordem final. Posteriormente, os estoicos definiram a ordem total como a justa e apropriada disposição dos objetos em seus lugares, com vistas a atingir um fim. Com fundamento no finalismo aristotélico, São Tomás de Aquino sustenta que todas as operações dos corpos materiais tenderiam a um fim, ainda que

\footnotetext{
${ }^{16}$ ARISTÓTELES, 1984, p. 26-29; 40-43.

${ }^{17}$ ABBAGNANO, Nicola. Dicionário de filosofia. Trad. Alfredo Bosi. $21^{\text {a }}$ ed. São Paulo: Martins Fontes, 1998, p. 731 .

${ }^{18}$ KANT, 2000, p. 172-183.
} 
inconsciente. Essa regularidade das relações seria intencional e desejada, pois obedeceria à "ordem dos fins" concebida pela inteligência soberana de Deus. ${ }^{19}$

A ideia de ordem teleológica é identificada por I. Kant aos conceitos de ordem natural e ordem moral, ou reino dos fins. Isso porque a capacidade de conhecer exige o princípio da determinação completa, segundo o qual dentre todos os predicados possíveis das coisas, somente um deles pode ser adequado a elas. Assim, no mundo da natureza, o Deus-artesão da metafísica é substituído pelo Deus-avalista, cuja função é apenas validar a unidade sistemática da natureza. Daí ser possível considerar todas as coisas da natureza, segundo uma ordem sistemática, como se fossem organizadas de acordo com a intenção dessa causa suprema, de modo a propiciar a representação da natureza segundo leis teleológicas. Produto da vontade autônoma, a ordem moral é a união sistemática de valores universais. A chave da integralidade do reino dos fins é a liberdade, princípio fundamental da vida moral. ${ }^{20}$

Por fim, o terceiro significado do termo ordem distingue hierarquia e grau. Na lição de São Tomás de Aquino, a ordem pode ser compreendida como hierarquia, composta de diversos graus, ou como grau individual da própria hierarquia. Nesse sentido, existiriam várias ordens de um único grau; logo, a ordem é simplesmente o grau ou nível de uma ordem total. ${ }^{21}$

Em suma, a presente dissertação adota um sentido particular do termo de conceito ordem, a qual expressa a ideia de conjunto de relações seriais, empíricas ou formais, as quais podem ser expressas segundo regularidades ou uniformidades, entre certos elementos. $\mathrm{O}$ conjunto pressupõe um princípio fundamental que justifica sua existência e implica sua finalidade, sendo passível de hierarquização ou graduação.

\subsubsection{Ordem econômica: empírica ou normativa}

O significado do termo ordem não se esgota em sua definição conceitual, pois carece da respectiva finalidade, razão pela qual é preciso compreendê-lo aplicado às relações

\footnotetext{
${ }^{19}$ ARISTÓTELES, 1984, p. 40-43. MORA, 2001, p. 2162-2165.

${ }^{20}$ KANT, 2000, p. 482-486. KANT, 1997, p. 93. GIANNOTTI, José Arthur. Kant e o Espaço da História Universal. In: KANT, Immanuel. Idéia de uma história universal de um ponto de vista cosmopolita. São Paulo: Brasiliense, 1986.

${ }^{21}$ MORA, 2001, p. 2164-2165.
} 
econômicas. A ordem econômica na vida social pode ser distinguida em duas concepções: empírica e normativa. Como cada abordagem enfoca questões totalmente heterogêneas, é necessário explicitar a diferença dos métodos e como são empregados, sob pena de prejudicar uma correta análise com resultados intencionais ou confundir tais resultados desejados com recomendações não comprováveis empiricamente.

Em um primeiro sentido, ordem econômica é ordem normativa da economia, isto é, pertencente à esfera moral do dever-ser. Esse mundo ideal designa um conjunto de normas que se relacionam validamente, de modo a respeitar uma ordem de regras que se pretende livre de contradições lógicas internas. Na perspectiva jurídico-dogmática, a ordem econômica, entendida como ordem jurídica da economia, investiga o sentido válido de suas regras e princípios. Isso significa que tal validade é aferida pela "capacidade de fundamentação" e "criticibilidade" da mediação racional-discursiva das proposições positivas desse pensamento. $^{22}$

No segundo sentido, o objetivo é extrair das relações econômicas regularidades empiricamente verificáveis entre os elementos, a fim de compreender suas causas verdadeiras. Daí ter por objetivo primário descrever e não formular juízos de valor sobre os fatos observáveis. A noção empírica de ordem econômica situa seu exame sobre as razões orientadoras, as quais garantem certa coerência e estabilidade aos comportamentos relevantes de determinada economia concreta. A vigência de certa ordem econômica depende da eficácia das respectivas estruturas em orientar as relações econômicas segundo seus princípios e finalidades. Quando, entretanto, a violação dos fundamentos da ordem econômica converte-se em regra, então esta passa, mediante um processo de desestruturação transitória, a ter vigência limitada ou desaparece. ${ }^{23}$

Não obstante a obviedade das distinções apontadas, cumpre destacar que, no presente trabalho, o termo ordem econômica é adotado em sentido empírico, pois é o instrumento mais adequado para investigar, nos contextos históricos e nos processos de transformação das relações econômicas internacionais, o fenômeno da cláusula da nação mais favorecida. Com isso, verificar-se-ão as razões causais e finais pelas quais a CNMF foi adotada como regra

\footnotetext{
${ }^{22}$ NEVES, António Castanheira. Metodologia Jurídica - Problemas Fundamentais. Coimbra: Coimbra, 1993, p. 35. WEBER, Max. Economia e Sociedade. Trad. Regis Barbosa e Karen Barbosa. Vol. 1, Brasília: Universidade de Brasília, São Paulo: Imprensa Oficial do Estado de São Paulo, 1999, p. 4; 209-210.

${ }^{23}$ WEBER, 1999, p. 19-20; 209-211. NUNES, António José Avelãs. Uma introdução à Economia Política. São Paulo: Quartier Latin, 2007, p. 60.
} 
jurídica ordenadora dos sistemas internacionais de comércio, bem como a respectiva eficácia social como fator de motivação efetiva dos comportamentos econômicos.

\subsubsection{Ordem econômica na vida internacional}

Por ordem econômica internacional, entende-se a estrutura regular e uniforme formada pelas relações econômicas internacionais, cuja interação entre os elementos é orientada por objetivos hierarquizados. Posta a definição, a partir dos pressupostos conceituais analisados, é preciso examiná-la em seus detalhes.

No ponto de partida estão as relações econômicas, as quais consistem em relações de poder orientadas, segundo preceitos racionais referentes a fins e valores, a satisfazer primariamente o desejo de obter utilidades. Utilidade significa a probabilidade, real ou suposta, concreta e particular de aplicabilidade, presente ou futura, cuja presumível importância como meios para os fins orienta as relações econômicas. As utilidades, que podem se expressar na forma de fatores e bens de capital, encontrar-se-ão no âmbito das relações econômicas apenas quando forem objetos do exercício de poder de produção e disposição. $^{24}$

As relações econômicas constituem ações relacionais de poder, cujo objeto referencial são as utilidades. Nesse particular, é imprescindível esclarecer que o termo poder não é aqui encarado segundo as teorias jurídico-política ou economicista. Isso significa que o poder não é um objeto sujeito à apropriação ou um mecanismo de reprodução da dominação econômica de classes. Na verdade, poder só é enquanto jogo intencional de relações fáticas, múltiplas e móveis, desiguais e instáveis. O poder surge de qualquer localidade da ordem social e é exercido em rede. Por consequência, o poder não pode ser apropriado, ou simplesmente deduzido, a partir do centro até os elementos moleculares da sociedade, ou ainda identificado como instrumento ideológico. Em síntese, as características do poder são imaterialidade, imanência-relacional, impassibilidade de apropriação e não ideologizável.

\footnotetext{
${ }^{24}$ WEBER, 1999, p. 39-41. PICONE, Paolo; SACERDOTI, Giorgio. Diritto internazionale dell'economia: raccolta sistematica dei principali atti normativi internazionali ed interni con testi introduttivi e note. Milão: Franco Angeli, 1983, p. 33-34.
} 
$\mathrm{Na}$ ordem econômica internacional, as relações de poder perpassam, caracterizam e constituem as estruturas sociais, por meio de discursos verdadeiros e jurídicos. Nesse sentido, a dinâmica das interações da vida econômica exige a produção de discursos verdadeiros, pois estes vinculam os atores normativamente por trazerem consigo efeitos específicos de poder. ${ }^{25}$

A internacionalidade do termo ordem econômica não tem o condão de restringir a investigação empírico-analítica à atividade dos Estados; mas, visa enfatizar o foco na estrutura formada pelo conjunto dos mais relevantes sujeitos das relações econômicas, os quais não precisam estar, necessariamente, dotados de poder soberano. Com efeito, a ordem econômica internacional é concebida de modo abrangente, envolvendo todas as relações econômicas, contínuas ou descontínuas, entre atores, públicos ou privados. Isso não significa limitar seu alcance apenas a uma única matriz estrutural, mas explicitar que todas as suas relações estão localizadas no mundo sensível. ${ }^{26}$

Na realidade, as relações econômicas demonstram que a descentralização do poder no plano internacional não é incompatível com a formação de regularidades e uniformidades da estrutura empírico-comportamental. Embora sejam fundamentais, os objetivos da ordem econômica internacional não resultam necessariamente do esforço consciente ou planejado de seus atores, visto que podem derivar de relações reiteradas, responsáveis por conformar suas subordens. De todo o modo, algumas normas subjacentes à ordem podem decorrer de planejamento consciente para manutenção das estruturas. Quando numa ordem internacional surge um sistema de ordenação normativa, aceito pela maioria ou pelos mais relevantes de seus sujeitos, este é denominado governança internacional. ${ }^{27}$

A ordem econômica internacional é, assim, um padrão uniforme e previsível de relações econômicas internacionais, cujos princípios e finalidades podem ser objetos de uma governança econômica internacional. Desse modo, ao localizar certa ordem econômica internacional em um continuum temporal, permite-se identificar e analisar suas características

\footnotetext{
${ }^{25}$ FOUCAULT, Michel. Microfísica do Poder. Trad. Roberto Machado. Rio de Janeiro: Graal, 2008, p. 179-183. POGREBINSCHI, Thamy. Foucault, para além do poder disciplinar e do biopoder. Revista Lua Nova, [s.1.], v. 63, 2004, p. 179-183.

${ }^{26}$ ROSENAU, James N. Governança, ordem e transformação na política mundial. In: ROSENAU, James N.; CZEMPIEL, Ernst-Otto (Org.). Governança sem governo: ordem e transformação na política internacional. Trad. Sérgio Barth. Brasília: Universidade de Brasília, São Paulo: Imprensa Ofícial do Estado de São Paulo, 2000, p. 25-28.

${ }^{27}$ ROSENAU, 2000, p. 14-20.
} 
particulares, as quais se desenvolvem em três subordens fundamentais: axiológica, comportamental e institucional-legal.

\subsubsection{Subordens: comportamental, axiológica e institucional-legal}

Como regularidade uniforme e previsível de relações econômicas, a ordem econômica internacional é formada pela combinação de valores, comportamentos e instituições legais que asseguram durabilidade às expectativas cognitivas e o funcionamento da economia mundial. Com efeito, esses elementos constituem as três subordens estruturais da economia internacional:

A subordem comportamental envolve as relações fáticas entre os agentes econômicos, as quais manifestam a interação entre interesses, expectativas normativas e cognitivas, discursos de verdade, paradigmas tecnológicos e os arranjos sociais de poder. Com o exame empírico-analítico das relações econômicas, é possível descrever as formas econômicas e os modos de coordenação dominantes nos sistemas econômicos, que conformam a estrutura comportamental da ordem econômica internacional. Das regularidades observáveis são extraídas expectativas cognitivas, as quais permitem controlar contingências estruturais. Daí também ser possível aferir qual a forma concreta da governança internacional e determinar, por meio de exames de falseabilidade, a eficácia dos discursos cognitivos e normativos. Desse modo, é no plano comportamental que estão situados os jogos de poder que selecionam, dentre as verdades conflitantes, aquela que sobrepujará as demais na formação de um discurso verdadeiro com efeitos de poder.

A subordem axiológica trata, no nível intersubjetivo, dos sistemas de valores morais e éticos que filtram os acontecimentos econômicos internacionais antes de provocar uma reação dos agentes econômicos para produzir discursos de verdade. Inseridos nessa estrutura, encontram-se, por um lado, os sistemas normativos da governança internacional; e, por outro, as escolas de conhecimento que sustentam seus diagnósticos e prognósticos sobre as relações econômicas internacionais, mediante discursos verdadeiros, cujas finalidades consistem em definir o escopo e os métodos das ciências, apresentar exames empíricos dos fundamentos da 
economia internacional e prescrever normas de condutas aos atores econômicos. Em cada período histórico, são encontradas, entretanto, diversas proposições, em geral conflitantes, que alegam conhecer a verdade final e comprovada sobre a vida econômica. $\mathrm{O}$ discurso verdadeiro prevalecente será produto das disputas de poder.

A subordem institucional-legal está relacionada à dimensão legal da ordem predominante, visto que alude aos sistemas jurídicos e às instituições criadas para executar as políticas resultantes da interação entre as subordens. A função do discurso jurídico é assegurar maior estabilidade às expectativas normativas dos agentes econômicos, de modo a conferir durabilidade às relações internacionais dinamicamente em transformação. Para fortalecer o cometimento das normas jurídicas, criam-se as instituições com o objetivo de instaurar uma relação de autoridade entre os sujeitos relacionados. O que confere caráter jurídico às normas é, justamente, a institucionalização dessa relação de autoridade. Dessa forma, o processo de institucionalização depende da inserção dos discursos normativos nos mecanismos disciplinares, para produzir efeitos de verdade e poder. Exemplo de instituições são os tratados e contratos internacionais, visto que as partes presumem que a expectativa global e anônima da sociedade internacional é esperar o cumprimento do que foi pactuado. ${ }^{28}$

Produto da combinação interativa e multidirecional dos fluxos causais das três subordens, a ordem econômica internacional é instrumento de análise empírico-analítica que será utilizado de forma indivisível. Com efeito, a dinâmica relacional das estruturas axiológica, comportamental e institucional-legal contribui decisivamente para conformar as características predominantes e reconhecíveis de uma ordem de certo período histórico, a qual demanda uma leitura histórico-causal não linear. Todavia, não basta o exame estático da ordem econômica internacional, na medida em que o processo de transformações da ordem econômica internacional é relevante tanto para compreender a nova configuração da economia internacional, bem como para propor e prescrever toda a sorte de normas. Daí ser essencial examinar as causas responsáveis por alterar a dinâmica ideacional, comportamental e institucional.

O modelo dinâmico permite compreender os fatores constitutivos de cada ordem, a partir da interação de suas subordens, a qual tende a impedir ou acelerar os processos de modificação estrutural. Desse modo, as alterações na relação entre as subordens podem

\footnotetext{
${ }^{28}$ ROSENAU, 2000, p. 25-34. FOUCAULT, 1999, p. 27-30. FERRAZ JR., 2001, p. 101-110.
} 
resultar numa decadência ou reconstituição da ordem precedente. Segundo James Rosenau, quanto maior for a especificidade e complexidade da dinâmica estrutural da ordem vigente, maior a probabilidade de ocorrer uma reconstituição limitada, que levaria a mudanças dentro da ordem, ao invés do colapso fundamental, o qual implicaria decadência total das estruturas. Em suma, enquanto um processo dinâmico entre regularidades comportamentais e finalidades, a configuração de uma nova ou reconstituída ordem econômica internacional dependerá da estabilização de novos hábitos e expectativas cognitivas e normativas, o que pode demandar tempo e consensos gerais. ${ }^{29}$

\subsubsection{Governança da ordem econômica internacional}

O termo de conceito governança é empregado por James Rosenau para descrever as "funções que precisam ser executadas para dar viabilidade a qualquer sistema humano, mesmo que o sistema não tenha produzido organizações e instituições incumbidas explicitamente de exercê-las". Isso explicita que a ideia de governança não se confunde com a noção de governo, apesar de ambos se referirem a comportamentos relacionais orientados por sistemas normativos de valores e fins.

Por governo, entendem-se relações sustentadas por uma autoridade formal e centralizada, que detém o monopólio do uso da força, cujo poder coercitivo garante a eficácia de suas normas institucionalizadas. Por não ser uma organização que monopoliza o uso da força, a governança está apoiada em princípios e finalidades comumente construídos pelos sujeitos, que podem ou não derivar de responsabilidades formalmente prescritas e não dependem necessariamente de poder coercitivo. Daí a condição de existência da governança estar intrinsecamente ligada à efetividade de suas normas, o que não ocorre com o governo, visto que podem ser ineficazes sem que deixem de ser consideradas inexistentes. Como não existe vinculação de dependência ou de subordinação entre governo e governança, há cenários que tão somente a presença de um dos tipos se manifesta.

\footnotetext{
${ }^{29}$ ROSENAU, 2000, p. 34-41.
} 
A governança é um fenômeno mais amplo do que governo, pois consiste em um sistema de ordenação de expectativas que depende da aceitação, tácita ou expressa, de todos, ou dos mais relevantes, atores. Assim, por estar sujeita à eficácia, a governança é sempre efetiva, ou deixa de existir. Em razão disso, existe um vínculo estreito entre governança e a ideia de ordem, na medida em que os padrões relacionais desta podem ser orientados por finalidades previamente planejadas, as quais podem ter a função de preservação da estrutura.

No plano econômico internacional, a ausência de uma autoridade central com monopólio da força não significa inexistir uma estrutura de ordenação, o que pressuporia interações caóticas entre os atores. O termo governança econômica internacional expressa um conjunto de relações de poder orientadas conscientemente por certas finalidades econômicas, as quais não exigem a exclusão de governos nacionais ou supranacionais, mas presumem a ausência de uma autoridade suprema. Desse modo, a governança econômica internacional atua na dinâmica estrutural da ordem econômica internacional, modelando seus objetivos, de acordo com a ideologia prevalecente do jogo de poder, mas ainda dentro dos limites permitidos por sua estrutura. ${ }^{30}$

\subsubsection{O ponto de partida: a cláusula da nação mais favorecida e a ordem econômica internacional}

O estudo da cláusula da nação mais favorecida tem a virtude de ser simultaneamente um tema clássico e contemporâneo. Clássico, pois é objeto de numerosas investigações ao longo dos séculos. Ainda assim contemporâneo, já que a temática permanece atual, em razão do surgimento de novos desafios oriundos das transformações estruturais e conjunturais da ordem econômica internacional. Sua origem remonta às práticas comerciais dos mercadores do século XI, embora o termo nação mais favorecida venha a surgir apenas no século XVIII, por isso é comum associá-la aos tratados de comércio internacional. Ressalva-se, contudo, que tal vinculação material não constitui uma regra, visto que a CNMF não está limitada a qualquer escopo. Previsto em incontáveis instrumentos jurídicos, o instituto é encontrado em uma

\footnotetext{
${ }^{30}$ ROSENAU, 2000, p. 14-20.
} 
multiplicidade de aspectos materiais e formais, o que impede um exame exaustivo de suas infinitas aplicações. $^{31}$

As questões envolvendo a definição jurídica do termo de conceito da cláusula da nação mais favorecida serão tratadas detalhadamente no Capítulo 3.2. Cabe, entretanto, apresentar uma conceituação provisória, a fim de compreender seu papel na ordem econômica internacional. O tratamento da nação mais favorecida consiste na promessa do Estadopromissor de não discriminar comercialmente o Estado-beneficiário em favor de terceiros Estados. Em outros termos, é estabelecida a obrigação do Estado-promissor de estender todas as concessões ou favores acordados no passado, ou que poderão vir a ser acordados no futuro, aos produtos, agentes e instrumentos comerciais do Estado-beneficiário, de forma que o comércio mútuo nunca seja em bases menos favoráveis àquelas usufruídas por um terceiro Estado, cujas relações comerciais bilaterais tenham sido realizadas sobre bases mais favoráveis. $^{32}$

Após séculos de regime feudal, transformações abalariam as estruturas econômicas da Europa cristã. Por um lado, a abertura das rotas mercantis pelas Cruzadas e, por outro, o declínio do poder temporal da Igreja permitiram o processo de consolidação dos Estados soberanos e a ascensão do modo de produção mercantil. Cientes dos benefícios gerados pelo comércio, os Estados passaram a tributar os mercadores estrangeiros, como forma de indenização pela permissão de comercializar em seu domínio e pela segurança oferecida. Os nascentes direitos aduaneiros não previam a isonomia entre os contribuintes. Por isso, o desenvolvimento dessas incipientes relações econômicas internacionais demandou a elaboração de instrumentos jurídicos capazes de assegurar proteção e previsibilidade suficientes para os mercadores exercerem suas atividades. ${ }^{33}$

Nesse contexto, a utilização da cláusula da nação mais favorecida começa a ser difundida pelos comerciantes italianos, franceses e espanhóis, quando percebem que

\footnotetext{
${ }^{31}$ USTOR, Endre. First report on the most-favoured-nation clause. Yearbook of the International Law Commission, [s.l.], v. II, 1969. Disponível em <http://www.un.org/law/ilc/index.htm>. Acesso em: 10 out. 2006. Documento da ONU n. A/CN.4/213, p. 159.

${ }^{32}$ SNYDER, Richard. The Most-Favored-Nation Clause: An analysis with particular reference to recent treaty practice and tariffs. Nova York: King's Crown Press, 1948, p. 10. USTOR, Endre. Third Report of the Special Rapporteur. Yearbook of the International Law, [s.1.], v. II, 1972. Disponível em <http://www.un.org/law/ilc/index.htm>. Acesso em: 10 out. 2006. Documento da ONU n. A/CN.4/257 and Add.1, p. 163.

${ }^{33}$ WEBER, Max. História geral da economia. Trad. Calógeras A. Pajuaba. São Paulo: Mestre Jou, 1968, p. 191 214.
} 
fraquejaria a tentativa de obter monopólio na exploração de mercados estrangeiros. O desenvolvimento e a expansão comercial impediram a concretização de tais objetivos monopolistas, levando-os a construir relações que, se não melhores, ao menos equivalentes às dos seus rivais. Foi, justamente, pela insistência de Veneza que, no século XII, o imperador bizantino concedeu a ela direitos e privilégios semelhantes aos outorgados a Gênova e Pisa. Assim, constatadas infrutíferas as tentativas de monopolizar os mercados estrangeiros, tais promessas unilaterais de não discriminação aduaneira foram comumente acordadas entre os Estados. $^{34}$

A elaboração do instituto voltaria a ser refinada apenas no século $\mathrm{XV}$, devido a um forte ciclo de expansão do comércio internacional que exigiu uma reorganização das relações econômicas. Sob o auspício do mercantilismo, os Estados utilizavam principalmente dois instrumentos jurídicos: as concessões comerciais, discriminatórias ou não discriminatórias, e os monopólios. Todavia, atores emergentes incidiram sobre a ordem econômica internacional mercantil, modificando suas estruturas. A Liga Hanseática e as repúblicas italianas começavam a ser desafiadas no comércio europeu pelos franceses e escandinavos, enquanto Grã-Bretanha e Holanda investiam, ao arrepio de Espanha e Portugal, na conquista dos mercados coloniais.

No confronto das barreiras monopolísticas e discriminações comerciais com a procura pela maximização das vantagens comerciais, a cláusula da nação mais favorecida despontou como a única opção dos Estados Mercantis para difundir e incorporar vantagens auferidas pelos diversos tratados. Para adaptar-se ao novo padrão de relações econômicas internacionais, a CNMF passa a ser outorgada bilateralmente. Com o transcurso do tempo, a forma bilateral do instituto teve o condão de conectar os diversos tratados comerciais não discriminatórios, cujo efeito em rede foi diminuir as retaliações comerciais, propiciando maior segurança e previsibilidade aos agentes econômicos. Emblemático, o Tratado de Paz e Comércio de Utrecht, celebrado entre Grã-Bretanha e França em 1713, estabeleceu, em seu artigo $8^{35}$, a forma moderna da cláusula da nação mais favorecida. ${ }^{36}$

\footnotetext{
${ }^{34}$ USTOR, 1969, p. 159.

35 "It is further agreed and concluded, as a general Rule, That all and singular the Subjects of each Kingdom, shall, in all Countrys and Places, on both sides, have and enjoy at least the same Privileges, Libertys, and Immunitys, as to all Dutys, Impositions, or Customs whatsoever, relating to Persons, Goods and Merchandizes, Ships, Freight, Seamen, Navigation and Commerce; and shall have the like Favour in all things as the Subjects of
} 
Nesse particular, é fundamental compreender a íntima conexão entre a difusão da cláusula da nação mais favorecida e o declínio do mercantilismo. As Revoluções Americana, Francesa e Industrial transformaram as estruturas da ordem econômica internacional, tendo por resultado mudanças ideológicas e o surgimento do Estado Liberal. Enquanto a visão mercantilista sustentava que nas relações comerciais há nações vencedoras, as quais enriquecem à custa das outras, o pensamento liberal propugnava a harmonia internacional de interesses, em razão dos ganhos mútuos decorrentes da especialização e da divisão internacional do trabalho. Isso justifica a vinculação entre a CNMF, enquanto instrumento de não discriminação comercial, e o ideal capitalista-liberal de ganhos de reciprocidade mútua. ${ }^{37}$

Não obstante o contributo à expansão do comércio internacional, o instituto também foi empregado como instrumento de políticas imperialistas europeias. Nas relações com a Ásia, a CNMF na forma unilateral era frequentemente imposta pelos Estados europeus aos países vencidos como termo de rendição. Na América Latina, a política europeia era utilizar os laços de dependência econômica para obrigar os Estados recém-independentes a firmar acordos comerciais não discriminatórios. Celebrado entre Brasil e Grã-Bretanha, o tratado de 1810 prevê o reconhecimento de privilégios à potência inglesa e a outorga da cláusula da nação mais favorecida. Tais obrigações comerciais implicaram sensíveis limitações à recentemente conquistada soberania brasileira no campo econômico. ${ }^{38}$

Com a intensificação do uso, foram necessárias constantes adequações da cláusula da nação mais favorecida às mais distintas realidades econômicas, razão pela qual surgiram diversas versões adaptadas, as quais serão objeto da Seção III. Todavia, devido aos impactos nas relações econômicas internacionais, é preciso examinar as aplicações da CNMF nas formas condicionada e incondicionada. Das primeiras manifestações até o fim do século XVIII, o instituto era preliminarmente concebido apenas na forma denominada incondicionada. Por isso, esse modelo é considerado a forma típica de concessão do

France, or any other foreign Nation, the most favour'd, have, possess and enjoy, or at any time hereafter may have, possess or enjoy."

${ }^{36}$ JACKSON, John H. World Trade and the Law of GATT. Indianapolis: Robbs-Merrill, 1969, p. 250. USTOR, 1969 , p. 160.

${ }^{37}$ DAL RI JR., Arno. O Direito Internacional Econômico em Expansão: Desafios e Dilemas no Curso da História. In: DAL RI JR., Arno; OLIVEIRA, Odete Maria de (org.). Direito internacional econômico em expansão: desafios e dilemas. Ijuí: Unijuí, 2003, p. 98. OSER, Jacob; BLANCHFIELD, William C. História do pensamento econômico. Trad. Carmem Terezinha dos Santos. São Paulo: Atlas, 1983, p. 74-75.

${ }^{38}$ USTOR, 1969, p. 160. FURTADO, Celso. Formação Econômica do Brasil. São Paulo: Companhia Editora Nacional, 2000, p. 33. 
tratamento da nação mais favorecida, visto que permite à parte-beneficiária usufruir, automaticamente, de todos os benefícios concedidos, ou a serem concedidos, em qualquer campo, pela parte-promissora a terceiras partes, prescindindo do cumprimento de requisições ou compensações. ${ }^{39}$

Surgida com o artigo II $^{40}$ do tratado celebrado entre França e Estados Unidos em 1778, a forma condicionada ganhou notoriedade, pois foi defendida pela diplomacia estadunidense pós-independência. Componente central de sua política comercial, o modelo condicionado visava proteger a indústria nascente dos novatos Estado Unidos, visto que os Estados europeus atuavam para excluí-los de seus domínios coloniais, enquanto pretendiam penetrar em seu mercado interno. Relutante na abertura comercial, a diplomacia estadunidense comprometia-se a garantir acesso a seu mercado interno, desde que, em retorno, fosse garantido seu ingresso no mercado europeu. Por isso, adotava-se nos tratados comerciais a cláusula da nação mais favorecida condicionada, a qual dispunha que nenhuma das partes-contratantes estava obrigada a estender, imediata e incondicionalmente, aos produtos da outra parte, as vantagens que tivessem sido acordadas aos produtos de terceiros países, em retorno pelas concessões recíprocas. Em síntese, as partes eram obrigadas a estender as vantagens, somente se e quando a outra parte outorgasse benefícios equivalentes àqueles concedidos pelo terceiro Estado. A interpretação estadunidense da CNMF teve uma rápida expansão pelas políticas de comércio internacional, alcançando seu ápice entre os anos de 1830 e $1860 .^{41}$

Essa breve introdução histórica da cláusula da nação mais favorecida na ordem econômica internacional permite extrair algumas de suas características essenciais. Como produto da prática mercantil, a CNMF é um instituto jurídico que foi desenvolvido em diversos formatos, a fim de adaptar-se às exigências das relações econômicas internacionais. Sua principal função é assegurar um tratamento não discriminatório entre as partescontratantes, cujos efeitos, em época de expansão comercial, é fomentar, por meio de tratados bilaterais, a criação de redes comerciais, as quais propiciavam previsibilidade e segurança aos

${ }^{39}$ SCHWARZENBERGER, 1955, p. 73.

40 "The Most Christian King and the United States engage mutually not to grant any particular favour to other nations, in respect of commerce and navigation, which shall not immediately become common to the other Party, who shall enjoy the same favour, freely, if the concession was freely made, or on allowing the same compensation, if the concession was conditional."

${ }^{41}$ SETSER, Vernon G. Did Americans Originate the Conditional Most-Favored-Nation Clause? The Journal of Modern History, [s.1.], v. 5, 1933, p. 319-323. JACKSON, John H.; DAVEY, William J. Legal problems of international economic relations: cases, materials, and text on the national and international regulation of transnational economic relations. $2^{\text {a }}$ ed. St. Paul: West Pub., 1986, p. 431. USTOR, 1969, p. 161. 
agentes econômicos. A expansão ou retração do uso da CNMF e, por consequência, a sua capacidade de interligar mercados, é inversamente proporcional ao predomínio de políticas autárquicas e restritivas de comércio. Por fim, a cláusula da nação mais favorecida pode ser empregada na forma condicionada ou incondicionada, enquanto seu modo de vinculação pode ser consensual ou coercitiva, o que pode implicar danos às economias internas, à medida que impõe restrições à soberania econômica.

Estudada sua origem, será possível analisar detalhadamente o papel desempenhado pela cláusula da nação mais favorecida nos três períodos que abrangem as diferentes configurações estruturais da ordem econômica internacional capitalista: liberal, fragmentadaneoliberal e contemporânea. 


\subsection{ORDEM ECONÔMICA INTERNACIONAL LIBERAL}

O presente Capítulo não tem a pretensão de debruçar-se exaustivamente sobre todas as minúcias da ordem econômica internacional liberal. Na verdade, o objetivo é muito mais modesto, pois foca a investigação tão somente sobre os aspectos estruturais que confluíram para imprimir transformações multidimensionais à noção de cláusula da nação mais favorecida. Desse modo, apresentar-se-á um panorama geral, enquanto os capítulos seguintes se debruçar-se-ão com maior cuidado sobre pontos de particular interesse para a reflexão.

A ordem econômica internacional liberal tem uma importância fundamental para este estudo, pois foi no contexto do modelo de governança econômica internacional, capitaneado pela Grã-Bretanha, que houve um salto qualitativo da cláusula da nação mais favorecida. As profundas mudanças socioeconômicas promovidas pelas revoluções setecentistas resultaram, no século XIX, na grande expansão do comércio mundial. Isso impulsionou a difusão do liberalismo e do capitalismo, os quais demandavam instrumentos jurídicos que permitissem o fortalecimento das expectativas cognitivas e normativas dos agentes econômicos.

Desenvolvida pela práxis mercantil nos séculos precedentes, a cláusula da nação mais favorecida guardava as virtudes necessárias para promover segurança e estabilidade às relações econômicas internacionais, visto veicular diretamente o princípio da não discriminação e indiretamente os princípios da reciprocidade e transparência. Amplamente utilizada pelas potências europeias, o instituto, em sua forma incondicionada, teve o condão de criar uma rede interligada de tratados bilaterais de comércio, responsável por conectar mercados nacionais ao redor do globo. Como será analisado, a CNMF passaria a ser reconhecida como a lex generalis do comércio internacional, no contexto da ordem econômica internacional liberal. $^{42}$

Em junho de 1815, as Guerras Napoleônicas chegaram ao fim com a vitória das potências europeias, Grã-Bretanha, Prússia, Áustria, Rússia e Holanda sobre os franceses na

\footnotetext{
${ }^{42}$ LAFER, Celso. Da Reciprocidade no Direito Internacional Econômico - O convênio do Café de 1976. Tese apresentada ao Concurso para Livre-Docente de Direito Internacional Público do Departamento de Direito Internacional da Faculdade de Direito da USP, São Paulo, 1977, p. 6.
} 
batalha de Waterloo. O significado da derrota do exército francês representou o apogeu do regime monarquista-absolutista e o início das perseguições aos ideais liberais e nacionalistas. Os Estados aliados reuniram-se no Congresso de Viena para estabelecer uma nova ordem internacional, organizada por um modelo de governança fundado sobre o ideal de equilíbrio de forças. Essa estrutura policêntrica, formalizada nos tratados de 1815, pretendia explicitamente impedir a recorrente busca por uma situação de hegemonia político-militar na Europa, tendo por princípio o balanceamento do poder estatal.

O exame dos noventa e nove anos subsequentes ao Congresso de Viena demonstra o êxito da governança instituída pelos Estados aliados. Excetuando as diferenças ideológicas e os anos entre 1856 e 1875, os países mantiveram firme o compromisso coletivo de preservar as estruturas fundamentais da ordem internacional. Em razão disso, o período passou a ser conhecido como a Paz dos Cem Anos, pois a efetividade do Concerto Europeu serviu para impedir o surgimento de uma hegemonia continental, prevenindo as hostilidades entre as grandes potências. Todavia, assim que a ordem dinástica estabilizou-se, seus fundamentos econômicos ruíram rapidamente.

Com particular relevância nesse processo erosivo, a Grã-Bretanha foi parte da coalizão que conformou a governança política europeia, porém, graças a conflitos ideológicos, sua participação era oscilante. Em diversos períodos, as discordâncias conduziram ao seu afastamento e à indiferença com respeito às questões continentais. Embora ostentasse o título de potência econômica, por dominar o comércio com as Américas e o Sul da Ásia, a GrãBretanha não detinha uma posição hegemônica, mercantil ou militar, na Europa. França e Prússia exerciam o predomínio cultural e artístico. A Rússia era a maior potência militar, enquanto a Áustria guardava influência decisiva sobre o panorama diplomático. Nesse sentido, percebe-se que o poderio econômico não se transformou instantaneamente em influência política, a qual era considerada prioritária em relação aos demais temas, razão pela qual as relações comerciais eram manipuladas estrategicamente para fortalecer e reforçar suas posições militares. $^{43}$

\footnotetext{
${ }^{43}$ HÖLSTI, Kalei J. Governança sem governo: a poliarquia na política internacional européia do século XIX. In: ROSENAU, James N.; CZEMPIEL, Ernst-Otto (Org.). Governança sem governo: ordem e transformação na política internacional. Trad. Sérgio Barth. Brasília: Universidade de Brasília, São Paulo: Imprensa Oficial do Estado de São Paulo, 2000, p. 47-55.
} 
Com o fim das Guerras Napoleônicas, a contestação ao mercantilismo ganhou força na Grã-Bretanha, visto que as medidas restritivas penalizavam os interesses dos setores mais dinâmicos da economia. Após árdua batalha, os defensores do livre-comércio venceram a contenda, o que promoveu uma ampla reforma legal. Concomitantemente, a Europa foi palco de uma expansão comercial extraordinária, que gerou recursos capazes de fortalecer os Estados, bem como de promover uma rápida dispersão da ideologia liberal. Em razão disso, a Grã-Bretanha liberalizou seu comércio exterior e iniciou uma corrida para celebrar tratados comerciais, nos quais estava inserida a cláusula da nação mais favorecida. Com efeito, cria-se uma rede de relações econômicas internacionais, institucionalizadas por acordos internacionais de livre-comércio, tendo o Império Britânico em seu centro. ${ }^{44}$

Diante desse cenário, cumpre esclarecer o sentido atribuído à ordem econômica internacional ao adjetivá-la de liberal. O adjetivo busca exprimir as facetas ideacional, comportamental e jurídica que marcaram predominantemente o período inaugurado pelas Revoluções Americana, Francesa e Industrial e encerrado com a eclosão da Primeira Guerra Mundial. As características estruturais da ordem liberal consistem na dispersão do discurso liberal, no florescimento e consolidação do modo de produção capitalista e na afirmação do Estado Liberal e do direito internacional de coexistência.

O termo liberal tem origem na escola de pensamento que defende, em última essência, a realização da liberdade nas relações sociais. O conjunto desses discursos foi intitulado de liberalismo. De fato, há estudiosos que afirmam não ser possível congregar os discursos políticos, econômicos e morais sob uma rubrica comum, pois, além de possuírem lógica e regras próprias e distintas, expressam as reivindicações da ascendente burguesia. Ainda que pesem tais críticas acerca da clareza ou da unidade sistemática, a imprecisão do termo liberalismo demonstra justamente a amplitude do fenômeno, cujos reflexos incidiram sobre os diversos campos do conhecimento humano.

Desde sua gênese, os filósofos liberais demonstraram possuir uma tendência favorável à abertura do comércio internacional. Embora não tivessem interesse em sustentar a liberalização comercial pelos ganhos econômicos auferidos, os maiores expoentes do liberalismo advogavam a favor do livre-comércio, por acreditarem na capacidade deste de

\footnotetext{
${ }^{44}$ FRIEDEN, 2008, p. 17-19. HOBSBAWM, Eric J. A Era do Capital: 1848-1875. Trad. Luciano C. Neto. São Paulo: Paz e Terra, 1982, p. 45-50.
} 
corroer os pilares do absolutismo, bem como servir de elemento de equilíbrio nas relações internacionais, visto ter efeitos positivos para a manutenção da paz entre as nações. O produto discursivo desse liberalismo foi consubstanciado na forma da doutrina política do pacifismo liberal, que preconiza ser o espírito do comércio capaz de sobrepor-se ao espírito da guerra. ${ }^{45}$

A perspectiva liberal da economia tem íntima ligação com a ideia de mercado, a qual possui, no século XVIII, não um significado meramente técnico, mas que remete a uma problemática implícita de regulação social e política. Nesse particular, o liberalismo concebeu, por meio da teoria da troca e da divisão do trabalho, a possibilidade de as relações internacionais serem constituídas como uma soma de resultados diferentes de zero. A consequência da representação da sociedade como mercado reside na recusa global do político. Logo, não é mais a política conflituosa, mediada pelo direito, que deve governar a sociedade, mas sim o mercado que, como modelo alternativo de organização social, permite a autorregulação da sociedade pelo próprio interesse. Sob o regime de livre-comércio, o progresso é alcançado pela especialização das nações naquilo em que possuem vantagem comparativa, aumentando o bem-estar social geral. ${ }^{46}$

As Revoluções setecentistas e os discursos liberais incidiram sobre o direito internacional, modificando-o, sem, contudo, romper com os fundamentos estabelecidos nos tratados internacionais de Westfália de 1648. Formado por uma sociedade estamental e hierarquizada, o Estado Moderno cede lugar ao Estado Liberal, cuja função é constituir um sistema político e preservar a sociedade civil, fundada sobre a ideia de liberdade, igualdade e autonomia da vontade. Por isso, o Estado Liberal é caracterizado internamente pela separação de poderes, decorrente do constitucionalismo liberal, pelo monopólio da força e pelo desenvolvimento do direito privado. No plano internacional, o Concerto Europeu criou uma ordem mais diplomática do que jurídica, baseada na acomodação de interesses e na proteção dos pequenos Estados ante a voracidade das potências. Coube aos Estados Liberais a consolidação do direito internacional público de coexistência, centrado precipuamente no princípio da soberania. $^{47}$

\footnotetext{
${ }^{45}$ BOBBIO, Norberto. Teoria geral da política: a filosofia política e as lições dos clássicos. Michelangelo Bovero (org.). Trad. Daniela B. Versiani. Rio de Janeiro: Campus, 2000, p. 529-534. DAL RI JR., 2003, p. 78. ${ }^{46}$ GILPIN, Robert. A economia política das relações internacionais. Trad. Sérgio Bath. Brasília: UnB, 2002, p. 45-49. ROSANVALLON, Pierre. O liberalismo econômico: história da idéia de mercado. Trad. Antonio P. Rocha. Bauru: EDUSC, 2002, p. 7-11.

${ }^{47}$ LAFER, 1977, p. 2.
} 
Todavia, o esgotamento gradual das virtualidades do Concerto Europeu levou à Primeira Guerra Mundial. A desagregação dos valores e interesses comuns, que asseguravam o equilíbrio necessário à manutenção da governança econômica internacional, implicou profundas transformações estruturais da ordem econômica internacional. Com efeito, os vínculos jurídicos, estabelecidos ao longo dos anos entre os Estados comercialmente competidores, foram rompidos, o que afetou a própria ideia de tratamento da nação mais favorecida. Defensores do protecionismo econômico sustentavam que a CNMF era "unnatural", pois obrigava os Estados a tratar em bases não discriminatórias tanto os países aliados, como os não aliados. Enfim, a ordem liberal esfacelou-se nos escombros da Primeira Grande Guerra Mundial. ${ }^{48}$

\subsubsection{Ideologia do pacifismo liberal}

O fim das Guerras Napoleônicas marcou o término do período revolucionário. Não obstante o caráter legitimista e reacionário do Congresso de Viena, os anos vindouros foram profícuos para a disseminação através da Europa da ideologia do pacifismo liberal, enquanto resposta do liberalismo para a problemática da guerra nas relações internacionais. Os dogmas liberais não nasceram como teorias de legitimação da elite, pelo contrário, foram construídos de forma dispersa e pulverizada, conforme as exigências das forças econômicas, da ascensão da burguesia à condição de classe dominante e da consolidação da Grã-Bretanha como potência comercial.

As raízes da doutrina do pacifismo liberal remontam aos filósofos do Iluminismo, os quais defendiam a liberalização do comércio internacional, cujos objetivos consistiam em desgastar o poder absoluto do soberano e promover o equilíbrio nas relações internacionais, culminando na paz entre as nações. O pensamento iluminista sobre a forma de assegurar a paz, por meio da normatização da vida internacional, incidia frontalmente com os fundamentos

\footnotetext{
${ }^{48}$ USTOR, 1969, p. 162. LAFER, 1977, p. 7.
} 
teóricos da concepção absolutista-mercantilista de Jean Bodin, predominante à época, que concebia o comércio como mero instrumento político de dominação. ${ }^{49}$

A reflexão acerca dos efeitos danosos do comércio internacional à dominação soberana foi objeto da célebre obra do Barão de Montesquieu, Do Espírito das Leis. Na percepção do filósofo francês, o comércio edulcora os costumes e estabelece a paz, na medida em que cura os preconceitos e medos, enquanto promove a cooperação e a interdependência positiva entre as nações. O espírito do comércio une as nações, pois exige a dependência recíproca dos parceiros. A expansão do mercado está relacionada com a constituição de um governo republicano, visto a monarquia ter pouco a ganhar, devido ao seu interesse por luxo.

Embora seja favorável à intervenção estatal, esta deve servir para regulamentar o fluxo comercial, sem criar restrições arbitrárias e injustificadas. Montesquieu condena severamente a utilização de políticas discriminatórias no comércio internacional, o que expressa sua rejeição quanto a práticas que levem à submissão de uma nação a outra, bem como demonstra o incentivo ao desenvolvimento de uma relação comercial ampla e aberta. Constata-se um verdadeiro entusiasmo de Montesquieu com as relações econômicas internacionais, devido ao fato de o comércio, como elemento de equilíbrio, conduzir naturalmente à paz. Desse contexto, surge o discurso sobre a solidariedade internacional dos mercados, justificando a liberdade dos fluxos comerciais. ${ }^{50}$

Os escritos de Montesquieu constituíram-se em um solo fértil, do qual brotaram diversas linhas de pensamento que procuravam teorizar sobre a relação entre comércio e paz. Dentre as diversas correntes, duas foram particularmente importantes para a construção do pacifismo liberal. As escolas de vocação econômica centraram suas análises na construção da noção de sociedade como mercado, livre da mediação política. Em consonância com teoria do contrato social, as escolas de índole política desenvolveram teorias que seriam reunidas sobre o título de pacifismo institucional.

Os fundamentos discursivos do pacifismo liberal passam obrigatoriamente pelo tema da teoria da instituição social através do mercado, o qual não era concebido somente como técnica, mas remetia a uma problemática da regulação social e política. Defendida pelos

\footnotetext{
${ }^{49}$ DAL RI JR., 2003, p. 78-83.

${ }^{50}$ MONTESQUIEU, Charles Louis de Secondat. Do espírito das Leis. Os Pensadores: Montesquieu. Trad. Leôncio Martins. V. II, São Paulo: Nova Cultural, 2000, p. 11-24. BINOCHE, Bertrand. Indroduction à De l'Esprit des Lois de Montesquieu. Paris: PUF, 1998, p. 331.
} 
filósofos iluministas ingleses e escoceses, a teoria propunha a emancipação da atividade econômica da moral, por meio da liberalização do comércio internacional, a ser conquistada mediante o enfraquecimento do Estado. Dessa perspectiva sociológica e política do conceito de mercado, idealiza-se o arquétipo da sociedade de mercado, na qual a sociedade civil é autorregulada pelo interesse sem mediações políticas.

A construção da representação da sociedade como mercado alcança seu pleno contorno com Adam Smith, em cuja obra reside a recusa da política, como meio de resolução de conflitos sociais. Há um rompimento com as teorias do contrato social em prol da defesa da ideia de mercado, o qual não é mero mecanismo de alocação de recursos, mas um sistema de organização social anti-hierárquica. Nesse sentido, ganha novo enfoque a problemática da guerra e paz entre as nações, na medida em que conceber economicamente a ordem internacional exige rejeitar as fronteiras políticas e adotar uma perspectiva desterritorizada de sociedade.

A desvinculação com a ideia de espaço geográfico permitiu compreender o mundo como uma rede cuja extensão é o limite do mercado. Isso implica um duplo movimento de dissociação e de inversão dos espaços, os quais rompem com a unidade político-econômicojurídica centrada na figura do território soberano. Nessa dimensão não geográfica está a chave da riqueza das nações, pois a divisão do trabalho e o mecanismo de troca constituem o motor da prosperidade numa sociedade de mercado. $\mathrm{O}$ crescimento econômico que conduz à riqueza decorre primordialmente da divisão do trabalho e da vantagem absoluta, as quais dependem da escala do mercado.

O livre-comércio permite às nações especializarem-se naquilo que produzem melhor, a fim de tornarem-se ricas e poderosas. Com isso, rejeita-se a concepção mercantilista de que o comércio internacional é como um jogo de soma zero, onde sempre haveria uma nação vencedora e outra perdedora, razão pela qual pertence ao domínio do Estado. Baseada na noção de harmonia de interesses, Adam Smith demonstra que as trocas voluntárias entre os países beneficiam ambos, sem haver a necessidade de excedentes. O conflito bélico é, portanto, substituído pela disputa empresarial, na forma de concorrência. A visão smithiana 
redefine a guerra enquanto instrumento da paz, subvertendo a representação da política global. $^{51}$

Diversos filósofos trataram sobre o espírito do comércio nas relações internacionais, mas foi Immanuel Kant que marcou definitivamente a filosofia pacifista. Em 1795, I. Kant publica, em forma de tratado internacional, sua obra decisiva sobre a temática: $\grave{A} P a z$ Perpétua: um projeto filosófico. Sua importância histórica não reside precipuamente na ideia da paz, mas no projeto de torná-la perpétua, mediante a eliminação permanente da guerra. $\mathrm{O}$ projeto diferencia-se radicalmente da concepção, então predominante, de que a solução para os inevitáveis conflitos entre os Estados consistia na manutenção de um equilíbrio mecanicista de forças, o qual dependia do recurso à guerra como remédio para o eventual e previsível desequilíbrio. $^{52}$

A solução racional do problema da paz universal só poderia nascer, como assevera Norberto Bobbio, da hipótese hobbesiana de um estado primordial da humanidade, caracterizado pela guerra de todos contra todos, cuja antítese não poderia ser outra senão a paz de todos com todos, ou seja, a consolidação de uma paz perpétua e universal. Esse estado de pacificação perpétua só poderia ser concretizado quando também os Estados tivessem saído do estado de natureza, nas suas relações recíprocas, tal como dele saíram os indivíduos. Para alcançar esse objetivo, os Estados deveriam firmar um pacto capaz de uni-los em uma confederação permanente.

Observa N. Bobbio que esse pacto kantiano não é o pactum subiectionis, com base no qual os contraentes sujeitam-se a um poder comum, de modo a criar uma federação de Estados, mas um pactum societatis, o qual, por não originar um poder acima de cada um dos contraentes, repousa sobre a ideia de instituir uma confederação. Desse modo, por temer a formação de uma monarquia universal, I. Kant propôs a criação de uma confederação que, exatamente pela falta de um poder comum, continuaria sendo um Estado de direito provisório e não se transformaria em um Estado de direito peremptório.

Para solucionar uma incompletude teórica relacionada à própria concepção do Estado, I. Kant introduziu uma condição, como garantia de eficácia do pacto: os Estados contratantes

\footnotetext{
${ }^{51}$ SMITH, Adam. A Riqueza das Nações: Uma Investigação sobre sua Natureza e suas Causas. Os Economistas. Trad. Luiz João Baraúna. V. I, São Paulo: Nova Cultural, 1996, p. 65-80. ROSANVALLON, 2002, p. 7-18; 4779; 107-135.

${ }^{52}$ BOBBIO, 2000, p. 524-525.
} 
devem ser todos constituídos na forma republicana de governo. Na perspectiva de N. Bobbio, qualquer que fosse a forma de confederação almejada, a proposta kantiana exigia certo grau de homogeneidade dos Estados em relação ao seu regime interno. Tal pressuposto responde a um princípio de igualdade dos contratantes, o qual não é tão somente extrínseco, visto demandar dos Estados o domínio soberano, mas também intrínseco, já que estes devem ser regidos por constituições similares.

Partindo dessa perspectiva contratualista, I. Kant reconhece o espírito do comércio como uma forma de garantir a paz, uma vez que as relações mercantis não podem coexistir com a guerra. Nota-se, entretanto, que o contratualismo kantiano desenvolve-se exclusivamente no plano lógico-teorético, de forma a adquirir uma expressão formal, sem nenhuma subordinação à realidade concreta, histórica, ou psicológica, relevantes para JeanJacques Rousseau. Assim, despido de aspectos latentes que concorreriam à separação dos Estados, como a grande diversidade de línguas e de religiões, I. Kant constata existir uma tendência natural dos povos à construção de uma rede de relações comerciais, a qual propiciaria um convívio mais harmonioso e, por consequência, ensejaria a instituição da paz perpétua. $^{53}$

O discurso iluminista trilhou um longo caminho no século XIX, dando origem a uma das principais correntes filosóficas do pacifismo, denominada pacifismo institucional. Formado por um conjunto de teorias, o pacifismo institucional considera como causa precípua das guerras o modo pelo qual são reguladas e organizadas as relações de poder entre grupos políticos e Estados, na medida em que estes recorrem constantemente ao uso da violência para solução decisiva de conflitos. O pacifismo institucional possui três linhas principais que comungam da ideia de que o Estado é o centro de indagação teórica.

O pacifismo democrático tem como alvo o Estado despótico, ou seja, enfatiza-se uma forma particular de governo, não o Estado como instituição. A proposta consiste em transformar o Estado, de modo a transferir aos governados o poder de controle sobre os governantes, na confiança, ou ilusão, de impedir a fase final do conflito armado. A conclusão lógica, no plano internacional, seria a criação de uma federação de Estados capaz de

\footnotetext{
${ }^{53}$ BOBBIO, 2000, p. 526-527. REALE, Miguel. Horizontes do direito e da História. São Paulo: Saraiva, 1956, p. 145-172. KANT, Immanuel. Paz perpétua: ensaio filosófico e outros opúsculos. Trad. Raphael Benaion. Rio de Janeiro: Borsoi, 1939.
} 
solucionar definitivamente o problema da guerra, mediante um processo de estatização universal da sociedade.

$\mathrm{Na}$ concepção do pacifismo socialista, o Estado, por ser naturalmente despótico, representa o instrumento de dominação de uma classe social sobre a outra. Daí não ser suficiente a mera transformação do Estado, mas a sua eliminação ou extinção. O objetivo é a formação de uma sociedade sem Estado, por meio do processo de desestatização até a instauração de uma sociedade regulada e limitada pela concórdia, decorrente do fim dos conflitos de classe.

Inspirado nas ideias liberais, o pacifismo liberal sustenta que o recurso à força para solucionar os conflitos internacionais cessaria, automaticamente, se o ésprit du commerce, predominasse sobre o ésprit du conquête. O Estado deveria governar o menos possível, permitindo a expansão da sociedade civil, mediante a redução gradual das funções estatais. No mesmo sentido das demais correntes, o principal alvo é o Estado, visto que, por ser considerado a causa principal das guerras, devem-se reduzir drasticamente seus poderes. ${ }^{54}$

Noberto Bobbio expressa, em síntese, a concepção das três formas de pacifismo institucional: "não haverá paz verdadeira senão quando os povos conquistarem o poder estatal” (pacifismo democrático); "não haverá paz verdadeira senão quando a sociedade sem classes tornar inútil a relação de dominação na qual sempre consistiu a organização política de uma determinada comunidade" (pacifismo socialista); e "não haverá paz verdadeira senão quando a organização militar tiver perdido grande parte do seu próprio vigor em proveito da organização industrial" (pacifismo liberal). Diante disso, conclui-se que as três correntes do pacifismo institucional têm em comum:

\begin{abstract}
a consideração da paz como o resultado de um processo histórico e progressivo, no qual está inscrita como resultado necessário a passagem de uma fase histórica, na qual as diferentes etapas do progresso humano foram o efeito de guerras, para uma fase nova, na qual, ainda que por diferentes razões, reinará a Paz Perpétua, porque haverá de se desenvolver uma forma de convivência tão distinta daquela que caracterizou a história humana até hoje que será cada vez mais improvável a guerra como meio para solucionar os conflitos (concepção democrática da paz), ou, então, serão cada vez mais difundidos os conflitos que não precisam da guerra para ser solucionados (concepção mercantil da paz), ou então serão cada vez mais raros os mesmos conflitos pelos quais indivíduos e grupos, em outros períodos históricos, recorrem à guerra (concepção socialista da paz). ${ }^{55}$
\end{abstract}

\footnotetext{
${ }^{54}$ BOBBIO, 2000, p. 527-530. BOBBIO, Norberto. Direito e Estado no pensamento de Emanuel Kant. Trad. Alfredo Fait. São Paulo: Mandarim, 2001, p. 260.

${ }^{55}$ BOBBIO, 2000, p. 530-532.
} 
No contexto da ordem econômica internacional liberal, a Grã-Bretanha valeu-se do discurso do pacifismo liberal para defender os valores da burguesia capitalista inglesa, enquanto princípios da governança econômica internacional. Desenvolvido no século XIX, o discurso pacifista-liberal britânico foi construído sobre as ideias iluministas e o pensamento liberal das Escolas Positivista e Utilitarista.

Expoente liberal, Benjamin Constant constatou a importância do espírito do comércio nas relações internacionais, pois o fator distintivo das sociedades modernas sobre as antigas seria justamente o progressivo predomínio do papel do comerciante sobre o do soldado. O comércio e a guerra são meios diferentes de alcançar o mesmo objetivo, pois diferentemente do comerciante, o poderoso conquistador nunca se valerá da troca para conseguir o objeto de desejo, mas tão somente da violência. Isso significa que o comércio modifica a própria natureza da guerra, na medida em que evita usurpação pela força e institui uma relação de cooperação. Desse modo, a era das sociedades militares, que marcou a história milenar do homem, seria gradualmente substituída pela era das sociedades industriais, cuja principal característica é a recusa à violência bélica para solucionar os problemas essenciais do desenvolvimento econômico e civil. ${ }^{56}$

$\mathrm{Na}$ doutrina positivista, Henry S. Maine e Herbert Spencer definiram o progresso da civilização em razão do processo de crescente contratualização da sociedade. $\mathrm{O}$ desenvolvimento social seria alcançado mediante a passagem gradativa de um regime institucional, próprio das sociedades de base militar, para um regime contratual, correspondente às sociedades de estrutura industrial. Preconizavam os positivistas que assistirse-ia o crescimento da sociedade mercantil em contração da militar, tendo por efeito a retração da atuação do Estado na esfera das relações privadas, as quais eram entendidas como paritárias em detrimento da esfera das relações públicas com caráter não igualitário, ou de supremacia de uma parte sobre outra. Haveria, assim, segundo o ideal de um contratualismo in fieri, a transferência do contrato do início para o fim da vida social, de sorte que aquilo que anteriormente era fonte de juridicidade passa a ser termo final do processo evolutivo. Com isso, visava-se à expansão da sociedade civil mediante a redução gradual das funções do

\footnotetext{
${ }^{56}$ CONSTANT, Benjamin. Political writings. Trad. Biancamaría Fontana. Cambridge: Cambridge University Press, 1988, p. 51-54.
} 
Estado, o qual era historicamente caracterizado por um poder de comando exclusivo e irresistível. $^{57}$

Em substância, essa era a visão de Richard Codben, que asseverava que os conflitos armados resultavam da política econômica dos Estados, enquanto a solução para a paz estaria, justamente, vinculada a uma transformação da política do mercantilismo para a de livrecomércio. Daí sustentar a visão rousseauniana de um mundo de pequenos Estados autossuficientes que mantivessem relações recíprocas mínimas: "o menor relacionamento possível entre os governos, a maior conexão possível entre as nações do mundo”. Isso justifica que R. Cobden acreditava no sentido mais rígido e absoluto da não intervenção, opondo-se inclusive à intervenção nos conflitos internacionais. Entretanto, defendia que a promoção da maior interação sistemática possível nos campos econômico e social era tão importante quanto a interação mínima em assuntos estratégicos e políticos. Desse modo, graças à aceitação pelos governos da prática econômica do laissez faire, os Estados poderiam existir em isolamento político recíproco, ao mesmo tempo em que coexistiriam com uma interdependência econômica. $^{58}$

Sob essa perspectiva econômica, David Ricardo aperfeiçoou as teorias de Adam Smith acerca dos benefícios mútuos gerados pelo comércio internacional às nações, ao introduzir suas reflexões sobre a teoria dos custos comparativos. Os princípios das vantagens comparativas reformularam a teoria econômica liberal, pois demonstrou que o fluxo de comércio entre os países é determinado pelo custo relativo, e não absoluto, dos bens produzidos. A divisão internacional do trabalho está baseada numa relação de custos comparativos, de modo que os países tenderiam a especializar-se naqueles produtos cujos custos sejam comparativamente menores. Dessa forma, preleciona D. Ricardo que:

Num sistema comercial perfeitamente livre, cada país naturalmente dedica seu capital e seu trabalho à atividade que lhe seja mais benéfica. Essa busca de vantagem individual está admiravelmente associada ao bem universal do conjunto dos países. Estimulando a dedicação ao trabalho, recompensando a engenhosidade e propiciando o uso mais eficaz das potencialidades proporcionadas pela natureza, distribui-se o trabalho de modo mais eficiente e mais econômico, enquanto, pelo aumento geral do

\footnotetext{
${ }^{57}$ BOBBIO, 2000, p. 651. REALE, 1956, p. 145. MAINE, Henry Sumner. Ancient law: its connection with the early history of society, and its relation to modern ideas. Nova York: Charles Scribner, 1867, p. 160-165. BOBBIO, Norberto. O futuro da democracia: uma defesa das regras do jogo. Trad. Marco Aurélio Nogueira. Rio de Janeiro: Paz e Terra, 1997, p. 129.

${ }^{58}$ BULL, Hedley. A sociedade anárquica: um estudo da ordem política mundial. Trad. Sérgio Bath. Brasília: Universidade de Brasília, 2002, p. 283-284. BOBBIO, 2001a, p. 260. WOODS, Thomas E. Cobden on freedom, peace, and trade. Journal Human Rights Review, [s.l.], v. 5, n. 1, 2003, p. 77-90.
} 
volume de produtos, difunde-se o benefício de modo geral e une-se a sociedade universal de todas as nações do mundo civilizado por laços comuns de interesse e de intercâmbio. ${ }^{59}$

É imprescindível, por fim, examinar as lições de John Stuart Mill. O grande ícone do pacifismo liberal inglês acreditava existir uma harmonia de interesses internacionais, os quais não precisavam conflitar com os interesses nacionais. Nesse particular, o comércio tinha o importante papel de ser o principal instrumento para construir a cooperação entre as nações. Isso porque as vantagens econômicas provenientes das relações mercantis seriam superadas, em termos de importância, pelos respectivos efeitos de ordem intelectual e moral. A relação comercial seria o elo de comunicação capaz de estabelecer o contato entre as sociedades, cujo efeito é permitir o reconhecimento da riqueza das demais nações como um fator positivo, promotor do progresso global. Daí tornar a guerra obsoleta, visto reforçar e multiplicar a possibilidade de concreção dos interesses pessoais, os quais se opõem a ela por natureza. Conclui, assim, J. S. Mill que "a ampliação e o rápido incremento do comércio internacional, por serem o esteio principal da paz no mundo, representam a grande permanente garantia para o progresso ininterrupto das ideias, das instituições e do caráter do gênero humano" ${ }^{60}$

No contexto de um mundo unificado pela rápida expansão econômica, o discurso do pacifismo liberal foi capturado pela Grã-Bretanha e empregado com a finalidade harmonizar os valores subjacentes às relações econômicas internacionais em torno dos princípios liberais. Os fundamentos da ideologia liberal repousavam, em resumo, sobre a noção de Estado Liberal, o qual deveria intervir minimamente na esfera privada, sobre um direito internacional de coexistência, cujo objetivo é assegurar meramente a não intervenção nas relações internacionais, visto imperar a liberdade soberana de contratar, bem como sobre a liberdade das relações econômicas, as quais promoveriam a paz, por meio do progresso mútuo e contínuo decorrente dos benefícios do livre-cambismo, da especialização e das vantagens comparativas.

Assim, consolida-se o pacifismo liberal sobre a tese de que a liberdade do comércio internacional produz vantagens a todas as nações, independentemente das condições particulares de desenvolvimento. O fortalecimento das expectativas cognitivas dos agentes

\footnotetext{
${ }^{59}$ RICARDO, David. Princípios de Economia Política e Tributação. Os Economistas. Trad. Paulo Henrique R. Sandroni. São Paulo: Nova Cultural, 1996, p. 97-107.

${ }^{60}$ MILL, John Stuart. Princípios de Economia Política com Algumas de suas Aplicações à Filosofia Social. Os Economistas. Trad. Luiz João Baraúna. V. II, São Paulo: Nova Cultural, 1996, p. 157-158.
} 
internacionais teve por efeito estabilizar e conformar a estrutura ideacional da ordem econômica internacional liberal, contribuindo para promover a cooperação econômica e garantir um longo período sem conflitos bélicos.

\subsubsection{Estado Liberal e o direito internacional de coexistência}

A dispersão da ideologia liberal associada às mudanças comportamentais decorrentes da afirmação do modo capitalista de produção provocou transformações na concepção mercantil de Estado e no direito internacional. $\mathrm{O}$ direito internacional não é indiferente às mudanças sociais, na medida em que as relações entre os agentes internacionais são influenciadas não apenas por comportamentos regulares e crenças compartilhadas, mas também por regras e instituições. Dessa forma, a compreensão da ordem econômica internacional liberal demanda o exame de sua estrutura institucional-legal, de modo a verificar como esta se adaptou à configuração da economia internacional de índole capitalista-liberal.

A concepção e o exercício do poder no âmbito do Estado e a evolução do pensamento jusfilosófico influenciam a relação de coordenação e oposição entre os países. Disso resulta que toda a noção e prática do direito internacional estão vinculadas às mudanças internas do próprio Estado e da filosofia do Direito. ${ }^{61}$

A transformação das monarquias europeias em Estados Modernos, no século XVI, assinalou a consolidação de uma ideia de Estado que supõe um poder central e soberano capaz de exercer a plenitude das funções estatais sobre um território claramente definido. Formado por um amplo processo de concentração de poder na figura do monarca, o Estado Moderno é caracterizado pela centralização administrativa e pelo mercantilismo econômico, mas está no poder soberano, em sua dimensão interna e externa, seu elemento determinante. Note-se que, internamente, o Estado Moderno era sustentado por uma sociedade estamental e hierarquizada, em que a divisão do trabalho era definida segundo um conjunto de direitos e obrigações expressos nos regimes absolutistas.

${ }^{61}$ VISSCHER, Charles de. Théories et realités en droit international public. Paris: Pedone, 1970, p. 42-44. 
No plano internacional, os Tratados de Westfália de 1648 consagram uma nova ordem internacional que encerrou a Guerra dos Trinta Anos. Intitulados de Carta Constitucional da Europa, consagraram definitivamente a separação entre o poder espiritual e o temporal, bem como reconheceram o poder soberano como absoluto e perpétuo. Juridicamente, os acordos westfalianos podem ser considerados como o ponto de partida de toda a evolução do direito internacional contemporâneo, pois foi responsável por institucionalizar seus princípios basilares, bem como por assegurar os primeiros elementos de um direito internacional público, ao reconhecerem a soberania e a igualdade dos Estados como princípios fundamentais das relações internacionais.

A Paz de Westfália representou, no contexto jurídico, um divisor de águas das relações internacionais, visto que seus pressupostos permaneceram válidos e praticamente incontestáveis até 1945. Foi responsável por consolidar um padrão previsível de relações, integrado por valores compartilhados, comportamentos rotinizados e instituições. Nesse particular, a manutenção dessas estruturas foi garantida pela atuação de três sistemas normativos, que estabeleceram os princípios da política mundial, as regras de coexistência e as regras de cooperação. A ordem westfaliana foi suportada, assim, por um conjunto de Estados soberanos que detinham competência para se autorregularem mediante um conjunto de normas morais e jurídicas. ${ }^{62}$

As Revoluções Americana, Francesa e Industrial e as Guerras Napoleônicas tiveram grande impacto na concepção de Estado Moderno, o que resultou na alteração das formas de exercício do poder, na medida em que, ao romperem com o discriminação estamental, desencadearam a corrosão da estrutura socioeconômica e a transformação normativa. Presentes no Congresso de Viena, os Estados concordaram em não mais permitir o livreajustamento da balança de poder, razão pela qual decidiram estabelecer uma governança internacional policêntrica e não hegemônica. Ainda que pesasse o caráter legitimista nas negociações, o discurso liberal, que já havia se difundido pela Europa, estava presente nas medidas acolhidas pela aliança vitoriosa. Tal processo possibilitou o surgimento de uma nova concepção de Estado e de Direito. ${ }^{63}$

\footnotetext{
${ }^{62}$ NGUYEN, Quoc Dinh; DAILLIER, Patrick; PELLET, Alain. Direito internacional público. Trad. Vítor Marques Coelho. Lisboa: Fundação Calouste Gulbenkian, 1999, p. 43-44. AMARAL JR., 2008, p. 29-35.

${ }^{63}$ LAFER, 1977, p. 2. HÖLSTI, 2000, p. 47-55.
} 
O nascimento do Estado Liberal, no século XIX, pressupunha um relacionamento entre sistema político e sociedade civil, envolvendo a ideia de igualdade e autonomia da vontade. O discurso liberal incidiu sobre a noção de Estado, o que levou, no âmbito jurídico interno, ao desenvolvimento do direito privado e à limitação do poder estatal, na forma do direito constitucional clássico. No plano internacional, a insegurança das guerras napoleônicas permitiu o sucesso do Concerto Europeu, que criou uma ordem mais diplomática do que jurídica, baseada na acomodação de interesses e na proteção dos pequenos Estados ante a voracidade das potências. Do mesmo modo, o Estado Liberal possibilitou a consolidação de um direito internacional público de coexistência.

A ideologia liberal, que preconizava a mínima intervenção estatal, e o Concerto Europeu, cuja governança diplomática assentava-se sobre o consenso das grandes potências, impactaram o direito internacional, restringindo seu papel à regulamentação do uso da força pelos Estados. O restrito escopo desse direito internacional público de coexistência, criado pelo Estado Liberal, permitiu a formação de um conjunto pouco numeroso de normas jurídicas, cuja preocupação essencial era delimitar as competências interestatais e prescrever obrigações negativas de mútua abstenção.

Em razão disso, os discursos jurídicos de coexistência restringiam-se a tratar sobre: (i) soberania, que garantia a liberdade e igualdade entre os Estados; (ii) reconhecimento e consenso, que operacionalizavam o exercício da soberania; (iii) boa-fé; (iv) liberdade dos mares; (v) autodefesa, que concedia ao Estado o direito de decidir, de acordo com a boa-fé, a retaliação apropriada, no caso de violação de direitos e obrigações internacionais; e (vi) responsabilidade internacional, a qual envolvia a reparação do dano, na hipótese de descumprimento das normas internacionais. Dessa forma, ao abster-se de normatizar juridicamente as questões econômicas, o Estado Liberal outorgou a disciplina das relações internacionais econômicas aos agentes privados, autorreduzindo sua atuação. A temática da transferência de recursos, interna ou internacional, estava sob a égide do direito privado, em que imperava o contrato e o princípio da autonomia da vontade. ${ }^{64}$

Contudo, à medida que o Estado Liberal passou a visar à expansão de seus mercados, segundo a concepção de livre-comércio, provocou um relevante problema de relacionamento

\footnotetext{
${ }^{64}$ LAFER, 1977, p. 2-4. FRIEDMANN, Wolfgang G. The changing structure of international law. Nova York: Columbia University Press, 1964, p. 471-472. SCHWARZENBERGER, 1955, p. 214-371.
} 
entre ordenamentos jurídicos. Isso porque o direito privado estatal não respondia aos anseios mercantis, visto não assegurar precisamente a quais normas os comerciantes estariam sujeitos em suas trocas internacionais. Preocupados em conferir segurança e durabilidade às relações internacionais, os agentes econômicos passaram a exigir normas jurídicas capazes de propiciar maior estabilidade e previsibilidade a suas expectativas.

Nesse contexto, a intervenção do Estado era requerida em quatro situações, para: (i) estabelecer a liberdade de comércio, segundo a concepção ocidental-liberal; (ii) prescrever, quando celebrassem tratados de comércio e navegação, direitos de proteção mínima aos comerciantes; (iii) garantir que os líderes da África e Pacífico iriam conceder igualdade de oportunidades para as empresas privadas; e (iv) celebrar tratados comerciais com os antigos Estados inimigos. Tais necessidades justificam o desenvolvimento, ao longo do século XIX, dos tratados de comércio e navegação, que, frequentemente, disciplinaram no território de cada uma das partes a atividade econômica dos estrangeiros. Nesse particular, encontra-se o Tratado de 1810, celebrado entre Portugal e Grã-Bretanha, que estabelecia direitos e privilégios aos mercadores ingleses nos domínios portugueses, bem como estipulava um dispositivo simbolicamente mais relevante para as relações econômicas internacionais: a cláusula da nação mais favorecida. ${ }^{65}$

No século XIX, a cláusula da nação mais favorecida passa a desempenhar um papel central nas relações econômicas internacionais, pois possibilitou a uniformização dos discursos jurídicos e a liberação do comércio. A Grã-Bretanha valeu-se da CNMF quase exclusivamente na forma incondicionada, pois tinha por objetivo estabelecer um tratamento não discriminatório entre as partes, cujos efeitos, em época de expansão comercial, resultaram na criação de redes comerciais, sustentadas por tratados bilaterais. Note-se que o instituto diferenciava-se das demais disposições típicas do direito internacional de coexistência, visto que seu discurso jurídico-convencional imputava aos Estados obrigações positivas de cooperação.

Em suma, a capacidade da estrutura institucional-legal de estabilizar as expectativas da ordem econômica internacional foi restringida pela ideologia do pacifismo liberal, expressa na não intervenção e na autorregulação, e pela governança diplomática fundada sobre o Concerto

\footnotetext{
${ }^{65}$ SCHWARZENBERGER, Georg. The principles and standards of international economic. Recueil des Cours, Leiden, v. 117, n. 1, 1966, p. 23. LAFER, 1977, p. 4-5. FURTADO, 2000, p. 33.
} 
de Viena. O sistema jurídico internacional era concebido essencialmente como um conjunto de discursos jurídicos que veiculavam essencialmente normas negativas de mútua abstenção, responsáveis por permitir a coexistência das liberdades externas dos Estados Liberais. Exceção relevante era a cláusula da nação mais favorecida, que imputava obrigações negativas de abstenção e positivas de cooperação.

\subsubsection{A Era do Livre-comércio britânico: a consolidação da supremacia da cláusula da nação mais favorecida nos tratados bilaterais de comércio}

O período da Paz dos Cem Anos foi marcado por uma governança internacional de caráter essencialmente diplomático. O Concerto Europeu foi capaz de garantir a estabilidade das relações interestatais, impedindo a hegemonia de uma grande potência. No plano axiológico, o pensamento liberal difundiu-se, corroendo os fundamentos do absolutismomonárquico, enquanto que, na economia, assistiu-se à consolidação do modo de produção capitalista. O impacto das transformações socioeconômicas na estrutura institucional-legal teve por efeito a conformação do Estado Liberal e do direito internacional de coexistência, produzindo um sistema jurídico internacional constituído essencialmente por normas negativas de abstenção.

Nesse contexto, a ordem econômica internacional liberal destaca-se por ter instituído uma governança internacional com distintas particularidades em relação às relações internacionais gerais. Apesar de o desafio revolucionário ter sido simbolicamente vencido nas cercanias de Bruxelas em 1815, a Grã-Bretanha despontou como potência econômica capitalista e ferrenha defensora dos ideais liberais. Se o equilíbrio de poder do Concerto Europeu assegurou politicamente a paz, a rápida difusão das relações econômicas e da ideologia liberal teve o condão de corroer as carcomidas estruturas da decadente ordem econômica mercantil. Isso permitiu à Grã-Bretanha impor, ao longo do século XIX, sua supremacia hegemônica na economia mundial, por meio da consolidação de uma governança econômica internacional, conquistada pela superioridade de recursos, legitimada pelo discurso 
do pacifismo liberal e institucionalizada por uma rede de tratados de comércio e navegação interconectados pela cláusula da nação mais favorecida.

À época das Guerras Napoleônicas, a ordem econômica internacional mercantil já começava a se enfraquecer. O Estado Moderno era o patrono das políticas econômicas mercantilistas, as quais compreendiam as relações comerciais como um mero instrumento para geração de riqueza e poder. Sob as políticas mercantilistas, foram construídos os regimes de exploração colonial, cujas principais características eram o dirigismo e o monopólio das relações econômicas em benefício do Estado. Para compensar o comércio desfavorecido, os Estados Modernos comprometiam-se a prover força militar para proteger as nações subjugadas. Dentro dessa lógica econômica, o poder militar permitia o crescimento econômico, enquanto este, sob o controle mercantilista, financiava a expansão militar.

Todavia, as revoluções setecentistas introduziram profundas modificações nas estruturas econômicas. Na Grã-Bretanha, os industriais desenvolveram inovações tecnológicas que revolucionaram a economia, resultando em um salto qualitativo que permitiu a eles ganhar competitividade perante os demais mercados. Os interesses econômicos surgidos na Revolução Industrial britânica contrastavam com a própria concepção de mercantilismo, o qual passou a ser considerado irrelevante ou danoso às relações comerciais. Isso porque paulatinamente aumentava o desejo financeiro-industrial de desmantelar o regime mercantilista britânico, criado originalmente para combater a hegemonia mercantil holandesa, mediante a eliminação das barreiras comerciais dos países. Isso permitiria ampliar o mercado consumidor, possibilitando auferir ganhos mútuos, em razão do aumento das vendas e da diminuição dos custos. À medida que a City de Londres se tornava o centro financeiro mundial, crescia o interesse no livre-comércio, visto que permitia aos banqueiros financiar a compra de produtos britânicos e garantir aos estrangeiros obter recursos para adimplir suas dívidas, por meio da exportação de matéria-prima barata. ${ }^{66}$

A revogação das Corn Laws consolidou a vitória do liberalismo na Grã-Bretanha, enquanto a celebração do Tratado Cobden-Chevalier simbolizou, no plano internacional, o rompimento com os postulados-chave do protecionismo em prol da liberalização do comércio a todos os Estados. O abandono do mercantilismo pela Grã-Bretanha representou a possibilidade de novas opções de política econômica aos demais países. Ao superar os

\footnotetext{
${ }^{66}$ FRIEDEN, 2008, p. 17-20.
} 
problemas inerentes à política mercantilista, como as alianças militares e monopólios, abriu-se caminho para os Estados integrarem-se ao mercado global.

Nesse cenário, França e Grã-Bretanha celebraram, em 23 de janeiro de 1860, um abrangente tratado comercial que liberalizou o comércio, conhecido como Tratado CobdenChevalier, por meio do qual decidiram adotar a cláusula da nação mais favorecida, bem como reduzir substancialmente suas tarifas e abolir proibições quanto às importações. Não obstante o simbolismo do acordo, é imprescindível ressaltar uma diferença determinante acerca das obrigações assumidas do tratamento da nação mais favorecida. O Tratado estabeleceu que os benefícios reciprocamente auferidos de outros países poderiam ser condicionalmente estendidos pela França, enquanto deveriam ser outorgados incondicionalmente pela GrãBretanha. Rapidamente, os britânicos constataram que as vantagens pendiam desequilibradamente em favor da França. Para compensar essa situação desfavorável, os britânicos iniciaram uma ousada corrida para firmar tratados de comércio, contendo a CNMF incondicionada. Desde então, a forma incondicionada passou a ser exclusivamente usada na Europa, apesar do retorno ao protecionismo em $1873 .^{67}$

Essa nova onda capitalista-liberal, que invadiu a Europa na segunda metade do século XIX, reintroduziu a cláusula da nação mais favorecida incondicionada, cuja utilização havia perdido espaço para o protecionismo ou para a forma condicionada. Com o comércio internacional crescendo de duas a três vezes mais rápido do que as economias domésticas, a CNMF passou a ser amplamente empregada nos tratados de comércio e navegação, tendo por objetivo diminuir drasticamente as tarifas aduaneiras e institucionalizar a integração dos mercados mundiais. Por assegurar a interdependência das relações econômicas internacionais, atribuiu-se à cláusula da nação mais favorecida o status de lex generalis do comércio internacional.

Nesse sentido, a cláusula da nação mais favorecida incondicionada possibilitou a uniformização e a liberalização comercial, pois funcionava como um mecanismo automático de adaptação econômica e restrição ao poder de império dos Estados. De fato, a Grã-Bretanha foi capaz de orientar as relações econômicas internacionais, ao aliar o discurso do pacifismo liberal à rede de tratados bilaterais, permitindo a ela unificar, sem o emprego de força militar, a economia mundial em torno da noção de livre-comércio, de Estado Liberal e da autonomia

${ }^{67}$ DAL RI JR., 2003, p. 98. USTOR, 1969, p. 162. JACKSON; DAVEY, 1986, p. 432. 
da vontade privada. Contida a intervenção econômica estatal e conectados os mercados domésticos pela CNMF, os agentes econômicos britânicos foram eficientemente hábeis para obter vantagens no livre-jogo do comércio internacional, concedendo a Londres o controle sobre a ordem econômica internacional. ${ }^{68}$

Envolto com as exigências empíricas e axiológicas, o sistema internacional de comércio sofreu um processo de transformação no século XIX, na medida em que todos os tratados de comércio passaram a dispor da cláusula da nação mais favorecida, cuja função congrega obrigações negativas de coexistência e positivas de cooperação. Os Estados Unidos empregavam a forma condicionada da CNMF em seus acordos comerciais; já a Europa advogava pela interpretação incondicionada do instituto. Nas demais regiões, ambas as variações eram empregadas em tratados comerciais, segundo a necessidade econômica. Diante da centralidade das políticas comerciais no princípio da não discriminação, Stanley Hornbeck reconhece que a cláusula da nação mais favorecida era "the corner-stone of all modern commercial treaties". 69

A grande expansão do comércio internacional exigia intensificar a interdependência econômica além dos limites dos efeitos do tratamento da nação mais favorecida. Isso implicou a elaboração de novos instrumentos capazes de abrir mercados nacionais, tais como as uniões aduaneiras, as quais foram responsáveis por possibilitar o processo de integração regional na Europa. Os primeiros movimentos com esse objetivo não serviram somente para fins econômicos, mas também como instrumentos de harmonização política e uniformização jurídica dos Estados envolvidos. Graças ao incipiente direito internacional econômico, viabilizou-se o processo de unificação dos Estados Germânicos, o qual culminou na constituição da Zollverein. Celebrado em 22 de março de 1833, o tratado previu os três princípios, que se tornariam fundamentais para as uniões aduaneiras: a tarifa externa uniforme, a liberdade de comércio no interior da unidade econômica e o compartilhamento de receitas. $\mathrm{O}$ sucesso da iniciativa germânica favoreceu, ao longo do século XIX, a instituição de outras uniões aduaneiras na Europa. ${ }^{70}$

\footnotetext{
${ }^{68}$ LAFER, 1977, p. 6. SCHWARZENBERGER, Georg. International law and order. Londres: Stevens \& Sons, 1971, p. 129-134.

${ }^{69}$ HORNBECK, Stanley K. The Most-Favored-Nation Clause. American Journal of International Law, [s.1.], v. 3, n. 2, 1909, p. 619-647.

${ }^{70}$ DAL RI JR., 2003, p. 100.
} 
No contexto da proliferação de tratados internacionais econômicos, que previam a liberalização comercial e a formação de uniões aduaneiras, os agentes econômicos internacionais passaram a demandar maior transparência e uniformidade normativa para o comércio internacional, de modo a garantir maior previsibilidade e segurança jurídica em face do crescente número de tarifas existentes. Em 1873, os Estados reuniram-se no Congresso Internacional do Comércio e da Indústria de Bruxelas, para negociar a criação de uma organização internacional de índole estritamente técnica, que servisse como referência para o intercâmbio de documentos oficiais e para a regulamentação das tarifas alfandegárias fixadas pelos governos. Estabelecida em 1890, a União Internacional para a Publicação das Tarifas Aduaneiras, com sede em Bruxelas, foi a primeira organização de caráter multilateral com o objetivo de facilitar e padronizar as relações comerciais entre os Estados. ${ }^{71}$

A difusão do princípio da não discriminação, veiculado pelo pacifismo liberal e institucionalizado pela cláusula da nação mais favorecida, começou a sofrer diversas restrições, com a progressiva perda de lucratividade do comércio. A eclosão da Grande Depressão, fenômeno macroeconômico caracterizado pela gradual e progressiva queda dos preços mundiais no período de 1873 a 1896, contribuiu para a insatisfação em torno do livrecomércio. A desuniforme queda dos preços causou pessimismo e incerteza, pois a drástica diminuição das receitas dos produtos agrícolas não foi acompanhada pela redução do valor das manufaturas, tampouco promoveu a correção dos empréstimos contraídos anteriormente.

A Grande Depressão teve efeitos diversos sobre as principais potências, inclusive provocando atritos ainda maiores do que os assistidos nas últimas décadas. Os Estados Unidos e o recém-formado Império Alemão decidiram empregar instrumentos protecionistas para desenvolver suas indústrias nascentes. Na França, a proclamação da Terceira República possibilitou o ressurgimento do protecionismo, responsável pela denúncia do Tratado CobdenChevalier em 1872 e pela proclamação das Tarifas Méline em 1892. Ainda que pesassem grandes desafios, a Grã-Bretanha foi o único país industrial a intensificar o livre-comércio, de modo a instituir uma estrutura simbiótica, formada pelos produtos primários e mercado consumidor dos países subdesenvolvidos e pelas manufaturas e financiamentos britânicos.

\footnotetext{
71 ALMEIDA, Paulo Roberto de. Formação da diplomacia econômica no Brasil: as relações econômicas internacionais no Império. São Paulo: Senac, 2001, p. 375-377. DAL RI JR., 2003, p. 101.
} 
Apesar do caráter internacionalista do capitalismo, essas transformações refletiram rapidamente nas relações econômicas internacionais, pois os Estados centravam sua preocupação nas economias nacionais. A luta por mercados externos, que, na maior parte do século XIX, estava limitada a promover a competição comercial entre agentes privados, livre, então, da intervenção estatal, ganha novos contornos. Inicialmente, os países apenas intensificaram o emprego de práticas protecionistas e discriminatórias, cujos resultados foram as restrições quanto à inclusão da cláusula da nação mais favorecida nos tratados comerciais e o aumento tarifário. Em seguida, as potências europeias partiram para uma corrida de expansões coloniais na África, Oriente Médio e Ásia, tendo por finalidade a conquista de novos mercados. Na última década, as sombras da guerra já surgiam por toda a parte, ameaçando as estruturas da ordem econômica internacional. ${ }^{72}$

Todavia, no fim de 1896, os preços mundiais já haviam se recuperado, encerrando a Grande Depressão. Em seu lugar, suceder-se-iam duas décadas de crescimento e globalização, período conhecido como a Era de Ouro do capitalismo global. Diante do relaxamento das tensões, os governos entregaram, com entusiasmo, suas economias à exportação, o que resultou no mais próximo de um mercado mundial sem barreiras para produtos, capitais e trabalho que o planeta já vira. Os benefícios da expansão econômica beneficiaram todos os países, os quais assistiram ao aumento de sua produção e renda. O comércio internacional, que correspondia em 1896 a menos de 8 bilhões de dólares, atingiu mais de 18 bilhões em 1913.

A reversão da grande deflação de 1873-1896, o desenvolvimento tecnológico e a relativa estabilidade econômica contribuíram para a rápida integração dos mercados. Em momentos anteriores, quando o comércio era arriscado e custoso, não participar dele não tinha efeitos nocivos. Entretanto, a coesão proporcionada pelo padrão-ouro, comércio e finanças internacionais acabou por implicar um alto preço a ser pago para os agentes econômicos que optassem pelo isolamento. Desse modo, o fato de a Era de Ouro ter abandonado as políticas mercantilistas parecia ser plenamente justificável, visto que as vantagens auferidas pelo liberalismo econômico e o modo de produção capitalista eram significativas.

\footnotetext{
${ }^{72}$ FRIEDEN, 2008, p. 23-26. LAKE, David A. British and American Hegemony Compared: Lessons for the Current Era of Decline. In: FRIEDEN Jeffry A.; LAKE, David A. (ed.). International political economy: perspectives on global power and wealth International Political Economy: Perspectives on Global Power and Wealth. $4^{\mathrm{a}}$ ed. Londres: Routledge, 1999, p. 127-130. USTOR, 1969, p. 162. KINDLEBERGER, Charles P. The Rise of Free Trade in Western Europe, 1820-1875. The Journal of Economic History, [s.1.], v. 35, n. 1, 1975, p. $37-41$.
} 
No entanto, abaixo da superfície já havia tensões e abusos no capitalismo global, o que promoveu uma crescente insatisfação de diversos países prejudicados. A integração econômica gerou um enorme descontentamento dos países periféricos, os quais eram impedidos de desfrutar dos benefícios produzidos. A manutenção compartilhada das estruturas da ordem econômica internacional revelava-se excessivamente dispendiosa, enquanto as vantagens eram canalizadas para o prazer de poucos. Isso resultou em críticas ao discurso do pacifismo liberal, o qual sustentava que o mercado global era um poderoso mecanismo para a prosperidade e a paz entre as nações. ${ }^{73}$

A partir de agosto de 1914, a presença de uma guerra mundial rondou, impregnou e assombrou o cotidiano europeu. Para a maioria dos Estados ocidentais, uma guerra entre as potências europeias não passava de uma lembrança histórica ou de um exercício teórico futuro. A principal função dos exércitos era preservar as sociedades de insurgentes civis. Todavia, o esgotamento gradual dos fundamentos do Concerto Europeu e a perda de efetividade da governança econômica internacional britânica levaram à Primeira Guerra Mundial. O sistema internacional de comércio, composto por tratados comerciais e uniões aduaneiras, desmoronou junto com o sonho de uma paz liberal perpétua. Todas as garantias comerciais, especialmente aquelas asseguradas pela cláusula da nação mais favorecida, desapareceram com os estrondos de canhões.

Diante disso, é possível extrair as características estruturais da ordem econômica internacional liberal. Na subordem comportamental, o modo de produção capitalista era o fator dominante das relações econômicas internacionais. Graças à Revolução Industrial, os agentes econômicos britânicos estiveram durante décadas em vantagem em relação aos seus competidores, transferindo para Londres o poder de controle sobre as mais relevantes questões econômicas. Ainda que a supremacia comercial começasse a ser contestada no final do século XIX, a Grã-Bretanha permanecia como o centro de transações comerciais e financeiras internacionais. Nesse sentido, o pluralismo de agentes garantiu a ampliação sem precedentes do mercado mundial, o qual integrou grande parte das economias.

$\mathrm{Na}$ subordem axiológica, a ideologia do pacifismo liberal foi adotada por grande parte das potências europeias. Com exceções pontuais, a guerra e o intervencionismo estatal haviam sido banidos da Europa, permitindo às relações econômicas internacionais autorregularem-se,

\footnotetext{
${ }^{73}$ FRIEDEN, 2008, p. 29-42.
} 
conforme os interesses econômicos. O caráter internacional do capitalismo transcendeu a teoria liberal, revelando-se um imperativo para o funcionamento e organização do mercado mundial. A Grã-Bretanha valeu-se do discurso do pacifismo liberal para ampliar o mercado consumidor de seus produtos, retirar as restrições que pairavam para o fluxo internacional de capitais e neutralizar os descontentamentos com os benefícios assimétricos do capitalismoliberal. Recorreu-se, inclusive, ao liberalismo para justificar a política imperialista, visto que o despotismo seria legítimo se empregado para trazer povos bárbaros às relações civilizadas.

Enfim, a principal característica da subordem institucional-legal foi a preservação dos fundamentos da Paz de Westfália. O discurso liberal e as relações capitalistas não exigiram o rompimento com o paradigma da soberania territorial do Estado, porém imprimiram importantes modificações. As concepções de Estado Liberal e o direito internacional de coexistência buscaram concretizar o ideal de liberdade negativa, o qual apregoava a não intervenção estatal na vida privada e a autonomia da vontade.

Não obstante, o incipiente direito internacional da economia inovou, na medida em que possibilitou aos Estados comprometerem-se com obrigações positivas de mútua cooperação. Nesse particular, a cláusula da nação mais favorecida incondicionada é um símbolo da própria ordem econômica internacional, visto positivar as acepções positiva e negativa do conceito liberal de liberdade. Por isso, foi empregada para conectar os diversos tratados bilaterais de comércio, tendo por efeito assegurar à Grã-Bretanha a governança econômica internacional. Embora a construção dessa rede de acordos comerciais integrados contribuísse para a formação de um sistema internacional de comércio, a institucionalização, por meio de tratados bilaterais, revelou-se insuficiente para garantir a previsibilidade e segurança jurídica. Essa fragilidade institucional foi constatada quando a eclosão da Primeira Guerra Mundial esfacelou todo o arcabouço jurídico construído ao longo do século XIX pela Grã-Bretanha. 


\subsection{A ORDEM ECONÔMICA INTERNACIONAL FRAGMENTADA}

No mesmo diapasão do precedente, a finalidade do presente Capítulo é examinar os reflexos das transformações decorrentes do colapso estrutural da ordem econômica internacional liberal sobre a cláusula da nação mais favorecida, bem como as razões que impediram tanto a reconstituição da ordem precedente como a conformação integrada de novas subordens. Nesse particular, investigam-se o processo de fragmentação e as características gerais das ordens parciais de cooperação econômica, na exclusiva medida em que forem relevantes para a compreensão das modificações incorridas pela CNMF no contexto da ordem econômica internacional fragmentada.

A gradual desagregação dos fundamentos responsáveis pela coesão das estruturas da ordem internacional levou à Primeira Guerra Mundial. Em contraste com o pensamento pacifista institucional, cujo objetivo era evitar o recurso à força para solução de conflitos, as ideias da Escola Realista apregoavam que a guerra não seria um acidente evitável, mas uma consequência natural da eterna luta entre as nações. $O$ discurso realista fundamentou as ascendentes atitudes belicosas e protecionistas, as quais serviram para comprometer a governança internacional do Concerto Europeu. A figura do Estado passou a ser contestada na vida social, na medida em que se exigiu dele um papel ativo na defesa dos interesses nacionalistas na esfera internacional, o que demandou a ruptura com o paradigma liberal da não intervenção e autorregulação da vida privada.

A expansão econômica virtuosa no início do século XX gerou prosperidade capaz de fortalecer a paz internacional e a integração mundial. $O$ consenso em torno da globalização econômica, da harmonia de interesses e do governo mínimo mantinha-se pelo aparente sucesso do discurso do pacifismo liberal. No entanto, percebe-se que as relações econômicas internacionais pré-1914 não foram totalmente positivas, pois os benefícios do crescimento econômico não estavam disponíveis a todos, mas restritos a uma elite. A Pax Britannica foi 
comprometida pelo jogo do capitalismo internacional, o qual demandou dos países o emprego de técnicas belicosas de expansão, na forma dos regimes imperialistas.

Nesse sentido, o conflito armado não apenas rompeu as relações jurídicas entre os Estados adversários, como também afetou a própria ideia da cláusula da nação mais favorecida, causando, mesmo que temporariamente, um recrudescimento do seu uso. Os ideólogos do protecionismo sustentavam que os efeitos da cláusula da nação mais favorecida eram "unnatural", visto obrigarem os Estados a tratar igualmente tanto os países aliados como os mais distantes. Obviamente, no caso dos inimigos, os tratados foram resolvidos; mas, com exceção desse extremo, as relações com os demais Estados podiam variar abruptamente, desde amigáveis até congelantes. ${ }^{74}$

No baixar da poeira de pólvora e enxofre, a ordem mundial havia sofrido uma drástica mudança. Os Estados Unidos deixaram de ser um mero observador passivo e se tornaram a principal potência militar e econômica, com desejos de ampliar sua influência globalmente. Os países europeus estavam arrasados política e economicamente, o que propiciou extremismos domésticos e conflitos ideológicos. A falência do regime czarista implicou na Revolução Soviética de 1917, da qual surge a União das Repúblicas Socialistas Soviéticas. Desse modo, após a Primeira Guerra Mundial, o mundo caiu em um círculo vicioso, visto que a economia internacional entrou em colapso, causando crises internas e extremismos, agravados pelos movimentos nacionalista e protecionista. ${ }^{75}$

Com o fim da Era do Livre-comércio britânico, iniciou-se um período de trinta anos de transformações estruturais, o qual foi marcado por conflitos sociais, econômicos e ideológicos. A guerra comprometeu grande parte da Europa, o que resultou na escassez de alimentos, desarticulação da produção industrial e desorganização dos meios de transporte. Em razão disso, assiste-se ao rápido alastramento de políticas protecionistas, responsáveis por desgastes comerciais que se agravaram na forma de guerras econômicas, culminando em conflitos armados. As disputas e acirramentos eram amplamente pulverizados, repercutindo no tensionamento das relações entre classes sociais e entre comerciantes de diferentes países, bem como na interação econômica internacional.

\footnotetext{
${ }^{74}$ USTOR, 1969, p. 162. LAFER, 1977, p. 7. FRIEDEN, 2008, p. 143-145. VERBIT, Gilbert P. Preferences and the public law of international trade: the end of most-favoured-nation treatment? In: KOJANEC, Giovanni. International Trade Agreements: workshop 1968/Les Accords de Commerce International: colloque 1968. Recueil des Cours. V. 68, Leiden: Sijthoff, 2002, p. 26.

${ }^{75}$ HÖLSTI, 2000, p. 78-82. HOBSBAWM, 1998, p. 454-460.
} 
Coube à Conferência de Paz de Versalhes de 1919 restabelecer os termos de convivência na Europa após os conflitos da Primeira Guerra, a fim de regulamentar a ordem internacional. Embora o armistício houvesse sido alcançado com fundamento no discurso pacifista-liberal de Woodrow Wilson, os demais Aliados resistiram ao idealismo dos 14 Pontos, alinhando-se ao revanchismo francês e ao discurso do protecionismo econômico. Os jogos de poder fomentaram as desavenças, resultando no desfazimento da tentativa de restabelecer o Concerto Europeu e o livre-comércio. ${ }^{76}$

Durante a Conferência, a rejeição ao liberalismo revelou-se tão evidente que a cláusula da nação mais favorecida tornou-se um símbolo dos desastres causados pelo capitalismoliberal. A guerra implicou na reversão da atuação britânica, causando entraves ao comércio internacional, os quais não mais superáveis pelo jogo da cláusula da nação mais favorecida em uma perspectiva bilateral. A nova e complexa realidade das relações econômicas internacionais era caracterizada por uma economia internacional e multipolar, nãos mais capitaneada pela Grã-Bretanha. O Secretário de Comércio da França, Clementel, expressou o descontentamento com o livre-comércio, em 15 de dezembro de 1918, afirmando que "the Government has denounced all commercial conventions which embody the most-favourednation clause. That clause will not reappear. [...] It will never again poison our tariff policy”.

Os Estados Unidos, contudo, opunham-se à submissão dos derrotados a instrumentos de discriminação econômica, pois foram tais medidas que conduziram àquela situação de conflito armado. Os séculos precedentes demonstraram que o ressentimento dos países discriminados é responsável por envenenar as relações econômicas internacionais e dificultar a manutenção da paz. Daí a igualdade de condições comerciais entre todas as nações ser uma das quatorze ideias defendidas pelo presidente W. Wilson, em 1918, com a finalidade de alcançar a paz. Por isso, a incidência de tarifa, alta ou baixa, deveria tratar a todos os países igualmente.

Para superar o impasse franco-estadunidense, os Aliados decidiram impor aos países derrotados os Tratados de Paz, cujos objetivos eram controlar a Alemanha, impedir a expansão da Revolução Bolchevique, dividir as linhas fronteiriças da Europa e dos domínios coloniais, bem como tornar impossível outra guerra que devastasse o mundo, mediante a criação da Liga

\footnotetext{
${ }^{76}$ HOBSBAWM, Eric J. Era dos Extremos: O breve século XX: 1914-1991. Trad. Marcos Santarrita. São Paulo: Companhia das Letras, 2007, p. 40-42.
} 
das Nações. Como sanção pelos malefícios causados na guerra, os Aliados exigiram que a Alemanha reconhecesse expressamente ser a única culpada pelos conflitos armados. O Tratado impôs, porém, medidas extorsivas que previam o pagamento de imensas reparações por tempo indefinido e mecanismos de discriminação comercial. Além disso, a Alemanha comprometeuse, durante cinco anos, a conceder unilateralmente o tratamento da nação mais favorecida aos Estados Aliados. A principal consequência dessa paz punitiva foi impedir a restauração da economia alemã, da qual dependia a própria estabilidade europeia. Isso obrigou a Alemanha a sujeitar-se aos empréstimos estadunidenses, os quais viriam a escassear em $1929 .{ }^{77}$

Ante a impossibilidade de retornar ao equilíbrio promovido pelo Concerto Europeu, o Pacto da Liga das Nações ("LdN") surgiu como proposta de criar uma nova ordem mundial de natureza mais jurídica do que diplomática. Síntese do discurso pacifista-liberal e realista, a LdN foi a primeira tentativa em larga escala de padronizar os problemas políticos internacionais sobre uma base racional. O escopo consistia em regular as relações entre os Estados de acordo com certos princípios, entre os quais a paz e a não discriminação. Os princípios representavam um esforço de, mediante a cooperação internacional, limitar consensualmente o arbítrio dos Estados no exercício de sua soberania, nos limites prescritos pelo direito internacional público de coexistência. ${ }^{78}$

Para evitar os fatores econômicos que suscitaram a Primeira Guerra, atribuiu-se à Liga das Nações o objetivo de fomentar a adoção, por todos os Estados-membros, de normas multilaterais sobre a igualdade de tratamento nas atividades comerciais. O Pacto previu, em seu artigo 23, que, com reserva e em conformidade com as disposiçõos das convenções internacionais existentes à época ou que seriam posteriormente ulteriormente concluídas, os Membros da Liga tomariam "as disposições necessárias para assegurar a garantia e a manutenção da liberdade do comércio e trânsito, assim como equitativo tratamento comercial a todos os membros da Liga”. Em razão disso, a LdN ocupou-se de várias questões econômicas, financeiras e comerciais, em especial a cláusula da nação mais favorecida incondicionada, objeto de inúmeros estudos e relatórios, os quais recomendavam a adoção

\footnotetext{
${ }^{77}$ VINER, Jacob. International Economics. Glencoe: Free Press, 1951, p. 95; 355. KEYNES, John Maynard. As consequiências econômicas da paz. Trad. Sérgio Bath. São Paulo: Imprensa Oficial do Estado, Brasília: Universidade de Brasília, 2002, p. 67-69. HOBSBAWM, 2007, p. 101-103.

${ }^{78}$ CARR, Edward Hallett. Vinte Anos de Crise: 1919-1939: Uma Introdução ao Estudo das Relações Internacionais. Trad. Luiz Alberto F. Machado. Brasília: Universidade de Brasília, São Paulo: Imprensa Oficial do Estado de São Paulo, 2001, p. 40. LAFER, 1977, p. 8.
} 
desta por todos os Estados-membros, assim como discutiam diversos problemas, ambiguidades e políticas a ela atribuídas. ${ }^{79}$

Todavia, no período subsequente à Primeira Guerra, a cláusula da nação mais favorecida não voltou a reconquistar sua antiga posição de fundamento central nas políticas comerciais. A destruição da economia europeia nos quatro anos de guerra, seguida pela hiperinflação e depressão econômica de 1921 a 1924, resultou no colapso das moedas nacionais e do comércio internacional. Diferentemente da ordem econômica internacional liberal, cuja governança era capitaneada pela Grã-Bretanha, os Estados Unidos rejeitaram a posição de regente da economia global. O isolacionismo estadunidense tornou-se política governamental a partir de 1920, devido ao veto do Senado aos planos de paz de Woodrow Wilson e à participação do país na Liga das Nações. Em virtude disso, os Estados Aliados adotaram medidas restritivas ao comércio. A defesa da reciprocidade nos tratados de comércio internacional, a preocupação econômica com a reconstrução e a declarada oposição da França e da Espanha impediram o rápido retorno da utilização da CNMF.

Após alguns anos de paz, que permitiram a estabilização e recuperação das relações econômicas internacionais, a economia parecia retornar a promover o crescimento global. A expansão econômica estimulou grandes mudanças socioeconômicas. O típico isolamento político e econômico dos Estados Unidos não viria, enfim, a impedir o gradual retorno da cláusula da nação mais favorecida. Contudo, foi graças à necessária união de esforços entre Itália, Reino Unido, Alemanha e outros aliados que se tornou possível enfrentar a posição protecionista da França e da Espanha.

Diante da mudança de dinâmica no comércio internacional, os Estados Unidos alteraram radicalmente sua política comercial internacional, visando refletir seu novo interesse econômico-exportador. A tradicional política comercial estadunidense, centrada na cláusula da nação mais favorecida condicionada, provou-se inadequada aos novos interesses exportadores. Ao oferecer tratamento não discriminatório, os EUA começaram a obter o mesmo tratamento dos demais países, o que, consequentemente, reduziu a discriminação quanto aos seus produtos exportados. Assim, o Tariff Act de 1922 concedeu poderes ao Executivo

\footnotetext{
${ }^{79}$ JACKSON, 1969, p. 250.
} 
estadunidense para, durante as negociações de tratados comerciais, oferecer a CNMF na forma incondicionada. $^{80}$

O Caso John T. Bill Co versus Estados Unidos materializa historicamente a mudança na política dos EUA. Nesse litígio paradigmático, os importadores de bicicletas de origem alemã arguiram junto à Corte de Apelação dos Estados Unidos o reembolso de tributos que teriam sido pagos indevidamente, graças ao acordo comercial entre EUA e Alemanha, o qual previa a forma incondicionada da cláusula da nação mais favorecida. A relevância do caso está intimamente ligada aos discursos proferidos no Senado estadunidense, os quais tiveram o condão de justificar a assinatura do acordo e a adoção da nova política comercial. ${ }^{81}$

O ano de 1927 foi particularmente importante para cláusula da nação mais favorecida, em razão de três acontecimentos. Primeiro, a França decidiu romper simbolicamente com a política de reciprocidade nas relações econômicas internacionais, ao celebrar com a Alemanha um tratado comercial contendo a CNMF. Segundo, a Espanha aprovou uma norma interna, autorizando o Executivo a convencioná-la em pactos internacionais. Terceiro, a Conferência Econômica Internacional da Liga das Nações conferiu um grande impulso nos usos e estudos da cláusula da nação mais favorecida. Graças ao relatório formulado pelo grupo de peritos, composto principalmente por George W. Wickersham e pelo Professor Barbosa de Magalhães, a Assembleia da LdN aprovou uma relevante resolução que estabelecia a nova orientação da política comercial internacional para um regime liberal e igualitário de comércio:

The Committee accordingly decided to attempt to devise treaty making methods by which a general reduction of tariffs could gradually be effected and their stability ensured, and which would encourage the conclusion of bilateral conventions affording the contracting States equal commercial opportunities and establishing their trade on a footing that would make it impossible to dig pitfalls for other countries.

The Committee has conducted this technical investigation in the conviction that the adoption of the solutions to which it will lead may very greatly improve the position of international trade and become a determining factor in the pacification of international commercial relations [...]. With this intention the Committee, in compliance with a particularly explicit recommendation of the Conference, has undertaken to codify most-favoured-nation treatment, which should be either the central principle or the normal outcome of every commercial negotiation. [The Committee would soon furnish particulars], which might serve as a basis for international engagements, with regard to its mechanism, its scope, and its bearing on multilateral conventions.

\footnotetext{
${ }^{80}$ SNYDER, 1948, p. 80-81. USTOR, 1969, p. 163. FRIEDEN, 2008, p. 158-164.

${ }^{81}$ JACKSON; DAVEY, 1986, p. 435-438.
} 
[The Committee also envisaged the] examination of those general, special and geographical exceptions of which the introduction seems desirable on account of established international practice or the peculiar circumstances of certain States. [Finally, the Committee expressed its conviction that] well-considered action in the matter of commercial conventions based on the most-favoured-nation clause must speedily bring about the re-establishment of regular currents of trade, which will no longer have to contend with a policy of protectionism and isolation. ${ }^{82}$

Em consequência das mudanças estadunidense e franco-espanhola, a cláusula da nação mais favorecida incondicionada retornou ao centro das relações econômicas internacionais. Nesse particular, ressalta-se que a adoção da política de não discriminação pelos Estados Unidos implicou praticamente no desaparecimento da forma condicionada dos pactos comerciais. Isso porque, entre 1920 e 1940, dos cerca de seiscentos tratados contendo a $\mathrm{CNMF}$, apenas nove previam a forma condicionada. ${ }^{83}$

Dissonante com o discurso de paz e estabilidade econômica da LdN, os elementos que desestruturaram a ordem internacional ainda não haviam se acomodado. A eficácia dos princípios do Pacto foi limitada, pois, ao contrário do Concerto Europeu, a Liga das Nações não foi o resultado do esforço conjunto das grandes potências da época, razão pela qual acabou não reunindo condições e recursos de poder suficientes para manter a governança internacional. Não é preciso esmiuçar o texto dos acordos firmados em Versalhes para perceber que não serviriam para perpetuar a paz, visto que a recusa dos países vencedores em reincorporar os derrotados fomentava a insatisfação e a discórdia nas relações internacionais. Ao já tenso cenário político viria a ser inserida a mais gravosa crise econômica do capitalismo: a grande crise de 1929.

Nesse contexto, o Estado Liberal também sofreu profundas transformações. A Revolução Soviética de 1917 promoveu a ascensão do modelo de Estado Social, o qual implementou a planificação econômica, no âmbito interno, além de monopolizar o comércio exterior, no plano internacional. Os demais países foram atingidos pelos efeitos da quebra da Bolsa de Valores de Nova York em 1929, seguida pelo colapso econômico do capitalismo global. Fenômeno único em termos de profundidade e amplitude, a Grande Depressão pôs fim à oscilante recuperação econômica da década de 1920, bem como enterrou o projeto pacifista-

\footnotetext{
${ }^{82}$ USTOR, 1969, p. 169-170.

${ }^{83}$ USTOR, 1969, p. 163.
} 
liberal. Com isso, exigiu-se ao Estado a intervenção, interna e externamente, na sociedade, de modo a promover uma guerra econômica em um cenário de paz militar.

Na tentativa de minimizar os reflexos destrutivos da crise econômica, o Estado passou a intervir na economia, a fim de corrigir as falhas do mercado doméstico. Em consonância com o discurso nacionalista-protecionista, surge o Estado Intervencionista para exercer um efetivo controle sobre as relações econômicas internas e externas. Para adequar-se às novas funções, elaborou-se um complexo regime de importações e exportações, subordinado a diretrizes internas de direito econômico. A adoção de medidas protecionistas, como o fechamento dos mercados nacionais mediante a elevação das tarifas externas, o recurso a práticas lesivas ao comércio internacional, como o dumping, e a introdução de políticas de subsídios e de diminuição de exportação culminou com a destruição das condições que propiciariam o ressurgimento da cláusula da nação mais favorecida, o que resultou em um rápido alastramento de barreiras ao comércio entre as nações. ${ }^{84}$

Em 1930, a sociedade internacional reagiu fortemente em face à adoção pelos Estados Unidos da polêmica tarifa Smoot-Hawley. É interessante observar que, como resultado dessa política estadunidense, em 1931, os trinta e seis maiores Estados exportadores passaram a exercer o controle de importação e exportação, operando de forma discriminatória. Em 1932, o Reino Unido abandonou simbolicamente o livre-comércio, que fora tão fundamental para a identidade econômica inglesa, estabelecendo tarifas aduaneiras. Não bastasse o rompimento com o princípio do livre-intercâmbio numa economia mundial combalida pelo protecionismo, os ingleses constituíram o sistema imperial de comércio preferencial da Comunidade Britânica de Nações (British Commonwealth).

A rápida desintegração da política comercial alcançou a Convenção sobre a Abolição das Proibições de Importação e Exportação. Celebrada durante a Convenção Econômica da Liga das Nações de 1927, a referida Convenção, que dispunha acerca de um acordo especial entre Dinamarca, Japão, Holanda, Noruega, Portugal, Reino Unido e Estados Unidos, representava uma vitória dos esforços do pós-guerra em prol da liberação comercial. O resultado foi sua denunciação por todos os Estados-partes em 1934. Em feliz síntese das

\footnotetext{
${ }^{84}$ LAFER, 1977, p. 7. MOREIRA, Adriano. Teoria das Relações Internacionais. $4^{\mathrm{a}}$ ed. Coimbra: Almedina, 2002, p. 432. HOBSBAWM, 2007, p. 43-45.
} 
transformações socioeconômicas, Eric Hobsbawm constata que "a Grande Depressão destruiu o liberalismo econômico por meio século". 85

As relações econômicas internacionais não tinham mais por objetivo outorgar mútuas concessões conforme as respectivas necessidades, mas assegurar que o comércio entre as nações fosse realizado em bases de rígido equilíbrio, guiado pelos princípios da reciprocidade e da autonomia. Ao examinar os cerca de quinhentos tratados bilaterais, celebrados entre 1931 e 1939, a cláusula da nação mais favorecida aparecia em apenas $42 \%$ destes. O contraste é grande ao comparar os dados com aqueles coletados antes de 1931, os quais apontavam a utilização da CNMF em 90\% dos acordos comerciais.

Não sem justificativa, a Alemanha Nazista foi a maior praticante da discriminação e da restrição comercial. O discurso protecionista alemão condenava o tratamento da nação mais favorecida, visto considerá-lo um dispositivo vicioso do desacreditado liberalismo econômico. Sob o comando de Hjalmar Schacht, foram utilizados todos os tipos de controle econômico e comercial, a fim de garantir a autossuficiência da economia e prover condições para a guerra.

Tal conjunto de fatores, somado à completa ausência de conjuntura política, impediu que os estudos e esforços da Liga das Nações em matéria econômica se convertessem no estabelecimento de uma ordem econômica internacional dotada de maior grau de institucionalização. Devido à falta de mecanismos de cooperação internacional, a ideologia do protecionismo autárquico disseminou-se entre os Estados, de modo a fomentar a criação de regimes econômicos preferenciais, correspondentes aos impérios coloniais de outrora. Assim, o período entreguerras foi responsável por exibir as mais perniciosas vicissitudes do protecionismo comercial, sendo um dos principais fatores para a eclosão da Segunda Guerra Mundial. As formas jurídicas utilizadas para instrumentalizar o tratamento discriminatório foram refinadas de tal sorte a compor um verdadeiro leque de armas, tais como monopólios e medidas preferenciais, subsídios, quotas e outras. O plano de unificar estruturalmente a ordem econômica internacional somente viria a ser novamente defendido pelos Aliados, após $1945 .^{86}$

Os últimos pilares da ordem econômica internacional liberal finalmente ruíram. Nem a recuperação parcial da economia, o processo de institucionalização das relações internacionais pela Liga das Nações ou tentativa de renovação do discurso do pacifismo liberal foram

\footnotetext{
${ }^{85}$ JACKSON, 1969, p. 251. USTOR, 1969, p. 163-164. HOBSBAWM, 2007, p. 499.

${ }^{86}$ USTOR, 1969, p. 163. LAFER, 1977, p. 8. MOREIRA, 2002, p. 433. BAILEY, S. H. The political aspect of discrimination in International Economic Relations. Economica, [s.1.], n. 35, 1932, p. 94-95.
} 
capazes de estabilizar as estruturas em desagregação. A Grande Depressão destruiu os padrões de comportamento econômico. $\mathrm{O}$ discurso protecionista baniu o comprometimento com a governança econômica internacional. O nazifascismo rejeitou a integração global e o mercado em favor da autarquia, do Estado Intervencionista e da repressão aos trabalhadores. O liberalismo cedia lugar à social-democracia. Ante o insucesso de superar os desafios do capitalismo, do liberalismo e da LdN, eclodiu a Segunda Guerra Mundial, tragando todos os países para uma espiral de violência e destruição sem precedentes na história.

O término da Segunda Guerra Mundial possibilitou o aparecimento de uma dimensão verdadeiramente universal no relacionamento entre os povos e os Estados. Os vencedores assumem sempre o privilégio de impor os elementos estruturais da nova ordem internacional. A Aliança, fundamental para os tempos de guerra, perderia gradualmente suas virtualidades durante a reconstrução das relações internacionais. O comprometimento com a paz seria um desafio, visto que o espírito pessimista da reunião de Yalta cederia à desconfiança sobre as possibilidades de Estados Unidos e URSS cooperarem em prol da governança internacional.

Nesse sentido, mal terminada a guerra, a humanidade era arrastada a encarar os lampejos de uma peculiar Terceira Guerra Mundial. Isso porque, como observou Thomas Hobbes, "a guerra não consiste apenas na batalha, ou no ato de lutar, mas naquele lapso de tempo durante o qual a vontade de travar batalha é suficientemente conhecida". A Guerra Fria entre as superpotências, que dominou o cenário internacional na segunda metade do breve século XX, foi sem dúvida um desses períodos. ${ }^{87}$

De todo modo, o espírito dos Aliados, ainda em 1945, esboçava o ânimo de construir a paz, por meio da cooperação internacional. Surge, assim, na reunião de São Francisco, a Organização das Nações Unidas (“ONU”), criada, justamente, como uma coalizão de esforços de constitucionalização da ordem internacional. A Carta da ONU, como expressão positivada desse fenômeno, contribuiu para alterar definitivamente o direito internacional público de coexistência, mediante o estabelecimento de princípios e limites lógico-racionais aceitáveis acerca da conduta dos Estados.

\footnotetext{
${ }^{87}$ FRIEDEN, 2008, p. 158-164. HOBSBAWM, 2007, p. 101-103. SARAIVA, José Flávio S. A agonia européia e a gestação da nova ordem internacional (1939-1947). In: SARAIVA, José Flávio S. (org.). Relações internacionais: Entre a preponderância européia e a emergência americano-soviética (1815-1947). V. 1, Brasília: IBRI, 2001, p. 250. HOBBES, Thomas. Leviatã ou Matéria, Forma e Poder de um Estado Eclesiástico e Civil. Os Pensadores: Thomas Hobbes. Trad. João Paulo Monteiro e Maria Beatriz N. da Silva. São Paulo: Nova Cultural, 2000, p. 109.
} 
O projeto da nova ordem econômica internacional inscreve-se, justamente, contra os discursos protecionistas e o radicalismo nacionalista do período entreguerras, fortemente marcado pela proliferação de técnicas autárquicas de discriminação comercial, que contribuíram, largamente, para a eclosão da Segunda Guerra Mundial. Valendo-se da experiência histórica desastrosa das Guerras Mundiais, como também dos trabalhos desenvolvidos pela Liga das Nações, os arquitetos da Carta das Nações Unidas estabeleceram numerosas previsões acerca das relações econômicas internacionais. Os $\operatorname{artigos} 1^{\mathbf{o}}$ a $3^{\circ}$ consagram a cooperação econômica como uma das finalidades da organização, razão pela qual se instituiu o Conselho Econômico e Social, bem como dispõem acerca dos princípios que a fundamentam: a boa vizinhança e a liberdade de comércio.

Figurados na Carta da ONU, os princípios da descentralização e especialização tornariam possível compatibilizar os diversos modelos jurídicos de cooperação econômica, os quais viriam a ser constituídos em respostas às necessidades e interesses dos membros da comunidade internacional. É importante notar que, graças a essas formas de governança econômica internacional, houve a consolidação de um direito internacional da cooperação, permitindo a passagem de normas predominantemente negativas de abstenção para normas positivas de mútua colaboração. A verdadeira natureza desse processo só é compreendida por uma análise da nova realidade em que o direito se encontrava. Percebe-se, a partir desse momento, o aparecimento dos imperativos positivos no direito internacional. ${ }^{88}$

A Carta das Nações Unidas simboliza o distanciamento da relação clássica entre ordem e poder, fruto da melhor distribuição individual entre os Estados da facldade de negação, bem como aponta na direção de uma ordem mundial que, para ser efetiva, precisa se apoiar mais na convergência dos interesses e menos no arbítrio da coerção. A sociedade internacional abandona a tentativa de estabilizar o comportamento dos Estados por meras expectativas cognitivas, optando por assegurar a durabilidade das relações internacionais preponderantemente pelas expectativas normativas. Com isso, desenvolve-se o direito internacional de cooperação, cuja função consiste em aprofundar e estender os laços entre os Estados, na medida em que, para adotar normas de mútua colaboração, exige-se o consenso.

\footnotetext{
${ }^{88}$ LAFER, 1977, p. 9. CARREAU, Dominique; JUILlARD, Patrick. Droit international économique. $4^{\mathrm{a}}$ ed. Paris: Librairie générale de droit et de jurisprudence, 1998, p. 41-42. NGUYEN; DAILLIER; PELLET, 1999, p. 947.
} 
Essa concepção democrática compreende que o vínculo formado pelos pactos sociais não pode ser imposto de fora, mas deve ser criado e constituído internamente, a fim de conferir ao acordo uma dimensão efetiva de aceitação. Todavia, a sociedade internacional, marcada pela diferenciação de suas partes, encontrava-se em um momento de confrontação industrial e ideológica, em que os temas da ordem econômica internacional ligavam-se imperfeitamente, exigindo respostas específicas e exclusivas para a institucionalização das expectativas normativas de certo padrão de relações internacionais. ${ }^{89}$

A cooperação internacional não conseguiria resistir ao fim da Segunda Guerra, pois o medo e a raiva do comunismo pelos países ocidentais e a recíproca desconfiança da União Soviética resultaram no rápido retorno às hostilidades, dedicadas à total destruição do modo de vida de seus opositores. Sob o embate ideológico, a Guerra Fria teve o condão de fomentar dois movimentos retroalimentáveis: a corrida armamentista e a fragmentação da ordem econômica internacional.

A devastação resultante das Guerras Mundiais foi responsável por desagregar os carcomidos pilares constitutivos da ordem econômica internacional liberal. Contudo, superada a tempestade, não sobreveio um período de bonança. Isso porque, encerradas as transformações, não houve elementos prevalecentes em cada subordem, o que impediu o processo de dominação e uniformização estrutural. Tal fator conduziu à formação de ordens econômicas parciais, cujas dimensões axiológica, institucional e comportamental nutrem coesão interna, mas incompatibilidade e conflitos externos, implicando tendências de diferenciação funcional, repulsa e exclusão.

Nesse contexto, Estados Unidos e União Soviética tentaram fracionar a economia internacional em dois grandes blocos de cooperação, cada qual com suas respectivas normas, valores e modos de produção. Em linhas gerais, as duas propostas de governança econômica internacional tinham por objetivo institucionalizar uma divisão internacional do trabalho adequada a seus interesses e às características de seus modelos de produção econômica, os quais seriam disciplinados por um conjunto coerente de normas, orientadas em função das ideologias dominantes. Sob a ótica neoliberal, a divisão é o produto do livre-jogo de forças do

\footnotetext{
${ }^{89}$ LAFER, 1977, p. 27-31. FERRAZ JR., 2001, p. 103.
} 
mercado. Dentro do ideal socialista, ela resulta da vontade dos Estados, de acordo com uma planificação coordenada de suas trocas econômicas. ${ }^{90}$

a) Ordem parcial de cooperação capitalista-neoliberal

Diferentemente do período entreguerras, quando o internacionalismo estadunidense de Woodrow Wilson era pouco popular, a liderança dos Estados Unidos foi aceita, ainda que relutante, pelos países capitalistas aliados. O Reino Unido, após a celebração do Acordo sobre Empréstimo e Arrendamento (Lend-Lease) e da Carta do Atlântico em 1941, juntou-se aos EUA na construção da ordem econômica internacional que deveria vigorar com o término da Segunda Guerra. Todavia, a ascensão da União Soviética viria a impedir a consolidação de uma ordem global de vocação capitalista-neoliberal, obrigando as relações econômicas internacionais a escolher entre modelos de governança econômica internacional.

A ordem parcial de cooperação econômica, constituída em torno da hegemonia econômico-militar dos Estados Unidos e do apoio inglês, era estruturada sobre a ideologia neoliberal, a livre-expansão dos fluxos econômicos e comerciais e a construção de organizações internacionais para assegurar a realização dos objetivos propostos. Nesse contexto, a social-democracia e a ideia de bem-estar social modificaram a noção de Estado, exigindo intervenção estatal nas relações civis, bem como a própria concepção de direito internacional.

Ante a devastação do continente europeu e asiático, os EUA compreenderam que o exercício da hegemonia não poderia fundar-se no mero uso da força, sob pena de reincidir nos equívocos do pós-Primeira Guerra. Isso requereu não apenas o convencimento dos países aliados acerca das virtualidades intrínsecas do novo modelo de governança econômica internacional, mas também o consenso necessário para conferir legitimidade às instituições multilaterais e eficácia às respectivas decisões.

\footnotetext{
${ }^{90}$ WIGHT, Martin. A Política do Poder. Trad. Carlos Sérgio Duarte. Brasília: Universidade de Brasília, São Paulo: Imprensa Oficial do Estado de São Paulo, 2002, p. 225-227. CARREAU; JUILLARD, 1998, p. 40-41.
} 
A segurança militar e previsibilidade das expectativas econômicas dos aliados foram asseguradas graças ao compromisso dos Estados Unidos de protegê-los dos riscos decorrentes da Guerra Fria. Aliviados da preocupação com a elevação dos gastos militares para fazer frente à ameaça soviética, os países capitalistas europeus e asiáticos focaram na reconstrução econômica, cujo principal desafio era a superação das debilidades da economia internacional sem recorrer ao unilateralismo autárquico e a medidas protecionistas e discriminatórias, típicas dos pregressos trinta anos de crise. A ordem capitalista-neoliberal começou, então, a ser erguida sobre os pilares monetário, financeiro e comercial. ${ }^{91}$

As negociações sobre o capital e as finanças internacionais correram paralelas às negociações comerciais. Isso porque, enquanto as políticas comerciais suscitavam grandes controvérsias e tensões entre os Estados, todos tenderiam a ganhar com a recuperação de um sistema monetário e financeiro internacional. A partir de 1940, John Maynard Keynes e Harry Dexter White, respectivos representantes dos tesouros estadunidense e inglês, formularam propostas para as relações monetárias internacionais e os investimentos globais do pósguerras, as quais visavam recuperar as virtudes do Acordo Monetário Tripartite. Em 1944, eles obtiveram êxito em preparar uma proposta que conciliava a estabilidade internacional de um padrão ouro-dólar com a flexibilidade doméstica para intervenções cambiais, bem como resolvia-se o entrave dos investimentos internacionais em grandes empreendimentos, necessários para a reconstrução europeia e asiática.

A Conferência Monetária e Financeira de Bretton Woods, realizada no início de julho de 1944, reuniu, sob a liderança de J. M. Keynes e H. D. White, as delegações aliadas, com o objetivo de delinear a ordem financeira e monetária do pós-guerra. Foram criados o Fundo Monetário Internacional ("FMI") e o Banco Internacional para a Reconstrução e o Desenvolvimento ("BIRD”), posteriormente conhecido como Banco Mundial, duas das três chaves-mestras da ordem econômica que vigoraria a partir de 1945. Além disso, foi aprovada uma recomendação em que vinha salientada a necessidade de constituir uma terceira instituição que viesse a disciplinar as questões concernentes ao comércio internacional.

O sistema monetário internacional criado em Bretton Woods era único, pois nunca existira uma organização como o FMI, à qual os Estados concordariam em subordinar suas decisões econômicas, a fim de evitar que os déficits externos se convertessem em crises

\footnotetext{
${ }^{91}$ FRIEDEN, 2008, p. 275-278. AMARAL JR., 2008, p. 35-36.
} 
econômicas. O FMI pretendia estimular a cooperação internacional e a estabilidade do câmbio, por meio de um sistema multilateral de pagamentos destinado a reduzir a intensidade e a duração dos desequilíbrios das contas externas dos Estados-partes. Tampouco houve uma instituição como o BIRD, que contava com amplos recursos para serem emprestados a governos ao redor do mundo, tendo por finalidade financiar projetos de médio e longo prazo.

O programa de Bretton Woods revelou-se, porém, ineficiente, quase inoperante, em razão dos urgentes desafios de reconstruir as economias dos países assolados pela guerra. Em 1947, o iminente colapso econômico, associado à crescente ameaça socialista, impeliu os Estados Unidos a lançarem-se em um esforço global contra os soviéticos na forma do Plano de Recuperação Econômica ("Plano Marshall”). Legitimado pelo discurso neoliberal, o objetivo do Plano Marshall era reconstruir as economias capitalistas dos aliados, bem como solidificar a posição dos EUA como regente da governança econômica internacional e defensor do mundo ocidental na Guerra Fria. ${ }^{92}$

Concomitantemente, o terceiro pilar estrutural da ordem capitalista-neoliberal começou a ser concebido em 1944 por negociadores ingleses e estadunidenses. As propostas iniciais tinham em vista a criação de uma organização internacional capaz de institucionalizar valores e regras caros à ideologia neoliberal e aos interesses capitalistas. Influenciados pelo discurso do pacifismo liberal, defensor da obtenção da paz pelo comércio, de modo a impedir o recurso à força para a solução de controvérsias internacionais, os Estados Unidos e o Reino Unido apresentaram aos países aliados a Carta Proposta para o Estabelecimento da Organização Internacional do Comércio ("Carta Proposta"). O objetivo da Carta Proposta era restabelecer as regras do jogo de mercado às relações econômicas internacionais; porém, diferentemente do período do laissez faire laissez passer, desacreditado devido aos abalos sofridos pelas Guerras Mundiais, propunha-se uma governança comercial de caráter institucional, mediante a criação de uma organização internacional sobre comércio e a adoção de normas de conduta comercial.

Fundamentada na recomendação de Bretton Woods, os Estados Unidos propuseram, no seio das Nações Unidas, a convocação de uma conferência para tratar sobre a criação de uma organização internacional sobre comércio. Em 1946, a proposta foi aceita, cabendo ao Conselho Econômico e Social da ONU emanar a convocação para a United Nations Conference on Trade and Employment. Realizada em Havana em 1947, a Conferência teve o

\footnotetext{
${ }^{92}$ FRIEDEN, 2008, p. 278-292.
} 
propósito de completar o quadro institucional-regulatório de Bretton Woods. A Carta de Havana estabelecia a Organização Internacional do Comércio e previa um código de bom comportamento para o comércio internacional. A OIC não teria somente a função de policiar e observar o cumprimento dos direitos e obrigações contidos na Carta, mas, também, a competência para decidir sobre a norma a ser aplicada em casos concretos. O código de bom comportamento comercial prescrevia regras e princípios, cuja disposição formava um sistema orgânico de normas jurídicas, as quais imputavam comandos e proibições aos Estados-partes. Nesse particular, a cláusula da nação mais favorecida foi inserida na minuta da Carta da OIC em uma posição de destaque, pois seria a ela atribuída a função de ordenação das relações econômicas internacionais. ${ }^{93}$

Todavia, devido a fatores domésticos e internacionais, os Estados Unidos decidiram retirar, em 1950, seu apoio à Carta de Havana. Apesar do fracasso do projeto estadunidense, um subproduto das negociações acabou por assumir parte dos objetivos que caberiam à Organização Internacional do Comércio. Durante a Conferência de Genebra, foi assinado um acordo tarifário interino, em 30 de outubro de 1947, denominado Acordo Geral sobre Tarifas e Comércio (“GATT”). Sua concepção deriva diretamente da ideia da Carta de Havana, pois foi elaborado como a primeira de uma série de negociações tarifárias que seriam conduzidas sob o auspício daquela nova instituição. Em razão disso, o escopo do GATT era mais restrito do que o que havia sido proposto para a OIC, bastando perceber que diversos capítulos relevantes não foram previstos.

Em que pese sua natureza jurídica contratual, o Acordo Geral sobre Tarifas e Comércio serviria a seus Estados-partes, por mais de 45 anos, como estrutura institucional da governança econômica internacional neoliberal. O texto do GATT restringia materialmente sua atuação ao comércio de bens, bem como dispunha sobre suas funções, as quais eram essencialmente organizar as negociações multilaterais de comércio, produzir normas jurídicas e administrar um mecanismo de solução de controvérsias. ${ }^{94}$

Em suma, a ordem parcial capitalista-neoliberal foi estruturada sobre os pilares monetário, financeiro e comercial, na forma de organizações e tratados internacionais, que visavam institucionalizar as expectativas cognitivas e normativas dos agentes econômicos

\footnotetext{
${ }^{93}$ DAL RI JR., 2003, p. 113. CARREAU; JUILLIARD, 1998, p. 42.

${ }^{94}$ LAFER, 1971, p. 42.
} 
internacionais. Sob orientação da ideologia neoliberal, criaram-se o Fundo Monetário Internacional, o Banco Mundial e o Acordo Geral sobre Tarifas e Comércio para disciplinar as relações econômicas internacionais, conforme as necessidades da economia capitalista de livre-mercado e do Estado de bem-estar social. Na posição de regência, os Estados Unidos garantiam a governança econômica internacional, utilizando-a para fortalecer-se em face dos desafios da Guerra Fria.

\section{b) Ordem parcial de cooperação socialista}

Os pontos de partida e de chegada da reconstrução da Europa oriental e ocidental diferiram profundamente, visto que a devastação foi infinitamente maior nas regiões central e oriental do continente, onde ocorreram as batalhas mais destrutivas da Segunda Guerra. O lado oriental da Cortina de Ferro deparava-se com imensos custos para a reconstrução de suas economias. Além disso, os países orientais eram organizados economicamente em torno do Estado, responsável por controlar autarquicamente os fatores de produção. Em face dessas condições, a União das Repúblicas Socialistas Soviéticas incentivaram a formação de Estados Sociais, os quais, por meio do direito econômico e do planejamento estatal, nacionalizaram e estatizaram as empresas privadas; também planificaram a economia, de modo a favorecer o desenvolvimento de indústria pesada, bem como controlar o comércio internacional.

Sob a disciplina socialista-soviética, a União Soviética e os países socialistas recuperaram-se rapidamente dos danos causados pela guerra. Isso simbolizou a consolidação de um modelo social alternativo, estruturado sobre uma economia centralmente planificada, organizada por um Estado Social e orientada pela ideologia socialista. No plano internacional, a governança econômica exercida pela URSS ofereceu rápido crescimento econômico, igualdade e melhorias sociais. ${ }^{95}$

Em janeiro de 1949, a União Soviética e seus aliados criaram, por meio de um comunicado, o Conselho de Assistência Econômica Mútua ("Comecon"), que consistia em uma organização internacional, cujo objetivo primordial era promover o desenvolvimento

\footnotetext{
${ }^{95}$ FRIEDEN, 2008, p. 294-298.
} 
econômico dos Estados-partes. A história da organização pode ser dividida em três fases. Na primeira, o Comecon surge como um movimento político ad hoc em resposta ao Plano Marshall. Iniciada em 1962, a segunda fase atribui à instituição traços supranacionais. Na terceira, o redesenho organizacional de 1971 confere características de mecanismo de integração econômica, por meio de planos de coordenação planificada e abertura ao mercado.

O comunicado de 1949 estabeleceu os princípios e objetivos da organização. Caberia ao Comecon a função de administrar o comércio interestatal, por meio de metas quantitativas preestabelecidas, e fomentar o intercâmbio de experiências técnicas e econômicas, de modo a fortalecer a união e a solidariedade do mundo socialista. O comunicado serviu, ainda, para condenar os Estados Unidos e aliados pela tentativa de boicotar os países socialistas nas relações econômicas internacionais, visto que estes não estavam dispostos a subordinar as respectivas soberanias ao ditatorial Plano Marshall.

Curiosamente, apenas em 14 de dezembro de 1959, os Estados-partes decidiram aprofundar a institucionalização da organização, por meio da celebração da Carta do Conselho de Assistência Econômica Mútua. De acordo com a Carta, o Comecon tinha por finalidade promover o desenvolvimento econômico, orientado pela divisão internacional socialista do trabalho, e melhorar as condições de vida da população. Na dimensão política, deveria fortalecer a unidade e a solidariedade dos Estados-partes e desenvolver a cooperação no interesse da construção do socialismo e comunismo. Todavia, o Comecon teve dificuldades em cumprir seus objetivos econômicos, visto que as medidas autárquicas limitavam consideravelmente qualquer assistência mútua.

Em 1962, os Estados-partes adotaram os Princípios Básicos da Divisão Internacional Socialista do Trabalho e fortaleceram a estrutura da organização, na tentativa de promover a coordenação multilateral do comércio no bloco socialista. Com isso, o Comecon passou a estabelecer as formas de coordenação dos planos econômicos nacionais, bem como a organizar as relações comerciais entre os Estados; porém, não tinha competência para dispor sobre as relações monetárias ou financeiras.

O Programa Global para Aprofundamento e Aperfeiçoamento da Cooperação e Desenvolvimento da Integração Econômica Socialista dos Países Membros do Comecon de 1971 foi acordado com a finalidade de conciliar dois modelos de integração: o modelo de mercado e o modelo de coordenação planificada. No entanto, a síntese não prosperou, na 
medida em que não foi possível conferir flexibilidade necessária à livre-circulação de mercadorias, aos planejadores domésticos e às empresas estatais. ${ }^{96}$

Sob orientação da ideologia socialista, a ordem parcial de cooperação foi centralizada na figura do Estado Social, cuja função era planejar a economia centralmente planificada. Em razão disso, cabia ao Comecon a simbólica tarefa de coordenar as relações econômicas, bem como de fomentar o auxílio técnico e econômico entre os Estados-partes. Na posição de liderança, a União das Repúblicas Socialistas Soviéticas exercia a governança econômica, empregando-a como instrumento para expandir sua influência sobre os países socialistas, alinhando-os contra os rivais da Guerra Fria.

\section{c) Ordem parcial de cooperação desenvolvimentista}

Enquanto as potências guerreavam pelo predomínio do heartland mackinderiana, os países subdesenvolvidos da América Latina, Ásia e África iniciavam um árduo processo de emancipação político-econômica, visto não haver um modelo socioeconômico pronto a ser copiado, ou caminho fácil a ser seguido. Iniciado após a Segunda Guerra, esse esforço de superação e reivindicação dos países subdesenvolvidos durou algumas décadas, podendo ser dividido em duas fases. A primeira foi marcada pelo processo de descolonização e independência político-econômica, enquanto a segunda foi caracterizada pela organização de grupos de pressão, cujo objetivo era atuar conjuntamente no âmbito das relações internacionais.

Tão logo as colônias conquistaram a liberdade e os países latino-americanos emergiram do isolamento imposto pela depressão econômica e pela Segunda Guerra, passaram a implementar uma nova estratégia de desenvolvimento socioeconômico. $\mathrm{O}$ modelo era fundado sobre o nacionalismo econômico, medidas protecionistas ao comércio internacional e intervenção autárquica para acelerar a industrialização. Dentro de uma década após a Segunda

\footnotetext{
${ }^{96}$ SZAWLOWSKI, Richard. The system of the international organizations of the communist countries. Leiden: Sijthoff, 1976, p. 46-73. LAVIGNE, Marie. International political economy and socialism. Trad. David Lambert. Nova York: Cambridge University, 1991, p. 54-57.
} 
Guerra, um Terceiro Mundo de países subdesenvolvidos e não alinhados impunha mais um fracionamento à ordem econômica internacional.

Após 1945, a América Latina serviu de guia para grande parte dos países subdesenvolvidos. O colapso da economia mundial teve por efeito desarticular o modo de produção agroexportador dominante, conduzindo a região, antes um bastião do livre-comércio, em direção ao nacionalismo econômico, desenvolvimentismo e populismo. Superadas as medidas meramente emergenciais ao estancamento da desintegração dos mercados mundiais, os países engajaram-se em um esforço para executar a política econômica conhecida como industrialização por substituição de importações (“ISI”), a qual visava à produção doméstica de bens antes importados. Os instrumentos da ISI seriam a imposição de altas barreiras comerciais, concessão de incentivos e subsídios para a indústria, constituição de empresas públicas e monopólios estatais.

As práticas nacionalistas foram legitimadas pelo discurso nacional-desenvolvimentista elaborado pela Comissão Econômica para a América Latina e Caribe ("Cepal”). A Cepal contestava o liberalismo clássico, advogando que subsidiar e proteger a indústria nascente seriam formas eficientes e legítimas de promover o desenvolvimento econômico. Isso porque os efeitos positivos da industrialização não se limitavam à economia, conferindo benefícios diretos à sociedade. Liderados por Raúl Prebisch, os cepalistas acreditavam que o preço das matérias-primas e dos produtos agrícolas, produzidos predominantemente pelos países subdesenvolvidos, tendia a deteriorar-se com o tempo, enquanto o valor dos bens industrializados tendia a subir. ${ }^{97}$

As políticas cepalistas rapidamente difundiram-se entre os países subdesenvolvidos, resultando em um acelerado crescimento econômico. A ideologia desenvolvimentista acreditava na importância do Estado como agente organizador da economia e promotor do desenvolvimento. Valendo-se do direito econômico, caberia ao Estado Desenvolvimentista estruturar, direta ou indiretamente, a cooperação entre governo e setor privado. Nas relações econômicas internacionais seria preciso inserir o tema do desenvolvimento no discurso jurídico internacional. Exceto por raros tratados bilaterais, normas positivas de cooperação

\footnotetext{
${ }^{97}$ FRIEDEN, 2008, p. 324-335. NASSER, Rabih Ali. A OMC e os países em desenvolvimento. São Paulo: Aduaneiras, 2002, p. 235-236.
} 
eram estranhas ao direito internacional vigente, cuja preocupação enfocada era predominantemente as relações de coexistência.

A expressão internacional dessas transformações consolidou-se com a Conferência de Bandung de 1955, na qual dezenas de países subdesenvolvidos uniram-se para demonstrar seu interesse comum de traçar um caminho intermediário entre a proposta capitalista-liberal do Primeiro Mundo e o programa socialista-planificador do Segundo Mundo. Os princípios da Declaração de Bandung simbolizaram, historicamente, o início da reivindicação do Terceiro Mundo por uma nova ordem econômica internacional.

Graças ao amplo reconhecimento internacional, o discurso cepalista-terceiro-mundista obteve condições para exigir alterações nas estruturas axiológica e institucional-legal da ordem internacional. Isso legitimou o pleito dos países subdesenvolvidos perante a ONU para convocar a primeira Conferência das Nações Unidas para o Comércio e Desenvolvimento (“Unctad") de 1964. O sucesso da Unctad viria a permitir sua institucionalização permanente, passando a constituir um fórum propagador do discurso desenvolvimentista. Sua principal bandeira consistia na defesa da divisão internacional do trabalho e do intervencionismo estatal na organização da economia internacional, como instrumentos de governança imprescindíveis e indissociáveis para a diminuição da distância do pleno desenvolvimento.

No Ato Final da Unctad I, os países subdesenvolvidos decidiram criar um exclusivo grupo político, denominado Grupo dos 77, cuja principal função é coordenar seus interesses coletivos nas negociações com os países desenvolvidos, bem como aumentar a cooperação nas relações recíprocas. Em 1967, o Grupo dos 77 adotou a Carta de Argel, na qual manifestava suas propostas na forma de um programa para o desenvolvimento. ${ }^{98}$

O movimento terceiro-mundista obteve diversas vitórias no âmbito da ONU, difundindo o discurso do desenvolvimento econômico. No decurso da sexta sessão extraordinária, a Assembleia Geral das Nações Unidas adotou, na forma das Resoluções $n^{\circ}$ 3.201 e 3.202, uma declaração e um programa de ação relativos à instauração de um nova ordem econômica internacional. Em seguida, a ONU aprovou a Carta de Direitos e Deveres Econômicos dos Estados e a Carta sobre Desenvolvimento e Cooperação Econômica Internacional, as quais apontam para a necessidade de substituir a ordem econômica

\footnotetext{
${ }^{98}$ LAFER, 1998, p. 20-21. MOREIRA, 2002, P. 436. LUZ, Rodrigo. Relações econômicas internacionais: teoria e questões. $2^{\mathrm{a}}$ ed. Rio de Janeiro: Elsevier, 2008, p. 356.
} 
internacional preexistente, por meio de um programa de ação que, se desenvolvido, implicaria uma intervenção da comunidade internacional no sentido de propiciar aos países subdesenvolvidos a conquista da independência econômica. ${ }^{99}$

Com efeito, reconhece-se a existência de uma velha ordem e a necessidade de construção de uma nova ordem normativamente regulada, a qual rejeitaria a coação econômica dos países desenvolvidos e implementaria instrumentos solidários de redução da desigualdade entre os Estados. O programa desenvolvimentista fundava, assim, a nova ordem econômica internacional sobre os princípios da equidade, da igualdade soberana, da cooperação e da interdependência econômica e social, da vinculação entre liberalização comercial e tratamento preferencial e não recíproco para os países subdesenvolvidos, cuja finalidade seria corrigir as desigualdades e retificar as injustiças, permitindo a eliminação do fosso crescente entre os países desenvolvidos e subdesenvolvidos. ${ }^{100}$

Na década de 1970, o movimento terceiro-mundista atinge seu ápice; porém, a lógica da confrontação passa a encontrar resistência dos países desenvolvidos em aceitar as resoluções e os projetos adotados no âmbito da ONU. Olivier Long, Diretor-Geral do GATT, reconhece que todas as áreas da atividade internacional foram afetadas pelo discurso desenvolvimentista, em especial as normas do sistema GATT. Os debates entre desenvolvimentistas e neoliberais exigiram a criação, em 1958, de uma comissão para examinar as razões que impediam um maior equilíbrio nas relações econômicas internacionais. O resultado foi o Haberler Report - Trends in International Trade, o qual demonstrou que as normas do comércio internacional implicavam um desequilíbrio desfavorável aos países subdesenvolvidos. Em 1964, Raúl Prebisch examinou os efeitos da cláusula da nação mais favorecida sobre as relações econômicas internacionais, concluindo que o instituto servia apenas para regular o comércio entre países de desenvolvimento equivalente.

\footnotetext{
${ }^{99}$ ONU. General Assembly. Resolution n. 3.201 (S-VI), 1 may 1974. Declaration on the Establishment of a New International Economic Order. Disponível em: <http://daccessdds.un.org/doc/RESOLUTION/GEN/NR0/071/94/IMG/NR007194.pdf?OpenElement>. Acesso em 1 out. 2009. ONU. General Assembly. Resolution n. 3.202 (S-VI), 1 may 1974. Programme of Action on the Establishment of a New International Economic Order. Disponível em: <http://daccessdds.un.org/doc/RESOLUTION/GEN/NR0/071/94/IMG/NR007194.pdf?OpenElement>. Acesso em 1 out. 2009. ONU. General Assembly. Resolution n. 3.281 (XXIX), 12 dez. 1974. Charter of Economic Rights and Duties of States. Disponível em: <http://daccessdds.un.org/doc/RESOLUTION/GEN/NR0/738/83/IMG/NR073883.pdf?OpenElement>. Acesso em 1 out. 2009.

${ }^{100}$ NGUYEN; DAILLIER; PELLET, 1999, p. 907-909.
} 
Em razão disso, os Estados-partes do Acordo Geral sobre Tarifas e Comércio decidiram adotar, em 26 de novembro de 1964, a Parte IV, intitulada de "Comércio e Desenvolvimento", a qual representa a principal vitória dos países subdesenvolvidos no que se refere ao comércio internacional. A Parte IV introduz a noção de tratamento especial e diferenciado no sistema GATT, com a finalidade de promover o comércio dos países subdesenvolvidos, por meio de instrumentos jurídicos que ampliem o acesso de seus produtos aos mercados desenvolvidos e reduzam as tarifas de importação, em bases não recíprocas. ${ }^{101}$

A ordem parcial de cooperação desenvolvimentista guardava características estruturais particulares que a distinguia das demais. $\mathrm{O}$ discurso terceiro-mundista surge como terceira via frente às ideologias neoliberal e socialista. Buscava-se construir, por meio de reformas institucionais e axiológicas, uma nova ordem econômica internacional centrada na ideia de desenvolvimento econômico e independência política. A noção de Estado modificou-se em função das demandas por intervenção direta nas relações econômicas, a fim de coordená-las em prol da superação das desigualdades. No plano internacional, a Unctad é criada para ser fórum, a partir do qual os países subdesenvolvidos puderam reivindicar a superação do subdesenvolvimento, por meio de instrumentos jurídicos de cooperação capazes de assegurar o tratamento especial e diferenciado. Por não haver país hegemônico, a governança econômica internacional dependia do constante concerto entre os países subdesenvolvidos.

\section{d) A desarticulação das ordens parciais de cooperação econômica}

O início da década de 1970 foi o principal divisor de águas para a ordem econômica internacional fragmentada. Quase todos os países capitalistas-neoliberais, socialistasplanificadores e terceiro-mundistas-desenvolvimentistas cresceram rápida e continuamente, propagando um sentimento de prosperidade que parecia reinar na economia mundial.

A ordem parcial capitalista foi a primeira a sofrer com instabilidades econômicas. $\mathrm{O}$ sistema monetário internacional, apesar do início letárgico, operava nos moldes previstos por

\footnotetext{
${ }^{101}$ LONG, Olivier. Law and its limitations in the GATT multilateral trade system. Londres: Graham \& Trotman, Boston: M. Nijhoff: Kluwer Academic Publishers, 1987, p. 91-109. NASSER, 2002, p. 246-251. NGUYEN; DAILLIER; PELLET, 1999, p. 907-923.
} 
seus fundadores. Nas décadas de 1950 e 1960, o FMI assegurou o funcionamento dos mecanismos de conversibilidade monetária e de paridade fixa entre o ouro e dólar. O compromisso de Bretton Woods estimulou o comércio, os investimentos e as finanças internacionais. O crescente fortalecimento da interdependência econômica entre os países capitalistas fomentou a ideia de que a economia mundial restringia as políticas nacionais, responsáveis por limitar o desenvolvimento dos mercados globais.

Todavia, o maior desafio veio da frente monetária e foi imposto ao padrão ouro-dólar, considerado o núcleo da ordem parcial capitalista no pós-Segunda Guerra. O regime monetário começou a exibir sinais de fragilidade devido ao agravamento da crise econômica estadunidense. A elevação dos déficits públicos para fazer frente às exigências da Guerra Fria, associada à expansão inflacionária, repercutiu internacionalmente, elevando os preços dos produtos e causando um profundo desequilíbrio da taxa de câmbio. A desconfiança acentuou a pressão dos demais países desenvolvidos para converter suas reservas de dólar em ouro. A desintegração das expectativas forçou os Estados Unidos a optar entre os compromissos internacionais e os objetivos domésticos.

Em 15 de agosto de 1971, os Estados Unidos decidiram suspender a conversibilidade do dólar em ouro e impôs uma sobretaxa de 10\% sobre as importações, com vistas a obrigar os europeus e japoneses a reapreciar o valor das respectivas moedas em relação ao dólar. Em complemento, adotou o controle de preços e salários para conter o risco de aceleração da inflação, bem como desvalorizou o dólar em 10\%. As medidas unilaterais estadunidenses destruíram o pilar central do sistema monetário internacional, tendo danosos efeitos sobre a economia global. Em 1973, os Estados-partes decidiram ratificar a decisão dos Estados Unidos, ao permitir a livre-flutuação da taxa de câmbio. No âmbito jurídico, o sistema Bretton Woods somente viria a incorporar as mudanças na reunião do FMI em Kingston em 1973, quando os Estados-partes, sensíveis à crise do petróleo, decretaram o fim da disciplina financeira internacional em prol das prioridades domésticas.

As meteóricas ascensão e decadência são perspicazmente explicadas por Jeffry Frieden: "o sistema foi arruinado por dois aspectos, ambos resultados do sucesso de Bretton Woods". O sistema monetário internacional entrou em colapso devido a escolhas políticas e não por decisões técnico-econômicas. A paridade ouro-dólar era politicamente atraente por estabilizar moedas e estimular o comércio e os investimentos, livres das restrições domésticas. 
Contudo, a integração econômica, por demandar adaptações ao padrão ouro-dólar, exigia que os governos moldassem suas políticas internas para acomodar a taxa de câmbio, o que sacrificaria os objetivos nacionais. Isso era algo inesperado para o governo estadunidense, desacostumado a subordinar questões internas aos mercados globais, razão pela qual se decidiu pelo fim do sistema Bretton Woods. ${ }^{102}$

Enquanto o Primeiro Mundo reconsiderava seus planos para a economia global, os países subdesenvolvidos questionavam o desenvolvimento via intervencionismo estatal. As políticas de industrialização por substituição de importações apresentavam sucessos, mas também consequências indesejadas. A ISI causou problemas crônicos nas balanças comercial e de pagamentos, dada a necessidade de importação de mercadorias de que não dispunham internamente. Os países tendiam a grandes déficits orçamentários e à inflação, o que ameaçava constantemente suas políticas sociais e econômicas. Na década de 1960, tal dinâmica era responsável pela formação de círculos viciosos de déficits no orçamento e na balança comercial e de pagamentos, bem como de inflação e de recessão. A insatisfação econômica e o nacionalismo político criaram uma mistura volátil que culminou no agravamento das tensões sociais, as quais, em certos casos, foram controladas por regimes autoritário-militares.

Depois da expansão do discurso desenvolvimentista na década 1970, o movimento de reivindicação por uma nova ordem econômica internacional perde força, na medida em que os países desenvolvidos impedem a produção concreta de resultados substanciais. Paralelamente, há uma gradual guinada em direção à estratégia mais pragmática de subordinação das relações econômicas internacionais, o que leva ao esvaziamento da Unctad. Assiste-se, assim, à adoção de políticas de liberalização comercial e à diluição do ímpeto de confrontação que caracterizaram a atuação dos países não alinhados nas últimas décadas. ${ }^{103}$

O mundo socialista também estava mergulhando em dificuldades, visto que a planificação econômica não conseguia obter o mesmo sucesso de outrora. As reformas econômicas em prol da descentralização e liberação comercial eram lentas e sofriam constantes interrupções, em razão do compromisso ideológico dos governos com a equidade socioeconômica. Os problemas econômicos dos países socialistas guardavam grande semelhança com os desafios enfrentados pelos países subdesenvolvidos. As economias

\footnotetext{
${ }^{102}$ FRIEDEN, 2008, p. 361-368. AMARAL JR., 2008, p. 45-46.

${ }^{103}$ FRIEDEN, 2008, p. 373-378. NASSER, 2002, p. 244-245.
} 
centralmente planificadas ofereciam poucos incentivos para o desenvolvimento tecnológico, visto que o sistema socialista beneficiava a estabilidade e a segurança em detrimento dos riscos. Daí as diferenças em termos tecnológicos entre os países do Comecon e do GATT terem crescido continuamente após 1960.

Apesar do aumento do investimento em ciência e tecnologia, os países socialistas passaram a comprar equipamentos dos países capitalistas, a fim de diminuírem o abismo tecnológico. O comércio não solucionou os problemas. A ideologia antiexportação restringiu a pauta de mercadorias comercializáveis, pois a produção concentrava-se nas necessidades domésticas. Fatalmente, as exportações de commodities não seriam mais suficientes para pagar as importações necessárias, implicando na diminuição do padrão de vida. Os dias de glória do Comecon, assim como os de Bretton Woods e da Unctad, haviam chegado ao fim.

As ordens parciais de cooperação econômica atingiram os objetivos de seus arquitetos. Os países capitalistas alcançaram a integração econômica, por meio do livre-mercado e do Estado de bem-estar social. Os países desenvolvimentistas conseguiram a independência econômica e política, por meio da ISI e do Estado Desenvolvimentista. Os países socialistas construíram um Estado Social que proporcionou rápido desenvolvimento industrial e crescimento econômico, combinados com distribuição de renda. Todavia, graves desafios comprometiam a continuidade de cada projeto político-econômico. ${ }^{104}$

A partir de 1973, as tensões acumuladas, em virtude do conflito de concepções entre as três ordens parciais de cooperação econômica, atingiram o ápice. Os choques do petróleo e o aumento exponencial dos preços das commodities deterioraram o padrão formado pelas relações econômicas internacionais desde o pós-Segunda Guerra. O crescimento dos países capitalistas desacelerou bruscamente, gerando o fenômeno do desemprego e da estagflação. Os mercados financeiros aproveitaram-se do fim de Bretton Woods para especular com as moedas ao redor do mundo. Países desenvolvimentistas e socialistas tomaram empréstimos, desencadeando uma onda de inadimplência semelhante às crises econômicas da década de 1930.

As diversas ideologias disputavam a liderança sem sucesso. Nacionalistas e internacionalistas, neoliberais e intervencionistas, capitalistas e socialistas, esquerda e direita confrontavam-se sobre o curso das políticas econômicas, nacionais e internacionais. Os

\footnotetext{
${ }^{104}$ FRIEDEN, 2008, p. 379-383.
} 
conflitos de concepção polarizaram-se e tensionaram as relações sociais. Nos países capitalistas, o consenso centrista da social-democracia havia se desintegrado. Os regimes totalitário-socialistas democratizavam-se, enquanto as democracias desenvolvimentistas foram arruinadas. O equilíbrio de forças deslocou-se do comprometimento com as governanças econômicas internacionais para as limitações à integração.

Com a desconstrução do sistema monetário internacional, os países capitalistas estavam livres para utilizar as taxas cambiais em estímulo à economia. A rápida expansão ampliou a demanda por bens agrícolas e matérias-primas, gerando inflação em todo o mundo. A Organização dos Países Exportadores de Petróleo (“Opep”) foi criada por países subdesenvolvidos com o objetivo de controlar a produção e comercialização do petróleo. A Opep promoveu aumentos rápidos e exponenciais de preço, que ficaram conhecidos como choques do petróleo. Isso causou consequências adversas à economia internacional, a qual não mais possuía o eixo de estabilidade garantido por Bretton Woods. Apesar das políticas de estimulo econômico, a ordem parcial capitalista mergulhou na pior recessão desde 1930, cujo reflexo político foi a expansão dos partidos de esquerda em todos os países e a crise do Estado de bem-estar social.

Os países socialistas e desenvolvimentistas encontravam-se em situação ainda mais difícil, pois dependiam dos empréstimos externos para adquirir produtos tecnológicos, alavancar o desenvolvimento, ou pagar pelo petróleo importado. Para conter o explosivo crescimento da dívida externa, os países subdesenvolvidos adotaram políticas de estimulo à exportação. Isso proporcionou bons resultados, mas inundou os países capitalistas de produtos baratos, acirrando a competição com os setores industriais locais. Além disso, a desarticulação no centro do capitalismo permitiu o alargamento da influência do bloco socialista sobre os países subdesenvolvidos. A competição geopolítica intensificou-se, jogando o mundo em uma polarização ainda maior. ${ }^{105}$

As crises e polarização crescentes receberiam uma resposta conservadora e neoliberal. Os Estados Unidos e os demais países capitalistas implementaram medidas de controle monetário e inflacionário. Esse choque econômico forçou a alta das taxas de juros reais, cujo efeito foi aniquilar a inflação e deslocar o equilíbrio de forças em direção aos investidores. $\mathrm{O}$

${ }^{105}$ FRIEDEN, 2008, p. 387-396. 
fim da espiral inflacionária implicou aumento da taxa de desemprego e perda do poder de compra dos trabalhadores.

A nova realidade macroeconômica levou os países endividados à crise da dívida externa. A elevação das taxas de juros, os choques do petróleo, a recessão dos países capitalistas resultaram no encarecimento dos empréstimos, o qual não foi acompanhado pelo aumento dos preços dos produtos exportados. Os devedores necessitavam de novos financiamentos para rolarem as dívidas. O carrossel parou em 1982, quando o México decretou moratória, seguido por outros países subdesenvolvidos, que não mais encontravam linhas de crédito. Os credores organizaram-se para criar um formato-padrão de renegociação da dívida. O devedor devia procurar o Fundo Monetário Internacional para apresentar um programa de estabilização e ajustes econômicos.

$\mathrm{O}$ impacto foi imediato. A economia enfraquecida levou à década perdida dos anos 1980. Isso provocou movimentos de redemocratização ou de abrandamento de governos autárquicos. Houve o abandono das políticas de industrialização por substituição de importações em prol de medidas de liberalização econômica. Com isso, os pilares da ordem parcial desenvolvimentista ruíram rapidamente, implicando o rompimento com a ideologia cepalista-terceiro-mundista, na contestação do Estado Desenvolvimentista e no esvaziamento da Unctad.

As transformações não ficaram restritas ao Primeiro e Terceiro Mundo: a ordem parcial socialista viria a sofrer a maior mudança de todas. O acúmulo dos problemas econômicos, desde o fim da década de 1970, tornou péssima a condição dos países socialistas, contribuindo para o abandono gradual da insustentável política de planificação econômica em favor dos mercados internacionais. Seguiram-se os movimentos de abertura política e de reestruturação econômica, tendo por objetivo modernizar o regime socialista-planificador em vez de retornar ao capitalismo. Contudo, durante o processo de transição, a União das Repúblicas Socialistas Soviéticas desintegrou-se. A ideologia socialista, o Estado Social, a política autárquica, a planificação econômica, o Comecon e a Guerra Fria haviam chegado ao fim, de forma muito mais rápida e pacífica do que qualquer um poderia ter previsto. ${ }^{106}$

A crise da década de 1970 promoveu profundas transformações socioeconômicas que exigiram respostas adequadas das ordens parciais de cooperação econômica. A incapacidade

\footnotetext{
${ }^{106}$ FRIEDEN, 2008, p. 396-402.
} 
das ordens parciais socialista e desenvolvimentista de apresentar soluções adequadas aos desafios conduziu ao esgotamento das virtualidades que mantinham sua coerência. $\mathrm{O}$ rápido processo de desintegração das estruturas axiológica, comportamental e institucional-legal desmantelou os respectivos modelos de governança econômica internacional rumo ao regime capitalista-neoliberal de acepção estadunidense. Os países subdesenvolvidos passaram a contestar a ideologia desenvolvimentista-terceiro-mundista, responsável por cinquenta anos de ISI, o que levou ao enfraquecimento do Estado Desenvolvimentista. Isso resultou no deslocamento da Unctad como fórum de coordenação econômica internacional e no aborto da construção da nova ordem econômica internacional. O colapso da ordem socialista decorreu do abandono da política de planificação econômica, do rompimento da ideologia socialista, da revisão do Estado Social e do fim do Comecon.

O fim da Guerra Fria propiciou o encerramento do mundo estruturado em torno de polaridades definidas, na medida em que houve a diluição, embora não a eliminação, de conflitos de concepção sobre como organizar a vida econômica global. O novo cenário político e econômico permitiu o prevalecimento da ideologia neoliberal globalizante, a qual defende a integração dos mercados nacionais, regionais e globais. Isso conduz à conclusão da Rodada Uruguai e à criação da Organização Mundial do Comércio, a qual institucionaliza a ordem econômica internacional contemporânea. ${ }^{107}$

\subsubsection{Neoliberalismo, Socialismo e Desenvolvimentismo: os conflitos de concepção}

$\mathrm{O}$ início do século XX foi marcado por uma profunda desagregação de seus fundamentos, cuja consequência foi a fragmentação da estrutura axiológica. Predominante nas relações econômicas internacionais, o liberalismo passou a ser contestado, primeiramente, pelo socialismo e, em seguida, pelas ideologias extremistas surgidas da erupção do barbarismo em 1914. Nos trinta anos de enfraquecimento do pacifismo liberal, espalharam-se pela Europa movimentos radicais e nacionalistas que rejeitavam o discurso socialista, fundando seus

${ }^{107}$ FRIEDEN, 2008, p. 403. LAFER, 1998, p. 20-21. 
dogmas sobre valores nazifascistas. O processo de enfrentamento fortaleceu o espírito belicoso, culminando na Segunda Guerra. Encerradas as Grandes Guerras, a desgastada ideologia liberal foi incapaz de agregar os interesses dos Estados e restaurar a ordem econômica internacional em torno de um predominante e coeso sistema de valores. Já no prólogo da Guerra Fria, vislumbrava-se que a ruptura axiológica para a conformação das três ordens parciais de cooperação econômica, cada qual orbitando ao redor de ideologias distintas.

O período da Guerra Fria foi caracterizado por um estado de paz negativa, marcado pela prevalência de polaridades definidas, tais como Ocidente-Oriente, Norte-Sul e LesteOeste. O estado de paz negativa retrata uma situação conflituosa entre grupos políticos, que não recorrem à força para resolvê-los, mas interagem mediante uma violência coletiva, durável e organizada. A violência estrutural consiste no jogo contínuo de poder entre os atores internacionais, os quais se valem de mecanismos institucionais para impor uma verdade, cujos efeitos poderosos possibilitam o exercício legítimo da dominação.

Nesse contexto de paz armada, formaram-se variados blocos de países detentores de concepções significativamente diferentes sobre a forma de organizar a vida em sociedade, nacional ou internacional. A heterogeneidade de valores teve por efeito tensionar as relações internacionais, na medida em que superava o mero conflito de interesse, produzindo verdadeiros conflitos de concepção. O movimento de diferenciação funcional e de exclusão, próprio das ideologias, favoreceu a consolidação e perpetuação dos conflitos de concepção, implicando o agravamento das disputas pela hegemonia entre Estados Unidos e URSS. Com isso, os sistemas ideológicos demandaram a constituição de modelos de governança econômica internacional apropriados a concretizar as respectivas visões sobre como promover os interesses comuns. ${ }^{108}$

Os arquitetos das três ordens parciais de cooperação econômicas tinham por objetivo constituir mecanismos institucionais que permitissem direcionar as relações econômicas internacionais no sentido de concretizar os valores concebidos a priori. O conflito de concepção decorre da profunda diferença de interpretação de cada ideologia sobre a forma ideal de relacionamento entre sociedade, Estado e indivíduos. As três ideologias responsáveis

${ }^{108}$ LAFER, 1998, p. 20-21. BOBBIO, 2000, p. 514-517. WEBER, 1999, p. 139-142. 
por dividir a humanidade ao longo do século XX em prol da manutenção das estruturas

axiológicas das ordens parciais são: o neoliberalismo, o desenvolvimentismo e o socialismo. ${ }^{109}$

\section{a) Neoliberalismo}

A ordem parcial capitalista adotou a ideologia neoliberal como fundamento axiológico das suas relações econômicas e instituições internacionais. O neoliberalismo é herdeiro da tradição do pacifismo liberal, responsável por manter a coesão da ordem liberal do século XIX, cujo objetivo é alcançar a paz, por meio do comércio, impedindo o recurso à força para solução de controvérsias internacionais. No fim da Segunda Guerra, os formuladores de políticas de comércio internacional dos Estados Unidos e do Reino Unido adotaram tais pressupostos positivos da relação entre comércio e paz para elaborar os acordos de Bretton Woods e a Proposta da Carta de Havana, a qual criaria a Organização Internacional do Comércio.

Os liberais clássicos consideravam que a liberdade do comércio internacional produz benefícios a todas as nações, independentemente das condições particulares de desenvolvimento. A interdependência economia, por criar laços positivos entre as sociedades e promover a harmonização dos interesses, é um instrumento de propagação e fortalecimento do estado de paz. Ainda que desprovidos das sofisticadas formulações matemáticas, os pacifistas liberais acreditavam que Estado Liberal, direito internacional de coexistência e a liberdade das relações econômicas seriam suficientes para promover a paz, por meio do progresso mútuo decorrente das vantagens do livre-cambismo, da especialização e das vantagens comparativas.

Diversas críticas subsequentes exigiram profundas reflexões e refinamentos à ideologia liberal. A Escola Realista teceu questionamentos acerca da ideia de contratualismo, promotora do utópico universalismo axiológico, e de sociedade internacional integrada por interesses e benefícios mútuos, enquanto as indagações metodológicas e dogmáticas dos desenvolvimentistas e socialistas requereram modificações nas noções de livre-comércio,

${ }^{109}$ LAFER, 1998, p. 102. 
especialização e vantagens comparativas. Coube aos neoclássicos revisitar as teorias clássicas, reinterpretando os postulados à luz dos novos desafios estruturais. ${ }^{110}$

Apesar da rápida dispersão da crítica realista, esta demonstrou ser incapaz de interpretar a complexidade das relações econômicas internacionais, pois sua perspectiva estatocêntrica não permite compreender o paradigma da sociedade em rede. Conectada pela revolução eletrônica e de transporte, as interações econômica dependem de constante cooperação, o que desafia a lógica conflituosa dos realistas. Da crescente interdependência econômica, ressurge o pacifismo institucional kantiano como reflexão necessária à compreensão e planejamento de uma sociedade de múltiplos atores e dinâmico processo de integração.

Do processo de contestação, surge uma cisão no pensamento econômico liberal, responsável por dividir os neoclássicos nas alas conservadora e liberal. Os neoliberais conservadores são conhecidos por defenderem fervorosamente os princípios do laissez-faire, enquanto os liberais moderaram sua análise, admitindo a intervenção do Estado no domínio econômico, com a finalidade de corrigir as imperfeições do capitalismo. Isso porque acreditavam poder mitigar do capitalismo a sua inerente instabilidade, por meio de ativas políticas monetárias e fiscal, regulamentação concorrencial, políticas distributivas e combate às externalidades.

Os aspectos importantes da teoria econômica liberal foram modificados para incorporar novos elementos e revisões dogmáticas. A principal contribuição foi de John Maynard Keynes, que rompe com a passividade determinista do liberalismo clássico, fundado sobre o conjunto teórico integrado pelas noções de livre-mercado autorregulado, de justiça distributiva centrada na produtividade marginal e da tendência de alocação automática dos preços ao ponto de eficiência ótima. Isso permitiu defender a intervenção do Estado para permitir coordenação e correções das relações econômicas, objetivando o bem-estar. Daí surge a ideia de Estado de bem-estar social. $^{111}$

\footnotetext{
${ }^{110}$ LAFER, 1998, p. 102. GILPIN, 2002, p. 195-197. OLIVEIRA, Odete Maria de. Relações Internacionais: estudos de introdução. Curitiba: Juruá, 2001, p. 75-79.

${ }^{111}$ OLIVEIRA, 2001, p. 123-128. KEOHANE, Robert O. After hegemony: cooperation and discord in the world political economy. New Jersey: Princeton, 1984, p. 5-7. HUNT, E. K. História do Pensamento Econômico: uma perspectiva crítica. Trad. José Ricardo B. Azevedo e Maria José C. Monteiro. $2^{\mathrm{a}}$ ed. Rio de Janeiro: Elsevier, 2005, p. 403-406; 435-436.
} 
Além disso, introduziram-se aos modelos econômicos neoclássicos novos elementos, como o custo de transportes, admissão de maior mobilidade dos fatores de produção entre países e a importância das vantagens de escala para explicar o comércio. Desenvolve-se o modelo de Hecksher-Ohlin-Samuelson ("H-O”) que tornou mais fluída, dinâmica e abrangente a teoria das vantagens comparativas, ao considerar que um país estará em posição vantajosa em razão da abundância relativa e da combinação mais lucrativa e eficiente de seus fatores de produção.

Surgem teorias que não mais enfatizam o intercâmbio industrial, como pressuposto por David Ricardo e pelo modelo $\mathrm{H}-\mathrm{O}$, optando por aplicar a teoria das firmas ao comércio internacional, a fim de examinar a relação entre investimento estrangeiro direto e o comércio intrafirmas e interfirmas. Com isso, enfoca-se no exame do fluxo comercial que se passa inteiramente dentro de uma mesma empresa transnacional ou entre várias empresas que cooperam mediante acordos de cooperação empresarial (joint ventures). Ao reconhecer essas transformações, cresce a importância da competição monopolística ou imperfeita, à medida que incidem sobre a internacionalização da produção e os ganhos de escala global.

A despeito dos fracassos passados e das revisões doutrinárias, os neoliberais acreditam, em essência, que o comércio e a interdependência constituem uma fonte de relações pacíficas entre as nações, pois os benefícios recíprocos tendem a promover interações cooperativas. Enquanto os interesses políticos tendem a dividir, a economia neoliberal tende a unir os países, ao formar laços e compromissos comuns. No entanto, os neoclássicos reconheceram que nem todos ganham no curto prazo, sendo tais benefícios potenciais. Isso porque o bem-estar aumentaria e, no longo prazo, todos seriam contemplados, caso seguissem com a especialização das vantagens comparativas e a divisão internacional do trabalho. O argumento econômico favorável ao livre-comércio reside, portanto, no aumento e na maximização da riqueza mundial. ${ }^{112}$

${ }^{112}$ GILPIN, 2002, p. 197-202. 


\section{b) Socialismo}

A ideologia socialista está fundada nas ideias lançadas por Karl Marx e Friedrich Engels, em meados do século XIX. Embora considerassem o capitalismo como um sistema global, suas teses não formaram um conjunto sistemático de reflexões sobre as relações internacionais. Tal tarefa coube principalmente às gerações de adeptos que os sucederam. Além disso, tendo adotado o socialismo como sua ideologia oficial, a União Soviética e a China o modificaram para servir a seus interesses nacionais.

A teoria marxista possui quatro elementos essenciais. O primeiro é a abordagem dialética ao conhecimento e à sociedade, que define a natureza da realidade como dinâmica e conflituosa. Os desequilíbrios e transformações sociais decorrem da luta de classes e do choque das contradições inerentes aos fenômenos sociais e políticos. Não há uma harmonia social inerente que promova o retorno à situação de equilíbrio. $\mathrm{O}$ segundo elemento consiste na abordagem materialista da história, que permite vislumbrar o desenvolvimento das forças produtivas e as atividades econômicas como motores das mudanças históricas, cujo funcionamento remete à luta classista a respeito da distribuição do produto social. O terceiro é uma perspectiva geral do desenvolvimento capitalista. O modo de produção capitalista e seu destino são determinados por um conjunto de leis econômicas de transformação da sociedade. O quarto elemento é um compromisso normativo com o socialismo, isto é, buscar a construção da sociedade socialista não como apenas um objetivo desejável, mas enquanto uma meta a ser alcançada.

O capitalismo é um modelo caracterizado pela propriedade privada dos meios de produção e pela existência de trabalhadores assalariados. A essência da singular produtividade repousa em sua natureza dinâmica, caracterizada pela busca dos capitalistas por lucros em uma economia de mercado concorrencial, seguida da acumulação de capital, bem como pela transformação do trabalho em mercadoria, sujeitando-o ao mecanismo de preços. Segundo o marxismo, a origem, a evolução e o fim do sistema capitalista são determinados por três leis econômicas inevitáveis. 
A primeira é a lei da proporcionalidade que sustenta haver uma contradição intrínseca no capitalismo entre a sua capacidade de produzir bens e a possibilidade dos consumidores de adquiri-los. A falta de proporção recorrente entre oferta e demanda, em razão da anarquia do mercado, provoca flutuações econômicas e depressões periódicas. A segunda lei é a da concentração do capital. A força motriz do capitalismo é a busca de lucros e a consequente necessidade de acumular e investir sentida pelo capitalista individual. Isso resulta na concentração da riqueza nas mãos dos poucos agentes eficientes, ao custo do empobrecimento cada vez maior das demais classes. A terceira é a lei da taxa de lucro cadente. À medida que o capital acumula-se, tornando-se mais abundante, sua taxa de retorno declina, o que diminui o incentivo para investir. O crescimento da eficiência e da produtividade, em razão do investimento em tecnologia e redução da dependência da mão de obra, tende a aumentar o desemprego e diminuir o lucro. Com a perda do incentivo para investir, o resultado seria a estagnação econômica e o empobrecimento do proletariado.

O núcleo da crítica marxista estaria, em suma, na ideia de que, embora individualmente os capitalistas sejam racionais, o sistema capitalista é em si mesmo irracional. Com o tempo tais contradições internas conduziriam o capitalismo a sua própria destruição, sendo substituído pelo socialismo. ${ }^{113}$

Na perspectiva de Karl Marx, o socialismo não poderia ser meramente criado como uma socialização dos meios de produção, pois deveria decorrer de uma construção social, cujo desenvolvimento econômico seria, desde o começo, superior ao capitalismo avançado. Não seria possível criar uma estrutura plenamente socialista sobre uma base produtiva inferior ao sistema capitalista burguês, por isso a revolução deveria eclodir em países desenvolvidos. Diante disso, os socialistas propuseram a criação de um regime intermediário entre o socialismo e o capitalismo.

Desse modo, concebe-se a sociedade de transição para acelerar o processo de desenvolvimento econômico, a fim de alcançar o socialismo. Para isso, a ideologia socialista formulou um modelo de produção, cujas características essenciais são a estatização dos meios de produção e o planejamento central da economia. O Estado ganha a função de regente da economia, na medida em que intervém diretamente sobre as relações sociais, seja para determinar e organizar a expansão econômica ou produzir direta ou indiretamente os bens de

${ }^{113}$ GILPIN, 2002, p. 53-55. 
consumo. Diferentemente das economias capitalistas guiadas pela maximização do lucro, a economia planificada seria regida pelo Estado Social na forma de planos centralmente estabelecidos. O modelo socialista foi projetado para industrializar o mais rápido possível um país atrasado e subdesenvolvido, conforme os ditames de uma economia de comando. Portanto, o que impedia a União das Repúblicas Socialistas Soviéticas de ser uma sociedade socialista não era o problema da propriedade dos meios de produção, mas o nível de desenvolvimento das forças produtivas. ${ }^{114}$

Todavia, quando a revolução proletária que traria o fim da economia capitalista não ocorreu, os marxistas tornaram a examinar as razões que impediam seu desaparecimento do cenário global. A revisão do pensamento de Karl Marx converteu sua teoria econômica na ideologia socialista, a qual passaria a abranger as relações políticas e econômicas entre os Estados. Nessa perspectiva, as relações internacionais são compreendidas como fenômenos históricos, nas quais o Estado, enquanto superestrutura, é dependente da estrutura socioeconômica, expressão da evolução histórica determinada essencialmente pelas forças histórico-econômicas. O comportamento internacional do Estado manifesta os interesses da classe dominante no interior do país. Na mesma medida, os conflitos entre os Estados são o reflexo da estrutura socioeconômica interna dos diversos países. As disputas internacionais são caracterizadas por um confronto de políticas expansionistas agressivas, típicas do capitalismo imperialista-monopolista, constituídas, por um lado, pelo antagonismo existente entre os interesses das classes dominantes e, por outro, pelas constantes lutas pelo poder entre classes dominantes e dominadas.

A teoria sobre o imperialismo como estágio supremo do capitalismo decorre da tese marxista da progressiva evolução do capitalismo conducente a uma concentração da produção. Daí a passagem de um sistema imerso em rivalidades concorrenciais entre as classes burguesas dominantes para um capitalismo monopolista, síntese do capital bancário e industrial na forma de uma oligarquia financeira. Nesse cenário imperialista, o globo é dividido pelas grandes potências capitalistas, cuja constante expansão impede a crise do capitalismo, na medida em que suas forças produtivas se desenvolveriam e amadureceriam

${ }^{114}$ SEGRILLO, Ângelo. O declínio da União Soviética. Rio de Janeiro: Record, 2000, p. 61-65. HOBSBAWN, 2007, p. 371-375. 
sem serem vítimas da estagnação e revolução. A expansão necessária seria a pedra-chave da destruição eventual do sistema capitalista internacional. ${ }^{115}$

A economia capitalista internacional promove o desenvolvimento mundial, mas de forma desigual, visto que os países crescem a taxas diferenciadas, o que demanda uma postura imperialista. O imperialismo ultramarino é responsável por reforçar as desigualdades de desenvolvimento entre os Estados, bem como por conduzir, em razão das modificações nas relações de subordinação, a novas partilhas de recursos, o que implica, fatalmente, no recurso à força. Com efeito, os socialistas adicionaram uma quarta lei às três originalmente propostas por K. Marx: a lei do desenvolvimento desigual. Segundo essa nova lei, os países crescem e acumulam capital em taxas diferenciadas. À medida que as taxas de juros diminuem, os países são obrigados a adotar o imperialismo para expandir seus mercados, variar seus investimentos e obter matérias-primas. A ordem capitalista monopolista-imperialista é caracterizada por relações econômicas internacionais instáveis, pois, graças ao desenvolvimento desigual, são marcadas pelo conflito e rivalidade, os quais tendem necessariamente à guerra.

Essa concepção de ordem capitalista global assistiria à emergência de embriões socialistas. A vitória do socialismo estaria assegurada, não com a espera pela eclosão de revoluções proletárias isoladas em diversos países, mas por um processo de hegemonia em escala mundial. Caberia à URSS colocar-se em posição de constante competição com o capitalismo, primeiramente para alcançá-lo e depois superá-lo. ${ }^{116}$

A ideologia socialista defende, a partir de uma análise materialista-histórica marxista, o rompimento das estruturas da ordem capitalista imperialista, por meio do desenvolvimento industrial de países subdesenvolvidos e da revolução socialista mundial. Desse modo, o modelo socialista de desenvolvimento tem na economia centralmente planificada e no Estado Social as chaves estratégicas para acelerar o processo de superação das sociedades de transição para as socialistas plenas.

\footnotetext{
${ }^{115}$ OLIVEIRA, 2001, p. 117-118. GILPIN, 2002, p. 55-56.

${ }^{116}$ OLIVEIRA, 2001, p. 118-119. GILPIN, 2002, p. 58-59. SEGRILLO, 2000, p. 105-112.
} 


\section{c) Desenvolvimentismo}

A fragmentação axiológica não se encerrou na polarização entre neoliberais e socialistas. As críticas realista e marxista não foram capazes de cooptar os países subdesenvolvidos, pois não ofereciam respostas às suas necessidades particulares, surgidas com o processo de emancipação político-econômico. Superados os problemas emergenciais, inicia-se uma busca por soluções que permitissem superar estruturalmente o paradigma do subdesenvolvimento. Cientes de que a sociedade internacional é muito mais complexa do que apregoava a Escola Realista, o novo modelo procurou centrar sua atenção nas relações econômicas internacionais, a fim de observar quais elementos implicam uma situação de subordinação de certos países a outros, mantendo um cenário de desigualdade e dominação que justifica a exploração e dependência.

O desenvolvimentismo finca suas raízes na tese da dependência, cuja origem remonta aos estudos desenvolvidos pela Comissão Econômica para a América Latina e Caribe. Sua principal contribuição está em examinar as relações internacionais a partir do ângulo econômico, visando compreender a questão do desenvolvimento e do subdesenvolvimento. Formado por diversas correntes de pensamentos, o movimento dependentista produziu um conjunto de teorias sobre o desenvolvimento econômico e sobre a dependência que as relações econômicas causam.

Desde o princípio, a dependência foi considerada elemento intrínseco das relações internacionais de domínio e submissão. Isso significa que a teoria da dependência pressupõe qualquer reflexão econômica acerca do subdesenvolvimento, uma vez que a subordinação dependente antecede o próprio subdesenvolvimento. Foi a partir das relações econômicas de poder e verdade que se desenvolveram os estudos sobre o desenvolvimentosubdesenvolvimento, cujo objetivo era conhecer as estruturas e consequências do capitalismo como categoria econômica histórica do neocolonialismo e da expansão do capitalismo central na periferia. Seu maior mérito foi introduzir a economia, antes tratada como matéria autônoma, nas relações de dominação internacional. Para isso, foi necessário reinterpretar os 
paradigmas neomarxista estadunidense e estruturalista da Cepal, resultando na noção da dependência, extraída da assimetria das relações econômicas internacionais, da política das nações hegemônicas em cada período histórico, dos seus modelos de exploração econômicofinanceira e dos aspectos multidimensionais da criação e da alocação de fatores de produção, que permitiam a apropriação do excedente econômico. ${ }^{117}$

Nesse particular, é preciso enfatizar que o termo dependência é plurívoco, razão pela qual diversas interpretações têm sido a ele atribuídas. A dependência, entendida como condição histórica, como estado de sujeição, ou como efeito dependente de causa, apresenta sentido tão genérico que não é redutível à teoria como mero conhecimento especulativo. Segundo a óptica filosófica e moral, a noção de dependência está incluída nas teorias das desigualdades fundamentais, aplicadas às relações internacionais entre o centro e a periferia, legitimadas em nome da civilização e aceitas pela servidão voluntária das lideranças subdesenvolvidas. Outra corrente constata que as categorias de dependência e imperialismo estão imbricadas, pois são conceitos conexos e reciprocamente condicionantes, correspondendo a dois polos complementares, interdependentes, diversos, antagônicos e dialéticos. Apesar dos inúmeros trabalhos e investigações existentes sobre a dependência, não se adotou uma definição unitária e precisa.

A teoria da dependência não se limitou a examinar os aspectos econômicos, expandindo seus estudos à dimensão política e sociocultural. Isso porque a dependência dos países subdesenvolvidos não é apenas econômica, mas técnica, política, militar, cultural e ideológica. Sua peculiaridade está em considerar o mundo como uma única ordem global, na qual as relações de poder, por estarem inseridas numa estrutura capitalista, produzem situações conflituosas de desigualdade e dependência. Desse modo, diferente da ideologia do pacifismo liberal, preocupada com a estabilidade, a teoria de dependência volta-se para a mudança ou ruptura das estruturas, domésticas e internacionais, essenciais para a superação do subdesenvolvimento.

Dos estudos multidimensionais da teoria da dependência, surge, no contexto da Cepal, a ideologia desenvolvimentista, que adota uma abordagem histórico-estruturalista para examinar as relações econômicas internacionais, sob a perspectiva polarizada de centro e

\footnotetext{
${ }^{117}$ OLIVEIRA, 2001, p. 91-98. MACHADO, Luiz Toledo. A teoria da dependência na América Latina. Estudos Avançados, [s.1.], v. 13, n. 35, 1999, p. 200-201.
} 
periferia. O objetivo é explicar a situação de marginalidade em que vivem os países, cuja lógica de dependência perpetua a situação de subdesenvolvimento. Os desenvolvimentistas recusavam a teoria liberal, a qual era incapaz de compreender as relações econômicas em estado de dependência; logo, aprofundaram-se nas estruturas econômicas para descobrir as causas do desenvolvimento e do subdesenvolvimento. ${ }^{118}$

O primeiro desafio envolvia a redefinição das perspectivas sobre desenvolvimento e subdesenvolvimento, os quais não poderiam ser examinados separadamente, pois compreendem um único processo estrutural. O termo desenvolvimento possui diversos sentidos, podendo ser entendido como a evolução de uma ordem social, à medida que esta, mediante a acumulação e o progresso técnico, eleva a produtividade do conjunto de sua força de trabalho. Outro significado possível está centrado na ideia de satisfação das necessidades humanas elementares. Não obstante as variações particulares, o desenvolvimento foi compreendido não como um fator alheio à estrutura social, mas como relação de dependência entre centro e periferia capitalista, o que demandou recusar a tentativa de desvinculação do conceito com as estruturas axiológica ou institucional.

Devido ao duplo esforço de redefinição de perspectivas, a análise histórico-estrutural requer, para interpretar o desenvolvimento global, o exame das conexões entre as estruturas econômica, social e política das sociedades subdesenvolvidas e desenvolvidas. O subdesenvolvimento consiste em uma realidade histórica, que se originou na expansão do capitalismo comercial e se consolidou ao longo dos séculos, mediante a vinculação de diversas economias de diferentes graus e sistemas de produção e distribuição a um mercado em escala mundial. O subdesenvolvimento deve ser compreendido como um fenômeno da história moderna, paralelo ao desenvolvimento, como um aspecto intrínseco da difusão da revolução industrial e da estrutura global capitalista. Daí não ser possível seu estudo isolado enquanto uma fase superável do processo de desenvolvimento, mas como situação de paralelismo dependente das econômicas desenvolvidas, as quais detêm condições para o exercício da governança econômica internacional. ${ }^{119}$

\footnotetext{
${ }_{118}^{118}$ OLIVEIRA, 2001, p. 99-107. MACHADO, 1999, p. 200-202.

${ }^{119}$ MACHADO, 1999, p. 200-202. FURTADO, Celso. Introdução ao Desenvolvimento: enfoque históricoestrutural. São Paulo: Paz e Terra, 2000, p. 15-20. CARDOSO, Fernando Henrique; FALETTO, Enzo. Dependência e desenvolvimento na América Latina: ensaio de interpretação sociológica. Rio de Janeiro: Civilização Brasileira, 2004, p. 37-40.
} 
Nesse contexto, os cepalistas desenvolveram novas teorias para as relações econômicas internacionais. A teoria alternativa do comércio internacional apresentada por Raúl Prebisch foi o primeiro grande rompimento com a teoria econômica clássica, na medida em que expressou sua insatisfação com a premissa liberal acerca dos ganhos econômicos da divisão internacional do trabalho, bem como enfatizou a relevância dos termos de troca nas relações entre centro e periferia. A teoria das vantagens comparativas seria responsável por distorcer as estruturas econômicas nacionais da periferia, provocando um desenvolvimento desvirtuado, no qual as relações e termos de troca comerciais, envolvendo os países industriais e países agroexportadores, teriam por efeito reforçar os laços de dependência e subordinação. Desse modo, ao inferir que se registrava uma forte tendência a aumentar a lacuna entre centro e periferia, dada a deterioração secular dos termos de troca, formularam-se soluções objetivando a industrialização, mediante a implementação de mecanismos de substituição de importações e de proteção à indústria nascente.

Interessante notar que as vantagens da industrialização para o desenvolvimento não foram originalmente elaboradas pelo pensamento desenvolvimentista. Sua origem está presente no debates nos séculos XVIII e XIX, realizados em países que, no século XXI, podem ser considerados como industrializados e desenvolvidos. Os primeiros questionamentos sobre o excessivo otimismo em torno das virtudes da especialização e do livre-comércio como instrumentos para a criação de uma estrutura econômica adequada ao desenvolvimento surgiram dentro do próprio liberalismo. John Stuart Mill parece aceitar a possibilidade de uma política de industrialização, cujo objetivo é fomentar a indústria nascente. Entretanto, foram nas obras de Alexander Hamilton e Friedrich List que as teorias sobre a estreita interdependência entre protecionismo, industrialização e progresso econômico desenvolveramse, assim como as críticas à doutrina liberal.

Os desenvolvimentistas também contestaram os dogmas liberais do monetarismo e do comércio internacional, traduzidos nas políticas do Fundo Monetário Internacional e do GATT respectivamente. Partindo da premissa de que as exportações de matérias-primas estavam sujeitas a termos de troca que flutuavam a curto prazo, mas se deterioravam a longo prazo, defendiam a adotação de medidas protecionistas, na forma de altas tarifas alfandegárias e de metas de investimento de capital estrangeiro. Seu objetivo era diminuir o impacto da instabilidade econômica causado pelo comércio externo e pela balança de pagamentos 
deficitária. Todavia, esse programa era incompatível com as exigências do FMI para concessão de empréstimo e da política de redução tarifária do GATT, razão pela qual se buscou, no plano internacional, uma presença ativa da Unctad para promover a necessária cooperação entre os países subdesenvolvidos.

Por fim, era necessário redefinir a noção de Estado, na medida em que dele seria demandado intervir diretamente nas relações sociais para alavancar o desenvolvimento econômico. Caberia ao Estado Desenvolvimentista a tarefa de implementar o conjunto de políticas comerciais e econômicas conhecidas como industrialização por substituição de importações. Posteriormente, tais políticas divergiram para dois modelos de ISI, cuja distinção estava no enfoque da industrialização para o mercado interno ou externo. ${ }^{120}$

Em suma, a ideologia desenvolvimentista teve o mérito de construir sobre as bases da teoria da dependência uma nova forma de analisar as relações econômicas internacionais. A partir da polaridade centro e periferia do capitalismo global, compreende-se quais elementos econômicos, sociais ou políticos são responsáveis por sujeitar os países subdesenvolvidos ao domínio dos países desenvolvidos, bem como adotar medidas que permitissem superar esse estado de dependência. Nesse contexto, o papel do Estado Desenvolvimentista é fundamental para intervir na vida social, a fim de propiciar as condições necessárias ao desenvolvimento, enquanto caberia à Unctad promover a cooperação econômica entre os países de Terceiro Mundo.

A queda do muro de Berlim simbolizou a diluição, embora não a eliminação, dos conflitos de concepção sobre como organizar a vida mundial. A partir desse novo macrocontexto político, econômico e axiológico, há a transição do estado de paz negativa para o estado de paz positiva. Há, portanto, o fim da ordem internacional estruturada em torno de polaridades definidas, com a prevalência de uma ideologia nos jogos de poder e verdade das relações internacionais: o neoliberalismo. ${ }^{121}$

\footnotetext{
${ }^{120}$ OLIVEIRA, 2001, p. 114-116. FURTADO, 2000, p. 20-23. MILL, 1996, p. 497-499. BRAGA, Márcio Bobik. Raúl Prebisch e o Livre Comércio: as Origens do Pensamento Econômico Estruturalista. CADERNOS PROLAM/USP, São Paulo, v. 2, n. 13, 2008, p. 84-87. PREBISCH, Raúl. La cooperación internacional en la política de desarrollo latinoamericana. In: GURRIERI, Adolfo. La obra de Prebisch en la CEPAL. México: Fondo de Cultura Económica, 1982, p. 364-365.

${ }^{121}$ LAFER, 1998, p. 22.
} 


\subsubsection{Estado Intervencionista e $\quad$ direito internacional de cooperação}

A fragmentação da ordem econômica internacional esteve intrinsecamente vinculada às rupturas inerentes às estruturas comportamental e axiológica. As transformações valorativocomportamentais impactaram convergentemente o Estado e o direito internacional, pois, independentemente da ideologia e dos interesses, as alterações promoveram a fragilização do paradigma westfaliano centrado na soberania. Os principais fatores que atuaram para transformar as concepções do direito internacional de coexistência e do Estado Liberal foram: a Revolução Russa de 1917, as Guerras Mundiais, a Grande Depressão de 1929, o movimento de emancipação político-econômica dos países subdesenvolvidos, a adoção da Carta das Nações Unidas e a fragmentação da ordem internacional pós-1945.

Até a eclosão da Primeira Guerra Mundial, o direito internacional era essencialmente eurocêntrico, bilateral e centrado no princípio da soberania, cuja finalidade era servir de elemento estabilizador das relações internacionais. Seu objetivo era disciplinar as relações entre os Estados Liberais por meio de comandos negativos de mútua abstenção, as quais visavam assegurar a coexistência entre as liberdades externas interestatais, restringir o uso da força, bem como institucionalizar a dominação e a subordinação entre os países. No âmbito interno, o direito constitucional clássico imputava ao Estado Liberal o dever de não intervenção e a função de servir apenas como garantidor da segurança e do cumprimento das leis e contratos. O sistema jurídico era, assim, concebido como um conjunto restrito de discursos imperativos de proibição, os quais impediam a intervenção do Estado na esfera de liberdade alheia, mediante a imposição de limitações recíprocas de atuação. ${ }^{122}$

Em decorrência das exigências axiológicas e econômicas, há uma reformulação no conceito de Estado. O processo de revisão conceitual tem início após a Primeira Guerra Mundial, seguido pelos impactos da Grande Depressão e da Segunda Guerra Mundial, cujos efeitos incidiram sobre o Estado Liberal, transformando-o em Estado Intervencionista. O paradigma do Estado Liberal era construído por um direito positivo instrumental, segundo critérios de racionalidade formal e legitimidade racional-legal, que objetivava somente o

${ }^{122}$ AMARAL, JR., 2006, p. 82. LAFER, 1977, p. 7-11. 
controle da sociedade. Daí o direito constitucional clássico dispor somente dos direitos fundamentais individuais, da separação dos poderes e do princípio da legalidade.

Em resposta às mudanças socioeconômicas, o direito constitucional adota um caráter programático, cuja finalidade é instaurar um novo Estado capaz de assegurar os direitos individuais e concretizar os direitos coletivos, sociais e econômicos. Para realizar esse programa, revisa-se a noção de Estado, de modo a atribuir-lhe o objetivo de regulamentar as atividades sociais, interceder, direta ou indiretamente, na economia, bem como delimitar o campo da autonomia da vontade no âmbito contratual privado. Para conferir contornos jurídicos à intervenção estatal sobre a sociedade, exigiu-se uma teoria funcionalista do direito capaz de formalizar as políticas de planejamento estatal, segundo uma racionalidade material, que visava direcionar a sociedade e organizar o mercado.

Nas três ordens parciais de cooperação econômica, concretizou-se a revisão paradigmática do conceito de Estado, o qual assumiu, em cada qual, formato e funções particulares, de acordo com os respectivos valores e interesses. Guardadas as diferenças adaptativas, o Estado de bem-estar social, o Desenvolvimentista e o Social detinham comumente um núcleo essencial: a noção de Estado Intervencionista. Com efeito, a atuação sistemática do Estado Intervencionista sobre as estruturas econômicas provocou uma transformação no direito positivo, de modo a deslocar o centro de gravidade das normas jurídicas de conteúdo econômico do direito comercial para uma nova constelação de regras e institutos. O novo direito econômico surge como o conjunto de discursos prescritivonormativos que confere contorno jurídico à intervenção estatal na realização da política econômica. Inserida no contexto ideológico neoliberal, socialista e desenvolvimentista, coube à norma jurídica instrumentalizar a ação estatal sobre a economia, de modo a produzir, direta ou indiretamente, bens e serviços, coordenar as relações econômicas e corrigir as imperfeições de mercado. ${ }^{123}$

As novas exigências funcionais do Estado Intervencionista expressaram-se internacionalmente na forma dos modelos de governança econômica internacional. As ordens parciais valeram-se do direito internacional econômico para instituir organizações

\footnotetext{
${ }^{123}$ LAFER, 1977, p. 7. FARIA, 2004, p. 185-199. BOBBIO, 2007, p. 41-47. COMPARATO, Fábio Konder. O indispensável direito econômico. In: Ensaios e Pareceres de Direito Empresarial. Rio de Janeiro: Forense, 1978, p. 464-466. GRAU, Eros Roberto. A ordem econômica na Constituição de 1988: interpretação e crítica. $11^{a}$ ed. São Paulo: Malheiros, 2006, p. 41-44.
} 
internacionais e estabelecer regras jurídicas, que permitiram coordenar as relações econômicas internacionais. Como será pormenorizadamente examinado no Capítulo 3.1, o direito internacional econômico compreende o conjunto de discursos jurídicos que disciplinam, por meio de instrumentos públicos ou privados, as relações econômicas internacionais, tendo por finalidade estabilizar as expectativas normativas dos agentes econômicos. Isso permite a instalação de um horizonte de previsibilidade, calculabilidade e custo de transação em face das relações econômicas internacionais.

Concomitantemente, as transformações estruturais conduziram os Estados à tentativa de instituir uma ordem mundial de natureza mais jurídica do que diplomática, por meio da celebração do Pacto da Liga das Nações, o qual criou uma organização internacional de aspiração universal. Sua finalidade era normatizar as relações entre os Estados, de acordo com certos princípios internacionais, os quais representavam a pretensão de limitar consensualmente o arbítrio dos Estados mediante a cooperação. Não obstante o colapso da Liga das Nações, a proposta serviu para revelar os novos parâmetros de relacionamento entre os Estados. Enquanto as preocupações do direito internacional de coexistência repousavam no princípio da reciprocidade, na restrição do uso da força e na execução das obrigações bilaterais, o direito internacional era objeto de novas demandas socioeconômicas, as quais requeriam normas que possibilitassem institucionalizar a cooperação entre homens e Estados, a fim de modelar a realidade das relações internacionais.

Os reflexos foram amplos sobre o direito internacional, o qual, a partir do final da Segunda Guerra, transformou-se em direito de regulamentação, responsável por definir o comportamento dos Estados, visando satisfazer os valores e interesses gerais da comunidade internacional. Não mais restrito à lógica legalista clássica, o direito internacional de cooperação é constituído por discursos jurídico-imperativos de mútua cooperação. O aparecimento das normas positivas marca um novo estágio de aprofundamento das relações internacionais, no qual o direito assume um papel promocional na cooperação entre os sujeitos, deixando de ser apenas imperativos negativos protetores da soberania territorial.

Em razão disso, assiste-se a uma explosão normativa, decorrente da diversificação material que passa a ser incorporada ao direito internacional. À medida que os interesses da sociedade internacional alargam-se, verifica-se uma multiplicação e inversão de prioridades. Anteriormente focadas na manutenção da paz e segurança, as relações internacionais que 
começaram a tratar de temas coletivos, como a regulamentação econômica e social, proteção do meio ambiente e dos recursos marinhos, entre outros. As regras de alcance universal convivem com a tendência de diferenciação e especificação, conforme a necessidade subjetiva de cada Estado ou objetiva quanto à matéria regulada. ${ }^{124}$

Com o crescimento das preocupações internacionais sobre as diversas áreas, há o reconhecimento de normas de caráter comunitário, fruto do consenso sobre certos valores fundamentais, as quais não são deixadas a livre disposição do jogo bilateral entre os Estados. O direito internacional de cooperação não tem por objetivo intervir nas relações diplomáticas intergovernamentais ou na solução de conflitos entre Estados. Na realidade, esse novo direito internacional regulamenta as experiências de colaboração positiva, de modo a desenvolver uma sensação de comunidade no cenário interestatal, bem como concretizar, progressivamente, a noção de responsabilidade coletiva dos Estados em face da sociedade internacional.

A principal consequência do aprofundamento das relações entre os Estados mediante a adoção de discursos jurídicos de mútua cooperação foi o movimento de integração política e econômica internacional. A passagem de normas negativas para normas positivas traduz juridicamente a mudança qualitativa da conduta do Estado diante das necessidades de maior coordenação e cooperação nas atividades internacionais. $\mathrm{O}$ aumento da interdependência pode ser entendido como a evolução gradual em direção a um sistema coletivo de tomada de decisões, em substituição a meios e processo exclusivamente nacionais. Nesse sentido, ressalta-se que a construção do processo decisório coletivo varia, dependendo do modelo jurídico, em razão da matéria e da competência.

Desse modo, após a Segunda Guerra, ao direito internacional foi incorporada a função de minimizar e diminuir os conflitos e ressaltar os aspectos de cooperação nas relações entre Estados, por meio da institucionalização de organizações internacionais. A adoção da Carta das Nações Unidas não aboliu a ordem de Westfália, mas promoveu a institucionalização de

\footnotetext{
${ }^{124}$ AMARAL, JR., 2006, p. 82. FRIEDMANN, 1964, p. 61-62. LAFER, 1977, p. 7-11. BOBBIO, Norberto. Teoria da norma jurídica. Trad. Fernando P. Baptista e Ariani B. Sudatti. Bauru: Edipro, 2001, p. 109-111. BOBBIO, Norberto. Da estrutura à função: novos estudos de teoria do direito. Trad. Daniela B. Versiani. Barueri: Manole, 2007, p. 69-74.
} 
interesses comunitários, o que simboliza a positivação universal da noção de sociedade internacional. $^{125}$

No contexto de um direito internacional econômico, a cláusula da nação mais favorecida tem desempenhado um importante papel prático, na medida em que é amplamente adotada pelos mais relevantes e complexos tratados, com o objetivo de evitar a discriminação nas relações entre as partes-contratantes. Objeto do presente estudo, a CNMF positivada no artigo I:1 do Acordo Geral sobre Tarifas e Comércio é notória por simbolizar uma aplicação paradigmática do direito internacional econômico. ${ }^{126}$

O direito internacional de cooperação, as organizações internacionais e o Estado Intervencionista representaram a resposta da estrutura institucional-legal às transformações socioeconômicas decorrentes do esgotamento das virtudes da ordem liberal. Com isso, o sistema jurídico internacional passou a ser concebido como um conjunto de normas negativas de mútua abstenção e positivas de mútua cooperação, tendo por finalidade precípua disciplinar o uso da força e regular a colaboração entre os Estados Intervencionistas. As ideologias e interesses dos países voltados aos sistemas econômicos exigiram a formação de um direito internacional econômico que permitisse organizar as relações econômicas internacionais, segundo suas concepções. Nesse particular, a ordem parcial neoliberal utilizou o direito internacional econômico para constituir o GATT e nele positivar a cláusula da nação mais favorecida como regra geral de suas interações comerciais.

\footnotetext{
${ }^{125}$ FRIEDMANN, 1964, p. 61-62. LAFER, 1977, p. 11-13. NGUYEN; DAILLIER; PELLET, 1999, p. 60-65. SIMMA, Bruno. From bilateralism to community interest in international law. Recueil des Cours, Leiden, v. 250, n. 6, 1994, p. 217-221.

${ }^{126}$ LAFER, 1977, p. 20-21. CARREAU; JUILLARD, 1998, p. 5-6. NORTH, C. Douglass. Institutions, transaction costs, and the rise of merchant empires. In: TRACY, James D. (ed.). The Political Economy of Merchant Empires. Nova York: Cambridge University Press, 1991, p. 22-25. WILLIAMSON, Oliver E. The Mechanisms of Governance. Nova York: Oxford University Press, 1996, p. 93-107.
} 


\subsubsection{A Era do Livre-comércio estadunidense: o GATT e a construção multilateral da cláusula da nação mais favorecida}

O breve século $X X$ tem início com a eclosão da Primeira Guerra Mundial e se encerra no colapso da URSS. Nem superada a Era da Catástrofe, os países já se encontravam na Guerra Fria, tendo que aliar-se à ideologia neoliberal ou socialista. O confronto entre Estados Unidos e União Soviética teve por consequência a fragmentação da ordem internacional em três ordens parciais de cooperação econômica, dotadas de estruturas particulares e diferenciadas. Nesse cenário de paz negativa, consolidaram-se três modelos de governança econômica internacional, os quais guardavam, cada qual, programas específicos sobre como organizar a divisão internacional do trabalho, segundo certo modo de produção econômico, disciplinado por um sistema de normas, orientadas em função da ideologia dominante.

A ordem parcial neoliberal foi estruturada sobre os pilares monetário, financeiro e comercial, na forma de organizações e tratados internacionais, que visavam institucionalizar as expectativas cognitivas e normativas dos agentes econômicos internacionais. Sob orientação da ideologia neoliberal, criaram-se o Fundo Monetário Internacional, o Banco Mundial e o Acordo Geral sobre Tarifas e Comércio, com a finalidade de disciplinar as relações econômicas internacionais, conforme as necessidades da economia capitalista de livremercado. Na posição de regente, os Estados Unidos conferiram legitimidade e eficácia social à governança econômica internacional, bem como utilizaram-na para fortalecer-se em face dos desafios da Guerra Fria.

O presente Capítulo tem por finalidade examinar as características históriconormativas essenciais da vertente comercial da ordem parcial de cooperação econômica neoliberal, na medida em que nela se insere o GATT, tratado internacional no qual está positivada, no artigo I:1, a cláusula da nação mais favorecida, objeto deste trabalho. Ressaltese, entretanto, que esta análise tem por enfoque especifico o papel da CNMF na governança econômica internacional neoliberal, visto que o instituto será detalhadamente examinado nas Seções III e IV. 
Em retrospecto, o fim da Era do Livre-comércio britânico teve terríveis consequências para as relações comerciais. A Primeira Guerra não apenas rompeu os vínculos jurídicocomerciais entre os Estados adversários, como também afetou a própria ideia do tratamento da nação mais favorecida, implicando no recrudescimento de seu uso. Após a destruição da economia internacional, a carência de dois fatores essenciais impediu o retorno da CNMF à posição central nas políticas de comércio internacional: a previsibilidade e a confiança mútua entre os agentes econômicos.

Durante os trinta anos da Era da Catástrofe, os defensores do protecionismo comercial sustentaram que a cláusula da nação mais favorecida simbolizava todas as vicissitudes da combalida ideologia liberal. Revelador dos efeitos erosivos do tratamento da nação mais favorecida, S. H. Bailey aponta que o princípio da não discriminação nas relações comerciais compromete a confiança dos agentes econômicos, pois:

At the periods when the tide of international confidence and economic prosperity is high there appears to be a fair chance of safe and easy navigation, but when the political or economic waters fall, reefs and rocks are exposed and offer the prospect of certain shipwreck. ${ }^{127}$

Tal sentimento de antagonismo ao discurso jurídico não discriminatório espalhou-se entre os Estados. Fato histórico representativo, a proposta dos aliados na Conferência Econômica de 1916 previa submeter os inimigos à sistemática discriminação econômica, a qual se concretizou na forma dos Tratados de Paz. Nesse contexto, foi imposto aos derrotados o dever de outorgar unilateralmente aos vencedores a cláusula da nação mais favorecida, a qual, por estar eivada de uma simbologia negativa, era concebida como uma sanção pelos danos provocados na Primeira Guerra Mundial.

No entanto, foi durante o período entreguerras que pela primeira vez cogitou-se conferir efeitos multilaterais à cláusula da nação mais favorecida, com o objetivo de aumentar a estabilidade político-econômica e a confiança recíproca. Devido aos impactos econômicos devastadores da Primeira Guerra Mundial e da Grande Depressão, a Liga das Nações decidiu examinar quais fatores resultaram na criação de barreiras protetivo-discriminatórias ao comércio internacional. O Relatório Wickersham-Magalhães apresentado na Conferência Econômica Internacional conferiu um grande impulso ao retorno do instituto ao cenário

${ }^{127}$ HOBSBAWM, 2007, p. 26-27. BAILEY, S. H. Reciprocity and the Most-Favoured-Nation Clause. Economica, [s.1.], n. 42, 1933, p. 428-429. 
internacional. Todavia, as tentativas da $\mathrm{LdN}$ de propor um tratado internacional multilateral que estipulasse a CNMF não obtiveram condições político-econômicas de vingar, mas serviriam de fundamento para a regulamentação do comércio internacional no pós-Segunda Guerra.

Assim, após o insucesso liberal no campo econômico e as Guerras Mundiais no político, a vitória dos Estados Unidos propiciou o ressurgimento da crença de que as atividades concernentes à economia internacional deveriam ser regidas por normas multilaterais que conduzissem à interdependência pacífica entre os Estados. Na concepção dos neoliberais estadunidenses, o colapso da ordem liberal demonstrou que a discriminação e o protecionismo comercial não poderiam mais ser superados pelo jogo da cláusula da nação mais favorecida no âmbito das relações bilaterais.

Historicamente, as primeiras linhas sobre a positivação de um conjunto de tratados comerciais que disciplinasse uma pluralidade de Estados têm origem na tendência à institucionalização da vida internacional, mediante a criação de organismos internacionais. Resultado direto das experiências do século XIX, o fenômeno da normatização das relações econômicas, concretizado pela constituição de organizações internacionais de índole técnica e uniões aduaneiras, foi recepcionado e transposto pelos neoliberais para o campo social e político após a Primeira Guerra. Nesse sentido, a diplomacia estadunidense teve papel decisivo no esforço para institucionalizar um arcabouço jurídico multilateral capaz de regular e disciplinar as relações econômicas internacionais no pós-1945. ${ }^{128}$

Decisivo para a modelação da ordem neoliberal, o Secretário de Estados dos EUA Cordell Hull, adepto convicto do pacifismo liberal, defendeu a criação de instituições internacionais que promovessem a paz e o comércio internacional entre os países: I have never faltered and I will never falter on my belief that enduring peace and the welfare of nations are indissolubly connected with friendliness, fairness, equality and the maximum practible degree of freedom in international trade. ${ }^{129}$

Seguindo a ideologia do pacifismo liberal, os Estados Unidos defenderam a eliminação de entraves comerciais entre os países, com a finalidade de fomentar a estabilidade político-

\footnotetext{
${ }^{128}$ LAFER, 1971, p. 41. DAL RI JR., 2003, p. 101-105. USTOR, 1969, p. 169-170. VERBIT, 2002, p. 26-27. ALMEIDA, 2001, p. 375-377.

${ }^{129}$ LAFER, 1998, p. 102. DAM, 1970, p. 12. ALLEN, William. The International Trade Philosophy of Cordell Hull, 1907-1933. American Economic Review, [s.1.], v. 43, n. 1, 1953, p. 101-116.
} 
econômica e a confiança mútua, assegurar condições duradouras à paz mundial e conferir maior eficiência econômica e bem-estar internacional. Sob os auspícios da Organização das Nações Unidas, os EUA e o Reino Unido apresentaram, em dezembro de 1945, a Carta Proposta para o Estabelecimento da Organização Internacional do Comércio, na qual previase a criação de um código comercial que, sob jurisdição de uma nova organização internacional, regulamentaria as relações econômicas internacionais. Em 1946, o Conselho Econômico e Social da ONU convocou seus Estados-membros a participar da Convenção das Nações Unidas sobre Comércio e Emprego. Para compreender a Carta Proposta, é imprescindível examinar os fundamentos que dão origem ao modelo de governança econômica internacional apresentado pelos Estados Unidos, com apoio do Reino Unido, e como as precedentes negociações anglo-estadunidenses nela repercutiram.

Em agosto de 1945, os Estados Unidos haviam alcançado o nível mais alto de poderio militar, político e econômico jamais visto. Seus planos para a ordem internacional pósSegunda Guerra, arquitetados desde 1939, deveriam se valer de sua estratégica posição hegemônica para serem rapidamente implementados. O plano estadunidense foi construído sobre duas vertentes: institucional e funcional. O aspecto estrutural consistia na criação de uma organização internacional sobre comércio, na medida em que a coordenação econômica por meio de relações jurídicas bilaterais demonstrou ser excessivamente frágil. Na dimensão funcional, o objetivo era institucionalizar um código comercial capaz de regular e disciplinar as relações econômicas internacionais, segundo os princípios da não discriminação, reciprocidade, livre-comércio e multilateralismo.

Por sua vez, o Reino Unido encontrava-se em situação crítica; tendo sua economia destruída e dependente de auxílio externo, acumulava débitos crescentes com os EUA, em razão da respectiva ajuda militar e econômica. Nesse cenário, a diplomacia estadunidense condicionou a manutenção do Acordo sobre Empréstimo e Arrendamento ao irrestrito apoio inglês ao plano de estabelecer um sistema multilateral de comércio, formatado segundo a ideologia neoliberal. Apesar da aparente fragilidade, a diplomacia inglesa não pretendia se subordinar facilmente aos interesses dos EUA, pois desejava preservar seus privilégios 
comerciais, os quais desempenhariam importante função como motor de recuperação econômica. $^{130}$

O primeiro aspecto tratado por EUA e Reino Unido foram as características e a extensão funcional do discurso jurídico-convencional que seria proposto. Como já havia ocorrido nas negociações da Carta do Atlântico, as diplomacias estadunidense e inglesa centravam seus esforços na tentativa de solucionar a divergência acerca da relação entre comércio e emprego. Nos mesmos moldes do artigo 7 da Carta do Atlântico, em cuja redação final prevaleceu a vontade inglesa, o Reino Unido defendia a necessidade de manter uma relação positiva e interdependente entre emprego e comércio, de modo que a obtenção de níveis elevados de atividade econômica e de empregos seriam condicionantes para a liberalização do comércio internacional. Contudo, para os Estados Unidos, a retomada do crescimento econômico e da geração de empregos dependia da abertura comercial. Subjacente ao embate ideológico, o verdadeiro objetivo estadunidense na negociação era o desmantelamento dos mecanismos de proteção e discriminação comercial adotados pelo Reino Unido.

Os EUA toleraram as demandas inglesas por discriminação e proteção, pois visavam garantir a estabilidade política e exercer a liderança na nova governança econômica internacional. Todavia, a diplomacia estadunidense perseguia dois objetivos que, apesar de não serem absolutamente incompatíveis, eram de difícil coordenação. Primeiramente, defendiam a liberalização da economia mundial, mediante a multilateralização da cláusula da nação mais favorecida, a fim de acomodar suas necessidades de expansão comercial, bem como de saciar seus valores neoliberais. Paralelamente, pretendiam construir e manter a unidade de seus aliados em torno de um projeto comum, conferindo a este a legitimidade necessária para garantir a respectiva eficácia social. Ante tais pretensões, os Estados Unidos acreditavam ser capazes de, sem qualquer oposição, alcançar os dois objetivos, os quais garantiriam a prosperidade econômica e a paz mundial.

Aproveitando-se da inexperiência estadunidense, duas foram as estratégias da diplomacia inglesa para lograr êxito em uma situação de evidente assimetria de condições. A primeira consistia na contestação dos princípios ideológicos neoliberais, os quais inspiraram o

${ }^{130}$ MILLER, James N. Origins of the GATT - British Resistance to American Multilateralism. [s.1.]: Jerome Levy Economics Institute Working Paper n. 318, Cambridge University, 2000. Disponível em <http://www.levy.org/pubs/wp318.pdf>. Acesso em: 29 jan. 2009, p. 1-2. HUDEC, 1975, p. 9. 
arcabouço jurídico para a ordem econômica do pós-1945. A segunda trata do esforço para a ampliação do foro de discussão, o qual não poderia restringir-se a meros debates bilaterais, na medida em que, por ser de interesse coletivo, deveria ser objeto de negociações multilaterais. Com isso, pretendia-se diluir o poder dos Estados Unidos. ${ }^{131}$

A primeira estratégia foi executada com êxito. Devido a sua posição pragmática, os ingleses conseguiram convencer os negociadores de $\mathrm{C}$. Hull a recuar nos quatro principais pontos sobre políticas comerciais de interesse britânico: sistemas de preferência comercial, quotas, cartéis e comércio com empresas estatais.

Não há dúvida de que o tema mais relevante era a abolição dos sistemas internacionais de preferência comercial. Os Estados Unidos exigiam a abolição completa e imediata do sistema imperial de comércio preferencial da Comunidade Britânica de Nações, uma vez que simbolizava a mais perigosa barreira ao comércio: a discriminação. Entretanto, foram convencidos a aceitar a posição inglesa de que a eliminação não poderia ser imediata, devendo ser condicionada a recíprocas concessões tarifárias dos EUA.

Quanto às restrições quantitativas, os negociadores estadunidenses aceitaram a posição do Reino Unido de que as quotas seriam permitidas como remédios para suprir os efeitos negativos de uma balança de pagamentos desfavorável. As quotas teriam, assim, uma função preventiva ou corretiva em períodos de desequilíbrio.

Orientada pelas ideias reformistas de defesa da concorrência vigentes à época, a diplomacia estadunidense também demandava o desmantelamento dos cartéis. Todavia, os argumentos ingleses sobre a importância dos monopólios para a estabilidade de preços e condições comerciais convenceram os Estados Unidos a aceitar que a futura organização sobre comércio internacional seria mais apta a investigar casualmente as condutas e os impactos dos monopólios sobre as relações comerciais.

Finalmente, os Estados Unidos exigiam a proibição de relações econômicas com empresas estatais de comércio. A diplomacia inglesa sustentou ser possível estabelecer regras para um comércio não discriminatório com tais empresas públicas. Essa proposta seria aceita, desde que as referidas companhias atuassem no mercado nas mesmas condições dispensadas a agentes privados. $^{132}$

\footnotetext{
${ }^{131}$ GARDNER, Richard N. Sterling-Dollar Diplomacy, The Origins and the Prospects of Our International Economic Order. $2^{\text {a }}$ ed. Nova York: McGraw-Hill, 1969, p. 13. MILLER, 2000, p. 13.

${ }^{132}$ MILLER, 2000, p. 3-5.
} 
Não obstante a surpresa dos ataques ingleses às políticas neoliberais, os quais conduziram às concessões em matéria comercial, James N. Miller constata ser contraintuitivo o modelo institucional adotado pelos Estados Unidos, bem como o fato de a diplomacia estadunidense ter aceitado as pressões do Reino Unido para submeter a Carta Proposta a negociações multilaterais. Na verdade, os ingleses apenas tiraram vantagem dos riscos inerentes à ideologia neoliberal, a qual sustentava a importância da construção de um sistema multilateral de comércio de aspiração universal.

Ao invés de usarem sua influência hegemônica para impor uma carta de livre-comércio rígida aos países aliados, ou adotarem uma política comercial bilateral, centrada na cláusula da nação mais favorecida, como a desenvolvida pela Grã-Bretanha, os Estados Unidos optaram por estabelecer uma organização internacional de caráter multilateral. Seu objetivo era promover a paz e a liberalização comercial, por meio de um multilateralismo procedimental e axiológico, o que implicaria na dificultosa tarefa de, respectivamente, negociar reciprocamente concessões tarifárias e alcançar o consenso sobre os princípios e políticas da governança econômica internacional. ${ }^{133}$

Desse modo, é preciso investigar os múltiplos sentidos do termo de conceito multilateral, a fim de aferir as consequências de institucionalizar uma organização internacional de índole multilateral. Isso permitirá esclarecer a confusão correntemente encontrada na doutrina, a qual costuma reduzir ou identificar qualquer sistema internacional de comércio ao sistema multilateral de comércio. Com a compreensão das diferentes construções conceituais da noção de multilateralismo, será possível compreender os efeitos da arquitetura jurídica sobre a estrutura institucional-legal da ordem parcial de cooperação econômica neoliberal.

No plano etimológico, o primeiro documento em que o termo multilateral é empregado para descrever um acordo internacional data de 1858, enquanto a expressão multilateralismo só viria a ser utilizada em 1928. Isso sugere que as noções de multilateral e multilateralismo, que viriam a ser estipuladas no Acordo Geral sobre Tarifas e Comércio, foram reinterpretadas, ou mesmo construídas, no contexto das Guerras Mundiais. A gênese do sistema multilateral de comércio está intrinsecamente ligada ao plano de pacificação neoliberal, cujo objetivo era evitar a repetição dos acontecimentos desastrosos que culminaram na desestruturação da

\footnotetext{
${ }^{133}$ MILLER, 2000, p. 7-9.
} 
ordem liberal. No entanto, apesar da veemente defesa da interdependência comercial propagada por Cordell Hull, o multilateralismo somente ganhou relevância no debate da política de comércio internacional nos Estados Unidos no período subsequente à Segunda Guerra. Para ilustrar o desconhecimento da temática, recorreu-se aos dois maiores dicionários da língua inglesa, Oxford English Dictionary e Webster's New International Dictionary, respectivamente, a fim de verificar historicamente a construção dos sentidos do termo. ${ }^{134}$

Editado em 1934, o Webster's second edition define multilateral como “A1. Having many sides; many-sided. 2. Participated in by more than two states; as a multilateral treaty. Cf. UNILATERAL, BILATERAL. 3. Law of a contract, having three or more parties". Note-se que não há qualquer referência à expressão multilateralismo. Já na terceira edição de 1961, encontra-se o termo multilateralismo, definido como "freedom of international trade and currency transfers so as to achieve for each country a trading balance with the total trading area but not necessarily with any one particular country B contrasted with bilateralism". Assim, a expressão “multilateralism”, que não havia sido reconhecida em 1934, veio associada, após a Segunda Guerra, à ideia de liberdade comercial e balança de pagamentos. ${ }^{135}$

No mesmo diapasão, o Oxford English Dictionary, em sua primeira edição de 1933, não prevê a expressão multilateralismo, ou qualquer referência a Estados, ao definir multilateral: "A1. Having many (i.e. more than four) sides". Na edição de 1989, foi incluído o termo multilateralismo, além de ampliar-se a definição de multilateral: "A multilateral, (...) 3. Pertaining to or concerning three or more countries, esp. of the trade and financial agreements made by them, or of the control of (part of) their armed forces by a supranational authority. (...) Hence multilateralism, the quality of being multilateral (sense 3)". ${ }^{136}$

Com isso, percebe-se que, durante o período entreguerras, os Estados Unidos realizaram uma revisão técnica e cultural do signo. Em vista dessas substanciais mudanças de significado, a ideia de multilateralismo prevista no GATT sugere ter sido, literalmente, inventada no decorrer das negociações internacionais das décadas de 1930 e $1940 .{ }^{137}$

\footnotetext{
${ }^{134}$ POWELL, Lindsey. In Defense of Multilateralism. New Haven: Yale Center for Environmental Law and Policy, p. 5. Disponível em <http://www.yale.edu/gegdialogue/docs/dialogue/oct03/papers/Powell.pdf>. Acesso em: 30 jan. 2009.

${ }^{135}$ WEBSTER, Noah. Webster's New International Dictionary. $2^{\text {a }}$ ed. Londres: G. Bell \& Sons, 1934. WEBSTER, Noah. Webster's New International Dictionary. $3^{a}$ ed. Chicago: G. \& C. Merriam, 1961.

${ }^{136}$ MURRAY, James A. (ed.). The Oxford English Dictionary. $1^{a}$ ed. v. VI, Oxford: Clarendon Press, 1933. . The Oxford English Dictionary. 2a ed. v. X, Oxford: Clarendon Press, 1989.

${ }^{137}$ MILLER, 2000, p. 9.
} 
Curiosamente, o isolamento comercial do Brasil nas últimas décadas parece ter repercutido sobre a língua portuguesa de tal forma que o Dicionário Aurélio apresentou, em sua edição de 1994, apenas a definição de multilateral: "que se faz ou realiza entre várias nações, instituições ou pessoas". Enquanto a palavra multilateralismo pode ser encontrada na edição de 1999, nos seguintes termos: "Prática do comércio internacional de forma não discriminatória, em que cada país comercia com os demais nas mesmas condições". ${ }^{138}$

A doutrina tem utilizado o termo mutilateralismo por mais de cinquenta anos, sendo que apenas alguns poucos teóricos têm trabalhado para esclarecer seus significados. Em 1956, Richard N. Gardner definiu o termo exclusivamente em relação ao comércio internacional:

For the purpose of this history we may define such a system as one in which barriers to trade and payments are reduced to moderate levels and made non-discriminatory in their application. This objective is obviously not the same as free trade. [...] Multilateralism does not mean the elimination, but only the reduction, of tariffs and other trade barriers. Any trade barriers remaining after this reduction, however, must be non-discriminatory in their application. ${ }^{139}$

Ao examinar atentamente a definição, percebe-se que R. Gardner incorporou os objetivos do próprio preâmbulo GATT $^{140}$ à definição. Esse reducionismo reflete a ambição dos negociadores estadunidenses, no cenário de negociações da Carta de Havana, em estabelecer fundamentos axiológicos ao sistema internacional de comércio. Em razão disso, James A. Carporaso observa que o acréscimo do sufixo ismo ao radical multilateral sugere o caráter ideológico do termo e não uma consideração sobre a forma de relacionamento. Desse modo, para compreender o multilateralismo será necessário procurar por um conceito mais acurado. $^{141}$

Apenas na década de 1980, Robert Keohane apresentou uma nova concepção estrutural de multilateralismo, a qual consiste em reduzir o fenômeno à prática de coordenação das políticas nacionais em grupos de três ou mais Estados. Comparando as posições de R. Gardner e R. Keohane, John G. Ruggie propôs uma classificação de multilateralismo, segundo a

\footnotetext{
${ }^{138}$ FERREIRA, Aurélio Buarque de Holanda. Dicionário Aurélio Básico da Língua Portuguesa. Rio de Janeiro: Nova Fronteira, 1994, p. 446. FERREIRA, Aurélio Buarque de Holanda. Novo Aurélio Século XXI: o dicionário da língua portuguesa. $3^{\mathrm{a}}$ ed. Rio de Janeiro: Nova Fronteira, p. 1378.

${ }^{139}$ GARDNER, 1969, p. 13.

140 "To contribute to rising standards of living and full employment by entering into reciprocal and mutually advantageous arrangements directed to the substantial reduction of tariffs and other barriers to trade and to the elimination of discriminatory treatment in international commerce."

${ }^{141}$ CAPORASO, James A. International Relations Theory and Multilateralism: The Search for Foundations. International Organization, [s.1.], v. 46, n. 3, 1992, p. 601.
} 
natureza dos conceitos, em qualitativo e nominal, respectivamente. Não obstante, questionou as razões pelas quais os Estados substituiriam a governança internacional de base bilateral por uma multilateral. $^{142}$

À luz dessas considerações, J. Miller apresenta uma nova classificação dos diversos sentidos de multilateralismo, por meio da qual examina as origens do GATT, para determinar sua natureza e funções institucionais.

Multilateralismo procedimental consiste em um processo de negociação, envolvendo diretamente três ou mais participantes, com a finalidade de desenvolver uma política comum. Nessa perspectiva processual, os Estados podem participar de instituições multilaterais, cujos princípios não defendem necessariamente, pois sua atuação resume-se a negociar vantagens mútuas.

Multilateralismo axiológico é desenvolvido a partir do momento em que há consenso suficiente acerca dos princípios e políticas, segundo as quais os participantes irão coordenar suas ações, ainda que nem todos os países tenham contribuído para o desenho da política comum. Assim, os Estados comprometem-se a cooperar, pois acordaram com os princípios do relacionamento.

Multilateralismo instrumental designa o relacionamento baseado na busca por benefícios, em que os participantes decidem coordenar suas condutas sem tê-las previamente negociado ou sem acreditar nos princípios e objetivos estabelecidos pelo sistema.

Multilateralismo coercitivo é a imposição de determinada coordenação política a países mais fracos e dependentes, por um Estado mais poderoso, de modo a forçá-los, por meios econômicos, políticos ou militares, a subordinarem-se. ${ }^{143}$

Diante dessas possibilidades, os Estados Unidos examinaram os três principais modelos de governança econômica internacional a que tiveram acesso, para estabelecer os contornos institucionais de sua proposta:

O Modelo Nazista de Hjalmar Schacht era defendido por muitos membros da diplomacia estadunidense. Fundado sobre vínculos bilaterais, o regime é apontado como o pior exemplo de coerção e discriminação, pois foi desenhado e implementado para garantir um déficit deliberado da balança comercial perante seus parceiros comerciais. Em seguida, os

\footnotetext{
${ }^{142}$ RUGGIE, John Gerard. Multilateralism: the Anatomy of an Institution. International Organization, [s.1.], v. 46, n. 3, 1992, p. 561-568.

${ }^{143}$ MILLER, 2000, p. 9-10.
} 
alemães obrigavam seus parceiros a amortizarem seus créditos, por meio de reinvestimentos na própria Alemanha, ou, ainda, pela compra de produtos alemães sobrevalorizados. O modelo também incluía a manipulação de países fracos, mediante controle cambial.

O incipiente Modelo Soviético consistia na imposição de relações comerciais entre Moscou e seus satélites. O modelo foi construído sobre um regime de subordinação e planejamento das economias centralmente planificadas em função de seus interesses hegemônicos.

O Modelo Britânico era comparativamente o mais equilibrado dos regimes. Inspirado na governança internacional britânica do século XIX, serviu para consolidar a posição da GrãBretanha como centro de uma rede de acordos bilaterais, interligados pela cláusula da nação mais favorecida. Além disso, esse modelo já era conhecido e aplicado pelos EUA desde 1934, por meio do Reciprocal Trade Agreements Act, o qual contribuiu para a negociação de uma série de acordos bilaterais, cujos benefícios eram estendidos, por meio dos efeitos incondicionados do tratamento da nação mais favorecida.

Influenciada pelos pensamentos neoliberais de Cordell Hull, a diplomacia estadunidense adotou como estrutura institucional a criação de uma organização internacional, à qual caberia conduzir o processo de institucionalização da governança econômica internacional, inspirada no modelo britânico. Seu objetivo consistiria na positivação de políticas econômicas neoliberais, as quais deveriam promover, por meio do comércio, estabilidade político-econômica, confiança mútua e condições duradouras à paz mundial, bem como conferir maior eficiência econômica e bem-estar internacional. Em outras palavras, pretendia-se concretizar um multilateralismo axiológico, fundado em princípios do pacifismo neoliberal, por meio do estabelecimento de um multilateralismo procedimental, na forma de uma organização internacional sobre comércio.

Assim, a decisão estadunidense de advogar a favor de um multilateralismo procedimental e axiológico foi sem precedente na história das relações econômicas internacionais. Isso porque os Estados Unidos patrocinaram, voluntariamente, a criação de uma instituição internacional, cujo modelo operacional diminuiria a sua própria soberania, além de limitar sua hegemonia. ${ }^{144}$

${ }^{144}$ MILLER, 2000, p. 9-12. GARDNER, 1969, p. 12. 
Os principais reflexos das negociações entre os Estados Unidos e o Reino Unido podem ser constatados pelas próprias conferências internacionais, convocadas a fim de instituir a Organização Internacional do Comércio. As negociações multilaterais foram iniciadas na Conferência de Londres, em 1946, continuadas nas Conferências de Nova York e Genebra, em 1947, e finalizadas na Conferência de Havana, onde foi redigida, em 1948, a Carta de Havana. Para Clair Wilcox, principal representante estadunidense na negociação da Carta de Havana, a OIC era um projeto "distintamente americano".

A estrutura da Carta de Havana buscava refletir o interesse da maioria dos Estados em instituir uma espécie de código para o comércio internacional, comprometido com a relação entre livre-comércio e pleno emprego. O documento conformava um sistema de normas jurídicas, composto por comandos positivos e negativos, aplicável a todos os Estados-partes. A Organização Internacional do Comércio não seria restrita à função de policiar e observar o cumprimento das normas contidas na Carta de Havana, mas teria competência normativa para produzir discursos jurídico-decisórios acerca de casos concretos a ela submetidos.

A cláusula da nação mais favorecida, que estava no centro da diplomacia comercial estadunidense, foi incluída na minuta da Carta de Havana em 1946, sofrendo posteriormente apenas duas variações em relação à proposta original. Devido à expectativa do relevante papel a ser exercido, o representante dos EUA propôs, sem êxito, realocar a posição da CNMF para constar nos cinco princípios básicos da Organização Internacional do Comércio. ${ }^{145}$

Nesse contexto, é importante considerar um fato bastante incomum, ocorrido durante o processo de preparação da Conferência de Havana. O Secretário-geral das Nações Unidas convidou os Estados responsáveis pelo Comitê Preparatório a propor a aplicação antecipada do conteúdo do artigo 17 da minuta da Carta de Havana, relativo à redução das tarifas alfandegárias mediante negociações. Tal iniciativa já antecipava a oposição estadunidense ao texto integral da Carta de Havana, a qual se revelaria um projeto excessivamente complexo e ambicioso, distante dos interesses originários dos Estados Unidos

Após uma declaração a favor da Carta de Havana, em 24 de março de 1948, pelo então Secretário de Estado, General George C. Marshall, os Estados Unidos decidiram, em dezembro de 1950, retirar seu apoio à Carta Proposta. Sem o suporte de seu principal

\footnotetext{
${ }^{145}$ WILCOX, Clair. A Charter for World Trade. Nova York: Macmillan, 1949, p. 159. MILLER, 2000, p. 9. DAL RI JR., 2003, p. 112-113. CARREAU; JUILLARD, 1998, p. 51. GARDNER, 1969, p. 12.
} 
patrocinador, a Organização Internacional do Comércio não encontrou condições de institucionalizar-se. São apontados três fatores estruturais para o insucesso do projeto estadunidense, no final da década de quarenta: (i) as mudanças políticas e econômicas no cenário global; (ii) a alteração na conjuntura política interna dos EUA, em razão da ascensão dos republicanos ao controle do Congresso; e (iii) os defeitos da Carta de Havana, responsáveis por provocar a oposição de setores da economia estadunidense e a crítica de conservadores neoliberais, os quais a consideravam pouco ambiciosa e excessivamente protecionista para um acordo de livre-comércio.

Em pontual consideração sobre as justificativas, constata-se que o primeiro motivo é relativo às profundas transformações conjunturais do cenário mundial de 1945 a 1950. Quando lançada a negociação para a Organização Internacional do Comércio, os Estados Unidos, apoiados por seus aliados, viviam a utopia de alcançar a paz mundial e o livre-comércio, por meio do estabelecimento de uma organização intergovernamental de vocação multilateral e universal. Todavia, em 1950 já era clara a nova divisão do mundo em torno de duas potências, as quais utilizariam a manipulação econômica para limitar as influências recíprocas, cujo efeito foi a fragmentação da ordem econômica internacional. Além disso, a reconstrução da Europa ocidental, patrocinada pelos EUA, demonstrava-se lenta e extremamente cara. A ascendente ameaça da Guerra Fria exigiu a elaboração do Plano Marshall, tendo por consequência condenar a proposta de criação do sistema multilateral de comércio à marginalidade

Em relação aos defeitos da Carta de Havana, Kenneth Dam apresenta três importantes pontos críticos: (i) dispositivos divergentes dos princípios do livre-comércio e da não discriminação permitiam a manutenção de diversas exceções protecionistas e discriminatórias; (ii) o sistema financeiro internacional, regulamentado pelo Fundo Monetário Internacional, não estava devidamente preparado para as mudanças a serem provocadas pela Carta de Havana, sendo necessária a implementação de instrumento de controle cambial; (iii) a própria concepção da estrutura institucional da OIC e o conteúdo normativo da Carta de Havana, os quais haviam sido acordados como um código substantivo de comércio, ao invés de terem sido 
elaborados para servir como um mecanismo procedimental de solução de controvérsias internacionais. $^{146}$

Fracassado o projeto estadunidense de criar uma Organização Internacional do Comércio com a finalidade de instituir uma governança econômica internacional mais jurídica do que diplomática, o artigo 17 da Carta de Havana passaria a ser utilizado para salvaguardar parte dos resultados obtidos. Fruto da estratégia de duas vias da diplomacia estadunidense, um subproduto das negociações acabou por assumir parte dos objetivos que caberia à OIC. Durante a Conferência de Genebra, foi celebrado um acordo tarifário interino, com prazo de duração de três anos, que consistia em uma espécie de antecipação parcial da Carta de Havana. Denominado de Acordo Geral sobre Tarifas e Comércio, sua concepção deriva diretamente da Carta de Havana, pois consubstancia o primeiro acordo de uma série de negociações tarifárias que seriam conduzidas sob o auspício da nova organização internacional.

A governança das relações econômicas internacionais passou a ser exercida em torno da estrutura jurídica do GATT. Seu escopo era, porém, bem mais restrito se comparado à Carta de Havana, inclusive no que dizia respeito ao comércio internacional, pois disciplinava somente o segmento de bens, excluindo setores essenciais como agricultura e serviços. Diversos capítulos relevantes da Carta de Havana não foram nele previstos, tais como: Emprego e Atividade Econômica, Desenvolvimento Econômico e Reconstrução, Práticas Restritivas de Negócios e Acordos Intergovernamentais de Produtos Primários. Além disso, o GATT era essencialmente um tratado internacional, razão pela qual carecia de uma estrutura institucional adequada, aspecto que colheu, ao longo das décadas vindouras, grande controvérsia doutrinária acerca de sua natureza jurídica. Suas normas e decisões, concebidas segundo uma racionalidade procedimental, eram particularmente sujeitas aos jogos de poder diplomático.

Não obstante, o GATT serviu a seus Estados-partes por mais de 45 anos como fórum de negociação tarifária, centro de produção de normas jurídicas e mecanismo de solução de controvérsias. Depois de entrar em vigor, foram promovidas, no âmbito do GATT, oito rodadas de negociação internacional. As cinco primeiras rodadas visaram à redução

\footnotetext{
${ }^{146}$ CARREAU; JUILLARD, 1998, p. 51. DAL RI JR., 2003, p. 115. DIEBOLD JR., William. The end of I.T.O. Princeton: Princeton University Press, 1952, p. 14. DAM, 1970, p. 14-16.
} 
multilateral de barreiras tarifárias ${ }^{147}$, sendo que apenas as três últimas tiveram alguma implicação significativa para a cláusula da nação mais favorecida e o sistema multilateral de comércio. $^{148}$

A Rodada Kennedy foi, sem dúvida, a experiência multilateral mais sofisticada desde a celebração do GATT. Isso porque, quando iniciada em 1964, foi obrigada a dividir a primazia com outra conferência sobre comércio mundial, a Unctad. A realização simultânea dessas duas reuniões em Genebra simbolizou a necessidade de o clube de ricos prestar atenção aos pleitos dos países subdesenvolvidos quanto às barreiras e preferências comerciais e ao princípio da reciprocidade. O forte impacto político da Unctad permitiu incutir ideias desenvolvimentistas na ordem parcial neoliberal. Após uma longa negociação, as normas do GATT foram finalmente modificadas, a fim de incluir a Parte IV, a qual estabelece um tratamento especial e diferenciado aos Estados-partes subdesenvolvidos.

Após o êxito obtido por cerca de vinte anos, traduzido no formidável corte de tarifas aduaneiras, o GATT defrontou-se com a exacerbação do protecionismo, decorrente da emergência de países subdesenvolvidos e do Japão como novos competidores comerciais e das sucessivas crises do petróleo de 1973 e 1979. Transcorrida nesse período conturbado, a Rodada Tóquio assistiu ao acirramento das disputas por novos mercados e à persistente recessão dos anos 1970, responsáveis respectivamente pelo surgimento do novo protecionismo e do quarto surto de regionalismo e pelas baixas taxas de desenvolvimento. Tal situação provocou adoção de mecanismos protecionistas e discriminatórios pelos Estados-partes.

Além disso, esse ciclo de negociação inseriu sua marca no GATT ao produzir os primeiros acordos plurilaterais sobre as principais matérias regulamentadas no Acordo Geral sobre Tarifas e Comércio. Conhecidos como códigos, tais tratados eram firmados em separado, tendo por finalidade possibilitar aos Estados-partes aderirem a certas políticas comerciais que propiciavam maior compromisso com a integração comercial. Desprovidos de vinculação erga omnis, esses acordos preferenciais constituem conjuntos de comandos negativos e positivos, que conformam um código comercial especializado, com validade limitada aos Estados signatários. A alcunha de GATT à la Carte refere-se justamente a esses pactos de abrangência restrita, que exacerbam o aspecto contratual da relação jurídica. Ao

\footnotetext{
${ }^{147}$ Rodada Genebra, de 1947; Rodada Annecy, de 1948; Rodada Torquay, de 1950; Rodada Genebra, de 1956; e a Rodada Dillon, de 1960 a 1961.

${ }^{148}$ LAFER, 1971, p. 42. CARREAU; JUILLARD, 1998, p. 139. JACKSON, 1997, p. 109-112.
} 
examinar a natureza jurídica desses tratados, John H. Jackson reconhece o surgimento de uma nova estrutura de cláusula da nação mais favorecida, a qual denominou de códigocondicionada. $^{149}$

Com o agravamento da crise econômica, o sistema multilateral de comércio passou a sofrer incontáveis reveses com as contínuas infrações à cláusula da nação mais favorecida e ao princípio da não discriminação. A utilização em larga escala pelos países desenvolvidos de direitos antidumping, salvaguardas, medidas compensatórias, bem como a proliferação de acordos preferenciais de comércio, tinha por objetivo acobertar práticas notoriamente protecionistas e discriminatórias. No mesmo sentido, avolumam-se os contenciosos comerciais entre Estados Unidos, Comunidades Europeias (“CE”) e Japão, cada qual defendendo seus interesses em detrimento de soluções negociadas multilateralmente. Diante do agravamento das tensões, os Estados-partes decidiram convocar a Rodada Uruguai para impedir a iminente guerra comercial e fortalecer o sistema GATT.

Nesse contexto, instaura-se o último ciclo de negociações comerciais do GATT, que transcorreu de 1986 a 1993, sendo responsável por promover o mais difícil, controverso e complexo acordo comercial. Com o inesperado fim da Guerra Fria, a Rodada Uruguai ganha importância ímpar, pois confluíram interesses no sentido de unificar institucionalmente a ordem econômica internacional, sob liderança dos Estados Unidos. Com isso, os Estados celebraram o Acordo Constitutivo da Organização Mundial do Comércio, ao qual atribuiu-se ampla competência normativa sobre as relações econômicas internacionais.

Em pontual resumo, as transformações mais sensíveis incorridas pelo sistema multilateral de comércio são: (i) a criação da própria Organização Mundial do Comércio; (ii) a instituição do Órgão de Solução de Controvérsias; (iii) o surgimento do conceito de empreendimento único (single undertaking), que superou a dimensão à la carte; e (iii) a assinatura dos acordos sobre setores econômicos relevantes: a) agricultura; b) têxteis; c) comércio de serviços; d) medidas relativas a investimento; e) propriedade intelectual. Com isso, há uma ampliação sem precedentes dos efeitos da cláusula da nação mais favorecida

${ }^{149}$ LAFER, 1971, p. 50-51. LONG, 1987, p. 104-105. GARDNER, Richard N. Em busca da Ordem Mundial. Rio de Janeiro: Forense, 1964, p. 158-161. HUDEC, Robert E. Enforcing international trade law: the evolution of the modern GATT Legal System. Salem: Butterworth Legal Publishers, 1993, p. 13-25. TREBILCOCK, Michael J.; HOWSE, Robert. The Regulation of International Trade. $3^{\mathrm{a}}$ ed. Nova York: Routledge, 2005, p. 24. JACKSON, Jackson H. The World Trading System: Law and Policy of International Economic Relations. $2^{\mathrm{a}}$ ed. Cambridge: MIT, 1997, p. 161. PETERSMANN, Ernst-Ulrich. The GATT/WTO Dispute Settlement System: International Law, International Organization and Dispute Settlement. Londres: Kluwer Law International, 1997, p. 47-50. 
sobre áreas do comércio internacional nunca antes regulamentadas multilateralmente. Por consequência, o número de desafios à CNMF aumentou proporcionalmente à expansão de incidência material. ${ }^{150}$

Os elementos essenciais da vertente comercial da ordem parcial de cooperação econômica neoliberal residiam na posição hegemônica dos Estados Unidos, na prevalência da ideologia neoliberal e na nova dimensão institucional, sendo esta decorrente da noção de Estado Intervencionista e de direito internacional de cooperação. Essas características convergiram para modelar a governança internacional do comércio, na qual a regência das relações comerciais é capitaneada pelos EUA, segundo os princípios do pacifismo neoliberal e as normas positivadas no Acordo Geral sobre Tarifas e Comércio.

O sistema multilateral de comércio instituído pelo GATT é o resultado da combinação das concepções de multilateralismo axiológico e procedimental. Axiológico por requerer o consenso sobre os valores e políticas econômicas comuns que conduzem à harmonização, cooperação e coordenação das ações dos Estados-partes. E procedimental, em razão da demanda por envolvimento dos países no processo de negociação, cuja finalidade é determinar tais objetivos e valores a serem alcançados. Nesse particular, a cláusula da nação mais favorecida foi inserida no GATT, implicando o fortalecimento das expectativas normativas e a diminuição dos custos de transação. Seu valor simbólico garantiu a ela o status de pedraangular do sistema GATT na medida em que nele positiva multilateralmente o princípio da não discriminação.

${ }^{150}$ DAL RI JR., 2003, p. 131-133. JACKSON, 1997, p. 157. HUDEC, 1993, p. 103-108 


\subsection{ORDEM ECONÔMICA INTERNACIONAL CONTEMPORÂNEA}

Em 1991, a União das Repúblicas Socialistas Soviéticas entrou rápida e inesperadamente em colapso, levando consigo a ordem parcial de cooperação econômica socialista, o regime comunista, a política autárquica, a planificação econômica, o Estado Social e a ideologia socialista. A crise da década de 1970 conduziu as economias na direção dos mercados domésticos e internacionais. Os países capitalistas desenvolvidos superaram os problemas internos e seguiram rumo à ortodoxia financeira, ao conservadorismo político e à integração econômica. Os países subdesenvolvidos abandonaram as políticas de Industrialização por Substituição de Importações e promoveram progressivamente reformas liberalizantes, adotando, no processo, a ideologia neoliberal. Os países socialistas, com exceções pontuais, desistiram da planificação econômica e incorporaram, em velocidade variada, princípios capitalistas e neoliberais.

O fim da Guerra Fria incidiu diretamente sobre o arranjo estrutural que tornava possível um mundo fragmentado em torno de polaridades definidas. Isso teve por efeito diluir, embora não eliminar, os conflitos de concepção sobre como organizar a vida econômica global. No processo de unificação da ordem econômica internacional, os elementos constitutivos da ordem parcial de cooperação econômica neoliberal são globalizados, em razão da prevalência da governança estadunidense no jogo de poder e verdade internacional, enquanto os aspectos nucleares da ordem parcial desenvolvimentista são incorporados, se compatíveis, na nova ordem global. Nesse cenário de paz positiva, a criação da Organização Mundial do Comércio simbolizou a inauguração de um novo contexto político e econômico das relações econômicas internacionais. Diante disso, poder-se-ia afirmar que o mundo teria chegado ao fim da história? Não haveria qualquer desafio à nova ordem econômica internacional neoliberal?

Tais questionamentos, que há tempos eram predominantemente objeto de trabalhos acadêmicos, ganham relevo e essencialidade, em face da eclosão, em setembro de 2008, da 
maior crise econômico-financeira vislumbrada pelo sistema capitalista desde a Grande Depressão de 1929. Devido justamente à complexidade da sociedade contemporânea, este Capítulo é dedicado a analisar pontualmente as características estruturais da ordem econômica internacional, na exata medida em que se mostrem necessárias à investigação das transformações, dos desafios sistêmicos e das contradições concernentes à cláusula da nação mais favorecida.

Nesse particular, destacam-se, desde os primeiros sinais de desestruturação da ordem polarizada até os primeiros anos do século $\mathrm{XX}$, três temas sensíveis à cláusula da nação mais favorecida: globalização, regionalismo e protecionismo.

\section{a) Globalização}

Os arautos do livre-mercado brandem suas bandeiras em louvor ao capitalismo global neoliberal, o qual passou a imperar com a unificação da ordem econômica internacional. A ideia da globalização ressurge no início da década de 1980 com ar de novidade. Inserido em temas econômicos, o fenômeno é considerado decisivo para as relações econômicas internacionais contemporâneas, pois vem provocando profundas mudanças, ao deslocar o centro gravitacional da vida econômica do Estado para o mercado. O fortalecimento da ideologia neoliberal implica o ressurgimento do mercado como principal meio de organização das relações sociais, o que conduz ao retorno aos debates travados na antiga ordem liberal vigente no século XIX. Em um curto período de tempo, a globalização passou rapidamente da utopia atingível, do sonho capitalista-neoliberal, à causa determinante das mazelas mundiais, responsável por incitar protestos ao redor do globo. Diante desses aspectos multidimensionais e controvertidos, a única certeza é a de que as estruturas da ordem econômica internacional contemporânea são fortemente afetadas pelo processo globalizante.

Tomado o termo em seu sentido amplo, a história conheceu diversos surtos de globalização, em razão dos mais variados motivos. As mais recentes e relevantes expressões desse fenômeno consistem na expansão ultramarina perpetrada por espanhóis e portugueses nos séculos XV e XVI, responsável por alargar o mundo conhecido com a descoberta das rotas 
comerciais para a Ásia e com a conquista das Américas. No século XIX, o imperialismo europeu, liderado pela Grã-Bretanha, promoveu uma segunda onda de conquistas, resultando na reorganização do mapa colonial. Embora as barbáries das Grandes Guerras e a Grande Depressão tenham contido a tendência ao fortalecimento da interdependência, as alianças estratégicas da Guerra Fria possibilitaram conferir ao conflito entre as duas superpotências uma dimensão verdadeiramente mundial. Nesse sentido, a degradação ambiental, ao assumir proporções planetárias, é produto dos movimentos globais. Daí ser necessário compreender as especificidades do processo de globalização contemporâneo, de modo a distingui-lo das ondas precedentes.

O termo globalização permite uma multiplicidade de sentidos, cuja compreensão demanda sua reconstrução histórica e acompanhamento dos fatores que implicaram a acumulação de novos significados. É preciso, pois, optar por uma dentre as variadas definições. Neste trabalho, globalização é entendida como fenômeno social caracterizado pela intensificação sem precedentes das relações que conectam pessoas e localidades ao redor do mundo, segundo uma lógica dialética e contraditória. O processo globalizante é caracterizado pelo alargamento e adensamento dos vínculos, no qual o local e o universal são reciprocamente modelados por complexas redes de interligações, em nítido contraste aos fenômenos sociais de feitio unidirecional. A singularidade das relações contemporâneas advém da eliminação das restrições de espaço e tempo, fruto direto da Revolução Informacional, a qual ensejou a presença simultânea e instantânea em âmbito global. ${ }^{151}$

Em seu aspecto econômico, globalização designa um conjunto de processos econômicos interligados, que, a partir da década de 1970, vêm expandindo e se destacando qualitativamente. Surgida das estruturas da ordem parcial neoliberal, a crise do padrão monetário mundial, desencadeada pelo fim da paridade dólar-ouro, acarretou no colapso do sistema Bretton Woods. A crise monetária associada aos choques do petróleo deflagrou transformações socioeconômicas que resultaram no esgotamento das políticas econômicas keynesianas, causando descontrole inflacionário, estagnação econômica, saturação do mercado

${ }^{151}$ GILPIN, Robert. O Desafio do Capitalismo Global: a economia mundial no século XXI. Trad. Clóvis Marques. Rio de Janeiro: Record, 2004, p. 33-34. AMARAL JR., 2006, p. 52-58. KEOHANE, Robert O.; NYE, Joseph S. Introduction. In: NYE, Joseph S.; DONAHUE, John D. (Org.). Governance in a globalizing world. Washington: Brookings Institution Press, 2000, p. 2-4. GIDDENS, Anthony. As consequiências da modernidade. Trad. Raul Filker. São Paulo: UNESP, 1991, p. 69-70. CASTELLS, Manuel. A sociedade em rede. Trad. Roneide V. Majer. São Paulo: Paz e Terra, 1999, p. 43-66. 
de bens duráveis e problemas de liquidez internacional. Respostas à exaustão do modelo econômico do Estado Intervencionista de bem-estar social apareceram em quatro diferentes vertentes. $^{152}$

A primeira vertente consiste nas transformações das ciências em técnicas produtivas, as quais foram responsáveis pelo surgimento da economia capitalista-informacional e da sociedade em rede. Embora não faça história, a técnica transforma os meios e instrumentos da convivência humana. O processo globalização foi suportado e acelerado pelas inovações tecnológicas, as quais propiciaram o advento da sociedade pós-industrial, fundada no conhecimento e na inovação. Daí a novidade qualitativa desse fenômeno residir, justamente, na revolução dos meios de comunicações, o que resultou na eliminação das restrições espaçotempo, modificando definitivamente a percepção do mundo em escala planetária.

A tecnologia da informação revolucionou as relações sociais, implicando, a partir da década de 1980, a reestruturação da ordem parcial neoliberal. Isso não significa aceitar o dilema do determinismo na relação entre sociedade e tecnologia; mas, rejeitam-se as concepções que sustentam ser a tecnologia elemento determinante da sociedade, ou ser a sociedade hábil em prescrever o curso da transformação tecnológica. $\mathrm{Na}$ verdade, tal contradição é aparente, pois tecnologia é sociedade, e esta não pode ser compreendida sem seus instrumentos tecnológicos. Dessa forma, o surgimento do novo paradigma tecnológico iniciou o processo de transformação das estruturas sociais.

Característica distintiva da Revolução Informacional é a aplicação do conhecimento e da informação na geração de novos conhecimentos e dispositivos de processamento da informação, de modo a formar um ciclo de realimentação cumulativo entre a inovação e seu uso. A difusão cíclica implica a amplificação de seu poder, na medida em que a tecnologia deixa de ser apenas uma ferramenta a ser empregada, mas torna-se um processo a ser continuamente desenvolvido pelos usuários, que a utilizam e a redefinem.

Com isso, há a aproximação entre os processos sociais de criação e manipulação de símbolos e as forças produtivas, o que vem propiciando a reestruturação da economia capitalista. As consequências são vislumbradas na configuração da sociedade informacional, a qual é formada, por um lado, pelo novo sistema econômico e tecnológico denominado capitalismo informacional, cuja principal fonte de produtividade está na tecnologia de geração

${ }^{152}$ FARIA, 2002, p. 59-85. 
de conhecimentos, de processamento de informação e de comunicação de símbolos. E, por outro, por redes que constituem a nova forma de organização social. Essa sinergia alterou profundamente as possibilidades de comunicação na sociedade, gerando a percepção de que poder, riqueza e liberdade passaram a depender das condições de acesso e controle dessas novas tecnologias e das informações nelas veiculadas. ${ }^{153}$

Permeável às novas ideias do conservadorismo neoliberal, o setor financeiro foi pioneiro em promover a abertura comercial, em um movimento a favor da revogação dos monopólios estatais, da progressiva desregulamentação dos mercados, da reestruturação e universalização do sistema financeiro, bem como da crescente mobilidade e desmaterialização monetária. Os conservadores defendiam que as debilidades decorrentes do Estado de bemestar social poderiam ser superadas por políticas monetaristas e pela diminuição da intervenção estatal nas relações econômicas. Suas consequências foram a tentativa de remodelar a própria noção de Estado Intervencionista e a remoção dos controles à livrecirculação de capitais.

Desde meados dos anos 1970, a suspensão dos controles de capital, a criação de novos instrumentos financeiros e os avanços tecnológicos têm contribuído para intensificar a integração do sistema financeiro. A revolução financeira vem conectando estreitamente as economias nacionais, aumentando significantemente o volume de capital disponível e, em certos casos, acelerando o crescimento econômico, razão pela qual passou a exercer um profundo impacto na economia global. A consequência por desregulamentar, intensificar e promover maior dinamismo aos fluxos financeiros expressa-se nas tendências à volatilidade e à especulação. A gigantesca escala, velocidade e natureza especulativa dos movimentos financeiros transfronteiriços tornaram os governos vulneráveis às mudanças bruscas na circulação. Quando investidores internacionais decidem abandonar um mercado em busca de melhores oportunidades de lucro ou por suspeita de instabilidade econômica, há a possibilidade, a depender da intensidade, de causar graves prejuízos à economia nacional, regional e, inclusive, global. Nesse particular, ressalta-se a crise econômico-financeira de setembro de 2008, que, originada em problemas estruturais da economia doméstica dos

${ }^{153}$ FARIA, 2002, p. 75-86. CASTELLS, 1999, p. 43-66. FERRAZ JR., Tercio Sampaio. Direito Constitucional: liberdade de fumar, privacidade, Estado, Direitos Humanos e outros temas. São Paulo: Manole, 2007, p. 260. 
Estados Unidos, teve seus efeitos catastróficos rapidamente alastrados ao redor do globo, colocando diversos países próximos do colapso.

No plano da organização industrial, o modo de produção fordista foi superado pelo modelo de especialização flexível, cuja ênfase na racionalização das estruturas organizacionais e dos procedimentos decisórios deflagrou um processo de reengenharia, que incorreu na crescente concentração de grupos econômicos, visando à redução de custos e ganhos de escala. $^{154}$

Por fim, a globalização econômica, ao induzir à complementaridade entre comércio internacional e investimento estrangeiro direto, altera radicalmente a atuação dos atores privados. No passado, comércio e investimentos eram tratados como atividades distintas sujeitas a regulamentações específicas. Para as corporações transnacionais, comércio e investimentos não são estratégias alternativas, mas meios complementares de desenvolver a produção em âmbito mundial. Essas observações revelam que, não obstante à defesa do livrefluxo de capitais de longo prazo, os investimentos estrangeiros diretos estão altamente concentrados e desigualmente distribuídos intrafirma, razão pela qual tendem a procurar mercados grandes ou potenciais.

Controlando a maior parte dos capitais de investimento, da tecnologia e da produção em todo mundo, as empresas transnacionais tornaram-se os principais agentes da globalização econômica, visto atuarem em diversos países, segundo uma diretriz uniforme que assegura certa coerência estratégica às ações de suas unidades nacionais, cuja finalidade é diminuir os custos e obter o máximo de retorno. Por movimentarem vultosos recursos, as empresas globais detêm posição privilegiada nas relações econômicas internacionais, obrigando os Estados a concederem generosos benefícios para atraí-las. A globalização das estratégias empresariais tem por efeito lançar os Estados em um tabuleiro, a fim de confrontarem-se como peças em um contínuo e ininterrupto jogo de xadrez, no qual a satisfação da vitória é efêmera e momentânea, pois depende do esforço reiterado para manter a melhor oferta. ${ }^{155}$

Todas essas vertentes convergem para conferir os contornos originais do processo contemporâneo de globalização econômica, o qual ganharia impulso com o fim da ordem fragmentada. Entretanto, ainda que a globalização seja o mais relevante fator da economia

\footnotetext{
${ }^{154}$ FARIA, 2002, p. 87-95. GILPIN, 2004, p. 37-40.

${ }^{155}$ GILPIN, 2004, p. 40-41. GILPIN, 2002, p. 288-290. BECK, Ulrich. O que é Globalização? Equívocos do globalismo: respostas à globalização. Trad. André Carone. São Paulo: Paz e Terra, 1999, p. 121-123.
} 
internacional no início do século XXI, a extensão e as consequências, positivas e negativas, da economia globalizada têm sido exageradas e sobrevalorizadas, na medida em que as economias domésticas permanecem como fator decisivo das relações internacionais dos Estados.

A globalização e a interdependência possuem um papel relevante em interligar as economias nacionais. Todavia, o fenômeno está longe de ser justo e equitativo acerca da distribuição de seus benefícios. O declínio da participação da parcela mais pobre da população na renda global foi acompanhado pela concentração de renda nos países desenvolvidos. Críticas ferrenhas são endereçadas às desigualdades mundiais, destacando que a globalização, ao aprofundar o fosso entre ricos e pobres, fomenta os conflitos sociais e internacionais. Ainda que muitos problemas socioeconômicos decorram de fatores domésticos, não é menos verdade que a globalização pouco fez para promover maior equidade na distribuição mundial de riqueza. As instabilidades financeiras da década de 1990 somadas aos protestos políticos evidenciam as tensões entre o global e o local, entre o mercado e o social.

Os benefícios do capitalismo global não surgem sem custos. As corporações podem tomar empréstimos a juros baixos nos mercados financeiros internacionais, o que as expõem a exigências e controles dos investidores. $\mathrm{O}$ comércio internacional permite baratear os custos e aumentar a variedade e qualidade dos bens consumidos, acarretando a competição indesejada para produtores domésticos. A dívida externa permite aos Estados aumentar seus gastos, mas sujeitam-nos a crises cambiais. Países abrem suas fronteiras à economia mundial e oferecem aos cidadãos eficientes potencial para alcançar riqueza e sucesso; porém, podem condenar outros a condições difíceis e dolorosas. Não há comércio sem concorrência, finanças sem riscos, ou investimentos sem obrigações. É inerente à economia capitalista neoliberal a produção de efeitos positivos e negativos.

A integração econômica internacional produz, em geral, benefícios econômicos à sociedade. Os demais modelos de governança econômica internacional surgidos após a Primeira Guerra foram desastrosos ao mundo. Entretanto, apostar em uma globalização a qualquer custo seria igualmente equivocado, bem como uma demonstração de ignorância acerca dos fatores que conduziram ao declínio da ordem liberal. Nesse sentido, a história recente das relações econômicas internacionais demonstra dois aspectos importantes: as 
economias funcionam melhor quando são livres e não discriminadas; as economias funcionam melhor quando são governadas com vistas a aplacar as fontes de insatisfação.

Desse modo, o desafio à ordem economia internacional contemporânea não reside nas políticas neoliberais em si, mas consiste em aliviar as tensões entre economia global e política global, por meio da solução do problema central da globalização: a governança econômica internacional. A integração econômica e os desafios sociais são fenômenos imbricados, razão pela qual exigem coordenar movimentos globalizantes e programas comprometidos com melhorias sociais. A governança econômica internacional deve ser responsável por organizar o desenvolvimento econômico e assegurar a distribuição mais justa de seus benefícios. ${ }^{156}$

\section{b) Regionalismo}

O regionalismo é um fenômeno multidimensional, pois congrega elementos políticos, econômicos, culturais e sociais. O fenômeno é constituído na forma de tratados internacionais ou como efeito direto da crescente interdependência entre os países. Em termos amplos, é percebido pelos atores internacionais como uma estratégia para potencializar, viabilizar e concretizar determinados interesses e valores, tanto nacionais quanto coletivos, os quais estabelecem o ritmo e a intensidade da coordenação interestatal. A diversidade de experiências de integração regional implica distintas estruturas institucionais, as quais conformam o direito internacional e a disposição do arranjo cooperativo aos objetivos particulares.

Em sua vertente econômica, o regionalismo é um instrumento utilizado pelos Estados para fortalecer sua posição nas relações econômicas internacionais, a fim de concentrar fluxos econômicos e influenciar a governança econômica internacional. Com isso, os Estados podem exercer, no nível regional, o controle que são incapazes de obter no nível nacional e global. A dimensão econômica também está sujeita a subdivisões: comercial, financeira e monetária. ${ }^{157}$

\footnotetext{
${ }^{156}$ GILPIN, Robert. Global Political Economy: understanding the international economic order. Princeton: Princeton University, 2001, p. 3. FRIEDEN, 2008, p. 496-502. AMARAL JR., 2006, p. 64-65.

${ }^{157}$ HVEEM, Helge. Political Regionalism: master or servant of economic internationalization? In: HETTNE, Björn; INOTAI, András; SUNKEL, Osvaldo (Eds.). Globalism and the New Regionalism. Londres: Palgrave Macmillan, 1999, p. 90. AMARAL JR., 2006, p. 66-67.
} 
Em breve resumo histórico, o regionalismo surge na primeira metade do século XIX na forma das primeiras uniões aduaneiras, cujo escopo era facilitar a integração econômica de regiões que compartilhassem semelhanças culturais. Por vezes, os países e regiões valiam-se desse instrumento para iniciar um processo aglutinador que resultaria na formação de um novo Estado. Em razão disso, tais tratados não tinham por efeito excetuar o tratamento da nação mais favorecida, não comprometendo o movimento de liberalização comercial. A Zollverein, formada pelos estados germânicos, é símbolo dessa primeira onda de regionalismo.

Após a Primeira Guerra Mundial, foram celebrados tratados internacionais que tinham por finalidade consolidar os impérios coloniais, por meio da formação de um sistema preferencial de comércio, e instituir medidas discriminatórias e protecionistas capazes de impedir ou dificultar as relações econômicas com terceiros Estados. Reflexo do esgotamento da ordem liberal, a British Commonwealth foi a mais importante manifestação dessa segunda onda de regionalismo.

A terceira onda de regionalismo tem início com o fim da Segunda Guerra, constituindo dois períodos distintos. O primeiro tinha por escopo permitir a reorganização do comércio na Europa ocidental e desta com suas antigas colônias, as quais buscavam se integrar à realidade internacional. Os marcos desse movimento foram o Tratado de Roma de 1957, constitutivo da Comunidade Econômica Europeia (“CEE”), e a Convenção de Yaoundé de 1963. No segundo período, visava-se criar economias de escala, como parte da política desenvolvimentista de ISI. A Associação Latino-Americana de Livre-Comércio (“ALALC”) é o mais importante exemplo. $^{158}$

Desde meados da década de 1980, houve uma renovação do espírito de integração regional, a partir do qual surgiu um novo impulso em direção ao regionalismo econômico. Denominada de novo regionalismo, a quarta onda tem diferenças fundamentais em comparação ao movimento regional das décadas de 1950 e 1960, possuindo um significado muito maior para a economia mundial. Inaugurado pelo Ato Único Europeu de 1986, o novo regionalismo repercutiu universalmente, tendo por efeito positivo aumentar a integração das atividades econômicas no contexto específico dos acordos preferenciais de comércio. Com

\footnotetext{
${ }^{158}$ MANSFIELD, Edward D.; MILNER, Helen V. The New Wave of Regionalism. International Organization, [s.l.], v. 53, n. 3, 1999, p. 602. GIBB, Richard. Regionalism in the World Economy. In: GIBB, Richard; MICHALAK, Wieslaw (Eds.). Continental trading blocs: the growth of regionalism in the world economy. Nova York: John Wiley \& Sons, 1994, p. 1. VINER, Jacob. The Customs Union Issue. Nova York: Carnegie Endowment for International Peace, 1950, p. 12-14.
} 
efeito, parcela considerável do comércio internacional ocorre sob a tutela desses tratados internacionais. Nos limites estipulados para a presente investigação, o fenômeno do regionalismo contemporâneo será examinado segundo quatro perspectivas: histórica (interna e externa), ideológica e institucional-legal.

Na perspectiva histórica interna, o início do movimento remonta ao começo da década de 1980, período no qual a Europa ocidental encontrava-se imersa na crise econômica e no pessimismo. Para superar a paralisia, os países europeus começaram a planejar uma fusão radical de seus mercados domésticos. A criação de um mercado europeu completamente integrado era vislumbrada como medida essencial para garantir o rejuvenescimento da estagnada economia europeia. Aprovado o Ato Único Europeu, os Estados-membros da CEE iniciaram imediatamente a implementação de suas políticas integracionistas. O sucesso propiciado pela formação de um mercado único, dotado das quatro liberdades econômicas, impulsionou os países da CEE em direção a uma proposta ainda mais ambiciosa: a unificação monetária. A celebração do Tratado de Maastricht em 1992 estabeleceu a União Europeia ("UE”), bem como dispôs sobre as novas medidas de coordenação econômica, a criação do Banco Central Europeu e a formação da união monetária. Para todos os propósitos econômicos, os Estados-membros da UE tornariam-se, em 1999, a maior unidade econômica mundial.

Os resultados positivos obtidos com a integração europeia estimularam todos os países a aderir ao novo regionalismo, em especial os Estados Unidos. Primeiramente, os EUA criaram a Iniciativa da Bacia do Caribe, que concedeu aos países da região e seu entorno acesso preferencial ao mercado estadunidense. Em seguida, Estados Unidos e Canadá converteram sua histórica relação econômica na forma de um acordo de livre-comércio. Em 1994, o México uniu-se a eles, resultando na celebração do Tratado de Livre-Comércio da América do Norte ("Nafta"), o qual seria o pioneiro em unir países desenvolvidos e subdesenvolvidos sob a mesma área de livre-comércio. Na década seguinte, o Nafta removeria todas as barreiras à circulação de bens, capitais e serviços.

No mundo subdesenvolvido, Brasil e Argentina iniciaram em 1985 negociações para a criação de uma área de livre-comércio, que, por fim, acabou por incluir Uruguai e Paraguai. O 
Mercado Comum do Sul (“Mercosul”) começou a atuar em 1994, tendo por objetivo fortalecer suas economias, por meio da combinação de seus mercados. ${ }^{159}$

Compreendidos os fatores internos, é preciso verificar os elementos externos à lógica integracionista regional e os respectivos impactos conjunturais. Inseridas no jogo de poder e verdade, as relações econômicas entre Estados Unidos e a Europa Ocidental costumam variar da cordialidade à exclusão, da cooperação à competitividade predatória, em razão dos interesses, valores e necessidades econômicas particulares. Com o fim da Segunda Guerra, os EUA patrocinaram a criação do sistema multilateral de comércio, contando com amplo apoio europeu. Por sua vez, o projeto de integração europeia recebeu suporte da potência estadunidense. Os conflitos surgiram quando os países europeus ocidentais decidiram acelerar a regionalização ao arrepio do processo de abertura comercial em âmbito multilateral. Cientes dos efeitos discriminatórios e protecionistas produzidos pelos acordos preferenciais de comércio, os Estados Unidos decidiram empregar sua influência dominante sobre a ordem parcial neoliberal para acelerar a liberalização comercial, na tentativa de equilibrar tais desvantagens econômicas.

Nesse sentido, a cada passo em direção à integração regional, os países europeus obtiveram uma reação proporcional estadunidense. A criação da Comunidade Econômica Europeia levou às reduções tarifárias acordadas nas Rodadas Dillon e Kennedy. A Rodada Tóquio foi lançada para equilibrar a primeira ampliação da CEE. Em resposta ao Ato Único Europeu de 1986, os Estados Unidos iniciaram a tratativas relativas ao Nafta. A relutância das Comunidades Europeias em se empenhar na conclusão da Rodada Uruguai e a preocupação com a afirmação de uma autossuficiência europeia resultaram numa mudança definitiva de percepção e comportamento dos EUA, os quais iniciaram uma intensa corrida para celebrar acordos de livre-comércio.

Temendo que a excessivamente letárgica Rodada Uruguai não chegasse a bom termo, diversos países preferiram aderir a acordos preferenciais de comércio. À medida que os países subdesenvolvidos liberalizavam suas economias, abandonando as políticas de ISI, perceberam a necessidade de evitar uma exposição direta à concorrência internacional, por meio da celebração de APC, os quais poderiam assegurar ganhos na economia de escala para suas indústrias e defender-se das práticas discriminatórias dos EUA e da UE. A disputa entre o

${ }^{159}$ FRIEDEN, 2008, p. 407-409. GILPIN, 2004, p. 62. 
regional e o multilateral produziu, no final da década de 1990, um saldo de uma centena de arranjos preferenciais, os quais foram majoritariamente negociados a partir da década de 1980.

De modo geral, o ressurgimento do regionalismo como fenômeno relevante para as relações econômicas internacionais está inserido no contexto de transformações estruturais da ordem parcial neoliberal, possuindo cinco fatores históricos de destaque. Primeiro, o fim da Guerra Fria permitiu aos países capitalistas dedicarem-se à realização de seus interesses econômicos. Segundo, o sucesso do projeto de integração europeu. Terceiro, a ascensão da doutrina da política comercial estratégica e o declínio das teorias de integração, as quais vinculavam os acordos preferenciais de comércio a um necessário processo integracionista. Quarto, o evidente desinteresse de certos Estados-partes do GATT, principalmente as Comunidades Europeias, em progredir com as negociações comerciais da Rodada Uruguai. Cinco, a mudança de postura dos Estados Unidos perante seus aliados.

O quarto surto de regionalismo econômico expressa, assim, o esforço dos Estados em responder adequadamente aos problemas políticos cotidianos e aos desafios de uma economia global e interdependente. Os arranjos regionais servem para aumentar a cooperação e a confiança entre as partes-contratantes, ampliar a dimensão do mercado, gerar economia de escala, diminuir custos de transação, bem como fortalecer sua autonomia e poder de barganha nas negociações comerciais internacionais. Os grupos de Estados permitem a mútua proteção em um mundo incerto, graças à globalização intensamente competitiva e transformadora.

Nos primeiros anos do século XXI, o regionalismo exige quatro características principais: (i) o agrupamento entre países de nível equivalente ou diferenciado de desenvolvimento; (ii) a enorme discrepância do nível de institucionalização, em razão de convivência entre estruturas institucionais simples e sofisticadas; (iii) o caráter multidimensional do fenômeno, visto não focar apenas questões econômico-comerciais; (iv) o fortalecimento da identidade regional, mediante o aprofundamento do vínculo entre indivíduo e uma comunidade mais ampla. ${ }^{160}$

Parcela dos ideólogos atribui ao novo regionalismo, ainda que sujeito a críticas, um elemento diferenciador adicional: a abertura estrutural. A expressão regionalismo aberto incorpora três características conformadoras do conceito. Primeiro, a liberdade associativa

\footnotetext{
${ }^{160}$ GILPIN, 2004, p. 63. HURRELL, Andrew. O ressurgimento do regionalismo na política mundial. Contexto Internacional, Rio de Janeiro, v. 17, n. 1, 1995, p. 25-28. PANAGARIYA, Arvind. Regionalism in trade policy: essays on preferential trading. Singapura: World Scientific, 1999, p. 31-35.
} 
permite e encoraja à acessão de novos Estados. Segundo, a necessidade de consistência com o disposto no artigo XXIV do GATT. E, por último, liberdade comercial, que consiste na possibilidade de as partes-contratantes liberalizarem seu comércio, unilateral ou reciprocamente, com terceiros Estados não partes.

Particularmente aos processos de integração econômica, destaca-se que, enquanto a terceira onda de regionalismo tinha por objetivo a liberalização comercial, por meio de áreas de livre-comércio e uniões aduaneiras, o novo regionalismo vem promovendo a integração em suas três vertentes: comercial, financeira e monetária. Além disso, os fenômenos regionais têm conduzido à formação de níveis variados de coordenação das relações econômicas internacionais. Essa tendência vem fomentando temores acerca da possibilidade do surgimento de uma nova forma de fragmentação da ordem econômica internacional contemporânea em blocos econômicos rivais, centrados nas três economias dominantes: Estados Unidos, Comunidades Europeias e Japão. ${ }^{161}$

Não obstante, o elemento geográfico, que denominava o fenômeno, tem se diluído ao longo do tempo, ao passo que os acordos preferenciais são cada vez mais transregionais e mesmo transcontinentais. A intensificação das relações econômicas internacionais transformou Estados Unidos, Comunidades Europeias e os blocos do leste e sudeste asiáticos, como a Associação de Nações do Sudeste Asiático (“ASEAN"), em centros promotores de APC. A incorporação do regionalismo às estratégias das potências econômicas serve para aumentar ou preservar seus próprios ganhos relativos e protegê-los de competidores externos que ameacem seu bem-estar econômico, bem como compartilhar os benefícios de uma economia global em expansão.

Os Estados passaram, assim, a conceber suas estratégias econômicas vertidas em três planos. No plano multilateral, as decisões de cooperação vinculam praticamente todos os países ao sistema multilateral de comércio. O nível regional é constituído por acordos preferenciais que visam concretizar planos econômicos mais ambiciosos. E, finalmente, a camada doméstica em que estão presentes os condicionantes internos e onde devem ser executadas as políticas econômicas. Nesse cenário, o jogo das relações econômicas internacionais ganha complexidade, pois os Estados devem coordenar sua atuação simultânea em três níveis, a fim de otimizar os benefícios nas variadas frentes. É evidente que os três

${ }^{161}$ GILPIN, 2004, p. 63-64. 
níveis de negociação comunicam-se, visto que, por não constituírem sistemas autocontidos, suas dinâmicas internas ressoam nas demais camadas, afetando o comportamento estatal. ${ }^{162}$

Nesse sentido, a globalização e o regionalismo são processos que, apesar de possuírem lógicas próprias e atores não necessariamente coincidentes, influenciam-se mutuamente, na medida em que coexistem, relacionam-se e podem assumir importância distinta ou antagônica em razão da conjuntura. A porosidade das fronteiras, presente na interligação das três dimensões de interesses, transforma temas tradicionalmente domésticos em regionais e multilaterais; e vice-versa.

Inseridos na lógica da globalização versus a lógica da fragmentação, o sistema multilateral de comércio e os sistemas regionais interligam-se, por meio de vínculos institucionais complexos. O SMC é institucionalizado pela Organização Mundial do Comércio, tendo por finalidade liberalização multilateral do comércio internacional, orientada pela cláusula da nação mais favorecida e pelos princípios da não discriminação, reciprocidade, transparência, cooperação e paz. Os regimes regionais não são vinculados ao sistema GATT/OMC, razão pela qual a proliferação de APC pode implicar a expansão de vínculos preferenciais, sobreposição de competências ratione materiae, desinteresse nas rodadas multilaterais de negociações comerciais, bem como o aumento da suscetibilidade dos países subdesenvolvidos à influencia dos países desenvolvidos. ${ }^{163}$

Sob a perspectiva ideológica, é preciso compreender os fundamentos da lógica subjacente à complexidade relacional entre a globalização multilateral e o regionalismo preferencial. A solução de tensões entre esses processos adquire importância decisiva, dado o impacto na economia global. Daí a governança econômica internacional ser responsável por coordená-los no sentido de aumentar a estabilidade e a confiança nas interações entre agentes econômicos, bem como promover o bem-estar mundial. Entretanto, as políticas internacionais de cooperação econômica dependem da perspectiva, de complementaridade ou de antagonismo, que se tem sobre o relacionamento entre globalização e regionalismo e sobre os sistemas multilateral e regionais de comércio.

${ }^{162}$ GALVIN, Bridig; LANGENHOVE, Luk Van. Trade in a world of regions. In: SAMPSON, Gary P.; WOOLCOCK, Stephen (Eds.). Regionalism, multilateralism, and economic integration: the recent experience. Tóquio: United Nations University Press, 2003, p. 277-278. CRAWFORD, Jo-Ann; FIORENTINO, Roberto V. The Changing Landscape of Regional Trade Agreements. Genebra: WTO Publication, 2003. Disponível em <http://www.wto.org>. Acesso em: 28 de junho de 2009. Discussion Paper n. 8, p. 4-5. GILPIN, 2004, p. 65.

${ }^{163}$ AMARAL JR., 2006, p. 71-73. LAFER, 1998, p. 48. PRAZERES, Tatiana Lacerda. A OMC e os blocos regionais. São Paulo: Aduaneiras, 2008, p. 377-382. 
Os neoliberais conservadores sustentam que a globalização econômica acabará triunfando sobre o regionalismo, pois há um movimento linear e inexorável, impulsionado por forças econômicas e tecnológicas, que conduzem a economia internacional a níveis cada vez mais elevados de integração. Esse processo geral de integração econômica pode ser eventualmente impedido por forças irracionais ou interesses paroquiais, as quais só conseguem resistir, por breve período de tempo, às pressões do mercado global. Desse modo, ainda que possam obter êxitos parciais, as integrações regionais constituem apenas elementos de contribuição e de transição para uma economia global sem fronteiras.

Contemplando um horizonte diferente, há economistas e ideólogos que acreditam que o fim da Guerra Fria e o acirramento da competição econômica global poderão engendrar um novo processo de fragmentação da ordem econômica internacional. Os blocos regionais, por serem constituídos pelos interesses e valores de seus Estados-partes, podem ser mais suscetíveis a pressões protecionistas, ou concentrar vantagens que os coloquem em posição de impor políticas comerciais, estratégicas ou discriminatórias, prejudicando os demais países. Com isso, a ordem econômica internacional seria cindida em regiões econômicas, as quais seriam preferíveis ao nacionalismo e ao protecionismo comercial.

Por fim, há uma terceira corrente que defende que a globalização e o regionalismo estão em um processo dialético não linear de integração econômica. Haveria uma relação de complementaridade entre os dois movimentos, visto que os acertos regionais não passam de uma tentativa dos Estados de controlar o que não conseguem fazê-lo no âmbito nacional ou multilateral. ${ }^{164}$

$\mathrm{Na}$ dimensão institucional, a relação de antagonismo e complementaridade entre sistema multilateral de comércio e sistemas regionais pode ser examinada em termos normativos, negociais e funcionais.

Dentre os elementos antagônicos, destaca-se o impacto negativo que os regimes preferenciais têm sobre as normas de comportamento e organização positivadas no sistema multilateral de comércio. O desafio regulatório surge da transversalidade temática, cujas consequências implicam os conflitos entre normas regionais e multilaterais e a complexidade regulatória, responsável por originar um emaranhado de regras. Os desafios institucional e sancionatório resultam da sobreposição das jurisdições dos mecanismos de solução de

${ }^{164}$ GILPIN, 2004, p. 64-68. 
controvérsias, os quais podem produzir decisões conflitantes sobre o mesmo caso. Quanto ao processo negociador, o regionalismo pode reduzir a ambição dos Estados nas negociações multilaterais, à medida que seus interesses e recursos são desviados em prol de outros objetivos, tendo por consequência a diminuição geral dos possíveis benefícios acordados. Ainda que possam ser coordenados, os APC têm por escopo privar terceiros não partes dos benefícios acordados, sendo, funcionalmente, antagônicos com o sistema GATT/OMC.

Ao contrário, há fatores positivos que sugerem a complementaridade entre os sistemas regionais e o SMC. A partir da concepção de que os fenômenos são convergentes, constata-se que os regimes preferenciais têm a função de acelerar o processo de integração econômica. Nesse sentido, a regulação internacional, por meio de acordos preferenciais, pode servir de laboratório experimental para a futura multilateralização de certos temas; propiciar a convergência normativa, facilitando a harmonização e uniformização dos discursos jurídicoconvencionais; e promover abertura comercial. Com efeito, assistir-se-ia à diluição da resistência acerca das novas disciplinas, ao adensamento de juridicidade, à possibilidade de incorporação de bem-sucedidas experiências regionais. O processo negociador poderia ser, enfim, beneficiado pela diminuição de propostas nas negociações multilaterais, em razão da tendência à concentração dos interesses estatais em pautas regionais, propiciando ganho de eficiência. Além disso, haveria incentivos cruzados para promover a liberalização nos níveis regionais e multilateral, o que beneficiaria o multilateralismo.

O desafio imposto pelo regionalismo ao multilateralismo vislumbra fatores negativoantagônicos e fatores positivo-complementares. Na perspectiva de Tatiana L. Prazeres, as dificuldades geradas pelo regionalismo são claras, concretas e operam no presente, enquanto os benefícios são potenciais, futuros e incertos. Em linhas gerais, o SMC e os acordos preferenciais seriam antagônicos no curto prazo, mas nutririam um potencial de complementaridade no médio prazo. Em síntese, num retrato presente, o vetor de antagonismo ganha destaque e, apenas num filme futuro, a força da complementaridade adquire maior relevância na relação regionalismo e multilateralismo comercial. ${ }^{165}$

$\mathrm{Na}$ dialética relação entre os processos de globalização e de regionalismo reside um dos mais sensíveis desafios da ordem econômica internacional contemporânea, em virtude de

\footnotetext{
${ }^{165}$ AMARAL JR., 2008, p. 168. PRAZERES, 2008, p. 377-382. HART, Herbert L. A. O Conceito de Direito. Trad. A. Ribeiro Mendes. Lisboa: Fundação Calouste Gulbenkian, 2001, p. 53-57.
} 
seu potencial transformador. Os riscos e possibilidades dos acordos preferenciais de comércio aumentam as incertezas das relações econômicas internacionais, na medida em que enfraquecem as expectativas normativas, institucionalizadas no sistema multilateral de comércio. Subjacente às diversas teorias, o jogo de poder entre os agentes econômicos determinará o conteúdo sobre o regionalismo prevalecente no discurso verdadeiro, cujos efeitos poderosos de captura incidirão sobre as instituições internacionais. Assim, a gestão da tensão entre o regionalismo preferencial e a globalização multilateral cabe à governança econômica internacional, a qual é responsável por direcionar tais movimentos para a concreção dos objetivos da ordem econômica internacional contemporânea.

\section{c) Novo protecionismo}

As sucessivas rodadas de negociação do GATT foram responsáveis por reduzir as barreiras tarifárias, as quais foram originalmente concebidas como instrumentos de políticas estatais pela ideologia protecionista clássica. Todavia, à medida que as tarifas aduaneiras eram eliminadas, proliferaram barreiras não tarifárias e outras medidas para proteger, restringir ou discriminar nas relações econômicas internacionais.

Embora não seja um fenômeno novo, as barreiras não tarifárias passaram a constituir um fator importante dos fluxos econômicos globais, em razão da eliminação gradual das barreiras tarifárias. O novo protecionismo manifesta-se distintivamente na forma de barreiras não tarifárias, acordos de restrição voluntária de exportação, medidas unilaterais de defesa comercial e acordos preferenciais de comércio. Os novos instrumentos protecionistas e discriminatórios tornaram-se um obstáculo importante para a liberalização comercial, visto que muitas vezes tomam a forma de medidas governamentais internas, com o objetivo de manipular os fluxos econômicos internacionais, o que implica infração aos dispositivos do sistema multilateral de comércio.

A denominação novo protecionismo decorre, justamente, desse caráter velado que diferencia as políticas e medidas por ele defendidas. Daí a dificuldade de combater os dispositivos protecionistas ocultados na forma de atos administrativos, leis domésticas e 
práticas governamentais. Em razão disso, torna-se complicada a tarefa de distinguir entre barreiras não tarifárias e outras medidas estatais lícitas, como a inspeção alfandegária. A falta de transparência impede aferir com precisão o impacto desses atos ilícitos no volume total do comércio mundial; porém, seus efeitos têm suscitado transformações no padrão de comportamento dos atores econômicos internacionais. ${ }^{166}$

A ascensão e a proliferação do novo protecionismo têm produzido mudanças estruturais nas relações econômicas internacionais, cujos efeitos são, até certo ponto, contraditórios. Primeiramente, promovem a oligopolização e cartelização de setores econômicos, criando barreiras de entrada a novos agentes econômicos. Em segundo, obrigam os países a investir em aprimoramentos tecnológicos e buscar exportar produtos com maior valor agregado. O terceiro efeito tem provocado transformação organizacional e espacial da indústria. Nas décadas de 1950 a 1970, o fluxo comercial era predominantemente interfirma, ou seja, entre setores econômicos de países diferentes. Devido ao novo protecionismo, impulsionado pela globalização, as interações econômicas têm se deslocado para o comércio intrafirma, responsável por concentrar o intercâmbio comercial dentre as empresas do mesmo grupo econômico, localizadas em diferentes países. Isso explica a dispersão territorialmente, por meio de investimento estrangeiro direto, das empresas transnacionais, para países que não sejam objeto de medidas restritivas impostas pelos países importadores.

$\mathrm{Na}$ década de 1970, a letargia no processo de liberalização comercial e o movimento em direção ao novo protecionismo incidiram sobre os Estados Unidos, provocando crescentes temores quanto ao declínio de sua superioridade econômica. O primeiro esforço para preservar os setores industriais de relevância política e econômica foi adotar medidas restritivas de comércio, as quais serviam para dividir o mercado mundial e distribuir seus fragmentos. $\mathrm{O}$ Acordo Multifibras de 1973 estabeleceu restrições às importações têxteis e de vestuário de países em desenvolvimento, tendo por efeito violar o princípio da não discriminação do GATT. O novo protecionismo ganhou impulso nas décadas seguintes, resultando na celebração de acordos preferenciais e acordos de restrição voluntária, bem como na imposição de barreiras não tarifárias para a proteção de setores estratégicos, como aço, automóveis e produtos eletrônicos, da concorrência japonesa e de países subdesenvolvidos. Enquanto nos Estados Unidos o recurso protecionista preferido eram os arranjos de restrição voluntária, os

${ }^{166}$ GILPIN, 2002, p. 228-234. 
europeus ocidentais desenvolveram medidas de defesa comercial, inconsistentes com as normas do GATT.

Diante disso, constata-se que os instrumentos do novo protecionismo vêm aumentando dramaticamente a discriminação nas relações econômicas internacionais em franca violação aos princípios e regras da Organização Mundial do Comércio. A proliferação de acordos preferenciais de comércio e de medidas contingenciais tem empiricamente transformado a regra geral do tratamento da nação mais favorecida em determinante excepcional para os fluxos comerciais. Isso tem por efeito provocar a erosão do princípio da não discriminação, implicando a desestruturação do sistema multilateral de comércio. ${ }^{167}$

Em síntese, o novo protecionismo ameaça os fundamentos da governança econômica internacional, na medida em que contesta as normas, jurídicas e morais, e modifica os padrões de comportamento sobre os quais a ordem econômica internacional neoliberal foi erigida. Com efeito, o sistema multilateral de comércio sofre um processo de desestruturação, causado pelos reflexos colidentes das dimensões ideacional e comportamental. Essa tensão estrutural empírico-ideacional exige da governança econômica internacional o controle e a orientação das relações econômicas internacionais em direção à concreção de seus princípios, desde que respeitadas as garantias institucionais.

\subsubsection{A Era do Livre-comércio globalizado: os desafios sistêmicos e a institucionalização da cláusula da nação mais favorecida na OMC}

Existiram apenas duas eras de governança eficaz da economia capitalista internacional. A Era do Livre-comércio britânico é caracterizada pela regência da Grã-Bretanha, por quase um século, das relações econômicas internacionais, orientada pela ideologia liberal e executada pelo Estado Liberal. No século XIX, o livre-mercado e a globalização econômica lograram realizações sem paralelo na história. O êxito da liderança britânica estava em direcionar a ordem liberal, por meio de uma rede de tratados bilaterais, conectados pela cláusula da nação mais favorecida. O sistema monetário internacional era baseado no clássico

${ }^{167}$ GILPIN, 2004, p. 64-68. SUTHERLAND, 2004, p. 19. 
padrão-ouro, o qual promovia a estabilidade monetária e de preços, bem como permitia ao Banco da Inglaterra estimular a economia mundial, mediante taxa de juros. O início da Primeira Guerra revelou, porém, as fragilidades desse modelo de governança.

Encerrados os trinta anos de crise, a Era do Livre-comércio estadunidense seguiu-se imediatamente à Segunda Guerra Mundial. Apesar da divisão mundial em polaridades definidas, os Estados Unidos foram responsáveis por conduzir a construção da ordem parcial de cooperação econômica neoliberal, a qual se propunha a ser erigida livre dos erros que levaram ao esgotamento da ordem liberal. Para reger as relações econômicas internacionais, os EUA patrocinaram a criação de organizações internacionais multilaterais de aspiração universal, responsáveis por institucionalizar os sistemas monetário, financeiro e comercial. Constituídos pelos acordos de Bretton Woods, FMI e BIRD tinham por finalidade assegurar a estabilidade monetária e prover recursos financeiros às interações entre os países. Como a Organização Internacional do Comércio não logrou condições para vigorar, coube ao GATT ordenar, contratualmente, o sistema multilateral de comércio, bem como promover a liberalização do comércio internacional.

Caracterizadas por vibrantes períodos de crescimento econômico acompanhados por estabilidade e previsibilidade nas relações internacionais, as duas Eras de Livre-comércio tinham em comum a convergência entre os interesses da potência dominante e as exigências de criação e manutenção das estruturas da ordem econômica internacional. Grã-Bretanha e Estados Unidos quiseram e foram capazes de utilizar seus recursos e posição para promover uma eficaz governança econômica internacional. ${ }^{168}$

$\mathrm{Na}$ sombra da Guerra Fria, as alianças, valores e instituições imbricaram-se para conformar as estruturas de cada ordem parcial de cooperação econômica, nas quais a economia internacional se desenvolvia. Os Estados Unidos e seus aliados em geral subordinavam os potenciais conflitos de interesse à necessidade de manter uma forte cooperação política e de segurança. A ênfase nas questões político-militares reforçava os laços responsáveis por salvaguardar a coesão da economia capitalista e facilitar a resolução de divergências importantes. Ainda que os Estados Unidos se valessem de sua influência política para obter concessões econômicas dos diferentes parceiros aliados, seus objetivos eram evidentemente focados em estratégias de defesa.

${ }^{168}$ GILPIN, 2004, p. 69-71. 
O desaparecimento da ameaça socialista conferiu a posição de única superpotência hegemônica aos Estados Unidos. Sob a tutela estadunidense, os valores neoliberais triunfaram e o mundo, na perspectiva de pensadores neoliberais, estava no limiar de uma era de prosperidade, democracia e paz sem precedentes. Todavia, quando a URSS ruiu, a correlação de forças que sustentava a governança econômica neoliberal já demonstrava sinais de enfraquecimento, pois não encontrava o mesmo empenho dos EUA ou a disposição da Europa ocidental e Japão em segui-la, como ocorreu no período subsequente à Segunda Guerra. A queda do muro de Berlim simbolizou não apenas a vitória neoliberal, mas permissão para os países capitalistas desenvolvidos começarem a promover políticas unilaterais e enfatizar soluções regionais para os desafios econômicos. Essas mudanças nas prioridades nacionais, regionais e internacionais refletiram-se nas políticas externas estatais, implicando importantes consequências para o futuro da ordem econômica internacional. Com isso, a estreita cooperação das décadas passadas afrouxara, acarretando graves repercussões negativas para a paz e bem-estar mundiais.

Nesse período transitório, a economia doméstica dos países desenvolvidos foi marcada por três fases de transformações distintas. A década de 1970 foi assolada por altas e crescentes taxas de inflação. Nos anos de 1980, a ameaça inflacionária foi derrotada, ao custo da contração de enormes déficits orçamentários. No decorrer da década de 1990, os Estados reduziram ou zeraram seus déficits. Assim, antes do fim do século, a maior parte dos países desenvolvidos tinha inflação baixa, déficits orçamentários pequenos e controlados, amplos setores públicos e rede de programas sociais. ${ }^{169}$

Sob a tutela estadunidense, a governança econômica neoliberal foi responsável por estabelecer os seus dois principais marcos institucionais do pós-Segunda Guerra: os acordos de Bretton Woods e o GATT. No entanto, a partir da década de 1960, a liderança dos Estados Unidos entra em processo de deterioração. O abandono pelos EUA do sistema monetário internacional, estruturado sobre taxas de câmbio fixas nos anos 1960, o movimento em direção a um novo protecionismo em meados de 1970, seguidos do deslocamento do apoio ao multilateralismo a uma política comercial de cunho geoeconômico e estratégico, nas décadas de 1980 e 1990, tiveram o condão de minar severamente a posição de regente dos Estados Unidos e, por consequência, o suporte à recém-integrada ordem econômica internacional

${ }^{169}$ FRIEDEN, 2008, p. 403-407. LAFER, 1998, p. 20-21. GILPIN, 2004, p. 29-33. 
neoliberal. Essa ambígua agenda estadunidense, que oscilava entre o posicionamento unilateral-protecionista e a promoção do institucionalismo-multilateral, resultou na desvinculação necessária das atuações de seus aliados.

A Europa ocidental também se voltou para questões domésticas e regionais, em detrimento das soluções globais. Suas energias passaram a focar a construção política da União Europeia e a concretização da união econômica, visando à organização de uma economia globalmente competitiva, capaz de fortalecer sua posição perante os EUA e Japão.

O Japão reorientou sua atuação política e econômica internacionais, concentrando sua atenção na região asiática do Pacífico, cuja economia passou a ser estreitamente vinculada à dele. Dispondo de amplo apoio governamental, as empresas transnacionais japonesas criaram redes de produção integradas em diversos países subdesenvolvidos, tendo por objetivo aumentar a competitividade global das corporações. Apesar do revés com as crises financeiras do Leste Asiático e os problemas econômicos domésticos, o Japão tem liderado o processo de fortalecimento da economia regional, refletindo a confiança e independência do país na ordem econômica internacional. ${ }^{170}$

Nesse complexo cenário, a regência da governança econômica internacional tornou-se uma tarefa mais relevante e difícil de empreender no contexto da globalização e das crises econômicas capitalistas. O processo de integração econômica mundial, por meio de fortalecimento e expansão das relações econômicas internacionais e da sociedade informacional, tem se caracterizado por sua excessiva celeridade, o qual não vem sendo acompanhado pela edificação de estruturas de governança adequadas. Os neoliberais conservadores apontam para uma concomitante passagem de um modelo de organização da vida internacional centrado nos Estados para um modelo regido pelo mercado. Os problemas de instabilidade e desorientação decorrem, assim, de uma economia mundial que ainda se encontra parcialmente integrada, mas que se adiantou à integração política.

Na década de 1980, as instituições de Bretton Woods e o GATT já haviam perdido sua capacidade de contribuir para a gestão da economia internacional altamente integrada, visto não terem instrumentos para lidar com os desafios decorrentes dos processos de globalização e de regionalismo, os quais se relacionam segundo lógicas contraditórias de aprofundamento versus alargamento. Sob a liderança dos Estados Unidos, a Rodada Uruguai expressou a

${ }^{170}$ GILPIN, 2004, p. 23-24. 
prevalência da ideologia neoliberal, na medida em que obteve sucesso em reunir os países desenvolvidos e subdesenvolvidos para estabelecer a nova arquitetura institucional do comércio internacional fundada sobre os princípios do livre-comércio, recíproco e não discriminatório.

O reflexo normativo consistiu na celebração de diversos acordos comerciais, dentre os quais o mais relevante é o Acordo Constitutivo da Organização Mundial do Comércio (“Acordo OMC”), que constituiu a primeira organização internacional pós-Guerra Fria. A OMC foi instituída para estruturar a vertente comercial da ordem econômica internacional, mediante a universalização do multilateralismo axiológico e procedimental herdado do GATT. Devido ao fim dos conflitos de concepção, foi atribuído à OMC o escopo de regular as relações internacionais de comércio, mediante a institucionalização das expectativas normativas dos agentes econômicos internacionais. ${ }^{171}$

Produto das transformações estruturais que permitiram a globalização das estruturas da ordem parcial neoliberal, a Organização Mundial do Comércio pode ser interpretada de acordo com uma óptica institucional ou normativa. Entendida como organização, a OMC é dotada de personalidade jurídica própria; logo, sujeita de direitos e deveres na ordem internacional, tendo por finalidade governar o mercado mundial, mediante o exercício de sua competência reguladora do espaço econômico e sancionadora dos conflitos internacionais. Concebida como ordenamento jurídico, a OMC é um sistema internacional de comércio, no qual estão inseridas as normas que disciplinam as relações econômicas internacionais, segundo uma lógica própria e princípios específicos. As Seções II e III examinam as particularidades do sistema GATT/OMC, cabendo ao presente Capítulo analisar as características e desafios, que os processos socioeconômicos endereçam à OMC.

A economia mundial nunca esteve tão distante de um controle hegemônico. $\mathrm{O}$ progressivo abandono dos Estados Unidos da regência internacional, em prol de uma política econômica focada no novo protecionismo e regionalismo econômico, orientados por doutrinas realistas defensoras do unilateralismo, abriu um vácuo que vem sendo preenchido pela Organização Mundial do Comércio. A perda da hegemonia e exclusividade estadunidense permitiu à OMC posicionar-se na qualidade de gestor das relações econômicas internacionais. União Europeia e Japão vêm fortalecendo suas posições, mas não conseguiram alcançar a

${ }^{171}$ GILPIN, 2004, p. 68-71. LAFER, 1998, p. 26. 
liderança, enquanto os países subdesenvolvidos, como Brasil, Rússia, Índia, China e Coreia do Sul ganham espaço e competitividade para beneficiarem-se da liberalização econômica. No tabuleiro do comércio internacional, os jogos de poder e verdade envolvem Estados, empresas transnacionais, organizações internacionais, organizações não governamentais, todos os quais visam orientar as expectativas cognitivas e normativas sobre a economia global.

A OMC tem papel relevante na coordenação das relações econômicas internacionais, em especial dos Estados-membros, os quais adotam políticas comerciais, internas e externas, confiantes na previsibilidade e segurança jurídica do sistema multilateral de comércio. Ainda que sua personalidade jurídica assegure autonomia internacional, a OMC depende da cooperação de seus Membros para concretizar suas funções. Devido ao poder normativo e sancionatório, as empresas transnacionais passaram a considerá-la em suas estratégias comerciais. Finalmente, ela tem servido como guardiã das estruturas axiológica e normativa da ordem econômica internacional. ${ }^{172}$

Diferentemente das instituições de Bretton Woods, a OMC não administra recursos, mas regula as relações comerciais entre seus Estados-membros, por meio da continuidade e ruptura institucional-legal em relação ao GATT. A continuidade decorre da institucionalização do sistema multilateral de comércio pela OMC, de modo a conferir efeito erga omnis aos princípios e regras do GATT. Com isso, há a passagem de uma ordem internacional heterogênea, composta de sistemas axiológicos de valores contrapostos, para uma ordem internacional homogênea, cuja visão compartilhada permitiu a universalização da ideologia neoliberal. A ruptura decorre da insuficiência regulatória e institucional do GATT frente às tensões provocadas pelos desafios estruturais da globalização, do regionalismo e do novo protecionismo. Por não deter status de organização internacional, o GATT atuava apenas em nome e no limite dos interesses de seus Estados-partes. Daí seus mecanismos institucionais e as normas positivadas não serem adequados à ordem econômica internacional globalizada sob os valores neoliberais, cuja dinâmica comportamental via-se intensificada graças à interdependência e interpenetração dos mercados domésticos, regionais e global, mas imprevisível devido à falta de institucionalização.

${ }^{172}$ GILPIN, 2004, p. 71-73. FIORI, José Luís. Sobre o poder global. Novos estudos - CEBRAP, São Paulo, n. 73, 2005 , p. 71-72. Disponível em <http://www.scielo.br/scielo.php?script=sci_arttext\&pid=S010133002005000300005\&lng=pt\&nrm=iso>. Acesso em: 24 out. 2009. MCGUIRE, Steven M.; LAWTON, Thomas C. Does the WTO matter? In: VACHANI, Sushil (Org.). Transformations in global governance. Northampton: Edward Elgar Publishing, 2006, p. 49-52. 
Fomentados pela lógica da globalização, os acordos da Rodada Uruguai promoveram uma abrangente positivação codificante do direito internacional econômico de cooperação, tendo por efeito o alargamento e o aprofundamento institucional, sem precedentes, do sistema multilateral de comércio. A acessão de novos Estados simboliza o processo de alargamento ratione personae da incidência normativa, conferindo às regras e princípios uma vocação universal. Impressiona constatar que apenas vinte e três foram partes-contratantes originais do GATT em 1947, enquanto cento e vinte e quatro Estados participaram da constituição da Organização Mundial do Comércio em 1994. O aprofundamento resulta da transferência de competência ratione materiae, com a finalidade de regular setores econômicos anteriormente excluídos do GATT. O acordo de pretensões antagônicas entre países desenvolvidos e subdesenvolvidos permitiu ampliar sensivelmente o universo temático-normativo, o qual passou a abranger agricultura, têxteis, serviços, propriedade intelectual, medidas de investimentos relacionadas ao comércio e outros. Nesse particular, ressalta-se o imprescindível papel conferido à cláusula da nação mais favorecida de positivar, nos diversos acordos do SMC em houver sido inserida, o princípio da não discriminação, com a finalidade de promover a multilateralização, automática e incondicionalmente, dos resultados da Rodada Uruguai a todos os Estados-membros. ${ }^{173}$

As organizações internacionais são importantes para a vida internacional, razão pela qual despontam, ao lado dos Estados, como titulares de direitos e obrigações, os quais não se confundem com os de seus membros. Sua crescente institucionalização e competência transversal são responsáveis por moldar uma espécie de constitucionalismo mundial. No âmbito econômico, as organizações internacionais são necessárias para corrigir as falhas de mercado representadas pelas externalidades transnacionais, implementar e fiscalizar os princípios e regras internacionais e regulamentar os bens públicos internacionais, como a paz, o desenvolvimento econômico e o bem-estar.

O GATT, enquanto tratado internacional, carecia de uma estrutura institucional apta a exercer o controle sobre as indiferenças axiológicas, incompatibilidades normativas e divergências de interesse e política econômica de seus Estados-partes. O diferencial institucional da OMC está na autonomia internacional e no estabelecimento de órgãos

${ }^{173}$ AMARAL JR., 2006, p. 110-112. LAFER, 1998, p. 22-23. VIRZO, Roberto. A Sucessão entre Organizações Internacionais e a Transformação do GATT em OMC. In: DAL RI JR., Arno; OLIVEIRA, Odete Maria de (Org.). Direito internacional econômico em expansão: desafios e dilemas. Ijuí: Unijuí, 2003, p. 182-183. 
administrativos capazes de analisar e sugerir modificações no próprio sistema multilateral de comércio e aperfeiçoamentos no mecanismo de solução de controvérsias, responsável por garantir a supervisão das condutas dos Estados-membros, o controle dos discursos normativos e o fortalecimento da efetividade das medidas disciplinares.

A homogeneidade estrutural da ordem econômica internacional permite à OMC direcionar o potencial de sociabilidade, que permeia as relações econômicas internacionais em direção a interações coordenadas, segundo a ideia de um mercado globalizado, que não funciona em um jogo de soma-zero. Essa interdependência organizada entre uma multiplicidade de economias nacionais, blocos regionais e mercado global requer um ator capaz de reger a cooperação e o confronto de interesses. A OMC administra esses relacionamentos conflituosos e cooperativos, por meio de transparência das interações, de mediação e conciliação diplomática, e da juridicização do conflito. Foi justamente para disciplinar o unilateralismo das razões de estado e a violação das regras e princípios internacionais que dotaram-na do Entendimento sobre as Regras e Procedimentos que Governam a Solução de Controvérsias (“ESC”) e criaram o Mecanismo de Revisão das Políticas Comerciais. ${ }^{174}$

O artigo III:4 do Acordo OMC estabelece o Mecanismo de Revisão das Políticas Comerciais, cujo objetivo é instrumentalizar o princípio da transparência nas relações econômicas internacionais. O dever de transparência é fundamental para fortalecer as expectativas normativas, conferindo previsibilidade comportamental. A publicidade expõe erga omnes as políticas públicas domésticas e regionais à permanente avaliação de sua razoabilidade, o que restringe o recurso ao unilateralismo e às medidas inconsistentes com o sistema multilateral de comércio.

Da tensão político-econômica, surgem as controvérsias internacionais. A tensão política é um antagonismo cuja pretensão não é claramente definida, sujeita a reações passionais, o que a torna refratária à solução pacífica, mediada pela racionalidade jurídica. As relações de poder entre os Estados têm se relevado de duas formas. A tensão de equilíbrio consiste em interações conflituosas, nas quais os atores dispõem de recursos homogêneos, o

\footnotetext{
${ }^{174}$ AMARAL JR., 2006, p. 96-100. LAFER, 1998, p. 109-111. FARIA, 2002, p. 151. VIEIRA, José Luiz Conrado. A integração econômica internacional na era da globalização: aspectos jurídicos, econômicos e políticos sob prismas conceitual e crítico. São Paulo: Letras \& Letras, 2004, p. 385. CARREAU; JUILLARD, 1998, p. 55-57. HART, 2001, p. 53-57. AMARAL JR., 2006, p. 96-100.
} 
que suaviza e facilita a pacificação. A tensão de hegemonia designa um contexto no qual um ator exerce a dominação sobre os demais, razão pela qual tende a agir unilateralmente, segundo suas próprias estratégias. À medida que impede a racionalização da disputa, a solução de controvérsias internacionais sobre as consequências das tensões políticas dificulta a formulação das pretensões em termos jurídicos, podendo ter efeito deletério, caso arrestem-se por períodos prolongados. Isso porque a postura passional é incompatível com a ordenação argumentativa de índole jurídico-institucional.

Para evitar a formação de situações políticas desagregadoras da economia internacional, os países desenvolvidos e subdesenvolvidos criaram o Órgão de Solução de Controvérsias da OMC, o qual constitui um tertium super partes e tertium inter partes, figurando-se como um terceiro-para-a-paz, cuja finalidade é universalizar o sistema multilateral de comércio, dirimir disputas econômicas internacionais e assegurar a paz, segurança e equidade internacional. A solução de conflitos é o objetivo mínimo do direito, entendido como técnica normativa de manutenção da segurança e paz social ou como ordenamento jurídico responsável por disciplinar o uso legítimo da força para concretizar a eterna busca da humanidade por regularidade e paz nas relações sociais.

A adoção do ESC promoveu um adensamento de juridicidade, responsável por alterar qualitativamente a natureza do mecanismo de solução de controvérsias econômicas. O mecanismo do GATT foi, originalmente, formado em torno de um conjunto de técnicas diplomáticas de solução de disputas, o qual guarda, explícita e implicitamente, relação com o poder dos litigantes. Nesse modelo de características power-oriented, o país mais forte tende a utilizar sua posição dominante para submeter os países enfraquecidos a seus interesses. As reformas introduzidas pelo ESC tiveram por efeito aprofundar a institucionalização do mecanismo de solução de controvérsias, tornando-o gradativamente um modelo de vocação rule-oriented, cujas características fundamentais são a constituição de um terceiro imparcial para julgar a disputa e a adoção de uma racionalidade jurídica na formulação do discurso jurídico-decisório. $^{175}$

O debate acerca do modelo de adjudicação opôs, na história do sistema multilateral de comércio, os países que defendiam a maior legalidade aos que apregoavam os benefícios da

\footnotetext{
${ }^{175}$ LAFER, 1998, p. 27-28. BODENHEIMER, Edgar. Ciência do Direito. Trad. Enéas Marzano. Rio de Janeiro: Forense, 1966, p. 185. KELSEN, Hans. Teoria Geral do Direito e do Estado. São Paulo: Martins Fontes, 1999, p. 31-32. VISSCHER, 1970, p. 95-105. BOBBIO, 2000, p. 565. JACKSON, 1997, p. 109-112.
} 
flexibilidade das técnicas diplomáticas. Sob a liderança dos Estados Unidos, os legalistas advogavam a favor de uma legitimidade procedimental, fundada sobre uma racionalidade jurídica e ética de responsabilidade, que ressaltavam a necessidade de limites temporais precisos, da justificação das decisões e da legitimidade da sanção, em razão do consenso negativo dos Estados. Patrocinados pelas Comunidades Europeias, os defensores da jurisprudência diplomática enfatizam a natureza eminentemente política dos acordos da OMC. Isso significa que as regras e princípios do SMC deveriam se sujeitar a ajustes hermenêuticos, com a finalidade de preservar a legitimidade dos compromissos.

As principais críticas endereçadas ao mecanismo de solução de controvérsias do GATT enfatizavam quatro pontos. Primeiro, a falta de limite temporal e a incerteza intrínseca ao procedimento. A ausência de rigor e clareza das decisões proferidas. A dúvida quanto à imperatividade do relatório, devido à sujeição deste ao consenso positivo dos Estados-partes. Por fim, a incerteza decorrente da vagarosa adoção das decisões e da insegurança acerca do cumprimento das recomendações proferidas. A frustração com as deficiências do modelo orientado pelo poder tornou-se um dos principais temas da Rodada Uruguai. A necessidade dos países europeus de conterem o movimento dos EUA em direção ao unilateralismo e protecionismo econômico alterou sua histórica posição, resultando na celebração do Entendimento sobre as Regras e Procedimentos que Governam a Solução de Controvérsias.

Todavia, a evolução progressiva do mecanismo de solução de controvérsias GATT/OMC no sentido de institucionalizar um sistema cada vez mais jurisdicionalizado e orientado pelo direito é objeto de críticas. Em termos gerais, os críticos do adensamento de juridicidade apontam que a incorporação dos conflitos pela $\mathrm{OMC}$, em prejuízo às soluções negociadas, traria consequências nocivas ao ambiente diplomático, implicando a deterioração das relações econômicas internacionais. Os opositores do legalismo sustentam que a publicidade da contenda prejudica a negociação de um acordo, visto que, ao relevar a acusação, os litigantes tornam-se intransigentes. Alegam, também, que a mera proposição de uma demanda simboliza um ato contencioso, responsável por prejudicar o relacionamento entre os Estados-membros litigantes. Por fim, suscitam a possibilidade de uma escalada de 
demandas jurisdicionalizadas, devido ao revanchismo em resposta à decisão da controvérsia. $^{176}$

Constituído pelo ESC na forma de um órgão especializado do Conselho Geral (“CG”) da OMC, o Órgão de Solução de Controvérsias tem a função de autorizar a criação de painéis, adotar relatórios elaborados por estes e pelo Órgão Permanente de Apelação ("OPA”), supervisionar a execução das recomendações sugeridas pelos painéis e pelo OPA, bem como autorizar a imposição de medidas compensatórias. Dessa forma, o novo mecanismo de solução de controvérsias pretende, corrigir os vícios que impregnavam o modelo do GATT.

Para evitar o risco de ser capturado pelo dilema do forum-shoppping, o ESC delimitou, em seu artigo I:1, que suas regras e procedimentos abrangem todos os acordos do sistema multilateral de comércio. A inversão da regra de consenso assegurou a automaticidade da instauração de painel e da adoção de relatório elaborado pro este e pelo Órgão de Apelação. O estabelecimento de prazos para todas as etapas proporcionou maior certeza. A criação do OPA, enquanto instância recursal, tem a função de manter a coesão, equilíbrio e efetividade do sistema multilateral de comércio. Com isso, os painéis e o Órgão de Apelação transformaram a jurisprudência diplomática em uma verdadeira jurisprudência normativa, orientada por uma racionalidade jurídica e sujeita ao devido processo legal. Todavia, apenas o Órgão de Solução de Controvérsias é competente para conferir o exequatur ao relatório; logo, a imperatividade dos relatórios está sujeita à homologação por um órgão político-diplomático.

Ao combinar a lógica diplomática, que privilegia as técnicas de negociação, e a lógica jurisdicional, centrada em torno das garantias procedimentais e de decisões fundamentadas e vinculantes, o ESC criou um mecanismo de solução de disputas composto por órgãos jurisdicionais e órgão político. Os painéis e o Órgão Permanente de Apelação devem analisar os litígios, segundo uma perspectiva jurídica. O Órgão de Solução de Controvérsias, orientado diplomaticamente, reúne todos os Membros da OMC para o exercício político de administrar e conferir efeito imperativo aos discursos jurídico-decisórios. Isso representa a construção de uma nova concepção de responsabilidade internacional, cuja função é preservar a legalidade e a licitude nas relações econômicas internacionais. Com isso, transcender-se-iam as partes

\footnotetext{
${ }^{176}$ JACKSON, 1997, p. 109-112. DAVEY; William J. Dispute Settlement in GATT. Fordham International Law Journal, [s.1.], v. 11, n. 51, 1987, p. 67-70. TREBILCOCK, Michael J.; HOWSE, Robert. The regulation of international trade. $2^{\mathrm{a}}$ ed. Londres: Routledge, 2002, p. 55-56. HUDEC, 1975, p. 26. LAFER, 1998, p. 26-28.
} 
envolvidas numa disputa em prol da prioritária proteção dos princípios e interesses comuns da sociedade internacional. ${ }^{177}$

Diante de um contexto marcado pelos processos de globalização e regionalização e pela deterioração da liderança estadunidense, a Organização Mundial do Comércio desponta como um excepcional ator internacional, que, graças a sua autonomia jurídica e ao poder regulatório e sancionatório institucionalizados, vem ocupando a posição de regente das relações econômicas internacionais. Daí a interação entre Estados-membros e OMC não poder ser mais entendida simploriamente em termos de submissão ao poder soberano. A obrigatoriedade dos acordos, a integralidade do sistema multilateral de comércio e a automaticidade na instauração de um procedimento perante o OSC têm por efeito conferir à OMC um poder disciplinar que incide diretamente sobre os Estados e indiretamente sobre os governos nacionais e os formadores de política econômica.

Em contraste com as características ímpares do poder soberano, o poder disciplinar da OMC tem por objetivo aumentar a utilidade individual, tendo por função principal o bom adestramento. O poder disciplinar é exercido por meio da vigilância contínua e de um sistema minucioso de coerções materiais, em contraposição com o poder soberano caracterizado por um sistema de obrigações descontínuas. Na perspectiva da governança econômica internacional, a disciplina consiste em uma modalidade de exercício de poder, que comporta um conjunto de instrumentos, técnicas e procedimentos, cujos objetivos são tornar o exercício do poder menos custoso, intensificar sua eficácia, bem como ampliar a cooperação e a utilidade individual.

O sucesso do exercício do poder disciplinar deve-se à utilização de três mecanismos: o olhar hierárquico, a sanção normalizadora e o exame. $\mathrm{O}$ olhar hierárquico surge da ideia do Panóptico de Jeremy Bentham, que permite manter uma vigilância permanente em seus efeitos e descontínua em suas ações. O conceito arquitetônico desse mecanismo substitui a forma piramidal e a noção de centralidade do poder soberano por uma modalidade disciplinar, na qual o poder é, em essência, relacional e opera em rede. O Mecanismo de Revisão das

${ }^{177}$ AMARAL JR., 2006, p. 214-226. LAFER, 1998, p. 123-135. 
Políticas Comerciais cumpre essa função no âmbito da OMC, na medida em que as normas de transparência visam restringir a atuação estatal, sem violar os acordos da OMC. ${ }^{178}$

$\mathrm{Na}$ essência de qualquer poder disciplinar sempre funciona um mecanismo de sanção normalizadora. A punição é inerente à disciplina, pois está relacionada à função de reduzir os desvios de conduta, assegurando o processo de correção do comportamento. A arte de punir não tem por objetivo a mera repressão, mas a produção de um saber-poder específico sobre os indivíduos, por meio da análise de atos, desempenhos e comportamentos, bem como da comparação e diferenciação, qualitativa e quantitativa, dos sujeitos, possibilitando a formação de tribunais sociais. O mecanismo sancionatório estabelecido pelo ESC tem, justamente, o objetivo de normalizar o comportamento estatal, mediante a suspensão de benefícios obtidos em razão da interdependência econômica, bem como produzir efeitos intimidadores devido à transparência dos procedimentos litigiosos.

O terceiro mecanismo é o exame, cuja função consiste em combinar as técnicas de vigilância hierárquica e sanção normalizadora. Cabe ao exame estabelecer uma visibilidade, a partir da qual se pode individualizar e sancionar os infratores. Esse processo permite a subjetivação dos que são percebidos como objeto e a objetivação dos que se sujeitam. Com o exame, o Estado passa a ser, concomitantemente, efeito e objeto do poder e do saber, na medida em que se submete ao procedimento investigatório do Órgão de Solução de Controvérsias, o qual é orientado por uma racionalidade jurídica nos limites dispostos pelo ESC. Assim, o poder disciplinar, exercido por meio dos mecanismos de vigilância panóptica, sanção normalizadora e o exame, tem por efeito a observação e a classificação, individual e contínua, em forma de controle de punição e recompensa, e direcionamento das relações econômicas internacionais. ${ }^{179}$

A prevalência da ideologia neoliberal desarticulou os conflitos de concepção em torno da organização da sociedade internacional, tendo por efeito sujeitar as disputas econômicas ao sistema multilateral de comércio, na forma de conflitos de interesses. A OMC tem, pois, a função de evitar a guerra, mediante a sujeição das relações econômicas internacionais ao SMC. Isso significa que as disputas sobre comércio internacional nada mais é do que a guerra

${ }^{178}$ MCGUIRE; LAWTON, 2006, p. 52-54. FOUCAULT, 2008, p. 187-188. FOUCAULT, Michel. Vigiar $e$ Punir: nascimento da prisão. Trad. Raquel Ramalhete. 34a ed. Petrópolis: Vozes, 2007, p. 143; 179-182. FOUCAULT, 2005, p. 143-148. LAFER, 1998, p. 27-28.

${ }^{179}$ FOUCAULT, 2005, p. 121-122. FOUCAULT, 2007, p. 148-155. LAFER, 1998, p. 127-129. 
comercial continuada por outros meios. A manutenção da paz neoliberal não suspende a silenciosa guerra econômica ou neutraliza o desequilíbrio de forças, mas reinsere dentro da OMC as relações de poder e verdade na forma de conflitos de interesses disciplinados por normas jurídicas. Na prática, as regras do consenso positivo e do empreendimento único exigem um amplo e recíproco compromisso, o que demanda das negociações multilaterais uma organização econômica da dominação segundo uma lógica organizacional de clubes.

Com o reconhecimento de sua autoridade judicante, a OMC tornou-se capaz de influenciar os fluxos do comércio internacional por meio de poderosos discursos jurídicos que normalizam o comportamento dos Estados-membros. Em uma sociedade internacional caracterizada por múltiplos centros de produção de discursos especializados, a OMC, graças à competência legal e à reputação de autoridade legítima, está em posição de exercer um amplo controle dos efeitos dessas verdades sobre as políticas econômicas dos Estados, por meio da produção de discursos jurídicos. Entretanto, a Organização Mundial do Comércio não é indiferente ou imune aos jogos de poder e verdade, visto que o exercício do controle de legalidade e de licitude pelo Órgão de Solução de Controvérsias está sujeito às relações de força e de interesse entre os atores internacionais e aos confrontos teórico-ideológicos, os quais incidem diretamente sobre o sistema multilateral de comércio, implicando diminuição da eficácia sancionatória e da coesão axiológica, respectivamente. ${ }^{180}$

Nesse particular, insere-se a problemática protagonizada pelos desafios sistêmicos e pela cláusula da nação mais favorecida. Prevista no artigo I:1 do GATT, a CNMF tem por objetivo principal positivar o princípio da não discriminação no sistema multilateral de comércio, em resposta aos efeitos nocivos que o protecionismo e a discriminação exerceram no período subsequente à Primeira Guerra. Devido à maior institucionalização, conferida pelo adensamento de juridicidade e pelo princípio do empreendimento único, imputa-se ao sistema multilateral de comércio expectativas de que venha a guardar, nas relações normativas, uma coerência jurídica. À CNMF coube a função de organizar tais interações normativas, de modo a estender, automática e incondicionalmente, a todos os Estados-membros as melhores condições comerciais.

\footnotetext{
${ }^{180}$ FOUCAULT, 1999, p. 21-26. WOLFE, Robert. Um passeio pelos "clubes" da OMC. Pontes Bimestral, v. 3, n. 4, ago.-dez. 2007. Disponível em <http://ictsd.net/i/news/12451>. Acesso em: 2 nov. 2009.
} 
As práticas estatais e os discursos políticos e econômicos a favor do novo protecionismo e do regionalismo econômico vêm ameaçando de desautorização as regras e princípios nucleares do sistema multilateral de comércio. Esses dois movimentos fático e axiológico permitem, ao recorrerem a regras de calibração previstas no SMC, excetuar o tratamento da nação mais favorecida, de modo a autorizar a formação de relações comerciais em bases discriminatórias e protecionistas.

A proliferação, sobreposição e entrelaçamento de acordos preferenciais de comércio têm suscitado a constituição de redes entrecruzadas de estruturas jurídicas bilaterais e plurilaterais discriminatórias, sendo tal fenômeno denominado de spaghetti bowl. Enquanto a aplicação de medidas restritivas ao comércio também tem se difundido nas relações econômicas internacionais, visto que os Estados-membros têm buscado flexibilizar suas obrigações devido a pressões econômicas e políticas nacionais.

Devido ao substancial impacto nas expectativas dos agentes econômicos, o spaghetti bowl e as medidas protecionistas ameaçam a função unificadora de sentido da cláusula da nação mais favorecida, cujo resultado é a erosão da ideia de livre-mercado mundial. Com efeito, as reiteradas quebras de expectativas normativas pelo comportamento dos Estadosmembros implicam problemas de coesão e de eficácia normativa ao sistema multilateral de comércio, os quais são denominados de desafios sistêmicos.

Com efeito, o sistema multilateral de comércio sofre um processo de desestruturação, causado pela interação das dimensões ideacional e fática. $\mathrm{Na}$ dimensão ideacional, os defensores dos APC justificam que seus objetivos são aprofundar o processo de liberalização comercial e promover a globalização econômica, os quais são interrompidos pela falta de consenso das rodadas multilaterais de negociação comercial e pelas limitações que o multilateralismo procedimental impõe aos Estados-membros que desejam uma integração econômica mais célere e profunda. Por sua vez, o discurso do novo protecionismo assevera que os instrumentos protecionistas e discriminatórios permitem relaxar certas obrigações, a fim de manter a estabilidade do sistema multilateral de comércio, facilitar a cooperação econômica, administrar o processo de liberalização, compensar a celebração de acordos mais profundos de integração e fomentar o desenvolvimento econômico setorial.

Ainda que legalmente as regras de calibração do SMC assegurem a validade desses tratados de preferência comercial e medidas contingenciais, na dimensão axiológica, a 
crescente tendência à valorização do protecionismo e da discriminação, dentro de uma lógica de fragmentação e aprofundamento, atenta contra os valores constitutivos da OMC. ${ }^{181}$

No plano comportamental, as análises empíricas demonstram que a participação de Estados nos acordos preferenciais e o recurso a medidas discriminatórias e protecionistas têm modificado suas atuações, ao ficarem mais hesitantes e menos cooperativos nas negociações multilaterais. Essa tendência é nociva para um mercado em processo de globalização, implicando consequências potencialmente desastrosas como a sujeição de países subdesenvolvidos a interações lesivas a sua economia doméstica, visto que, por dependerem das exportações aos países desenvolvidos, podem ser coagidos a submeterem seus interesses nacionais e sua soberania econômica ao controle de agentes externos.

Essa tensão fático-axiológica incide sobre a OMC, exigindo um controle de legalidade e de licitude dos APC e das medidas protetivo-discriminatórias. O controle de estruturas é realizado pela verificação da adequação formal dos atos e dos instrumentos jurídicos às condições previstas no SMC. O controle de condutas consiste no exame comportamental do respeito dos Estados-membros aos deveres e obrigações materiais. ${ }^{182}$

Diante desses desafios sistêmicos ao sistema multilateral de comércio, o presente trabalho propôs-se a verificar se a cláusula da nação mais favorecida, positivada no artigo I:1 do GATT, permanece como regra determinante para os controles de estruturas e de condutas exercidos pelo Órgão de Solução de Controvérsias. A resposta à questão-problema será investigada, segundo uma racionalidade jurídica, no desenvolver das próximas Seções.

No entanto, é essencial ressaltar que, por estar inserida no bojo das relações de poder e verdade, a Organização Mundial do Comércio é influenciada pelos atores internacionais, em especial aqueles detentores de posição dominante, o que resulta na formação de dois movimentos. O primeiro é dedicado a restringir os efeitos de poder do discurso da OMC, mediante a produção descentralizada de discursos verdadeiros contrários ao SMC. O segundo consiste na tentativa de cooptar os intérpretes da OMC, a fim de sujeitar o processo de construção do discurso jurídico a intervenções estranhas à lógica jurídico-normativa estabelecida pelo sistema multilateral de comércio.

181 SUTHERLAND, 2004, p. 19-23. OMC. World Trade Report 2009: Trade Policy Commitments and Contingency Measures. Genebra: WTO Publications, 2009, p. 21-39.

${ }^{182}$ SUTHERLAND, 2004, p. 19-27. FERRAZ JR., 2001, p. 202-210. 
Contemporaneamente, os centros produtores de conhecimento econômicos e de relações internacionais têm ganhado relevância no contexto do comércio internacional. As diversas escolas e teorias têm sido empregadas pelos atores internacionais para influenciar a atuação da Organização Mundial do Comércio, seja para fortalecer a posição desta como regente do comércio global, expor suas limitações ou contestar seu desempenho. A problemática dos discursos políticos e econômicos relaciona-se com os desafios sistêmicos, na medida em que têm efeitos poderosos no plano axiológico e empírico.

$\mathrm{Na}$ dimensão axiológica, as ideologias orientadas por um estadocentrismo ou por um protecionismo-discriminatório buscam restringir o discurso jurídico-convencional da OMC. Tais correntes de pensamento legitimam o unilateralismo estatal e apregoam a ineficácia do direito internacional, com o fim de comprometer a efetividade normativa e social do sistema multilateral de comércio. Na dimensão empírica, os Estados-membros valem-se desses discursos político-econômicos para justificar suas condutas inconsistentes perante o sistema GATT/OMC. Isso é possibilitado graças ao receio dos Estados-membros, em especial dos países subdesenvolvidos, em iniciar um procedimento perante o Órgão de Solução de Controvérsias ou em aplicar medidas compensatórias autorizadas pela OMC ao infrator de cujo mercado seja economicamente dependente. Desse modo, os discursos políticoeconômicos e as práticas estatais, orientadas segundo razões de estado, têm por efeito fortalecer a tensão fático-axiológica incidente sobre o sistema multilateral de comércio. ${ }^{183}$

Concomitantemente, assiste-se ao movimento de cooptação fático-axiológica dos intérpretes escolhidos para compor os painéis e o Órgão de Apelação, cujo resultado pode acarretar a diluição do caráter jurídico de suas decisões em prol de discursos políticoeconômicos. A cooptação dos intérpretes tem início no próprio procedimento de escolha, visto que os candidatos dependem de indicação pelos próprios Membros, o que já evidencia um controle político da escolha. Ainda que o artigo 8:9 do ESC determine que os membros designados devam atuar com independência e imparcialidade, a despeito de sua nacionalidade, é evidente que suas decisões estão sujeitas a elementos estranhos ao sistema multilateral de comércio. A formação sociocultural e jurídica, as interações políticas e as ideologias políticoeconômicas exercem intensa influência sobre os intérpretes, o que pode implicar a produção

${ }^{183}$ OMC. World Trade Report 2007: Six decades of multilateral trade cooperation: What have we learnt? Genebra: WTO Publications, 2007, p. 89-94. FOUCAULT, 1999, p. 21-22. FERRAZ JR., 2001, p. 194-195. TREBILCOCK; HOWSE, 2002, p. 129-130. 
de discursos jurídico-decisórios, que positivem verdades políticas ou econômicas inconsistentes com a racionalidade e as normas do SMC.

Nesse sentido, afigura-se a ameaça da apreensão do pensamento jurídico por teorias que concebem o direito como mero instrumento, submetido e manipulado por uma racionalidade finalística, funcional e tecnológica. Segundo essa escola, o direito serve apenas para ajustar as pretensões contraditórias e encontrar soluções de compromisso, razão pela qual não passa de uma técnica instrumental de engenharia social. $O$ objetivo do pensamento jurídico seria produzir soluções socialmente úteis e convenientes, compromissadas com uma ética utilitarista de convicção, e não assegurar as respostas axiológico-normativamente válidas e fundamentadas. Com isso, o intérprete ganharia ares tecnocráticos, convertendo-se em planejador social, cujas decisões devem ter em mente a eficácia social e não a justeza; ou seja, os efeitos do discurso jurídico-decisório deixam de ser aferidos teleologicamente, para serem objetos de cálculo social de rendimento global.

Severas críticas são endereçadas a essa racionalidade jurídica de índole funcional técnico-finalística: a mais relevante para esse estudo trata da perda do caráter judicante da decisão. O intérprete, ao tornar-se um planificador social, deixa de ser orientado predominantemente pelas normas jurídicas, para recorrer a modelos preestabelecidos de decisão. Desse modo, o Órgão de Solução de Controvérsias deixaria de ter a função de assegurar certeza e segurança jurídica, para determinar quais as melhores políticas econômicas segundo um sistema de preferências, ponderado pela eficácia. A decisão serviria, assim, para difundir globalmente os programas econômicos prevalecentes no jogo de verdades e interesses. Contudo, tal racionalidade não se coaduna com os princípios do sistema multilateral de comércio. ${ }^{184}$

Globalização, multilateralismo, regionalismo, novo protecionismo e o desgaste da liderança estadunidense compõem o conjunto de desafios enfrentados pela governança econômica internacional contemporânea, tendo por função orientar as complexas e conflituosas relações econômicas internacionais, segundo os valores neoliberais e as normas jurídicas internacionais. Em razão disso, a Organização Mundial do Comércio foi criada pelos países desenvolvidos e subdesenvolvidos para servir como um terceiro-para-a-paz, com a

\footnotetext{
${ }^{184}$ CARVALHO, Evandro Menezes de. Organização Mundial do Comércio: cultura jurídica, tradução e interpretação. Curitiba: Juruá, 2008, p. 227. NEVES, 1993, p. 55-71.
} 
finalidade de reger o mercado global mediante a universalização do sistema multilateral de comércio, a instituição de um mecanismo disciplinar, o controle dos conflitos econômicos internacionais e a manutenção da paz, segurança e equidade internacionais

Nesse particular, surgem os desafios sistêmicos que colocam em xeque a imperatividade e a eficácia normativa da cláusula da nação mais favorecida no âmbito do sistema multilateral de comércio, bem como promovem a ineficácia social de seu discurso jurídico-convencional. Certas ideologias econômicas e políticas tentam desautorizá-la no intuito de minar os poderosos efeitos da CNMF sobre os Estados-membros, enquanto as práticas protecionistas e discriminatórias dos países podem comprometer sua eficácia como norma orientadora das relações econômicas internacionais. 


\section{SEÇÃO II}

\section{A CLÁUSULA dA NAÇÃo MAIS FAVORECIDA NO SISTEMA MULTILATERAL DE COMÉRCIO}


Na Seção I, a cláusula da nação mais favorecida foi examinada enquanto discurso jurídico, cuja principal função é assegurar aos agentes econômicos que suas relações recíprocas sejam constituídas em bases não discriminatórias. Com a deterioração da liderança hegemônica estadunidense, a governança econômica internacional passa a ser regida pela Organização Mundial do Comércio. Reformulado no bojo do processo de adensamento de juridicidade, o Órgão de Solução de Controvérsias é o mecanismo disciplinar responsável por exercer o controle de condutas e estruturas das relações econômicas internacionais, o que assegura maior durabilidade às expectativas normativas, visto que a OMC direciona os fluxos econômicos em direção aos objetivos consagrados nos tratados que compõem o sistema multilateral de comércio.

No complexo contexto de relações que conformam os movimentos de globalização, regionalização e novo protecionismo, assiste-se à proliferação de acordos preferenciais de comércio e de medidas restritivas ao comércio, bem como à valorização da discriminação e do protecionismo comercial. Desse fenômeno surgem os desafios sistêmicos que ameaçam a imperatividade e a eficácia normativa da cláusula da nação mais favorecida no âmbito do sistema multilateral de comércio, como também promovem a ineficácia social de seu discurso jurídico-convencional.

Diante disso, a Seção II apresenta um exame analítico do conceito de sistema multilateral de comércio, no qual são investigadas as relações e os elementos estruturais da noção de sistema internacional de comércio, do qual o termo sistema multilateral de comércio é espécie. A relevância de determinar a noção de sistema GATT/OMC reside no emprego desse instrumento para analisar o processo hermenêutico e a decisão próprios dos intérpretes da OMC. Com efeito, será possível reintroduzir as questões que os desafios sistêmicos suscitam à cláusula da nação mais favorecida, não sob a influência de discursos políticoeconômicos, mas analisadas a partir um olhar jurídico-pragmático. 


\subsection{CONCEITO DE SISTEMA INTERNACIONAL DE COMÉRCIO}

O termo de conceito sistema multilateral de comércio, ou sistema GATT/OMC, é utilizado livremente pela literatura, sem, contudo, precisar qual de seus múltiplos sentidos está sendo empregado. A definição do conceito é fundamental, pois servirá como instrumento capaz de proporcionar uma congruência dinâmica entre os mecanismos de controle social, tais como normas, princípios, valores e instituições. O sistema é constituído normativamente pelo comportamento social, cabendo ao intérprete identificar suas características essenciais, de modo a conferir-lhe um mínimo de coerência e razoabilidade para que se possa dominá-lo e exercitá-lo tecnicamente. Daí ser necessário examinar criticamente o SMC à luz dos desafios sistêmicos de coerência e eficácia.

O sistema multilateral de comércio é uma construção específica baseada na ideia de sistema internacional de comércio, a qual tem origem no conceito de sistema de direito. Não há, porém, consenso dogmático acerca do significado de sistema de direito, em razão das diferentes construções do termo sistema. A relevância de precisar o significado do termo sistema está em evitar que, por encerrar uma pluralidade de sentidos, torne a investigação equívoca. Embora de origem grega, o atual significado da palavra sistema não corresponde àquele utilizado pelo pensamento grego clássico. Ainda assim, examinar seus indícios contribui para compreender sua construção. O termo sistema tem sua raiz etimológica na expressão grega systema, cujo sentido estrito significava composto, enquanto o extensivo aludia à ideia de totalidade construída, composta de várias partes. Posteriormente, agregou-se ao termo o sentido específico de ordem, resultando na noção de totalidade bem ordenada. Por fim, os estoicos atribuíram-lhe uma conotação ligada à techne, de modo a defini-lo como sistema de conceitos. ${ }^{185}$

\footnotetext{
${ }^{185}$ FERRAZ JR., Tercio Sampaio. Conceito de sistema no direito: uma investigação histórica a partir da obra jusfilosófica de Emil Lask. São Paulo: Revista dos Tribunais; Edusp, 1976, p. 9.
} 
O emprego do termo foi somente retomado nos séculos XVII e XVIII. Partindo do sentido estoico de techne, os filósofos atribuíram ao sistema o significado de método de busca da verdade. Para Christian Wolff, o sistema é mais que um esquema ordenado de verdades, sendo, sobretudo, o nexus veritatum, o qual pressupõe a correção e a perfeição formal da dedução, segundo uma ideia de composição orgânica, ou seja, as verdades guardam sistemicamente relação entre si e com seus princípios. Posteriormente, Johann Heinrich Lambert formulou um conceito geral e abstrato de sistema, livre de conteúdo material, no qual a relação entre os elementos é determinada segundo regras lógicas de dedução. Essa construção fechada é fundada no modelo mecanicista, cujo princípio basilar sugere uma relação de identidade entre o todo e a soma das partes, possibilitando o desmonte e remontagem do sistema. A noção de sistema era, assim, moldada ao procedimento matemático.

Rompendo com o modelo mecânico, Immanuel Kant subordinou o fundamento do sistema à unidade do princípio. Partindo da natureza arquitetônica da razão, sistema significa uma relação articulada, e não um amontoado de elementos, reunidos sob uma única concepção. Desse modo, a retirada ou o acréscimo de qualquer elemento destrói ou modifica o todo como unidade orgânica, a qual pressupõe um princípio teleológico. Isso significa que o sistema não poderia ser decomposto e recomposto, sem incorrer em perdas, visto que o todo precede os elementos, os quais são mais do que simples agregação.

Dessa forma, o conceito de sistema é formado pela combinação de ordem e techne, resultando em um conjunto de relações entre elementos, o qual pressupõe um princípio fundamental que justifica tecnicamente sua existência e funcionalidade. Para os fins dessa investigação, esse ponto de partida filosófico é suficiente para compreender a construção do sistema de direito. Para a dogmática jurídica, sistema é um conceito operacional importante que surge associado ao problema da validade normativa. Nesse particular, é preciso destacar que para o pensamento jurídico a noção de sistema está intimamente correlacionada ao tipo de razão predominante. ${ }^{186}$

Historicamente, a ideia de sistema de direito foi introduzida pela Escola de Direito Natural, a qual concebia o direito, material e formal, como um conjunto de normas

${ }^{186}$ ABBAGNANO, 1998, p. 908-910. FERRAZ JR., 1976, p. 9. KANT, 2000, p. 492-501. FERRAZ JR., Tercio Sampaio. Direito, retórica e comunicação: subsídios para uma pragmática do discurso jurídico. São Paulo: Saraiva, 1973, p. 132-133. 
obrigatórias, deduzidas de um sistema fechado de fórmulas abstratas de valor universal. Ao identificar o direito à ciência normativa, submetendo-o a um pressuposto de validade, os jusnaturalistas utilizaram o conceito de sistema enquanto nexus veritatum, a fim de alcançar o ideal de uma ordenação exaustiva, a partir de um conjunto finito e relativamente limitado de relações. Essa sistemática jusnaturalista incide em dois problemas. No aspecto formal, o direito pressupõe uma identidade entre validade lógico-racional e validade jurídica, onde as normas aparecem como direito transcendente e absoluto, de modo que a totalização produzida por tal sistemática unitária resulta em um monismo metodológico infrutífero. Enquanto que materialmente, ao admitir a possibilidade de uma dedução de todo o conteúdo jurídico, a partir de postulados universais, implica uma racionalização global que destrói a historicidade típica do direito. Note-se, portanto, uma confusão entre o fundamento de validade da norma e o seu conteúdo.

O positivismo jurídico concebeu o direito como um conjunto fechado e autônomo, que se manifesta na forma de um sistema dinâmico de conceitos e proposições jurídicas, em íntima relação lógico-dedutiva. O sistema positivista consiste em uma unidade imanente, perfeita e acabada, da qual é possível extrair a solução válida de qualquer controvérsia, visto ser o sistema livre de lacunas verdadeiras, devendo as aparentes sofrer correções por meio da interpretação. A crítica endereçada ao positivismo está fundada na unilateralidade lógicometodológica, a qual reduz o sistema jurídico a um conjunto hierárquico de proposições e conceitos formalmente encadeados, segundo os graus de generalidade e especificidade. Isso significa que o direito positivista desconhece a pluralidade da realidade empírica imediatamente dada em relação à simplificação quantitativa e qualitativa dos conceitos gerais. Esse desconhecimento conduz qualquer sistema positivista ao fracasso, pois o direito revela-se enquanto realidade complexa, numa pluralidade de dimensões que aponta para uma estrutura necessariamente aberta, de uma historicidade imanente. ${ }^{187}$

Sob pena de superficialidade, é preciso, ainda que pontualmente, examinar a problemática da racionalidade jurídica empregada pelo jusnaturalismo e positivismo. No domínio cultural, o termo ratio significa etimologicamente uma relação discursiva. Entendese por relação discursiva a relação entre certa posição e certos pressupostos, formais ou materiais, os quais discursivamente a sustentam, de modo a conferir-lhe sentido ou

${ }^{187}$ FERRAZ JR., 1976, p. 10-23; 29-38. 
justificação. A racionalidade pode ser discriminada em três modalidades básicas: puramente lógica, teórica e prática. Dadas as diferenças intencionais e estruturais dessas modalidades, é imprescindível atentar para qual dos tipos de racionalidade corresponde o pensamento jurídico em análise. Dois fatores têm sido determinantes para essa compreensão: a concepção de direito pressuposta pelo pensamento jurídico e a atitude intencional desse pensamento perante o direito.

Ao analisar essas três modalidades básicas em face do pensamento jurídico positivista e jusnaturalista, percebe-se uma coincidência na intrínseca ligação destes com a racionalidade teórica. Isso porque, ao se ponderar sobre aqueles dois fatores determinantes para a compreensão jurídica, constata-se que essas Escolas clássicas compreendem o direito como objeto, segundo uma intenção teorética. Formado por construções racionais de universalidade teórico-explicativa, o discurso jurídico clássico tem caráter cognitivo, cuja finalidade é encontrar o fundamento da norma-objeto em outras normas, por meio de métodos válidos de experimentação lógico-objetiva. Apesar da rivalidade histórica, jusnaturalistas e positivistas têm em comum uma concepção normativista e estritamente dogmática do direito, orientada por uma razão lógico-dedutiva. Enquanto o jusnaturalismo propõe apreender e determinar normativamente o direito segundo a lei da razão, mediante a construção de um sistema axiológico, tendo por objetivo afirmar a verdade ontológica de uma dogmática especulativa, o posivismo defende um normativismo capaz de exprimir uma legalidade prescrita, nos termos de um sistema dinâmico de normas, a fim de manifestar a verdade de uma dogmática simplesmente reprodutivo-conceitualista. Assim, não obstante as diferentes concepções do direito, essas dogmáticas concebem o sistema de direito como um sistema fechado e autônomo, o qual deve ser aplicado no plano decisório segundo uma lógica formalista.

A objeção levantada ao pensamento jusnaturalista e positivista consiste na impossibilidade de acolher uma racionalidade teórica no plano da decisão jurídica. Isso porque a exigência moderna de objetividade na realização do direito implica numa mediação normativamente constitutiva incompatível com uma dogmática de índole lógico-formal. Assim, a crítica à racionalidade teórica permite vislumbrar a natureza prático-decisória do fenômeno jurídico, resultando na abertura do direito a uma racionalidade pragmática, a qual se manifesta na forma de um discurso argumentativo resultante de uma relação intersubjetiva. Essa racionalidade prática expressa-se na forma de um discurso que visa à validade, em 
sentido estrito, e à fundamentação, ou à justificação comunicativa, de modo a excluir o absoluto e o impessoal, bem como confirmar o histórico-concreto e a intencionalidade pragmática. ${ }^{188}$

Numa perspectiva pragmático-argumentativa, normas são entendidas como discursos jurídicos, os quais decorrem de relações de poder e verdade entre os sujeitos, mediadas por mensagens. A comunicação normativa opera no nível do conteúdo ou relato e no nível dos cometimentos ou das relações. Essas interações tratam da relação de autoridade entre os agentes. Dessa forma, os discursos normativos constituem um sistema de interações, de modo que os comunicadores normativos estão em constante processo de definição de seus relacionamentos. É, nesse ponto, que surge a ideia de controle das situações comunicativas, o qual procura garantir a imperatividade da norma, a fim de terminar com os conflitos, pondolhes um fim. Daí a importância da noção de sistema de direito, que consiste em uma técnica de controle organizacional da comunicação normativa, tendo por objetivo a questão da validade.

A partir da noção de controle, o discurso normativo é compreendido como interação válida de normas. Por norma válida, entende-se a relação entre os discursos normativos, segundo os aspectos de relato e de cometimento. Para ser válida, é preciso que a relação de autoridade esteja imunizada contra a possível desconfirmação do sujeito. Fundamentada em uma autoridade de outra instância, a relação de imunização de uma norma repousa em outra norma. Desse modo, a validade é uma qualidade relacional, pois depende do conjunto de relações globais de autoridade, que tecnicamente assumem a forma de ordenamento normativo. Esse ordenamento jurídico é um conjunto de elementos normativos e não normativos, denominados repertório, os quais são organizados por regras de relacionamento, denominadas estrutura. Nesse sentido, ordenamento é sistema, cuja função é permitir a integração coerente das normas num conjunto, dentro do qual é possível identificá-las como normas jurídicas válidas. Assim, a seleção do repertório e da estrutura pertinente ao sistema de direito é uma opção teórica de fundamento zetético. ${ }^{189}$

\footnotetext{
${ }^{188}$ NEVES, 1993, p. 34-37; 49-52. KELSEN, 2000, p. 79-113. PERELMAN, Chaï; OLBRECHTS-TYTECA, Lucie. Tratado da argumentação. Trad. Maria Ermantina Galvão. $2^{\mathrm{a}}$ ed. São Paulo: Martins Fontes, 2005, p. 1-4. ${ }^{189}$ COMPARATO, Fábio Konder; SALOMÃO FILHO, Calixto. Poder de controle na sociedade anônima. $4^{\mathrm{a}}$ ed. Rio de Janeiro: Forense, 2005, p. IX-XI. FERRAZ, JR., Tercio Sampaio. Teoria da norma jurídica: ensaio de pragmática da comunicação normativa. Rio de Janeiro: Forense, 1978, p. 102-105; 140-141. FOUCAULT, 1999, p. 27-30. FERRAZ JR., 2001, p. 170-174.
} 
O sistema de direito é um sistema diferenciado, constituído por características particulares e autorregulado. Em relação ao ambiente, o sistema jurídico é do tipo aberto, o que permite grande variabilidade ao trocar informações com outros sistemas sociais, os quais influem diretamente sobre ele, modificando-o. Sua autonomia assegura, porém, a capacidade de regular o que deve ser juridicizado, de modo a impedir que um evento de qualquer dos outros sistemas sociais seja necessariamente incorporado ao sistema. A finalidade do sistema normativo é, pois, impedir a continuação de conflitos, resolvendo-os. Quanto ao conjunto, os sistemas jurídicos são sistemas globais e não somativos. Isso significa que possuem, respectivamente (i) coerência; logo, por serem interdependentes, as partes e o todo são reciprocamente afetados por variações; e (ii) qualidades que não resultam da simples soma das partes. Essa qualidade do sistema jurídico é a sua imperatividade, a qual trata sobre as relações de imunização normativa. ${ }^{190}$

Como o presente estudo tem por foco investigar a cláusula da nação mais favorecida na ordem econômica internacional, o conceito de sistema de direito será aplicado aos discursos jurídicos próprios do direito internacional econômico, os quais decorrem das relações de poder e verdade entre os agentes econômicos. Com efeito, sistema internacional de comércio é definido como um conjunto axiológica e teleologicamente organizado de discursos jurídicos, produzidos pelas relações econômicas internacionais, cujas regras de coesão das interações normativas permitem, mediante o controle de validade, a solução internacional de controvérsias.

${ }^{190}$ FERRAZ JR., 1978, p. 102-105; 141-142. FERRAZ JR., 2001, p. 249. 


\subsection{A OMC COMO SISTEMA MULTILATERAL DE COMÉRCIO}

À luz da definição de sistema internacional de comércio, será apresentado o conceito de sistema multilateral de comércio. Examinar-se-á, neste Capítulo, a construção histórica e as características institucionais do sistema GATT/OMC. Isso permitirá extrair suas particularidades, a partir das quais serão analisados, nos Capítulos subsequentes, os objetivos, os elementos constitutivos, bem como o conjunto de regras estruturais dos SMC.

A doutrina originalmente hesitou em reconhecer o caráter global ao sistema GATT/OMC, na medida em que havia controvérsias sobre a natureza jurídica e a aplicabilidade do Acordo Geral sobre Tarifas e Comércio. Como a Organização Internacional do Comércio não encontrou meios de entrar em vigor, o caráter interino do GATT suscitava indagações acerca da institucionalização de uma única ordem econômica internacional, o que refletia sobre o âmbito de incidência e eficácia do SMC.

A história do sistema multilateral de comércio pode ser observada como um processo descontinuado de institucionalização e normatização das relações econômicas internacionais. Embrião do SMC, o Acordo Geral sobre Tarifas e Comércio foi o primeiro instrumento por meio do qual se veiculou o discurso jurídico-convencional fundante dos vínculos jurídicos multilaterais e disciplinador das relações econômicas entre Estados. Corporificado em um tratado internacional, o GATT manifesta a vontade dos Estados-contratantes de produzir uma verdade jurídica na forma de regras e princípios de direito internacional econômico. Seus enunciados linguísticos expressam a verdade consensual predominante do jogo estratégico e polêmico de discursos dos Estados. Daí preâmbulo e cláusulas expressarem o texto prevalecente entre as diferentes propostas apresentadas individualmente pelos distintos países durante a negociação. ${ }^{191}$

\footnotetext{
${ }^{191}$ FOUCAULT, Michel. A verdade e as formas jurídicas. Trad. Roberto Machado e Eduardo Morais. Rio de Janeiro: NAU, 2005, p. 7-10. CARVALHO, 2008, p. 134-143; 174-181.
} 
Produto histórico das relações econômicas internacionais, o Acordo Geral sobre Tarifas e Comércio guarda particularidades distintivas, quais sejam, a observância da reciprocidade dos interesses, o multileralismo axiológico-procedimental e a natureza relacional de suas obrigações. Os interesses comuns e o caráter de permanência conferiram uma aparência institucional ao GATT, o qual passaria a designar tanto o tratado internacional quanto uma instituição contratualista. Nesses primeiros anos, o sistema multilateral de comércio era compreendido como um conjunto de normas pragmático-procedimentais, que visava à consolidação de uma jurisprudência diplomática para o fim de orientar a solução de conflitos econômicos internacionais.

Essa flexibilidade normativa permitia às partes recorrer aos meios diplomáticos para selarem, por meio de negociações e acordos, disputas comerciais. Inerentes à técnica diplomática, as relações de poder e verdade entre os Estados conflituosos determinavam, em detrimento de qualquer norma positiva, o resultado da barganha. Desse modo, o sistema GATT, por ser orientado pelo resultado segundo uma racionalidade maquiavélico-hobbesiana de vencedor-perdedor, assegurava ao Estado vitorioso impor sua vontade no litígio, de modo a disciplinar o comportamento do Estado perdedor. John H. Jackson denominou essa técnica de solução de controvérsias econômicas internacionais, guiada predominantemente por flexíveis normas procedimentais e meios diplomáticos, de sistema power-oriented. ${ }^{192}$

No decorrer das rodadas de negociação comercial, o progressivo crescimento ratione personae do número de Estados-partes associado ao alargamento ratione materiae da competência normativo-regulatória do sistema multilateral de comércio resultaram no aumento dos conflitos comerciais entre os Estados, o que veio a exigir a utilização mais frequente dos procedimentos para solução de controvérsias. Em razão disso, as Partes buscaram conferir maior durabilidade às expectativas normativas, com o fim de assegurar maior previsibilidade e segurança às normas do sistema GATT. Isso propagou um processo de construção de medidas de confiança (confidence building measures) dos Estados na instituição, implicando na perda progressiva da predominância das técnicas diplomáticas em razão do fortalecimento dos meios jurídicos de solução de controvérsias. O resultado foi a codificação do direito econômico internacional na forma dos acordos comerciais celebrados no final da

\footnotetext{
${ }^{192}$ BHAGWATI, Jagdish. Protecionismo versus comércio livre. Trad. Mário Salviano. Rio de Janeiro: Nórdica, 1990, p. 30-40. JACKSON, 1997, p. 109-112. DAM, 1970, p. 4-5. PETERSMANN, 1997, p. 69. HUDEC, 1975, p. 26. LAFER, 1998, p. 26-28.
} 
Rodada Uruguai, sendo o Acordo Constitutivo da Organização Mundial do Comércio o mais relevante.

A OMC, enquanto organização internacional paradigma do contexto pós-Guerra Fria, diferencia-se das demais por fornecer um marco institucional comum, visto congregar competências regulatórias, decisórias e executórias, as quais têm o condão de promover a credibilidade, aceitação e observância do sistema multilateral de comércio. Como a institucionalização depende da inserção dos discursos normativos em mecanismos disciplinares mais efetivos, foram introduzidas no SMC normas primárias de comportamento/obrigação, que convergem à expectativa dos Estados para a promoção de objetivos comuns, e normas secundárias de organização/competência. Com isso, a OMC consolidou o processo de juridificação do espaço econômico mundial em níveis desconhecidos pelos GATT, bem como promoveu a legalização da jurisprudência diplomática e despolitização da solução de controvérsias, o que operou uma mudança conceitual do sistema GATT/OMC. ${ }^{193}$

Nesse particular, a institucionalização do sistema multilateral de comércio somente se tornou efetiva graças à introdução de duas imprescindíveis confidence building measures. A primeira consistiu na positivação do artigo II:1 do Acordo OMC, o qual prevê que a "OMC constituirá o quadro institucional comum para a condução das relações comerciais entre seus Membros". Daí surge o conceito de empreendimento único (single undertaking), que confere aos acordos da OMC a natureza de um ordenamento jurídico integrado, ao qual todos os Estados-membros estão vinculados. Sua função é imputar aos intérpretes autênticos o dever de assegurar a coerência interna do sistema GATT/OMC, a fim de evitar fragmentação e contradições normativas. Apesar dos diversos acordos terem sido negociados separadamente, sua interpretação deve ser cumulativa, simultânea e harmoniosa. Com isso, marca-se a passagem de uma dimensão diplomático-contratual das relações internacionais para uma dimensão institucional.

A segunda medida consistiu no adensamento de juridicidade, proveniente da celebração do Entendimento sobre as Regras e Procedimentos que Governam a Solução de Controvérsias, o qual confere ao mecanismo de solução de controvérsias da OMC elementos

${ }^{193}$ FARIA, 2002, p. 111-149. LAFER, 1998, p. 22-28. HART, 2001, p. 53-57. PETERSMANN, Ernst-Ulrich. The Dispute Settlement System of the World Trade Organization and the Evolution of the GATT Dispute System Since 1948. Common Market Law Review, [s.1.], v. 31, 1994, p. 1157-1244. 
jurisdicionais singulares, sem que fossem totalmente excluídos os diplomáticos. $\mathrm{O}$ fortalecimento das técnicas jurídicas de solução de disputas, cujas características fundamentais consistem no respeito voluntário dos Estados a normas jurídico-prescritivas de conduta, julgamentos imparciais por terceiro e monopolização do uso da força, retirou dos Estados a competência para decidir sobre a licitude e a legalidade dos respectivos comportamentos, o que previne desequilíbrios, decorrentes da utilização abusiva de posição dominante, na solução de confrontos comerciais.

Para assegurar a coesão e a eficácia do sistema multilateral de comércio, o processo de institucionalização foi responsável por estabelecer os dois principais mecanismos disciplinadores da OMC, o Conselho Geral e o Órgão de Solução de Controvérsias, os quais têm competência para exercer o controle de condutas e estruturas das relações entre os agentes econômicos. Cabe ao CG e ao OSC interpretarem as normas do SMC, em especial a cláusula da nação mais favorecida, a fim de determinar casualmente se os acordos preferenciais de comércio, as medidas contingenciais e as práticas dos Estados-membros violam regras e princípios do sistema GATT/OMC.

Há, assim, uma profunda mudança de percepção dos Estados sobre o sistema GATT/OMC, o qual passa a ser orientado pela legalidade segundo uma racionalidade grociokantiana de cooperação e objetividade. Daí atribuir ao Órgão de Solução de Controvérsias competência para controlar juridicamente as relações econômicas internacionais, de modo a conferir maior estabilidade às expectativas normativas dos Estados-membros, limitar o risco de abuso de poder e reduzir o custo de transação, promovendo a liberdade e o bem-estar econômico. Após debruçar-se sobre essa técnica de solução de controvérsias econômicas, guiada predominantemente por normas materiais e meios jurídicos, J. Jackson denominou-a de sistema rule-oriented. ${ }^{194}$

Não obstante, ressalta-se que os meios diplomáticos e os meios jurídicos de solução de controvérsias não são excludentes; pelo contrário, são empregados de forma combinada nos diversos mecanismos internacionais de solução de disputas. $\mathrm{O}$ adensamento da juridicidade do

${ }^{194}$ JACKSON, 1997, p. 109-112. DAM, 1970, p. 4-5. PETERSMANN, 1997, p. 85. LAFER, 1998, p. 29-32. AMARAL JR., 2006, p. 131-133. PETERSMANN, Ernst-Ulrich, Dispute settlement in international economic law - lessons for strengthening international dispute settlement in non-economic areas. Journal of International Economic Law, [s.1.], v. 2, n. 2, 1999, p. 189-199. MARCEAU, Gabrielle. Balance and coherence by the WTO Appellate Body: who could do better? In: SACERDOTI, Giorgio; YANOVICH, Alan; BOHANES, Jan (org.). The WTO at Ten: The Contribution of the Dispute Settlement System. Cambridge University Press, 2006, p. 326$327 ; 347$. 
mecanismo de solução de controvérsias da OMC implicou na redução da sua dimensão diplomática, mas não a eliminou. O ESC combina a lógica diplomática, que privilegia os meios negociais sujeitos a abusos de poder, à lógica jurisdicional, que preza as garantias procedimentais e a produção de decisões vinculantes para as partes litigantes. Sem esmiuçar o debate sobre a natureza jurídica, admite-se qualificar o mecanismo de solução de controvérsias da OMC como quase-judiciário, na medida em que é estruturado sobre órgãos jurisdicionais e órgãos políticos. Enquanto aos painéis e ao Órgão de Apelação cabe examinar as pretensões jurídicas e decidi-las, o Órgão de Solução de Controvérsias, de caráter essencialmente político, reúne todos os Estados-membros para administrar o mecanismo e tomar decisões juridicamente vinculantes, inclusive avalizar o relatório daqueles. ${ }^{195}$

Constatada a predominância de sua natureza jurídico-institucional, proceder-se-á ao exame do sistema multilateral de comércio, mediante a verificação de suas características singulares, as quais são responsáveis por diferenciá-lo dos demais sistemas internacionais de comércio. Serão, primeiramente, analisados os elementos que compõem o repertório do SMC, sendo, em seguida, verificadas as regras de relacionamento que conformam a estrutura sistêmica.

\subsubsection{O repertório: os discursos normativos do SMC}

O objetivo de examinar o repertório de um sistema de direito é determinar quais são os elementos válidos para fundamentar as decisões dos órgãos judicantes. Os elementos constituintes dos sistemas internacionais de comércio são essencialmente os discursos normativos de direito internacional econômico, produzidos pelas relações econômicas de poder e verdade. As normas podem assumir a forma de regras ou princípios, conforme acordadas, expressa ou implicitamente, pelas partes quando da formação de certo sistema.

${ }^{195}$ LAFER, 1998, p. 126. AMARAL JR., 2006, p. 126-227. CARREAU; JUILLARD, 1998, p. 82-84. LONG, 1987, p. 83-85. 
Tradicionalmente, as normas do comércio internacional podem ser classificadas segundo os agentes, públicos ou privados, ou segundo sua natureza, interna ou internacional. ${ }^{196}$

Os sistemas internacionais de comércio, formados exclusivamente pelas relações interestatais, costumam restringir estruturalmente os discursos normativos vinculantes aos arrolados no artigo 38 do Estatuto da Corte Internacional de Justiça. Embora não disponha de uma lista exaustiva, o artigo 38 reconhece que as fontes de direito internacional são: (i) os tratados; (ii) os costumes; (iii) os princípios gerais do direito; (iv) a jurisprudência; e (v) a doutrina dos juristas mais qualificados. Quanto aos princípios, esses decorrem da vontade comum dos Estados; logo, costumam variar conforme a concepção predominante de economia internacional. ${ }^{197}$

Guardadas as devidas proporções, o artigo 7 do Entendimento sobre Solução de Controvérsias cumpre, no sistema multilateral de comércio, função similar ao artigo 38 do Estatuto da ICJ, visto especificar quais são os discursos normativos aplicáveis aos Estadosmembros pelo Órgão de Solução de Controvérsias. Dessa forma, o repertório de normas institucionalizadas é restrito: (i) aos acordos da OMC, bem como a outros tratados internacionais aludidos por aqueles; (ii) aos costumes; (iii) aos princípios gerais de direito; (iv) aos relatórios dos painéis e do Órgão de Apelação; (v) aos ensinamentos dos mais qualificados publicistas; e (vi) a outras normas internacionais porventura existentes. ${ }^{198}$

O preâmbulo do Acordo Constitutivo da Organização Mundial do Comércio estabelece os objetivos primários do sistema GATT/OMC, os quais têm a dupla função de disciplinar as relações econômicas entre os Estados-membros, bem como vincular as decisões do Órgão de Solução de Controvérsias. Nos exatos termos do Acordo OMC:

Reconhecendo que as suas relações na esfera da atividade comercial e econômica devem objetivar a elevação dos níveis de vida, o pleno emprego e um volume considerável e em constante elevação de receitas reais e demanda efetiva, o aumento da produção e do comércio de bens e de serviços, permitindo ao mesmo tempo a utilização ótima dos recursos mundiais em conformidade com o objetivo de um desenvolvimento sustentável e buscando proteger e preservar o meio ambiente e incrementar os meios para fazê-lo, de maneira compatível com suas respectivas necessidades e interesses segundo os diferentes níveis de desenvolvimento econômico [...].

\footnotetext{
${ }^{196}$ CARREAU; JUILLARD, 1998, p. 11-12. FERRAZ JR., 2001, p. 173.

${ }^{197}$ NGUYEN; DAILLIER; PELLET, 1999, p. 101-106.

${ }^{198}$ PALMETER, David; MAVROIDIS, Petros C. The WTO Legal System: Sources of Law. The American Journal of International Law, [s.1.], v. 92, n. 3, 1998, p. 398-413. AMARAL JR., 2006, p. 271-272.
} 
Do texto normativo, extrai-se que os princípios fundamentais do sistema multilateral de comércio são: (i) paz; (ii) não discriminação; (iii) soberania; (iv) desenvolvimento; (v) cooperação multilateral; (vi) reciprocidade; e (vii) transparência. Embora não seja objeto do presente trabalho debruçar-se sobre os problemas concernentes à natureza jurídica dos princípios e à respectiva relação com as regras, é pertinente ressaltar que na própria conceituação de sistema de direito os princípios exercem o imprescindível papel de organizador dos discursos normativos. Desse modo, os princípios têm a função precípua de orientar axiológica e teleologicamente os elementos normativos e a aplicação das regras de estrutura, em prol da concreção dos objetivos do sistema GATT/OMC. ${ }^{199}$

Portanto, o repertório do sistema multilateral de comércio, ainda que não vede expressamente o emprego de elementos não normativos nas decisões do Órgão de Solução de Controvérsias, é restrito aos discursos jurídicos de direito internacional econômico especificados pelo artigo 7 do ESC.

\subsubsection{Regras de estrutura: a interpretação do SMC}

As regras que tratam sobre a interação entre os elementos podem resultar do acordo entre os agentes econômicos. Todavia, são raros os sistemas jurídicos que estabelecem expressamente determinada forma de relacionamento normativo, uma vez que dificilmente há consenso na filosofia ou na teoria geral do direito sobre quais regras de estrutura devem ser adotadas. Em razão disso, o artigo 38 do Estatuto da Corte Internacional de Justiça não estabelece regras de relacionamento normativo, visto não haver a pretensão de positivar $a$ priori estruturas hierárquicas entre costumes, tratados e princípios gerais do direito, cabendo à relação desses elementos traduzir as expectativas normativas da ordem econômica internacional.

\footnotetext{
${ }^{199}$ HILF, Meinhard. Power, Rules and Principles - Which orientation for WTO/GATT Law? Journal of International Economic Law, [s.1.], v. 4, n. 1, 2001, p. 111-130. HOEKMAN, Bernard. The WTO: Functions and Basic Principles. In: HOEKMAN, Bernard M.; MATTOO, Aaditya; ENGLISH, Philip (ed.). Development, trade, and the WTO: a handbook. Washington: World Bank Publications, 2002, p. 41-49.
} 
A regra geral de estrutura do sistema GATT/OMC está prevista no artigo 3.2 do Entendimento sobre as Regras e Procedimentos que Governam a Solução de Controvérsias, o qual prevê que o objetivo do mecanismo de solução de controvérsias da OMC é controlar os discursos normativos abrangidos no artigo 7, "em conformidade com as normas correntes de interpretação do direito internacional público". Por reconhecer a falta de consenso acerca das regras de relacionamento normativo, o artigo 3.2 atribui ao Órgão de Solução de Controvérsias competência de selecioná-las e aplicá-las argumentativamente na solução de conflitos comerciais. Disso, conclui-se que, para determinar quais são as regras de estrutura do sistema multilateral de comércio, deve-se investigar o discurso jurídico-decisório produzido pelos intérpretes da OMC.

Na lição de Hans Kelsen, a interpretação jurídica distingue-se em duas espécies: interpretação autêntica, realizada por um órgão competente aplicador da norma, e interpretação dogmática, que resulta de organismo que não detém aquela qualidade. Com efeito, somente o discurso normativo produzido pelo intérprete autêntico é dotado de enunciado vinculante, não se confundindo com os comentários e pareceres dos doutrinadores. O sistema multilateral de comércio atribui, por meio do artigo 2 do ESC, competência ao Órgão de Solução de Controvérsias para apreciar as controvérsias a este apresentadas, interpretar e aplicar as normas e procedimentos, supervisionar a implementação das decisões e recomendações, bem como autorizar a suspensão de concessões e de outras obrigações determinadas pelos acordos abrangidos. ${ }^{200}$

Para auxiliá-lo na administração do mecanismo de solução de disputas, o OSC conta com dois órgãos decisórios, os grupos especiais, comumente conhecidos como painéis e o Órgão Permanente de Apelação, aos quais foi outorgado o poder de controle sobre os discursos normativo-decisórios. De acordo com o ESC, os painéis realizam uma típica função de órgão de primeira instância, incluindo a análise fático-normativa da controvérsia e a apresentação de relatórios, enquanto o OPA é dedicado a controlar os discursos veiculados nas referidas recomendações. Os relatórios desses órgãos auxiliares não são dotados, porém, de força vinculante per si, visto dependerem formalmente da respectiva adoção, ainda que por consenso positivo, pelo OSC, cujas decisões são legalmente dotadas de efeitos de coisa julgada (res judicata). Portanto, a Organização Mundial do Comércio conferiu ao Órgão de

${ }^{200}$ KELSEN, 2000, p. 387-397. 
Solução de Controvérsias a autoridade do discurso jurídico-decisório, com a finalidade de exercer o controle de legalidade e de licitude das relações econômicas internacionais, mediante a interpretação dos acordos OMC. ${ }^{201}$

Em que pesem as discussões sobre a natureza quase-judicial do OSC, o artigo 3.2 do Entendimento sobre Solução de Controvérsias atribui a seus órgãos auxiliares, em especial o Órgão de Apelação, funções puramente judiciais, na medida em que os incumbe de "trazer segurança e previsibilidade ao sistema multilateral de comércio”. Daí o tratamento dispensado por eles às demandas para seguir pari passu os procedimentos judiciais que conformam os discursos normativo-decisórios. Embora os painéis do GATT tenham relutado em explicitar quais métodos de interpretação eram empregados na solução de controvérsias, graças ao adensamento de juridicidade promovido pelo ESC, foi outorgada ao Órgão de Solução de Controvérsias competência para determinar as regras de estrutura aplicáveis.

Já em seu primeiro relatório, concernente ao Caso United States - Standards for Reformulated and Conventional Gasoline (“US - Gasoline”), o Órgão de Apelação identifica haver um liame vinculante entre o disposto no artigo 3.2 do ESC e o artigo 31 da Convenção de Viena sobre Direito dos Tratados de 1969 (“CVDT”). O segundo relatório, relativo ao Caso Japan - Taxes on Alcoholic Beverages, ampliou e consolidou o entendimento prévio, ao referir-se também ao artigo 32 da CVDT. Nesse sentido, as decisões do OPA têm o condão de reconhecer que as "regras gerais de interpretação" da Convenção de Viena de 1969 têm natureza de norma costumeira de direito internacional, razão pela qual cumprem com os requisitos do referido artigo $3.2 .^{202}$

A relevância dessas decisões de reconhecimento justifica-se fundamentalmente por seu duplo efeito. Primeiro, ao admitir a autoridade da Convenção de Viena sobre Direito dos Tratados, o Órgão de Apelação rejeitou expressamente a concepção de que o sistema multilateral de comércio é um sistema autocontido, não devendo ser interpretado como isolado clinicamente do direito internacional público. O relatório, ao reconhecer a conexão entre o sistema GATT/OMC e a estrutura institucional-legal da ordem econômica internacional,

${ }^{201}$ AMARAL JR., 2006, p. 323-328. CARVALHO, 2008, p. 185-189.

${ }^{202}$ OMC. United States - Standards for Reformulated and Conventional Gasoline. Report of the Appellate Body, 29 abr. 1996. Disponível em <http://www.wto.org/english/tratop_e/dispu_e/cases_e/ds2_e.htm>. Acesso em: 9 jul. 2009. Documento da OMC n. WT/DS2/AB/R, p. 15-18. OMC. Japan - Taxes on Alcoholic Beverages. Report of the Appellate Body, 4 out. 1996. Disponível em <http://docsonline.wto.org/DDFDocuments/t/WT/DS/8ABR.WPF>. Acesso em: 9 jul. 2009. Documento da OMC n. WT/DS8/AB/R, WT/DS10/AB/R, WT/DS11/AB/R, p. 9-11. 
elucida as dúvidas que pairavam sobre abertura sistêmica do SMC. Isso fundamenta as remissões aos princípios e regras de direito internacional público que se sucederão nos relatórios do Órgão de Solução de Controvérsias. ${ }^{203}$

Segundo, a decisão estabelece as regras de relacionamento do sistema multilateral de comércio, ao adotar os artigos 31 e 32 como métodos hermenêuticos aplicáveis pelo Órgão de Solução de Controvérsias na interpretação dos acordos OMC. Verifica-se uma ruptura em relação à interpretação político-subjetivista vigente no GATT, centrada essencialmente na apuração da intenção dos Estados por meio dos históricos trabalhos preparatórios, na medida em que se impõe aos painéis e ao OPA o dever de interpretar as normas da OMC como qualquer outro tratado internacional. A adoção das regras de estrutura da CVDT permite aos intérpretes autênticos cuidar com maior segurança e previsibilidade dos detalhes, especificidades e complexidades dos acordos $\mathrm{OMC}$, resultando no fortalecimento das expectativas normativas.

A Convenção de Viena sobre Direito dos Tratados expressa a melhor síntese possível das negociações internacionais acerca das regras gerais de interpretação, as quais refletiam a polêmica jurídico-dogmática, entre propugnadores das teorias subjetivistas e objetivistas, subjacentes à própria filosofia e teoria geral do direito. Enquanto a doutrina subjetivista defende que cabe ao intérprete compreender o pensamento do legislador, focando-se numa interpretação ex tunc, a doutrina objetivista sustenta que a norma goza de um sentido próprio, determinada por fatores objetivos, independente, até certo limite, da vontade original do legislador, razão pela qual se centra na interpretação ex nunc. Ciente da necessidade de estabelecer um rol geral de normas versáteis e flexíveis, a CVDT não positivou regras de estrutura cogentes de qualquer corrente dogmática. Dessa forma, para não se vincular a correntes teóricas, os artigos 31, 32 e 33 codificaram justamente as regras de interpretação costumeiramente empregadas no direito internacional público, cujo escopo é servir de guia

\footnotetext{
${ }^{203}$ MARCEAU, Gabrielle. Um pedido pela coerência no direito internacional. Elogios para a proibição ao "isolamento clínico" na solução de controvérsias na OMC. In: MERCADANTE, Araminta; MAGALHÃES, José Carlos de (Coord.). Solução e prevenção de litígios internacionais. Trad. Adalberto Nader. V. III, Rio de Janeiro: Forense, 2003, p. 318-322. OMC, United States - Standards for Reformulated and Conventional Gasoline, Report of the Appellate, p. 15-16.
} 
procedimental para a decidibilidade dos intérpretes, a fim de promover a coerência sistêmica. $^{204}$

Nos termos do artigo 31.1, o "tratado deve ser interpretado de boa-fé segundo o sentido comum atribuível aos termos do tratado em seu contexto e à luz de seu objetivo e finalidade". O texto jurídico-convencional da CVDT expressa as três regras de estrutura fundamentais do direito dos tratados: (i) o sentido ordinário; (ii) que deve levar em consideração seu contexto; e (iii) à luz do seu objeto e fim. $\mathrm{O}$ artigo 31.2 aprofunda a análise contextual. $\mathrm{O}$ artigo 31.3 dispõe sobre outras técnicas que visam à coerência da interpretação. $\mathrm{O}$ artigo 32 versa sobre regras suplementares, enquanto o artigo 33 trata dos critérios para interpretar tratados expressos em dois ou mais idiomas. Todas essas normas perfazem um conjunto de métodos hermenêuticos, cujo objetivo é orientar os intérpretes autênticos para os problemas de decidiblidade de conflitos, os quais podem ser de ordem sintática, semântica ou pragmática.

Os problemas sintáticos versam sobre questões gramaticais, lógicas e sistemáticas. A interpretação gramatical examina as conexões léxicas, servindo de instrumento revelador de equivocidades que conduzem a conflitos. A interpretação lógica é uma técnica hermenêutica empregada para determinar inconsistências decorrentes da violação do princípio lógico da identidade. Pressupõe-se, nesse caso, que a conexão de uma expressão normativa com as demais do contexto é importante para compreender o significado correto, evitando-se que um mesmo termo tenha consequências distintas. A interpretação sistemática enfrenta questões de compatibilidade num todo estrutural. Esse método hermenêutico pressupõe a unidade do sistema jurídico, o que possibilita a organização hierárquica das fontes normativas. Os métodos sintáticos de interpretação são utilizados amplamente para identificar as questões, mas não criam as condições necessárias de decidibilidade.

Diferentemente da ordem sintática, as questões semânticas referem-se ao significado das palavras ou de sentenças, cujos desafios são a ambiguidade e a vagueza. Há duas técnicas semânticas de interpretação. O método histórico consiste no recurso aos precedentes normativos e aos trabalhos preparatórios, tendo por objetivo determinar o conjunto de circunstâncias que marcaram a nomogênese jurídica. $\mathrm{O}$ método sociológico tem a pretensão de

\footnotetext{
${ }^{204}$ AMARAL, 2006, p. 323-340. ABI-SAAB, Georges. The Appellate Body and Treaty Interpretation. In: SACERDOTI, Giorgio; YANOVICH, Alan; BOHANES, Jan (org.). The WTO at Ten: The Contribution of the Dispute Settlement System. Cambridge: Cambridge University Press, 2006, p. 457-458. FERRAZ, 2001, p. 260264. BROWLIE, 1997, p. 650.
} 
examinar as condições contemporâneas, para determinar as funções do comportamento e das instituições sociais. Essa técnica hermenêutica entende que as relações humanas são causais, tendo uma razão prática para existir. Com fundamento nas informações históricas, a interpretação assume a forma conotativa para o controle de ambiguidade, cujo escopo é definir o símbolo por sua intenção-existencial. Enquanto as informações sociológicas permitem o controle da vaguidade dos termos por meio da interpretação denotativa, tendo por objetivo definir o símbolo segundo sua extensão funcional.

Tem-se, por fim, as questões pragmáticas de interpretação que se reportam numa relação comunicativa ao controle valorativo dos símbolos, cuja problemática está centrada na generalização dos valores. Os problemas peculiares à relação entre emissor e receptor são enfrentados por meio dos métodos teleológico e axiológico. A interpretação teleológica consiste na atribuição de um propósito às normas, para concreção dos objetivos do sistema de direito. A interpretação axiológica postula a valoração de situações segundo os princípios da vida social. Os métodos pragmáticos exigem do intérprete a participação ativa no processo de construção dos sentidos. Seu processo interpretativo, em oposição à técnica sistemática que também postula uma coerência interna, parte das consequências avaliadas e retorna ao interior do sistema. Desse modo, a norma é apenas um referencial, sujeitando-se ao controle exercido pelo hermeneuta para concreção dos valores e fins da previsão legal. ${ }^{205}$

No Caso US - Gasoline, o Órgão de Apelação declara que os termos do tratado constituem o fundamento do processo interpretativo, devendo ser examinados segundo seu sentido ordinário, conforme o contexto e à luz do objeto e finalidade do tratado. Esse posicionamento de conceder maior peso ao critério textual revela uma vocação hermenêutica objetivista, mediada por métodos sintáticos de interpretação. Não obstante os limites intrínsecos dessas técnicas exegéticas, a interpretação dos acordos OMC traz subjacente a dificuldade adicional de possuir três discursos jurídico-convencionais autênticos, agravando o desafio do hermeneuta de atribuir sentido lexical aos símbolos. Isso explica as frequentes referências nos relatórios do OPA a dicionários, particularmente ao The New Shorter Oxford Dictionary, que, nas palavras de críticos, tem se tornado um verdadeiro acordo abrangido.

Nesse particular, é preciso estar ciente de que a linguagem, enquanto produto de um processo histórico, consubstancia os valores culturais de uma sociedade, servindo tanto para

${ }^{205}$ FERRAZ, 2001, p. 282-285. 
propiciar a compreensão como para transmitir a cultura. Ao importar o conteúdo textual para outra língua, a tradução constrói uma ponte entre duas culturas, resultando em um choque de visões de mundo. Tais considerações ganham especial relevância no direito internacional, o qual é desenvolvido e aplicado em contexto marcado pelo plurilinguismo e multiculturalismo jurídico. Daí constatar que o inglês tem prevalecido na guerra das línguas oficiais da OMC, garantindo, por meio da construção interpretativa, a influência da cultura jurídica estadunidense na determinação dos conteúdos de verdade dos acordos do sistema multilateral de comércio. ${ }^{206}$

O recurso aos dicionários, enquanto meio de fundamentação do sentido ordinário de enunciados, é uma estratégia discursiva, cujo objetivo é evitar o esvaziamento do conteúdo normativo ocasionado por interpretações que buscam privar o direito de seu efeito prático e, sobretudo, de legitimidade. A dicionarização do método sintático-textual visa, assim, promover maior estabilidade às expectativas e univocidade ao discurso normativo. Isso não significa excluir os demais métodos hermenêuticos, mas enfatizar que a tônica interpretativa do OPA tem viés lexical, o que determina o percurso da leitura adotado por esse órgão decisório.

No entanto, o discurso normativo-dicionarizado não consiste simplesmente numa tentativa de se produzir uma espécie de esperanto jurídico capaz de suprimir a polissemia plurilinguística dos termos legais, o que seria comparável aos conceitos predeterminados de sistemas axiológicos formalizados. As deficiências do instrumento linguístico evidenciam as limitações da interpretação dicionarizada. Ciente disso, o Órgão de Apelação não restringe sua interpretação ao método sintático-lexical, razão pela qual já declarou, no Caso United States Tax Treatment for "Foreign Sales Corporations", que "we must look beyond dictionary meanings, because, as we have said before, 'dictionary meanings leave many interpretive questions open”, ou seja, é necessário ir além dos sentidos dados pelos dicionários. Com efeito, ao apontar para a possibilidade de superar a circunscrição dessa racionalidade jurídica puramente lógica, abre-se o debate sobre os métodos hermenêuticos apropriados ao discurso jurídico-decisório da OMC. ${ }^{207}$

\footnotetext{
${ }^{206}$ CARVALHO, 2008, p. 143-154; 247-285.

${ }^{207}$ CARVALHO, 2008, p. 285-287. OMC. United States - Tax Treatment for "Foreign Sales Corporations". Report of the Appellate Body, 24 fev. 2000. Disponível em
} 
$\mathrm{Na}$ esteira da objeção já levantada ao pensamento jurídico teorético, o Órgão de Apelação percebe que o significado de um termo de conceito não se resume ao sentido ordinário previsto nos dicionários. Os conteúdos normativos não resultam da verificação transcendental da palavra, pois a moderna exigência de objetividade na realização do direito implica uma mediação normativamente constitutiva incompatível com uma dogmática hermenêutica de índole lógico-formal. O processo de construção de uma cultura jurídica comum no âmbito do SMC depende do papel primordial exercido pelo Órgão de Solução de Controvérsias, na medida em que, ao exercer, por meio de seus órgãos auxiliares, o controle dos discursos normativos, suas decisões têm por efeito definir a verdade da OMC.

O reconhecimento da necessidade de ir além do método sintático-dicionarizado permite vislumbrar a natureza prático-decisória do fenômeno jurídico, resultando na abertura do sistema multilateral de comércio a uma racionalidade pragmática, a qual se manifesta na forma de um discurso argumentativo resultante de uma relação intersubjetiva. Essa racionalidade prático-jurisprudencial manifesta-se na forma de um discurso que visa à validade, em sentido estrito, e à fundamentação, ou à justificação comunicativa, de modo a excluir o absoluto e o impessoal, bem como confirmar o histórico-concreto e a intencionalidade pragmática. Por isso, o discurso jurídico-decisório, mediado por métodos pragmáticos, pode contribuir para assegurar maior previsibilidade às expectativas normativas dos Estados, visto buscar a área de consenso dentro da qual certo discurso verdadeiro será prevalecente.

Sujeito aos jogos de poder e verdade, o referido consenso não é estático ou definitivo, mas tem a função de produzir poderosos efeitos que conferem legitimidade ao discurso veiculado. Não se deve ignorar que, subjacente à questão das regras de estrutura, vislumbra-se a existência de relações de poder que visam determinar a influência do discurso jurídicodecisório, vis-à-vis às verdades técnico-econômicas e aos discursos políticos, sobre as interpretações do direito da OMC. A busca por esse caráter prático-consensual do discurso jurídico-decisório tem levado o Órgão de Apelação a conferir maior relevância aos métodos pragmáticos no processo de interpretação, implicando na imposição aos Estados-membros de condutas, axiológica ou teleologicamente orientadas, que vão além de seus interesses iniciais.

<http://docsonline.wto.org/DDFDocuments/t/WT/DS/108ABR.DOC>. Acesso em: 1 jun. 2009. Documento da OMC n. WT/DS108/AB/R, par. 129. 
Nesse sentido, a racionalidade jurídica do OSC não estaria restrita apenas ao aspecto pragmático-argumentativo, pois o discurso jurídico encontra sua validade, material e formal, no sistema multilateral de comércio. As decisões concretas não podem confirmar quaisquer fins pretendidos, ainda que fundados em normas a priori válidas, ou incorrer num finalismo absoluto de convicção ou num formalismo de mera adequação funcional. Devem, sim, cuidar para expressar um conteúdo prático segundo critérios teleológicos, histórica e legitimamente programados, os quais se realizam validamente em referência ao contexto integrante do SMC. 208

Em suma, as regras de estrutura do sistema multilateral de comércio, referidas no artigo 3.2 do ESC, estão reconhecidamente arroladas nos artigos 31 e 32 da CVDT. O Órgão de Solução de Controvérsias emprega as regras de relacionamento normativo, segundo uma racionalidade jurídico-pragmática, tendo por objetivo produzir uma decisão, validamente justificada no ordenamento, em termos formais e finalísticos. Nesse processo jurisprudencial de construção do discurso decisório, o intérprete deve atentar-se para os limites do exame textual, mediado por métodos sintáticos, os quais são dificultados pelas questões pertinentes ao embate das diversas culturas jurídicas em disputa pela hegemonia linguística, sem se descuidar da concreção do objeto e dos fins do direito da OMC.

Diante do exposto, o termo de conceito sistema multilateral de comércio revela-se como um conjunto de discursos normativos, previstos no artigo 7 do ESC, e organizados, nos termos do artigo 3.2, por normas correntes de coesão do direito internacional, codificadas nos artigos 31 e 32 da CVDT, visando à concreção dos princípios fundamentais dispostos no Acordo OMC.

${ }^{208}$ CARVALHO, 2008, p. 287-294. PERELMAN; OLBRECHTS-TYTECA, 2005, p. 1-4. NEVES, 1993, p. 35$37 ; 71-81$. 


\subsection{REINTRODUZINDO OS DESAFIOS SISTÊMICOS À LUZ DO ARTIGO I:1 DO GATT}

Como observado na Seção I, o sistema multilateral de comércio vem sofrendo com ameaças de desautorização de suas regras e princípios nucleares, em razão da proliferação de acordos preferenciais de comércio e de medidas restritivas ao comércio, os quais visam, mediante a utilização de regras de calibração, relaxar os efeitos do tratamento da nação mais favorecida, a fim de estabelecer relações comerciais em bases protetivo-discriminatórias. Os defensores dos APC justificam que seus objetivos são aprofundar o processo de liberalização comercial e promover a globalização econômica, os quais são interrompidos pela falta de consenso das rodadas multilaterais de negociação comercial. Já os proponentes das medidas restritivas ao comércio sustentam que a função destas é permitir aos Estados flexibilizar as respectivas políticas comerciais, a fim de enfrentar toda a sorte de dificuldades econômicas. No plano jurídico, os instrumentos de discriminação e de proteção econômica encontram seu fundamento de validade nas próprias regras de exceção previstas no próprio SMC.

Ainda que justificáveis por argumentos políticos e econômicos, as análises empíricas demonstram que a opção dos Estados por acordos preferenciais e mecanismos de restrição comercial tem modificado suas atuações, ao ficarem mais hesitantes e menos cooperativos nas negociações multilaterais. Devido ao substancial impacto nas expectativas dos agentes econômicos, esse fenômeno ameaça a função unificadora de sentido da cláusula da nação mais favorecida, cujo resultado prático é a erosão da ideia de livre mercado mundial. Assim, as reiteradas quebras de expectativas, em razão de condutas protecionistas e discriminatórias dos Estados, implicam problemas de coesão e eficácia social ao sistema multilateral de comércio, o qual sofre um processo de desestruturação, causado pela desagregação das dimensões ideacional e fática da ordem econômica internacional. ${ }^{209}$

Na perspectiva comportamental, a proliferação de acordos preferenciais de comércio e de medidas restritivas conduz ao aumento de comportamentos protecionistas e

\footnotetext{
${ }^{209}$ SUTHERLAND, 2004, p. 19-27. OMC, 2009, p. 156.
} 
discriminatórios nas relações econômicas internacionais, o que é nocivo para um mercado em processo de globalização, visto fragmentá-lo em movimentos de regionalização. Além disso, permite-se aos Estados econômica e politicamente mais fortes valerem-se de instrumentos jurídicos para sujeitar os países subdesenvolvidos a tratados internacionais lesivos a sua economia interna, na medida em que estes, por serem dependentes dos mercados desenvolvidos, veem seus interesses nacionais e sua soberania econômica controlados por agentes externos. A não observância da cláusula da nação mais favorecida aponta para a perda de eficácia social do sistema multilateral de comércio na determinação das relações econômicas internacionais.

No plano axiológico, a crescente tendência à valorização do protecionismo e da discriminação, dentro de uma lógica de fragmentação e aprofundamento, atenta contra os valores constitutivos do sistema multilateral de comércio. Até recentemente execrada, a ideologia protecionista-discriminante ressurge impulsionada pelos discursos dos Estados e pelas sucessivas crises do capitalismo global. Os discursos políticos e econômicos de vocação protetivo-discriminatórios têm por finalidade contrapor-se aos princípios liberais subjacentes às regras do SMC e contestar a legitimidade institucional da OMC. Isso porque as ideologias, enquanto sistemas normativos fechados e delimitados, atuam na conjugação de valores, hierarquizando-os, de modo a funcionarem como mecanismos estabilizadores dos núcleos significados dos discursos jurídico-normativos. O embate ideológico fragiliza a coerência axiológica do sistema GATT/OMC, a qual é responsável por ordenar e integrar os sentidos dos núcleos significativos das normas da OMC. Com efeito, a contestação do princípio da não discriminação reflete diretamente sobre a cláusula da nação mais favorecida, implicando a respectiva perda da capacidade de assegurar simbolicamente a coesão do sistema multilateral de comércio.

Essa tensão fático-axiológica incide sobre a Organização Mundial do Comércio, na forma de práticas estatais, orientadas segundo razões de estado e de discursos políticoeconômicos, os quais visam à sedimentação de verdades que legitimem a aplicação de tratamentos discriminatórios e protecionistas, ainda que resultem na desestruturação do sistema multilateral de comércio. Portanto, os desafios sistêmicos são responsáveis por provocar problemas de coesão e eficácia normativa ao sistema GATT/OMC. 
Nesse contexto, incertezas e inseguranças pairam quanto à capacidade do mecanismo de solução de controvérsias de construir discursos jurídico-decisórios que, nos termos do artigo 3:4 do ESC, tenham "por objetivo encontrar solução satisfatória para a matéria em questão, de acordo com os direitos e obrigações emanados pelo presente Entendimento e pelos acordos abrangidos". Isso porque o Órgão de Solução de Controvérsias tem competência institucional exclusiva para decidir sobre os conflitos entre Estados-membros, conforme disposto no artigo 23 do ESC, razão pela qual é objeto de jogos de poder que buscam discipliná-lo segundo seus interesses e verdades pressupostas.

A finalidade do ato decisório é justamente encerrar uma disputa social, juridicizando-o mediante um complexo processo institucionalizado de absorção das inseguranças decorrentes das múltiplas e incompatíveis condições sociais de possibilidade. A decisão jurídica diferencia-se por ser capaz de impor aos conflitos jurídicos um fim. A relevância do OSC está em seu poder de imputar, graças ao procedimento jurídico, efeitos de poder ao discurso prevalecente do jogo de verdades. Em face dos desafios sistêmicos, a cláusula da nação mais favorecida, enquanto discurso jurídico-convencional, positivado no artigo I:1 do Acordo Geral sobre Tarifas e Comércio, está sujeita aos discursos verdadeiros de índole político-econômica e fundados sobre racionalidades estranhas à jurídica, os quais se confrontam na tentativa de predominarem na construção do discurso jurídico-decisório do Órgão de Solução de Controvérsias. $^{210}$

Com o adensamento de juridicidade, o processo decisório foi institucionalizado na forma do Entendimento sobre Solução de Controvérsias, o qual imputa ao intérprete autêntico o dever de decidir, segundo uma racionalidade jurídica pragmático-argumentativa e conforme os termos formais e materiais, previstos no sistema multilateral de comércio. Para encerrar os conflitos internacionais, mediante normas e meios jurídicos, o Órgão de Solução de Controvérsias deve exercer o controle de legalidade e de licitude sobre as relações econômicas entre os Estados-membros. O controle de estrutura serve para verificar a validade formal dos instrumentos jurídicos, tais como os APC e as medidas restritivas, em face das condições $a$ priori estabelecidas no SMC. O controle de condutas consiste no exame do respeito aos deveres materiais impostos aos Estados pelos acordos da OMC.

${ }^{210}$ SUTHERLAND, 2004, p. 19. FERRAZ JR., 2001, p. 104-115; 305-317. FOUCAULT, 2005, p. 7-10. TEUBNER, Gunther. How the law thinks: toward a constructivist epistemology of law. Law \& Society Review, [s.l.], v. 23, n. 5, 1989, p. 727-730. 
O processo de adensamento de juridicidade e de neutralização político-econômica dos conflitos comerciais internacionais permitiram superar o conceito de sistema multilateral de comércio power-oriented, concebido enquanto um conjunto de normas pragmáticoprocedimentais que visava à consolidação de uma jurisprudência diplomática e estruturado em torno de uma racionalidade jurídico-teorética de vocação lógico-formalista, mediada por métodos sintático-lexicais de interpretação. Com isso, os desafios sistêmicos são reintroduzidos no sistema GATT/OMC de natureza rule-oriented, cujas características essenciais, decorrentes do aprofundamento institucional, compreendem um conjunto de normas materiais e formais, orientado por uma legalidade segundo uma racionalidade jurídicopragmática de vocação prático-consensual, mediada por métodos sintáticos, semânticos e, principalmente, pragmáticos de interpretação.

Diante disso, a questão-problema ganha nova dimensão, pois uma resposta pragmaticamente fundamentada aos problemas de coerência e eficácia normativa incidentes sobre o artigo I:1 do GATT extrapola os limites do exame analítico-sintático, o que exige recorrer a outras formas de análise jurídica. Daí ser necessário analisar os pressupostos e as consequências empíricos, axiológicos e normativos da cláusula da nação mais favorecida, a fim de desenhar os parâmetros de decidibilidade ao Órgão de Solução de Controvérsias, bem como verificar se o papel por ela desempenhado, em suas relações normativas, tem assegurado consistência ao sistema multilateral de comércio. Nesse contexto, as decisões do OSC serão estudadas, com o objetivo de apurar se a CNMF é, no âmbito dos controles de legalidade e licitude, a norma determinante em face das regras de exceção que induzem efeitos discriminatórios e protecionistas. Assim, o escopo é investigar em que medida os papéis multidimensionais da cláusula da nação mais favorecida são relevantes para a resolução dos conflitos na OMC.

À luz dos desafios sistêmicos, é preciso reconhecer que a cláusula da nação mais favorecida é um fenômeno complexo, que demanda, num primeiro momento, seu recorte, redução e simplificação, de modo a ser possível tratá-la enquanto objeto de conhecimento, para, em seguida, examinar sua interpretação e aplicação. Nesses termos, a investigação da CNMF como regra determinante para decidibilidade dos intérpretes autênticos da Organização Mundial do Comércio será dividida em duas partes, pois a construção de uma resposta 
pragmática à questão-problema exige empregar, de forma inter-relacionada, as três dimensões da dogmática jurídica: analítica, hermenêutica e argumentativa. ${ }^{211}$

Na Seção III, empregar-se-á um exame predominantemente analítico e hermenêutico, tendo por objetivo determinar os elementos do instituto, bem como seus critérios de interpretação do discurso jurídico-convencional. O estudo debruçar-se-á sobre a cláusula da nação mais favorecida, a fim de analisar (i) seu conceito e natureza; (ii) o contexto histórico que permitiu a respectiva positivação no sistema multilateral de comércio; (iii) a forma estrutural e material; bem como (iv) as funções estruturais e materiais.

Na Seção IV, os discursos jurídico-decisórios do Órgão de Solução de Controvérsias serão examinados sob a perspectiva da dogmática hermenêutica e da argumentação, de modo a verificar os significados sintático-gramaticais imputados aos termos previstos no texto do artigo I:1, bem como as decisões que tratam da relação de coerência entre a CNMF e as demais regras do sistema multilateral de comércio, em particular as respectivas regras de calibração. Com isso, analisar-se-á em que medida os efeitos jurídicos da cláusula da nação mais favorecida contribuem para resguardar a consistência sistêmica e assegurar a eficácia normativa do sistema multilateral de comércio. Em face disso, será possível endereçar uma resposta jurídico-pragmática à questão-problema.

${ }^{211}$ FERRAZ JR., 2001, p. 83-91. 


\section{SEÇÃO III}

\section{O DISCURSO JURÍDICO-CONVENCIONAL DA CLÁUSULA DA NAÇÃO MAIS FAVORECIDA}


Na Seção II, a noção de sistema multilateral de comércio foi explorada, tendo em vista esclarecer seus contornos analítico-conceituais, com a finalidade de servir de instrumento jurídico-dogmático para o controle dos discursos normativos da Organização Mundial do Comércio. A partir do conceito de sistema GATT/OMC, a presente Seção tem por objetivo investigar a cláusula da nação mais favorecida, enquanto regra determinante para a decidibilidade dos intérpretes autênticos da OMC. Isso demanda um exame analítico e hermenêutico do artigo I: 1 do Acordo Geral sobre Tarifas e Comércio, tendo por enfoque suas características normativas e as respectivas relações sistêmicas.

Inicia-se a análise das multifacetadas dimensões do discurso jurídico-convencional da cláusula da nação mais favorecida, por meio da verificação do contexto histórico-social que implicou a respectiva positivação, bem como de seus elementos conceituais, estruturais e funcionais. Isso permite apreendê-lo objetivamente, para, em seguida, examinar os possíveis sentidos a ele atribuídos, tendo em vista as condições de decidibilidade de conflitos. Os critérios de aplicação do artigo I:1 do GATT são encontrados a partir de uma constante confrontação entre seus aspectos normativo-conceituais e a experiência decorrente da práxis mercantil e jurisprudencial. Com isso, busca-se esclarecer as condições quanto ao controle das consequências possíveis da incidência da CNMF sobre as relações entre Estados-membros. É exatamente o processo de neutralização político-econômica do conflito comercial internacional, perpetrado por uma racionalidade jurídico-pragmática incita ao sistema GATT/OMC, que possibilita projetá-lo numa dimensão harmoniosa, na qual os desafios sistêmicos podem ser regulados e decididos pelo Órgão de Solução de Controvérsias.

Desse modo, pretende-se extrair analiticamente os elementos do artigo I:1 do GATT, a fim de traçar os parâmetros hermenêuticos que condicionam a produção válida de discursos jurídico-decisórios sobre a cláusula da nação mais favorecida, dotados de coerência e razoabilidade jurídica. 


\subsection{O DISCURSO JURÍDICO-CONVENCIONAL DO ARTIGO I:1 DO GATT}

A cláusula da nação mais favorecida, ao ser positivada no artigo I:1 do Acordo Geral sobre Tarifas e Comércio, ganhou concreção na forma de um discurso jurídico-convencional internacional. Em sua origem, esse discurso foi veiculado por um negócio jurídico multilateral, produto da vontade de vinte e três Estados, sujeitos de direito internacional. Devido à velocidade das transformações socioeconômicas, intensifica-se a complexidade e a densidade das relações econômicas internacionais, o que vem progressivamente exigindo a adoção de medidas institucionais que reforcem a previsibilidade e a segurança jurídica. Nessa conjuntura, os tratados internacionais passam a ser os instrumentos jurídicos mais adequados para responder aos anseios de regulação e organização da economia internacional, cuja dinâmica não pode esperar a cristalização do costume internacional.

O tratado internacional é uma manifestação de vontades concordantes imputáveis a dois ou mais sujeitos de direito internacional, destinando-se a produzir efeitos jurídicos segundo as regras de direito internacional. Seu enunciado linguístico expressa um consenso, construído a partir de diferentes propostas textuais apresentadas durante o processo negociador. Com a aprovação do texto, surge a presunção de que o discurso acordado não pertence apenas a uma parte, pois simboliza a mensagem comum dos pactuantes. Nesse particular, ressalta-se que o discurso jurídico-convencional não apenas permite a comunicação, mas também cria direitos e deveres recíprocos a todas as partes-contratantes. A vinculação do comportamento aos termos do tratado não decorre apenas da observância das formalidades que o validam, mas também do conteúdo jurídico-material que dele emana.

$\mathrm{O}$ texto do tratado exprime culturalmente o direito internacional, visto sua forma e conteúdo serem próprios da prática jurídica moderna, que encontrou no Estado o seu centro irradiador de normas. A juridicidade do discurso independe de uma instituição legislativa supranacional, cabendo ao tratado a função de fundar o sistema internacional de comércio e institucionalizar as expectativas normativas dos agentes econômicos. O Acordo Geral sobre 
Tarifas e Comércio é o discurso jurídico-convencional constituinte do sistema multilateral de comércio, a partir do qual se desencadeia uma produção de novas manifestações jurídicotextuais. $^{212}$

O GATT divide-se tematicamente em quatro partes. A Parte I estabelece as regras gerais da política comercial, tendo por objetivo organizar o funcionamento do sistema multilateral de comércio, em especial as disposições sobre a não discriminação comercial, regimes preferenciais e tarifas aduaneiras. A Parte II dispõe sobre o código de bom comportamento comercial, enquanto a Parte III regulamenta os procedimentos acerca do funcionamento do GATT. Adicionada somente em 1965, a Parte IV versa sobre a relação comércio e desenvolvimento entre os países desenvolvidos e subdesenvolvidos.

Inserido na Parte I do GATT, o artigo I:1 expressa textualmente a cláusula da nação mais favorecida consubstanciada na forma de discurso jurídico-convencional:

\begin{abstract}
ARTIGO I - TRATAMENTO GERAL DE NAÇÃO MAIS FAVORECIDA.
1. Qualquer vantagem, favor, imunidade ou privilégio concedido por uma parte contratante em relação a um produto originário de ou destinado a qualquer outro país, será imediata e incondicionalmente estendido ao produtor similar, originário do território de cada uma das outras partes contratantes ou ao mesmo destinado. Este dispositivo se refere aos direitos aduaneiros e encargos de toda a natureza que gravem a importação ou a exportação, ou a elas se relacionem, aos que recaiam sobre as transferências internacionais de fundos para pagamento de importações e exportações, digam respeito ao método de arrecadação desses direitos e encargos ou ao conjunto de regulamentos ou formalidades estabelecidos em conexão com a importação e exportação bem como aos assuntos incluídos nos $\S 2$ e 4 do artigo III. $^{213}$
\end{abstract}

O artigo I:1 do GATT positiva a regra geral da cláusula da nação mais favorecida no contexto do comércio de bens entre os Estados-membros. Todavia, como observado por A. McNair, não há um conceito ou texto únicos da CNMF; logo, cada manifestação requer uma análise independente. Nesse sentido, deve-se esclarecer que, embora o presente estudo tenha por objeto o referido artigo I:1, há outros dispositivos nos acordos da OMC que preveem um direito específico ao tratamento da nação mais favorecida. ${ }^{214}$

No Acordo Geral sobre Tarifas e Comércio, a cláusula da nação mais favorecida pode ser encontrada em versões especializadas, as quais tratam de: (i) filmes cinematográficos

\footnotetext{
${ }^{212}$ CARVALHO, 2008, p. 133-143.

${ }^{213}$ BRASIL. Lei n. 313, 30 jul. 1948. Autoriza o Poder Executivo a aplicar, provisoriamente, o Acordo Geral sobre Tarifas Aduaneiras e Comércio, reajusta a Tarifa das Alfândegas e dá outras providências. Diário Oficial da União, Poder Executivo, Brasília, DF, 3 ago. 1948.

${ }^{214}$ MCNAIR, Arnold Duncan. The Law of Treaties. Oxford: Clarendon, 1961, p. 285.
} 
(artigo IV:b); (ii) regulamentação quantitativa interna (artigo III:7); (iii) liberdade de locomoção (artigo V:2,5,6); (iv) marcas de origem (artigo IX:1); (v) restrições quantitativas (artigo XIII:1); (vi) comércio com empresas estatais (artigo XVII); (vii) medidas de auxílio ao desenvolvimento econômico (artigo XVIII:20); e (viii) medidas para produtos em escassez (artigo XX:j).

Com a conclusão da Rodada Uruguai, cresceram os desafios para o instituto da cláusula da nação mais favorecida, uma vez que esta foi inserida nos novos temas incorporados ao sistema multilateral de comércio, tais como o comércio de serviços e direitos de propriedade intelectual. O artigo 2 do Acordo Geral sobre o Comércio de Serviços ("GATS") e o artigo 4 do Acordo sobre Aspectos dos Direitos de Propriedade Intelectual Relacionados ao Comércio ("TRIPS") estabelecem a regra geral do tratamento da nação mais favorecida nas áreas jurídico-econômicas que regulamentam. Contudo, isso não significa que as construções dogmáticas e jurisprudenciais sobre o artigo I:1 do GATT poderão ser livremente intercambiáveis com os novos temas, pois a especificidade de cada manifestação positiva da CNMF deve ser investigada em seus detalhes. ${ }^{215}$

Diante disso, proceder-se-á ao exame analítico e hermenêutico das especificidades conceituais, históricas, estruturais e funcionais do artigo I:1 do Acordo Geral sobre Tarifas e Comércio.

${ }^{215}$ JACKSON, 1969, p. 255. JACKSON, 1997, p. 157. CARREAU; JUILLARD, 1998, p. 230-231. 


\subsection{O CONCEITO DE CLÁUSULA DA NAÇÃo MAIS FAVORECIDA}

Sob a perspectiva das relações empíricas, a Seção I analisou a cláusula da nação mais favorecida no contexto das ordens econômicas internacionais. Por ser produto históricopragmático das relações internacionais, é complexa a tarefa de encontrar uma única definição capaz de consolidar os séculos de utilização e teorização do instituto. Ainda que fascinante, seria um trabalho hercúleo e desnecessário reunir e examinar todas as manifestações normativas, descritivas e prescritivas da CNMF. Portanto, a presente dissertação objetivará investigar tão somente esse fenômeno aplicado como norma jurídica de direito internacional econômico.

Cabe, primeiramente, compreender no que consiste o direito internacional econômico, na medida em que estabelece os parâmetros da investigação. Como observado na Seção I, as considerações econômicas jamais estiveram ausentes do direito internacional, visto que as relações internacionais não existem no vácuo. Todavia, foram as transformações estruturais do pós-Guerras Mundiais que implicaram no aprofundamento da especificação desse discurso jurídico. A demanda do Estado Intervencionista por mecanismos disciplinares que instrumentalizassem a regulamentação estatal das relações econômicas, nacionais ou internacionais, visava corrigir as imperfeições do mercado e assegurar a cooperação internacional. Foi, assim, no jogo de poder e verdade entre teorias liberais e intervencionistas, concernentes ao papel que deve ser desempenhado pelo Estado na economia, que surgiram as primeiras noções, específicas e diferenciadas, de direito internacional econômico. ${ }^{216}$

Historicamente, o conceito de direito internacional econômico começa a ser construído a partir do reconhecimento da existência dos Estados soberanos, cujas fronteiras territoriais constituem os limites de sua atuação política e econômica. O direito internacional clássico era concebido como um conjunto normativo de proibições, as quais permitiriam a coexistência das

${ }^{216}$ NGUYEN; DAILLIER; PELLET, 1999, p. 891. CARREAU; JUILLARD, 1998, p. 5-6. 
liberdades externas. Com as transformações socioeconômicas no pós-Segunda Guerra, assistiu-se a uma mudança qualitativa nas relações econômicas internacionais.

A Carta da Organização das Nações Unidas contribuiu para alterar definitivamente o caráter protetivo do direito internacional público de coexistência, mediante o estabelecimento de princípios e limites lógico-racionais aceitáveis à conduta dos Estados, os quais eram também compatíveis com as estruturas institucionais-legais das ordens parciais de cooperação econômica. Graças a esses sistemas normativos, utilizados pela governança econômica internacional, houve a consolidação de um direito internacional de cooperação, cujo objetivo era desenvolver uma sensação comunitária. Isso permitiu a passagem de discursos jurídicos predominantemente negativos de abstenção para normas positivas de mútua colaboração. $\mathrm{O}$ direito internacional econômico seria, portanto, um direito expansionista, pois, fundado na ideia de que o enriquecimento dos Estados é uma finalidade legítima, torna-se necessário assegurar a estabilidade das relações de interdependência econômica. ${ }^{217}$

As definições propostas de direito internacional econômico podem ser agrupadas segundo critérios formais ou funcionais. As diferentes concepções doutrinárias resultam em modos radicalmente distintos de conceber a estrutura institucional-legal da ordem econômica internacional. Na perspectiva formalista, há dois grupos de teorias: (i) as que defendem que o direito internacional econômico não consiste em um ramo autônomo, sendo apenas o direito internacional público aplicado à atividade econômica ${ }^{218}$; e (ii) aquelas que, baseando-se nas particularidades quanto ao fundamento e técnica, sustentam tratar-se de ramo específico de direito internacional, sem constituir, porém, uma disciplina autônoma ${ }^{219}$.

Segundo um enfoque funcional, as doutrinas reconhecem a normatividade do conjunto das relações atinentes aos fluxos internacionais dos fatores e bens de produção. No entanto, dividem-se segundo critérios subjetivos ou objetivos. Na visão stricto sensu, ou subjetivista, o direito internacional econômico compreende tão somente as normas validamente produzidas pelas relações econômicas interestatais, tendo por finalidade a direção da política econômica internacional. Logo, cabe aos Estados o papel de impulsionar a mútua cooperação, a fim de unificar as ordens econômicas nacionais, não por mera via de fato, mas como decorrência da

\footnotetext{
${ }^{217}$ LAFER, 1977, p. 27-29. FRIEDMANN, 1964, p. 471-472. CARREAU; JUILLARD, 1998, p. 9.

${ }^{218}$ SEIDL-HOHENVELDERN, Ignaz. International Economic Law. $3^{\mathrm{a}}$ ed. [s.1.]: Kluwer Law International, 1999, p. 1.

${ }^{219}$ SCHWARZENBERGER, 1966, p. 5-17. CARREAU; JUILLARD, 1998, p. 7.
} 
criação de sistemas normativos internacionais. Na acepção clássica de Georg Schwarzenberger, o direito internacional econômico é um ramo do direito internacional público que trata: (i) da propriedade e exploração de recursos naturais; (ii) da produção e distribuição de bens; (iii) das transações internacionais de caráter econômico e financeiro; (iv) de moeda e finanças; (v) de serviços relacionados; e (vi) do status e da organização daqueles que se dedicam a esse conjunto de atividades. A definição restritiva tem por objetivo manter uma rigorosa coerência lógico-formal da disciplina, de modo a determinar suas fontes jurídicas, âmbito de aplicação e sujeitos de direito. ${ }^{220}$

$\mathrm{Na}$ concepção latu sensu, ou objetivista, enfocam-se as relações econômicas internacionais, independente da natureza dos agentes econômicos, de modo a não distinguir as fontes jurídicas segundo sua origem. O foco estaria na noção de mercado mundial de fatores e bens de produção, não importando a natureza da fonte normativa, mas sua aplicação. Para Celso Lafer, o direito internacional econômico consiste na regulamentação da economia internacional, por meio de normas, internas ou internacionais, que regem as relações entre os sujeitos participantes. Disso resulta a importância de identificar não apenas as fontes diretas, mas também as reconhecidas e delegadas, entendidas não apenas no seu aspecto técnicoformal, mas também no plano da eficácia dos comportamentos, em que a dimensão prospectiva e operacional expressa a experiência jurídica em toda a sua concreção e dinamicidade. $^{221}$

$\mathrm{Na}$ tentativa de sintetizar essas distintas concepções, Ileana Giovan sugere que o direito internacional econômico, (i) em sua origem e âmbito de aplicação, é um ramo do direito internacional; (ii) por seu conteúdo material e sua problemática, dinâmica e específica, está inserido no direito econômico; e (iii) pelos sujeitos e relações que regula, participa do direito público e privado. $^{222}$

A economia mundial, caracterizada pelo processo de unificação dos mercados, não permite restringir formalmente o escopo da análise jurídica, sem incorrer em conclusões irrealistas. Para o presente trabalho, o direito internacional econômico compreende o conjunto de discursos jurídicos que disciplinam, por meio de instrumentos públicos ou privados, as

\footnotetext{
${ }^{220}$ THEMAAT, Pieter Verloren van. The Changing Structure of International Economic Law. Haia: Nijhoff, 1981, p. 9-10. SCHWARZENBERGER, 1966, p. 5. CARREAU; JUILLARD, 1998, p. 9.

${ }^{221}$ PICONE; SACERDOTI, 1983, p. 33-34. LAFER, 1977, p. 20-21.

${ }^{222}$ GIOVAN, Ileana. Derecho internacional económico y relaciones económicas internacionales. Buenos Aires: Abeledo-Perrot, 1992, p. 77-79.
} 
relações econômicas internacionais, tendo por finalidade estabilizar as expectativas normativas dos agentes econômicos internacionais. Assim, a diferenciação e especificidade do direito internacional econômico não decorrem dos sujeitos, mas da finalidade dos discursos jurídicos produzidos pelas relações internacionais. Entretanto, considerando que o objeto da presente análise consiste na análise da cláusula da nação mais favorecida positivada no sistema multilateral de comércio, enfatizar-se-ão os instrumentos de direito internacional público e as relações entre os Estados-membros do GATT/OMC.

No contexto de um direito internacional econômico em expansão, a cláusula da nação mais favorecida tem desempenhado um importante papel prático, na medida em que é amplamente adotada pelos mais relevantes e complexos tratados, com o objetivo de evitar a discriminação nas relações entre os Estados-contratantes. Por não ser exclusivamente utilizada na ceara das relações econômicas internacionais, há diversas concepções, gerais ou restritas, da CNMF. Desse modo, examinar-se-ão as mais notórias e relevantes definições analíticodogmáticas, de modo a apresentar o conceito que servirá de critério para a análise do artigo I:1 do Acordo Geral sobre Tarifas e Comércio.

Numa perspectiva generalizada, Georges Scelle define a cláusula da nação mais favorecida como uma previsão em que dois governos se preparam para participar, em princípio, reciprocamente de qualquer sistema legal mais vantajoso do que eles já tenham estabelecido, ou que venham a estabelecer em relação a outros governos. Na lição de Daniel Vignes, a CNMF é uma disposição de um tratado que estabelece a concessão, por um Estado a outro, de vantagens que já tenha uma vez concedido, ou que poderá vir a conceder a outros Estados. $^{223}$

Como observado na Seção I, a criação, desenvolvimento e diferenciação funcional da cláusula da nação mais favorecida estão intrinsecamente vinculados à prática mercantil, a qual empregou o instituto amplamente em seus acordos de comércio. Dessa forma, na perspectiva restrita ao direito internacional econômico, Richard Snyder a define como uma previsão, frequentemente inserida nos tratados comerciais entre Estados, que obriga a parte-concedente a estender à Parte-beneficiária todas as concessões ou favores acordados no passado, ou que poderão vir a ser acordados no futuro, referentes aos produtos, agentes e instrumentos

${ }^{223}$ SCELLE, Georges. Précis de droit des gens: principes et systematique. V. II, Paris: Sirey, 1934, p. 384. VIGNES, Daniel. La clause de la nation la plus favorisée et la pratique contemporaine: problèmes posés par la Communauté économique européenne. Recueil des cours, Leiden, v. 130, n. 2, 1970, p. 213. 
comerciais de terceiros Estados, a fim de que o comércio mútuo entre as partes-contratantes nunca seja realizado em bases menos favoráveis do que aquelas usufruídas por outros Estados. E, completa que "the fundamental point is equality based upon the treatment received by any third country" 224 . Nas palavras de Nomubi Ito, a CNMF personifica o princípio da equidade de tratamento nas relações econômicas internacionais, cujo objetivo é colocar todas as nações em bases iguais de competição comercial ${ }^{225}$.

No âmbito do sistema GATT/OMC, John H. Jackson ensina que, essencialmente, a cláusula da nação mais favorecida é uma obrigação de tratar as atividades de um particular Estado estrangeiro, bem como seus cidadãos, de forma tão favorável quanto são tratadas as atividades de outro Estado. Com efeito, "the result of a nation being a beneficiary of an MFN clause is that nation can comb all of the treaties and all of the actual treatment is more favourable than that granted to it - in which case, the beneficiary can argue that such better treatment is owed to it ${ }^{, 226}$. Na concepção de Thiébaut Flory, a CNMF consiste em uma disposição convencional, pela qual as duas partes-contratantes, A e B, concordam que se, posteriormente, qualquer uma delas celebrar com terceiro Estado C um tratado comercial, dispondo de vantagens especiais a $\mathrm{C}$, esses benefícios serão incorporados ipso facto ao acordo inicial $^{227}$.

As diferentes explicações expõem a dificuldade da doutrina em encontrar uma definição típico-conceitual padrão e uniformizada da cláusula da nação mais favorecida. A origem comercial assegurou ao instituto grande flexibilidade, o que possibilitou aplicá-lo em tratados de diferentes escopos, sendo, porém, tormentosa a tarefa de harmonizar seu significado. Por estarem inseridas nos diversos tratados internacionais, as CNMF atuam como normas operativas, variando segundo as disposições contratuais. Nesse sentido, alerta Arnold McNair para a existência de diferentes aplicações do instituto, logo, qualquer generalização de seu significado e efeitos deve ser cuidadosamente realizada. Isso porque "speaking strictly, there is no such thing as the most-favoured-nation clause: every treaty requires independent examination" 228 . Entretanto, G. Schwarzenberger defende que "although there is no such

\footnotetext{
${ }^{224}$ SNYDER, 1948, p. 10.

${ }^{225}$ ITO, Nomubi. La clause de la nation la plus favorisée. Paris: Les Editions internationales, 1930, p. 18.

${ }^{226}$ JACKSON, 1997, p. 161.

${ }^{227}$ FLORY, Thiébaut. Le G.A.T.T., droit international et commerce mondial. Paris: Librairie générate de droit et de jurisprudence, 1968, p. 14.

${ }^{228}$ MCNAIR, 1961, p. 285.
} 
thing as the m.f.n. clause, there is such a thing as the m.f.n. standard" ${ }^{229}$. Assim, a cláusula da nação mais favorecida é passível de investigação teórico-conceitual e pragmáticoexperimental.

Devido ao papel de regra organizadora da vertente comercial das ordens econômicas internacionais, os jogos de poder e verdade acerca da definição da cláusula da nação mais favorecida não ficaram restritos à academia. Reconhecendo a relevância do instituto para as relações econômicas entre Estados, organismos públicos e privados debruçaram-se sobre a temática, resultando na produção de diversos estudos que visaram desenhar tipicamente um modelo unificado e abstrato, mais ou menos sofisticado, com o objetivo de determinar sua raison d'être. A delimitação do núcleo da CNMF tem por objetivo proporcionar ao intérprete parâmetros harmônicos prévios para a decisão de conflitos comerciais, cujos efeitos são assegurar previsibilidade e segurança jurídica às expectativas normativas dos agentes econômicos. $^{230}$

A Liga das Nações, por meio de seu Comitê de Especialistas para a Progressiva Codificação do Direito Internacional, aprovou, em 1927, seu relatório sobre a cláusula da nação mais favorecida, cujo enfoque principal era determinar os efeitos dela sobre os tratados internacionais. Criado para preparar o referido relatório, o Subcomitê, composto pelo Relator, Sr. George W. Wickersham, e pelo Prof. Barbosa de Magalhães, não encontrou surpreendentemente um consenso entre seus membros. O Relatório Wickersham constatou que a Primeira Guerra Mundial rompeu a continuidade histórica da utilização da CNMF, porém não seria necessário proceder a um trabalho de codificação do instrumento, visto que as regras comuns de interpretação judiciária já seriam adequadas. No entanto, Barbosa de Magalhães discordou da conclusão, apontando inexistir no relatório elementos que justifiquem tal assertiva. Pelo contrário, seria preciso determinar critérios não vinculantes de interpretação sobre o significado e função da CNMF, a fim de assistir aos intérpretes, estatais e judiciais, sobre a respectiva aplicação e efeitos. O Comitê decidiu que a regulamentação internacional da cláusula da nação mais favorecida, ainda que desejável, encontraria sérios obstáculos, razão pela qual não seria objeto de uma conferência específica para codificá-la. ${ }^{231}$

\footnotetext{
${ }^{229}$ SCHWARZENBERGER, 1971, p. 139.

${ }^{230}$ SCHWARZENBERGER, 1966, p. 69.

${ }^{231}$ LdN. Committee of Experts for the Progressive Codification of International Law. The Most-Favoured-Nation Clause. The American Journal of International Law, [s.1.], v. 22, n. 1, 1928, p. 133-156.
} 
Seguiram-se, posteriormente, outras tentativas institucionalizadas de apropriação conceitual do instituto para respectiva codificação, de acordo certos interesses. O Institut de Droit Internacional ("IDI") aprovou duas resoluções sobre a cláusula da nação mais favorecida. Na sessão de 1936, adotou-se o relatório preparado por Boris Nolde, cuja preocupação era contribuir para a construção jurídica e interpretação da CNMF em matéria de comércio e navegação. Dentre as previsões, essa resolução dispõe que a cláusula da nação mais favorecida confere ao beneficiário o mesmo tratamento outorgado, incondicional e automaticamente, pelo promissor a terceiras partes. Considerando as profundas mudanças no campo das relações econômicas internacionais, o IDI decidiu adotar, na sessão de 1969, uma segunda resolução, apresentada por Pierre Pescatore, por meio da qual se posiciona acerca dos efeitos da CNMF nos acordos multilaterais de comércio. ${ }^{232}$

Devido à solicitação dos Estados-membros da ONU, a Comissão de Direito Internacional da Organização das Nações Unidas (“CDI”) decidiu, em 1967, nomear um relator especial, Endre Ustor, para preparar um relatório detalhado sobre o impacto da cláusula da nação mais favorecida no direito dos tratados, não restrito ao aspecto comercial, tendo por objetivo harmonizar e codificar o seu significado. O resultado da pesquisa é impressionante, visto que foram apresentados um trabalho introdutório seguido por sete relatórios, aos quais se acresceram mais comentários e revisões. Nesse particular, ressalta-se o terceiro relatório, submetido à CDI em 1972, no qual E. Ustor, atento às dificuldades para definir conceitualmente a CNMF, propõe dividir a análise do instituto segundo sua forma e materialidade. $^{233}$

Nos termos do terceiro relatório, a cláusula da nação mais favorecida é uma estrutura normativa que pode ser prevista em um tratado, de modo a positivar uma obrigação jurídica. Assumida por uma ou mais partes-promissoras, a obrigação consiste em conceder o tratamento da nação mais favorecida a uma ou mais partes-beneficiárias. Quando cada uma das partes-contratantes concorda em outorgar mutuamente o tratamento da nação mais

\footnotetext{
${ }^{232}$ IDI. Resolução n. 2, 23 abr. 1936, Sessão de Bruxelas. Les effets de la clause de la nation la plus favorisée en matière de commerce et de navigation. Rapporteur Boris Nolde. Disponível em <http://www.idiiil.org/idiF/resolutionsF/1969_edi_02_fr.pdf>. Acesso em: 10 fev. 2009. IDI. Resolução n. 3, 10 set. 1969, Sessão de Edimburgo. The Most Favoured Nation Clause in Multilateral Conventions. Rapporteur Pierre Pescatore. Disponível em <http://www.idi-iil.org/idiF/resolutionsF/1936_brux_03_fr.pdf>. Acesso em: 10 fev. 2009.

${ }^{233}$ USTOR, Endre. The most-favoured-nation clause in the law of treaties: working paper. Yearbook of the International Law Commission, [s.1.], v. II, 1968. Disponível em <http://www.un.org/law/ilc/index.htm>. Acesso em: 10 out. 2006. Documento da ONU n. A/CN.4/L.127, p. 165-166.
} 
favorecida, todas serão promissoras e beneficiárias simultaneamente. Nas palavras de Endre Ustor:

"Most-favoured-nation clause" means a treaty provision whereby an obligation is undertaken by one or more granting States to accord most-favoured-nation treatment to one or more beneficiary States. When, as is the usual case, the contracting States undertake to accord most-favoured-nation treatment to each other, each of them becomes thereby a granting and a beneficiary State simultaneously. ${ }^{234}$

O mérito de E. Ustor está, justamente, na cisão estrutural e funcional do instituto. Isso permite examinar, analiticamente, a cláusula e o tratamento da nação mais favorecida, de modo a verificar os efeitos no plano da legalidade e da licitude respectivamente. Com isso, é imprescindível analisar o significado de tratamento da nação mais favorecida, o qual consiste na promessa de tratar em termos não menos favoráveis que aqueles concedidos pela partepromissora a terceiras partes, em relação à determinada esfera material de pessoas e objetos das relações internacionais. Se não houver exceção expressa, a obrigação alcança todos os benefícios, independentemente da estrutura jurídica pela qual venha a ser outorgada pela parte-promissora à parte-beneficiária, ou seja, pode ser na forma de normas, internacionais ou domésticas, ou ainda simples prática estatal. Apoiado no artigo 3, E. Ustor explica que:

\footnotetext{
"Most-favoured-nation treatment" means treatment upon terms not less favourable than the terms of the treatment accorded by the granting State to any third State in a defined sphere of international relations with respect to determined persons or things. Unless otherwise agreed, (...) applies irrespective of the fact whether the treatment accorded by the granting State to any third State is based upon treaty, other agreement, autonomous legislative act or practice. ${ }^{235}$
}

Diante disso, conclui-se que a cláusula da nação mais favorecida é um fenômeno jurídico complexo que não é passível de ser objeto de padronização, na medida em que, por ser uma construção da práxis comercial, pode ser encontrada nos mais variados modelos. No entanto, ao examiná-la analiticamente, é possível extrair seus elementos essenciais e dividi-los estrutural e materialmente. Assim, a cláusula passa a designar a forma do discurso jurídico, cujos efeitos incidem sobre o plano da legalidade, enquanto o tratamento consiste no conteúdo prescritivo-material da obrigação, de modo que produz efeitos sobre o plano da licitude dos comportamentos dos agentes econômicos.

\footnotetext{
${ }^{234}$ USTOR, 1972, p. 162.

${ }^{235}$ USTOR, 1972, p. 162.
} 


\subsection{POSITIVAÇÃO NO SISTEMA MULTILATERAL DE COMÉRCIO}

Produto da experiência jurídico-mercantil, a cláusula da nação mais favorecida é um complexo instituto de direito internacional econômico que detém grande relevância para as relações econômicas internacionais. Na Seção I, foi examinado o papel desempenhado por ela nos três períodos que abrangem as diferentes configurações estruturais da ordem econômica internacional capitalista. Constatou-se que, naqueles diferentes contextos, a CNMF ascendeu à posição de regra central dos sistemas internacionais de comércio, tendo por função assegurar as expectativas normativas dos agentes em âmbito mundial. Com efeito, apreender objetivamente as especificidades da cláusula da nação mais favorecida inseridas no sistema GATT/OMC demanda investigar o histórico processo de negociações que resultou na sua positivação no artigo I:1 do Acordo Geral sobre Tarifas e Comércio.

Como observado na Seção 1, a ordem econômica internacional liberal esfacelou-se, restando apenas escombros quando do final das Guerras Mundiais. A preferência pelas relações discriminatórias conduziu à desconstrução dos fundamentos fático-axiológicos da cláusula da nação mais favorecida, implicando seu desuso. Tal cenário caótico começa a se transformar com a emergência dos Estados Unidos como a única potência capitalista. Decididos a restabelecer as estruturas da ordem econômica capitalista, os EUA empreenderam esforços na edificação de um novo modelo de governança econômica internacional que não incidisse sobre os mesmo erros do passado. Para assegurar o sucesso da reconstrução de um mercado internacional, concebido segundo princípios liberais, a nova ordem econômica deveria enfatizar o fortalecimento da estrutura institucional-legal, a fim de garantir a segurança e a previsibilidade das expectativas normativas, por meio de um sistema internacional de comércio, estruturado sobre a ideia de multilateralismo procedimental e axiológico. Com o apoio do Reino Unido, os Estados Unidos prepararam a Carta Proposta para o Estabelecimento da Organização Internacional do Comércio, na qual se previa a 
criação de um código de comércio que, sob jurisdição de uma nova organização internacional, regulamentaria as relações comerciais internacionais.

A Parte I sobre política comercial era, certamente, o capítulo mais importante da Carta Proposta, pois positivou os valores e princípios que deveriam governar o comércio internacional. Devido a sua natureza flexível e adaptativa, os proponentes optaram por organizar o sistema de comércio internacional em torno da cláusula da nação mais favorecida, à qual caberia instrumentalizar os princípios da não discriminação, reciprocidade e transparência. Na perspectiva dos Estados Unidos, a CNMF era tão fundamental que seus efeitos deveriam incidir sobre todos os aspectos do acordo comercial proposto, não estando restritos apenas a irradiar multilateralmente os benefícios oriundos das concessões tarifárias resultantes de negociações. Com essa atribuição funcional de organizadora de sentido do sistema multilateral de comércio, a cláusula da nação mais favorecida ganhou estrutura e finalidades desconhecidas anteriormente. Daí a novidade do modelo estadunidense de reconstruí-la, ou construí-la multilateralmente. ${ }^{236}$

Na reunião de 1946 do Comitê Preparatório para a Conferência das Nações Unidas sobre Comércio e Emprego, os Estados Unidos apresentaram uma versão detalhada da cláusula da nação mais favorecida na forma incondicionada, cujo texto era baseado, segundo aponta seu representante, nos estudos desenvolvidos pela Liga das Nações. Com exceção da Austrália, que sustentava não ser necessária a inclusão da CNMF, visto que as obrigações previstas já eram suficientemente fortes, não houve dificuldades para que se obtivesse rápida aceitação da proposta. Essa facilidade em alcançar o consenso explica-se em razão das grandes potências comerciais já terem cedido previamente, no contexto das negociações que trataram do auxílio financeiro concedido a elas pelos Estados Unidos para aplacar a profunda crise econômica que assolava a Europa no pós-guerras. Os EUA condicionaram tal financiamento para a reconstrução da economia europeia à celebração do Acordo sobre Empréstimo e Arrendamento e da Carta do Atlântico, a qual previa, em seu artigo $7^{\circ}$, o compromisso dos Estados de empenharem-se na criação de um sistema internacional de comércio. Formulado pelo Secretário de Estado Cordell Hull, o plano estadunidense refletia os ideais liberais de seu

${ }^{236}$ KOCK, Karin. International trade policy and the GATT 1947-1967. Stockholm: Almqvist \& Wiksell, 1969, p. 43. 
idealizador, que acreditava na não discriminação e no livre-comércio como mecanismos de preservação da paz mundial. ${ }^{237}$

Embora houvesse certo consenso acerca da estipulação da cláusula da nação mais favorecida, os Estados divergiam quanto aos limites de seus efeitos. A batalha travada no Comitê visava, nas palavras de Karin Kock, determinar "how far one would go in introducing exceptions without putting the whole principle at stake”. De um lado, os Estados Unidos defendiam a aplicação ampla e irrestrita da CNMF incondicionada, cedendo apenas para exceções temporárias que seriam, posteriormente, eliminadas. No extremo oposto, os países subdesenvolvidos demandavam uma série de regras de calibração, cujo tratamento excepcional chocava-se com os planos e ideais estadunidenses para a nova ordem econômica internacional. Dessa forma, os trabalhos preparatórios expressaram as disputas de poder acerca dos termos linguísticos do discurso jurídico-convencional que positivou a CNMF. ${ }^{238}$

O Comitê Preparatório sobre o Artigo I:1 foi, então, dividido em grupos para analisar os aspectos controversos da cláusula da nação mais favorecida, os quais focavam-se essencialmente: (i) nas alterações da redação original; (ii) na precisão linguística; (iii) nos contratos governamentais; e (iv) nas preferências comerciais.

\section{a) Tentativa de adicionar novas redações}

Durante os trabalhos do Comitê Preparatório, diversas sugestões acerca da redação da cláusula nação mais favorecida foram endereçadas, as quais, caso adotadas, alterariam drasticamente seu escopo, razão pela qual foram todas rejeitadas. As mais relevantes propostas versavam sobre: (i) empréstimos intergovernamentais para a aquisição de produtos do Estadocredor; (ii) a inserção de uma versão da cláusula trabalhista, a qual imporia uma exceção ao tratamento da nação mais favorecida, caso o Estado-beneficiário não assegurasse condições mínimas de trabalho; (iii) a inclusão da antiga cláusula de proteção mercantil, a qual estendia os efeitos da TNMF aos direitos dos empresários estrangeiros; e (iv) regras de calibração da

\footnotetext{
${ }^{237}$ JACKSON, 1969, p. 251-252. KOCK, 1969, p. 46.

${ }^{238}$ JACKSON, 1969, p. 253. KOCK, 1969, p. 43.
} 
$\mathrm{CNMF}$, as quais permitiriam relaxar os efeitos do tratamento da nação mais favorecida, de modo a excetuá-lo em relação aos acordos preferenciais de comércio, existentes ou futuros, que estivessem abertos à acessão de todos os Estados-contratantes. ${ }^{239}$

\section{b) Precisão linguística}

Foram abordadas questões acerca da definição de certos termos essenciais da cláusula da nação mais favorecida. As expressões "originating in" e "like products" eram particularmente preocupantes, visto que implicam efeitos diretos e determinantes sobre as relações econômicas internacionais. Como, entretanto, o objetivo do Comitê Preparatório era alcançar um consenso, os termos poderiam prescindir de definições minuciosas. Isso permitiu incorporá-los, ainda que acarretassem prejuízos à previsibilidade e segurança normativa. Postergaram-se, assim, os debates sobre os significados a trabalhos futuros, a serem realizadas no âmbito da Organização Internacional de Comércio, à luz das práticas e usos dos tratados comerciais. $^{240}$

\section{c) Contratos Governamentais}

Na proposta original apresentada pelos Estados Unidos, a redação da cláusula da nação mais favorecida previa a extensão dos efeitos do tratamento da nação mais favorecida aos contratos públicos. Tal dispositivo obrigava o Estado-parte a garantir aos agentes econômicos estrangeiros tratamento idêntico ao concedido aos nacionais nas licitações públicas. ${ }^{241}$ Embora tenha sido aprovada pelo Comitê, essa disposição foi excluída na Conferência Preparatória de Londres, devido às ambiguidades e desentendimentos inerentes ao texto, como o caso de

\footnotetext{
${ }^{239}$ JACKSON, 1969, p. 253-255.

${ }^{240}$ JACKSON, 1969, p. 253-255.

${ }^{241}$ A redação original previa: the principle underlying this paragraph shall also extend to the awarding by Members of government contracts for public work, in respect of which Member shall accord fair and equitable treatment to the commerce of the other Members. (JACKSON, 1969, p. 254)
} 
projetos de defesa nacional, e à compreensão de que essa matéria deveria ser objeto de negociações específicas que envolvessem o comércio com empresas estatais. ${ }^{242}$

\section{d) Preferências comerciais}

Nos termos da proposta original dos Estados Unidos, a cláusula da nação mais favorecida deveria incidir diretamente sobre os Estados-partes, tendo por efeito absoluto extinguir todos os acordos preferenciais de comércio, com exceção das uniões aduaneiras.

Por ser inaceitável para Reino Unido e França, a diplomacia inglesa, nas negociações bilaterais de preparação da Carta Proposta, obteve êxito em convencer os negociadores de C. Hull sobre a impossibilidade de desmantelar imediatamente os sistemas de preferenciais comerciais. Confrontados com a perspectiva pragmática das negociações tarifárias, os Estados Unidos aceitaram essas exceções históricas, pois esperavam alcançar dois objetivos. Primeiramente, teriam o efeito de impedir a proliferação de acordos preferenciais, bem como congelar os existentes, incluindo seus próprios sistemas de preferências com Cuba e República das Filipinas, o que restringiria as exceções ao princípio da não discriminação. Segundo, incorporar ao texto disposições que estabelecessem uma gradual redução e, por fỉm, eliminação das barreiras e medidas preferências, por meio das negociações comerciais.

Na visão dos países subdesenvolvidos, o direito a celebrar acordos de livre-comércio era essencial para o respectivo desenvolvimento econômico e industrial. Nesse ponto, é interessante ressaltar a atuação da delegação brasileira, a qual defendia arduamente os sistemas de preferência comercial. Isso porque argumentava que o princípio da reciprocidade teria um papel mais importante para os países subdesenvolvidos do que a não discriminação, sendo, portanto, necessário estipular exceções à América Latina, em consideração às suas características políticas, geográficas e éticas. Além disso, outras delegações apontaram que a Carta Proposta não deveria reconhecer um tratamento igualitário entre países desenvolvidos e subdesenvolvidos acerca dos direitos relativos à celebração de APC. Isso porque, caso perdurassem os sistemas históricos de preferência, haveria uma clara discriminação em face

${ }^{242}$ JACKSON, 1969, p. 253-255. 
das pequenas economias, visto que se demandam mais recursos para a constituição de uniões aduaneiras do que as áreas de livre-comércio. Com isso, a Carta Proposta teria a função de consolidar o status quo, de modo a prejudicar os países subdesenvolvidos, ao mantê-los como meros exportadores de matérias-primas.

Ainda assim, os Estados Unidos e o Reino Unido opuseram-se fortemente às propostas dos países subdesenvolvidos, sustentando que existia uma grande diferença entre introduzir novos acordos preferenciais de comércio e disciplinar àqueles há muito tempo estabelecidos, aos quais o mercado mundial já havia se adaptado. Além disso, critérios geográficos não seriam razões suficientes para constituir preferências, visto que permitiriam interpretações unilaterais pelos países beneficiados. Finalmente, tais propostas seriam inconsistentes com a arquitetura comercial da nova ordem econômica internacional, pois possibilitariam a introdução de novos sistemas preferenciais em um contexto de não discriminação e eliminação de preferências.

Todavia, a delegação libanesa apresentou uma proposta capaz de destravar as negociações. Essa consistia em defender que o tratamento ora aplicado às uniões aduaneiras deveria incidir sobre as áreas de livre-comércio, uma vez que guardam características semelhantes. Nesse particular, ressalta-se que os acordos de livre-comércio compartilham as mesmas condições e limitações das uniões aduaneiras, com exceção de que estas têm o ônus adicional de harmonizar e manter uma tarifa externa comum. Convencidos de que as ALC seriam um estágio anterior para o desenvolvimento de uma união aduaneira, os Estados Unidos aprovaram a proposta libanesa. Essa ideia recebeu suporte dos países subdesenvolvidos, pois áreas de livre-comércio permitiriam a eles auferirem as mesmas vantagens das uniões aduaneiras, sem a dificuldade do processo de harmonização tarifária e normativa. $^{243}$

Após árdua negociação, os Estados encontraram um consenso sobre a cláusula da nação mais favorecida. Fruto do jogo de poder, essa versão da CNMF, que futuramente viria a ser positivada, consubstanciou a verdade prevalecente à época. Assim, ao confrontar a redação original estadunidense com a versão positivada no artigo I:1 do Acordo Geral sobre Tarifas e Comércio, conclui-se que os objetivos originais dos Estados Unidos foram alcançados parcialmente. Os efeitos do tratamento da nação mais favorecida foram delimitados por duas

${ }^{243}$ MILLER, 2000, p. 3-5. KOCK, 1969, p. 43-45. JACKSON, 1969, p. 253-255. DAM, 1970, p. 18-19. 
principais regras de calibração: (i) os acordos preferenciais de comércio já consolidados, denominados sistemas históricos de preferência (artigo I); e (ii) os acordos preferenciais de comércio de atuação restrita, cujas espécies são as áreas de livre-comércio e uniões aduaneiras (artigo XXIV). ${ }^{244}$

${ }^{244}$ DAM, 1970, p. 18-19. JACKSON, 1969, p. 255. 


\subsection{ESTRUTURA NORMATIVA: PACTUADA, INCONDICIONADA E BILATERAL}

Por estar inserida no Acordo Geral sobre Tarifas e Comércio, a cláusula da nação mais favorecida está prevista, consensualmente, em um tratado internacional multilateral. Não obstante, para compreendê-la é necessário examinar analiticamente as características estruturais e abstratas do instituto, bem como os elementos concretos de sua positivação no GATT.

\subsubsection{Fonte do direito: tratado e declaração unilateral de vontade}

Dentre as diversas molduras formais do discurso jurídico-normativo no âmbito do direito internacional econômico, a ampla maioria da dogmática reconhece a cláusula da nação mais favorecida como uma norma jurídica pactuada em um tratado internacional ou outorgada por declaração unilateral de vontade. Isso significa que a concessão do tratamento da nação mais favorecida depende de expressa manifestação da vontade pela parte-promissora, ou seja, a vontade é elemento intrínseco do instituto. Desse modo, apesar da difusa experimentação do instituto na práxis mercantil, não há qualquer evidência doutrinária ou jurisprudencial de que a CNMF tenha se desenvolvido na forma de costume internacional ou princípio geral de direito.

\section{a) Costume internacional}

Previsto no artigo 38 do Estatuto da Corte Internacional de Justiça, o costume internacional é uma norma jurídica consuetudinária, formada por dois elementos: material e 
formal-relacional. $\mathrm{O}$ cumprimento reiterado de comportamentos (elemento material), devido à convicção de obrigatoriedade (elemento relacional), forma o costume. Não é qualquer uso cotidiano que forma um costume, mas tão somente os comportamentos, positivos ou negativos, que atendam ao fator temporal; isto é, sejam repetidos ao longo do tempo, de forma a consolidar uma prática geral, constante e uniforme. Isso permite a formação da opinio júris sive necessitatis, a partir da institucionalização da expectativa consensual dos agentes econômicos. Esse processo de institucionalização repousa em procedimentos, rituais e silêncios presumidamente aprovadores dos sujeitos, os quais devem ser reconhecidos pela opinio juris. ${ }^{245}$

Não constitui prática uniforme das relações econômicas internacionais o tratamento não discriminatório entre os agentes. Em cada período histórico, constata-se o predomínio de um modo de relacionamento econômico, o que não significa ser este o único, mas que coexiste com outras práticas. Por terem uma forte interação com os pensamentos econômicos vigentes, as formas de interação tendem a variar entre as perspectivas protecionistas e liberais, segundo bases monopolísticas, preferenciais, recíprocas ou não discriminatórias. A liberdade de decidir as condições do relacionamento é garantida pelos princípios da soberania econômica e liberdade comercial. Apenas na hipótese das partes optarem por um relacionamento em bases não discriminatórias, seria possível pactuar ou outorgar unilateralmente a cláusula da nação mais favorecida. Assim, por não contar com os elementos materiais e relacionais, conclui-se que o costume internacional não é estruturalmente um discurso normativo adequado para suportar a CNMF. ${ }^{246}$

\section{b) Princípio geral de direito internacional}

Os defensores da teoria do direito natural procuraram demonstrar que o direito ao tratamento da nação mais favorecida não decorria apenas de uma declaração ou tratado

${ }^{245}$ FERRAZ JR., 2001, p. 237-239. NGUYEN; DAILLIER; PELLET, 1999, p. 301. BROWNLIE, Ian. Princípios de direito internacional público. Trad. Maria M. Farrajota, Maria J. Santos, Victor R. Stockinger, Patrícia G. Teles. Lisboa: Fundação Calouste Gulbenkian, 1997, p. 16-19.

${ }^{246}$ SCHWARZENBERGER, 1966, p. 41-52. 
internacional, mas também poderia ser reconhecido como um princípio deduzido do princípio da igualdade ou do princípio da liberdade de comércio. Segundo a perspectiva racionalista, os princípios internacionais são normas universalmente válidas, pois são inerentes a todas as sociedades humanas. Em razão de um princípio superior de justiça natural, o sistema jurídico deve garantir ao homem padrões mínimos de decência e respeito, por meio da dedução racional de princípios. ${ }^{247}$

A escola jusnaturalista defende que a cláusula da nação mais favorecida é a expressão jurídico-econômica do princípio da igualdade de direitos, previsto no artigo $2^{\circ}$ da Carta das Nações Unidas. Impedir a discriminação nas relações econômicas internacionais é uma função logicamente dedutível do artigo $2^{\circ}$, em conjunto com o artigo $1^{\circ}$ da Carta, o qual prevê o desenvolvimento das relações amistosas entres os Estados como princípio fundamental da ONU. Outros sustentaram que o princípio da nação mais favorecida encontra fundamento lógico no princípio da liberdade de comércio. A importância da CNMF não decorre de seu papel empírico-axiológico historicamente consagrado, mas de enfatizar a igualdade de tratamento e a amizade. Não encarado como sacrifício voluntário de parcela da soberania econômica, o instituto é considerado elemento essencial para a promoção das condições pacíficas e necessárias para florescimento do comércio internacional, evitando, portanto, a mávontade promotora da tensão envolvendo as práticas econômicas discriminatórias.

Embora a aparente lógica dos raciocínios conduza ao reconhecimento da CNMF como princípio do direito internacional econômico, percebe-se, ao examiná-los apuradamente, que as construções carecem de fundamento, pois há uma confusão entre o fundamento de validade e o conteúdo dos institutos. A regra da nação mais favorecida opera calibrando as expectativas das partes-contratantes, mediante a extensão das vantagens econômicas concedidas a terceiras partes. Isso não possibilita deduzir a priori uma obrigação de tratamento não discriminatório ou amigável entre as partes, mas reconhecer que, dentre os possíveis efeitos desse mecanismo, encontram-se garantias recíprocas de benefícios comerciais. Além disso, confunde-se, materialmente, o princípio de liberdade de comércio com seu objetivo, a igualdade comercial. Os princípios são comandos imperativos e vinculantes, porém não impõem comportamentos específicos aos destinatários, mas visam concretizar os objetivos dos sistemas normativos. Desse modo, caso declarada a existência do princípio da nação mais favorecida, os Estados

${ }^{247}$ SCHACHTER, Oscar. International Law in Theory and Practice. Boston: Martinus Nijhoff, 1991, p. 50-55. 
teriam o dever de conceder indiscriminadamente o tratamento da nação mais favorecida a todos os demais, possibilidade esta negada inclusive pelos jusnaturalistas. $\mathrm{O}$ equívoco dessa argumentação axiológico-dedutiva está em pretender fundar materialmente a validade jurídica numa relação lógico-racional, ignorando a diferença estrutural entre regras e princípios. ${ }^{248}$

\section{c) Tratado internacional e declaração unilateral de vontade}

Ainda que seja possível construir dogmaticamente um conceito idealizado do instituto, é praticamente consenso da doutrina que, para ser legalmente vinculante, a estrutura da cláusula da nação mais favorecida corresponde a uma regra jurídica, que deve, no plano internacional, decorrer da vontade, consensual ou unilateral, do promissor. A parte somente pode invocar o direito ao tratamento da nação mais favorecida caso essa obrigação tenha sido voluntariamente outorgada, por meio de tratado ou concessão unilateral. Isso porque a experiência comprova que a utilização da CNMF só é concebível e aceita pelos agentes econômicos quando decorrente do comprometimento e interdependência nas relações econômicas internacionais. Dessa forma, apesar dos méritos envolvidos, não serão empregados os termos princípio, standard ou régime à cláusula da nação mais favorecida, em razão de um maior rigor e precisão técnico-conceitual.

A Corte Internacional de Justiça, no Caso Rights of Nationals of the United States of America in Morocco, reconheceu que a cláusula da nação mais favorecida tinha natureza contratual, devendo, por consequência, ser objeto das regras gerais de direito internacional, em especial as relativas ao direito dos tratados. Nas palavras da ICJ: "it is not established that most-favoured-nation clauses in treaties with Morocco have a meaning and effect other than such clauses in other treaties or are governed by different rules of law",249.

Desse modo, ao ser prevista em tratados bilaterais, plurilaterais e multilaterais, a estrutura da cláusula da nação mais favorecida tem por objetivo assegurar ao Estado-

\footnotetext{
${ }^{248}$ HAZARD, John N. Commercial Discrimination and International Law. American Journal of International Law, [s.1.], v. 52, n. 3, 1958, p. 495. SCHWARZENBERGER, 1971, p. 138.

${ }^{249}$ ICJ. Rights of Nationals of the United States of America in Morocco (France v. United States of America). Report of Judgments, advisory opinions and orders, 1952. Disponível em <http://www.icjcij.org/docket/files/11/1927.pdf>. Acesso em: 10 fev. 2009, p. 204.
} 
beneficiário o exercício do direito, presente ou futuro, concedido pelo Estado-promissor a um terceiro Estado. O efeito da obrigação é duplicar as relações bilaterais, incorporando os benefícios outorgados a terceiros ao pacto entre promissor e beneficiário. Isso implica na questão sobre a fonte do direito do Estado-beneficiário, visto ser esse titular do direito de reclamar a extensão das vantagens, ou a respectiva responsabilização por lesão, em caso de recusa pelo Estado-promissor. ${ }^{250}$

Não havendo tratados colaterais entre o Estado-promissor e terceiros Estados e tendo o direito requerido pelo Estado-beneficiário fundamento em ato unilateral, interno, legislativo ou de fato, do Estado-promissor, não há dúvidas de que a fonte do direito está no tratado que prevê a cláusula da nação mais favorecida entre o Estado-promissor e o Estado-beneficiário. Isso porque não haveria qualquer outro instrumento de direito internacional que pudesse dispor do tratamento da nação mais favorecida em favor do Estado-beneficiário. As dúvidas surgem, entretanto, com a celebração dos tratados mútuos, pois não há consenso entre os juristas sobre a fonte do direito do Estado-beneficiário. Parte dos juristas entende que o direito do Estado-beneficiário tem origem no tratado bilateral, celebrado entre promissor e terceiros Estados; logo, a cláusula da nação mais favorecida seria uma obrigação bilateral, vazia e condicionante. Por outro lado, parcela considerável sustenta que a fonte do direto está, justamente, no tratado celebrado entre o Estado-promissor e o Estado-beneficiário, ou seja, é com base nesse tratado que o Estado-beneficiário pode invocar seu direito. ${ }^{251}$

A controvérsia sobre a fonte do direito do Estado-beneficiário foi suscitada no Caso Anglo-Iranian Oil Company, proposto perante a Corte Internacional de Justiça, em 1952. O Reino Unido, autor da demanda e Estado-beneficiário, alegou que a cláusula da nação mais favorecida é essencialmente uma obrigação condicional, que, desprovida de conteúdo material, outorga o tratamento da nação mais favorecida à parte-beneficiária, não guardando, porém, qualquer relação com terceiros. Como a fonte de direito estaria nos tratados colaterais, a CNMF não teria, assim, qualquer conteúdo até o Estado-promissor conceder benefícios a terceiros Estados. Na perspectiva do Irã, réu e Estado-promissor, a cláusula da nação mais favorecida envolve um compromisso real, o qual não é determinado, mas suscetível a variações quanto à extensão material. Os tratados posteriores não implicam novas obrigações

\footnotetext{
${ }^{250}$ SCHWARZENBERGER, 1971, p. 138.

${ }^{251}$ USTOR, 1973, p. 170.
} 
para o Estado-promissor, mas alteram o âmbito de aplicação da antiga obrigação. Com isso, a fonte do direito estaria no tratado original que previu a $\mathrm{CNMF}^{252}$

A ampla maioria dos juízes da Corte Internacional de Justiça decidiu no sentido de reconhecer os argumentos apontados pelo Irã. A ICJ entendeu que a fonte do direito do Estado-beneficiário é o tratado original que contém a cláusula da nação mais favorecida. Isso confere ao Estado-beneficiário o direito de exigir do Estado-promissor o cumprimento da obrigação avençada, bem como reconhece que a relação bilateral de uma terceira parte, independente e isolada do tratado original, não pode produzir qualquer efeito legal entre as partes, res inter alios acta. ${ }^{253}$

Em seu voto dissidente, o juiz Hackworth defendeu que a cláusula da nação mais favorecida é uma obrigação condicionada relacionada a direitos futuros, ou seja, o direito é válido, mas funciona como uma moldura vazia. De fato, a CNMF somente produzirá efeitos com a concessão de um favor a terceiros Estados, de modo que esse novo direito internacional não surge apenas de tratados antigos e independentes, mas necessita também de novos acordos internacionais, que asseguram vigor à sua existência. Assim, "the new treaty is, in law and in fact, the fountain-head of the newly acquired rights". E acrescenta que "it is the later treaty, and not the most-favoured-nation clause, that embraces the assurance upon which reliance is sought to be placed". 254

Nesse sentido, o juiz Levi Carneiro, em parte relevante de seu voto dissidente, apontou que a cláusula da nação mais favorecida não produz efeitos por si, visto depender dos tratados posteriormente celebrados, que conferem vantagens a terceiros. Logo, a CNMF não seria instrumento hábil a conferir direitos, carecendo de qualquer utilidade, caso não restassem vantagens outorgadas a terceiros Estados. Por consequência, não subsistiria qualquer direito, se a concessão fosse ab-rogada. Assim, por ser meramente uma "conditional guarantee of a future concession", a cláusula da nação mais favorecida não produz efeitos permanentemente, pois são eventuais e dependentes da contínua existência de outro acordo, o qual seria a verdadeira fonte do direito. $^{255}$

\footnotetext{
${ }^{252}$ ICJ. Anglo-Iranian Oil Co. (United Kingdom v. Iran). Pleadings, 1952. Disponível em <http://www.icjcij.org/docket/index.php?p1=3\&p2=3\&code=uki\&case=16\&k=ba>. Acesso em: 10 fev. 2009, p. 533; 616 .

${ }^{253}$ ICJ. Anglo-Iranian Oil Co. (United Kingdom v. Iran). Report of Judgments, advisory opinions and orders, 1952. Disponível em <http:// www.icj-cij.org/docket/files/16/1997.pdf〉. Acesso em: 10 fev. 2009, p. 109.

${ }^{254}$ ICJ, Anglo-Iranian Oil Co. (United Kingdom v. Iran), Report of Judgments, 1952, p. 141.

${ }^{255}$ ICJ, Anglo-Iranian Oil Co. (United Kingdom v. Iran), Report of Judgments, 1952, p. 157-158.
} 
Embora o caráter condicional da cláusula da nação mais favorecida não seja contestado pela doutrina, as conclusões a que os juízes dissidentes chegaram, partindo desse entendimento, não foram seguidas pelos demais juristas, ou pela maioria da Corte. Na concepção de G. Schwarzenberger, os privilégios concedidos pelo Estado-promissor ao terceiro Estado devem ser estendidos ao Estado-beneficiário como de direito.

Caso o beneficiário não renuncie, ele continuará titular do direito de usufruir desses privilégios, enquanto forem concedidos a terceiros Estados. O fundamento desse direito está na obrigação da cláusula da nação mais favorecida prevista no tratado original em vigor, sendo, assim, insignificante a fonte jurídica empregada para a concessão do benefício a terceiro Estado. Com efeito, apesar de a terceira parte, normalmente, formar um tertium comparationis, a CNMF não assegura a esta o direito de reivindicar o tratamento da nação mais favorecida em relação aos acordos celebrados entre beneficiário e promissor. ${ }^{256}$

Segundo Endre Uster, a decisão da Corte Internacional de Justiça parece estar em consonância com o direito dos tratados, em particular quanto ao efeito dos tratados sobre os Estados não partes de uma relação recíproca. A percepção de que uma terceira parte é a origem do direito do beneficiário da cláusula da nação mais favorecida está em desacordo com o artigo 36 da Convenção de Viena sobre o Direito dos Tratados. Para o direito de um Estado ter origem em um tratado de que não é parte, deve respeitar duas condições. Primeiramente, as partes devem estipular no tratado, por meio do acordo de vontades, a concessão de direitos a terceiros Estados. E, segundo, o Estado-beneficiário deve exercer os direitos nos termos do tratado. Percebe-se, assim, que o direito do Estado-beneficiário de usufruir de um tratamento mais vantajoso não tem origem no tratado celebrado entre o Estado-promissor e o terceiro Estado. E, logicamente, por não ser aplicável o artigo 36 da CVDT, o Estado-beneficiário só pode fundamentar sua exigência contra o Estado-promissor no tratado que estabelecer a $\mathrm{CNMF}^{257}$

Ante o exposto, conclui-se que o artigo I:1 do GATT é uma regra consensual de direito internacional econômico, inserida em um tratado internacional pactuado multilateralmente,

\footnotetext{
${ }^{256}$ SCHWARZENBERGER, 1971, p. 138-140.

${ }^{257}$ USTOR, 1972, p. 170.
} 
tendo por objetivo positivar a cláusula da nação mais favorecida entre os Estados-contratantes, os quais passam a figurar como promissores e beneficiários das vantagens outorgadas. ${ }^{258}$

\subsubsection{Condicionalidade: forma incondicionada}

A produção de efeitos jurídicos pela cláusula da nação mais favorecida é diretamente dependente da forma condicional pactuada ou outorgada pelas partes-contratantes. Essa condição é elemento da estrutura normativa do instituto, a qual pode assumir três formas distintas: incondicionada, condicionada ou código-condicionada. A condicionalidade tem importância central nas relações econômicas internacionais, na medida em que cada forma, ao instrumentalizar certos objetivos, expõe claramente os valores predominantes da política econômica vigente.

\section{a) Forma incondicionada}

Devido à predominância frente às demais estruturas condicionais, a cláusula da nação mais favorecida é, historicamente, identificada com sua forma incondicionada. Celebrada entre as partes-contratantes, a concepção incondicionada da obrigação constitui a forma típica de concessão do tratamento da nação mais favorecida, o qual permite, automaticamente, à parte-beneficiada usufruir, sem requisições ou compensações, de todos os favores concedidos, ou a serem concedidos, pela parte-promissora, em qualquer campo, a uma terceira parte. Com efeito, a CNMF incondicionada insere juridicamente o princípio da não discriminação no âmago da relação comercial, de modo a regulá-la em bases de igualdade de tratamento. ${ }^{259}$

Como relatado na Seção I, a CNMF foi construída historicamente na prática mercantil; logo, surgiram diversos conflitos sobre a correta interpretação do instituto. Considerando os

${ }^{258}$ SCHWARZENBERGER, 1971, p. 138. SCHWARZENBERGER, 1966, p. 74-75. USTOR, 1972, p. 162. JACKSON, 1997, p. 157. FLORY, 1968, p. 14. NGUYEN; DAILLIER; PELLET, 1999, p. 225.

${ }^{259}$ SCHWARZENBERGER, 1966, p. 73. 
efeitos empíricos nas relações econômicas internacionais, a doutrina esteve empenhada, durante o século XIX, em determinar como interpretar a cláusula da nação mais favorecida quando a redação do tratado não estivesse expressa ou clara quanto à forma condicional adotada. A principal divisão doutrinária decorria da constante defesa dos Estados Unidos em prol da forma condicionada, enquanto a posição europeia sustentava que a forma pressuposta e geral era incondicionada. Com isso, diversas foram as propostas de codificação do instituto. ${ }^{260}$

O Institut de Droit International, em sua Resolução no 3 de 1936, intitulada "The effects of the most-favoured-nation clause in matters of commerce and navigation", aponta que a cláusula da nação mais favorecida é incondicionada, salvo expressa disposição em contrário. Daí prever que "the clause confers upon the nationals, goods and ships of the contracting countries, as a matter of right and without compensation, the regime enjoyed by any third country. 261

Em 1973, a Comissão de Direito Internacional defendeu, em seu quarto relatório sobre a cláusula da nação mais favorecida, a presunção da forma incondicionada. Nesse sentido, o artigo $6^{\circ}$ estabelece que, com exceção da hipótese de previsão expressa de condições de reciprocidade material, a cláusula da nação mais favorecida é incondicionada; logo, "the granting State is obliged to accord and the beneficiary State is entitled to receive mostfavoured-nation treatment irrespective of whether the favours accorded by the granting State to any third State are accorded gratuitously or against compensation ". ${ }^{262}$

Em suma, a estrutura incondicionada estabelece a obrigação do Estado-promissor de estender, automaticamente, ao Estado-beneficiário, livres de quaisquer condições, os direitos outorgados a terceiros Estados, referentes à matéria-objeto prevista no tratado internacional. No contexto do sistema multilateral de comércio, o Acordo Geral sobre Tarifas e Comércio adotou expressamente a forma incondicionada em seu artigo I:1: “qualquer [...] privilégio concedido por uma parte contratante em relação a um produto originário de ou destinado a qualquer outro país, será imediata e incondicionalmente estendido ao produtor similar [...]".

\footnotetext{
${ }^{260}$ HYDE, Charles Cheney. Concerning the interpretation of treaties. American Journal of International Law, [s.1.], v. 3, n. 1, 1909, p. 57. USTOR, Endre. Fourth Report of the Special Rapporteur. Yearbook of the International Law, [s.1.], v. II, 1973. Disponível em <http://www.un.org/law/ilc/index.htm>. Acesso em: 10 out. 2006. Documento da ONU n. A/CN.4/266, p. 99.

${ }^{261}$ IDI, Resolução n. 2, 23 abr. 1936.

${ }^{262}$ USTOR, 1973, p. 98.
} 


\section{b) Forma condicionada}

A construção condicionada da cláusula da nação mais favorecida era, originalmente, defendida pela diplomacia dos Estados Unidos. Apresentada no Capítulo 1.1.6, a interpretação condicionada era componente essencial da política comercial estadunidense, cujo objetivo era proteger sua indústria nascente. Nas relações mercantis, os tratados comercias previam a condição de que nenhuma das partes-contratantes era obrigada a estender, imediata e incondicionalmente, aos produtos da outra parte, as vantagens que tivessem sido outorgadas a terceiros, em razão de concessões recíprocas. Com efeito, a extensão das vantagens era condicionada à concessão pela outra parte-contratante de vantagens equivalentes àquelas negociadas com terceiros. Com a emergência dos Estados Unidos como potência, após a Primeira Guerra Mundial, a forma condicionada deixou de ser adequada aos seus planos comerciais. Para obter sucesso na penetração nos mercados internacionais, era necessária a eliminação da discriminação contra produtos estadunidenses, fator que seria mais facilmente alcançado mediante a adoção da forma incondicionada. ${ }^{263}$

Concebida como regra instrumental do princípio da reciprocidade, a forma condicionada não opera automaticamente, pois produz efeitos distintos, dependendo dos requisitos prévios de extensão dos benefícios entre as partes-contratantes. Na hipótese de uma vantagem ser livremente outorgada por uma parte-contratante a terceiras partes, deverá ser estendida a outra parte-contratante destinuída de condições. No entanto, caso o benefício seja concedido a terceiros, em bases recíprocas, isto é, demandando-se uma vantagem compensatória como pagamento, somente será possível a outra parte-contratante gozar desta, caso ofereça um benefício equivalente. ${ }^{264}$

Resultado das relações de poder na ordem econômica internacional, o estabelecimento da forma incondicionada no Acordo Geral sobre Tarifas e Comércio simbolizou a prevalência de uma verdade: o princípio da não discriminação. A positivação da cláusula da nação mais favorecida incondicionada não é despropositada; pelo contrário, expressa justamente a

\footnotetext{
${ }^{263}$ USTOR, 1973, p. 98. SNYDER, 1948, p. 243.

${ }^{264}$ LdN, 1928, p. 136.
} 
conformação da estrutura institucional-legal a certos princípios e valores da estrutura axiológica. Assim, é necessário comparar as características normativas de cada modelo condicional, a fim de compreender se a conformação do sistema multilateral de comércio atende às razões fático-axiológicas dos agentes econômicos, examinadas na Seção I.

O primeiro aspecto consiste na problemática acerca do padrão de troca de benefícios. Enquanto na forma incondicionada as concessões outorgadas pelas partes-contratantes são estendidas automaticamente, em bases não discriminatórias, na forma condicionada, as concessões, por fundamentarem-se na reciprocidade, demandam constantes negociações sobre a equivalência mútua das vantagens. Nesse particular, a subjetividade dos agentes econômicos torna quase impossível alcançar um acordo satisfatório acerca da compensação de cada benefício, na medida em que é difícil afirmar com exatidão a equivalência das diversas vantagens simultaneamente negociadas.

A segunda questão é pertinente à automaticidade do efeito que estende os benefícios às partes. Os efeitos da estrutura incondicionada são automáticos, não demandando qualquer assentimento das demais partes-contratantes. A forma condicionada, porém, exige a manifestação plena de anuência. Isso permite às partes recusarem-se a conceder um valioso benefício, alegando, simplesmente, que o contrabenefício não é igual ou equivalente. De fato, as características determinantes dos países da comunidade internacional são tão díspares que há situações em que é impossível oferecer os mesmos benefícios, pois o que é muito valioso para um, pode não o ser para outro. Todavia, decisões autárquicas, tomadas muitas vezes em razão da disparidade de poder, tendem a causar tensões nas relações econômicas internacionais. Daí a importância da forma incondicionada que, ao desencorajar os debates sobre a reciprocidade substancial de certo privilégio, evita discriminações.

Devido à necessidade de constantes negociações e sucessivos pagamentos para encontrar um preço aceitável para os benefícios, a liberalização do comércio sob uma política condicionada é excessivamente vagarosa e, portanto, incompatível com o ritmo exigido pelo processo de globalização econômica. Ao tratar da relação entre tempo político e tempo econômico, esse terceiro aspecto conduz as partes a preferirem o tratamento incondicionado, pois a operacionalização automática confere celeridade e capacidade adaptativa ao sistema multilateral de comércio, de modo a prescindir de um segundo processo de negociação de índole compensatória. 
Por incitar debates sobre a equivalência das concessões, o regime condicionado compromete a eficácia dos acordos, pois permite às partes-contratantes evitar o pleno cumprimento dos pactos assumidos. Com isso, inviabiliza-se estruturalmente um sistema multilateral de comércio fundado na não discriminação, na medida em que, ao adotar um mecanismo de caráter recíproco, permite a discriminação quanto ao pagamento dos benefícios. Isso incide diretamente na confiança das partes, refletindo sobre a eficácia da norma em assegurar as expectativas normativas da política comercial. ${ }^{265}$

Todos esses aspectos contribuíram para adoção da forma incondicionada no sistema GATT/OMC. Com a positivação no SMC, a cláusula da nação mais favorecida incondicionada atua como peça central do mecanismo de liberalização do comércio, pois permite acelerar o processo de abertura econômica, mediante a generalização automática dos benefícios outorgados pelos Estados-membros.

O regime incondicionado não está, porém, livre de falhas. Os críticos apontam que, ao optar por ele, os Estados-membros decidiram privilegiar a igualdade formal em detrimento da material. Isso porque não é sempre que a CNMF irá beneficiar todos homogeneamente, propiciando melhoras no bem-estar. Por consequência, receava-se o retorno ao unilateralismo e protecionismo pelos Estados, seja devido a pretensões legítimas de discriminação comercial, tendo por foco a manutenção da reciprocidade, seja em razão das situações em que partes auferissem vantagens em detrimento dos demais, mediante emprego da superioridade políticoeconômica ou por deficiência institucional-normativa. Todavia, mesmo após a institucionalização, a cláusula da nação mais favorecida não deixou de produzir efeitos perversos, permitindo o aparecimento de três fenômenos nocivos: foot-dragger, free-rider e critical mass.

Considerando que a estrutura do sistema GATT/OMC é centrada no multilateralismo procedimental, cujo objetivo é negociar regras gerais e abstratas aplicáveis a todos os seus membros, um Estado pode, deliberadamente, dificultar a adoção de acordos consensuais. Denominados foot-draggers, a intenção desses agentes econômicos é impedir a expansão e o aprofundamento das normas materiais do sistema multilateral de comércio, de forma a restringir-lhes o alcance ao mínimo denominador comum. Por outro lado, os free-riders são

\footnotetext{
${ }^{265}$ SAYRE, Francis B. The Most-Favored-Nation Policy in Relation to Trade Agreement. The American Political Science Review, [s.1.], v. 33, n. 3, 1939, p. 417-419. SCHWARZENBERGER, 1966, p. 74. LdN, 1928, p. 136.
} 
países que buscam se beneficiar das concessões estendidas, incondicional e automaticamente, a todos os membros, sem, porém, apresentar qualquer oferta. Incidindo contra o princípio da reciprocidade, essa atuação política implica na diminuição da propensão dos Estados em apresentar compromissos adicionais. Isso reflete sobre as negociações, pois as partescontratantes que desejarem aprofundar o processo de liberalização optarão por fazê-lo, mediante o engajamento em grupos comerciais menores, guiados pelo princípio da reciprocidade, ao invés de esperar a emergência da massa crítica de concessões generalizadas pelo SMC. Apesar de não ser comprovada a eficácia para a ampliação comercial, tal estratégia é uma antítese à forma incondicionada, pois se assenta exclusivamente na reciprocidade.

Entretanto, o desequilíbrio crescente de direito e obrigações entre as partescontratantes foi se tornando cada vez menos tolerável. A Rodada Uruguai apresentou uma solução, ainda que temporária, aos problemas, a qual consiste na ideia do empreendimento único (single undertaking), cujo objetivo é demandar dos Estados-membros a aceitação de todos os acordos previamente estabelecidos, com exceção naquilo que dispõe o Anexo 4, referente aos Acordos Plurilaterais. Dessa forma, tratou-se de impedir, ou pelo menos coibir, o fenômeno do free-rider. ${ }^{266}$

Embora esses problemas institucionais e argumentos a favor da reciprocidade possam ser importantes, eles não têm o condão de justificar o abandono da forma incondicionada. Isso porque seria impraticável e insatisfatória a adoção de uma política de liberalização comercial internacional, tendo a reciprocidade como princípio dominante e disciplinador das negociações tarifárias. Nas palavras de Francis Sayre, a forma condicionada "involves negotiations which are not only increasing and difficult, but quite unnecessary and often costly. It is likely to lead to "padding" of tariff rates and heightening of trade barriers. It fails to protect producers for export from foreign discrimination", 267

\footnotetext{
${ }^{266}$ CARREAU; JUILLARD, 1998, p. 230-231. JACKSON, 1997, p. 158-159. DAVEY, William J.; PAUWELYN, Joost. MFN Unconditionaly: A Legal Analysis of the Concept in View of its Evolution in the GATT/WTO Jurisprudence with Particular Reference to the issue of "Like Product". In: COTTIER, Thomas; MAVROIDIS, Petros C. (ed.). Regulatory Barriers and the Principle of Non-discrimination in World Trade Law: Past, Present, and Future. Michigan: University of Michigan, 2000, p. 14-16.

${ }^{267}$ SAYRE, 1939, p. 419.
} 


\section{c) Forma código-condicionada}

Como vislumbrado, a aparente uniformização mundial em torno da forma incondicionada não implicou no abandono do regime condicionado, o qual veio a ganhar novas aplicações no sistema GATT/OMC, na forma dos tratados plurilaterais de comércio. Diferindo das estruturas clássicas, incondicionada e condicionada, os negociadores da Rodada Tóquio inovaram, ao formular um terceiro modelo da cláusula da nação mais favorecida, cujo objetivo era organizar os códigos comerciais paralelos. Denominados Side Agreements, os códigos previam que seus benefícios comerciais só seriam estendidos, mediante o tratamento da nação mais favorecida, às partes-contratantes que aderissem aos pactos especiais. Certos autores têm classificado essa modalidade como condicionada, porém a estrutura normativa encontrada nos códigos não corresponde estritamente ao conceito clássico, o qual tem como pressuposto uma negociação particular de reciprocidade de benefícios.

De atuação distinta, o código define previamente escopo, benefícios e forma do tratamento recíproco, os quais são outorgados automaticamente no ato da adesão. Daí denominar essa estrutura como forma código-condicionada, cuja vantagem é propiciar um incentivo para que os outros Estados venham a aderir e, consequentemente, submeter-se a um processo recíproco de harmonização e liberalização comercial, o qual tende a ser futuramente integrado à regra geral da não discriminação. As vantagens desse novo regime são: (i) incorporar ao sistema multilateral de comércio os anseios dos Estados por maior abertura comercial, incentivando a negociação em âmbito mundial; e (ii) restringir a atuação dos freeriders, visto exigirem a outorga de benefícios recíprocos. ${ }^{268}$

Com a adoção do empreendimento único, houve a diminuição da forma códigocondicionada, a qual foi incorporada na figura dos acordos plurilaterais, previstos no Anexo 4. Entretanto, há grande potencial em sua utilização, na medida em pode servir como mecanismo de incorporação dos interesses liberalizantes de certos membros ao sistema multilateral de comércio, o que diminui as tensões nas relações econômicas internacionais. Com isso, haveria

\footnotetext{
${ }^{268}$ JACKSON, 1997, p. 161-162.
} 
um incentivo à celebração de acordos plurilaterais, dotados de maior complexidade e capazes de lidar com as expectativas normativas dos Estados-membros, dentro do sistema GATT/OMC, restringindo-se, assim, o recurso aos acordos preferenciais de comércio.

\subsubsection{Relação obrigacional: estrutura bilateral}

Diversos são os modos de relacionamento obrigacional que podem ser estabelecidos pela cláusula da nação mais favorecida, a fim de regular a interação entre os agentes econômicos. Tradicionalmente as obrigações internacionais são classificadas em unilaterais e consensuais. Com o aprofundamento das relações econômicas, houve uma diferenciação estrutural da forma consensual, a qual foi classificada por Gerald Fitzmaurice em obrigações bilaterais e coletivas, sendo estas subdivididas em interdependentes e integrais. ${ }^{269}$

Ressalta-se, entretanto, que as naturezas obrigacionais não se confundem com suas fontes normativas. Identificar a forma das obrigações não significa analisar a respectiva origem jurídica, pois tratados bilaterais, plurilaterais e multilaterais podem conter deveres unilaterais, bilaterais e coletivos. Os acordos da Organização Mundial do Comércio são, predominantemente, tratados multilaterais, os quais servem de instrumento jurídico para estabelecer os direitos e deveres válidos. Isso não significa que todas as obrigações neles previstas têm natureza coletiva.

Os institutos jurídicos examinados em abstrato tendem a ser identificados com certa estrutura obrigacional. Suas características intrínsecas, responsáveis por determinar a respectiva forma, podem, todavia, ser alteradas, em razão do regime normativo em que a obrigação é inserida. A concreção em certo tratado pode implicar na transformação da natureza tradicional do instituto, ou na alteração de alguns de seus elementos típicos. Essa flexibilidade estrutural, embora dificulte a categorização ontológica, permite adaptar as obrigações às necessidades das relações econômicas internacionais. Com efeito, a obrigação

\footnotetext{
${ }^{269}$ FITZMAURICE, Gerald G. Third Report on the Law of Treaties of the Special Rapporteur. Yearbook of the International Law, [s.l.], v. II, 1958. Disponível em <http://www.un.org/law/ilc/index.htm>. Acesso em: 10 out. 2008. Documento da ONU n. A/CN.4/115 and Corr.1, p. 27-28.
} 
concretamente positivada irá prevalecer sobre a abstrata; logo, a concepção ideal do instituto será aplicável apenas quando houver lacunas na interpretação. ${ }^{270}$

A classificação das estruturas normativas das obrigações internacionais tem por finalidade extrair elementos que permitam resolver conflitos entre normas internacionais, identificar respectivas modificações e suspensões, bem como apurar, na hipótese de violação, as consequências legais, a titularidade do direito subjetivo e a extensão das contramedidas. Assim, examinar-se-ão as formas obrigacionais pelas quais a cláusula da nação mais favorecida tradicionalmente se expressa, de modo a verificar as características distintivas do artigo I:1 do GATT, bem como os impactos normativos no sistema multilateral de comércio, decorrentes de sua violação .

\section{a) Relacionamento unilateral}

As obrigações unilaterais têm grande importância histórica, como constatado na Seção I. Todavia, perdeu relevância no atual contexto das relações econômicas internacionais, pois sua funcionalidade tende a adaptar-se melhor a fases menos sofisticadas da economia internacional. Dois foram os momentos históricos em que a forma unilateral teve um papel relevante: o Imperialismo Britânico e o período entre as Guerras Mundiais. Isso porque a concessão unilateral da CNMF não visa disciplinar relações interdependentes em bases não discriminatórias, mas assegurar a exploração pela parte-beneficiada das vantagens outorgadas pela parte-promissora. Nesse particular, vislumbra-se como as relações de poder econômico apropriam-se dos institutos jurídicos para criar discursos verdadeiros.

A forma das obrigações não se confunde com o veículo jurídico no qual estão inseridas, ou seja, tratados podem prever obrigações unilaterais ou consensuais. Os Acordos de Paz de $1919^{271}$ impuseram aos Estados derrotados a outorga de concessões econômicas unilaterais em favor dos Aliados, os quais defendiam que esses tratados foram acordados em bases recíprocas. Entretanto, a previsão textual de mera reciprocidade formal não transforma o

\footnotetext{
${ }^{270}$ PAUWELYN, Joost. A Typology of Multilateral Treaty Obligations: Are WTO Obligations Bilateral or Collective in Nature? European Journal of International Law, [s.1.], v. 14, n. 5, 2003, p. 925-926.

${ }^{271}$ Bulgária (artigo 29); Hungria (artigo 33); Romênia (artigo 31); Finlândia (artigo 30); e Itália (artigo 82).
} 
regime da cláusula da nação mais favorecida de unilateral em consensual. Por exemplo, o Tratado de Paz da Hungria, em seu artigo $33^{272}$, é claro em dispor que, apesar de o direito dos Aliados ao tratamento da nação mais favorecida ser constituído segundo o princípio da reciprocidade, a CNMF continua a ser unilateral, visto não assistir à Hungria o direito de demandar o mesmo tratamento. ${ }^{273}$

Não obstante, salvo assegurarem direito a somente uma das partes, as obrigações unilaterais são estruturalmente similares às bilaterais; logo, serão estudadas conjuntamente. ${ }^{274}$

\section{b) Relacionamento consensual-bilateral}

Nos tratados econômicos, as obrigações consensuais podem ser classificadas em bilaterais e coletivas. Baseados na reciprocidade de interesses, os tratados bilaterais e plurilaterais são quase exclusivamente compostos por obrigações bilaterais, as quais dispõem acerca do intercâmbio mútuo de benefícios entre as partes; enquanto que nos tratados multilaterais podem ser encontradas também as obrigações coletivas, cujo objetivo é salvaguardar interesses coletivos. Com isso, a cláusula da nação mais favorecida pode ser estruturalmente constituída como uma obrigação unilateral, bilateral ou coletiva.

Em seu relatório sobre direito dos tratados à Comissão de Direito Internacional, Gerald Fitzmaurice propôs distinguir duas importantes consequências legais das obrigações bilaterais. A violação de dispositivo fundamental deveria autorizar as partes lesadas a suspender ou terminar os tratados. No caso das partes celebrarem acordos a posteriori, que venham a conflitar ou modificar as obrigações contraídas previamente, esses deveriam ser válidos, derrogando as disposições em contrário. A Convenção de Viena sobre o Direito dos Tratados, ainda que tenha rejeitado a distinção quanto à natureza das obrigações, incorporou parcialmente as sugestões propostas. Os artigos 60.1 e 60.2(b) preveem o direito individual do

272 " [...] the Hungarian Government shall [...] grant the following treatment to each of the United Nations which, in fact, reciprocally grants similar treatment in like matters to Hungary: (a) In all that concerns duties and charges on [...] the United Nations shall be granted unconditional most-favoured-nation treatment".

${ }^{273}$ SCHWARZENBERGER, 1966, p. 26; 73. USTOR, 1973, p. 99.

${ }^{274}$ SICILIANOS, Linos-Alexander. The Classification of Obligations and the Multilateral Dimension of the Relations of International Responsibility. European Journal of International Law, [s.1.], v. 13, n. 5, 2002, p. 1133. 
Estado de extinguir ou suspender tratados, em razão da violação de obrigação substancial. Já o artigo 30 dispõe acerca da prevalência na aplicação de tratados bilaterais sucessivos sobre os existentes previamente que tenham o mesmo objeto. ${ }^{275}$

Diferentemente da Convenção de Viena sobre o Direito dos Tratados, os Artigos sobre Responsabilidade do Estado (“ARE”), aprovados em 2001 pela Comissão de Direito Internacional, em muito se alinharam com a proposta classificatória de G. Fitzmaurice, visto distinguirem os direitos dos Estados lesados e de outros Estados em relação à violação de uma obrigação. Ao disciplinar a responsabilidade nas relações bilaterais, o artigo 42(a) assegura aos Estados direitos individuais para exigir cessação das infrações de deveres bilaterais, garantias de não repetição e reparação dos danos sofridos, assim como para tomar as contramedidas necessárias para garantir a tutela legal. ${ }^{276}$

Dessa forma, as obrigações unilaterais e bilaterais, que podem ser inseridas em tratados bilaterais, plurilaterais e multilaterais, têm por características garantir aos Estados: (i) direito individual de suspender ou extinguir tratados, em caso de violação de obrigações substanciais; e (ii) legitimidade ativa para exigir a responsabilização da parte infratora pelos danos causados.

Em suma, a estrutura bilateral da cláusula da nação mais favorecida é a expressão normativa dos interesses recíprocos dos agentes econômicos internacionais. Dessa forma, os direitos inerentes à CNMF podem ser opostos ao Estado-promissor, na hipótese de este não cumprir com as obrigações de estender as vantagens ao Estado-beneficiário. Caso sejam violadas, o Estado lesado terá o direito individual de suspender ou terminar com o tratado, bem como pleitear a responsabilização do Estado infrator.

\section{c) Relacionamento consensual-mutilateral}

As obrigações previstas nos tratados multilaterais podem ter natureza bilateral ou coletiva. Há tratados multilaterais formados unicamente por obrigações bilaterais, de modo a

\footnotetext{
${ }^{275}$ FITZMAURICE, 1958, p. 27-28.

${ }^{276}$ PAUWELYN, 2003, p. 912. SICILIANOS, 2002, p. 1139.
} 
compor um feixe de relações recíprocas, as quais podem ser individualizadas. Por outro lado, existem tratados multilaterais constituídos por obrigações coletivas, que não podem ser destacadas em componentes bilaterais, visto protegerem os interesses coletivos em face dos interesses individuais das partes. As obrigações coletivas podem, ainda, ser subdividas em integrais e interdependentes.

$\mathrm{Na}$ classificação proposta por Gerald Fitzmaurice para o direito dos tratados, as obrigações integrais não poderiam ser extintas ou suspensas pelas partes, devido à violação de dispositivos fundamentais. Isso porque a imperatividade normativa não depende da correspondente eficácia social em determinar o comportamento das partes. Além disso, qualquer tratado subsequente, celebrado entre as partes, que venha a conflitar diretamente com as obrigações integrais, será nulo e destituído de efeitos.

As obrigações interdependentes têm por característica a participação de todas as partes como condição de imperatividade do tratado. Em caso de violação de obrigação fundamental, as outras partes podem extinguir o tratado, mas não podem suspendê-lo, uma vez que há uma intrínseca vinculação entre vigor e eficácia normativa. Não obstante, tal como as obrigações integrais, qualquer tratado bilateral, celebrado posteriormente, que venha a conflitar com obrigações interdependentes será considerado nulo. ${ }^{277}$

Como observado, a Convenção de Viena sobre o Direito dos Tratados não adotou a classificação de G. Fitzmaurice, mas foi por ela influenciada. Com efeito, os artigos 41 e 58 proíbem a modificação ou suspensão de obrigações coletivas por obrigações bilaterais sucessoras, caso prejudiquem os direitos de terceiras partes ou sejam incompatíveis com os objetivos e finalidades do tratado multilateral. Por operarem no plano da ilicitude e não da validade, como originalmente proposto, a aplicação de tais dispositivos demanda uma difícil análise subjetiva de compatibilidade acerca dos objetivos e finalidades do tratado multilateral com o acordo inter se, o que acarreta um ônus adicional para determinar a existência de incompatibilidade. Em consonância com o artigo 34, que corporifica o princípio do pacta tertiis nec nocent nec prosunt, os artigos 41 e 58 proíbem tratados bilaterais sucessivos que produzam efeitos sobre terceiras partes, sem seu consentimento. ${ }^{278}$

\footnotetext{
${ }^{277}$ FITZMAURICE, Gerald G. Second Report on the Law of Treaties of the Special Rapporteur. Yearbook of the International Law, [s.l.], v. II, 1957. Disponível em <http://www.un.org/law/ilc/index.htm>. Acesso em: 10 out. 2008. Documento da ONU n. A/CN.4/107, p. 31-36.

${ }^{278}$ PAUWELYN, 2003, p. 913-915.
} 
O artigo 60.2(c) guarda a noção de obrigações interdependentes, na medida em que autoriza as partes inocentes a invocar a violação como causa de suspensão de tratados multilaterais, desde que tal infração modifique radicalmente as expectativas das partes. Esse dispositivo pressupõe que a violação por uma das partes tende a debilitar a eficácia normativa, de modo a não haver sentido em manter um vínculo jurídico constituído por obrigações interdependentes, baseadas na ideia de tudo ou nada. Daí a relação de reciprocidade entre as partes alcançar o mais alto estágio de interdependência obrigacional.

Ao proibir expressamente a extinção e suspensão dos tratados de caráter humanitário, o artigo 60.5 reflete a concepção de obrigações integrais, visto impedir, em nome do interesse comunitário, o exercício de direito individual nos casos de infrações substanciais aos deveres acordados. Além disso, os artigos 53 e 64 estabelecem que tratados conflitantes com normas de jus cogens são inválidos. Apesar de esses dispositivos incorporarem, parcialmente, a proposta das obrigações coletivas, as quais não poderiam ser derrogadas por tratados bilaterais, restringem sua aplicação a uma particular subespécie de obrigações integrais, o jus cogens. $^{279}$

Ao trazer a distinção entre obrigações bilaterais e coletivas, os Artigos sobre Responsabilidade do Estado da CDI reconhecem que os tratados multilaterais podem estipular obrigações coletivas que transcendem a esfera bilateral de relações, a fim de assegurar a prevalência do interesse comum sobre os individuais. $\mathrm{O}$ artigo 48.1 prevê a possibilidade de qualquer Estado recorrer à responsabilização de outro por violação de obrigações coletivas. Nesse particular, suas alíneas (a) e (b) permitem distinguir os dois tipos de obrigações coletivas: interdependentes e integrais. A alínea (a) visa à proteção do interesse coletivo de um grupo, por meio da autorização a qualquer Estado-parte para invocar a responsabilidade por violações de obrigações interdependentes. A alínea (b) dispõe acerca da proteção ao interesse comum da sociedade internacional, mediante concessão de legitimidade ativa a qualquer Estado para demandar a responsabilização daquele que violar essas obrigações integrais.

\footnotetext{
${ }^{279}$ DUPUY, Pierre-Marie. A General Stocktaking of the Connections between the Multilateral Dimension of Obligation and Codification of the Law of Responsibility. European Journal of International Law, [s.1.], v. 13, n. 5, 2002, p. 1071. ONU. General Assembly. ILC Report on the work of its fifty-third session, Official Records, Fifty-fifth Session, Supplement n. 10. Disponível em: 〈http://www.un.org/law/ilc/reports/2001/2001report.htm〉. Acesso em: 28 fev. 2009. Documento da ONU n. A/56/10, p. 296.
} 
Nesse particular, o intuito do ARE foi claramente codificar a decisão da Corte Internacional de Justiça no Caso Barcelona Traction, na qual distinguiu obrigações bilaterais e coletivas. ${ }^{280}$

Com efeito, destacam-se do artigo 48 características essenciais das obrigações coletivas. Enquanto a obrigação integral tem estrutura erga omnes, cujos efeitos são expandir a todos os Estados o direito de exigir a responsabilização por violações a interesses comuns da sociedade internacional, as obrigações interdependentes são essencialmente erga omnes partes, isto é, asseguram o direito a todos os Estados-partes de um tratado multilateral de responsabilizar a parte infratora. Assim, devido ao papel das obrigações erga omnes, o artigo 50.1 veda qualquer contramedida empregada pelo Estado lesado, cujo objetivo seja o não cumprimento do tratado.

No entanto, o escopo do artigo 48 limita-se a exigir a cessação do ato violador ou o cumprimento das obrigações de reparação a favor do Estado lesado, não assegurando o direito de requerer reparações. Os ARE reconheceram, porém, que algumas violações de obrigações coletivas poderiam afetar especificamente um ou mais Estados. Nesse sentido, o artigo 42(b) considera um Estado lesado, detentor de todos os direitos de reivindicar a responsabilização do infrator, em duas hipóteses: (i) quando for especialmente afetado pela violação; ou (ii) caso a violação altere radicalmente a expectativa normativa, implicando em mudanças de comportamento perante a obrigação. Com efeito, ao fundamentar uma demanda no artigo 48, os Estados visam defender interesses coletivos, não como sujeitos individuais de direito, mas como membros de uma coletividade. Por outro lado, o artigo 42(b) assegura aos Estados (i) reivindicar individualmente a proteção ao seu direito coletivo violado, e (ii) a possibilidade de exigir a responsabilização do Estado que, ao violar a obrigação interdependente, implique drásticas mudanças comportamentais. ${ }^{281}$

Desse modo, as características comuns das obrigações coletivas são a vedação a derrogações por tratados bilaterais sucessivos, bem como a possibilidade de qualquer Estado, vinculado a um grupo ou à sociedade internacional, pleitear a responsabilização pela infração de um interesse coletivo. Nas obrigações interdependentes, é possível suspender o tratado, desde que a infração altere substancialmente o comportamento, assim como reivindicar a responsabilidade por infração a interesses coletivos, dispondo de todos os direitos de um

\footnotetext{
${ }^{280}$ SICILIANOS, 2002, p. 1137.

${ }^{281}$ ONU, ILC Report, p. 300-320.
} 
Estado lesado. Por fim, as obrigações integrais distinguem-se por conformar interesses de toda a comunidade internacional; logo, os tratados multilaterais não podem ser suspensos pelas partes, ou serem aplicadas contramedidas.

Identificar estruturalmente a cláusula da nação mais favorecida como qualquer das obrigações coletivas é desafiador, pois tem sido historicamente utilizada como um instrumento jurídico das relações econômicas internacionais, as quais são bilaterais por excelência. Operacionalmente, ela tem por efeito duplicar e estender ao Estado-beneficiário os vínculos obrigacionais recíprocos contraídos entre Estado-promissor e terceiros Estados. Com isso, a doutrina tem concluído que, mesmo em tratados multilaterais, a CNMF mantém uma estrutura bilateral, pois, ao coordenar os feixes de relações recíprocas, tem por efeito tão somente coletivizar as concessões a todos os Estados-partes. Não haveria, portanto, qualquer alteração em sua forma obrigacional, visto ter apenas o condão de maximizar a reprodução das vantagens outorgadas, no contexto das relações econômicas bilaterais.

Nesse sentido, Joost Pauwelyn, ao investigar a natureza das obrigações da OMC, aponta que a cláusula da nação mais favorecida, positivada no artigo I:1, tem justamente uma estrutura bilateral, ainda que inserida nos tratados multilaterais do SMC. Isso não significa um enfraquecimento da imperatividade normativa, visto que as obrigações coletivas e bilaterais são igualmente vinculantes. A diferença reside na matriz de relacionamentos que conforma a estrutura obrigacional. Isto é, embora os negociadores visassem construir um instrumento jurídico que congregasse o interesse comum, tal objetivo prescinde de obrigações coletivas, na medida em que as obrigações da Organização Mundial do Comércio, por disciplinarem relações recíprocas comerciais, constituem essencialmente feixes de coletivização de interesses bilaterais. $^{282}$

Como a finalidade da OMC é aumentar o bem-estar por meio do comércio, as obrigações dificilmente teriam um caráter coletivo, pois os tratados foram desenhados para disciplinar as negociações comerciais individualizadas. Essas negociações tarifárias são processos recíprocos que buscam, por meio de um equilíbrio de concessões, alcançarem vantagens mútuas. Aponta J. Pauwelyn que o objetivo da liberalização comercial não é um interesse coletivo genuíno ou nobre, no sentido de transcender a soma dos interesses individuais. Por consequência, os direitos e obrigações são diferenciáveis e individualizáveis,

${ }^{282}$ PAUWELYN, 2003, p. 928-930. 
cuja infração afeta apenas um Estado em particular, não incidindo contra valores coletivos. Daí assistir apenas ao Estado-membro lesado que sofrer danos decorrentes da violação de uma regra o direito individual de exigir reparação.

Consubstanciado no Entendimento sobre Solução de Controvérsias, J. Pauwelyn aponta que o mecanismo de resolução de litígios da OMC tem três elementos principais que revelam sua função de administrador de conflitos bilaterais. Primeiro, o Órgão de Solução de Controvérsias não lida, de acordo com artigo XXIII:1 do GATT, com violações obrigacionais, mas com anulação ou diminuição de benefícios. Segundo, o OSC analisa apenas demandas interindividuais entre Estados-membros. Terceiro, a sanção eventualmente imposta deve ser exercida exclusivamente pelo Estado lesado. A autorização para suspensão das concessões demonstra o caráter bilateral do mecanismo, visto atuar numa relação interestatal e não coletiva. $^{283}$

As obrigações da OMC têm, essencialmente, natureza bilateral, que podem ser, em caso de violações, suspensas ou afastadas, bem como modificadas por tratados sucessivos. Os Estados lesados têm legitimidade ativa e individual para exigir a reparação pelos danos causados por um outro Estado-membro em decorrência da infração de seus direitos. Diante disso, a cláusula da nação mais favorecida, na concepção de J. Pauwelyn, consiste numa coleção de relações jurídicas bilaterais, cuja estrutura obrigacional é essencialmente bilateral. Em suas palavras:

The multiple MFN obligations set out in the WTO treaty, the cornerstone of the multilateral trading system, ensure that any trade advantage a country gives to another must be "multilateralised" and granted to all WTO members. As a result, MFN surely makes bilateral concessions collective in the sense that they must go to all other WTO members. But in substance, this "collectivisation" is nothing more than a duplication by the number of WTO members of the original bilateral concession. The bilateral concession is thereby granted from state to state to all other WTO members. It does not, by means of MFN, transcend into some "global common", more valuable than the sum total of the individual benefits it procures to each WTO member. ${ }^{284}$

A cuidadosa investigação de Joost Pauwelyn propiciou um detalhado exame analítico das estruturas obrigacionais predominantes no sistema multilateral de comércio. A conclusão de que a cláusula da nação mais favorecida, positivada no artigo I:1 do GATT, tem natureza

\footnotetext{
${ }^{283}$ PAUWELYN, 2003, p. 930-936.

${ }^{284}$ PAUWELYN, Joost. The nature of WTO obligations. Nova York: New York University School of Law, 2002, p. 12, 21-28. Disponível em <http://www.jeanmonnetprogram.org/papers/02/020101.rtf〉. Acesso em: 28 de fevereiro de 2009. Jean Monnet Working Paper 1/02.
} 
de obrigação bilateral parece estar em consonância com as construções doutrinárias. Em resumo, os aspectos que revelam o caráter bilateral do artigo I:1 são: (i) devido ao seu conteúdo aberto, a CNMF seria uma coletivização de obrigações bilaterais; por isso, (ii) ao ser violada, não afetaria o direito ou a expectativa normativa de todos os membros, mas apenas do Estado lesado; (iii) também não refletiria sobre os benefícios econômicos dos Estadosmembros; (iv) seu objetivo não é genuinamente coletivo, visto o comércio ser objeto de interesses individuais; e, finalmente, (v) o sistema multilateral de comércio não reconhece violação de direitos, mas apenas diminuição de benefícios; os quais (vi) somente podem ser pleiteados individualmente perante o OSC. 


\subsection{FUNCIONALIDADE: TRATAMENTO DA NAÇÃO MAIS FAVORECIDA}

No decorrer dos séculos, as transformações socioeconômicas têm exigido da estrutura institucional-legal renovações constantes e novas soluções jurídicas. Os institutos legais tendem a sofrer com desautorizações ou perda de eficácia em ciclos temporais cada vez menores, podendo ser condenados ao ostracismo, caso sejam incapazes de apresentar respostas jurídicas a novos problemas. Ainda que pesem os desafios sistêmicos, a cláusula da nação mais favorecida parece romper com tal tendência destrutivo-renovativa, pois, graças a sua capacidade adaptativa, sua importância tem aumentado, no contexto de progressivo aprofundamento institucional das relações econômicas internacionais.

Ao longo de sua história, a estrutura normativa da CNMF tem variado adaptativamente, de acordo com as formas de condicionalidade, as relações obrigacionais intersubjetivas e a extensão da materialidade dos discursos jurídico-normativos. Entretanto, o que torna a cláusula da nação mais favorecida sui generis não reside em suas variações e flutuações formais, mas, fundamentalmente, na permanência de suas características funcionais. Enquanto a interação dinâmica entre as estruturas modificam a ordem econômica internacional, o núcleo significativo da CNMF permanece imutável: o tratamento da nação mais favorecida (“TNMF”). Isso sugere que sua função primária não é afetada pelas particularidades das conjunturas históricas. Verifica-se, assim, que a razão de sua relevância reside no intrínseco vínculo entre o instituto e os interesses e valores fundamentais que orientam as relações econômicas internacionais, de modo expressar a imbricada interação entre direito, poder e verdade. ${ }^{285}$

$\mathrm{Na}$ ordem econômica internacional, a descentralização do poder político provoca incertezas e desconfianças nos agentes econômicos, resultando em um permanente estado de guarda e competitividade predatória. Para assegurar maior estabilidade às expectativas normativas, os Estados passaram a celebrar tratados comerciais, a fim de alterar tais

${ }^{285}$ SCHWARZENBERGER, 1966, p. 72. 
percepções, conferindo durabilidade às relações econômicas. Todavia, como os acordos são bilaterais e celebrados em bases recíprocas, os efeitos jurídicos, por serem restritos às partes, excluem terceiros Estados, o que tende a minar as tentativas de maior previsibilidade. Nesse contexto, a singularidade histórico-funcional do tratamento concedido pela cláusula da nação mais favorecida está em atuar em dois níveis distintos da normalização da sociedade internacional. $^{286}$

No plano do direito internacional econômico de coexistência, o tratamento da nação mais favorecida propicia a abstenção consensual de comportamentos comercialmente lesivos, ao reconhecer a igualdade soberana e assegurar a generalização incondicionada e automática das vantagens concedidas. Enquanto imperativo negativo, o TNMF proíbe prudentemente qualquer interação discriminatória entre Estado-promissor e terceiros Estados, em detrimento ao Estado-beneficiário. Como instituto do direito internacional econômico de cooperação, o tratamento da nação mais favorecida incita as partes-contratantes à interdependência econômica, ao incentivar a justaposição de interesses. O caráter positivo do TNMF consiste em um discurso jurídico de mútua cooperação que harmoniza as expectativas normativas, ao estender as concessões aos agentes econômicos, tendo por efeito acumular os benefícios reciprocamente outorgados. Constata-se, assim, que a cláusula da nação mais favorecida foi pioneira em incorporar discursos negativos e positivos, ainda que historicamente o período em que foi originada no século XVIII tenha sido marcado pelo direito internacional de coexistência.

Para compreender o papel desempenhado pela cláusula da nação mais favorecida no sistema multilateral de comércio, será analisado, primeiramente, o conceito de tratamento da nação mais favorecida, a fim de determinar quais são e investigar como operam suas funções fundamentais, para, em seguida, debruçar-se sobre suas específicas funcionalidades no contexto do sistema multilateral de comércio.

\footnotetext{
${ }^{286}$ LAFER, 1971, p. 8-10.
} 


\subsubsection{Conceito de tratamento da nação mais favorecida}

O tratamento da nação mais favorecida é o núcleo substantivo-obrigacional da cláusula da nação mais favorecida, no qual estão estabelecidas suas funções essenciais. O termo de conceito tratamento da nação mais favorecida consiste em um discurso jurídiconormativo que prescreve a obrigação de tratar a parte-beneficiária em termos iguais ou não menos favoráveis que aqueles concedidos pela parte-promissora a terceiras partes, em relação a determinado escopo material. ${ }^{287}$

A utilização do tratamento da nação mais favorecida nas relações internacionais dependerá do interesse das partes-contratantes em aplicá-lo limitada ou ilimitadamente sobre direitos, bens ou pessoas. Embora não exista restrição substancial a priori, a forma ilimitada do TNMF é incomum, visto a competência ser delimitada pelo próprio objeto do discurso jurídico-normativo. Daí ser possível encontrar versões da cláusula da nação mais favorecida com as mais variadas finalidades.

A Convenção Relativa ao Estatuto dos Refugiados de 1951 é exemplificativa, pois prevê, em seus diversos artigos, o tratamento da nação mais favorecida. Nos termos do artigo 13, “os Estados Contratantes concederão a um refugiado um tratamento tão favorável quanto possível, e de qualquer maneira um tratamento que não seja menos favorável do que o que é concedido, nas mesmas circunstâncias, aos estrangeiros em geral [...]".288

O Acordo Geral sobre Tarifas e Comércio estabelece, em seu artigo I:1, o "tratamento geral da nação mais favorecida", cujo escopo é restrito a questões comerciais e aduaneiras. Percebe-se, assim, ser ampla a aplicabilidade substantiva da cláusula da nação mais favorecida, cujos limites dependem dos interesses das partes, ou seja, o escopo material de operação do instituto está sujeito à vontade da parte-promissora do TNMF.

Independente do escopo material, o tratamento da nação mais favorecida guarda conceitualmente quatro características constantes. Primeiro, a incompatibilidade com o

\footnotetext{
${ }^{287}$ USTOR, 1972, p. 164.

${ }^{288}$ BRASIL. Decreto n. 50.215, 28 jan. 1961. Promulga a Convenção relativa ao Estatuto dos Refugiados, concluída em Genebra, 28 jul. 1951. Diário Oficial da União, Poder Executivo, Brasília, DF, 30 jan. 1961.
} 
comportamento discriminatório do promissor com o beneficiário, em favor de terceiros. Segundo, não há vedação ao tratamento preferencial entre as partes-contratantes, sendo possível o promissor conceder benefícios adicionais ao beneficiário, além daqueles outorgados a terceiras partes. Terceiro, os terceiros não partes formam uma tertium comparationis, de modo a servirem como pontos referenciais para verificar a não discriminação na interação entre as partes. Quarto, apesar de incentivar o comportamento cooperativo entre as partes, o discurso jurídico-normativo não prevê qualquer obrigação positiva de fazer, mas tão somente a proibição de realizar uma conduta discriminatória. Os direitos estendidos pelos efeitos do TNMF representam a exata contrapartida das vantagens concedidas pelo promissor a terceiros. Por ter conteúdo variável e variante, o tratamento da nação mais favorecida, na ausência de qualquer obrigação contraída perante terceiros Estados, não imputa qualquer comportamento às partes. ${ }^{289}$

Essas características gerais do instituto conformam as funções primárias do tratamento da nação mais favorecida, as quais consistem, em termos gerais, na proibição de comportamento discriminatório do promissor com terceiros, em prejuízo do beneficiado, na exigência de constante supervisão das relações internacionais, cujas mudanças exigem a dinâmica e automática autoadaptação das obrigações previstas. A delimitação material das possibilidades e a elasticidade obrigacional, associadas à natureza automática e incondicionada da operação, resultam em duas marcas singulares da cláusula da nação mais favorecida: a continuidade no tempo e a universalidade espacial. Com efeito, o TNMF tem o condão de atuar como um denominador comum de vantagens entre as partes-contratantes. ${ }^{290}$

Compreendido conceitualmente segundo uma perspectiva analítico-finalística, o tratamento da nação mais favorecida será investigado concretamente na forma do artigo I:1 do GATT, tendo por objetivo identificar as especificidades sistêmico-funcionais do discurso jurídico-convencional e determinar os respectivos limites hermenêuticos.

\footnotetext{
${ }^{289}$ SCHWARZENBERGER, 1966, p. 71.

${ }^{290}$ SCHWARZENBERGER, 1971, p. 133-134.
} 


\subsubsection{O tratamento da nação mais favorecida do artigo I:1 do GATT}

Para positivar o tratamento da nação mais favorecida nas relações econômicas internacionais, pressupõe-se a concordância das partes-contratantes com quatro condições basilares: (i) a clareza do escopo de abrangência material do instituto; (ii) a aceitação do tratamento igualitário e não discriminatório em relação a terceiras partes; (iii) a contínua cooperação entre as partes; e (iv) a necessidade de manter constante monitoramente das relações do promissor com terceiras partes. ${ }^{291}$

A Carta Proposta, apresentada por Estados Unidos e Reino Unido, propunha disciplinar as relações econômicas internacionais por meio de um modelo de governança institucional, centrado em um sistema de normas jurídicas e multilaterais de comércio. A escolha da cláusula da nação mais favorecida visava instrumentalizar os princípios regentes do novo sistema normativo, imputando obrigações substantivas aos Estados-partes. Entretanto, ao atribuir a finalidade de organizadora de sentidos do sistema, a CNMF foi reconstruída, ou construída multilateralmente, para atender aos interesses das partes. ${ }^{292}$ Assim, cuidadosa e estrategicamente previsto no Acordo Geral sobre Tarifas e Comércio, o artigo I:1 estabelece o tratamento da nação mais favorecida entre os Estados-partes, tendo por escopo:

[...] direitos aduaneiros e encargos de toda a natureza que gravem a importação ou a exportação, ou a elas se relacionem, aos que recaiam sobre as transferências internacionais de fundos para pagamento de importações e exportações, digam respeito ao método de arrecadação desses direitos e encargos ou ao conjunto de regulamentos ou formalidades estabelecidos em conexão com a importação e exportação [...]. ${ }^{293}$

No sistema multilateral de comércio, o tratamento da nação mais favorecida tem um papel central, na medida em que suas quatro funções típicas operam, dinâmica e integradamente, para a consecução dos objetivos estabelecidos nos acordos da OMC. Dessa

\footnotetext{
${ }^{291}$ SCHWARZENBERGER, 1966, p. 73.

${ }^{292}$ KOCK, 1969, p. 43.

${ }^{293}$ BRASIL, Lei n. 313, 1948.
} 
forma, é preciso investigar como as funções típicas da CNMF operam no sistema GATT/OMC, bem como verificar quais as implicações da construção multilateral do instituto.

A função informacional é uma obrigação implícita que exige dos Estados produção e gestão de conhecimentos sobre a sua econômica doméstica, de modo a manter-se ciente dos riscos no momento das negociações comerciais, bem como o exercício constante de supervisão das relações econômicas entre os demais Estados-membros. A função positiva consiste em fomentar as negociações recíprocas de vantagens, em especial as tarifárias, entre os Estados-membros, tendo por objetivo promover a cooperação e a interdependência comercial. Responsável pela vedação a interações discriminatórias, a função negativa impõe aos Estados-membros o dever de estender, incondicionada e automaticamente, as vantagens outorgadas. A estabilização de expectativas é a função que visa à continua aquisição e sobreposição de benefícios concedidos, de modo a assegurar um progressivo aprofundamento do processo de integração comercial, bem como garantir um denominador comum entre as partes, pela incorporação das listas de concessões ao SMC. ${ }^{294}$

\subsubsection{Função procedimental: informativa}

O artigo I:1 do GATT positivou a forma incondicionada da cláusula da nação mais favorecida, prescrevendo a obrigação material de estender, automaticamente e livre de quaisquer compensações, as concessões de vantagens a todos os Estados-membros. Com isso, os benefícios negociados bilateralmente são multilateralizados pelos efeitos da CNMF e, em seguida, incorporados permanentemente às listas de concessões. Em razão disso, os Estadosmembros não podem prescindir de informações acerca de sua economia doméstica, sob pena de assistir ao padecimento de importantes setores econômicos, caso não tenham mensurado corretamente os impactos da abertura comercial. No mesmo sentido, cabe aos Estados supervisionar, constantemente, as relações entre os demais membros, a fim de verificar a existência de discriminações e manter o controle dos riscos e possibilidades das negociações

\footnotetext{
${ }^{294}$ LAFER, 1971, p. 46.
} 
comerciais. Imputa-se, assim, um dever subjacente de produzir e administrar informações econômicas.

O tratamento da nação mais favorecida fortalece as expectativas dos Estados-membros no processo de negociações comerciais internacionais, ao promover a produção, dispersão e, por consequência, supervisão do conhecimento econômico entre os Membros. Buscando incentivar os fluxos econômicos e a reduzir as barreiras tarifárias e não tarifárias, a Organização Mundial do Comércio foi criada com o objetivo de institucionalizar o fórum multilateral de negociações comerciais, que outrora era desenvolvido no âmbito do GATT, bem como garantir o cumprimento das normas pertencentes ao sistema multilateral de comércio. Dessa forma, cabe à OMC disciplinar esse ambiente institucionalizado de negociações permanentes, de modo a assegurar que as relações econômicas obedeçam aos parâmetros normativos determinados pelos princípios da $\mathrm{OMC}$, em especial a não discriminação, a reciprocidade e a transparência.

Embora sejam numerosos e notórios os argumentos sobre os benefícios da abertura comercial, os Estados ainda hesitam em aceitá-los integral e indiscriminadamente. Isso porque, ao barganhar por novas concessões, eles consideram três aspectos comerciais: (i) o impacto da liberalização comercial na economia doméstica; (ii) a incerteza acerca de futuras alterações arbitrárias de barreiras tarifárias e não tarifárias pelos demais Estados-membros, de modo a afetar a importância relativa das concessões outorgadas; (iii) o problema do free-rider e do foot-dragger, os quais prejudicam o interesse dos Membros em negociar reciprocamente novas concessões; e (iv) os interesses políticos internos que são afetados, ao adotar uma política comercial não discriminatória, recíproca e transparente.

Os dois primeiros aspectos, que podem obstar o aprofundamento das relações econômicas internacionais, têm origem em incertezas decorrentes, principalmente, da falta de informação. O desconhecimento impede o cálculo de riscos, dificultando o progresso das negociações comerciais. Para mitigar tais preocupações, o artigo I:1 imputa, implicitamente, uma obrigação procedimental aos Estados-membros, que se revela no dever de produzir, supervisionar e gerir, interna e internacionalmente, o conhecimento econômico. ${ }^{295}$

\footnotetext{
${ }^{295}$ HOEKMAN, Bernard M.; KOSTECKI, Michel M. The Political Economy of the World Trading System: The WTO and Beyond. $2^{\mathrm{a}}$ ed. Oxford: Oxford University Press, 2001, p. 100. SCHWARTZ, Warren F.; SYKES, Alan O.. The economics of the most favored nation clause. In: BHANDARI, Jagdeep S.; SYKES, Alan O. (ed.).
} 
O controle interno deve ser realizado previamente pelo Estado mediante a organização de uma equipe de excelência, a fim de produzir conhecimentos técnico-quantitativos sobre sua economia doméstica, os quais serão empregados durante as rodadas de negociação. Considerando ser a reciprocidade um dos princípios-guia das negociações multilaterais, informações imprecisas, ou a simples falta, podem implicar em decisões equivocadas que venham a prejudicar ou sufocar o desenvolvimento de setores econômicos importantes. Isso porque, sem o devido controle ex ante, a assimetria informacional poderá ser demasiadamente custosa ao Estado, na medida em que as concessões por ele outorgadas serão incorporadas permanentemente aos acordos da OMC e estendidas automaticamente a todos os demais membros, sem a garantia de receber benefícios quid pro quo. ${ }^{296}$

Nesse particular, ressalta-se que o aumento da complexidade das estruturas de negociação tende a, historicamente, exigir saltos progressivos de especialização da gestão de informações econômicas dos Estados participantes. Nas primeiras cinco rodadas de negociações multilaterais, apenas tarifas foram objetos de concessões. Negociadas em bases produto a produto, as reduções tarifárias eram propostas por meio de listas de solicitações aos Estados importadores. Devido aos efeitos da cláusula da nação mais favorecida, os requerimentos e ofertas eram tipicamente realizados entre a parte importadora e a parte exportadora, resultando na bilateralização das negociações. O resultado foi a redução substancial de tarifas, porém o alcance desse corte era restrito aos produtos negociados. Nas Rodadas Kennedy e Tóquio, foram objetos de negociação vantagens tarifárias e não tarifárias. Os Estados-partes substituíram o modelo anterior por fórmulas de cortes lineares, ressalvadas com listas de exceções, nas quais se negociavam produto a produto. Com isso, houve um alargamento da base de produtos negociados, mas as reduções foram menos acentuadas. Finalmente, a Rodada Uruguai foi marcada pela livre escolha da fórmula a ser aplicada para as reduções tarifárias, desde que respeitados os limites mínimos estabelecidos, acompanhada por acordos de eliminação total de tarifas. Os Estados-membros devem, assim, ter em mente a importância de estar progressivamente mais bem informados sobre sua economia doméstica. $^{297}$

Economic Dimensions in International Law: comparative and empirical perspectives. Cambridge: Cambridge University Press, 1997, p. 78.

${ }^{296}$ SCHWARZENBERGER, 1966, p. 73. SCHWARTZ; SYKES, 1997, p. 46.

${ }^{297}$ TREBILCOCK; HOWSE, 2002, p. 116-124. 
Quanto à gestão internacional do conhecimento econômico, o tratamento da nação mais favorecida exige, indiretamente, que os Estados mantenham em constante supervisão as relações entre os demais Membros, visando evitar a diluição ou enfraquecimento das concessões previamente outorgadas. Esse dever procedimental não é simples, visto que obriga os Estados a exercer um controle ex post dos benefícios da negociação, de modo a reforçar a observância dos princípios da não discriminação, da reciprocidade e da transparência. Ciente da necessidade de acompanhar o cumprimento dos compromissos assumidos, o GATT recepcionou essa obrigação implícita ao TNMF na forma de seu artigo X, o qual estabelece aos Estados o dever de publicar toda e qualquer norma que possa influenciar os fluxos comerciais. Com efeito, a combinação dos artigos I:1 e X tem por objetivo assegurar a previsibilidade nas relações econômicas internacionais, propiciando maior segurança jurídica aos Estados para conduzirem-se pelo princípio da não discriminação. ${ }^{298}$

A interação dinâmica dos princípios da não discriminação e da transparência, no contexto do artigo I:1, tem impactos nos planos jurídico e econômico. Enquanto agentes econômicos, os Estados têm por objetivo desenvolverem-se economicamente, mediante a tomada de decisões racionais em relação à cooperação com terceiros, baseadas em modelos econômicos, os quais pressupõem conhecimento perfeito e atuação livre dos atores. Todavia, as novas escolas econômicas demonstram que as informações encontram-se assimetricamente dispersas entre os agentes, bem como as constantes intervenções dos Estados no comércio internacional têm, historicamente, fundamentação política, pouco importando a razão econômica. Para incentivar comportamentos não discriminatórios, é necessário assegurar a previsibilidade das relações por meio da diminuição da assimetria informacional. Daí a importante combinação dos artigos I:1 e X que, ao promoverem a dispersão do conhecimento mediante o princípio da transparência, possibilitam calcular os riscos para tomada de decisões em cenários reais, aumentando a confiança dos Estados-membros. Isso implica na diminuição dos custos de transação e, por consequência, no incentivo à observância do princípio da não discriminação. $^{299}$

\footnotetext{
${ }^{298}$ SCHWARTZ; SYKES, 1997, p. 46.

${ }^{299}$ NORTH, 1991, p. 22-25. WILLIAMSON, 1996, p. 251-260. ZOELLNER, Carl-Sebastian. Transparency: An Analysis of an Evolving Fundamental Principle In International Economic Law. Michigan Journal of International Law, [s.1.], v. 27, n. 2, 2006, p. 583-589.
} 
$\mathrm{Na}$ dimensão jurídico-normativa, o tratamento da nação mais favorecida que, tradicionalmente, corporifica o princípio da não discriminação, passa, em razão do sistema multilateral de comércio, a instrumentalizar também o princípio da transparência, ao exigir a produção e supervisão de informações econômicas. Enquanto o artigo I:1 impõe aos Estados a implícita obrigação procedimental de exercer continuamente um devido processo de conhecimento, o artigo $\mathrm{X}$ estabelece o dever material de transparência. Isso imputa aos Membros a obrigação de assegurar a disponibilidade e acessibilidade das informações acerca de políticas públicas e normas jurídicas e administrativas, internas ou internacionais, as quais são essenciais para o processo de decisão dos Estados, bem como para determinar a respectiva observância dos acordos da OMC.

Essa síntese de efeitos jurídico-econômicos tem orientado decisões do Órgão de Solução de Controvérsias da OMC. No Caso United States - Import Prohibition of Certain Shrimp and Shrimp Products, o Órgão de Apelação, ao examinar o cumprimento do artigo XX pelos Estados Unidos, acolheu a alegação de que estes não haviam estabelecido em suas leis internas um processo de certificação transparente e previsível a todos os Estados-membros. Por caracterizar um comportamento discriminatório injustificado e arbitrário, os Estado Unidos foram condenados pela violação do artigo XX. No Caso United States - Restrictions on Imports of Cotton and Man-made Fibre Underwear, o Órgão de Apelação, após examinar as medidas de salvaguardas contra a importação de vestuário, reconheceu a natureza procedimental do princípio da transparência, bem como observou ser a previsibilidade seu componente essencial. $^{300}$

Desse modo, o tratamento da nação mais favorecida ganha, no âmbito do sistema multilateral de comércio, uma função informacional, que consiste na imputação aos Estados da implícita obrigação procedimental de exercer um devido controle de conhecimento. Tal controle demanda produção, supervisão e gestão da informação econômica e normativa, doméstica e internacional, tendo por efeito a diminuição dos custos de transação e o aumento

\footnotetext{
${ }^{300}$ ZOELLNER, 2006, p. 601-604. CHAYES, Abraham; CHAYES, Antonia Handler. The New Sovereignty: Compliance with International Regulatory Agreements. Londres: Harvard University Press, 1998, p. 135-136. OMC. United States - Import Prohibition of Certain Shrimp and Shrimp Products. Appellate Body Report, 12 out. 1998. Disponível em <http://docsonline.wto.org/imrd/directdoc.asp?DDFDocuments/t/WT/DS/58ABR.doc> Acesso em: 14 mar. 2009. Documento da OMC n. WT/DS58/AB/R, par. 180-184. OMC. United States Restrictions on Imports of Cotton and Man-made Fibre Underwear. Appellate Body Report, 10 fev. 1997. Disponível em <http://docsonline.wto.org/imrd/directdoc.asp?DDFDocuments/t/WT/DS/24ABR.wpf>. Acesso em: 14 mar. 2009. Documento da OMC n. WT/DS24/AB/R, par. 21.
} 
da previsibilidade dos agentes econômicos, o que possibilita a tomada de decisões eficientes e segurança para observar o princípio da não discriminação pelos Estados-membros.

\subsubsection{Função positiva: cooperação}

Capaz de adaptar-se aos mais variados contextos, independentemente das características estruturais, sejam elas sociais, políticas ou econômicas, da sociedade internacional, o fator distintivo que permite à cláusula da nação mais favorecida atender a permanentes interesses e valores dos Estados reside em sua função cooperativa. A presença desse imperativo positivo reflete o caráter precursor do tratamento da nação mais favorecida, visto preconizar a construção de normas de mútua cooperação, que somente se desenvolveriam institucionalmente no século XX. Essa funcionalidade inovadora é responsável por justificar-se, historicamente, como regra ordenadora da ordem econômica internacional. ${ }^{301}$

Não obstante suas raízes remontarem ao período de apogeu do direito internacional de coexistência, a cláusula da nação mais favorecida era outorgada pelos Estados justamente para disciplinar as incipientes relações econômicas, cujo caráter contínuo e reciprocamente dependente demandava acordos relacionais que estabelecessem condições à cooperação. Essa razão a priori é evidenciada pelo interesse dos Estados de somente conceder o tratamento da nação mais favorecida caso houvesse a mútua pretensão de desenvolver intercâmbios comerciais em bases sucessivas e interdependentes. Dessa forma, ao lado da não discriminação, a CNMF tem por causa jurídica pressuposta institucionalizar parâmetros jurídico-normativos que garantam às partes, por um lado, segurança e previsibilidade nas relações comerciais existentes; e, por outro, a possibilidade de aprofundamento e engajamento futuro em novas interações.

O espírito liberal que permeou as negociações do Acordo Geral sobre Tarifas e Comércio objetivava estabelecer uma ordem econômica internacional, nos moldes preconizados pelo pacifismo mercantil. Assentado sobre um complexo mecanismo jurídico

${ }^{301}$ SCHWARZENBERGER, 1966, p. 133. CARREAU; JUILLARD, 1998, p. 9. LAFER, 1977, p. 27-29. 
que visava aumentar o bem-estar dos Estados-partes, por meio do aprofundamento da interdependência econômica, o GATT institucionalizou a cooperação comercial na forma de um fórum multilateral de negociações de políticas comerciais, das quais resultam acordos que integram o sistema multilateral de comércio.

Devido ao papel central que desenvolveria na ordem econômica internacional neoliberal, a cooperação foi recepcionada pelo sistema multilateral de comércio, na forma do princípio da reciprocidade. Daí o preâmbulo do GATT requerer aos Estados a conclusão de "acordos recíprocos e mutuamente vantajosos". No mesmo sentido, o preâmbulo do Acordo Constitutivo da Organização Mundial do Comércio de 1994 ratifica o compromisso dos Estados-membros com a cooperação comercial mediante a expressa incitação para celebrarem acordos comerciais, "na base da reciprocidade e de vantagens mútuas". Assim, o espírito da cooperação internacional é encontrado no núcleo significativo do princípio da reciprocidade, de modo a expressar, no sistema multilateral de comércio, uma preferibilidade de sentidos normativos. $^{302}$

A inclusão da cláusula da nação mais favorecida no GATT está em consonância com essa ideologia neoliberal. Isso porque, ao estabilizar as expectativas normativas, o tratamento da nação mais favorecida permite aos Estados o exercício de sua liberdade positiva, na forma de uma governança cooperativa de políticas comerciais internacionais. Nesse contexto, o artigo I:1 atua positivamente criando efeitos promotores da cooperação entre os Estadosmembros. Ressalta-se, porém, que não há obrigação de alcançar certa conformação econômica; o que existe é tão somente uma garantia de oportunidade para estreitar o relacionamento entre os Estados por meio de negociações comerciais. ${ }^{303}$

Todavia, ao examinar o sistema GATT/OMC, poder-se-ia sinalizar uma incoerência intrínseca entre a cláusula da nação mais favorecida incondicionada e o princípio da reciprocidade, visto este exigir um comportamento condicionado-compensatório e aquela uma relação não discriminatória. Essa aparente antinomia semântico-funcional não se verifica; pelo contrário, o princípio da reciprocidade é instrumentalizado pela operação da própria CNMF, na medida em que a função positiva do tratamento da nação mais favorecida tem por objetivo justamente fomentar a cooperação dos Estados-membros, a qual se concretiza segundo bases

\footnotetext{
${ }^{302}$ MONTESQUIEU, 2000, p. 11-18. BOBBIO, 2000, p. 529-534. HILF, 2001, p. 119. DAM, 1970, p. 12. ALLEN, 1953, p. 105.

${ }^{303}$ JACKSON, 1997, p. 437. FERRAZ, 2003, p. 112.
} 
recíprocas. Além disso, na governança econômica internacional, o princípio da reciprocidade incide sobre a CNMF no primeiro momento da dinâmica negocial instituída pela OMC, servindo como parâmetro para a conduta dos Estados previamente à celebração de acordos comerciais, os quais serão incorporados ao sistema multilateral de comércio. Assim, a atuação positiva do TNMF ocorre $a$ priori, objetivando promover a cooperação recíproca nas relações econômicas internacionais, enquanto o princípio da não discriminação exige uma conduta $a$ posteriori dos Estados-membros. ${ }^{304}$

Na ordem econômica internacional contemporânea, a relevância da função positiva do tratamento da nação mais favorecida, enquanto regra instrumental do princípio da reciprocidade encontra fundamentação no plano axiológico e econômico.

A raiz axiológico-conceitual do princípio da reciprocidade tem origem na noção moderna de liberdade positiva, cuja construção remonta ao confronto teórico entre John Locke e Jean-Jacques Rousseau. O foco do clássico debate liberal está, por um lado, em determinar se há uma esfera de ação do indivíduo que não deve sofrer obstrução coativa de terceiros; e, por outro, em delimitar o espaço no qual as pessoas possam autonomamente acordar com restrições à própria atuação. Embora a ideia de liberdade seja comumente concebida como a condição natural do ser humano e daí o estado de natureza, ambos os filósofos constroem diferentes explicações sobre quais são as ameaças a ela. Para J. Locke, a liberdade natural é ameaçada pelos conflitos decorrentes da introdução do dinheiro na sociedade. Em J. J. Rousseau, o perigo surge pela insuficiência dos indivíduos solitários em administrar os equívocos relacionais entre suas forças naturais e suas necessidades. A solução para ambos é garantir a liberdade por meio da celebração do contrato social. Com a constituição da ordem política, surge a liberdade civil, a qual vai exigir tanto o não impedimento (liberdade no sentido negativo) quanto a participação política (liberdade no sentido positivo).

Todos esses traços da liberdade moderna repercutem juridicamente. No sentido positivo, a autonomia da vontade confere a possibilidade de se vincular conforme os próprios interesses, obedecendo, portanto, à norma que resulta do livre engajamento. No sentido negativo, a lei concebe a liberdade como não impedimento, ao equalizar para todos os mesmos limites de liberdade. Essas características demonstram o caráter relacional da liberdade

\footnotetext{
${ }^{304}$ BAGWELL, Kyle; STAIGER, Robert W. The Economics of the World Trading System. [s.1.]: MIT Press, 2004, p. 16.
} 
moderna, cujo exercício seria sempre uma restrição (sentido positivo) e uma resistência (sentido negativo). Explica Tercio Sampaio Ferraz Jr. que "o sentido relacional da liberdade tornaria possível, assim, a concepção de direito subjetivo como a possibilidade de negar a interferência externa sobre um determinado espaço de ação (vida, propriedade, a própria liberdade) e como a de pretender não importa qual tipo de omissão de interferência indevida de qualquer um". 305

No plano internacional, a reciprocidade corporifica-se na noção de balança de poder, a qual serve para resguardar o princípio da liberdade entre os Estados. Disso surge a percepção de que os Estados estão numa relação de interdependência, cabendo ao direito internacional assegurar a reciprocidade, a qual consiste no tratamento idêntico ou equivalente que todas as partes mutuamente se dispensam. A importância do princípio da reciprocidade está na razão pelas quais os Estados negociam, fazem concessões, limitam suas pretensões e controlam sua conduta, de acordo com um cálculo de riscos, valores e interesses. Desse modo, pressupõe-se uma racionalidade mínima na avaliação das conveniências na elaboração de tratados e costumes internacionais. Como elemento fundamental do sistema multilateral de comércio, a reciprocidade está inserida no jogo cooperativo das negociações comerciais, por meio do qual os Estado desejam usufruir dos benefícios concedidos multilateralmente e evitar tanto a proliferação dos fenômenos do free-rider e do foot-dragger como a necessidade do pagamento compensatório, que seria realizado em caso de regência da forma condicionada da cláusula da nação mais favorecida. ${ }^{306}$

Diferentemente das análises axiológica e normativa, que buscam na função positiva do tratamento da nação mais favorecida evitar a tensão e promover a cooperação entre os Estados, o discurso econômico tem por foco examinar o papel desempenhado por essa funcionalidade quando inserida no jogo das negociações multilaterais de comércio. Com isso, procurar-se-á determinar os impactos, negativos ou positivos, em termos de bem-estar econômico, provenientes da adoção da cláusula da nação mais favorecida incondicionada e do princípio da reciprocidade nas relações econômicas internacionais.

\footnotetext{
${ }^{305}$ FERRAZ JR., Tercio Sampaio. Estudos de Filosofia do Direito. São Paulo: Atlas, 2003, p. 95-107. LAFER, Celso. O moderno e o antigo conceito de liberdade. In: Ensaios sobre a liberdade. São Paulo: Perspectiva, 1980, p. 11-24. BERLIN, Isaiah. Dois conceitos de liberdade. In: Quatro ensaios sobre a liberdade. Trad. Wamberto H. Ferreira. Brasília: Universidade de Brasília, 1981, p. 136-142.

${ }^{306}$ LAFER, 1977, p. 35-42.
} 
Com isso em mente, serão apresentadas três abordagens econômico-analíticas desenvolvidas por Kyle Bagwell e Robert W. Staiger, cujo objetivo é verificar quais problemas das interações comerciais podem ser solucionados com a adoção de um tratado multilateral, fundado sobre os princípios da reciprocidade e da não discriminação. Os modelos pretendem não apenas explicar o interesse econômico dos Estados em celebrar acordos comerciais, mas também os motivos pelos quais o sistema multilateral de comércio tem se mostrado resistente e estável ao longo do tempo. ${ }^{307}$

Construídos sobre a teoria neoclássica de bem-estar econômico, os modelos pressupõem que o equilíbrio de um mercado global competitivo, assentado sobre o livrecomércio, é capaz de maximizar o bem-estar global. A primeira e segunda abordagens visam examinar como as decisões estatais unilaterais acerca das políticas comerciais criam externalidades que afetam o bem-estar de terceiros Estados. Para isso, aplica-se o modelo de Auguste Cournot, no qual os Estados decidem, simultaneamente, o quanto produzir e o quanto exportar, pressupondo que o nível de produção de seus concorrentes é fixo. Nessa acepção, a decisão sobre a produção é determinada, estratégica e independentemente, das opções adotadas pelos demais Estados, caracterizando uma situação de jogo não cooperativo. Essa situação-problema, também conhecida como Dilema do Prisioneiro, retrata justamente o cenário em que os Estados, por não conhecerem a postura a ser adotada pelos demais, optam por situações que ofereçam os menores riscos ou perdas.

Adiciona-se, ainda, ao modelo o equilíbrio de Nash e o ótimo de Pareto. A teoria do equilíbrio de John Nash busca determinar o ponto de equilíbrio que representa a melhor resposta, estrategicamente escolhida de maneira não cooperativa por um Estado para confrontar as demais, sendo que nenhum pode ganhar mais com qualquer mudança unilateral em sua estratégia, dados os planos de ação correntes dos outros Estados. Nesse particular, ressalta-se que tal equilíbrio não cooperativo usualmente não é Pareto-ótimo, podendo ser melhorado mediante a adoção de acordos comerciais. O ótimo de Pareto é a situação de maximização da eficiência entre a alocação mundial de recursos e os respectivos fluxos comerciais, na qual qualquer mudança factível do bem-estar de pelo menos um Estado implicará perdas para os demais.

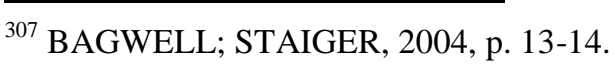


Desenvolvida a partir da análise econômica tradicional, a primeira abordagem aponta que os problemas das negociações comerciais residem nos termos de troca ou nas demais externalidades decorrentes da imposição unilateral de tarifas, as quais visam maximizar o bem-estar econômico doméstico. Nesse cenário não cooperativo, as externalidades, associadas à falta de um acordo comercial, induzem à formação de equilíbrio inferior àquele esperado pelos Estados, caso estes estivessem em um ambiente cooperativo. Assim, a adoção pelos Estados de um acordo multilateral permitiria escapar do Dilema do Prisioneiro.

O segundo modelo, denominado de abordagem de economia política, observa que os objetivos do governo são generalizados, de modo a incorporar outras considerações, especialmente políticas, ao bem-estar econômico doméstico. A generalização, ainda que tenha propiciado maior realismo, levou às mesmas conclusões da abordagem clássica, ou seja, que um acordo multilateral possibilitaria escapar do Dilema do Prisioneiro.

$\mathrm{Na}$ terceira abordagem, verifica-se outro tipo de problema para os acordos comerciais, o qual versa sobre a incapacidade dos Estados de estabelecer compromissos confiáveis para seu setor privado. Essa abordagem, conhecida como modelo de comprometimento, difere das demais, pois constata que a ineficiência de equilíbrio não decorre de uma externalidade, mas da inabilidade dos governos de se comprometerem com a implementação de políticas comerciais. Assim, como os interesses momentâneos dos Estados podem resultar na renúncia às políticas liberalizantes anunciadas previamente, o setor privado evita se comprometer com investimentos produtivos. Nesse cenário, a celebração de um tratado multilateral que vinculasse o Estado teria por efeito assegurar um programa crível de reformas liberalizantes, visto ser custoso para os governos retirarem-se de tais compromissos. Desse modo, o modelo sugere uma ligação entre o problema de credibilidade doméstica e uma externalidade transfronteiriça.

Os três modelos demonstram que o interesse de maximização do bem-estar econômico dos Estados conduz, em jogos não cooperativos, à imposição unilateral de tarifas em patamares superiores ao esperado. Isso implica uma situação de equilíbrio inferior ao que seria possível com a adoção de um acordo multilateral. Nesse sentido, K. Bagwell e R. Staiger sustentam que os Estados, ao celebrarem um tratado multilateral, concebido com base nos princípios da reciprocidade e da não discriminação, podem alcançar concessões mutuamente benéficas no comércio internacional, resultando em uma redução tarifária que se traduz em 
melhorias de Pareto. Há, portanto, dois modelos básicos possíveis. O modelo não cooperativo assume que as relações internacionais respondem a uma lógica de poder econômico, produtora de um ineficiente equilíbrio de Nash, na qual os Estados atuam unilateralmente, tendo por consequência externalidades na forma de termos de troca. O modelo cooperativo compreende relações orientadas por regras, as quais expressam os princípios acordados pelos Estados, responsáveis por instituir um processo de negociação tarifária. ${ }^{308}$

Segundo a perspectiva neoclássica, a celebração dos acordos que compõem o sistema multilateral de comércio representa a opção dos Estados em adotar um modelo cooperativo de relacionamento. Todavia, celebrar um acordo de reciprocidade comercial não é suficiente para alcançar um equilíbrio ótimo de tarifas, na medida em que as externalidades internacionais e a erosão das concessões podem tornar o acordo ineficaz. Em razão disso, a Organização Mundial do Comércio institucionaliza um ambiente particular de cooperação, no qual barreiras tarifárias e não tarifárias podem ser objetos de negociação. Tais tarifas resultam da combinação de negociações e medidas unilaterais dos Estados. Daí a relevância do artigo XVIII do GATT que regula as rodadas multilaterais de comércio, as quais são o principal instrumento de formação e consolidação tarifária. Como será examinado no Capítulo 3.5.6., a mera possibilidade de renegociação dos compromissos é nociva para a OMC, o que demanda medidas adequadas.

Nesse particular, a função positiva do tratamento da nação mais favorecida e o princípio da reciprocidade têm fundamental importância, pois, ao incidirem conjuntamente sobre as relações econômicas internacionais têm por objetivo fomentar um ambiente cooperativo. Isso implica uma situação singular de equilíbrio, resultando no aumento do bemestar econômico dos Estados. Cabe aos Estados o direito soberano de determinar suas tarifas aduaneiras, as quais implicam externalidades internacionais aos agentes econômicos.

Na dinâmica do sistema multilateral de comércio, a função positivo-cooperativa tem por efeito concentrar todas as externalidades provenientes das tarifas aduaneiras, na forma de termos de troca, enquanto o princípio da reciprocidade atua neutralizando-os, por meio das negociações multilaterais. Com isso, protegem-se os Estados-membros de um oportunismo

${ }^{308}$ BAGWELL; STAIGER, 2004, p. 16-39. BAGWELL, Kyle; STAIGER, Robert W. An Economic Theory of GATT. The American Economic Review, [s.1.], v. 89, n. 1, 1999, p. 219-226. SRINIVASAN, Thirukodikaval N. Nondiscrimination in GATT/WTO: was there anything to begin with and is there anything left? World Trade Review, Cambridge, v. 4, n. 1, 2005, p. 85-90. 
preferencial de outros Estados, bem como garantem um equilíbrio eficiente e politicamente ótimo de tarifas. Assim, o TNMF e o princípio da reciprocidade operam concertadamente, estruturando uma sistemática que permite aos agentes econômicos atingirem uma configuração politicamente ótima de tarifas, garantindo aos importadores acessos aos produtores mais eficientes.

Entretanto, paralelamente aos benefícios da eficiência da política tarifária, o amplo predomínio da natureza bilateral das obrigações do sistema multilateral de comércio implica contradições entre estrutura e função. Na perspectiva da racionalidade econômica, a inclusão da CNMF pode propiciar o aparecimento de externalidades positivas e negativas. Isso porque a sua natureza bilateral, quando inserida na dinâmica de negociações multilaterais, tem por efeito direto diminuir o número de tarifas para negociar, na medida em que uma vantagem bilateralmente concedida é estendida automaticamente aos demais Estados-membros. Contudo, a multilateralização dos benefícios resulta indiretamente na formação dos fenômenos do foot-dragger e do free-riding. ${ }^{309}$

Os Estados-membros da Organização Mundial do Comércio tem por objetivo negociar regras gerais e abstratas aplicáveis a todos. Todavia, por ser um sistema consensual, um Estado-membro pode, deliberadamente, dificultar a adoção de acordos comerciais. Denominado de foot-dragger, esse fenômeno consiste na tentativa de Estados de impedir a melhoria das normas do sistema multilateral de comércio, a fim de restringir o alcance das negociações tão somente ao mínimo denominador comum. Segundo a perspectiva econômica, pode-se verificar que esse fenômeno prejudica a formação do jogo cooperativo, o que resulta no retorno equilíbrio não cooperativo caracterizado pelo Dilema do Prisioneiro. ${ }^{310}$

Em uma negociação bilateral típica, não haveria espaço para o fenômeno do freeriding, porém os efeitos multilaterais do tratamento da nação mais favorecida implicam essa externalidade do sistema multilateral de comércio, a qual pode ser interpretada economicamente como positiva ou negativa. Free-riders são Estados que, durante as barganhas, buscam se beneficiar das concessões incondicionalmente estendidas a todos os países, sem, porém, fazer qualquer oferta, o que incide contra a natureza do princípio da reciprocidade. Atualmente, o crescente desequilíbrio dos direitos e das obrigações entre os

\footnotetext{
${ }^{309}$ CARREAU; JUILLARD, 1998, p. 230-231.

${ }^{310}$ JACKSON, 1997, p. 158-159.
} 
Estados-membros tem se tornado cada vez menos tolerável. Embora a conclusão da Rodada Uruguai tenha permitido solucionar aspectos relevantes dos problemas suscitados mediante a adoção da ideia do empreendimento único, isso não evitou, porém, impactos econômicos nas relações internacionais. ${ }^{311}$

Os defensores do aspecto positivo sustentam que o benefício propiciado pelo efeito multilateralizante da cláusula da nação mais favorecida está justamente em estender aos freeriders as vantagens outorgadas, de modo a diminuir amplamente as distorções internacionais. Assim, os custos para a liberalização do comércio diminuiriam, visto que os custos da barganha seriam compensados apenas uma vez, devido à generalização dos benefícios alcançados. Todavia, há diversos argumentos que apontam aspectos negativos.

Primeiro, caso os Estados rejeitem a apresentação de contraofertas, por considerarem que serão beneficiados pela concessão feita por terceiros, isso resultaria numa situação de ineficiência, pois haveria uma procrastinação na obtenção de um acordo, ou a composição aceita seria menos eficiente na redução tarifária. Segundo, quando a possibilidade de freeriding afeta as negociações estratégicas dos Estados. Ao adotar uma cláusula da nação mais favorecida, tem-se o objetivo de alcançar um equilíbrio cooperativo que seja Pareto-superior. Contudo, por não ser proibido o fenômeno do free-riding, os Estados não evitam conceder vantagens, para não incentivá-los. Com isso, rompem-se as condições de equilíbrio, pois as ofertas passarão a ser feitas pensando no efeito free-riding, ou seja, o Estado, ao apresentar sua proposta inicial, ofertará apenas o mínimo necessário para continuar as negociações. Desse modo, enquanto for possível o free-riding, os negociadores podem preferir estruturar suas concessões de forma que não ocorram em equilíbrio Pareto-eficiente. ${ }^{312}$

Os aspectos normativos, axiológicos e econômicos demonstram a relevância da função positiva do tratamento da nação mais favorecida para a ordem econômica internacional contemporânea. Em síntese, a funcionalidade positiva visa (i) promover a cooperação entre os Estados; (ii) instrumentalizar o princípio da reciprocidade nas negociações multilaterais de comércio; (iii) assegurar o pleno exercício da liberdade positiva, na forma das concessões comerciais, ofertadas pelos Estados; e (iv) promover a estabilização das perspectivas

\footnotetext{
311 JACKSON, 1997, p. 158-159. HORN, Henrik; MAVROIDIS, Petros C. Economic and legal aspects of the Most-Favored-Nation clause. European Journal of Political Economy, [s.1.], v. 17, n. 2, 2001, p. 255-258.

${ }^{312}$ SCHWARTZ, Warren F.; SYKES, Alan O. Toward a Positive Theory of the Most Favored Nation Obligation and Its Exceptions in the WTO/GATT System. International Review of Law and Economics, Nova York, v. 16, n. 1, 1996, p. 39-41.
} 
normativas dos agentes econômicos, por meio da construção de um ambiente cooperativo que esteja em situação de equilíbrio e Pareto-superior.

\subsubsection{Função negativa: não discriminação}

A função negativa do tratamento da nação mais favorecida consiste na proibição às práticas discriminatórias entre Estados-membros da Organização Mundial do Comércio. O artigo I:1 do GATT imputa o dever de estender automática e incondicionadamente aos Estados-membros qualquer vantagem outorgada bilateralmente, cujo efeito normativo é estabelecer o tratamento não discriminatório nas relações econômicas internacionais. Esse caráter prescritivo-negativo remonta à origem histórica do instituto, quando o direito internacional público era formado, predominantemente, por normas de abstenção, tendo por objetivo delimitar a esfera individual de não intervenção nas relações interestatais. Numa perspectiva sistêmica, o artigo I:1 instrumentaliza o princípio da não discriminação, consagrado nos preâmbulos do GATT e do Acordo OMC, o qual veda ao Estado a possibilidade de obter isoladamente, em vez de multilateralmente, tratamento econômico mais favorável.

O discurso jurídico-prescritivo do artigo I:1 consiste num comando negativo que determina uma obrigação de fazer aos Estados-membros. Como norma negativa, a redação expressa uma obrigação material de conduta, sendo resguardada por uma sanção. O dever de estender incondicionada e automaticamente as concessões outorgadas visa proibir a discriminação entre os Estados-membros. Para desencorajar o comportamento discriminatório, o artigo XXIII do GATT estabelece proteção às vantagens e concessões acordadas, mediante a aplicação de sanções aos Estados infratores. Tal caráter imperativo-coativo é inerente ao direito internacional público de coexistência, cuja função é assegurar a proteção e o convívio pacífico entre os Estados. Os comandos negativo-repressivos têm por objetivo impedir a 
intervenção de um Estado na esfera de liberdade alheia, por meio de uma limitação recíproca de liberdades. ${ }^{313}$

No coração do sistema multilateral de comércio está o princípio da não discriminação, o qual é operativamente instrumentalizado pelo tratamento da nação mais favorecida. Com isso, inscreve-se no núcleo significativo do artigo I:1 o valor da liberdade em seu sentido negativo de não discriminação. Isso permite integrar consistentemente os sentidos da cláusula da nação mais favorecida, de modo a exprimir uma preferência estabilizante das expectativas normativas, o que garante segurança e previsibilidade jurídicas aos Estados. Daí a necessidade de examinar o princípio da não discriminação, cuja construção está intrinsecamente vinculada à acepção clássica de liberdade, a qual se assenta sobre fundamentos axiológicos, econômicos e jurídico-normativos, a fim de determinar a essência e os limites da função negativa. ${ }^{314}$

O princípio da não discriminação está fundado axiologicamente na noção moderna de liberdade negativa, cuja construção remonta ao debate liberal acerca da determinação de uma esfera de ação individual, na qual não se deve sofrer obstrução coativa de terceiros. A liberdade negativa é entendida conceitualmente como não impedimento, no sentido de expressar um dever de omissão como objeto. Ao possibilitar a ausência de qualquer tipo de coação, o status negativus assegura aos indivíduos a liberdade de ação, dentro de certa área mínima que não pode ser violada arbitrariamente. A ideia de liberdade negativa envolve vinculações, na medida em que ser livre significa ser livre de algo. Por consequência, a expressão livre de aponta uma exceção que pressupõe uma vinculação precedente, na qual se abre a exceção.

A institucionalização jurídico-legal da liberdade negativa permitiu a impessoalização dos sujeitos nas relações de troca, cujo efeito foi equalizar as partes-contratantes, bem como tornou possível a concepção de direito subjetivo como a possibilidade de negar a interferência externa sobre um determinado espaço de ação. São nessas esferas de ação livre que as finalidades individuais encontram sua satisfação. Daí a liberdade negativa não ser constituída de proposições jurídico-normativas formadas por imperativos prescritivo-positivos. ${ }^{315}$

\footnotetext{
${ }^{313}$ BOBBIO, 2007, p. 54-62. CARREAU; JUILLARD, 1998, p. 9. LAFER, 1971, p. 47. FRIEDMANN, 1964, p. 471-472.

${ }^{314}$ FERRAZ JR., 2001, p. 110-112.

${ }^{315}$ FERRAZ JR., 2001, p. 107-112. BERLIN, 1981, p. 136-142.
} 
Na ordem econômica internacional, a noção de liberdade negativa é incorporada como atributo da soberania econômica do Estado. Como examinado no Capítulo 1.3.3., os negociadores do Acordo Geral sobre Tarifas e Comércio acreditavam que foram duas as causas que conduziram aos desastres da Segundo Guerra Mundial. Primeiro, as políticas de discriminação comercial, as quais contribuíram para a desintegração das expectativas dos agentes econômicos, comprometendo o relacionamento internacional. Segundo, a incapacidade da estrutura institucional-legal, carente de instrumentos jurídicos adequados, de responder apropriadamente às demandas decorrentes das transformações socioeconômicas da ordem econômica internacional. Nesse contexto, é cunhado o conceito do princípio da não discriminação, o qual consiste justamente na conformação positiva da noção negativa de liberdade no sistema multilateral de comércio. ${ }^{316}$

O princípio da não discriminação é, portanto, o maior objetivo do sistema multilateral de comércio, pois impõe limites à esfera de exercício da soberania econômica pelo Estado, garantindo que as relações econômicas internacionais possam se desenvolver livres de animosidades causadas por arbitrárias discriminações, que possam resultar na retroalimentação de ciclos de retaliação comercial. Isso permite diminuir as incertezas dos agentes econômicos, evitando o surgimento de tensões políticas que impliquem em insegurança jurídica. ${ }^{317}$

$\mathrm{Na}$ perspectiva econômica, a Escola Clássica sustenta que o princípio da não discriminação guarda uma importância central, visto haver a presunção de que o tratamento discriminatório nas relações econômicas é indesejável. Isso porque os Estados, ao aplicarem restrições aos agentes exportadores, de acordo com critérios discriminatórios, distorcem o mecanismo de formação de preços, comprometendo a alocação ótima de bens e de produtos no mercado. Decorrente da teoria das vantagens comparativas, a função negativa tem o condão de promover maior eficiência econômica, visto incentivar os importadores a comprar produtos melhores, com custos mais reduzidos, implicando na melhoria do bem-estar social. $A$ contrario sensu, a discriminação possibilita induzir o deslocamento de recursos para os produtores menos eficientes, mediante uma vantagem artificial em detrimento do mais eficiente, o que resulta na piora das condições de bem-estar.

\footnotetext{
${ }^{316}$ HUDEC, Robert E. The GATT legal system and world trade diplomacy. Nova York: Praeger Publishers, 1975, p. 5-6.

${ }^{317}$ JACKSON; DAVEY, 1986, p. 433.
} 
Ao vedar todos os comportamentos discriminatórios, o artigo I:1 do GATT procura concentrar institucionalmente as disputas comercias na forma de tarifas aduaneiras, as quais, por serem quantificáveis, permitiriam uma gestão mais eficiente das interações multilaterais, evitando custos decorrentes da administração de diversas tarifas bilaterais. O princípio da não discriminação, ao impor aos Estados o estabelecimento de uma tarifa aduaneira única, independentemente de critérios subjetivos, preserva um padrão simples de externalidades mundial. Com todas as tarifas controladas pela CNMF, prevalecerá um preço mundial comum, por meio do qual todas as externalidades serão canalizadas, implicando o aumento da eficiência das relações econômicas internacionais. Devido à redução da complexidade econômico-normativa, graças ao princípio da não discriminação, os Estados pertencentes ao sistema multilateral de comércio podem focar as negociações recíprocas em eliminar apenas o preço mundial. $^{318}$

Por fim, o efeito automático e incondicionado do tratamento da nação mais favorecida permite a redução dos custos políticos e econômicos das negociações, na medida em que, por não demandar novas tratativas sobre temas similares entre os Estados, reduzem esforços para obter condições gerais menos discriminatórias. ${ }^{319}$

A síntese da relação dialética entre argumentos liberais políticos e liberais econômicos resultou na positivação do princípio da não discriminação no preâmbulo do Acordo Geral sobre Tarifas e Comércio e, posteriormente, na ratificação pelo Acordo Constitutivo da OMC, respectivamente:

\footnotetext{
Almejando contribuir para a consecução dêsses objetivos, mediante a conclusão de acôrdos recíprocos e mútuamente vantajosos, visando à redução substancial das tarifas aduaneiras e de outras barreiras às permutas comerciais e à eliminação do tratamento discriminatório, em matéria de comércio internacional; (grifo nosso) ${ }^{320}$

Desejosas de contribuir para a consecução desses objetivos mediante a celebração de acordos destinados a obter, na base da reciprocidade e de vantagens mútuas, a redução substancial das tarifas aduaneiras e dos demais obstáculos ao comércio,
}

\footnotetext{
${ }^{318}$ SENGUL, Faruk. Essays on the Most Favored Nation Clause and the World Trading System. Tese de Doutorado apresentada à Dedman College, Southern Methodist University, 2006, p. 31-32. TREBILCOCK; HOWSE, 2005, p. 51-52. BAGWELL; STAIGER, 2004, p. 79-95. BAGWELL, Kyle; STAIGER, Robert W. Will preferential agreements undermine the multilateral trading system? Economic Journal, [s.l.], v. 108, n. 449, 1998, p. 1175-1176. BAGWELL; STAIGER, 1999, p. 240-241.

${ }^{319}$ HOEKMAN; KOSTECKI , 2001, p. 30-31.

${ }^{320}$ BRASIL, Lei n. 313, 1948.
} 
assim como a eliminação do tratamento discriminatório nas relações comerciais internacionais; (grifo nosso) ${ }^{321}$

Ressalta-se que o princípio da não discriminação é, justamente, fruto do acordo de vontades entre os Estados, ou seja, não é um princípio geral de direito econômico internacional imputável a todos os agentes econômicos internacionais. Nesse particular, é preciso esclarecer que o princípio da não discriminação não se confunde com o princípio da liberdade de comércio. Consagrado como o mais antigo princípio do direito internacional econômico, o princípio da liberdade de comércio consiste no direito irrestrito dos Estados de engajar-se em qualquer atividade comercial com terceiros. Isso significa que os Estados têm o direito de adotar quaisquer medidas, vedado apenas o uso da força, para proteger seus interesses econômicos, ainda que cause distúrbios nas relações econômicas internacionais, podendo inclusive estabelecer monopólios econômicos, celebrar acordos preferenciais de comércio e tratados sobre equidade de tratamento. Dessa forma, o princípio da liberdade de comércio autoriza o Estado a estabelecer interações econômicas em bases discriminatórias ou não discriminatórias. ${ }^{322}$

Deduzido do princípio da liberdade de comércio, o princípio da liberdade de troca consiste no direito de liberdade mercantil dos Estados, conformado pela ideologia do liberalismo político e econômico. O princípio da não discriminação é um princípio especializado e funcional, construído a partir do princípio da liberdade de troca. Por não ser um princípio geral do direito econômico internacional, o princípio da não discriminação depende de positivação, por meio de acordo expresso de vontades, para ser juridicamente vinculante. Daí a necessidade dos agentes econômicos de prevê-lo nos preâmbulos do GATT e do Acordo OMC, de modo a institucionalizar a ordem econômica internacional contemporânea.

Ao recepcionar os aspectos axiológicos, econômicos e normativos do princípio da não discriminação, a função negativa do tratamento da nação mais favorecida institui a proibição

\footnotetext{
${ }^{321}$ BRASIL. Decreto n. 1.355, 30 dez. 1994. Promulga a Ata Final que Incorpora os Resultados da Rodada Uruguai de Negociações Comerciais Multilaterais do GATT. Diário Oficial da União, Poder Executivo, Brasília, DF, 31 dez. 1994.

${ }^{322}$ SCHWARZENBERGER, 1966, p. 47-49. ICJ. Oscar Chinn (United Kingdom v. Belgium). Series A./B. of Judgments, orders and advisory opinions, 12 dez. 1934. Fascículo n. 63, Leiden: Sijthoff. Disponível em <http://www.icj-cij.org/pcij/serie_AB/AB_63/01_Oscar_Chinn_Arret.pdf >. Acesso em: 10 mar. 2009, p. 83-84. BAILEY, 1932, p. 89.
} 
de práticas discriminatórias nas relações econômicas entre os Estados-membros. A Organização Mundial do Comercio institucionaliza, na ordem internacional contemporânea, um sistema multilateral de comércio, cujo objetivo central é assegurar o bem-estar dos Estados-membros, por meio do aumento da interdependência comercial. Entretanto, o SMC estabelece claramente que o aumento do fluxo de comércio deve respeitar certas condições, sendo a vedação ao comportamento discriminatório a principal. Há, assim, um salto qualitativo-institucional a ser sempre considerado no cálculo das expectativas dos agentes econômicos. Diante disso, cabe ao artigo I:1 exercer um controle geral das condutas discriminatórias dos Estados-membros, assegurando-lhes, em razão dos efeitos da função negativa, o espaço de liberdade para o desenvolvimento das relações econômicas internacionais.

\subsubsection{Função estabilizadora: aquisição e acumulação de vantagens}

Construída, historicamente, como um instituto flexível e adaptável às transformações estruturais da ordem econômica internacional, a cláusula da nação mais favorecida, positivada no artigo I:1 do Acordo Geral sobre Tarifas e Comércio, é destituída de parte dessa maleabilidade. Isso é justificado pela incorporação das características aquisitivas e acumulativas ao tratamento da nação mais favorecida, o que promoveu uma reformulação da função de calibração na forma da função estabilizadora das relações econômicas internacionais.

O tratamento da nação mais favorecida primou tradicionalmente pela capacidade de tensionar e distender os vínculos normativo-prescritivos entre suas partes-contratantes. Por ser uma estrutura normativa flexível que não requer a obediência a priori de qualquer conduta definida ou objetiva, sua operação depende ou determina a concessão de vantagens do Estadopromissor a terceiros Estados, as quais, em via reflexa, são estendidas ao Estado-beneficiário. Com efeito, os direitos e obrigações fruídos na dinâmica do TNMF consistem na exata contrapartida dos benefícios outorgados pelo Estado-promissor. 
A ausência de qualquer vantagem contraída perante terceiros Estados implica um estado inercial permanente, não representando nada além de um discurso imperativo válido, mas destituído de obrigações concretas. Por ser uma moldura vazia, apenas produz efeitos se houver a concessão de um favor, passado ou futuro, a terceiros Estados. Todavia, ao entrar em operação, a estrutura é preenchida por um conteúdo variável e variante, que resulta em um processo dinâmico de aquisição e perda de direitos, os quais dependem da vigência dos tratados colateralmente celebrados. Desse modo, a histórica função do tratamento da nação mais favorecida consiste em calibrar os vínculos jurídicos entre as partes-contratantes, a fim de assegurar que deveres e responsabilidades respeitem um mínimo denominador comum, isto é, uma equidade de tratamento. ${ }^{323}$

Todavia, a dinâmica institucionalizada no sistema multilateral de comércio teve por consequência modificar substancialmente a função de calibração do tratamento da nação mais favorecida. A alteração somente pode ser compreendida mediante o exame sistemático dos acordos da OMC, em especial do GATT, visto que os efeitos decorrentes de diversos dispositivos transformam a histórica função de calibração em uma nova função estabilizadora das relações econômicas internacionais.

O GATT estabelece, em seu artigo II:1, que os Estados devem conceder "tratamento não menos favorável ao previsto na parte apropriada da lista correspondente, anexa ao presente Acordo". Ao salvaguardar as listas de concessões, criou-se um fenômeno completamente novo para as normas de comércio internacional. As listas consolidadas, que correspondem às concessões feitas pelos Estados durante as negociações multilaterais de comércio, são elementos adicionais à cláusula da nação mais favorecida. A sutil diferença está, justamente, no caráter aquisitivo das listas de concessões, cujo objetivo é restringir a soberania econômica dos Estados, a fim de impedir aumentos tarifários ou imposições de barreiras não tarifárias. Dessa forma, constata-se que um exame isolado do artigo I:1 conduz à equivocada conclusão de que a tradicional função de calibração foi institucionalizada. Porém, uma detida análise sistêmica revela que os efeitos do artigo II:1 sobre o sistema GATT/OMC implicam profundas transformações, das quais resultam a atribuição de um caráter aquisitivo ao TNMF. Esse efeito está em perfeita consonância com os princípios neoliberais subjacentes ao sistema

${ }^{323}$ ITO, 1930, p. 18. SCHWARZENBERGER, 1966, p. 71. ICJ, Anglo-Iranian Oil Co. (United Kingdom v. Iran), Report of Judgments, 1952, p. 141. 
multilateral de comércio, visto promover uma política comercial centrada na abertura comercial e na restrição à liberdade estatal de impor barreiras tarifárias e não tarifárias, além dos limites consolidados nas listas. ${ }^{324}$

No mesmo sentido, o artigo XXVIII do GATT também contribuiu para modificar a dinâmica clássica do tratamento da nação mais favorecida, na medida em que estabelece um intrincado sistema de consultas e compensações para autorizar a retirada das concessões outorgadas na forma das listas de compromissos do artigo II:1. O artigo XXVIII dispõe sobre os procedimentos necessários para os Estados-membros modificarem ou deixarem de aplicar qualquer compromisso assumido nas listas, apresentadas nos termos do artigo II. Para ser autorizado a retirar a concessão, o Estado deve entrar em negociações compensatórias com os Membros que venham a ser prejudicados. Na prática, os efeitos conjuntos dos dispositivos tornam quase impossível aos Estados o cancelamento das obrigações acordadas.

Daí Endre Ustor afirmar que a cláusula da nação mais favorecida é " a many-faceted multilateral commitment", pois a única forma de evitar a função estabilizadora é denunciar todos os acordos da OMC. Isso significaria renunciar, em razão de apenas uma obrigação, não só às concessões de um único país, mas às vantagens e benefícios conjunta e multilateralmente outorgados por todos os demais Estados. Percebe-se, assim, um segundo efeito sistêmico do tratamento da nação mais favorecida no GATT, que consiste na progressiva acumulação de vantagens outorgadas multilateralmente. Com isso, conclui Gerard Curzon que essas transformações funcionais são "an important new development and shows that the multilateral character of the Agreement adds up in tariff concessions to more than just a sum of bilateral concessions". 325

As contínuas rodadas de negociações multilaterais vêm resultando na contínua outorga de direitos e obrigações comerciais pelos Estados-membros, os quais são consolidados na forma das listas de concessões. Paralelamente, o custoso processo de retirada ou modificação das listas cria um convincente desincentivo aos Estados, tendo por consequência o acumulo progressivo de vantagens mercantis. A operação conjunta desses institutos cria um mecanismo

${ }^{324}$ CURZON, Gerard. Multilateral Commercial Diplomacy: The General Agreement on Tariffs and Trade and Its Impact on National Commercial Policies and Techniques. Nova York: Praeger, 1966, p. 62-64.

${ }^{325}$ CURZON, 1966, p. 65-70. USTOR, Endre. Second Report of the Special Rapporteur. Yearbook of the International Law, [s.1.], v. II, 1970. Disponível em <http://www.un.org/law/ilc/index.htm>. Acesso em: 10 out. 2006. Documento da ONU n. A/CN.4/228 and Add.1, p. 221-223. USTOR, Endre. Fifth Report of the Special Rapporteur. Yearbook of the International Law, [s.1.], v. II, 1974. Disponível em <http://www.un.org/law/ilc/index.htm>. Acesso em: 10 out. 2006. Documento da ONU n. A/CN.4/280, p. 133. 
de aquisição e acumulação sucessiva de benefícios, os quais são estendidos multilateralmente aos Estados-membros. Os efeitos da nova dinâmica normativa, ao incidirem sobre o artigo I:1, têm por consequência transformar a função de calibração em uma função estabilizadora das relações econômicas internacionais. Consolida-se, na forma da função estabilizadora, um mecanismo institucional de abertura econômica, a qual implica maior previsibilidade e segurança jurídica para a atuação dos Estados.

Concomitantemente aos argumentos jurídico-normativos, a racionalidade econômica permite apontar outra importante consequência subjacente à função estabilizadora do tratamento da nação mais favorecida: a prevenção quanto à erosão de benefícios. Historicamente, os Estados, induzidos pela função positiva do tratamento da nação mais favorecida, barganhavam por vantagens. Ainda assim, persistia certa relutância em outorgar vantagens, devido à incerteza gerada pela possibilidade de futura perda do valor relativo destas, caso benefícios maiores viessem a ser negociados por uma das partes-contratantes. Com a positivação da função estabilizadora, a falta de previsibilidade e de segurança jurídica é mitigada pela dinâmica normativa do sistema GATT/OMC. Nesse particular, é possível constatar que a incorporação das listas de compromissos aos acordos OMC, cumulada com a obrigação de renegociar as vantagens já consolidadas em bases recíprocas, permite diminuir o receio dos Estados. Daí demonstrarem K. Bagwell e R. Staiger que o TNMF tem por efeitos evitar a erosão dos benefícios, na medida em que elimina o oportunismo bilateral e exige que a renegociação seja politicamente eficiente, ou seja, condiciona a retirada de uma vantagem pela concessão de outra equivalente. ${ }^{326}$

${ }^{326}$ BAGWELL; STAIGER, 2004, p. 54-55. BAGWELL; STAIGER, 1999, p. 227-229. 


\section{SEÇÃO IV}

\section{O DISCURSO JURÍDICO-DECISÓRIO DA CLÁUSULA DA NAÇÃO MAIS FAVORECIDA}


Na Seção I, a cláusula da nação mais favorecida foi analisada enquanto elemento determinante das relações econômicas internacionais. A rápida proliferação dos acordos preferenciais de comércio e das medidas restritivas ao comércio decorre das transformações socioeconômicas que se intensificam com o fim dos conflitos de concepção. O processo implica reiteradas quebras de expectativas normativas, as quais incidem sobre o sistema multilateral de comércio, desestruturando-o. No centro da governança econômica internacional, a Organização Mundial do Comércio responde aos desafios sistêmicos, por meio do Órgão de Solução de Controvérsias, mecanismo institucional-disciplinar responsável por exercer o controle de condutas e de estruturas das práticas e atos jurídicos dos Estadosmembros.

Após investigar o conceito de sistema multilateral de comércio, a Seção II apreende juridicamente as tensões fático-axiológicas, segundo a racionalidade jurídica pragmáticoargumentativa de vocação prático-consensual, mediada por métodos sintáticos, semânticos e, principalmente, pragmáticos de interpretação. Isso permite recolocar os desafios sistêmicos em termos de decidibilidade de conflitos, enquanto resultante da incidência contínua da cláusula da nação mais favorecida sobre as relações econômicas internacionais.

Nesse contexto, a Seção III extrai analiticamente os componentes histórico-conceituais, estruturais e funcionais do artigo I:1 do GATT, de modo a construir parâmetros hermenêuticos para a decisão sobre a cláusula da nação mais favorecida positivada. Sua preocupação é expor os requisitos de validade e os sentidos jurídicos possíveis do discurso jurídico-convencional do artigo I:1, a fim de conferir ao intérprete autêntico os elementos necessários para construir um discurso jurídico-decisório, orientado por uma racionalidade jurídico-pragmática, que venha a prevalecer no sistema multilateral de comércio, a despeito dos poderosos efeitos de verdade dos discursos políticos ou econômicos.

Diante disso, a presente Seção investigará criticamente as decisões proferidas pelo Órgão de Solução de Controvérsias sobre o artigo I:1 do GATT, tendo por objetivo verificar se, ante os desafios sistêmicos, a cláusula da nação mais favorecida permanece como regra determinante para os controles de licitude e de legalidade. A análise dogmático-argumentativa versará sobre o exame da interpretação sintático-gramaticais imputada às expressões 
linguísticas do artigo I:1, bem como sobre a fundamentação das decisões concernentes à relação de coerência estrutural-funcional da CNMF com os demais dispositivos previstos no GATT, em particular as respectivas regras de calibração. Por fim, será abordado o impacto das construções jurisprudenciais sobre os limites incidentais do tratamento da nação mais favorecida sobre as relações econômicas internacionais.

A partir da combinação das conclusões das quatro Seções, analisar-se-á em que medida os efeitos jurídicos da cláusula da nação mais favorecida contribuem para resguardar a consistência sistêmica e assegurar a eficácia normativa do sistema multilateral de comércio. Com isso, será possível endereçar uma resposta jurídico-pragmática à questão-problema. 


\subsection{O DISCURSO JURÍDICO-DECISÓRIO DO ARTIGO I:1}

O Órgão de Solução de Controvérsias administra o mecanismo de solução de disputas, por meio de dois órgãos decisórios auxiliares, aos quais delega competência para o exame técnico-jurídico dos conflitos comerciais a ele apresentados. Salvo se recusado consensualmente pelo OSC, as decisões proferidas pelos painéis e pelo Órgão Permanente de Apelação são detentoras de autoridade jurídica, na medida em que obedecem a um procedimento institucionalizado, capaz de conferir certeza e segurança às relações econômicas internacionais, segundo uma racionalidade jurídico-pragmática. A procedimentalização do poder decisório da Organização Mundial do Comércio permite o controle da legalidade e da licitude, mediante a separação entre questões jurídicas e político-econômicas. Com isso, o sistema multilateral de comércio capta os conflitos econômicos como exercício controlado de poder, o que confere ao OSC autoridade para produzir discursos jurídico-decisórios. ${ }^{327}$

Nesse contexto, os discursos jurídico-decisórios que tenham por objeto o artigo I:1 do GATT serão examinados, buscando determinar, ante os desafios sistêmicos, o grau de imperatividade e eficácia normativa da cláusula da nação mais favorecida. Como analisado no Capítulo 1.4.1, os desafios sistêmicos têm origem nas transformações inerentes às estruturais axiológicas e comportamentais da ordem econômica internacional contemporânea. No plano fático, a proliferação de acordos preferenciais de comércio e de medidas restritivas conduz ao aumento do comportamento discriminatório e protecionista nas relações econômicas internacionais, prejudicando a construção de um mercado globalizado de pretensões multilaterais, isto é, livre do voluntarismo autárquico dos Estados-membros. Na perspectiva ideacional, os inconclusivos estudos político-econômicos sobre os efeitos da discriminação regional associada à valorização do protecionismo, segundo uma lógica fragmentária e predatória, têm por consequência a contestação dos princípios constitutivos do SMC, em especial a não discriminação. Elemento conjuntural agravante e desagregador, o impasse das

${ }^{327}$ CARVALHO, 2008, p. 189-198. FERRAZ JR., 2001, p. 305; 339-342. 
negociações comerciais multilaterais impede a OMC de encontrar soluções consensuais, por via diplomática, para os desafios sistêmicos.

A impossibilidade de alcançar um acordo multilateral satisfatório conduz a tensão dialética fático-axiológica, a refletir diretamente sobre o sistema multilateral de comércio, do qual são exigidas respostas jurídicas que assegurem estabilidade às expectativas normativas dos agentes econômicos. As possíveis soluções jurídicas institucionalizadas na OMC demandam a verificação da legalidade e da licitude do comportamento estatal, dos acordos preferenciais de comércio e das medidas contingenciais em face do artigo I:1 do GATT, por meio dos mecanismos de controle previstos. O controle de estruturas é realizado pela análise da adequação dos requisitos formais dos APC e das medidas restritivas às condições previstas no SMC. O controle de condutas consiste no exame do respeito aos deveres materiais pelos Estados-membros. Concluídos as investigações, os mecanismos institucionais proferem decisões aos Estados-membros na forma de discursos jurídico-normativos, os quais são construídos com fundamento no sistema multilateral de comércio.

Há, assim, um processo de elaboração do discurso jurídico-decisório, mediante a determinação da validade formal e material das normas a partir do sistema multilateral de comércio. Trata-se, pois, de verificar os múltiplos sentidos do texto normativo, a fim de delimitar o significado prevalecente que será aplicado nas decisões dos mecanismos de controle. A presente Seção IV enfoca o procedimento argumentativo que constrói a decisão acerca do artigo I:1 do GATT, na medida em que nele reside a peça-chave para a qual confluem as exigências e inseguranças decorrentes dos desafios sistêmicos.

As decisões jurídicas sobre a cláusula da nação mais favorecida impactam diretamente as estruturas comportamental, ideacional e institucional-legal. O exercício do controle sobre as relações de poder e verdade permite ao Órgão de Solução de Controvérsias transformar os conflitos normativos em comandos prescritivo-disciplinares dos limites do comportamento lícito dos Estados-membros principalmente no tocante ao princípio da não discriminação. Dessa forma, os capítulos subsequentes versarão sobre a eficácia normativa e prevalência argumentativa da cláusula da nação mais favorecida na decidibilidade dos conflitos normativos, bem como o respectivo impacto dos discursos jurídico-decisórios sobre sistema multilateral de comércio, no contexto dos desafios sistêmicos. 


\subsection{ANÁLISE DOS TERMOS LINGUÍSTICOS DO ARTIGO I: 1 DO GATT}

Os termos do discurso jurídico do artigo I:1 do GATT estão sujeitos a interpretações, as quais podem ser convergentes ou divergentes quanto ao sentido atribuído a determinadas expressões linguísticas. A riqueza hermenêutica, decorrente do plurilinguísmo e das diversas culturas jurídicas presentes no sistema multilateral de comércio, incide sobre o texto normativo, produzindo significados distintos sobre o mesmo termo. Nesse particular, o Órgão de Apelação reconheceu, no Caso US - Gasoline, que os métodos sintático-gramaticais são as técnicas de interpretação predominantes no processo decisório. Daí a relevância de examinar o artigo I:1, à luz dos sentidos lexicais a ele atribuídos nas decisões do Órgão de Solução de Controvérsias.

Todavia, a polissemia plurilinguística dos termos legais tende a revelar, no momento da decisão sobre conflitos econômicos, uma grande divergência de sentidos. Em que pese a tentativa de evitar o esvaziamento do conteúdo normativo, por meio do método sintáticodicionarizado, as deficiências inerentes ao instrumento linguístico evidenciam os limites da interpretação lexical. Em face disso, o OPA tem, desde o Caso United States - Tax Treatment for "Foreign Sales Corporations", declarado a necessidade de ir além dos sentidos dados pelos dicionários, superando a autocircunscrição à racionalidade jurídica puramente lógica. Com isso, há a abertura do processo de construção do discurso jurídico-decisório aos métodos semânticos e pragmáticos de interpretação. ${ }^{328}$

Devido à importância atribuída à interpretação das expressões linguísticas pelo Órgão de Solução de Controvérsias, proceder-se-á ao exame hermenêutico e argumentativo dos termos do artigo I:1 do GATT, o qual demandará recurso às construções da jurisprudência, da práxis diplomático-mercantil e da doutrina.

${ }^{328}$ CARVALHO, 2008, p. 285-287. 
a) "Qualquer vantagem, favor, imunidade ou privilégio..."

O artigo I:1 do GATT dispõe que a toda vantagem, favor, imunidade ou privilégio outorgado por Estados-membros da OMC a qualquer outro, incluindo Estados não Membros, incidirão os efeitos do tratamento da nação mais favorecida. As vantagens devem ser estendidas imediata e incondicionalmente a todos os Estados-membros; logo, Estados não membros carecem do direito de reivindicar tratamento semelhante. Assim, uma vantagem concedida pela França à Rússia, que atualmente não é Membro, deve ser estendida para o Brasil e China, mas não para Irã ou Cazaquistão, também não Membros.

Os termos "vantagem, favor, imunidade ou privilégio", por não serem suficientemente precisos, implicam dúvidas interpretativas acerca da natureza qualificadora dos atos. Para diminuir as incertezas causadas pela textura aberta dos termos do artigo I:1, é preciso conformar um núcleo significativo que integre consistentemente os significados, de modo a revelar uma preferência estabilizante das expectativas normativas, cujo efeito é assegurar a previsibilidade e segurança jurídica. Nesse sentido, ressalta-se a importância das decisões do Órgão de Solução de Controvérsias, as quais têm contribuído determinantemente para a consolidação dos parâmetros hermenêuticos do artigo I:1.

Dentre os diversos casos do Órgão de Solução de Controvérsias que trataram do significado do termo vantagem, a decisão do Caso India - Tax Rebates On Exports é precursora. Após examinar as alegações de que Índia concedia restituição tributária às importações de Estados-partes do GATT, com exceção do Paquistão, o painel decidiu que a outorga de vantagens, mediante normas domésticas, incorria em tratamento discriminatório; logo, inconsistente com o artigo I:1 do GATT. Ainda que o relatório careça de fundamentação adequada, o OSC deu o primeiro passo para as sucessivas ampliações do significado do termo vantagem no contexto do sistema multilateral de comércio. ${ }^{329}$

${ }^{329}$ GATT. India - Tax rebates on export. Ruling by the Chairman, 24 ago. 1948. Disponível em $\langle$ http://www.wto.org/english/tratop_e/dispu_e/48taxexp.wpf $>$. Acesso em: 10 abr. 2009. Documento da OMC n. BISD II/12. 
No Caso United States - Denial of Most Favoured Nation Treatment as to Non Rubber Footwear from Brazil ("US - MFN Footwear”), o Brasil alegou que, ao implementar as obrigações do artigo VI do GATT, que versam sobre medidas compensatórias, os Estados Unidos infringiram o artigo I:1, na medida em que trataram os calçados brasileiros de forma discriminatória. O Caso envolvia três normas domésticas dos Estados Unidos que disciplinavam a aplicação de medidas compensatórias. A adequação da legislação ao GATT não foi padronizada, resultando em regras que estabeleciam tratamentos diferentes sobre os exames de determinação de prejuízos de dumping ou de subsídios, bem como sobre os efeitos da revogação das medidas compensatórias em vigor. A cláusula 331 do 1974 Act previa um exame revisional automático que, em caso negativo, revogaria as medidas compensatórias por ela impostas. Os efeitos da revogação retroagiam até a data em que o produto adquiriu status de isenção tributária. Diferentemente, o tratamento da cláusula 104 do 1979 Act dispunha que as medidas compensatórias por ela impostas poderiam ser revogadas, mediante solicitação dos interessados por um reexame da aplicação. Na hipótese de resultado negativo, os efeitos retroagiriam até a data do pedido revisional.

O painel entendeu que a cláusula 313 do 1974 Act, ao estabelecer a retroatividade automática até a data prévia à imposição da medida compensatória, sem a necessidade de solicitação do exame revisional, estabeleceu um tratamento mais benéfico daquele disposto na cláusula 104 do 1979 Act. Diante disso, reconheceu-se que tal diferença "is properly considered to be an advantage within the meaning of Article I:1". Portanto, deveria ser estendida a todos os Estados-membros.

Além disso, o painel também decidiu que, apesar de diferentes regras poderem conceder vantagens e desvantagens particulares, o artigo I:1 "does not permit balancing more favourable treatment under some procedures against a less favourable treatment under others". Caso esse entendimento fosse aceito, os Estados-partes teriam o direito de derrogar as obrigações de terceiros de estender-lhe certas vantagens decorrentes do tratamento da nação mais favorecida, a fim de beneficiar-se de um tratamento privilegiado concedido por uma parte-contratante em outra oportunidade. Desse modo, tratamentos discriminatórios não são justificáveis por um balanceamento compensatório entre normas que prevejam benefícios e 
normas que estipulem desvantagens, visto que essa interpretação do "Article I:1 would defeat the very purpose underlying the unconditionality of that obligation". 330

O Caso European Communities - Regime for The Importation, Sale and Distribution of Bananas (“EC - Bananas III”) tem por objeto o regime de importação, distribuição e venda de bananas, estabelecido pelas Comunidades Europeias, em $1^{\circ}$ de julho de 1993. O Regulamento CE $n^{\circ} 404$ disciplinava os diferentes procedimentos para obtenção de licença para importação de bananas, submetidos aos países do grupo Ásia, Caribe e Pacífico (“ACP”) e aos Estados não tradicionais ou terceiros Estados. Os requisitos para importar bananas dos países ACP consistiam na apresentação da quantidade e origem dos produtos importados, bem como no acompanhamento de um certificado de origem ACP que atestasse os respectivos status de tradicional. As licenças de importação de terceiros Estados e países não tradicionais dependiam da classificação das mercadorias pelos importadores nas seguintes categorias condicionantes: (i) tipos de operadores; (ii) funções; e (iii) certificados de exportação.

Após a análise do regime de importação de bananas, o Órgão Permanente de Apelação confirmou a decisão do painel de que as tarifas e os requisitos procedimentais e administrativos aplicados aos países ACP diferiam daqueles aos quais terceiros Estados e países não tradicionais estavam submetidos. Ao comparar os regimes de licenças de importação de bananas, inclusive suas tarifas, categorias de operadores e funções, constatou-se haver um benefício conferido aos países ACP. Dessa forma, o OPA reconheceu que as regras do Regulamento CE $\mathrm{n}^{\circ} 404$ asseguravam privilégios discriminatórios aos Estados ACP, sendo inconsistentes com o artigo I:1 do GATT. Nas palavras do Órgão de Apelação:

[..] the Panel found that the procedural and administrative requirements of the activity function rules for importing third-country and non-traditional ACP bananas differ from, and go significantly beyond, those required for importing traditional ACP bananas.This is a factual finding. Also, a broad definition has been given to the term "advantage" in Article I:1 of the GATT 1994 by the panel in United States Non-Rubber Footwear.[...] For these reasons, we agree with the Panel that the activity function rules are an "advantage" granted to bananas imported from traditional ACP States, and not to bananas imported from other Members, within the meaning of Article I:1. Therefore, we uphold the Panel's finding that the activity function rules are inconsistent with Article I:1 of the GATT 1994. ${ }^{331}$

\footnotetext{
${ }^{330}$ GATT. United States - Denial of Most Favoured Nation Treatment as to Non Rubber Footwear From Brazil. Report by the Panel, 19 jun. 1992. Disponível em 〈http://www.wto.org/english/tratop_e/dispu_e/91nruber.wpf $>$. Acesso em: 10 abr. 2009. Documento da OMC n. DS18/R - BISD 39S/128, par. 6.8-6.17.

331 OMC. European Communities - Regime for the Importation, Sale and Distribution of Bananas. Report of the Appellate Body, 9 set. 1997. Disponível em <http://www.wto.org/english/tratop_e/dispu_e/cases_e/ds27_e.htm>. Acesso em: 10 abr. 2009. Documento da OMC n. WT/DS27/AB/R.
} 
Em suma, constata-se que as decisões do Órgão de Solução de Controvérsias apresentam uma interpretação extensiva dos termos "vantagem, favor, imunidade ou privilégio", de modo a reconhecer que qualquer ato, nacional ou internacional, relacionado a tarifas ou não, pode ser considerado inconsistente com o artigo I:1, na hipótese de produzir, fática ou normativamente, efeitos discriminatórios.

b) “... concedido a um produto..."

O termo produto tem por objetivo determinar o escopo de aplicação do artigo I:1. Isso significa que não foi positivada no Acordo Geral sobre Tarifas e Comércio uma cláusula da nação mais favorecida na forma ilimitada. Restringiu-se, estritamente, a materialidade do tratamento da nação mais favorecida ao comércio internacional de bens, de modo a deixar para outros acordos, partes ou não do sistema multilateral de comércio, os setores intangíveis, como o comércio de serviços, propriedade intelectual e os direitos empresariais. ${ }^{332}$

$\mathrm{O}$ artigo I:1 disciplina o mercado de bens, de modo a abranger: (i) "direitos aduaneiros e encargos de toda a natureza que gravem a importação ou a exportação, ou a elas se relacionem, aos que recaiam sobre as transferências internacionais de fundos para pagamento de importações e exportações"; (ii) "método de arrecadação desses direitos e encargos"; (iii) “conjunto de regulamentos ou formalidades estabelecidos em conexão com a importação e exportação"; (iv) "assuntos incluídos nos parágrafos $2^{\circ}$ e $4^{\circ}$ do artigo III", que tratam sobre tributação e regulamentação nacional; e (v) todas as questões aplicáveis apenas aos produtos.

Esses termos delimitadores do escopo do artigo I:1 também foram objetos de interpretações pelo Órgão de Solução de Controvérsias, expressas nos discursos jurídicodecisórios dos diversos relatórios adotados. Entende-se por direitos aduaneiros todas as tarifas, incluídas nas listas de compromisso ou não. Os encargos de toda a natureza abrangem taxas consulares, taxas de processamento de mercadorias e taxas de uso alfandegário ${ }^{333}$. As

\footnotetext{
332 JACKSON, 1969, p. 256-257.

333 GATT. Cuba - Consular taxes. Ruling by the Chairman, 24 ago. 1948. Disponível em $\langle$ http://www.wto.org/english/tratop_e/dispu_e/48contax.wpf $\rangle$. Acesso em: 10 abr. 2009. Documento da OMC n. BISD II/12. GATT. Spain - Tariff Treatment of Unroasted Coffee. Report of the Panel, 11 jun. 1981. Disponível
} 
sentenças método de arrecadação desses direitos e encargos e conjunto de regulamentos ou formalidades têm sido interpretadas no sentido de incluir a aplicação de regras antidumping. No que tange especificamente ao conjunto de regulamentos ou formalidades, estão nele incluídas as normas procedimentais domésticas que regulam a defesa comercial, isto é, aplicação de medidas antidumping e compensatórias e de salvaguardas ${ }^{334}$. Em relação ao artigo III, parágrafos $2^{\circ}$ e $4^{\circ}$, aplica-se o artigo I:1 sobre regras nacionais de tributação, inclusive àquelas que concedem descontos ou abatimentos tributários para os exportadores. ${ }^{335}$

c) “... originário de...” (regras de origem)

Durante as sessões do Comitê Preparatório, o termo originário de foi escolhido deliberadamente para excluir o conceito de proveniência. $\mathrm{O}$ objetivo era garantir uma ampla aplicação do tratamento da nação mais favorecida aos produtos comercializados entre os Estados-partes do GATT, incluindo os importados ou transportados por meio de terceiros Estados. Além disso, o Comitê Preparatório entendeu não ser necessário definir o termo, sugerindo que o tema deveria ser examinado posteriormente pela Organização Internacional do Comércio. Decidiu-se, por fim, que os Estados-partes teriam o direito de determinar, em sua legislação doméstica, as regras de origem, nas quais estariam expressos os critérios para atribuir a certo produto a procedência de um Estado em particular. ${ }^{336}$

Não sem razão, no decorrer das décadas, a importância das regras de origem no sistema multilateral de comércio está diretamente relacionada a sua utilização como (i) medida protecionista de restrição e discriminação comercial; (ii) instrumento de criação e administração de acordos preferenciais de comércio; e (iii) medida de estabelecimento de políticas preferenciais, visando beneficiar países em desenvolvimento.

em <http://www.wto.org/english/tratop_e/dispu_e/80coffee.wpf $>$. Acesso em: 10 abr. 2009. Documento da OMC n. L/5135 - BISD 28S/102, par. 4.2-4.3. GATT. United States - Customs User Fee. Report by the Panel, 2 fev. 1988. Disponível em <http://www.wto.org/english/tratop_e/dispu_e/87usrfee.wpf>. Acesso em: 10 abr. 2009. Documento da OMC n. L/6264 - BISD 35S/245, par. 120-126.

${ }^{334}$ OMC, US - MFN Footwear, Report by the Panel, 1992, par. 6.8. GATT. GATT Analytical Index. Disponível em <http://www.wto.org/english/res_e/booksp_e/gatt_ai_e/gatt_ai_e.htm>. Acesso em: 10 abr. 2009, p. 31 .

${ }^{335}$ OMC, India - Tax rebates on export, Ruling by the Chairman, 1948.

${ }^{336}$ GATT, GATT Analytical Index, p. 33-34. 
As regras de origem de um produto têm duas facetas básicas: a substantiva, que visa determinar a respectiva nacionalidade do produto, e a procedimental, que trata da certificação e outras formalidades que permitam à autoridade aduaneira atribuir a nacionalidade relevante. Assim, as regras de origem são um conjunto de critérios empregados para: (i) determinar a qual Estado, ou território aduaneiro, deve ser considerada a origem de uma certa importação, de modo a submetê-la às normas devidas, bem como possibilitar o controle estatístico do comércio internacional; e (ii) estabelecer uma distinção entre bens nacionais e importados, a fim de produzir estudos estatísticos que auxiliem o Estado à formulação de políticas econômicas. $^{337}$

Desse modo, caso as obrigações do tratamento da nação mais favorecida fossem verdadeira e integralmente respeitadas pelos Estados-membros em relação aos produtos e origens, não haveria a necessidade de dispor sobre regras de origem. Todavia, a prática demonstra que há uma considerável diferenciação de tratamento entre os produtos importados em decorrência da respectiva origem. Os problemas acerca das regras de origem surgem, principalmente, em três situações: (i) em relação aos Estados que são concomitantemente partes do sistema multilateral de comércio e de um acordo preferencial de comércio; (ii) em relação ao transporte de produtos; e (iii) quando da transformação substancial de um produto importado que será reexportado.

Em regra, os Estados-membros têm duas linhas tarifárias distintas, sendo que uma é aplicada aos Estados integrantes da Organização Mundial do Comércio, enquanto a outra incide sobre os Estados não Membros. Todavia, os Estado-membros que participam de acordos preferenciais de comércio estabelecem outras linhas tarifárias, as quais dispõem de tratamento mais benéfico às partes-contratantes. Isso resulta no avanço de relações discriminatórias entre os países, bem como no aumento da regulamentação burocrática sobre as regras de origem, em razão das dificuldades de determinar o regime aduaneiro a ser aplicado a cada produto importado ou reexportado. Note-se que não haveria qualquer problema se todos os Estados fossem somente Membros da OMC; porém, ainda são encontradas na ordem econômica internacional contemporânea diferentes relações jurídicas, nas quais participam os Estados-membros da OMC, partes ou não de acordos preferenciais de

\footnotetext{
${ }^{337}$ PIONTEK, Eugeniusz. European integration and international law of economic interdependence. Recueil des Cours, Leiden, v. 236, n. 5, 1992, p. 37.
} 
comércio, e Estados não Membros. Daí ocorrerem situações tais como um Estado produtor não ser Membro da OMC, o Estado reexportador ser, mas o Estado importador ser, além de Membro, parte de um APC. Assiste-se, assim, a um ganho de complexidade da regulação do comércio internacional, pois a tarifa incidente dependerá do exame de toda a legislação sobre regras de origem. ${ }^{338}$

Nas hipóteses de simples transporte de produto, aplica-se geralmente a regra de origem ao Estado produtor. Todavia, caso tenha sido objeto de um "substancial processing”, o produto poderá ser tratado como se originário do Estado reexportador. Com isso, questiona-se o significado e limites do processamento substancial. O sistema GATT/OMC não apresenta uma única resposta, na medida em que cada Estado é soberano para definir, razoavelmente, suas regras de origem, dependendo do interesse nacional.

Buscou-se na Rodada Uruguai por soluções para o excesso de lacunas e antinomias que a falta de uma estrutura-padrão de regras de origem produziam, uma vez que os Estados adotam regulamentações controversas e extraordinariamente complicadas, as quais são apontadas como formas de barreiras não tarifárias. As negociações resultaram no Acordo sobre Regras de Origem (“ARO”), o qual visa criar um sistema harmonizado de determinação de origem para todos os Estados-membros. O artigo 9 do ARO estabeleceu um programa de trabalho, cujos objetivos incluem a criação de regras de origem objetivas, compreensivas, previsíveis, transparentes, imparciais e coerentes. Para isso, o artigo 4 constituiu o Comitê sobre Regras de Origem da OMC que, em associação com a Organização Mundial Aduaneira (“OMA”), é responsável por conduzir o programa.

Durante a fase de transição para o sistema harmonizado, os Estados-membros comprometeram-se, nos termos do artigo 2, a assegurar que as regras de origem: (i) não serão utilizadas para a consecução direta ou indireta de objetivos comerciais; (ii) não criem efeitos restritivos, distorcivos ou desorganizadores do comércio internacional; e (iii) ao serem aplicadas às importações e às exportações, não sejam mais rigorosas do que aquelas utilizadas para determinar se uma mercadoria é nacional ou não, bem como não sejam empregadas para discriminar entre os Estados-membros.

O Acordo sobre Regras de Origem definiu, em seu artigo 1, que regras de origem são leis, regulamentos e determinações administrativas, de aplicação geral, utilizadas pelos

338 JACKSON, 1997, p. 167. 
Estados-membros para determinar a origem de todos os produtos, com exceção daqueles aos quais são concedidas tarifas preferenciais. O ARO incide sobre as regras de origem previstas apenas nos acordos não preferenciais de comércio, de modo a estabelecer parâmetros para a aplicação de: tratamento da nação mais favorecida, medidas antidumping, compensatórias e de salvaguardas, marcas de origem e restrições quantitativas.

Além disso, há duas abordagens relevantes sobre a imputação da origem dos produtos que também foram consideradas no ARO. Na primeira, os artigos 3 e 9 atribuem a origem de um determinado produto ao último Estado exportador, que tenha realizado uma transformação substancial. Isso significa reconhecer que na última mudança da posição do produto na classificação tarifária como critério determinante. Daí surge o problema da diferença de alíquota tarifária incidente sobre cada um dos diversos produtos, o qual pode implicar uma arbitrária atribuição pelos Estados da classificação da mercadoria.

A segunda é conhecida como a abordagem de valor adicionado. Prevista no artigo 9:2(iii), essa regra dispõe acerca da possibilidade de vincular a transformação substancial de uma mercadoria ao último Estado exportador que tenha adicionado certa porcentagem ad valorem aos produtos. No entanto, a abordagem de valor adicionado pode gerar reclamações dos Estados exportadores, uma vez que podem entender como injustas as regras adotadas pelos Estados importadores. Por exemplo, o Acordo de Livre-Comércio da América do Norte ("NAFTA"), celebrado entre Estados Unidos, Canadá e México contém um capítulo inteiro sobre regras de origem. Nesse capítulo, John H. Jackson destaca o controvertido artigo 403, o qual somente pode ser entendido como uma forma de restrição à importação competitiva dos produtos automotivos de terceiros Estados. ${ }^{339}$

A respeito das regras de origem, o Órgão de Solução de Controvérsias foi incitado a analisar apenas o Caso United States - Rules of Origin for Textiles and Apparel Products ("US - Rules of Origin”), no qual a Índia alegou que os Estados Unidos violavam o disposto no artigo 2(d) do ARO, pois suas regras de origem teriam produzido um injustificado tratamento diferenciado aos "closely related (Indian and European Communities) products". Tal afirmação era fundada em três pressupostos acumulativos. Primeiro, o artigo(d) imporia aos Estados-membros a obrigação de aplicar a mesma regra de origem a produtos "estreitamente relacionados”. Em segundo lugar, assume-se que a segunda sentença do artigo 2(d) deveria ser

${ }^{339}$ JACKSON, 1997, p. 168-169. 
interpretada no sentido de proibir não apenas a discriminação de juri entre os Estadosmembros, mas também a discriminação de facto. Terceiro, defende-se que, para determinar se uma regra de origem é discriminatória de facto, é preciso examinar se a regra tem por efeito imputar tratamento diferenciado e desvantajoso a certos Estados-membros, bem como verificar se as consequências dessa distinção são justificáveis.

Em seu relatório, o painel rejeitou as alegações da Índia, justificando que seus argumentos estavam fundamentados em uma equivocada interpretação do artigo 2(d), o qual não visa proibir a discriminação entre diferentes produtos importados, ainda que estreitamente relacionados, de diferentes Estados-membros. Nas palavras do painel, "it does not state that rules of origin 'shall not discriminate between closely related goods of other Members [...]'. Thus, the plain terms of the second clause do not support India's reading". Nesse diapasão, a expressão "mercadoria em questão", por estar no singular, indica que o artigo não está se referindo à discriminação entre produtos diferentes, ainda que relacionados. Na hipótese de o dispositivo ter sido concebido para evitar a discriminação entre diferentes produtos, haveria alguma indicação textual, como ocorre em outras disposições não discriminatórias da OMC, como os artigos I, III e IX do GATT. Na concepção do painel, haveria uma decisão similar, caso a Índia tivesse alegado que o artigo 2(d) também proibia a discriminação entre produtos que não fossem "similares" nem "diretamente concorrentes ou substituíveis". Em síntese, a interpretação do painel seria consistente com os objetivos do artigo 2(d), o qual visa apenas garantir que "[...] for a given good, the strictness of the requirements that must be satisfied for that good to be accorded the origin of a particular Member is the same, regardless of the provenance of the good in question [...]". 340

Considerando que os pressupostos eram acumulativos, ao rejeitar o primeiro, tornou-se desnecessário decidir sobre os demais. Não obstante, o painel decidiu examinar, em “arguendo basis”, o segundo e terceiro pressupostos suscitados pela Índia. Ainda assim, os argumentos indianos foram rejeitados, pois não conseguiram comprovar o nexo de causalidade entre a diferença de tratamento regulatório e os efeitos discriminatórios de facto.

As regras de origem estão intrinsecamente conectadas a práticas protecionistas. Contudo, assistiu-se nas últimas décadas a um aperfeiçoamento normativo tendo por objetivo

\footnotetext{
${ }^{340}$ OMC. United States - Rules of Origin for Textiles and Apparel Products. Report of the Panel, 20 jun. 2003. Disponível em <http://docsonline.wto.org/DDFDocuments/t/WT/DS/243R.doc> Acesso em: 14 abr. 2009. Documento da OMC n. WT/DS243/R, par. 6.244-6.250.
} 
restringir seus efeitos discriminatórios e distorcivos sobre o comércio internacional. Na decisão do Caso US - Rules of Origin, o painel, ainda que tenha reconhecido "arguendo" a possibilidade de práticas discriminatórias de facto, optou por restringir a incidência do tratamento da nação mais favorecida, no que tange às regras de origem, apenas a produtos idênticos.

d) “... a qualquer outro país...”

Qualquer vantagem outorgada por um Estado-membro a outro Membro deverá ser estendida para todos os demais Estados-membros. O Estado-membro que conceda privilégios a Estados não Membros também deve estender os mesmos benefícios aos demais Estadosmembros pertencentes à Organização Mundial do Comércio. Nesse particular, destaca J. Jackson que "the impact of GATT goes well beyond its membership". 341

Durante a Convenção de Genebra em 1947, foram debatidos quais os efeitos que o tratamento da nação mais favorecida poderia ter sobre os Estados não Membros do GATT, embora grande parte dessa temática esteja superada, tendo em vista que a ampla maioria dos Estados tenha aderido à OMC. É preciso destacar que, inicialmente, a ideia era rejeitar a extensão dos benefícios a terceiros Estados, mesmo na hipótese de tratados bilaterais que, dotados de cláusulas da nação mais favorecidas, fossem celebrados entre Estados-membros e Estados não Membros. Contudo, como demonstra o tratado comercial, firmado entre Estados Unidos e Paraguai, os Estados vêm, por meio dos usos e costumes, estendendo os benefícios outorgados por Estados-membros, no âmbito do sistema multilateral de comércio, àqueles Estados não Membros, com os quais tenham estabelecido promessas de não discriminação comercial. $^{342}$

É, portanto, atribuído aos termos "qualquer outro país" um sentido extensivo, tendo por efeito reconhecer a obrigação de estender os benefícios outorgados a Estados não membros aos demais Membros.

\footnotetext{
${ }^{341}$ JACKSON, 1969, p. 257.

${ }^{342}$ USTOR, 1973, p. 114.
} 
e) “...será imediata e incondicionalmente estendido...”

O artigo I:1 do GATT impõe uma obrigação incondicionada aos Estados-membros de tratar de forma não mais favorecida os demais países. Desse modo, qualquer vantagem outorgada a um Estado, Membro ou não, deve ser estendida a todos os Membros da OMC, livre de qualquer compensação recíproca. Como as formas condicionais da estrutura normativa da cláusula da nação mais favorecida foram analisadas detalhadamente no Capítulo 3.5.4., examinar-se-á neste tópico apenas a atribuição de significado ao termo "incondicionada", no âmbito da jurisprudência do Órgão de Solução de Controvérsias.

A primeira decisão sobre a expressão "incondicionalmente estendido" ocorreu no Caso Belgian - Family Allowances, no qual Dinamarca e Noruega alegaram que a legislação tributária da Bélgica violava o artigo I:1 do GATT, pois previa isenção fiscal para produtos adquiridos pela administração pública belga quando tais mercadorias tivessem origem em Estados cujos sistemas de previdência familiar cumprissem certos requisitos. Todavia, o reconhecimento dos referidos sistemas era passível de decisões discriminatórias. Daí decidir o painel que o artigo I:1 proibia à legislação tributária doméstica discriminar entre os Estadosmembros. No entanto, cumpre destacar que o relatório não é claro em explicitar se a existência de qualquer condicionamento interno viola o sistema multilateral de comércio, ou apenas normas que possam discriminar intencionalmente entre certos Estados. ${ }^{343}$

Posteriormente, o painel do Caso United States - Restrictions on Imports of Tuna, não adotado pelos Estados-partes, examinou a alegação do México de que o US Dolphin Protection Consumer Information Act violava o artigo I:1 do GATT, ao estabelecer condições discriminatórias e desfavoráveis segundo a especificação geográfica. O painel, ao examinar os requisitos impostos aos fornecedores para verificar a existência vantagens desfavoráveis, reconheceu que tais condições não resultavam em tratamento discriminatório. Com isso, pode-

${ }^{343}$ GATT. Belgian - Family Allowances. Report of the Panel, 7 nov. 1952. Disponível em $\langle$ http://www.wto.org/english/tratop_e/dispu_e/52famalw.wpf $>$. Acesso em: 10 abr. 2009. Documento da OMC n. G/32 - BISD 1S/59, par. 1-8. 
se concluir que o termo "incondicionalmente" não significa que é vedada a previsão de condições internas, mas apenas que tais restrições não venham a criar discriminações entre os Estados-membros. $^{344}$

Em um terceiro caso, proposto contra a Indonésia, foi requerido ao Órgão de Solução de Controvérsias interpretar a expressão incondicionada do artigo I:1 do GATT. O Caso Indonesia - Certain Measures Affecting the Automobile Industry tem por objeto uma série de medidas adotadas com relação a motores e componentes de veículos automotores, denominadas Indonesian National Car Programme, as quais confeririam vantagens cobertas pelo artigo I:1. Entretanto, os efeitos imediatos e incondicionados estariam restritos por condições prévias. Ao examinar a questão, o painel decidiu que, apesar de neutras quanto à origem geográfica, as regras de isenções fiscais eram inconsistentes com o artigo I:1, pois impunham condições para estender as vantagens concedidas.

Nas palavras do painel, "the existence of these conditions is inconsistent with the provisions of Article I:1 which provides that tax and customs duty benefits accorded to products of one Member [...] be accorded to imported like products from other Members “immediately and unconditionally". Desse modo, qualquer condição imposta aos Estados que não relacionada ao produto em si, é considerada discriminatória. Os produtos podem, assim, ser objetos de condições, desde que o critério não incorra em discriminação quanto ao local de produção da mercadoria, enquanto a mera prescrição de condições subjetivas aos Estados constitui per se a violação do artigo I: $1 .^{345}$

Em consonância, o Órgão de Solução de Controvérsias, no Caso Canada - Certain Measures Affecting the Automotive Industry ("Canada - Autos"), foi requerido a interpretar o significado do termo "incondicionalmente". Nessa demanda, Japão e Comunidades Europeias alegaram que certas medidas regulatórias do Canadá, as quais disciplinavam isenções fiscais concedidas ao comércio de veículos automotores, seriam inconsistentes com os acordos da OMC. As isenções fiscais eram outorgadas apenas quando os importadores cumpriam com certas condições previstas no Motor Vehicles Tariff Order de 1998 e no Special Remission

\footnotetext{
${ }^{344}$ GATT. United States - Restrictions on Imports of Tuna. Report of the Panel, 3 set. 1991. Disponível em <http://docsonline.wto.org/DDFDocuments/t/JCR/PANELS/91TUNA.WPF>. Acesso em: 10 abr. 2009. Documento da OMC n. DS21/R - BISD 39S/155, par. 5.43-5.44

${ }^{345}$ Indonesia - Certain Measures Affecting the Automobile Industry. Report of the panel, 2 jul. 1998. Disponível em <http://docsonline.wto.org/DDFDocuments/t/WT/DS/54R00.DOC > Acesso em: 14 mar. 2009. Documento da OMC n. WT/DS54/R, WT/DS55/R, WT/DS59/R, WT/DS64/R, par. 1-3; 14.144-14.148.
} 
Orders, sendo que, na prática, apenas um reduzido número de companhias locais era capaz de preencher tais requisitos para beneficiar-se das medidas. O painel decidiu que as normas canadenses eram inconsistentes com a cláusula da nação mais favorecida, baseado em dois elementos principais. Primeiro, o artigo I:1 é aplicável a discriminações de facto, o que inclui medidas domésticas que limitam os benefícios das isenções fiscais a certos importadores. Segundo, o painel reconheceu que, em razão das características do comércio intrafirma de produtos automotivos no Canadá, a limitação da aplicabilidade das isenções tributárias a certos importadores, que cumpriam requisitos únicos, tinha por efeito discriminar de facto quanto à origem os produtos que iriam beneficiar-se das vantagens.

Importante aspecto da decisão do Caso Canada - Autos está na rejeição pelo painel dos argumentos apresentados pelo Japão acerca do significado do termo "incondicionalmente". O Japão sustentava que, ao condicionar a concessão das vantagens tributárias a critérios não relacionados com o produto importado, o Canadá teria falhado em estender imediata e incondicionalmente as isenções fiscais aos produtos similares de todos os Estados-membros. Em sua defesa, o Canadá alegou que o artigo I:1 do GATT veda apenas o estabelecimento de condições relacionadas às origens do produto importado, sendo possível tratar produtos similares diferentemente, desde que tais distinções de tratamento sejam baseadas em outros critérios que não a nacionalidade. O painel decidiu que a interpretação do Japão não correspondia à acepção comum do termo "incondicionalmente" do artigo I:1, pois "whether an advantage within the meaning of Article $I: 1$ is accorded 'unconditionally' cannot be determined independently of an examination of whether it involves discrimination between like products of different countries". Isso significa que a palavra "incondicionalmente" do artigo I:1 não trata da concessão de uma vantagem per se, mas da obrigação de conferir aos produtos similares de todos os Estados-membros as vantagens outorgadas a qualquer outro Estado. Desse modo, condições podem ser impostas à concessão de um benefício, ainda que não relacionadas ao produto, sem necessariamente violarem o artigo I:1, na medida em que não produzam qualquer efeito discriminatório sobre as mercadorias importadas. ${ }^{346}$

Nos termos da decisão do painel:

\footnotetext{
${ }^{346}$ OMC. Canada - Certain Measures Affecting the Automotive Industry. Report of the Panel, 11 fev. 2000. Disponível em <http://docsonline.wto.org/DDFDocuments/t/WT/DS/139R.DOC〉 Acesso em: 14 mar. 2009. Documento da OMC n. WT/DS139/R, WT/DS142/R, par. 10.14-10.30.
} 
In sum, we believe that the panel decisions and other sources referred to by Japan do not support the interpretation of Article I:1 advocated by Japan in the present case according to which the word "unconditionally" in Article I:1 must be interpreted to mean that subjecting an advantage granted in connection with the importation of a product to conditions not related to the imported product itself is per se inconsistent with Article I:1, regardless of whether such conditions are discriminatory with respect to the origin of products. Rather, they accord with the conclusion from our analysis of the text of Article I:1 that whether conditions attached to an advantage granted in connection with the importation of a product offend Article I:1 depends upon whether or not such conditions discriminate with respect to the origin of products. $^{347}$

Dessa forma, constata-se que o Órgão de Solução de Controvérsias tem interpretado o termo "imediata e incondicionalmente", segundo uma racionalidade jurídico-pragmática, na medida em que procura guardar consonância entre as decisões pretorianas e a função negativa do tratamento da nação mais favorecida.

f) “...ao produto similar."

Não há dúvida de que "produto similar" é a expressão mais examinada do artigo I:1 do Acordo Geral sobre Tarifas e Comércio. Embora não seja objeto desta dissertação analisar exaustivamente o conceito de "produto similar", visto que o termo pode ser encontrado com diferentes significados em pelo menos quinze outros dispositivos do GATT, o presente tópico focará, genericamente, nos variados sentidos a ele atribuídos pela doutrina e jurisprudência.

A definição de "produto similar" tem importância nuclear para o artigo I:1. Isso porque a obrigação de o Estado-membro estender a mercadorias determinada vantagem outorgada a certo produto depende do reconhecimento daquelas como "produto similar". A qualificação de certos produtos como similares implica tratá-los em bases não discriminatórias. Considerando ainda que as negociações na Organização Mundial do Comércio têm por objetivo a redução de barreiras tarifárias e não tarifárias aplicadas sobre cada mercadoria diferente, não é surpresa que questionamentos quanto à similaridade de certos produtos ocorram. Desse modo, o estabelecimento dos critérios de classificação de similitude tem importância ímpar, pois terá

${ }^{347}$ OMC, Canada - Autos, Report of the Panel, par. 10.29. 
por efeito determinar as consequências jurídicas incidentes sobre um produto, especialmente as tributárias baseadas nas listas de compromissos dos Estados-membros. ${ }^{348}$

O critério mais ordinário de similaridade adota as características físicas como fator distintivo. Tomadas individualmente, as qualidades físicas surgem como conceito politicamente neutro, cuja dificuldade está em compreender quais diferenças conduzem a classificar produtos como semelhantes ou diferentes. Para determinar o grau de similitude física, é necessário o recurso a critérios que contenham conteúdo político, tal como a possibilidade dos produtos serem intercambiáveis. Considerando que o GATT é um tratado sobre comércio, parece razoável presumir que o termo "produto similar" é um conceito comercial, cuja preocupação central é a competitividade. Assim, a racionalidade subjacente ao artigo I:1 está em prevenir comportamentos discriminatórios mediante a proibição de tratamento diferenciado a certos produtos, que se revela na forma de distorções à competição destes.

Nesse sentido, percebe-se que as divergentes interpretações do artigo I:1, responsáveis por oferecer variados critérios para verificação da similitude entre produtos, guardam em comum a ideia de competitividade. Primeiramente, há o critério de substitutibilidade, ao qual cabe averiguar a percepção do consumidor quanto à funcionalidade dos produtos e em que medida estes podem ser substituíveis. Segundo, há o conceito de similaridade funcional que, mediante um exame de desempenho, determina a igualdade funcional das mercadorias. Terceiro, há critérios que, embora focados no produtor, não têm preocupação com a competitividade, tal como a natureza das matérias-primas, trabalhadores e outros. Do ponto de vista econômico, o princípio da não discriminação inerente ao artigo I:1 visa justamente direcionar a construção do significado de "produto similar", no sentido de vedar a proteção de certos bens e evitar distorções na alocação de recursos. ${ }^{349}$

A problemática central do artigo I:1 está em lidar com os diferentes tratamentos concedidos a cada produto, em decorrência das distintas regulamentações adotadas pelos Estados-membros. O fato de o Acordo Geral sobre Tarifas e Comércio aceitar, ainda que implicitamente, o emprego de barreiras tarifárias e de medidas regulatórias internas como

\footnotetext{
${ }^{348}$ TREBILCOCK; HOWSE, 2005, p. 65. JACKSON, 1969, p. 260.

${ }^{349}$ HUDEC, Robert E. "Like Product": The Differences in Meaning in GATT Articles I and III. In: COTTIER, Thomas; MAVROIDIS, Petros C. (ed.). Regulatory Barriers and the Principle of Non-discrimination in World Trade Law: Past, Present, and Future. Michigan: University of Michigan, 2000, p. 101-108.
} 
mecanismos de proteção, permite aos Membros, mediante a manipulação de suas linhas tarifárias e de regras domésticas, impor distinções discriminatórias entre os produtos importados. O direito de determinar os critérios de classificação tarifária assegura ao Estado a possibilidade de estabelecer uma taxonomia de aparente neutralidade, mas que, devido a distinções claramente específicas, confere tratamentos discriminatórios, prejudicando a competitividade entre as mercadorias.

Se as diferenças de tratamento têm por fundamento exclusivo a origem do produto, a regra, ao impor uma discriminação de jure, estará violando o artigo I:1. A discriminação baseada na origem do produto é uma situação extrema e facilmente identificada. No entanto, as demandas surgem, geralmente, das distinções de facto que não estão explicitamente ligadas às origens, mas na discriminação das diferentes mercadorias classificadas numa mesma categoria genérica, como, por exemplo, a diferenciação dentre as bebidas alcoólicas ou os tipos de café. É nesse ponto que o tema da similaridade surge em toda a sua complexidade. Daí constatarem a existência de dois tipos de discriminação: (i) as tarifárias entre produtos sujeitos a diferentes classificações taxonômicas; e (ii) as tarifárias dentro da mesma qualificação fiscal. Para determinar se um produto é similar, o painel tem examinado casualmente os produtos segundo diversos fatores, tais como: classificação tarifária, características físicas, finalidades, gostos e hábitos dos consumidores. ${ }^{350}$

$\mathrm{Na}$ categoria envolvendo discriminações tarifárias entre produtos sujeitos a diferentes linhas taxonômicas, a questão está em determinar os limites dos Estados-membros em refinar a distinção em suas classificações de tarifas. Durante os debates na sessão de Londres do Comitê Preparatório, foi reconhecido que a expressão "produto similar" tinha significados distintos dependendo do contexto que era incorporada nas cláusulas da Carta de Havana. Os desafios semânticos envolvendo "produto similar" são historicamente similares às questões decorrentes do conceito de regras de origem, visto ambos carecerem internacionalmente de uma precisa definição sobre o termo. Considerando que a imprecisão linguística nunca impediu um tratado comercial de funcionar, os negociadores optaram por não adotar qualquer definição, atribuindo a tarefa à Organização Internacional do Comércio. Na Conferência de Havana, foi ainda sugerido o método tarifário como forma de determinação da similaridade entre produtos. Entretanto, o fato da OIC não ter obtido condições de vigorar, coube ao Órgão

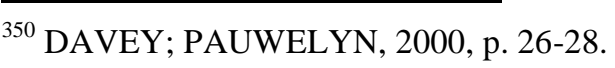


de Solução de Controvérsias esclarecer os sentidos da expressão "produto similar", sendo que jurisprudencialmente cinco casos foram relevantes para a questão. ${ }^{351}$

O Caso Australia - Subsidy on Ammonium Sulphate ("Australia - Ammonium Sulphate") tratou da classificação tarifária como determinante da similaridade. Os fatos estavam relacionados à alegação do Chile de que a Austrália tinha violado o artigo I:1 do GATT, por discriminar suas exportações de fertilizante à base de nitrato de sódio, ao retirá-lo do programa australiano de subsídio, enquanto mantinha o subsídio ao concorrente sulfato de amônia. Ao considerar que a demanda envolvia a distinção entre "produto similar" e "produto diretamente competitivo ou substituível”, os Estados-partes decidiram que o artigo I:1 é limitado apenas às questões referentes a "produto similar". Assim, sem definir "produto similar", o painel concluiu que os fertilizantes não eram produtos similares, pois eram classificados de forma distinta pelo sistema tarifário da Austrália e demais países. ${ }^{352}$

No Caso Germany - Treatment of Imports of Sardines ("Germany - Sardines"), a Noruega apresentou uma demanda em face da Alemanha por esta haver negado estender às sardinhas escandinavas os benefícios outorgados às sardinhas portuguesas. Após concluir que existiam diferenças biológicas entre os tipos de sardinha, o painel rejeitou os argumentos de discriminação pela origem das mercadorias, acolhendo implicitamente que não havia similaridade entre os produtos, os quais estavam sujeitos a distintas classificações tarifárias. Todavia, o painel considerou que as medidas tomadas pela Alemanha, por terem o objetivo de erodir os compromissos assumidos na Rodada Tóquio, violavam o artigo XXIII do GATT. ${ }^{353}$

Em 1981, o relatório do Caso Spain - Tariff Treatment of Unroasted Coffee ("Spain Coffee”) examinou a alegação do Brasil de que o Decreto Real no 1764/79, ao alterar a legislação espanhola dividindo a classificação unitária do café não torrado em cinco subcategorias, sujeitas a duas diferentes linhas tarifárias, violava o artigo I:1 do GATT. O

\footnotetext{
${ }^{351}$ ONU. Economic and Social Council. Preparatory Committee of the International Conference on Trade and Employment. Verbatim Report of the Twelfth Meeting of Committee II, 22 nov. 1946. Disponível em: $\langle$ http://www.wto.org/gatt_docs/English/SULPDF/90220016.pdf >. Acesso em: 28 fev. 2009. Documento da ONU n. E/PC/T/C.II/PV/12, p. 7-8. ONU. International Conference on Trade and Employment. Summary Record of the Fifth Meeting, 4 dec. 1947. Disponível em: <http://www.wto.org/gatt_docs/English/SULPDF/90190218.pdf>. Acesso em: 28 fev. 2009. Documento da ONU n. E/CONF.2/C.3/SR.5, p. 4.

${ }^{352}$ GATT. Australia - Subsidy on Ammonium Sulphate. Report adopted by the Contracting Parties, 3 abr. 1950. Disponível em <http://www.wto.org/english/tratop_e/dispu_e/50amosul.wpf>. Acesso em: 10 abr. 2009. Documento da OMC n. GATT/CP.4/39 - BISD II/188.

${ }^{353}$ GATT. Germany - Treatment of Imports of Sardines. Report adopted by the Contracting Parties, 31 out. 1952. Disponível em <http://www.wto.org/english/tratop_e/dispu_e/55starch.wpf >. Acesso em: 10 abr. 2009. Documento da OMC n. G/26 - BISD 1S/53.
} 
efeito da mudança teria por objetivo impor um tratamento tarifário menos favorável aos grãos brasileiros. O painel considerou que os diferentes tipos de café não torrados poderiam ser considerados "produto similar", na medida em que eram comercializados em uma mistura composta de variadas espécies, que tornava indistinguível as características particulares. Além disso, reconheceu que, apesar de a Espanha ter o direito de introduzir divisões em seu sistema tarifário, todos os demais Estados-membros não previam tratamentos distintos para os variados tipos de café não torrado, o que caracterizava uma tentativa de utilizar a classificação destes para introduzir um tratamento discriminatório em prol de suas ex-colônias. Assim, concluiu-se que "unroasted, non-decaffeinated coffee beans listed in the Spanish Customs Tariff [...] should be considered as 'like products' within the meaning of Article I: 1". 354

Na visão de Robert Hudec, o Caso Spain - Coffee simboliza um divisor de águas, pois decidiu que as práticas espanholas eram inconsistentes com a prática vigente do GATT em relação às distinções tarifárias. Daí sinalizar um rompimento da interpretação da definição de "produto similar", construída pelos Casos Australia - Ammonium Sulphate e Germany Sardines, cujo efeito jurídico é fundamentar a ideia de que o painel pode desconsiderar as nuances do sistema de classificações tarifárias, quando examina a similaridade entre os produtos. 355

O painel do Caso Japan - Tariff on Imports of Spruce, Pine, Fir (SPF) Dimension Lumber (“Japan - Lumber") rejeitou as alegações do Canadá de que certas espécies de madeira macia (softwood) eram competitivamente equivalentes, pouco importando de qual espécie de árvore tenha sido feita. Por consequência, negou o reconhecimento de que tais mercadorias seriam consideradas produtos similares para os propósitos do artigo I:1. O Canadá apontou que o sistema de classificação tarifária do Japão foi estruturado para submeter suas madeiras a uma tributação desfavorável em comparação aos demais tipos equivalentes de madeira. Isso porque o conceito de "dimension lumber" era estranho à agenda de negociação japonesa, bem porque todas as variações de madeira respeitavam o mesmo padrão, medida, qualidade e finalidade. O painel esclareceu que o Acordo Geral sobre Tarifas e Comércio permitiu aos Estados-membros uma ampla discricionariedade para estruturar seus sistemas de classificação tarifária. Enfatizou-se também que, embora a diferenciação tarifária seja um

\footnotetext{
${ }^{354}$ GATT, Spain - Tariff Treatment of Unroasted Coffee, Report of the Panel, 1981, par. 1.1-1.7; 4.1-4.12.

${ }^{355}$ HUDEC, 2000, p. 114-116.
} 
meio legítimo de política comercial, não deve ser empregada para discriminar produtos similares provenientes de diferentes origens. Em sua decisão, o painel afirmou que os argumentos canadenses sobre a classificação da "dimension lumber" não eram apropriados para configurar a similaridade de produtos à luz do artigo I:1. ${ }^{356}$

As decisões dos Casos Spain - Coffee e Japan - Lumber não são consistentes, particularmente devido às distintas abordagens adotadas pelos painéis. Na perspectiva de William Davey e Joost Pauwelyn, a decisão do Caso Japan - Lumber parece ter a melhor fundamentação, visto que aos Estados-membros deve ser garantido o direito de decidir exatamente a quais tarifas cada produto estará sujeito. Ainda que a Organização Mundial do Comércio tenha por objetivo a liberalização do comércio, é expressamente reconhecido que os Estados-membros devem negociar seus compromissos tarifários segundo os respectivos interesses domésticos. A prática de permitir aos Membros estabelecer subcategorias em seu sistema de classificação tarifária parece, portanto, estar consonante com o sistema multilateral de comércio. ${ }^{357}$

Tal perspectiva parece ser confirmada pela decisão do Órgão de Apelação no Caso European Communities - Customs Classification of Certain Computer Equipment (“EC $L A N^{\prime}$ '), no qual os Estados Unidos alegavam que a reclassificação de certos equipamentos eletrônicos pelas Comunidades Europeias tinha por objetivo aumentar a incidência tarifária sobre eles, em plena violação do artigo II do GATT. O OPA reverteu a decisão do painel, que declarou a violação do artigo II:1, a fim de reconhecer que as negociações tarifárias são um processo recíproco de demanda e concessão, no qual Estados exportadores e importadores buscam garantir seus interesses, mediante um complexo exame de verificação e checagem das ofertas. Assim, a lista de compromissos representa uma promessa tarifária de cada Membro, enquanto o conjunto delas representa um compromisso comunitário entre todos os Membros. $^{358}$

\footnotetext{
${ }^{356}$ GATT. Japan - Tariff on Imports of Spruce, Pine, Fir (SPF) Dimension Lumber. Report of the Panel, 19 jul. 1989. Disponível em <http://www.wto.org/english/tratop_e/dispu_e/88lumber.wpf>. Acesso em: 10 abr. 2009. Documento da OMC n. L/6470 - BISD 36S/167, par. 3.37-3.39; 5.7-5.10.

${ }^{357}$ DAVEY; PAUWELYN, 2000, p. 29.

${ }^{358}$ OMC. European Communities - Customs Classification of Certain Computer Equipment. Report of the Report of the Appellate Body, 5 jun. 1998. Disponível em <http://www.wto.org/english/tratop_e/dispu_e/cases_e/ds62_e.htm>. Acesso em: 10 abr. 2009. Documento da OMC n. WT/DS62/AB/R, WT/DS67/AB/R, WT/DS68/AB/R, par. 1-3; 101-111.
} 
Em suma, argumentam W. Davey e J. Pauwelyn que a reclassificação tarifária de produtos não especificadamente mencionados nas listas de negociações, como nos Casos de Japan - Lumber e EC - LAN, não deveria incorrer em violações ao artigo I:1. Isso porque a falta de compromissos vinculantes não ensejaria legítima expectativa aos Estados-membros ou inconsistência com as obrigações do GATT. Com exceção do Caso Spain - Coffee, essa concepção encontra respaldo na jurisprudência da OMC, a qual vem reconhecendo majoritariamente a discricionariedade dos Estados-membros de subdividir os produtos em diferentes categorias tarifárias, nos termos do artigo II, sem implicar violações ao artigo I:1. Pelo contrário, as decisões do Órgão de Solução de Controvérsias alinham os sentidos atribuídos ao termo "produto similar" às funções informativa, positiva e estabilizadora do artigo I:1, resultando na ponderação dos efeitos normativos da função negativa sobre o sistema multilateral de comércio ${ }^{359}$

Diferentemente dessa situação examinada, na qual o tratamento discriminatório ocorre entre produtos de diferentes linhas tarifárias, a segunda categoria de discriminações envolvendo "produtos similares" consiste em discriminações de produtos classificados na mesma linha tarifária. Nesse contexto, o Caso Indonesia - Autos é paradigmático, visto a Indonésia ter imposto uma incidência tributária mais benéfica aos automóveis e respectivos componentes, desde que cumprissem com certas condições prévias. Entretanto, a lista tarifária da Indonésia não distinguia per se tais produtos em diferentes linhas. Daí Comunidades Europeias, Estados Unidos e Japão promoverem uma demanda, na qual questionavam os limites hermenêuticos do termo "produto similar", o qual deveria ser interpretado mais restritivamente do que as expressões qualificadoras das linhas tarifárias nas quais estava inserido.

No Caso Indonesia - Autos, o tópico envolvendo "produto similar" é relativamente simples, visto que a Indonésia aplicou uma distinção de produtos baseada em critérios de origem, configurando um caso de discriminação de juri. Isso permite questionar se a mera discriminação pela origem basta para configurar uma violação do tratamento da nação mais favorecida, ou se é necessário demonstrar a existência de produtos similares. Na hipótese de prevalecer esse último entendimento, seria difícil determinar a discriminação nas relações econômicas internacionais, visto que os produtos sempre diferem em algum aspecto. A

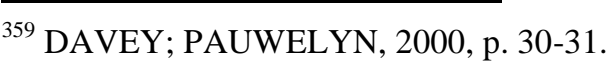


obrigação de comprovar a similaridade factual teria o condão de desviar a atenção de uma manifesta discriminação, focando-a na verificação da similitude dos produtos. Por isso, bastaria constatar a existência de uma discriminação de juri para incidir na violação do núcleo do artigo I:1, o qual visa proteger a expectativa de competitividade dos Estados-membros e não o fluxo atual de comércio. Nesse sentido, decidiu o painel que "a legislation itself may violate that provision if it could lead in principle to less favourable treatment of the same products.",360

Em suma, não há um consenso sobre os limites hermenêuticos do termo "produto similar, previsto no artigo I:1 do Acordo Geral de Tarifas e Comércio. No entanto, Robert Hudec salienta que a interpretação do conceito "produto similar" deve ser ampla, tendo por objetivo exigir uma justificação do Estado-membro acerca da imposição de específicas divisões do sistema de classificação tarifária, das diferentes incidências tributárias, bem como do distinto tratamento concedido por medidas regulatórias internas aos produtos importados. 361

Desse modo, ainda que pese o direito discricionário dos Estados-membros de qualificar as mercadorias segundo seus sistemas tarifários, a interpretação do termo "produto similar", em consonância com o sistema multilateral de comércio de vocação pragmático-finalística, teria por efeito superar a classificação centrada em torno de critérios meramente físicos, que facilitam a distinção discriminatória de mercadorias, em favor de critérios de similitude fundados sobre a noção de competitividade. Com isso, as práticas estatais estariam em harmonia com as quatro funções do tratamento da nação mais favorecida, positivadas no artigo I:1 do GATT.

\footnotetext{
${ }^{360}$ OMC, Indonesia - Autos, Report of the panel, par. 14.106-14.114; 14.137-14.142. DAVEY; PAUWELYN, 2000, p. 32-33.

${ }^{361}$ HUDEC, 2000, p. 110-112.
} 


\subsection{RELAÇÕES SISTÊMICO-NORMATIVAS DO ARTIGO I:1 DO GATT}

Conforme demonstrado pela análise estrutural, funcional e linguística do artigo I:1 do Acordo Geral sobre Tarifas e Comércio, a cláusula da nação mais favorecida constitui um poderoso instrumento jurídico de promoção dos princípios do sistema multilateral de comércio, particularmente a não discriminação, a reciprocidade e a transparência. As obrigações impostas pelo tratamento da nação mais favorecida disciplinam o relacionamento entre os Estados-membros, proibindo-os de discriminar em situações de fato ou de direito. Todavia, as relações de poder subjacentes ao GATT conduziram à inserção de dispositivos de calibração que excetuam a regra geral da CNMF, tendo por efeito diminuir sua imperatividade e eficácia normativa.

Construída, historicamente, como um instituto flexível e adaptável às transformações estruturais da ordem econômica internacional, a cláusula da nação mais favorecida, positivada no artigo I:1 do GATT, foi destituída de parte dessa maleabilidade. Isso decorre da incorporação das características aquisitiva e acumulativa ao tratamento da nação mais favorecida, o que promoveu uma transformação da função de calibração em função estabilizadora das relações econômicas internacionais. Com isso, os Estados Unidos pretendiam fortalecer a imperatividade e a eficácia normativa da CNMF, tendo por objetivo favorecer a institucionalização de um código comercial capaz de governar as relações econômicas internacionais, segundo os princípios da não discriminação, livre-comércio e multilateralismo. Caberia, portanto, ao tratamento da nação mais favorecida eliminar imediatamente os instrumentos protecionistas e discriminatórios empregados pelos Estadospartes.

Retomando brevemente o Capítulo 1.3.3., o Reino Unido e a Liga das Nações empreenderam os primeiros esforços no sentido de restabelecer a governança econômica internacional após a Primeira Guerra Mundial, por meio de tratados comerciais organizados em torno da cláusula da nação mais favorecida. Entretanto, tal tentativa malogrou 
copiosamente, em razão da divisão da ordem econômica internacional em blocos preferenciais e políticas protecionistas, que se relacionavam segundo uma lógica concorrente e excludente. Os instrumentos jurídicos empregados para impor tratamento discriminatório foram refinados, de tal sorte a formar um verdadeiro leque de armas econômicas, na forma de barreiras tarifárias e não tarifárias, incluindo medidas preferenciais, subsídios, quotas e outras. Assim, o período entreguerras foi responsável por exibir as mais perniciosas vicissitudes do protecionismo comercial, sendo um dos principais fatores para a eclosão da Segunda Guerra Mundial. Em razão disso, o plano de unificar estruturalmente a ordem econômica internacional somente viria a ser novamente defendido pelos Aliados após 1945 . $^{362}$

Durante as negociações que precederam a apresentação da Carta Proposta, referente à criação de uma organização internacional sobre comércio, os dispositivos de calibração foram exaustivamente analisados e debatidos pelos representantes dos Estados Unidos e Reino Unido. Guiada pela convicção neoliberal do Secretário de Estado Cordell Hull, a diplomacia comercial estadunidense sustentava o desmantelamento completo das medidas protecionistas e dos sistemas preferenciais, especialmente a Comunidade Britânica de Nações, os quais teriam sido os responsáveis por fomentar a discriminação e coerção nas relações comerciais, tendo por resultado a Grande Depressão econômica e as Guerras Mundiais. Os sistemas preferenciais representavam a mais perigosa manifestação política de barreira comercial, visto prejudicarem diretamente os exportadores estadunidenses. O Reino Unido guardava especial interesse na British Commonwealth, pois se valia dela para conservar o simbolismo do Império, assegurar a lealdade dos países aliados e beneficiar-se das vantagens econômicas. Como analisado, a hábil diplomacia inglesa foi capaz de desconstruir a concepção ideológica dos Estados Unidos sobre as preferências comerciais e medidas protecionistas, transferindo o debate do plano axiológico para o negocial.

Com o deslocamento do foco para as políticas comerciais, diminuiu a pressão ideológica neoliberal, permitindo à diplomacia inglesa e estadunidense negociarem, segundo uma racionalidade comercial-utilitarista, os termos da Carta Proposta, a qual viria a servir de fundamento para a elaboração do Acordo Geral sobre Tarifas e Comércio. Graças ao Reino Unido, os Estados Unidos aceitaram o emprego temporário, limitado e específico de regras de calibração, as quais permitiriam aos Estados-partes adotar medidas discriminatórias e

\footnotetext{
${ }^{362}$ BAILEY, 1932, p. 94-95.
} 
protecionistas, como ônus inerente ao processo de construção do sistema multilateral de comércio.

Não obstante, quando encerradas as negociações, o Acordo Geral sobre Tarifas e Comércio encontrava-se eivado de instrumentos, temporários e permanentes, de flexibilização obrigacional, cuja finalidade foi acomodar as questões mais sensíveis aos países capitalistas alinhados com os Estados Unidos, sem deixar de impor uma política comercial neoliberal para o comércio internacional. Desse modo, a despeito da ideologia neoliberal estadunidense, os Estados-partes, em especial o Reino Unido, não tinham por objetivo a construção de um sistema normativo rígido, razão pela qual procuraram lhe atribuir grande flexibilidade e fluidez, mediante a incorporação de numerosos dispositivos de calibração, na forma de exceções, reservas e renúncias, os quais estavam em consonância com a técnica de jurisprudência diplomática. Percebe-se que, pragmaticamente, houve a substituição da função de calibração, inerente à noção clássica da cláusula da nação mais favorecida, por regras de calibração, as quais visam ponderar a imperatividade e eficácia normativo-obrigacional do TNMF. $^{363}$

Segundo John H. Jackson, tais regras de calibração, permanentes ou temporárias, relaxaram as obrigações do tratamento da nação mais favorecida. Essa flexibilidade teria sido essencial na construção do GATT, pois se tratava de instituição nova e experimental, cujo propósito era regular o complexo e politicamente sensível comércio internacional no pósSegunda Guerra. As regras de calibração refletiram, portanto, o consenso possível dentre os interesses dos maiores defensores do livre-comércio à época, Estados Unidos e Reino Unido, sendo fundamentais para a criação e perseverança do Acordo Geral de Tarifas e Comércio. Nas décadas seguintes, houve a ampliação desse mosaico de dispositivos de relaxamento do artigo I:1, cujo efeito foi agravar a suscetibilidade do sistema multilateral de comércio poweroriented ao jogo de poder entre os Estados-partes, tornando-o incapaz de evitar a vindoura escalada de tratamentos discriminatórios e protecionistas. ${ }^{364}$

Há, aproximadamente, seis décadas da fundação do GATT, a cláusula da nação mais favorecida está longe de ser a regra determinante das relações econômicas internacionais, tornando-se quase uma exceção. Embora o comércio entre as maiores economias do mundo

\footnotetext{
${ }^{363}$ MILLER, 2000, p. 2-5.

${ }^{364}$ SCHWARZENBERGER, 1966, p. 71. HUDEC, 1975, p. 26-27. JACKSON, 1969, p. 170.
} 
continue a ser majoritariamente conduzido com base no artigo I:1, surgem questões complexas e preocupantes, envolvendo a interação entre os princípios da não discriminação, da reciprocidade e da transparência e o mosaico de regras de calibração. Com efeito, os dispositivos de flexibilização autorizam a proliferação dos acordos preferenciais de comércio e das medidas restritivas, sujeitando o sistema multilateral de comércio a problemas de coerência e eficácia normativa. ${ }^{365}$

Desse modo, será examinado, no contexto do sistema multilateral de comércio, o relacionamento entre o artigo I:1 e as principais regras de exceção do GATT, de modo a verificar se, ante os desafios sistêmicos, a cláusula da nação mais favorecida permanece como regra determinante para os controles de licitude e de legalidade.

\subsubsection{Preferências Históricas (Artigo I:2 e 3 do GATT)}

O colapso do sistema de comércio internacional de caráter contratual e bilateral implicou a emergência de sistemas preferenciais de comércio, os quais revelaram as nefastas características do regionalismo excludente e predatório. É, nesse contexto, que o Reino Unido, tradicional defensor do livre-comércio, celebrou o Tratado de Ottowa de 1932 com os Estados da Comunidade Britânica de Nações, o qual visava resolver seus problemas de desequilíbrio externo por meio de medidas protecionistas e discriminatórias, cujos efeitos consistiram na imposição de barreiras tarifárias e não tarifárias a terceiros Estados. O drástico afastamento do princípio de não discriminação levou a cláusula da nação mais favorecida ao ostracismo, na medida em que os demais países imperialistas seguiram o exemplo britânico nos respectivos sistemas coloniais. A política protecionista seria, assim, responsável por aumentar consideravelmente a fricção entre os Estados, no período anterior à Segunda Guerra Mundial.

Por essa razão, o primeiro tópico negociado entre os Estados Unidos e Reino Unido, para a formulação da Carta Preparatória, referia-se justamente aos sistemas preferenciais de comércio preexistentes. Não havia dúvidas de que tais sistemas imperialistas eram utilizados como armas comerciais, tendo por objetivo proteger e discriminar em favor próprio as

\footnotetext{
${ }^{365}$ SUTHERLAND, 2004, p. 19.
} 
relações econômicas internacionais. Todavia, os valores neoliberais da diplomacia estadunidense não eram suficientemente convincentes para os negociadores do Reino Unido, os quais defendiam os regimes preferenciais como condição sine qua non para apoiar a proposta de criação de uma organização internacional sobre comércio. Na verdade, os britânicos encontravam-se em uma difícil situação. Por um lado, não prescindiam do auxílio econômico dos Estados Unidos. Por outro, detinham um relacionamento único de gratidão e dependência com os Estados da British Commonwealth, visto estes terem, desde o começo da Segunda Guerra, apoiado o Reino Unido, bem como terem servido de mercados preferenciais aos produtos ingleses. O debate sobre sistemas preferenciais era, claramente, responsável por provocar fortes emoções nos dois lados do Atlântico.

Apesar dos conflitos de concepção, os negociadores conseguiram alcançar um acordo sobre o tópico. A Carta Proposta estabelecia que os sistemas preferenciais existentes naquela data fossem aceitos como exceção à regra geral da cláusula da nação mais favorecida, porém se sujeitariam a certas condições e limitações, cujos objetivos eram, no longo prazo, desmantelá-los completamente. Desse modo, propunha-se vedar aos Estados-partes o direito de criar novos regimes preferenciais de comércio, salvo na hipótese da constituição de união aduaneira. $^{366}$

O GATT recepcionou explicitamente a proposta da Carta Preparatória, de modo a incluir a referida regra de calibração na redação do próprio artigo I, no qual se estabelece a regra geral do tratamento da nação mais favorecida, excepcionando, em seus parágrafos 2 e 3 , os sistemas históricos de preferências arrolados nos Anexos de A a F. Ao limitar nominalmente as exceções, os Estados Unidos conseguiram impedir a proliferação e eliminar, gradualmente, os regimes preferenciais; enquanto o Reino Unido beneficiou-se, por anos, dos privilégios comerciais da British Commonwealth. Graças à rigidez do dispositivo e à gradativa diminuição das tarifas aduaneiras, as preferências históricas tornaram-se progressivamente menos importantes. A formação e o aprofundamento das Comunidades Europeias alteraram o significado das preferências históricas, na medida em que estas foram transformadas em acordos especiais do bloco. Daí as Convenções de Yaoundé e Lomé poderem ser consideradas

\footnotetext{
${ }^{366}$ FRANKEL, Jeffrey A. Regional trading blocs in the world economic system. Washington: Peterson Institute for International Economics, 1997, p. 126-128. USTOR, 1970, p. 219. BAILEY, 1932, p. 96. KOCK, 1969, p. 43-44.
} 
uma continuação material das exceções históricas previstas nos Anexos, apesar de diferente fundamentação legal. ${ }^{367}$

Apesar de constituir verdadeiro marco histórico, a regra de calibração, que autoriza a manutenção dos sistemas preferenciais de comércio, perdeu sua relevância em face do novo contexto das relações econômicas internacionais. Com efeito, a eficácia normativa e social do artigo I:2 do GATT evitou que, na ordem econômica internacional contemporânea, os regimes históricos figurassem como elemento problemático conformador dos desafios sistêmicos à cláusula da nação mais favorecida.

\subsubsection{Restrições Quantitativas (Artigos XI e XII do GATT)}

O segundo mais controverso tema das negociações entre Estados Unidos e Reino Unido, durante a formulação da Carta Proposta, versava sobre as restrições quantitativas. Os diplomatas de Cordell Hull rejeitavam veementemente a hipótese de autorizar o emprego de restrições quantitativas pelos Estados-partes, em razão das consequências discriminatórias e distorcivas da arma protecionista. Em princípio, a utilização de quotas de importações e medidas similares para proteção da produção doméstica deveria ser completamente banida. Os negociadores britânicos, porém, foram hábeis em sugerir a inclusão de uma permissão para a aplicação de quotas apenas nos casos de carência ou de excedência de produtos, bem como de desequilíbrio da balança de pagamentos. Por fim, os Estados Unidos aceitaram a regra de calibração que autoriza os Estados-partes a excepcionar, em hipóteses típicas, a obrigação de eliminar todas as restrições quantitativas, mas impuseram severas condições a qualquer outra forma de restrição quantitativa. ${ }^{368}$

O artigo XI do GATT determina a eliminação geral das restrições quantitativas, dispondo que "nenhuma parte contratante instituirá ou manterá [...] proibições ou restrições" aos produtos dos Estados-membros, salvo nas hipóteses previstas no parágrafo 2 do artigo XI e no artigo XII do GATT. O artigo XI:2 prevê que a vedação aos regimes de restrição ou

\footnotetext{
${ }^{367}$ JACKSON, John H. The jurisprudence of GATT and the WTO: insights on treaty law and economic relations. Cambridge: Cambridge University Press, 2000, p. 61-62. JACKSON, 1969, p. 264-265.

${ }^{368}$ MILLER, 2000, p. 5. KOCK, 1969, p. 46-47.
} 
proibição de importações e exportações não se aplica nas hipóteses de (i) penúria alimentar; (ii) carência de produtos essenciais; (iii) controle de qualidade; e (iv) medidas governamentais que tenham por finalidade administrar situações específicas do agronegócio. Não obstante as disposições do artigo XI:1, o artigo XII autoriza os Estados-partes a impor quotas quanto ao volume ou valor de qualquer mercadoria, "a fim de salvaguardar sua posição financeira exterior e o equilíbrio de sua balança de pagamentos".

É imperativo, no entanto, que as quotas permitidas respeitem o princípio da não discriminação, conforme disposto nos artigos I:1 e XIII. Nesse particular, ressalta-se que o relacionamento dos artigos I:1 e XIII com as restrições quantitativas deve submeter-se à regra da especialidade, conforme dispôs os Casos EEC - Restrictions on Imports of Apples e EEC Restrictions on Imports of Dessert Apples.

No Caso EEC - Restrictions on Imports of Apples de 1980, o painel, após examinar os argumentos apresentados pelo Chile acerca da inconsistência das medidas impostas pela Comunidade Econômica Europeia em relação ao artigo I:1, decidiu ser "more appropriate to examine the matter in the context of Article XIII which deals with the non-discriminatory administration of quantitative restrictions rather than Article I: 1". Apesar das quotas da CEE estarem em conformidade com o artigo XIII:3(b), o painel reconheceu, porém, que tais medidas violavam o tratamento da nação mais favorecida positivado no artigo XIII, pois estavam em desacordo com os respectivos parágrafos 1, 2(a)(d) e parte do 3(b). ${ }^{369}$

O Caso EEC - Restrictions on Imports of Dessert Apples de 1989 versou sobre a alegação do Chile de que as quotas de importação de sobremesas de maçã aplicadas pela CEE eram inconsistentes com o artigo I:1. O painel reiterou que na hipótese de restrições quantitativas é mais apropriado o exame de consistência das "EEC measures with the mostfavoured-nation principles of the General Agreement in the context of Article XIII”. E complementou: "This provision deals with the non-discriminatory administration of quantitative restrictions and is thus the lex specialis in this particular case”. Não obstante, as restrições quantitativas impostas pela Comunidade Econômica Europeia produziam ilícitos efeitos discriminatórios, razão pela qual foram consideradas inconsistentes com o disposto no artigo XIII. Constatou-se, assim, que o artigo XIII positiva no Acordo Geral sobre Tarifas e

\footnotetext{
${ }^{369}$ GATT. European Economic Community - Restrictions on Imports of Apples from Chile. Report of the Panel, 10 nov. 1980. Disponível em <http://www.wto.org/english/tratop_e/dispu_e/79apples.wpf>. Acesso em: 10 abr. 2009. Documento da OMC n. L/5047 - BISD 27S/98, par. 4.1; 4.11-4.21.
} 
Comércio uma versão ainda mais especializada da cláusula da nação mais favorecida, própria para restrições quantitativas, o que constitui uma lex specialis em relação ao artigo I: $1 .^{370}$

No Caso EC - Banana III, a diferença quanto à especialidade da cláusula da nação mais favorecida do artigo XIII foi decisiva para a reforma da decisão do painel pelo Órgão de Apelação. Em sua decisão reformadora, o OPA apontou que, embora o artigo I:1 e o artigo XIII do GATT tenham por finalidade a não discriminação, o seu relacionamento não é vinculante o suficiente para que a suspensão das obrigações do artigo I:1, outorgada com fundamento no artigo XXIV, implique a dispensa das CE dos deveres impostos pelo artigo XIII. O fato da renúncia temporária ao artigo XIII ter sido concedida apenas uma única vez pelos Estados-partes do GATT demonstra o caráter verdadeiramente excepcional da medida, bem como reforça a conclusão do Órgão de Apelação. ${ }^{371}$

Contudo, ao prever que as quotas devem ser impostas em bases não discriminatórias, criou-se um verdadeiro desafio ao conceito do tratamento da nação mais favorecida. Isso porque, embora os diversos sistemas de licença, baseados em quota global, em abertura igualitária a todos os Membros, ou em licitação por maior preço, pareçam ser consistentes com o princípio da não discriminação, tais modalidades de restrições quantitativas tendem a conservar preferências comerciais historicamente concedidas. Na explicação de J. Jackson, "when quotas or licenses are allocated on a geographical or enterprise basis [...] then to some extent MFN is not completely fulfilled, because different countries or enterprises will have different types of fixed rights". Dessa forma, o artigo XIII estabeleceria um "quasi" MFN principle”, visto que, na maioria dos casos, os sistemas de licença são tendentes a preservar o tratamento discriminatório vigente, prejudicando o produtor mais eficiente. ${ }^{372}$

Não obstante, as restrições impostas pelo tratamento da nação mais favorecida disposto no artigo XIII, podem ser afastadas nos termos do artigo XII e da seção B do artigo XVIII. Nessas hipóteses de profundo e geral desequilíbrio financeiro, capaz de prejudicar o fluxo de comércio internacional, o artigo XIV estabelece que o Estado-membro pode aplicar restrições às importações, dispensando os limites não discriminatórios. Com efeito, os Estados estarão dispensados temporariamente das limitações do artigo XIII para restabelecer seu equilíbrio

\footnotetext{
${ }^{370}$ GATT. European Economic Community - Restrictions on Imports of Dessert Apples. Report of the Panel, 22 jun. 1989. Disponível em <http://www.wto.org/english/tratop_e/dispu_e/88applec.wpf >. Acesso em: 10 abr. 2009. Documento da OMC n. L/6491 - BISD 36S/93, par. 12.20-12.28.

${ }^{371}$ OMC, EC - Bananas III, Report of the Appellate Body, par. 183-191.

${ }^{372}$ JACKSON, 1997, p. 164.
} 
financeiro numa base sã e saudável, sem prejudicar os interesses econômicos de outros Membros.

Diante do exposto, conclui-se que, nos casos envolvendo restrições quantitativas, 0 artigo I:1 tem sua eficácia normativa afastada em razão da especialidade do artigo XIII. Nesse particular, o Órgão de Solução de Controvérsias têm se destacado pela construção pragmáticofinalística de suas decisões. Ao analisar a relação do artigo XIII com os artigos XI e XII, o OSC tem confirmado o caráter excepcional dessa regra de calibração, fazendo prevalecer o tratamento da nação mais favorecida, em especial sua função de não discriminação, no exercício do controle de legalidade e licitude das relações entre os Estados-membros.

\subsubsection{Antidumping e medidas compensatórias (Artigo VI do GATT)}

O sistema multilateral de comércio tem dois instrumentos jurídicos, cuja função é evitar que o mercado doméstico de um Estado-membro seja lesado, em razão de práticas desleais ao comércio (unfair trade) perpetradas pelos demais Membros. O antidumping e as medidas contra subsídios são mecanismos de defesa comercial que permitem a incidência sobre certos produtos importados de um direito especial, visando neutralizar os efeitos nocivos de atos desleais ao comércio. A medida antidumping pode ser imposta aos produtos que tenham sido exportados por preços inferiores ao valor normal praticado no mercado interno do exportador. A medida antissubsídios é aplicável sobre produtos subsidiados por políticas governamentais, tendo por finalidade neutralizar a subvenção concedida. Constata-se, assim, que o direito antidumping e o direito de compensação têm natureza essencialmente discriminatória e protecionista; logo, consistem em regras de calibração da cláusula da nação mais favorecida. ${ }^{373}$

Por serem potencialmente danosos ao comércio internacional, o GATT positivou, em seu artigo VI, os institutos do antidumping e das medidas contra subsídios. A regulamentação multilateral permitiu a diminuição de conflitos acerca de suas aplicações discricionárias pelos Estados. Entretanto, o caráter amplo e genérico do artigo VI revelou-se insuficiente para a

\footnotetext{
${ }^{373}$ USTOR, 1970, p. 225.
} 
tarefa, o que exigiu, posteriormente, o aperfeiçoamento regulatório desses instrumentos jurídicos . Em razão disso, os Estados-partes formularam, na Rodada Kennedy, um detalhado Código Antidumping e, na Rodada Tóquio, um Código sobre Subsídios, nos quais foram previstas obrigações substantivas e procedimentais acerca da utilização dos institutos de defesa comercial.

O passo seguinte ocorreu na Rodada Uruguai, na qual os referidos Códigos foram substituídos, respectivamente, pelo Acordo sobre a Implementação do Artigo VI ("Acordo Antidumping") e pelo Acordo sobre Subsídios e Medidas Compensatórias (“Acordo SCM”). Note-se que o sistema multilateral de comércio passa a se referir a acordos e não mais a códigos. Isso decorre tanto do princípio de empreendimento único que imputa a todos os Estados-membros a condição de aderirem irrestritamente às normas-acordos, as quais deixam de ser meramente tratados facultativos, bem como do fato de estarem sujeitos ao Entendimento sobre Solução de Controvérsias. O objetivo do Acordo Antidumping e do Acordo SCM consiste em conferir regras mais claras e objetivas ao artigo VI, a fim de determinar com maior sorte de detalhes quais são as práticas lesivas ao comércio internacional, restringido com maior eficácia os critérios subjetivos antes existentes. ${ }^{374}$

A primeira manifestação em discurso jurídico-decisório sobre a relação entre os artigos I:1 e VI do GATT foi no Caso Swedish - Anti-Dumping Duties de 1955, no qual a Itália apresentou uma demanda em face da Suécia, alegando que o Decreto Real Sueco de 1954 era inconsistente com as obrigações do GATT. À época, o Decreto Real Sueco estabeleceu regras antidumping sobre a importação de meias de nylon, as quais permitiam ao governo sueco aplicar medidas e isentar da investigação produtos que fossem importados até certo valor mínimo, fixado administrativamente. A Itália considerou que o sistema de preço mínimo, como um procedimento antidumping, infringia o GATT, na medida em que discriminava os produtores de baixo-custo em prol dos exportadores de alto-custo, privando-os das vantagens decorrentes do tratamento da nação mais favorecida. Examinada a questão, o painel rejeitou a alegação italiana, sustentando que a utilização de práticas de dumping pelo Estado exportador, sem que haja imposição de medidas antidumping pelo Estado importador, não consiste em

\footnotetext{
${ }^{374}$ BENTLEY, Philip; SILBERSTON, Aubrey. Anti-dumping and Countervailing Action: Limits Imposed by Economic and Legal Theory. Cheltenham: Edward Elgar Publishing, 2007, p. 5-6. BAPTISTA, Luiz Olavo. Dumping e anti-dumping no Brasil. In: AMARAL JR., Alberto do (coord). OMC e o comércio internacional. São Paulo: Aduaneiras, 2002, p. 36. BARRAL, Welber. Dumping e Comércio Internacional. Rio de Janeiro: Forense, 2000, p. 95-96.
} 
uma violação ao artigo I:1, pois recorrer à proteção prevista no artigo VI é um direito e não obrigação do Estado lesado. Desse modo, o sistema de preços mínimos, estabelecido pelo Decreto Real Sueco, ainda que produza efeitos distorcivos no fluxo de comércio internacional, não é a priori inconsistente com a cláusula da nação mais favorecida. ${ }^{375}$

No Caso United States - Definition of Industry Concerning Wine and Grape Product de 1986, o painel declarou que o artigo VI, ao permitir a imposição de medidas contrárias ao tratamento da nação mais favorecida, constitui uma exceção ao artigo I:1, devendo, por consequência, ser interpretado restritivamente. Adicionalmente, o painel do Caso United States - Countervailing Duties on Fresh, Chilled and Frozen Pork from Canada de 1990 reconheceu ser proibida a imposição de encargos diferentes dos aduaneiros aos produtos importados arrolados nas listas de compromissos. Isso significa que os instrumentos jurídicos, cuja essência é discriminatória, somente podem ser aplicados nas hipóteses expressamente definidas pelo GATT, visto serem interpretados restritamente. Em razão disso, os Estados devem assegurar-se de que a sua legislação de defesa comercial esteja em estrita consonância com o artigo I:1 do GATT. ${ }^{376}$

Em 1960, o segundo relatório do grupo de especialistas sobre antidumping e medidas compensatórias do GATT dispôs que os Estados-partes devem, na hipótese em que os produtos importados com preço abaixo do normal tiverem origens diversas, empregar os instrumentos jurídicos do artigo VI de forma não discriminatória, ou seja, tratando igualmente todas as "dumped imports" em consonância com a CNMF. Nesse sentido, o painel do Caso US - MFN Footwear decidiu que as regras e formalidades aplicáveis aos direitos de compensação estão sujeitas aos limites da cláusula da nação mais favorecida. Isso significa que os Estados podem estabelecer, em sua legislação doméstica, diferentes regras sobre medidas antissubsídios para diferentes categorias de produtos, ou pode ainda isentar uma categoria.

\footnotetext{
${ }^{375}$ GATT. Swedish - Anti-Dumping Duties. Report of the Panel, 26 fev. 1955. Disponível em $<$ http://www.wto.org/english/tratop_e/dispu_e/54antidu.wpf >. Acesso em: 10 abr. 2009. Documento da OMC n. L/328 - BISD 3S/81, par. 1-17.

${ }^{376}$ GATT. United States - Definition of Industry Concerning Wine and Grape Product. Report of the Panel, 28 abr. 1992. Disponível em <http://www.wto.org/english/tratop_e/dispu_e/85winegr.wpf〉. Acesso em: 11 jun. 2009. Documento da OMC n. SCM/71 - BISD 39S/436, par. 3.22; 4.5. GATT. United States - Countervailing Duties on Fresh, Chilled and Frozen Pork from Canada. Report of the Panel, 11 jul. 1991. Disponível em $\langle$ http://www.wto.org/english/tratop_e/dispu_e/89pork.wpf〉. Acesso em: 11 jun. 2009. Documento da OMC n. DS7/R - BISD 38S/30, par. 4.4.
} 
Todavia, o artigo I:1 proíbe o tratamento discriminatório entre produtos similares pertencentes à mesma categoria e originados em territórios diferentes. ${ }^{377}$

Os institutos do antidumping e das medidas contra subsídios constituem regras de calibração que excetuam a cláusula da nação mais favorecida. Considerando que o artigo I:1 é a regra geral do sistema multilateral de comércio, o tratamento discriminatório somente pode ser aplicado dentro de certos limites impostos pelo tratamento da nação mais favorecida. Daí exigir-se tanto uma interpretação restritiva dos termos do artigo VI, como a proibição de impor medidas diferenciadas a produtos similares importados com preço abaixo do normal, classificados na mesma categoria, mas de origens díspares. Constata-se, portanto, que as medidas de flexibilização, ainda que tenham por efeito excepcionar certas obrigações, devem respeitar as quatro funções intrínsecas do artigo I:1 do GATT.

\subsubsection{Salvaguardas (Artigo XIX do GATT)}

No mesmo contexto de instrumentos jurídicos que permitem restringir as importações de mercadorias, as salvaguardas têm posição destacada no sistema multilateral de comércio. Isso porque, em uma ordem econômica internacional eivada de mecanismos protecionistas e discriminatórios, a salvaguarda é uma medida de defesa comercial que pode ser aplicada consistentemente com a cláusula da nação mais favorecida. Daí ser defendida pelos economistas, os quais apontam dois argumentos fundamentais.

Primeiro, enquanto as medidas antidumping e medidas contra subsídios pressupõem a alegação de práticas desleais ao comércio, cujas definições não encontram clara fundamentação econômica, a utilização das salvaguardas não está relacionada a honestidade mercantil, mas foca-se no desenvolvimento de políticas de ajuste econômico, que buscam garantir um período de tempo suficiente para aumentar a competitividade da indústria doméstica frente à concorrência internacional. Segundo, as salvaguardas foram desenhadas para proteger a indústria interna contra todos os produtos importados, independentemente de

377 GATT. Group of Experts on Anti-Dumping and Countervailing Duties. Second Report, 29 jan. 1960. Disponível em <http://www.wto.org/gatt_docs/English/SULPDF/90730046.pdf>. Acesso em: 11 jun. 2009. Documento do GATT n. L/1141, par. 26. GATT, US - MFN Footwear, Report by the Panel, par. 6.11-6.12; 7.2. 
sua origem. Desse modo, as salvaguardas são, em princípio, medidas não discriminatórias, ainda que protecionistas.

A versão moderna do instituto remonta à cláusula de escape (escape clause), empregada, desde 1934, pela política de liberalização comercial dos Estados Unidos, sob a rubrica dos Reciprocal Trade Agreements. No sistema multilateral de comércio, as salvaguardas foram, primeiramente, disciplinadas no artigo XIX do GATT e, após a Rodada Uruguai, no Acordo sobre Salvaguardas, o qual estabeleceu critérios mais claros e objetivos, assegurando rigorosas exigências para a adoção e manutenção dessas medidas. Nos termos do artigo XIX, os Estados estão autorizados a impor salvaguardas para proteger segmentos de mercado interno contra prejuízos ou ameaças de prejuízo, causados por aumentos abruptos e imprevistos nas importações de determinados produtos. As medidas impostas têm caráter temporário, com duração de três anos ou menos, pois devem vigorar enquanto for necessário para prevenir os danos, sob risco de o Estado-membro ser demandado no Órgão de Solução de Controvérsias, caso não consiga provar o aumento absoluto das importações. ${ }^{378}$

Apesar de o artigo XIX ter sido desenhado para respeitar a cláusula da nação mais favorecida, as salvaguardas vêm sendo empregadas de modo discriminatório, na medida em que podem ser impostas em face de Estados específicos. Na hipótese de um Estado ser autorizado a aplicar o artigo XIX, a salvaguarda poderá tomar a forma de uma tarifa ou uma restrição quantitativa. O formato do instrumento jurídico utilizado para implementar a salvaguarda poderá discriminar implícita ou explicitamente entre os Estados exportadores. Diferentemente da proteção por tarifas, as restrições quantitativas estão sujeitas a produzir efeitos discriminatórios entre os exportadores. Isso porque tendem implicitamente a conservar a participação histórica do exportador tradicional no mercado, em detrimento dos produtores mais novos e eficientes. Não obstante, o Estado utilizador de salvaguardas poderá discriminar explicitamente os demais Membros, caso venha a isentar os países em desenvolvimento ou os Estados-partes de acordos preferenciais de comércio das restrições impostas. ${ }^{379}$

No Caso Norway - Restrictions on Imports of Certain Textile Products de 1980, o painel examinou as alegações apresentadas por Hong Kong de que a medida de salvaguardas imposta pela Noruega violava os dispositivos do GATT. Com fundamento no artigo XIX, a

\footnotetext{
${ }^{378}$ JACKSON, 1997, p. 175-181. TREBILCOCK; HOWSE, 2005, p. 300-301.

${ }^{379}$ BOWN, Chad P.; MCCULLOCH, Rachel. Nondiscrimination and the WTO Agreement on Safeguards. World Trade Review, [s.1.], v. 2, n. 3, 2003, p. 327-348.
} 
Noruega introduziu um sistema global de quotas sobre nove produtos têxteis, sendo que as mercadorias originadas na Comunidade Econômica Europeia, na Associação Europeia de Livre-Comércio ("EFTA") e em seis países em desenvolvimento, com os quais foram celebrados acordos bilaterais de comércio, não estariam submetidos à medida de defesa comercial. O painel decidiu que o formato jurídico da salvaguarda, empregada pela Noruega em resposta a uma situação emergencial, deveria estar sujeito ao tratamento da nação mais favorecida positivado no artigo XIII. Com efeito, ao não atribuir a Hong Kong quotas de importação em bases não discriminatórias, as medida norueguesas foram declaradas inconsistentes com o artigo XIII. ${ }^{380}$

No mesmo sentido, o Acordo sobre Salvaguardas veio reiterar o dever dos Estadosmembros de respeitar o princípio da não discriminação ao estabelecer medidas de salvaguarda. $\mathrm{O}$ artigo 2.2 prevê que "safeguard measures shall be applied to a product being imported irrespective of its source". Todavia, as salvaguardas impostas na forma de restrições quantitativas ainda possibilitam impor tratamento discriminatório, implícita ou explicitamente. Desse modo, apesar do aprimoramento regulatório do instrumento no sentido de evitar a discriminação, as salvaguardas constituem uma regra de calibração da cláusula da nação mais favorecida.

\subsubsection{Suspensão de concessões e outras obrigações (Artigo XXIII do GATT)}

A doutrina aponta que uma das mais importantes transformações introduzidas pela Rodada Uruguai foi o aprimoramento do mecanismo de solução de controvérsias, em particular do regime acerca das sanções aplicáveis quando do descumprimento pelos Estadosmembros das regras do sistema multilateral de comércio. Na sistemática do Entendimento sobre as Regras e Procedimentos que Governam a Solução de Controvérsias, o Estado que for

\footnotetext{
${ }^{380}$ Norway - Restrictions on Imports of Certain Textile Products. Report of the Panel, 18 jun. 1980. Disponível em <http://www.wto.org/english/tratop_e/dispu_e/79textil.wpf>. Acesso em: 10 abr. 2009. Documento da OMC n. L/4959 - BISD 27S/119, par. 5-6; 14.
} 
condenado pelo Órgão de Solução de Controvérsias por não implementar o relatório do painel estará sujeito a sanções nele previstas.

Cumpre, preliminarmente, esclarecer que os acordos que compõem o sistema GATT/OMC não empregam o termo sanção para designar as consequências jurídicas decorrentes da infração de suas normas. Por tradição que remonta à Carta de Havana, o artigo XXIII do GATT prevê a possibilidade dos Estados-partes de autorizarem as partes lesadas a suspender as concessões ou obrigações acordadas, nos casos de graves violações normativas. No mesmo sentido, o Entendimento sobre Solução de Controvérsias, adotado na Rodada Uruguai, estabelece, em seu artigo 22, que os Estados-membros podem solicitar a suspensão, temporária, da aplicação de concessões e outras obrigações, nas hipóteses em que as decisões e recomendações do Órgão de Solução de Controvérsias não tiverem sido executadas pelo Estado infrator.

$\mathrm{Na}$ perspectiva de doutrinadores clássicos, como Robert Hudec, Clair Wilcox e Kenneth Dam, os remédios previstos no GATT previam apenas a compensação dos danos pelas infrações cometidas e nada mais. O objetivo era resguardar o equilíbrio contratual que a violação rompeu, de modo a assegurar as vantagens e obrigações acordadas contra os abusos que viessem a erodi-las. Nas palavras de C. Wilcox, "it is nowhere described as a penalty to be imposed on members who may violate their obligations or as a sanction to insure that these obligations will be observed".

Para Steve Charnovitz, o mecanismo de solução de controvérsias do GATT foi completamente renovado no novo contexto da $\mathrm{OMC}$, na medida em que teria havido a passagem do paradigma de equilíbrio, previsto pelo artigo XXIII do GATT, para o paradigma de sanções comerciais, instituído pelo artigo 22 do ESC. Ainda que tenham introduzido preciosas considerações, tais concepções acerca da natureza dos remédios do sistema GATT/OMC são excessivamente restritivas. Na obra de Hans Kelsen, a sanção tem por características fundamentais ser um ato coercitivo imposto por uma autoridade, que tenha por objetivo alterar a conduta dos sujeitos mediante a privação de um bem. Nesse sentido, Alberto do Amaral Jr. sustenta que esses elementos em nada destoam do instituído na OMC, visto ser a suspensão um "ato coercitivo, que se caracteriza pela interferência limitada na esfera de interesse protegido de outro Estado, mediante a privação temporária de direitos legitimamente estabelecidos”. A suspensão de concessões é, no domínio do sistema multilateral de comércio, 
uma sanção que visa restituir o equilíbrio que vigorava antes da infração, mediante a reparação dos danos sofridos. ${ }^{381}$

Os efeitos da sanção ultrapassam o relacionamento bilateral dos Estados-membros, repercutindo amplamente no fluxo de comércio internacional. Isso porque a sanção fortalece e promove, por um lado, o cumprimento das normas do sistema multilateral de comércio. Por outro lado, ela diminui os benefícios do livre-comércio, causando prejuízos tanto aos Estados exportadores quanto aos importadores. Apesar do discurso neoliberal, a suspensão das concessões fundamenta-se implicitamente numa visão mercantilista de que exportar significa vitória e importar, derrota. Esse modelo sancionatório prejudica o próprio escopo da OMC, que é o aumento do bem-estar, por meio da liberalização do comércio internacional mediante concessões recíprocas e tratamento não discriminatório. ${ }^{382}$

Assim, na possibilidade de um Estado-membro ser condenado por violação às normas do SMC, o Órgão de Solução de Controvérsias pode autorizar, com base no artigo 22 do ESC, a suspensão de concessões tarifárias ou do tratamento da nação mais favorecida. Com efeito, impõe-se exceções temporárias ao artigo I:1 do GATT, resultando no aumento da discriminação e diminuição do comércio. ${ }^{383}$

\subsubsection{Acordos Preferenciais de Comércio (Artigo XXIV do GATT)}

Não há qualquer dúvida de que os acordos preferenciais de comércio são o tema mais examinado da Organização Mundial do Comércio, sendo anualmente objeto de diversos trabalhos que analisam seus aspectos políticos, econômicos e jurídicos. A presente dissertação não tem a pretensão de investigar a questão exaustivamente, mas tão somente naquilo em que for pertinente à cláusula da nação mais favorecida. A relevância desta análise está justificada

\footnotetext{
${ }^{381}$ HUDEC, Robert E. The Gatt Legal System: A Diplomat's Jurisprudence. In: ___ . Essays on the nature of international trade law. Londres: Cameron May, 1999, p. 28-35. WILCOX, 1949, p. 159. DAM, 1970, p. 357367. CHARNOVITZ, Steve. Rethinking WTO Trade Sanctions. American Journal of International Law, [s.1.], v. 95, n. 4, 2001, p. 800-808. KELSEN, 2000, p. 121-124. AMARAL JR., 2006, p. 232-240.

${ }^{382}$ CHARNOVITZ, 2001, p. 792. LAWRENCE, Robert Z. Crimes \& Punishments: retaliation under the WTO. Washington: Institute for International Economics, 2003, p. 13-47. KRUGMAN, Paul R. What Should Trade Negotiators Negotiate About? Journal of Economic Literature, [s.l.], v. XXXV, n. 1, 1997, p. 113-120.

${ }^{383}$ JACKSON, 1997, p. 164. TREBILCOCK; HOWSE, 2002, p. 116.
} 
no ângulo adotado, qual seja, de investigar o artigo XXIV do GATT não restrito a si, mas em sua relação com o artigo I:1 do GATT. Nesse sentido, apresentar-se-ão, brevemente, a construção histórica e a fundamentação material do artigo XXIV, de modo a delimitar seus elementos essenciais, visando à análise da relação sistêmico-normativa à luz dos desafios sistêmicos.

Cumpre, primeiramente, esclarecer o significado do termo de conceito acordo preferencial de comércio. O artigo XXIV do Acordo Geral sobre Tarifas e Comércio, ao disciplinar as uniões aduaneiras ("UA") e as áreas de livre-comércio ("ALC"), não positiva um termo de conceito que designe o gênero desses tratados internacionais, celebrados entre entes dotados de autonomia sobre sua política comercial, cujo objeto consiste na outorga mútua e exclusiva de preferências comerciais. As demais denominações existentes, tais como acordos regionais de comércio ou blocos regionais de comércio, estão restritas ao escopo geográfico ou material, não explicitando verdadeiramente o ponto de diferenciação: a concessão de preferências comerciais em bases recíprocas e discriminatórias entre as partes do acordo. As áreas de livre-comércio e uniões aduaneiras são, portanto, duas espécies dentre outras do gênero acordo preferencial de comércio.

A origem do artigo XXIV está intrinsecamente ligada à Carta Proposta, formulada pela diplomacia estadunidense em 1946. Enquanto a Carta Proposta previa, em seu artigo 1, a cláusula da nação mais favorecida incondicionada, o artigo 33 dispunha acerca de uma única regra de calibração que permitia "the union for customs purposes of any customs territory and any other customs territory". Notadamente, esse dispositivo não estava previsto no artigo I, mas na parte de formalidades, servindo para definir um termo conceitual, a ser aplicado na própria Carta Proposta. É relevante esclarecer que, à época, as uniões aduaneiras vinham impregnadas de aspectos políticos, visto que serviam como momento precedente às unificações políticas. Como analisado no Capítulo 1.2.3., sua utilização remonta ao século XIX, quando as primeiras uniões aduaneiras foram constituídas com o escopo de facilitar a integração econômica de regiões que compartilhassem semelhanças econômicas e culturais, ou a dominação econômica de países vulneráveis. Dessa forma, por serem consideradas mais como uma questão de soberania e jurisdição estatal do que uma preferência comercial, os negociadores não vislumbravam sujeitar as UA às obrigações decorrentes do tratamento da 
nação mais favorecida, embora devessem, em razão de sua importância econômica, ser disciplinadas pelo futuro tratado.

Durante as negociações das Conferências de Londres e Genebra, sugestões foram incorporadas à Carta Proposta. Em 1948, a versão revisada do artigo 33 foi renumerada como artigo 42 e, depois, artigo 44 da Carta da Organização Internacional do Comércio. Entretanto, as alterações inseridas transformaram substancialmente o escopo do dispositivo, na medida em que incluíram as áreas de livre-comércio e os acordos interinos dentre as exceções. Diferentemente das uniões aduaneiras, que exigiam a criação de uma tarifa externa combinada com um processo de construção de instituições e de harmonização econômica, as ALC eram um conceito novo e pouco conhecido, cujo requisito predominante era tão somente a exigência da eliminação de barreiras sobre "substantially all the trade" entre seus contratantes. A justificativa técnico-econômica apresentada para introduzir as áreas de livre-comércio no artigo 44 não é suficiente para compreender as razões subjacentes à inclusão do descuidado instituto na regra de calibração da cláusula da nação mais favorecida. Com o fracasso da Carta de Havana, os Estados, ao negociarem o Acordo Geral sobre Tarifas e Comércio, acordaram por reintroduzir o disposto no artigo 44, na forma do artigo XXIV. ${ }^{384}$

Nesse contexto, torna-se imprescindível examinar o misterioso processo de negociação que conduziu os Estados Unidos, principais defensores do princípio da não discriminação e do multilateralismo, a cederem às pressões da diplomacia inglesa, dos países europeus e subdesenvolvidos, de modo a aceitar a ampliação das exceções à cláusula da nação mais favorecida. O principal objetivo da diplomacia estadunidense era construir um agrupamento coeso entre os países democráticos e capitalistas para fazer frente à ameaça soviética. Construída sobre princípios dogmático-neoliberais, a liderança dos EUA defendia que as relações econômicas internacionais deveriam pautar-se pela eliminação dos históricos regimes de preferências comerciais e dos instrumentos protecionistas empregados no período entreguerras. Entretanto, durante o processo negocial, diversos interesses convergiram para diluir os efeitos previamente concebidos para o tratamento da nação mais favorecida.

A primeira sorte de motivos está relacionada à proposta apresentada secretamente pelo Canadá aos Estados Unidos acerca da celebração de um acordo preferencial. Embora desejoso

\footnotetext{
${ }^{384}$ CHASE, Kerry. Multilateralism compromised: the mysterious origins of GATT Article XXIV. World Trade Review, [s.1.], v. 5, n. 1, 2006, p. 3-8.
} 
de aceitar a oferta, o Departamento de Estado foi obrigado a rejeitar a proposta, sob pena de ver sua liderança internacional ruir, ao ser acusado de hipocrisia. Houve, porém, uma contraproposta estadunidense que versou sobre a criação de uma união aduaneira, sendo esta prontamente rejeitada pelo Canadá, por temer a perda de sua soberania econômica. A solução seria encontrar um meio de instrumentalizar a preferência comercial, mas mantendo a autonomia aduaneira. Daí surge a ideia da área de livre-comércio, a qual viria a ser adotada no artigo 44, conforme a proposta endereçada por Síria e Líbano, os quais atuavam sob o patrocínio oculto de Estados Unidos e Canadá. ${ }^{385}$

Apesar de não ter encontrado as virtualidades necessárias para entrar em vigor, a proposta secreta de acordo preferencial entre Estados Unidos e Canadá permitiu o fortalecimento das pressões dos demais países, os quais visavam calibrar a rígida imputabilidade da cláusula da nação mais favorecida, por meio da área de livre-comércio. Além disso, preocupava os EUA a desagregação do bloco capitalista, pelo descontentamento dos países subdesenvolvidos. A pressão por alterações substanciais na Carta da OIC era o objetivo central dos países subdesenvolvidos, pois receavam que a rigidez do proposto artigo 15, que versava sobre as condições para outorga de preferências comerciais concernentes a programas de desenvolvimento econômico, vedasse as integrações regionais. Os negociadores estadunidenses sustentaram, por um lado, a santidade da CNMF e, por outro, a importância da exceção à ALC, a qual permitiria calibrar os efeitos do tratamento da nação mais favorecida, possibilitando uma forma de integração regional mais flexível, o que atenderia, consequentemente, aos interesses dos países subdesenvolvidos.

Não obstante, enfatiza-se que não haveria qualquer interesse dos países europeus na permissão para criação de áreas de livre-comércio. Privilegiado pelo tratamento excepcional outorgado às preferências históricas, nos termos do artigo I:1, o Reino Unido defendia a não flexibilização da cláusula da nação mais favorecida. Os demais países europeus capitalistas eram indiferentes a essa inclusão, pois estavam focados no processo de integração, por meio da criação de uma união aduaneira, não subsistindo qualquer relação com as ALC. Desse modo, o artigo XXIV foi desenhado para acomodar os interesses dos países europeus na autorização à constituição de uniões aduaneiras, bem como dos países subdesenvolvidos e dos Estados Unidos na formação de áreas de livre-comércio. Assim, ao autorizar a criação de

${ }^{385}$ CHASE, 2006, p. 12-14. 
acordos preferenciais de comércio, a regra de calibração permitiria suavizar os rigorosos efeitos das obrigações imputadas pela cláusula da nação mais favorecida. ${ }^{386}$

O período posterior à celebração do Acordo Geral sobre Tarifas e Comércio foi marcado por dois novos, diferentes e surpreendentes surtos de proliferação de acordos preferenciais de comércio, os quais encontraram fundamentação legal para justificar as relações discriminatórias na regra de calibração positivada no artigo XXIV. Analisado no Capítulo 1.4, o terceiro surto, iniciado no final da década de 1950 e encerrado em meados de 1970, tem por característica a celebração de APC com a finalidade de permitir, em um contexto de Guerra Fria, a reconstrução e organização do comércio regional, em especial da Europa capitalista e desta com suas ex-colônias. Exceto pelos acordos constitutivos da Comunidade Econômica Europeia e da Associação Europeia de Livre-Comércio, todos os demais tiveram pouco êxito, resultando na decadência do movimento. Os Estados Unidos, por sua vez, permaneceram comprometidos com o multilateralismo comercial. Na América Latina, foi constituída a Associação Latino-Americana de Livre-Comércio com o objetivo de criar uma área de livre-comércio entre os Estados-contratantes, porém encontrou poucas condições para desenvolver-se, sendo, posteriormente, substituída pela Associação Latino-Americana de Integração (“ALADI”), instituída pelo Tratado de Montevidéu de 1980.

Com o enfraquecimento da dialética relação da Guerra Fria no início na década de 1980, a quarta onda de proliferação é inaugurada pela entrada dos Estados Unidos no movimento pela celebração de acordos preferenciais de comércio. A conversão estadunidense é motivada pela tentativa de responder adequadamente aos problemas oriundos da conjuntura político-econômica da época, em especial a resistência europeia em realizar a nona rodada multilateral de comércio no âmbito do GATT. Com isso, os EUA passaram da inclemente defesa do multilateralismo à corrida por APC. O primeiro acordo de livre-comércio foi celebrado com Israel, em 1985, e com o Canadá, em 1989. Paralelamente, a Comunidade Econômica Europeia iniciou um processo de ampliação e aprofundamento, que levou à incorporação de novos Estados, enquanto, no cone sul da América Latina, o Tratado de Assunção criava o Mercado Comum do Sul. O que era, originalmente, uma tentativa de destravar as negociações multilaterais tornou-se um novo movimento circular de

\footnotetext{
${ }^{386}$ CHASE, 2006, p. 15-28.
} 
retroalimentação, cujo principal resultado foi a contribuição decisiva dos acordos preferenciais de comércio para a formação do spaghetti bowl. ${ }^{387}$

No plano econômico, os acordos preferenciais de comércio não encontram consenso entre os economistas acerca de seus impactos nas relações econômicas internacionais. Ainda que todos partam do princípio de que os APC têm por objetivo ampliar o bem-estar dos Estados-partes, as análises econômicas não conseguem determinar se os efeitos por eles produzidos contribuem para solapar ou colaborar com os esforços dispensados multilateralmente. Nos debates contemporâneos sobre artigo XXIV, há duas vertentes teóricas principais, construídas a partir das teorias clássicas do comércio internacional, cujas raízes remontam aos conceitos de vantagens comparativas e de especialização comercial, formulados por David Ricardo. O objetivo de ambas é apurar se faticamente os acordos preferenciais de comércio estimulam o livre-comércio e o crescimento econômico, resultando no aumento de bem-estar.

Primeiras a investigar o fenômeno da integração econômica, as Teorias Estáticas sustentam que a liberalização comercial permite aos Estados exportar produtos produzidos com mais eficiência e importar aqueles obtidos com menos eficiência. Com efeito, é possível aumentar a especialização da produção, tornando-a mais eficiente e produtiva, o que resulta no aumento de bem-estar. Ao debruçar o olhar clássico sobre a regra de calibração positivada no artigo XXIV, os economistas objetivam determinar se os acordos preferenciais de comércio têm por efeito ampliar o bem-estar.

Responsável por formular as bases fundamentais das Teorias Estáticas, Jacob Viner contribuiu com a criação de um modelo teórico para examinar os efeitos pretéritos e posteriores à entrada em vigor da união aduaneira. Com isso, introduziu-se a distinção entre os efeitos de criação de comércio e desvio de comércio. Define-se criação de comércio como o mecanismo de aferição do aumento dos fluxos comerciais entre partes-contratantes de uma união aduaneira, após a unificação dos preços das mercadorias no bloco em razão da queda das tarifas. O efeito é o preterimento dos produtores menos eficientes em favor dos mais eficientes. O desvio de comércio é o mecanismo que analisa a redução do comércio com os Estados não partes da UA, em benefício da ampliação das transações intrabloco. Com isso,

\footnotetext{
${ }^{387}$ MANSFIELD; MILNER, 1999, p. 600-604. BHAGWATI, Jagdish. Regionalism and Multilateralism: An Overview. In: MELO, Jaime de; PANAGARIYA, Arvind (Eds.). New Dimensions in Regional Integration. Nova York: Cambridge University Press, 1993, p. 29-31. SUTHERLAND, 2004, p. 19-20.
} 
preterir-se-iam os produtos importados do bloco, em função da estrutura tarifária. O resultado líquido dos efeitos de criação e desvio de comércio do conjunto de produtos comercializáveis indica se o APC é positivo ou não para o comércio internacional.

Desse modo, a melhor opção seria a existência de relações econômicas em bases multilaterais. As uniões aduaneiras seriam, no entanto, a segunda melhor alternativa para o comércio internacional, caso não fosse possível adotar a primeira alternativa, qual seja, a redução ou eliminação multilateral das barreiras tarifárias. ${ }^{388}$

A análise estática do bem-estar proporcionado pelos APC estaria hoje incompleta, caso não fossem apreciados seus ganhos dinâmicos, frutos do processo de integração. No contexto do quarto surto, surgiram as Teorias Dinâmicas, que examinam as implicações sistêmicas da massiva proliferação de acordos preferenciais de comércio em face do multilateralismo. O novo regionalismo incide diretamente sobre o sistema multilateral de comércio, provocando a criação de diferentes e arbitrárias regras de origem, as quais, ao sujeitarem os Estados a tratamentos particulares e discriminatórios, impactam na velocidade de ampliação ou restrição da liberalização multilateral do comércio.

Nesse sentido, as Teorias Dinâmicas não estão restritas à questão acerca da determinação dos benefícios ou malefícios de um acordo preferencial de comércio, mas buscam, adicionalmente, verificar se esses tratados têm por efeito acelerar ou desacelerar a velocidade do processo de redução das barreiras comerciais, em certo período de tempo. Há, assim, a superação da questão estática envolvendo a criação de comércio e o desvio de comércio, passando-se a focar no exame de uma nova relação dialética entre blocos construtivos (building blocks) e blocos obstrutivos (stumbling blocks) ao comércio multilateral. Daí a importância de se investigar quais são os efeitos dos APC sobre as expectativas dos Estados-membros quanto à liberalização multilateral do comércio, em dado período de tempo.

Diante desses problemas, Jagdish Bhagwati vem alertando para o fenômeno que denominou de spaghetti bowl, o qual consiste na sobreposição e entrelaçamento de acordos preferenciais de comércio e medidas de proteção comercial, o que implica a formação de redes entrecruzadas de barreiras tarifárias e não tarifárias, cuja incidência varia subjetivamente, de acordo com regras de origens arbitrariamente determinadas. Isso gera desafios sistêmicos a

${ }^{388}$ VINER, 1950, p. 41-56. 
uma ordem econômica internacional estruturada em torno de uma ideologia neoliberal e de instituições multilaterais, que passa a estar eivada de relações preferenciais, responsáveis por aumentar os custos de transação e a facilitar a utilização de instrumentos protecionistas. À guisa de liberalizar o comércio internacional, os APC têm servido para ironicamente recriar o caótico tratamento discriminatório e protecionista, o que resulta na ineficácia social da cláusula da nação mais favorecida dos anos 1930, então defendida pelas teorias protecionistas. $^{389}$

Fica evidente que, sem investigar, ainda que em linhas gerais, os jogos de poder e verdade das interações econômicas internacionais, seria incompleta a análise normativa da relação entre os artigos I:1 e XXIV do GATT. O artigo I:1 estabelece a regra geral do tratamento da nação mais favorecida, cujo principal objetivo é positivar o princípio da não discriminação, enquanto pressuposto axiológico imprescindível para os Estados-membros da Organização Mundial do Comércio alcançarem o desenvolvimento e o bem-estar econômico. Nos termos do artigo XXIV:4, a OMC reconhece que o aumento do bem-estar dos Estados tem íntima relação com a ampliação dos fluxos comerciais. Em razão disso, permite-se aos Membros acelerar a integração das economias, por meio da celebração de acordos preferenciais de comércio, desde que tenham "por finalidade facilitar o comércio entre os territórios constitutivos e não opor obstáculos ao comércio de outras Partes Contratantes com esses territórios".

Enquanto o artigo I:1 proíbe aos Estados-membros estabelecer tratamentos discriminatórios, o artigo XXIV, complementado pelo Acordo sobre a Implementação do Artigo XXIV ("Entendimento XXIV"), autoriza a celebração de acordos preferenciais de comércio, os quais têm o duplo efeito de facilitar o comércio entre as partes-contratantes e privar terceiros dessas vantagens reciprocamente outorgadas. Disso extrai-se que a relação lógico-formal entre os artigos I:1 e XXIV é concebida em bases antinômicas. O conflito normativo é evitado pelo artigo XXIV:5, o qual prevê que "as disposições do presente Acordo [GATT] não se oporão à formação de uma união aduaneira [...] uma área de livre-troca ou à adoção de acordo provisório". Dessa forma, o artigo XXIV:5 é uma regra de calibração que

\footnotetext{
${ }^{389}$ BHAGWATI, Jagdish; GREENAWAY, David; PANAGARIYA, Arvind. Trading Preferentially: Theory and Policy. The Economic Journal, [s.1.], v. 108, n. 449, 1998, p. 1128-1148. BHAGWATI, Jagdish; PANAGARIYA, Arvind. The Theory of Preferential Trade Agreements: Historical Evolution and Current Trends. The American Economic Review, [s.1.], v. 86, n. 2, 1996, p. 82-87.
} 
tem por efeito excepcionar as obrigações previstas no artigo I:1, nas hipóteses específicas daqueles acordos preferenciais de comércio previamente tipificados.

Por tratar-se de uma exceção à regra geral do tratamento nação mais favorecida, é necessário examinar os elementos estruturais que tipificam tais espécies de acordos preferenciais de comércio. Isso porque o não cumprimento pelo Estado de tais condições formais implica no não reconhecimento deles como exceções, tendo por consequência a incidência direta do tratamento da nação mais favorecida sobre a relação discriminatória. Os parágrafos 5 e 8 do artigo XXIV tipificam os elementos internos e externos das categorias jurídicas da união aduaneira e da área de livre-comércio, no âmbito do SMC.

A tipologia das uniões aduaneiras, e do respectivo acordo interino, tem dois requisitos internos: (i) a eliminação substancial de todas as barreiras ao comércio entre as partescontratantes; acumulada com (ii) a substituição de dois ou mais territórios aduaneiros por um único dotado de tarifa externa comum. O elemento externo imputa a proibição das partescontratantes de imporem barreiras tarifárias e não tarifárias mais restritivas, em sua totalidade, ao comércio com terceiros Estados não partes do que aquelas aplicadas antes da formação do APC.

A área de livre-comércio e respectivo acordo interino consistem no agrupamento de dois ou mais territórios aduaneiros, cujo requisito interno é a eliminação substancial de direitos aduaneiros e de outras regulamentações restritivas às trocas comerciais entre as partescontratantes constitutivas do APC. O elemento externo veda às partes-contratantes a possibilidade de sujeitarem terceiros Estados não partes a restrições tarifárias e não tarifárias mais rigorosas do que aquelas existentes anteriormente à formação da ALC.

Por fim, os acordos interinos para a formação de união aduaneira ou de área de livrecomércio devem incluir um plano e um programa de formação que disponham sobre a conclusão do acordo preferencial de comércio dentro de um período razoável de tempo. O Entendimento XXIV prevê, em seu parágrafo $3^{\circ}$, que o prazo razoável de tempo referente à formação de UA ou de ALC só deve exceder dez anos em situações excepcionais.

No tocante ao controle de consistência sistêmico-normativa entre artigo I:1 e XXIV, o sistema multilateral de comércio instituiu dois mecanismos: o Órgão de Solução de Controvérsias e o Comitê de Acordos Regionais de Comércio ("CARC”). 
Desde a celebração do Acordo Geral sobre Tarifas e Comércio, o mecanismo multilateral de controle de acordos preferenciais de comércio é foco de estudos e reformas. Disciplinado, ainda que precariamente, pelo artigo XXIV do GATT, o texto atribui ao mecanismo o objetivo de exercer um controle de compatibilidade estrutural entre os APC e as normas do sistema multilateral de comércio. Todavia, as relações de poder e verdade propiciaram uma reinterpretação normativa do instrumento, de modo a alterar sua finalidade de controle a priori de legalidade para procedimento a posteriori de legitimidade.

Antes da conclusão da Rodada Uruguai, o Conselho do GATT era o órgão multilateral competente para examinar, nos termos do artigo XXIV:7 do GATT, a compatibilidade prévia dos APC em formação com a cláusula da nação mais favorecida. Grupos individuais de trabalho, constituídos pelo Conselho, eram incumbidos de prepararem, mediante detidas análises estruturais, relatórios a serem a ele apresentados. Por atribuírem natureza essencialmente diplomática ao mecanismo multilateral, os Estados-partes entendiam que os relatórios não dispunham de autoridade para modificar a vontade das partes ou alterar os APC, restringindo-os a recomendar a adoção de medidas pontuais de adequação.

Com isso, o órgão multilateral tornou-se tão somente um procedimento ex post facto para reconhecer a legitimidade aos acordos preferenciais de comércio, ao invés de controlarlhes previamente a legalidade, como previsto no artigo XXIV. Com a multiplicação das UA e ALC, esse modelo entrou em crise, pois os cerca de 20 grupos de trabalho não tinham critérios únicos e objetivos para desempenhar sua atividade de reconhecimento ou não da legalidade dos acordos. Caso particularmente emblemático foi a impossibilidade dos grupos de apresentarem uma conclusão final sobre a compatibilidade dos acordos das Comunidades Europeias com o sistema multilateral de comércio. ${ }^{390}$

À luz do processo de adensamento de juridicidade, os Estados-membros acordaram o Entendimento sobre a Interpretação do Artigo XXIV do GATT, que simbolizou, mediante a transferência da competência ao Conselho sobre o Comércio de Bens ("CCB”), o primeiro passo em prol do aumento da institucionalização do mecanismo multilateral de controle. Logo em 1996, o Conselho Geral decidiu estabelecer o Comitê de Acordos Regionais de Comércio

\footnotetext{
${ }^{390}$ SOARES, Guido F. S. A compatibilidade da ALADI e do MERCOSUL com o GATT. Boletim de Integração Latino-Americana, [s.1.], $\quad$ n. $16, \quad 2005, \quad$ p. $\quad 5-6 . \quad$ Disponível em $<$ http://ftp.unb.br/pub/UNB/ipr/rel/bila/1995/781.pdf >. Acesso em: 3 fev. 2009. THORSTENSEN, Vera. OMC Organização Mundial do Comércio: as regras do comércio internacional e a rodada do milênio. São Paulo: Aduaneiras, 1999, p. 218.
} 
com a finalidade de centralizar em um único órgão o exame de compatibilidade dos APC. Ao CARC foi designada a função de analisar a legalidade dos acordos preferenciais de comércio, regulamentar o procedimento de verificação e assegurar a transparência das relações econômicas internacionais.

Por isso, o Comitê de Acordos Regionais de Comércio é dotado de competências para: (i) proceder ao exame de compatibilidade dos acordos preferenciais de comércio, em formação e já concluídos, em face do SMC, de acordo com as regras de procedimento e termos de referência adotados pelo $\mathrm{CCB}$; (ii) apresentar relatório ao $\mathrm{CCB}$, contendo as conclusões; (iii) determinar o formato dos relatórios a serem apresentados pelos Estados-membros partes do APC; (iv) desenvolver procedimentos de exame dos APC; (v) apresentar recomendações, quando necessário, acerca das implicações sistêmicas dos APC para o sistema multilateral de comércio. $^{391}$

Não obstante o mérito das iniciativas, o CARC é vítima da falta de consenso entre seus membros, razão pela qual não conseguiu apresentar até 2005 qualquer relatório ao CCB. Na realidade, apesar da tentativa de redirecioná-lo ao exercício do controle de compatibilidade estrutural, o mecanismo continuava atuando segundo a lógica do multilateralismo procedimental, que corporifica o interesse de certos Estados-membros em restringir-lhe a atuação como instrumento de legitimidade dos APC. Assim, em 2006, o Conselho Geral aprovou uma nova reforma que introduziu o Mecanismo de Transparência para os Acordos Regionais de Comércio ("Mecanismo de Transparência") no âmbito do CARC.

O Mecanismo de Transparência tem por objetivo aumentar a transparência nas relações envolvendo os Estados-membros. Por isso, imputa-se às partes-contratantes a obrigação de notificar a criação de um APC ao CARC o mais brevemente possível, bem como qualquer alteração que afete a respectiva implementação. Em seguida, o Secretariado da OMC deverá preparar, com base nas informações apresentadas pelas partes-contratantes, conforme formulário de submissão próprio, um relatório factual do APC. No entanto, o referido relatório não deve ser utilizado como base para solução de controvérsias, ou para criar direitos e obrigações. Ainda que relevante para a transparência das relações econômicas internacionais, essa reforma pouco contribuiu para o processo de institucionalização do CARC, visto que

\footnotetext{
${ }^{391}$ OMC. General Council. Decision n. WT/L/127, 7 fev. 1996. Disponível em <http://docsonline.wto.org/>. Acesso em: 3 fev. 2009.
} 
remanesce quase intacto o seu caráter diplomático-procedimental. Isso porque, apesar de o artigo XXIV atribuir ao mecanismo competência ilimitada para examinar a legalidade dos APC, permanecem os fatores que impedem o Comitê de Acordos Regionais de Comércio de buscar a consecução de seus objetivos originais. ${ }^{392}$

Ao investigar a prática corrente, constata-se que o Comitê de Acordos Regionais de Comércio ainda não conseguiu atuar satisfatoriamente como mecanismo multilateral de controle de legalidade. Dentre as diversas razões, a interpretação do artigo XXIV se sobressai, pois permite revelar os efeitos do poder disciplinar incidente sobre órgão multilateral decorrente dos jogos de poder e verdade entre os Estados-membros.

Primeiramente, cabe desmistificar a construção discursiva político-econômica, responsável por contestar a falta de autoridade institucional do CARC para declarar a incompatibilidade de certo APC e indicar modificações. Nos termos do artigo XXIV:7(a) do GATT, o Estado-membro que resolva participar de um APC “[...] fornecerá, a respeito dessa união ou dessa zona, todas as informações que lhes permitam endereçar às partes contratantes os relatórios e recomendações que julgar apropriados”. Na hipótese de acordo interino, o artigo XXIV:7(b) dispõe que caso este não seja "[...] suscetível de resultar em uma união aduaneira ou no estabelecimento de uma zona de livre-troca, nos prazos previstos pelas partes de acordo, ou que tais prazos não sejam razoáveis, farão recomendações às partes do acordo. As partes não manterão nem porão em vigor, conforme o caso, tal acordo, se não estiverem dispostas a modificá-lo, tendo em vista essas recomendações”.

Dessa forma, os Estados-membros são obrigados a fornecer todas as informações necessárias sobre o acordo preferencial de comércio, em formação ou constituído, permitindo a preparação do relatório. Além disso, por haver uma norma secundária de competência expressa, não há razão a priori para o CARC não exercer plenamente o controle de legalidade, podendo inclusive concluir que certo APC é inconsistente com o sistema multilateral de comércio, bem como recomendar alterações.

Esclarecida a jurisdição do Comitê de Acordos Regionais de Comércio, é preciso compreender as causas da inércia institucional. A morosidade do mecanismo está intimamente relacionada à noção de multilateralismo procedimental inerente às Regras de Procedimento

\footnotetext{
392 OMC. General Council. Decision n. WT/L/671, 18 dez. 2006. Disponível em <http://docsonline.wto.org/>. Acesso em: 3 fev. 2009.
} 
para Encontros do Comitê de Acordos Regionais de Comércio ("RPECARC"). Por haver desviado o foco da legalidade para a legitimidade, as RPECARC consubstanciaram um procedimento multilateral, na forma de regras que demandam votação consensual positiva pelos Estados-membros para tomada de decisão no âmbito do CARC. Daí o artigo 33 da RPECARC prever especificamente que, na impossibilidade de a decisão ser alcançada por consenso, o assunto em causa deve ser submetido ao Conselho sobre o Comércio de Bens ou Conselho Geral. Contudo, tal dispositivo, por não ser requisito formal previsto no SMC, não pode servir para obstar o funcionamento do mecanismo multilateral de controle. Além disso, a prática na $\mathrm{OMC}$ revela que decisões consensuais, quando não relacionadas a dispositivos fundamentais, não exigem necessariamente unanimidade. Isso é verdade no exame de compatibilidade, pois qualquer decisão do CARC que viesse a julgar incompatível dado APC implicaria no desagrado de um grupo de Estados-membros e, por consequência, nunca seria adotada, tornando o mecanismo inútil. ${ }^{393}$

Superadas as limitações de competência e de votação, é preciso verificar a lógica temporal do controle de legalidade. Ao analisar o artigo XXIV, percebe-se o predomínio de dispositivos dedicados ao controle a priori dos acordos preferenciais de comércio, ou seja, a função original do mecanismo era exercer um exame prévio dos APC notificados. Aprovada a compatibilidade dos acordos preferenciais de comércio com o SMC pelo Comitê de Acordos Regionais de Comércio, os Estados-membros teriam a legítima faculdade de celebrá-los. Certos interesses, porém, alteraram a interpretação do artigo XXIV, conduzindo a aplicação do mecanismo para direção oposta, na medida em que os APC têm sido notificados ex post facto.

Os efeitos fáticos da mudança temporal no procedimento de apreciação comprometeram a atuação do CARC, tornando-o praticamente irrelevante. Isso porque a dinâmica das relações econômicas internacionais, por ter uma lógica temporal diferente, produz poderosos efeitos de verdade que constrangem o controle normativo a evitar decisões que possam prejudicar o crescimento e a integração econômica. A impossibilidade de reagir às violações exerce um domínio real, pois submete os discursos jurídicos produzidos pela OMC aos discursos econômicos e políticos, fragilizando a autoridade institucional. Sob a perspectiva pragmática, a relação de cometimento entre OMC e Estados-membros é

\footnotetext{
${ }^{393}$ OMC. Committee on Regional Trade Agreements. Decision n. WT/REG/1, 2 jul. 1996. Disponível em <http://docsonline.wto.org/>. Acesso em: 3 fev. 2009. MAVROIDIS, Petros C. If I Don't Do It, Somebody Else Will (Or Won't). Journal of World Trade, [s.1.], v. 40, n. 1, 2006, p. 198.
} 
responsável por permitir a institucionalização do mecanismo multilateral de controle $a$ posteriori, porém as redes de poder e os discursos político-econômicos atuam no sentido de diminuir o consenso, a legitimidade e a eficácia social em torno da decisão. Dessa forma, ainda que o APC viole as normas do sistema multilateral de comércio, o exame estrutural ex post facto não encontra condições de declarar a incompatibilidade, devido à fragilidade institucional. $^{394}$

O Comitê de Acordos Regionais de Comércio é ineficaz, ainda que normativamente competente, para exercer o controle prévio de legalidade dos acordos preferenciais de comércio. Tal situação decorre da aceitação da interpretação do artigo XXIV, no sentido de transformá-lo em instrumento de reconhecimento procedimental de legitimação diplomática. O mecanismo multilateral de controle é, portanto, incapaz de contribuir para a coesão e eficácia normativa do sistema multilateral de comércio à luz dos desafios sistêmicos.

Atualmente, o Órgão de Solução de Controvérsias tem competência judicantecasuística no que se refere ao exame de compatibilidade entre artigos I:1 e XXIV do GATT. O sistema multilateral de comércio atribui ao OSC o exercício do controle jurídico de legalidade e de licitude das relações entre os Estados-membros. No entanto, a autoridade do OSC para julgar as demandas envolvendo a consistência do artigo XXIV foi objeto de discórdia entre os Estados-partes, desde a celebração do GATT em 1947 até a conclusão da Rodada Uruguai em 1994.

Durante esse período, dois painéis foram estabelecidos para examinar demandas relativas à legalidade de acordos preferenciais de comércio em face dos requisitos previstos no artigo XXIV. Nos dois primeiros casos, as decisões dos painéis não foram adotadas pelos Estados-partes. O primeiro painel, constituído para o Caso European Economic Community Tariff Treatment on Imports of Citrus Products from Certain Countries in the Mediterranean Region de 1985, demandou o exame de legalidade de certas medidas preferenciais concedidas pela Comunidade Econômica Europeia, sob o auspício do artigo XXIV, a países mediterrâneos. À época não havia qualquer decisão dos Estados-partes sobre a compatibilidade de qualquer APC. Isso implicou na decisão do painel de não se sub-rogar na competência para examinar a consistência desse APC com o artigo XXIV. Com isso, o painel

${ }^{394}$ MAVROIDIS, 2006, p. 203-204. FERRAZ JR., 2001, p. 106-107. 
concluiu que "the question of the conformity of the agreements with the requirements of Article XXIV and their legal status remained open". 395

O Caso European Economic Community - Import Regime for Bananas de 1994, que versou sobre o pedido declaratório de inconsistência do regime de importação de bananas estabelecido pela CEE, foi o segundo painel a tratar sobre o tema. Nessa oportunidade, decidiu-se que os acordos preferenciais de comércio são per se inconsistentes com o artigo XXIV; logo, os Estados estão sujeitos ao tratamento da nação mais favorecida, salvo se todos os requisitos típicos da área de livre-comércio ou da união aduaneira forem devidamente cumpridos. Surpreendentemente, o mesmo painel concluiu que a Convenção de Lomé, por não ser tipificada em nenhuma das espécies de APC previstas no artigo XXIV, consequentemente, não poderia ser declarada inconsistente em relação a esse dispositivo. Embora o relatório não tenha sido adotado pelos Estados-partes, o painel contribuiu de forma relevante para a interpretação do dispositivo:

This lack of any obligation of the sixty-nine ACP countries to dismantle their trade barriers, and the acceptance of an obligation to remove trade barriers only on imports into the customs territory of the EEC, made the trade arrangements set out in the Convention substantially different from those of a free trade area, as defined in Article XXIV:8(b). ${ }^{396}$

Os receios e incertezas decorrentes dos entendimentos divergentes acerca da competência judicante do Órgão de Solução de Controvérsias para exercer o controle de consistência envolvendo o artigo XXIV foram sanados no final da Rodada Uruguai. Na conclusão da rodada de negociações multilaterais, os Estados-partes adotaram o Entendimento sobre a Interpretação do artigo XXIV do GATT, que, embora não tenha alterado a redação do dispositivo, visou esclarecer, mediante a adoção de uma interpretação uniforme, algumas das suas ambiguidades. De fato, a mais relevante decisão versa sobre o reconhecimento da possibilidade de propor perante o OSC demandas que tenham como fundamento o artigo XXIV. O Entendimento XXIV, em seu parágrafo 12, estabelece que as disposições do GATT 1994 e o ESC podem ser invocados com respeito a qualquer assunto resultante da aplicação

\footnotetext{
${ }^{395}$ GATT. European Economic Community - Tariff Treatment on Imports of Citrus Products from Certain Countries in the Mediterranean Region. Report by the Panel, 7 fev. 1985. Disponível em <http://docsonline.wto.org/GEN_viewerwindow.asp?http://docsonline.wto.org:80/DDFDocuments/t/JCR/PANE LS/82CITRUS.WPF>. >. Acesso em: 10 abr. 2009. Documento da OMC n. L/5776, par. 4.6-4.10.

${ }^{396}$ GATT. EEC - Import Regime for Bananas. Report by the Panel, 11 fev. 1994. Disponível em <http://docsonline.wto.org/DDFDocuments/t/GG/DS/38-R.WPF>. Acesso em: 10 abr. 2009. Documento da OMC n. DS38/R, par. 159; 164.
} 
das disposições do artigo XXIV aos acordos preferenciais de comércio típicos. Com isso, foram afastados os argumentos sustentados principalmente pela Comunidade Econômica Europeia, nos casos precedentes, de que existia um procedimento autônomo para decidir sobre as questões envolvendo o artigo XXIV. ${ }^{397}$

O reconhecimento definitivo da competência do Órgão de Solução de Controvérsias quanto ao controle de estrutura e de conduta das relações dos Estados-membros integrantes de uniões aduaneiras, de áreas de livre-comércio e de acordos interinos estava em consonância com o processo de fortalecimento do mecanismo de solução de controvérsias, que propiciou a adoção do Entendimento sobre as Regras e Procedimentos que Governam a Solução de Controvérsias. Além de contribuir com o aperfeiçoamento da função judicante, a nova disciplina tem por objetivo corrigir os vícios que impregnavam o mecanismo anterior. $\mathrm{O}$ efeito pragmático é consumar a transição de um sistema orientado predominantemente por discursos diplomáticos, sustentados pelas relações de poder e verdade entre os Estados-partes, para um sistema orientado por uma racionalidade jurídica e discursos jurídico-convencionais. Daí a virtuosidade do ESC em combinar a razão diplomática, que privilegia a negociação direta entre os interessados, à lógica jurisdicional, preocupada com garantias procedimentais e com a produção de decisões obrigatórias entre as partes litigantes. Desprezar essa síntese discursiva, produto de uma dialética racionalidade político-jurídica, é perder de vista os elementos originais que permitiram ao mecanismo de solução de controvérsias ser um instrumento central do processo de "adensamento de juridicidade" da OMC.

O Entendimento sobre Solução de Controvérsias introduziu uma cisão funcional dos órgãos da OMC conforme seu caráter político e jurisdicional. Enquanto aos painéis e ao Órgão de Apelação foi outorgada a competência para exercer o controle de legalidade e de licitude sobre as demandas propostas segundo uma racionalidade jurídica, o Órgão de Solução de Controvérsias é composto por todos os Estados-membros para, segundo uma racionalidade política, exercer a função de administrar o mecanismo de solução de controvérsias, bem como tomar decisões juridicamente obrigatórias. Em termos hierárquicos, os painéis e o Órgão de Apelação estão subordinados ao Órgão de Solução de Controvérsias, ou seja, os órgãos jurisdicionais estão submetidos ao político, ao qual compete, ainda que por decisão consensual positiva, rejeitar um relatório ou adotar uma interpretação dos acordos que prevaleça sobre o

${ }^{397}$ JACKSON, 1997, p. 166. 
entendimento jurisprudencial considerado inadequado. ${ }^{398} \mathrm{Na}$ prática, porém, a dificuldade na obtenção do consenso e a relutância em adotar o voto majoritário têm reduzido o alcance e a extensão do controle político sobre os discursos jurídicos ex post facto. Isso explica a razão pela qual o controle político vem sendo empregado difusamente e a priori, de modo a fragilizar os fundamentos de verdade da racionalidade jurídica previamente às decisões dos órgãos jurisdicionais.

Com a passagem de um sistema multilateral de comércio de natureza power-oriented para um rule-oriented, o Órgão de Solução de Controvérsias superou os discursos políticos que impediam as decisões jurídicas sobre o artigo XXIV. O Caso Turkey - Restrictions on Imports of Textile and Clothing Products ("Turkey - Textiles") é paradigmático, visto ser a primeira decisão adotada sobre a consistência do artigo XXIV. O caso consiste na demanda apresentada pela Índia em face da Turquia, em razão de danos sofridos em decorrência da decisão turca de impor novas restrições quantitativas a seus exportadores têxteis, as quais seriam necessárias para a constituição da união aduaneira entre CE e a demandada. A relevância do caso era evidente, razão pela qual o painel começou o relatório apresentando uma reconstrução histórica do tema, na qual ressalvou que:

The relationship between the most-favoured-nation ("MFN") principle and Article XXIV of the GATT, which deals with free-trade areas and customs unions, has not always been harmonious. In 1947, their coexistence in the framework of international trade relations had been viewed as ultimately positive, reflecting the perception that genuine customs unions and free-trade areas were congruent with the MFN principle and directed towards the same objective, i.e. multilaterallyagreed trade liberalization. ${ }^{399}$

Primeiramente, o painel recorreu ao Entendimento XXIV para dispor sobre os limites de sua competência, qual seja, de exercer o controle de compatibilidade sobre quaisquer medidas adotadas pelos acordos preferenciais de comércio em face do artigo XXIV. No entanto, enfatiza que, por questões administrativas, o CARC é o órgão competente para examinar a compatibilidade do APC com o artigo XXIV. As partes apelaram sobre esse entendimento, o qual foi confirmado pelo Órgão de Apelação, mas por motivos diferentes. O controle de compatibilidade das medidas será exercido com base em dois requisitos, os quais

\footnotetext{
${ }^{398}$ AMARAL JR., 2006, p. 198-227. LAFER, 1998, p. 30-32.

${ }^{399}$ OMC. Turkey - Restrictions on Imports of Textile and Clothing Products. Report of the Panel, 31 maio 1999. Disponível em 〈http://docsonline.wto.org/DDFDocuments/t/WT/DS/34R.DOC> Acesso em: 14 mar. 2009. Documento da OMC n. WT/DS34/R, par. 1.1-2.9.
} 
são imputados às partes-contratantes. Primeiro, demonstrar que as medidas restritivas introduzidas nos APC estão em consonância com as condições impostas pelos parágrafos 5 e 8 do artigo XXIV. E, segundo, comprovar que o acordo preferencial de comércio depende da medida restritiva para existir. Diante disso, o Órgão de Apelação espera que " a panel, when examining such a measure, to require a party to establish that both of these conditions have been fulfilled". 400

Superada a questão preliminar sobre competência, o painel passou ao exame das alegações endereçadas pela Índia acerca do reconhecimento de inconsistência das medidas restritivas impostas pela Turquia. Para examinar os fatos e argumentos apresentados, o painel adotou o procedimento construído jurisprudencialmente pelo mecanismo de solução de controvérsias da $\mathrm{OMC}$, o qual imputa (i) à parte demandante o ônus de provar as violações normativas suscitadas; (ii) à parte que invocar uma exceção a comprovação de que todas as condições sejam cumpridas; e (iii) à parte que alegar um fato, o dever de prová-lo. Desse modo, coube à Índia demonstrar prima facie que as restrições quantitativas impostas pela Turquia violaram o disposto nos artigos XI e XIII do GATT e artigo 2.4 do Acordo sobre Têxteis e Vestuário. A Turquia não negou a existência das barreiras, mas apresentou uma defesa afirmativa fundada sobre o artigo XXIV do GATT; logo, o ônus da prova sobre o devido cumprimento dos requisitos essenciais da exceção é imputado àquela parte que a invoca. O painel examinou a defesa da Turquia fundada, particularmente, nos parágrafos 4, 5(a) e 8(a)(ii) do artigo XXIV. ${ }^{401}$

A Turquia alegou que as restrições quantitativas não violaram as diversas disposições do GATT, pois seriam elas compatíveis com o artigo XXIV, cuja natureza estrutural não pode ser entendida como uma justificativa, uma defesa, uma exceção ou uma suspensão. Na visão turca, a natureza especial do artigo XXIV é evidente, razão pela qual foi positivado na Parte III do GATT, e não na Parte II, como outras disposições sobre políticas comerciais. Nesse sentido, deve ser compreendido como uma lex specialis face aos direitos e obrigações dos Estados-membros, quando da formação dos acordos preferenciais de comércio tipificados. Isso

\footnotetext{
${ }^{400}$ OMC, Turkey -Textiles, Report of the Panel, par. 9.48-9.53. OMC. Turkey - Restrictions on Imports of Textile and Clothing Products. Appellate Body Report, 22 out. 1999. Disponível em <http://docsonline.wto.org/DDFDocuments/t/WT/DS/34ABR.DOC> Acesso em: 14 mar. 2009. Documento da OMC n. WT/DS34/AB/R, par. 58-59.

${ }^{401}$ OMC, Turkey -Textiles, Report of the Panel, par. 9.57-9.60.
} 
significa que a consistência das medidas deve ser verificada apenas em relação aos parágrafos de 5 a 9 do artigo XXIX, e não em face das demais provisões do GATT.

Após detalhado exame, o painel rejeitou o argumento de que o artigo XXIV é uma lex specialis de normatividade autocontida, sendo evidente seu vínculo intrínseco com todas as normas do sistema multilateral de comércio. Consequentemente, o painel decidiu que o artigo XXIV não autoriza uma exceção às obrigações previstas nos artigos XI e XIII, pois tais dispositivos não preveem nenhuma medida específica que permita, ou impeça, a formação de uniões aduaneiras. Em revisão do relatório, o Órgão de Apelação apontou que o painel analisou apenas perfunctoriamente o caput do artigo XXIV:5, sendo esse central para a solução do litígio. Isso porque o parágrafo $5^{\circ}$ ressalva expressamente que "as disposições do presente Acordo não se oporão à formação de uma aduaneira”. A exceção será aplicável apenas na hipótese em que os dispositivos do SMC tornarem impossível a constituição da UA, ou seja, as medidas inconsistentes são justificáveis, na medida em que forem essenciais para a formação do específico acordo preferencial de comércio típico. Procedeu-se, assim, ao controle de compatibilidade, como anteriormente descrito, para verificar se a Turquia cumpriu com as condições prévias. O Órgão de Apelação concluiu que:

\begin{abstract}
the Panel erred in its legal reasoning by focusing on sub-paragraphs 8(a) and 5(a) and by failing to recognize the crucial role of the chapeau of paragraph 5 in the interpretation of Article XXIV of the GATT 1994, but upholds the Panel's conclusion that Article XXIV does not allow Turkey to adopt, upon the formation of a customs union with the European Communities, quantitative restrictions on imports of 19 categories of textile and clothing products which were found to be inconsistent with Articles XI and XIII of the GATT 1994 and Article 2.4 of the ATC. [...] We wish to point out that we make no finding on the issue of whether quantitative restrictions found to be inconsistent with Article XI and Article XIII of the GATT 1994 will ever be justified by Article XXIV. We find only that the quantitative restrictions at issue in the appeal in this case were not so justified. ${ }^{402}$
\end{abstract}

O Caso Turkey - Textiles permite refletir sobre importantes aspectos da interação entre a cláusula geral da nação mais favorecida positivada no artigo I:1 e os acordos preferenciais de comércio tipificados no artigo XXIV. A constatação mais evidente está na relação estrutural entre os dispositivos. O artigo XXIV estabelece uma exceção geral e abstrata que incide tão somente sobre as previsões que impedem diretamente a formação dos acordos preferenciais de comércio. Isso tem por efeito retirar a imperatividade do artigo I:1, cuja função primordial não

\footnotetext{
${ }^{402}$ OMC, Turkey -Textiles, Report of the Panel, par. 9.87-9.90; 9.186-9.192. OMC, Turkey - Textiles, Appellate Body Report, par. 43-65.
} 
discriminatória é logicamente incompatível com os acordos preferenciais de comércio, visto esses permitirem tratamentos discriminatórios. A validade da exceção está intrinsecamente vinculada ao cumprimento das condições previstas nos parágrafos 5 e 8 do artigo XXIV, bem como à comprovação de que medidas restritivas impostas em violação ao sistema multilateral de comércio são essenciais para a existência do APC. Nesse particular, ressalta-se que cabe ao Estado-membro que invocar a exceção do artigo XXIV o ônus de provar a legalidade do acordo preferencial de comércio.

Diante do exposto, constata-se que o controle estrutural de acordo preferencial de comércio será exercido conjuntamente pelo CARC e pelo OSC. O Comitê de Acordos Regionais de Comércio tem competência para analisar a compatibilidade da união aduaneira, área de livre-comércio e acordo interino em relação ao sistema multilateral de comércio, inclusive os aspectos políticos e econômicos, enquanto o Órgão de Solução de Controvérsias é autorizado a examinar casualmente apenas a consistência das medidas dos APC, nas interações entre os Estados-membros, segundo uma racionalidade jurídica. O controle de legalidade visa, assim, verificar o cumprimento dos requisitos formais previstos nos parágrafos 5 e 8 do artigo XXIV.

Não obstante, o Órgão de Solução de Controvérsias não tratou com devido cuidado do segundo aspecto funcional do artigo XXIV. A relação entre os artigos I:1 e XXIV não pode ser concebida como meramente estrutural. Isso porque a permissão conferida pela regra de calibração para excepcionar a regra geral do tratamento da nação mais favorecida somente se justifica em razão dos objetivos previstos no artigo XXIV:4. Para ser válida, a medida de exceção deve cumprir com os requisitos formais, internos e externos, previstos nos parágrafos 5 e 8 .

Entretanto, para confirmar a licitude não basta uma análise de legalidade, deve-se justificar funcionalmente a pretensão segundo os objetivos do parágrafo 4. Daí ser imputado ao Estado-membro o ônus de comprovar que o acordo preferencial de comércio tem por escopo aumentar o bem-estar das partes-contratantes, mediante o aprofundamento da integração econômica e sem opor obstáculos a terceiros. Há, portanto, a necessidade de examinar se a união aduaneira, área de livre-comércio ou acordo interino é, além de válida, lícita. 
No sistema multilateral de comércio, o controle de licitude é exercido pelo Órgão de Solução de Controvérsias, ao qual cabe investigar, casualmente, se uma medida do acordo preferencial de comércio, que tenha cumprido com o disposto nos parágrafos 5 e 8 do artigo XXIV, não produz efeitos, diretos ou indiretos, em desacordo ou vedados pelo artigo XXIV:4, ou mesmo por outras disposições do SMC. A análise da licitude está diretamente associada à conduta dos Estados-membros, na medida em que tem por objeto avaliar se certo instrumento jurídico cumpre nas relações entre os Membros sua função pressuposta, ou é empregado para produzir efeitos empíricos que são proibidos pelo SMC. Para exemplificar, acordos preferenciais de comércio poderiam ser celebrados em estrito cumprimento aos dispositivos previstos no artigo XXIV:5 e 8; porém, serem utilizados não para aumentar o bem-estar das partes-contratantes mediante integração econômica e sem a oneração de terceiros, mas com a finalidade de esquivar-se das normas que proíbem a formação de tratamentos meramente discriminatórios, visando unicamente distorcer os fluxos comerciais em benefício próprio e dano alheio.

A cláusula da nação mais favorecida guarda, portanto, um papel central nas relações preferenciais constituídas sob o auspício do artigo XXIV. Primeiramente, o artigo I:1 é a regra geral que deve ser obedecida por todos, exceto na hipótese em que Estados-membros decidam celebrar um acordo preferencial de comércio tipificado, nos termos do artigo XXIV. Segundo, ser a causa jurídica pressuposta que justifica a imputação do ônus de provar o cumprimento dos requisitos formais do artigo XXIV às partes-contratantes. Por fim, contatou-se que o tratamento da nação mais favorecida é, em ultima ratio, uma norma de conduta que imputa aos Estados-membros a obrigação de respeitar o princípio da não discriminação; enquanto o artigo XXIV:4 estabelece que os APC somente podem ser empregados com a estrita finalidade de aumentar o bem-estar, sem prejudicar terceiros. Os artigos I:1 e XXIV:4 incidem conjuntamente sobre os Estados-membros, tendo por efeito a fixação de parâmetros gerais de comportamento, os quais servem para auxiliar o controle de licitude das medidas dos acordos preferenciais de comércio em face do SMC. 


\subsubsection{Suspensão de obrigações (Artigo XXV:5 do GATT e IX:3 e 4 do Acordo OMC)}

Algumas organizações internacionais permitem às partes dispensarem qualquer membro de certa obrigação, em razão de circunstâncias extraordinárias. Na forma do artigo XXV:5 do Acordo Geral sobre Tarifas e Comércio, os Estados-partes detinham a competência para conceder uma suspensão de obrigações (waiver) impostas a determinado Estado, mediante aprovação por votação com quórum qualificado de dois terços. Com a Organização Mundial do Comércio, o poder de suspender foi alterado, passando a ser atribuído à Conferência Ministerial, ou, nos períodos entre as sessões, ao Conselho Geral. Os parágrafos 3 e 4 do artigo IX do Acordo OMC preveem que os Estados-membros, apenas em circunstâncias excepcionais, podem conferir uma waiver por prazo nunca superior a um ano, devendo ser aprovada pela maioria de três quartos dos Membros. A suspensão de obrigações consiste, assim, na regra de calibração geral do sistema multilateral de comércio.

$\mathrm{Na}$ concepção de Kenneth Dam, as suspensões de obrigação guardam semelhanças com um ato declaratório, pois possuem uma dupla função: esclarecer as relações jurídicas e servir como uma lex specialis em benefício de um Estado-membro. A existência das waivers visa, essencialmente, evitar disputas e controvérsias entre os Membros, tendo especial importância nos momentos em que o agravamento das tensões nas relações econômicas internacionais venha a ameaçar a própria instituição. Entretanto, os efeitos da suspensão não se restringem a afetar diretamente a imputabilidade de uma obrigação atribuída a certo Estado, mas indiretamente têm por consequência jurídica modificar os direitos e deveres de todos os Membros. $^{403}$

Nesse particular, a concessão de suspensão do artigo I:1 do GATT constitui um caso particularmente sensível, pois implica problemas de coesão e eficácia normativa do sistema multilateral de comércio. Devido à importância estrutural e funcional da cláusula da nação

\footnotetext{
${ }^{403}$ DAM, 1970, p. 354-355. FOOTER, Mary E. An institutional and normative analysis of the World Trade Organization. Leiden: Martinus Nijhoff Publishers, 2006, p. 254.
} 
mais favorecida, o artigo XXX do GATT estabelece que quaisquer alterações da Parte I exigem a aceitação da unanimidade dos Membros. Daí surgirem dúvidas acerca do quórum necessário para aprovação de dispensa das obrigações do artigo I:1. Os argumentos legalistas sustentam haver uma diferença ratione temporis entre alteração e suspensão, enquanto os funcionalistas defendem os institutos, que, por terem efeitos semelhantes, devem respeitar o mesmo princípio consensual. Para harmonizar o entendimento, os Estados, em 1956, decidiram adotar o "Article XXV - Guiding Principles to be followed by the CONTRACTING PARTIES in considering applications for waivers from Part I or other important obligations of the Agreement", que visava estabelecer princípios interpretativos para orientar a outorga das waivers em face da Parte I do GATT. ${ }^{404}$

Adicionalmente, o painel do Caso United States - Restrictions on the importation of sugar and sugar containing products applied under the 1955 waiver and under the headnote to the schedule of tariff concessions decidiu que:

The Panel took into account in its examination that waivers are granted according to Article XXV:5 only in "exceptional circumstances", that they waive obligations under the basic rules of the General Agreement and that their terms and conditions consequently have to be interpreted narrowly. ${ }^{405}$

Não obstante às incertezas, o artigo I:1 foi, por diversas vezes, objeto de suspensões, as quais tiveram diferentes impactos sobre o SMC. Dentre os mais relevantes casos, a Convenção de Lomé exemplifica a problemática de permitir a aplicação da regra de calibração prevista no artigo XXV:5 para excetuar os efeitos do artigo I:1. Os conflitos reunidos sobre a rubrica “Guerra das Bananas” desdobraram-se em diversos capítulos, tendo por objeto central as tensas interações econômicas internacionais sujeitas ao relacionamento dos princípios da não discriminação, reciprocidade e desenvolvimento. Em 1994, as Comunidades Europeias e os países do grupo Ásia, Caribe e Pacífico apresentaram uma solicitação para concessão de suspensão temporária do artigo I:1. Ainda sob tutela do GATT 1947, os Estados-partes

\footnotetext{
${ }^{404}$ GATT, GATT Analytical Index, p. 884. GATT. Contracting-Parties. Decisão n. L/403, 7 set. 1955, $11^{\text {a }}$ sessão. Article XXV - Guiding Principles to be followed by the CONTRACTING PARTIES in considering applications for waivers from Part I or other important obligations of the Agreement. Disponível em <http://sulderivatives.stanford.edu/derivative?CSNID=90690142\&mediaType=application/pdf $>$. Acesso em: 22 mai. 2009. ${ }^{405}$ GATT, GATT Analytical Index, p. 884. GATT. United States - Restrictions on the importation of sugar and sugar containing products applied under the 1955 waiver and under the headnote to the schedule of tariff concessions. Report by the Panel, 7 nov. 1990. Disponível em <http://www.wto.org/english/tratop_e/dispu_e/89sugarc.wpf >. Acesso em: 22 mai. 2009. Documento da OMC n. L/6631 - BISD 37S/228, par. 5.9.
} 
decidiram conceder a Lomé Waiver, cujo prazo de vigência foi, posteriormente, estendido pelo Conselho Geral para 29 de fevereiro de 2000.

Entretanto, Equador, Guatemala, Honduras, México e Estados Unidos propuseram, em 1996, uma demanda em face das Comunidades Europeias para tratar dos limites interpretativos da suspensão que dispensava as partes-contratantes da Convenção de Lomé de cumprir com as obrigações do tratamento da nação mais favorecida. No Caso EC - Bananas III, o Órgão de Apelação decidiu que as obrigações inerentes ao artigo I:1 deveriam ser integralmente imputadas às $\mathrm{CE}$, exceto naquilo em que fossem expressamente dispensadas pela Convenção de Lomé. Com efeito, as medidas administrativas impostas pelas CE sobre o comércio de bananas não estavam inseridas no escopo da Lomé Waiver, sendo, portanto, declaradas inconsistentes com o artigo I: $1 .^{406}$

Ante o exposto, constata-se que o instituto da suspensão de obrigações, previsto no artigo XXV:5 do GATT e no artigo IX:3 e 4 do Acordo OMC, tem a natureza de regra geral de calibração do sistema multilateral de comércio, tendo por objetivo flexibilizar as obrigações imputadas aos Membros, desde que respeitado o princípio da reciprocidade. Ainda que sua função sistêmica tenha assegurado um quórum reduzido para outorga de suspensão à cláusula da nação mais favorecida, o artigo I:1 restringe finalisticamente seus efeitos. Isso porque qualquer waiver deve ser interpretada restritamente, excepcionando o tratamento da nação mais favorecida tão somente naquilo em que foi dispensado.

\subsubsection{Tratamento Especial e Diferenciado (Parte IV do GATT e Cláusula de Habilitação)}

O tratamento especial e diferenciado (special \& differential treatment - "S\&D") consiste em uma série de instrumentos jurídicos desenvolvidos no âmbito do direito econômico internacional, com a finalidade de colaborar com a redução das desigualdades nos

\footnotetext{
${ }^{406}$ OMC, EC - Bananas III, Report of the Appellate Body, par. 183-207. MYERS, Gordon. Banana wars: the price of free trade: a Caribbean perspective. Londres: Zed Books, 2004, p. 84-86. OMC. General Council. Decision n. WT/L/186, 8 out. 1996. EC - The Fourth ACP-EC Convention of Lomé, Extension of Waiver. Disponível em <http://docsonline.wto.org/DDFDocuments/t/WT/L/186.WPF>. Acesso em: 22 mai. 2009.
} 
níveis de desenvolvimentos entre os Estados-membros. Em breve retrospectiva histórica, percebe-se que, quando da celebração do Acordo Geral sobre Tarifas e Comércio em 1947, não havia um reconhecimento da condição de país em desenvolvimento, ou qualquer dispositivo legal que estabelecesse tratamento diferenciado. Construído sobre o auspício do princípio da soberania econômica, o GATT previa direitos e obrigações que deveriam ser aplicados uniformemente sobre todos os Estados-partes, ainda que 11 dos 23 pudessem ser considerados, à época, como países em desenvolvimento.

Como examinado no Capítulo 1.3.1., as relações econômicas internacionais assistiram à proliferação do pensamento desenvolvimentista, responsável por subsidiar a reivindicação dos países em desenvolvimento por mecanismos que permitissem: (i) a promoção da industrialização por políticas econômicas conhecidas como Industrialização por Substituição de Importações; (ii) incentivo a exportações de produtos industrializados, mediante programas de subsídios; e (iii) utilização de instrumentos de controle comercial para fazer frente a problemas de balança de pagamentos.

Nesse cenário, a introdução do S\&D no sistema multilateral de comércio remonta às primeiras negociações do GATT em 1947, nas quais se debateu a extensão do tratamento diferenciado que seria concedido aos países subdesenvolvidos. Nessa fase incipiente, o diferencial concedido pelo GATT está restrito ao artigo XVIII, o qual reconhece expressamente a importância do desenvolvimento econômico, razão pela qual permite a adoção de medidas de proteção à indústria nascente e de restrição de importações. ${ }^{407}$

Nos anos subsequentes, os debates entre desenvolvimentistas e neoliberais acerca das causas da persistência das disparidades de desenvolvimento econômico exigiu a criação de uma comissão de economistas liderados pelo Professor Gottfried Haberler, para examinar os fatores impeditivos de um maior equilíbrio entre os países desenvolvidos e subdesenvolvidos. O resultado foi o Haberler Report - Trends in International Trade de 1958, o qual constatou que as regras aplicáveis à época ao comércio internacional refletiam um desequilíbrio desfavorável aos interesses dos países subdesenvolvidos. Em razão disso, o grupo de especialistas recomendou: (i) a criação de programas de estabilização dos preços dos produtos agrícolas; e (ii) a redução das taxas de importação dos países desenvolvidos para produtos primários.

${ }^{407}$ NASSER, 2002, p. 246-251. 
Influenciados pelas ideias da Cepal, os países em desenvolvimento fomentaram a primeira Conferência das Nações Unidas para o Comércio e Desenvolvimento de 1964, a qual analisou como a relação entre comércio e desenvolvimento pode estimular o desenvolvimento econômico. Em seu Ato Final, a Unctad I estabeleceu, como um de seus objetivos principais, a introdução de tratamento especial e diferenciado no comércio entre países subdesenvolvidos e desses com os países desenvolvidos. Tais regras propunham a redução de tarifas de importação dos países desenvolvidos aos subdesenvolvidos segundo bases não recíprocas. ${ }^{408}$

Pressionados pelas reivindicações, os Estados-partes do GATT aprovaram, em 1965, o Protocolo de Introdução da Parte IV sobre Comércio e Desenvolvimento, cujo objetivo era promover o comércio dos países em desenvolvimento, por meio do aumento de acesso a mercado a seus produtos. A nova parte compreende três artigos alinhados com os principais pontos de interesse defendidos pela Unctad. O artigo XXXVI estabelece os princípios e objetivos que devem estar presentes nas relações com os países em desenvolvimento, tendo como principal inovação a flexibilização do princípio da reciprocidade. O artigo XXXVII dispõe acerca de outros compromissos sobre regras comerciais, assumidos pelos países desenvolvidos e países em desenvolvimento, visando prioritariamente à eliminação de restrições que imputem tratamento diferenciado entre produtos industrializados e primários. $\mathrm{O}$ artigo XXXVIII prevê uma obrigação dos Estados-partes de colaborarem coletivamente para possibilitarem a consecução dos objetivos enunciados na Parte IV. Assim, a Parte IV do GATT serve para conferir vantagens discriminatórias aos países em desenvolvimento, a fim de não ser requerida deles a reciprocidade de benefícios concedidos pelos países desenvolvidos. $^{409}$

Ainda que desenhada para fomentar o desenvolvimento e os interesses dos países em desenvolvimento no SMC, a Parte IV não dispõe de regras prescritivas de obrigações e responsabilidades, mas apenas de normas promotoras de melhores práticas. De fato, as medidas adotadas não propiciaram o aumento do acesso a mercado a produtos oriundos de países em desenvolvimento, o que resultou em ampla insatisfação.

408 UNCTAD. Secretariat. UNCTAD: a Brief Historical Overview. Disponível em <http://www.unctad.org/en/docs/gds20061_en.pdf〉. Acesso em: 22 mai. 2009. Documento da Unctad n. UNCTAD/GDS/2006/1, p. 13-14. MICHALOPOULOS, Constantine. Trade and Development in the GATT and WTO: the Role of Special and Differential Treatment for Developing Countries. Washington: World Bank, 2000. Disponível em <http://ssrn.com/abstract=630760>. Acesso em: 22 dez. 2009. World Bank Policy Research Working Paper n. 2388, p. 2-4.

${ }^{409}$ GATT, GATT Analytical Index, p. 1039-1040. 
Como as preocupações acerca da relação comércio e desenvolvimento não foram eficientemente recepcionadas pelo GATT, a Unctad se tornou o fórum central das propostas dos países em desenvolvimento. Ungida, posteriormente, a condição de órgão permanente da ONU, por meio da Resolução no 1.995 (XIX), a Unctad realizou a sua segunda sessão em Nova Deli, em 1968. Os Estados-partes do GATT que participaram da conferência expressaram sua concordância com os objetivos estabelecidos na Resolução 21(II), os quais tratam da criação do sistema geral de preferências. Fundado em bases não recíprocas e não discriminatórias, o SGP consiste em um mecanismo de concessão de tratamento comercial preferencial pelos países desenvolvidos em favor dos países em desenvolvimento, o qual visa (i) aumentar os ganhos de exportações dos países em desenvolvimento; (ii) promover sua industrialização; e (iii) acelerar seu crescimento econômico.

No entanto, a ideia de um sistema de tratamento especial e diferenciado proposto na Unctad era inconsistente com a cláusula da nação mais favorecida, na medida em que as regras preferenciais autorizariam relações discriminatórias e não recíprocas entre os Estadoscontratantes. Para o sistema geral de preferências não incorrer em conflitos normativos com o SMC, foi necessário desenvolver uma nova regra de calibração do tratamento da nação mais favorecida, a qual tomou a forma, inicialmente, de uma suspensão de obrigação aprovada pelos Estados-partes, nos termos do artigo XXV:5. Em 1971, os Estados-partes aprovaram uma waiver do artigo I:1 do GATT, por um período de 10 anos, para legitimar e permitir que todos os países desenvolvidos pudessem outorgar tratamentos tarifários preferenciais a produtos originados em países em desenvolvimento. ${ }^{410}$

Em 28 de novembro de 1979, com o término da vigência da suspensão de 1971, os Estados-partes decidiram estabelecer uma exceção permanente ao tratamento da nação mais favorecida. A Decisão sobre "Differential and More Favourable Treatment, Reciprocity and Fuller Participation of the Developing Countries", posteriormente referida como cláusula de habilitação (enabling clause), permite a concessão de tratamento especial e diferenciado aos países em desenvolvimento e, a partir de então, aos países menos desenvolvidos (“PMD”),

${ }^{410}$ ONU. General Assembly. Resolution n. 1995 (XIX), 30 dez. 1964. Establishment of the United Nations Conference on Trade and Development as an Organ of the General Assembly. Disponível em: <http://www.unctad.org/en/docs/ares1995xix_en.>. Acesso em: 28 fev. 2009. USTOR, 1970, p. 228. UNCTAD, UNCTAD: a Brief Historical Overview, p. 14-15. NASSER, 2002, p. 246-254. KECK, Alexander; LOW, Patrick. Special and Differential Treatment in the WTO: Why, When and How? Genebra: WTO, 2004. Disponível em <http://www.wto.org/english/res_e/reser_e/ersd200403_e.doc〉. Acesso em: 22 dez. 2009. Economic Research and Statistics Division, Staff Working Paper n. ERSD-2004-03, p. 3-5. 
tendo por objetivo facilitar e promover o comércio e desenvolvimento, sem as dificuldades inerentes ao princípio da reciprocidade e da não discriminação. Note-se que cláusula de habilitação permite - e não obriga - os países desenvolvidos a concederem tratamento preferencial aos países em desenvolvimento, ou seja, é uma norma de permissão, e não uma regra de obrigação. Nesse particular, a Decisão, em seu parágrafo 2(a), prevê que o tratamento tarifário preferencial, outorgado pelos países desenvolvidos aos produtos originados em países em desenvolvimento, não será considerado inconsistente com o artigo I:1, pois seus efeitos estarão limitados ao disposto no sistema geral de preferências, respeitando os princípios da generalidade, não discriminação e não reciprocidade. ${ }^{411}$

No âmbito jurisprudencial, o Caso US - MFN Footwear tem particular importância, pois foi o primeiro a questionar os limites da exceção à cláusula da nação mais favorecida, conferida pela cláusula de habilitação. Na demanda proposta pelo Brasil em face dos EUA, alega-se que a legislação estadunidense sobre sistema geral de preferências, ao conceder isenção tarifária a produtos originados em certos países em desenvolvimento, viola o princípio da não discriminação previsto no artigo I:1 do GATT. Preliminarmente, o painel reconheceu que o parágrafo 2(a) autoriza a outorga de "preferential tariff treatment accorded by developed contracting parties to products originating in developing countries in accordance with the Generalized System of Preferences". Isso significa que a cláusula de habilitação restringe expressamente a concessão do $\mathrm{S} \& \mathrm{D}$, no âmbito do $\mathrm{SGP}$, apenas às preferências tarifárias, o qual pode discriminar subjetivamente em razão dos Estados-partes em desenvolvimento beneficiados. Com isso, concluiu o painel que:

[...] there is no decision of the CONTRACTING PARTIES justifying the given inconsistency with Article I:1 of the non-tariff advantage accorded to duty-free products originating in countries beneficiaries of the United States GSP programme in the backdating of the effect of the revocation of countervailing duty orders. ${ }^{412}$

O Caso European Communities - Conditions for the Granting of Tariff Preferences to Developing Countries ("EC - Tariff Preferences") examinou a demanda apresentada pela Índia em face das Comunidades Europeias, na qual se alega que as condições impostas pelo Regulamento $\mathrm{CE} \mathrm{n}^{\circ}$ 2501/2001 para a concessão de tarifas preferenciais aos países em

\footnotetext{
${ }^{411}$ GATT. Contracting-Parties. Decision n. L/4903, 28 nov. 1979. Differential and more favourable treatment reciprocity and fuller participation of developing countries. Disponível em: <http://sulderivatives.stanford.edu/derivative?CSNID=90970166\&mediaType=application/pdf $>$. Acesso em: 2 jun. 2009 .

${ }^{412}$ OMC, US - MFN Footwear, Report by the Panel, 1992, par. 6.14-6.17.
} 
desenvolvimento, no âmbito do sistema geral de preferências, são inconsistentes com os artigos 4.7 e 6 do ESC, artigos I:1 e XXIII:2 do GATT 1994 e parágrafo 4(b) da cláusula de habilitação. O Regulamento CE no 2501/2001 prevê cinco diferentes modalidades de tarifas preferenciais, dentre as quais se encontra a modalidade de combate à produção e ao tráfico de drogas que disciplina a concessão de benefícios aos "countries undertaking effective programmes to combat drug production and trafficking". 413

$\mathrm{Na}$ perspectiva da Índia, a modalidade antidrogas implicaria na infração ao artigo I:1 do GATT, pois não era consistente com as três condições que um país desenvolvido deve considerar ao adotar um programa de SGP: (i) sua estrutura não deve discriminar entre países em desenvolvimento; (ii) deve ser benéfico a todos os países em desenvolvimento; e (iii) deve ser desenhado para responder positivamente às necessidades dos países em desenvolvimento. Todavia, o SGP das CE não cumpriria com nenhuma das condições. Primeiro, ao selecionar doze países, discrimina-os entre os demais países em desenvolvimento. Segundo, não beneficia os países em desenvolvimento, visto criarem oportunidades de acesso a mercado para alguns em prejuízo dos demais. E, finalmente, não são desenhados para propiciar reflexos positivos nos países em desenvolvimento, mas apenas nas Comunidades Europeias. ${ }^{414}$

O Órgão de Apelação reconheceu que o tratamento especial e diferenciado outorgado a países em desenvolvimento seria inconsistente com o artigo I:1, visto que há uma obrigação de estender, imediata e incondicionalmente, qualquer vantagem concedida a Estados-membros. Todavia, o parágrafo $1^{\mathrm{o}}$ da cláusula de habilitação permite aos Estados excepcionar o tratamento da nação mais favorecida, a fim de prover S\&D aos países em desenvolvimento, de acordo com certos princípios e condições. Essa aparente antinomia é resolvida pelo OPA mediante a aplicação da regra lex specialis derogat generalis: "the Enabling Clause, as the more specific rule, prevails over Article I: 1 ".

Para verificar a validade e licitude da medida do Estado-membro em relação à cláusula de habilitação, os painéis devem seguir um procedimento, em três etapas, que afere a consistência dessa relação normativa. Na primeira, o painel deve examinar se a medida

\footnotetext{
${ }^{413}$ CE. Regulamento (CE) n. 2820, $21 \mathrm{dez}$. 1998. Estabelece um sistema plurianual de preferências pautais generalizadas durante o período compreendido entre 1 de julho de 1999 e 31 de dezembro de 2001. L. 357 Jornal Oficial das Comunidades Europeias.

${ }^{414}$ OMC. European Communities - Conditions for the Granting of Tariff Preferences to Developing Countries. Report of the Panel, 1 dez. 2003. Disponível em <http://docsonline.wto.org/DDFDocuments/t/WT/DS/246R00.doc>. Acesso em: 1 jun. 2009. Documento da OMC n. WT/DS246/R, par. 4.8-4.30.
} 
contestada é inconsistente com o artigo I:1. Caso seja considerada inconsistente, o painel deve ponderar se a medida está em consonância com os requisitos da cláusula de habilitação. Por fim, na hipótese de entender que a medida é consistente com a cláusula de habilitação, o painel reconhecerá a validade e licitude da medida, cujo efeito é conter a eficácia normativa do artigo $\mathrm{I}: 1 .^{415}$

Desse modo, o Órgão de Apelação examinou, no contexto do EC - Tariff Preferences, os termos da enabling clause, em especial dos princípios da generalização, da não discriminação e da não reciprocidade, visando dispor sobre os limites hermenêuticos da regra de calibração. Ao investigar os termos dos princípios do SGP, constatou-se que o significado do termo generalizado é "apply more generally" ou "become extended in application". Embora pareça contrariar a própria ideia de tratamento preferencial, o termo generalizado foi inserido no texto da Decisão de 1979, objetivando eliminar os fragmentados sistemas de preferências coloniais, construídos pelas históricas relações de dependência.

$\mathrm{Na}$ decisão do painel, à expressão não discriminatória, prevista no parágrafo $3^{\circ} \mathrm{da}$ cláusula de habilitação, foi atribuído o sentido de obrigação, a qual imputaria aos Estados o dever de conceder tratamento idêntico a todos os países em desenvolvidos, sem qualquer diferenciação. Revendo essa decisão, o OPA apresentou nova interpretação à não discriminatória: dever dos Estados de conceder tratamento idêntico de tarifas preferenciais a todos os países em desenvolvimento beneficiários que estejam em situação similar. Nesse sentido, o Órgão de Apelação concluiu que

the term "non-discriminatory" in footnote 3 does not prohibit developed-country Members from granting different tariffs to products originating in different GSP beneficiaries, provided that such differential tariff treatment meets the remaining conditions in the Enabling Clause.

Com isso, o Órgão de Apelação rejeitou o entendimento da Índia e do painel de que todos os países em desenvolvimento devem ser tratados igualmente; porém, reconheceu que a modalidade antidrogas não contém critérios objetivos para distinguir os beneficiários. Daí o Regulamento CE nº 2501/2001 ser considerado inconsistente com o artigo I:1. ${ }^{416}$

\footnotetext{
${ }^{415}$ OMC. European Communities - Conditions for the Granting of Tariff Preferences to Developing Countries. Report of the Appellate Body, 7 abr. 2004. Disponível em <http://docsonline.wto.org/DDFDocuments/t/WT/DS/246ABR.doc>. Acesso em: 1 jun. 2009. Documento da OMC n. WT/DS246/AB/R, par. 91-101.

${ }^{416}$ OMC, EC - Tariff Preferences, Report of the Appellate Body, 2004, par. 142-174.
} 
Outrossim, o Órgão de Apelação reconheceu que cabe ao Estado-promissor o ônus de provar que o tratamento preferencial outorgado aos países em desenvolvimento cumpre com os princípios e condições da cláusula de habilitação. Isso retira o ônus do Estado-demandante de comprovar suas alegações de inconsistência acerca da medida contestada. Nas palavras do OPA:

We are therefore of the view that the European Communities must prove that the Drug Arrangements satisfy the conditions set out in the Enabling Clause. Consistent with the principle of jura novit curia, it is not the responsibility of the European Communities to provide us with the legal interpretation to be given to a particular provision in the Enabling Clause; instead, the burden of the European Communities is to adduce sufficient evidence to substantiate its assertion that the Drug Arrangements comply with the requirements of the Enabling Clause. ${ }^{417}$

Embora o SGP tenha sido concebido como instrumento jurídico promotor do desenvolvimento em benefício dos países em desenvolvimento, a sua estrutura propicia aos países desenvolvidos o controle das interações econômicas, visto ser assegurado a esses determinar os produtos, as preferências e os Estados beneficiários do tratamento diferenciado. Daí o Órgão de Solução de Controvérsias estar limitado a verificar se o cumprimento das condições da cláusula de habilitação é suficiente para assegurar a legalidade e licitude da exceção, cujo efeito é afastar a aplicação do artigo I:1. Em razão disso, não são investigados os efeitos indiretos decorrentes desse tratamento preferencial, os quais poderão ser inconsistentes com a própria causa jurídica pressuposta da enabling clause. Desse modo, o controle exercido pela Organização Mundial do Comércio sobre os programas estatais vinculados ao sistema geral de preferência não tem o condão de evitar a formação de relações discriminatórias de dependência e subordinação entre os países desenvolvidos e em desenvolvimento.

Ante o exposto, extrai-se das decisões jurisprudenciais que o Órgão de Apelação se autoimpôs uma limitação de competência, ao restringir sua análise da relação normativa entre o artigo I:1 do GATT e a cláusula de habilitação a um exame meramente estrutural. Cumpridos os requisitos formais arrolados na enabling clause, as medidas estatais serão consideradas válidas, independentemente de efeitos ilícitos que porventura sejam por elas produzidos. Em que pese a adoção de métodos sintático-dicionarizados de interpretação, o Órgão de Solução de Controvérsias teve o mérito de reconhecer a existência de uma relevante

${ }^{417}$ OMC, EC - Tariff Preferences, Report of the Appellate Body, 2004, par. 105-110. 
regra hermenêutica procedimental: a inversão do ônus da prova. Isso significa que é obrigação do Estado-promissor dos benefícios, outorgados aos países em desenvolvimento no âmbito do SGP, comprovar a validade e licitude da medida em face dos princípios e condições da cláusula de habilitação. 


\subsection{DISCRIMINAÇÃO DE FACTO E DE JURE}

A interpretação dos termos da cláusula da nação mais favorecida segue uma linha mestra: a proibição ao tratamento discriminatório. A análise dos fundamentos subjacentes às construções argumentativas, expostas nas decisões jurisprudenciais do mecanismo de solução de controvérsias, permite constatar a progressiva passagem de um processo decisório orientado por uma lógica diplomática de índole sintático-dicionarizada para uma racionalidade jurídica de vocação pragmático-funcionalista. Com isso, há a libertação do Órgão de Solução de Controvérsias do julgo predominante dos discursos políticos e econômicos, possibilitando o rompimento com as autolimitações hermenêuticas do discurso jurídico-decisório. O OSC passa, então, a se preocupar com as relações econômicas internacionais na forma de suas decisões.

Nesse sentido, as mudanças jurisprudenciais acerca da interpretação do artigo I:1 do GATT expressa a nova orientação pragmático-finalística do Órgão de Solução de Controvérsias. Considerando os desafios sistêmicos endereçados ao sistema multilateral de comércio, os discursos jurídico-decisórios têm decidido em prol da concretização do princípio da não discriminação nas relações econômicas internacionais. Daí a importância de examinar os dois sentidos particulares do termo discriminação no contexto do artigo I:1, a fim de determinar se a cláusula da nação mais favorecida é a regra determinante para os controles de conduta e de estruturas exercidos pelo OSC.

$\mathrm{Na}$ história do sistema multilateral de comércio, o tratamento da nação mais favorecida servia restritivamente para abolir as medidas impostas pelos Estados-membros que explicitamente discriminassem produtos em razão da origem. Os acordos celebrados no final da Rodada Uruguai tiveram por efeito o adensamento de juridicidade, o que resultou no fortalecimento dos princípios do SMC. Em razão disso, as recentes disputas propostas perante o OSC versam não apenas sobre violações explícitas ao artigo I:1, mas também sobre infrações implícitas que não se referem diretamente à origem do produto. Ainda que pairem dificuldades, a jurisprudência tem evoluído no sentido de disciplinar as medidas que, embora 
formalmente neutras quanto à origem, têm por efeito direto ou indireto discriminar entre os Estados-membros.

Quando uma medida estatal estabelece um tratamento que diferencia explicitamente dentre produtos similares em razão de sua origem, trata-se de uma discriminação de jure. Por outro lado, a sofisticação das barreiras discriminatórias ao comércio exige da Organização Mundial do Comércio o exercício de um controle jurídico-normativo dos atos soberanos, a fim de prevenir que tais medidas, apesar de origem neutra, não impliquem efeitos discriminatórios de facto. Há, assim, atos jurídicos e práticas estatais que, apesar de não imporem diretamente qualquer restrição quanto à origem, têm por efeito direto ou indireto discriminar de facto entre os produtos de Estados-membros.

Há dois grupos de preocupações envolvendo a temática da discriminação de facto e de jure. A primeira consiste na inquietação dos Estados-membros quanto ao perigo de excessiva intervenção do OSC em questões domésticas. A origem do receio reside na imprevisibilidade e insegurança decorrentes da passagem da racionalidade jurídica de essência sintáticodicionarizada para a pragmático-funcionalista. Isso resulta na indisposição dos Membros de admitirem o controle de legalidade e de licitude dos respectivos atos jurídicos e práticas estatais domésticos, neutros quanto à origem, pelo Órgão de Solução de Controvérsias. Segundo, a redação do artigo I:1 permite interpretá-la no sentido de impor o tratamento da nação mais favorecida sobre medidas discriminatórias tanto de jure quanto de facto? Quase por definição, a mera diferenciação de produtos tem por consequência discriminá-los de facto, na medida em que sempre certos Estados-membros serão beneficiados em detrimento de outros. Desse modo, constata-se que ambas as preocupações convergem para o mesmo ponto: a necessidade de ir além do mero controle estrutural-formalista por meio da determinação de parâmetros objetivos que assegurem quando uma discriminação de facto viola o sistema multilateral de comércio. ${ }^{418}$

O tratamento da nação mais favorecia, previsto no artigo I:1, impõe examinar se uma medida estatal implicar tratar diferentemente produtos similares de origens distintas. A cláusula da nação mais favorecida é violada quando atos jurídicos e práticas dos Estados-

\footnotetext{
${ }^{418}$ TREBILCOCK; HOWSE, 2005, p. 72. LAFER, 1998, p. 30-32. EHRING, Lothar. De Facto Discrimination in WTO Law: National and Most-Favored-Nation Treatment - or Equal Treatment? Nova York: New York University School of Law, 2001. Disponível em <http://www.jeanmonnetprogram.org/papers/01/013201.html>. Acesso em: 28 jun. 2009. Jean Monnet Working Paper n. 12/01, p. 1-2.
} 
membros têm por objetivo conceder vantagens, explícita ou implicitamente, a terceiros Estados, sem estendê-las automática e incondicionalmente a produtos originários de todos os demais Membros. O problema reside quando a medida estatal não discrimina explicitamente quanto à origem do produto, mas distingue segundo critérios não geográficos, tais como características físicas, preços, formas de produção e outros, tornando a verificação de complicada conclusão.

A distinção de produtos com bases em suas características somente será considerada infratora do artigo I:1 do GATT, caso o critério discriminante incida sobre mercadorias consideradas similares. Logo, qualquer análise quanto à licitude das medidas de origem neutra depende de prévia investigação quanto à similaridade do produto. Isso remete à conclusão prévia de que o termo "produto similar" é entendido em sentido amplo, guardando estreita relação com a noção de competitividade das mercadorias envolvidas. Com efeito, extrai-se que qualquer medida discriminatória, ainda que neutra quanto à origem, não deve ter por objetivo, direta ou indiretamente, distorcer, restringir, ou proibir o comércio de produtos competitivos entre si. Daí investigar as decisões do Órgão de Solução de Controvérsia, de modo a verificar se o controle exercido tem por escopo determinar a licitude dos objetivos subjacentes às medidas discriminantes impostas pelos Estados-membros. ${ }^{419}$

No contexto do GATT 1947, as decisões dos painéis confirmam que as discriminações explícitas quanto à origem eram as principais preocupações do recém-criado sistema multilateral de comércio. Percebe-se, porém, que diversas demandas já exteriorizavam a preocupação dos Estados-partes com a discriminação de facto. Os Casos Australia Ammonium Sulphate e Germany - Sardines foram os primeiros expressar a preocupação em relação aos efeitos ilícitos decorrentes de medidas validamente adotadas por outro Estado. O Caso Australia - Ammonium Sulphate versou sobre o tratamento diferenciado imposto pela Austrália aos fertilizantes, cujo efeito indireto discriminaria de facto o produto chileno. Entretanto, a suposta violação ao artigo I:1 não foi examinada, pois o painel não reconheceu haver similaridade entre os diferentes tipos de fertilizantes. No Caso Germany - Sardines, o painel novamente interpretou o termo "produto similar" em sentido estrito, resultando no não reconhecimento da similitude entre as sardinhas de diferentes espécies. Isso evitou a

\footnotetext{
${ }^{419}$ EHRING, 2001, p. 8-9. HUDEC, 2000, p. 110-112.
} 
condenação da medida adotada pela Alemanha, a qual, apesar de ser neutra quanto à origem, propiciava tratamento discriminatório de facto. ${ }^{420}$

Em um contexto ainda mais complexo, o Caso European Economic Community Programme of Minimum Import Prices, Licences and Surety Deposits for Certain Processed Fruits and Vegetable ("EEC - Minimum Import Prices”) examinou a alegação apresentada pelos Estados Unidos relativas às regras sobre preço mínimo de importação para concentrado de tomate, bem como sobre sistema de licenças e de garantias de depósito, aplicadas pela Comunidade Econômica Europeia a frutas e vegetais processados. O Regulamento do Conselho (CEE) n $n^{\circ} 516 / 77$, em seu artigo 10, exigia a constituição de uma caução, a qual serviria como garantia executável, para compensar a importação de quaisquer quantidades de concentrado de tomate por preço abaixo do mínimo estabelecido. Entretanto, a caução não seria requerida caso o Estado exportador garantisse que o preço de importação não fosse inferior ao mínimo. ${ }^{421}$

Em suas alegações, os Estados Unidos apontaram que o artigo 10 concedia uma vantagem condicionada aos Estados que assegurassem que suas exportações não seriam realizadas a preço inferior ao mínimo, o que seria vedado pela cláusula da nação mais favorecida. Isso teria resultado numa vantagem de facto aos exportadores de Estados garantidores, visto ter imputado aos demais o ônus de manter a caução. Adicionalmente, asseverou-se que apenas sistemas econômicos centralmente planificados ou empresas estatais de Estados Intervencionistas poderiam beneficiar-se com a referida exceção, pois isso envolve a obrigação de garantir um preço mínimo que somente é possível em economias de preços controlados.

A Comunidade Econômica Europeia defendeu que o artigo 10 era consistente com o artigo I:1 do GATT, pois não previa qualquer distinção baseada em sistemas econômicos, ou qualquer outro fator, dentre os exportadores, sendo assegurada a todos incondicionalmente a possibilidade de garantir o preço mínimo. Além disso, não seria verdadeira a alegação de que

\footnotetext{
${ }^{420}$ GATT, Australia - Ammonium Sulphate, Report by the Panel, par. 7-11. GATT, Germany - Sardines, Report by the Panel, par. 10-15.

${ }^{421}$ GATT. European Economic Community - Programme of Minimum Import Prices, Licences and Surety Deposits for Certain Processed Fruits and Vegetable. Report of the Panel, 18 out. 1978. Disponível em <http://www.wto.org/english/tratop_e/dispu_e/76minimp.wpf>. Acesso em: 7 jul. 2009. Documento OMC n. L/4687 - BISD 25S/68, par. 2.1-2.16.
} 
apenas certos sistemas econômicos poderiam beneficiar-se com a exceção, visto que países capitalistas liberais já demonstraram ser possível adotar idênticas provisões.

Ante o exposto, o painel rejeitou os argumentos dos Estados Unidos. Considerando que a garantia poderia ser apresentada tanto pelo importador como pelo Estado exportador, sendo igualmente exigida, independentemente da origem, o painel decidiu que a medida não era discriminatória nos termos do artigo I:1 do GATT. O painel concluiu, portanto, que a exceção à apresentação de caução para garantir o preço mínimo na importação de concentrado de tomate não era inconsistente com o tratamento da nação mais favorecida. ${ }^{422}$

A crítica suscitada a essa decisão enfoca a omissão do painel quanto à alegação da vantagem indevidamente concedida aos Estados na forma de exceção à constituição da caução. O painel interpretou que as duas garantias possíveis, a caução ou o seguro estatal, teriam o mesmo impacto sobre o agente exportador. Ao não analisar comparativamente as consequências de ambas as garantias sobre os agentes econômicos, o painel eximiu-se de verificar se o artigo 10 tinha por efeito indireto impor uma discriminação de facto entre os Estados. $^{423}$

Em contraste, o Caso European Economic Community - Imports of Beef from Canada (“EEC - Imports of Beef”) representou uma significante mudança de tendência das decisões do Órgão de Solução de Controvérsias do GATT. Nessa demanda, o Canadá alegou que as medidas para implementar as concessões acordadas na lista de compromissos da Rodada Genebra pela Comunidade Econômica Europeia não eram consistentes com o artigo I:1 do GATT. A CEE optou por implantar a concessão na forma de quotas de isenções tarifárias para carnes de alta qualidade, cujas regras de importação foram estabelecidas no Regulamento da Comissão (CEE) no 2972/79. O artigo 1(1)(d) desse Regulamento previa que as importações de carne de alta qualidade, caso fossem provenientes dos Estados Unidos, poderiam ser dispensadas de apresentar qualquer licença, se previamente certificada pela única agência autorizada pela CEE, a "Food Safety and Quality Service", que é órgão do Departamento de Agricultura estadunidense.

Primeiramente, o painel constatou que as carnes de alta qualidade exportadas pelos Estados Unidos e Canadá eram produtos similares. Daí, o painel constatou que os produtos

\footnotetext{
${ }^{422}$ GATT, EEC -Minimum Import Prices, Report of the Panel, par. 3.64-3.67; 4.19.

${ }^{423}$ TREBILCOCK; HOWSE, 2005, p. 73.
} 
exportados por outros Estados que não os EUA tinham o respectivo acesso ao mercado da CEE negado, visto ser a agência estadunidense a única habilidade a outorgar certificado de isenção do produto. Desse modo, o artigo 1(1)(d), apesar de não incorrer em ilegalidade, pois era neutro quanto à origem, tinha por efeito ilícito frustrar o acesso de produtos de terceiros Estados à CEE. O painel concluiu, portanto, que o Regulamento Comissão (CEE) no 2972/79 era inconsistente com o artigo I:1 do GATT. ${ }^{424}$

Embora o painel tenha empreguado a expressão "discriminação de facto" para qualificar a situação em análise, nota-se que o cerne da questão envolvia determinar se a medida imposta pela Comunidade Econômica Europeia produzia tratamentos discriminatórios. O painel concluiu no sentido de reconhecer que, apesar de válida, o Regulamento Comissão (CEE) n 2972/79 incorria em efeitos ilícitos, os quais eram inconsistentes com a cláusula da nação mais favorecida.

No mesmo diapasão, o Caso Spain - Coffee também trata, ainda que não nominalmente, de uma demanda envolvendo discriminação de facto. Embora o sistema de classificação tarifária da Espanha não discriminasse explicitamente o café não torrado brasileiro quanto à origem, o painel observou que os tipos de café exportados principalmente pelo Brasil eram sujeitos à tributação desfavorável em relação aos demais exportados por excolônias espanholas. Essa constatação foi fundamental, pois o painel não se restringiu a declarar que a Espanha falhou em estender o tratamento vantajoso aos demais tipos de café, mas reconheceu a existência de um nexo causal discriminante entre os produtos desfavorecidos e a respectiva origem no Brasil. Dessa forma, ao considerar todos os tipos de cafés como produtos similares, o painel decidiu que as diferentes tarifas eram origem neutra, porém produziam efeitos ilícitos, inconsistentes com o artigo I:1, já que discriminavam de facto as importações provenientes do Brasil em detrimento daquelas oriundas das excolônias. $^{425}$

A construção jurisprudencial envolvendo a discriminação de facto e de jure foi somente consolidada após as reformas institucionais promovidas pelo ESC no paradigmático Caso EC - Bananas III. Ao examinar, em sede de recurso, os limites de incidência

\footnotetext{
${ }^{424}$ GATT. European Economic Community - Imports of Beef from Canada. Report of the Panel, 10 mar. 1981. Disponível em <http://www.wto.org/english/tratop_e/dispu_e/80beef.wpf>. Acesso em: 7 jul. 2009. Documento OMC n. L/5099 - BISD 28S/92, par. 3.2-3.8; 4.1-4.3.

${ }^{425}$ GATT, Spain - Tariff Treatment of Unroasted Coffee, Report of the Panel, 1981, par. 4.1-4.12. EHRING, 2001, p. 11.
} 
obrigacional do tratamento da nação mais favorecida, o Órgão de Apelação declarou, pela primeira vez, que o artigo I:1 do GATT é aplicável a medidas que implicam discriminação de facto e de jure. No relatório, o OPA recorreu às decisões dos Casos EEC - Imports of Beef e Spain - Coffee para justificar a imposição da disciplina da cláusula da nação mais favorecidas, prevista também no artigo II do GATS, às condutas discriminatórias dos Estados-membros, não explicitamente declaradas por normas de diferenciação de produtos similares quanto à origem. Nas palavras do Órgão de Apelação:

The ordinary meaning of this provision does not exclude de facto discrimination. Moreover, if Article II was not applicable to de facto discrimination, it would not be difficult -- and, indeed, it would be a good deal easier in the case of trade in services, than in the case of trade in goods -- to devise discriminatory measures aimed at circumventing the basic purpose of that Article.

For these reasons, we conclude that "treatment no less favourable" in Article II:1 of the GATS should be interpreted to include de facto, as well as de jure, discrimination. We should make it clear that we do not limit our conclusion to this case. We have some difficulty in understanding why the Panel stated that its interpretation of Article II of the GATS applied "in casu". ${ }_{226}$

Não obstante, o Órgão de Apelação esclareceu que a causa pressuposta lícita de uma medida discriminatória imposta por um Estado não tem o condão de isentá-lo da responsabilidade pelos efeitos ilícitos por ela produzidos. Consonante com o relatório do Caso Japan - Taxes on Alcoholic Beverages, rejeitou-se o pleito das Comunidades Europeias de aplicar o teste de "fins e efeitos" (aims and effects), o qual visa demonstrar que a medida em análise não teria sido elaborada para impor um tratamento discriminatório entre produtos similares de Estados-membros, mas para perseguir legítimas políticas públicas. O referido teste de funcionalidade é irrelevante, pois, ainda que favorável às $\mathrm{CE}$, não tornaria lícitos os efeitos discriminantes do regime de licenças. Conclui-se, assim, que o artigo I:1 veda o tratamento discriminatório de facto, proibindo inclusive qualquer medida que estabeleça políticas públicas que violem esse preceito, independentemente das justificativas de caráter político ou econômico. $^{427}$

No Caso Canada - Autos, as medidas regulatórias impostas pelo Canadá, que limitavam a concessão de isenções tributárias a certos veículos importado, foram consideradas inconsistentes com o artigo I:1. Isso porque tais normas, apesar de neutras quanto à origem,

\footnotetext{
${ }^{426}$ OMC, EC - Bananas III, Report of the Appellate Body, par. 229-234.

${ }^{427}$ OMC, EC - Bananas III, Report of the Appellate Body, par. 206, 240-241. OMC, Japan - Taxes on Alcoholic Beverages, Report of the Appellate Body, p. 29-33.
} 
produziam efeitos discriminantes entre os importadores, os quais eram intensificados pelas características próprias da indústria automotiva, razão pela qual foram considerados ilícitos pelo Órgão de Solução de Controvérsias. Nesse particular, ressalta-se que a decisão do painel difere dos demais casos de discriminação de facto, pois se alegou que a discriminação decorria das condições concernentes à elegibilidade dos importadores para outorga dos benefícios tributários, não tendo por objeto a própria mercadoria importada. Essa distinção, todavia, não privou o painel de declarar a inconsistência das medidas com o artigo I:1, em razão dos efeitos discriminatórios de facto. ${ }^{428}$

Diante do exposto, é possível afirmar que a cláusula da nação mais favorecida vem se constituindo na regra determinante para a construção do discurso jurídico-decisório do Órgão de Solução de Controvérsias, em relação aos atos jurídicos e práticas estatais, responsáveis por impor relações discriminatórias. A racionalidade pragmático-finalística subjacente às decisões do OSC permite concluir que, embora os termos de facto e de jure não estejam expressos na redação do artigo I:1 do GATT, o tratamento da nação mais favorecida deve assegurar que as relações econômicas entre os Estados-membros não sejam conduzidas em qualquer base discriminatória.

No entanto, por ser fruto de uma construção jurisprudencial, Lothar Ehring aponta o surgimento de incertezas em relação ao parâmetro de incidência do artigo I:1 do GATT sobre os atos jurídicos e práticas estatais, ou seja, as decisões do OSC não explicita quais medidas poderão ser consideradas inconsistentes com a cláusula da nação mais favorecida. O receio justifica-se ainda pela falta de clareza acerca da natureza obrigacional. Desse modo, seria difícil precisar, a partir das decisões, se a obrigação do artigo I:1 imputa uma proibição à discriminação ou uma obrigação de tratamento igualitário. ${ }^{429}$

A inquietação finca suas raízes na própria compreensão de produto similar. A ordem econômica internacional contemporânea tem por característica a dinamicidade da inovação tecnológica, resultando na constante geração de produtos. A velocidade em que as novas mercadorias são elaboradas implica verdadeiro desafio regulatório à capacidade dos Estados de discipliná-las. Isso dificulta inclusive o processo de classificação, responsável por determinar as respectivas similaridades, segundo uma lógica de competitividade. O processo

\footnotetext{
${ }^{428}$ OMC, Canada - Autos, Report of the Panel, par. 10.38-10.45.

${ }^{429}$ EHRING, 2001, p. 26.
} 
de qualificação não é simples, visto exigir do regulador a responsabilidade pela avaliação dos riscos e da segurança do produto, os quais são imprescindíveis para o mercado consumidor.

Em razão disso, a proibição à discriminação de facto ampliou as incertezas quanto aos limites dos Estados para impor medidas que afetem produtos. O desafio regulatório é potencializado pela necessidade de compatibilizar as obrigações imputadas pela cláusula da nação mais favorecida com os demais deveres e responsabilidades do Estado, especialmente em relação ao meio ambiente, segurança, cultura, saúde, consumo e concorrência e outros. Com efeito, essa cessão parcial da soberania resulta em maior restrição ao poder legiferente e à autonomia fiscal dos Estados-membros, pois qualquer norma que imponha diferenciações, caso não seja devidamente justificada com fundamento no artigo XX do GATT, poderá ser objeto de questionamentos perante a OMC. ${ }^{430}$

Ainda que pesem as naturais incertezas decorrentes de decisões pretorianas, é relevante enfatizar que o artigo I:1 do GATT não impõe aos Estados qualquer obrigação estranha ao sistema multilateral de comércio. A cláusula da nação mais favorecida tem por função precípua positivar o princípio da não discriminação nas relações econômicas internacionais, e não de liberalizar ou desregulamentar as economias domésticas. Isso não significa exigir dos Estados um tratamento igualitário para todos os produtos importados, mas vedar atos jurídicos e práticas estatais que estabeleçam diferenciações entre produtos similares, visando beneficiar um Membro em detrimento de outros. Portanto, o artigo I:1 não retira dos Estados o poder de legislar sobre suas políticas comerciais, mas garante que, ao fazê-lo, os produtos similares sejam tratados de forma não discriminatória quanto à origem, tendo por finalidade assegurar o bem-estar dos Estados-membros, por meio do aumento da interdependência comercial, bem como evitar distorções à competitividade internacional, colhendo os benefícios da vantagem comparativa.

${ }^{430}$ EHRING, 2001, p. 27-29. 


\section{CONCLUSÃO}

No fluir da exposição desenvolvida na presente dissertação, os resultados da investigação foram pari passu enunciados e sumarizados, a fim de serem retomados no desdobrar do trabalho. As conclusões parciais de cada Seção e Capítulo compõem-se com a dos subsequentes, de modo a formar uma constelação de significados que contribuem para responder à questão-problema suscitada. Por essa razão, longe de realizar um resumo tópico de pouca valia, o encaminhamento mais apropriado é entrelaçar os significados, de modo a compor um todo coerente que permita o fechamento de toda a argumentação.

A análise de três momentos da ordem econômica internacional revelou que a cláusula da nação mais favorecida é um fenômeno jurídico-cultural complexo, imbricado histórica e axiologicamente na construção do capitalismo global. Isso demanda um estudo unitário do instituto, na medida em que seus fundamentos estruturais e funcionais relacionam-se intrinsecamente para estabelecer os parâmetros de sua aplicação.

Em razão disso, são empregados dois modelos teórico-conceituais, visando a distintos objetivos. Para examinar as regularidades empíricas das relações econômicas internacionais, em termos de realização das expectativas normativas, utiliza-se a noção de ordem econômica internacional, cuja finalidade é compreender as complexas relações entre poder, verdade e direito, conformadoras da cláusula da nação mais favorecida. O segundo modelo é o conceito de sistema multilateral de comércio que serve como instrumento de análise do processo de construção hermenêutico-argumentativa do discurso jurídico-decisório e da jurisprudência do Órgão de Solução de Controvérsias. Com efeito, o ponto central da dissertação consiste no exame da cláusula da nação mais favorecida na ordem econômica internacional, a partir do qual se investiga o discurso jurídico-convencional do artigo I:1 do GATT, em suas relações normativas no âmbito do sistema multilateral de comércio.

Durante o mais longo período de globalização econômica, a cláusula da nação mais favorecida incondicionada simbolizou o compromisso dos países com o livre-comércio. O instituto, que surge no bojo das práticas mercantis, destaca-se pela capacidade adaptativa, o 
que permite sua adequação estrutural e funcional às exigências dos diversos contextos históricos. Sua principal função é assegurar um tratamento não discriminatório entre as partescontratantes. Legitimada pela ideologia do pacifismo liberal e reforçada pela expansão do capitalismo industrial, a Grã-Bretanha utilizou a CNMF para conectar os tratados bilaterais de comércio, formando uma rede capaz de impedir a intervenção estatal discriminante e de ordenar o comércio internacional. O incipiente direito internacional da economia já trazia em seu bojo a concepção de obrigações positivas de mútua cooperação, as quais são necessárias para institucionalizar os vínculos jurídicos entre os agentes econômicos, a fim de promover a interdependência econômica pelo comércio, a paz e o bem-estar social.

Todavia, o entrelaçamento de acordos comerciais produziu um baixo grau de institucionalização normativa, demonstrando-se insuficiente para garantir a previsibilidade e segurança jurídica adequadas às relações econômicas internacionais. As tensões políticoeconômicas provocadas pela ascensão de novos atores conduziram a conflitos comerciais, enquanto o esgotamento das virtualidades da Era de Livre-comércio britânico levou ao esfacelamento da governança econômica internacional, ao rompimento dos laços jurídicos construídos no decorrer do século XIX e à eclosão das Guerras Mundiais. O exame da ordem econômica internacional liberal demonstrou que a cláusula da nação mais favorecida contribuiu com a expansão econômica capitalista e com a difusão de valores liberais, na medida em que positivou o valor da liberdade, conferindo estabilidade às expectativas normativas e preferibilidade por interações não discriminatórias.

A Primeira Guerra Mundial e a Grande Depressão não apenas romperam os frágeis vínculos jurídicos entre Estados adversários, como também afetaram a própria ideia de tratamento da nação mais favorecida. A desarticulação da economia mundial comprometeu a estabilidade e imprimiu um sentimento de desconfiança entre os agentes econômicos, impedindo o retorno da CNMF à posição central nas políticas de comércio internacional. $\mathrm{O}$ fim da Segunda Guerra Mundial concedeu novo fôlego ao instituto, visto que a diplomacia estadunidense tinha planos de reconstruir uma ordem neoliberal, regida por normas multilaterais, as quais conduziriam os países à interdependência pacífica.

Os trinta anos de crise demonstraram que o protecionismo e a discriminação não poderiam ser superados pelo jogo da cláusula da nação mais favorecida no âmbito de relações bilaterais. Os Estados Unidos propuseram, então, a criação da Organização Internacional do 
Comércio, à qual caberia reger as relações econômicas internacionais segundo os princípios neoliberais. Todavia, os reveses das negociações internacionais impediram-na de vigorar. Sob a sombra do embate político-ideológico, a Guerra Fria teve o condão de fragmentar a economia internacional em três ordens de cooperação econômica, fruto das relações de poder e da prevalência de certas ideologias. A sociedade internacional foi fracionada em torno de polaridades definidas, que originaram as ordens neoliberal, socialista e desenvolvimentista, fundadas numa diversidade heterogênea de sistemas normativos, axiológicos e jurídicos, que redundavam em conflitos de concepção acerca da forma de organizar a economia mundial.

Os esforços estadunidenses não foram completamente perdidos, na medida em que vinte e três países celebraram o Acordo Geral sobre Tarifas e Comércio, com o objetivo de estabelecer as normas gerais do comércio internacional. O GATT foi responsável por edificar a vertente comercial da estrutura institucional da ordem parcial de cooperação econômica neoliberal em torno de um multilateralismo procedimental e axiológico, bem como por servir de instrumento legítimo de fortalecimento da posição político-militar dos Estados Unidos. Os elementos essenciais da ordem parcial neoliberal residiam na posição hegemônica dos Estados Unidos, na prevalência da ideologia neoliberal e na nova dimensão institucional, a qual decorre da noção de Estado Intervencionista e de direito internacional de cooperação. Essas características convergem para modelar a governança internacional do comércio, na qual a regência das relações comerciais é capitaneada pelos EUA e orientada pelos princípios neoliberais e pelas normas do sistema GATT.

Ainda que de natureza contratual, o sistema multilateral de comércio conheceu um grau médio de institucionalização, graças a dois fatores: a expansão normativo-organizacional e a interferência hegemônica estadunidense. Os Estados-partes, por meio das rodadas de negociação, ampliaram progressivamente a competência regulatória, bem como conferiram órgãos administrativos ao GATT, para coordenar os fluxos de comércio internacional. Quanto à eficácia social, os Estados Unidos, ao empregarem sua liderança para assegurar o respeito às expectativas normativas, tornaram-se o mecanismo disciplinar das relações econômicas internacionais. Esses fatores contribuíram para a formação de um sistema orientado pelo poder, responsável por construir uma jurisprudência diplomática.

Prevista no artigo I:1 do GATT, a cláusula da nação mais favorecida sofreu profundas transformações estruturais e funcionais. A positivação multilateral permitiu estender, 
automática e incondicionalmente, a todos os Estados-partes os benefícios reciprocamente outorgados. Ainda que sirva como uma norma-feixe, responsável pela coletivização de relações jurídicas bilaterais, sua estrutura obrigacional permanece, porém, bilateral. Funcionalmente, o tratamento da nação mais favorecida ganha um papel dinâmico nas etapas sucessivas e integradas do SMC: (i) assegurar, por meio da função informacional, transparência e dispersão de conhecimento às relações econômicas internacionais; (ii) promover, enquanto função positiva, a cooperação internacional, a fim de eliminar ou reduzir, reciprocamente, as barreiras às trocas comerciais; (iii) vedar as práticas e instrumentos discriminatórios e protecionistas, tendo por função negativa estender, automática, multilateral e incondicionalmente, as vantagens concedidas; e (iv) conservar, enquanto função estabilizadora, as expectativas normativas dos agentes econômicos, mediante a incorporação dos compromissos negociados ao SMC.

A partir da década de 1980, diversas transformações socioeconômicas convergiram para modificar as macroestruturas que imprimiam a polarização definida às relações internacionais. Com a deterioração do bloco socialista e a ascensão econômica da Alemanha Ocidental e do Japão, os Estados Unidos decidiram retirar gradualmente seu irrestrito suporte ao GATT. Devido à dependência do apoio hegemônico estadunidense, o sistema multilateral de comércio de vocação diplomática perde o seu principal mecanismo disciplinar, responsável por garantir a eficácia social de suas normas. Isso possibilita o fortalecimento do regionalismo e do novo protecionismo no comércio internacional.

A abrupta queda do muro de Berlim revigorou o sentimento globalizante, inerente ao pacifismo neoliberal, implicando a diluição, embora não a eliminação, dos conflitos de concepção sobre como organizar a vida mundial. Globalização, multilateralismo, regionalismo, novo protecionismo e o desgaste da liderança estadunidense compõem o conjunto de desafios que surgem em face da governança econômica internacional contemporânea. Nesse contexto, a intensificação dos fluxos comerciais exigiu o fortalecimento das expectativas normativas, por meio de ampla juridificação das relações econômicas internacionais e do aprofundamento institucional do sistema multilateral de comércio. Para isso, a Organização Mundial do Comércio é criada para servir como mecanismo disciplinar institucionalizado e moldura jurídica da universalização das estruturas da ordem parcial neoliberal. 
A reformulação do mecanismo de solução de controvérsias possibilitou o adensamento de juridicidade, o que marcou a passagem paradigmática de um sistema multilateral de comércio orientado pelo poder para um ordenado pelo direito. O diferencial institucional da OMC está, justamente, na autonomia internacional e no estabelecimento de um Órgão de Solução de Controvérsias responsável por garantir a supervisão das condutas dos Estadosmembros, o controle dos discursos normativos e o fortalecimento da efetividade das medidas disciplinares, segundo uma racionalidade jurídica.

Ao longo do processo de institucionalização, iniciado em 1947 com o GATT e do alargamento da competência ratione personae e ratione materiae, a noção de cláusula da nação mais favorecida é modificada qualitativamente, passando a ser concebida como pilar ordenador de todo o sistema multilateral de comércio. Com a expansão do número de Estadosmembros, sua incidência foi globalizada, abrangendo os sistemas econômicos domésticos, regionais e global. Além disso, a transferência de competência regulatória à OMC e a codificação internacional incorporaram ao tratamento da nação mais favorecida uma sorte de novos setores econômicos.

Concomitantemente à universalização institucional da ordem econômica neoliberal, as relações econômicas internacionais assistiram ao fortalecimento dos desafios decorrentes da globalização, do regionalismo, do novo protecionismo e da desgastada liderança hegemônica estadunidense. As práticas estatais e os discursos político-econômicos favoráveis a políticas discriminatórias e comercialmente restritivas passaram a ameaçar de desautorização as regras e princípios nucleares do sistema multilateral de comércio, o qual não conta mais com o patrocínio dos Estados Unidos. Salvaguardada pelas regras de calibração da cláusula da nação mais favorecida, essa tendência fático-axiológica incita à difusão do spaghetti bowl e de medidas protecionistas, as quais flexibilizam as obrigações do tratamento da nação mais favorecida. Com efeito, as reiteradas quebras de expectativas normativas pelo comportamento dos Estados-membros implicam problemas de coesão e de eficácia normativa ao sistema multilateral de comércio, denominados desafios sistêmicos.

No centro da governança econômica internacional, a Organização Mundial do Comércio responde aos desafios sistêmicos, por meio de seu mecanismo disciplinar: o Órgão de Solução de Controvérsias. Resultado das reformas introduzidas pelo ESC, o adensamento de juridicidade aprofundou a institucionalização do mecanismo de solução de controvérsias do 
GATT, alterando-o qualitativamente de um modelo orientado pelo poder para um ordenado pelo direito. As características distintivas de um modelo de adjudicação rule-oriented são a constituição de um terceiro imparcial para julgar as disputas e a adoção de uma racionalidade jurídica na formulação do discurso jurídico-decisório.

Em virtude da ampliação da competência sancionatória-disciplinar, o processo decisório foi institucionalizado, imputando aos intérpretes autênticos o dever de decidir, segundo uma racionalidade jurídica pragmático-argumentativa, nos termos formais e materiais estabelecidos pelo SMC. O exercício do controle de estruturas e de condutas foi institucionalizado, de modo a assegurar maior eficácia social ao discurso jurídicoconvencional e, por consequência, durabilidade às expectativas normativas dos Estadosmembros. As decisões não podem confirmar quaisquer fins pretendidos, ainda que fundados em normas a priori válidas, devendo expressar um conteúdo prático segundo critérios teleológicos, histórica e legitimamente programados, os quais se realizam validamente em referência ao contexto integrante do sistema multilateral de comércio.

Com o reconhecimento de sua autoridade judicante, a Organização Mundial do Comércio tornou-se capaz de influenciar os fluxos do comércio internacional, por meio de poderosos discursos jurídicos que normalizam o comportamento dos Estados-membros. Isso não significa que a OMC seja indiferente ou imune aos jogos de poder e verdade, na medida em que o OSC está sujeito às relações de força e de interesse entre os atores internacionais e às disputas teórico-ideológicas, os quais incidem diretamente sobre o sistema multilateral de comércio, implicando diminuição da eficácia sancionatória e da coesão axiológica, respectivamente.

Nesse contexto, o Órgão de Solução de Controvérsias é confrontado com os desafios sistêmicos, frutos, em grande medida, da quebra reiterada das expectativas normativas em relação à cláusula da nação mais favorecida. Para garantir previsibilidade e segurança jurídica aos agentes econômicos, o OSC realiza a verificação da licitude e da legalidade das práticas estatais e dos atos jurídicos dos Estados-membros em face do artigo I:1 do Acordo Geral sobre Tarifas e Comércio. O controle de estruturas incide sobre a adequação dos requisitos formais dos atos jurídicos, enquanto o controle de condutas examina o respeito às obrigações materiais pelos Membros. Há, assim, um processo de elaboração procedimentalizada do discurso 
jurídico-decisório, mediante a separação de questões jurídicas e político-econômicas, seguida da determinação da validade formal e material a partir do SMC.

Em decisões reiteradas, o Órgão de Solução de Controvérsias tem afirmado que a cláusula da nação mais favorecida detém uma hierarquia superior às demais regras do sistema multilateral de comércio. Ainda que existam regras de calibração, o artigo I:1 incide teleologicamente sobre o comportamento e instrumentos jurídicos dos Estados-membros, o que exige um exame judicante que compreenda, inclusive, os efeitos indiretos que por ventura sejam legais, mas produzam efeitos ilícitos. A racionalidade pragmático-finalística subjacente às decisões jurisprudenciais permite afirmar que o tratamento da nação mais favorecida deve assegurar que as relações econômicas internacionais não sejam conduzidas em qualquer base discriminatória. Desse modo, à medida que rejeita os discursos políticos e econômicos em prol de um discurso jurídico-decisório dotado de racionalidade jurídico-pragmática, o OSC confere ao artigo I:1 maior imperatividade e eficácia normativa, tornando-o pilar ordenador do sistema multilateral de comércio.

Apesar das críticas endereçadas à Organização Mundial do Comércio, as decisões pretorianas têm visado à concreção do artigo I:1 do GATT. Isso implicou normativamente a consolidação de regras hermenêuticas favoráveis à CNMF, tais como: (i) a interpretação extensiva de seus termos linguísticos; (ii) a interpretação restritiva e legalista das regras de calibração em face do artigo I:1; (iii) a interpretação lógica-procedimental, a qual inverte o ônus de comprovação da legalidade, imputando-se ao Membro o dever de demonstrar o cumprimento de todos os requisitos formais da regra de calibração, sob pena de invalidade; (iv) a interpretação sistemática, que rejeita a tese de sistemas autocontidos ou lex specialis, autorizados pelo SMC; (v) a interpretação teleológica, por meio da qual não se limita o controle de licitude aos efeitos direito, de modo a estendê-lo à verificação da existência de efeitos indiretos ilícitos; e (vi) a interpretação axiológica que imputa a vedação à discriminação de juri ou de facto.

Ante a aparente e irresistível ascensão do regionalismo e do novo protecionismo, o Órgão de Solução de Controvérsias, ao sobrepor o discurso jurídico-convencional aos discursos político-econômicos e vedar as práticas soberanas unilaterais, tem simbolicamente reafirmado seu comprometimento institucional com os princípios e regras do sistema multilateral de comércio. 
Diante do exposto, é possível afirmar que a cláusula da nação mais favorecida vem se constituindo na regra determinante para a construção do discurso jurídico-decisório pelo Órgão de Solução de Controvérsias, em relação aos atos jurídicos e práticas estatais, responsáveis por impor relações discriminatórias. A confirmação jurisprudencial da imperatividade e da eficácia normativa do artigo I:1 do GATT reverbera reflexamente sobre os desafios sistêmicos, tendo o poderoso efeito de simbolizar aos agentes econômicos que os intérpretes autênticos, ao ponderarem sobre norma e práxis mercantil, exercem um efetivo controle das consequências em prol da incidência do tratamento da nação mais favorecida sobre as relações econômicas internacionais.

Em retorno ao início da dissertação, constata-se que a globalização não é um movimento socioeconômico inexorável e inevitável. O capitalismo global é a expressão predominante das interações das estruturas comportamental, axiológica e institucional da ordem econômica internacional contemporânea. O sistema multilateral de comércio contribui para conferir maior durabilidade às expectativas normativas dos agentes econômicos, mediante o fortalecimento institucional da cláusula da nação mais favorecida, na qual estão encerrados princípios e valores que permitem a governança econômica internacional. Ao confirmar a prevalência do artigo I:1 do GATT na decidibilidade de conflitos econômicos internacionais, a Organização Mundial do Comércio cumpre sua função de reger as relações econômicas internacionais, por meio da estabilização, da organização e do direcionamento das estruturas comportamentais e axiológicas.

O estudo da cláusula da nação mais favorecida permite apontar que o direito, enquanto discurso jurídico-pragmático, imputa comandos prescritivo-finalísticos, razão pela qual, se não utilizado para a consecução de seus objetivos, torna-se perfeitamente inútil. Divergente do pensar econômico e político, o direito realiza-se nas relações sociais concretas, sendo que comportamentos futuros, ainda que venham a ser orientados pelas expectativas normativas, não podem ser objetos de intervenção judicante direta. A apreciação jurídica está pragmaticamente comprometida em aferir as condutas e discipliná-las para a realização dos fins normativamente prescritos, enquanto ao pensamento político-econômico cabe analisar as interações sociais e sugerir orientações futuras, segundo seus pressupostos teoréticoideológicos. 
Conclui-se, portanto, que os desafios impostos ao artigo I:1 do GATT são presentes, o que exige respostas imediatas e consistentes da Organização Mundial do Comércio aos fenômenos do spaghetti bowl e da proliferação de medidas protecionistas ao comércio. 


\section{REFERENCIAS}

\section{a) Bibliografia}

ABBAGNANO, Nicola. Dicionário de filosofia. Trad. Alfredo Bosi. 21 a ed. São Paulo: Martins Fontes, 1998.

ABI-SAAB, Georges. The Appellate Body and Treaty Interpretation. In: SACERDOTI, Giorgio; YANOVICH, Alan; BOHANES, Jan (org.). The WTO at Ten: The Contribution of the Dispute Settlement System. Cambridge: Cambridge University Press, 2006.

ALLEN, William. The International Trade Philosophy of Cordell Hull, 1907-1933. American Economic Review, [s.1.], v. 43, n. 1, p. 101-116, 1953.

ALMEIDA, Paulo Roberto de. Formação da diplomacia econômica no Brasil: as relações econômicas internacionais no Império. São Paulo: Senac, 2001.

AMARAL JR., Alberto do. A solução de controvérsias na OMC e a aplicação do direito internacional público. Tese apresentada ao concurso para provimento do cargo de Professor Titular, junto ao Departamento de Direito Internacional da USP, 2006. . Introdução ao direito internacional público. São Paulo: Atlas, 2008.

AQUINO, Tomás de. O Ente e a Essência. Os Pensadores: Tomás de Aquino. Trad. Luiz João Baraúna. São Paulo: Nova Cultural, 2000a. . Súmula contra os gentios. Os Pensadores: Tomás de Aquino. Trad. Luiz João Baraúna. São Paulo: Nova Cultural, 2000b.

ARISTÓTELES. Metafísica (Livro I e II). Trad. Vincenzo Coceo. São Paulo: Abril, 1984.

BAGWELL, Kyle; STAIGER, Robert W. Will preferential agreements undermine the multilateral trading system? Economic Journal, [s.1.], v. 108, n. 449, p. 1162-1182, 1998. 248, 1999.

An economic theory of GATT. American Economic Review, [s.1.], v. 89, n. 1, p. 215. The Economics of the World Trading System. [s.1.]: MIT Press, 2004.

BAILEY, S. H. The political aspect of discrimination in International Economic Relations. Economica, [s.1.], n. 35, p. 89-115, 1932. 456, 1933.

Reciprocity and the Most-Favoured-Nation Clause. Economica, [s.1.], n. 42, p. 428- 
BAPTISTA, Luiz Olavo. Dumping e anti-dumping no Brasil. In: AMARAL JR., Alberto do (coord). OMC e o comércio internacional. São Paulo: Aduaneiras, 2002.

BARRAL, Welber. Dumping e Comércio Internacional. Rio de Janeiro: Forense, 2000.

BECK, Ulrich. O que é Globalização? Equívocos do globalismo: respostas à globalização. Trad. André Carone. São Paulo: Paz e Terra, 1999.

BENTLEY, Philip; SILBERSTON, Aubrey. Anti-dumping and Countervailing Action: Limits Imposed by Economic and Legal Theory. Cheltenham: Edward Elgar Publishing, 2007.

BERLIN, Isaiah. Dois conceitos de liberdade. In: Quatro ensaios sobre a liberdade. Trad. Wamberto H. Ferreira. Brasília: Universidade de Brasília, 1981.

BHAGWATI, Jagdish. Protecionismo versus comércio livre. Trad. Mário Salviano. Rio de Janeiro: Nórdica, 1990.

. Regionalism and Multilateralism: An Overview. In: MELO, Jaime de;

PANAGARIYA, Arvind (Eds.). New Dimensions in Regional Integration. Nova York:

Cambridge University Press, 1993.

.; PANAGARIYA, Arvind. The Theory of Preferential Trade Agreements: Historical

Evolution and Current Trends. The American Economic Review, [s.1.], v. 86, n. 2, p. 82-87, 1996.

.; GREENAWAY, David; PANAGARIYA, Arvind. Trading Preferentially: Theory and Policy. The Economic Journal, [s.1.], v. 108, n. 449, p. 1128-1148, 1998.

BINOCHE, Bertrand. Indroduction à De l'Esprit des Lois de Montesquieu. Paris: PUF, 1998.

BOBBIO, Norberto. O futuro da democracia: uma defesa das regras do jogo. Trad. Marco Aurélio Nogueira. Rio de Janeiro: Paz e Terra, 1997.

. Teoria geral da política: a filosofia política e as lições dos clássicos. Michelangelo

Bovero (org.). Trad. Daniela B. Versiani. Rio de Janeiro: Campus, 2000.

. Direito e Estado no pensamento de Emanuel Kant. Trad. Alfredo Fait. São Paulo:

Mandarim, 2001a.

Edipro, 2001b.

. Teoria da norma jurídica. Trad. Fernando P. Baptista e Ariani B. Sudatti. Bauru:

. Da estrutura à função: novos estudos de teoria do direito. Trad. Daniela B. Versiani.

Barueri: Manole, 2007.

BODENHEIMER, Edgar. Ciência do Direito. Trad. Enéas Marzano. Rio de Janeiro: Forense, 1966.

BOWN, Chad P.; MCCULLOCH, Rachel. Nondiscrimination and the WTO Agreement on Safeguards. World Trade Review, [s.1.], v. 2, n. 3, p. 327-348, 2003.

BRAGA, Márcio Bobik. Raúl Prebisch e o Livre Comércio: as Origens do Pensamento Econômico Estruturalista. CADERNOS PROLAM/USP, São Paulo, v. 2, n. 13, p. 76-99, 2008. 
BROWNLIE, Ian. Princípios de direito internacional público. Trad. Maria M. Farrajota, Maria J. Santos, Victor R. Stockinger, Patrícia G. Teles. Lisboa: Fundação Calouste Gulbenkian, 1997.

BULL, Hedley. A sociedade anárquica: um estudo da ordem política mundial. Trad. Sérgio Bath. Brasília: Universidade de Brasília, 2002.

CAPORASO, James A. International Relations Theory and Multilateralism: The Search for Foundations. International Organization, [s.1.], v. 46, n. 3, p. 599-632, 1992.

CARDOSO, Fernando Henrique; FALETTO, Enzo. Dependência e desenvolvimento na América Latina: ensaio de interpretação sociológica. Rio de Janeiro: Civilização Brasileira, 2004.

CARR, Edward Hallett. Vinte Anos de Crise: 1919-1939: Uma Introdução ao Estudo das Relações Internacionais. Trad. Luiz Alberto F. Machado. Brasília: Universidade de Brasília, São Paulo: Imprensa Oficial do Estado de São Paulo, 2001.

CARREAU, Dominique; JUILLARD, Patrick. Droit international économique. $4^{\mathrm{a}}$ ed. Paris: Librairie générale de droit et de jurisprudence, 1998.

CARVALHO, Evandro Menezes de. Organização Mundial do Comércio: cultura jurídica, tradução e interpretação. Curitiba: Juruá, 2008.

NEVES, António Castanheira. Metodologia Jurídica - Problemas Fundamentais. Coimbra: Coimbra, 1993.

CASTELLS, Manuel. A sociedade em rede. Trad. Roneide V. Majer. São Paulo: Paz e Terra, 1999.

CHARNOVITZ, Steve. Rethinking WTO Trade Sanctions. American Journal of International Law, [s.1.], v. 95, n. 4, p. 792-832, 2001.

CHAYES, Abraham; CHAYES, Antonia Handler. The New Sovereignty: Compliance with International Regulatory Agreements. London: Harvard University Press, 1998.

CHASE, Kerry. Multilateralism compromised: the mysterious origins of GATT Article XXIV. World Trade Review, [s.1.], v. 5, n. 1, p. 1-30, 2006.

COMPARATO, Fábio Konder. O indispensável direito econômico. In: Ensaios e Pareceres de Direito Empresarial. Rio de Janeiro: Forense, 1978.

; SALOMÃO FILHO, Calixto. Poder de controle na sociedade anônima. $4^{\mathrm{a}}$ ed. Rio de Janeiro: Forense, 2005.

CONSTANT, Benjamin. Political writings. Trad. Biancamaría Fontana. Cambridge: Cambridge University Press, 1988. 
CRAWFORD, Jo-Ann; FIORENTINO, Roberto V. The Changing Landscape of Regional Trade Agreements. Genebra: WTO Publication, 2003. Disponível em <http://www.wto.org>. Acesso em: 28 de junho de 2009. Discussion Paper $n^{\circ} 8$.

CURZON, Gerard. Multilateral Commercial Diplomacy: The General Agreement on Tariffs and Trade and Its Impact on National Commercial Policies and Techniques. Nova York: Praeger, 1966.

DAL RI JR., Arno. O Direito Internacional Econômico em Expansão: Desafios e Dilemas no Curso da História. In: DAL RI JR., Arno; OLIVEIRA, Odete Maria de (org.). Direito internacional econômico em expansão: desafios e dilemas. Ijuí: Unijuí, 2003.

DAM, Kenneth W. The GATT: Law and International Economic Organization. Chicago: University of Chicago Press, 1970.

DAVEY; William J. Dispute Settlement in GATT. Fordham International Law Journal, [s.1.], v. 11, n. 51, p. 51-109, 1987.

.; PAUWELYN, Joost. MFN Unconditionaly: A Legal Analysis of the Concept in View of its Evolution in the GATT/WTO Jurisprudence with Particular Reference to the issue of "Like Product". In: COTTIER, Thomas; MAVROIDIS, Petros C. (ed.). Regulatory Barriers and the Principle of Non-discrimination in World Trade Law: Past, Present, and Future. Michigan: University of Michigan, 2000.

DIEBOLD JR., William. The end of I.T.O. Princeton: Princeton University Press, 1952.

DUPUY, Pierre-Marie. A General Stocktaking of the Connections between the Multilateral Dimension of Obligation and Codification of the Law of Responsibility. European Journal of International Law, [s.1.], v. 13, n. 5, p. 1053-1081, 2002.

EHRING, Lothar. De Facto Discrimination in WTO Law: National and Most-Favored-Nation Treatment - or Equal Treatment? Nova York: New York University School of Law, 2001.

Disponível em <http://www.jeanmonnetprogram.org/papers/01/013201.html>. Acesso em: 28 jun. 2009. Jean Monnet Working Paper n. 12/01.

EVANS, Peter. The eclipse of the State? Reflections on Stateness in an Era of Globalization. World Politics, [s.1.], v. 50, n. 1, p. 62-87, 1997.

FARIA, José Eduardo. O direito na economia globalizada. São Paulo: Malheiros, 2002.

FERRAZ JR., Tercio Sampaio. Direito, retórica e comunicação: subsídios para uma pragmática do discurso jurídico. São Paulo: Saraiva, 1973. . Conceito de sistema no direito: uma investigação histórica a partir da obra jusfilosófica de Emil Lask. São Paulo: Revista dos Tribunais; Edusp, 1976. . Teoria da norma jurídica: ensaio de pragmática da comunicação normativa. Rio de Janeiro: Forense, 1978. . Introdução ao estudo do direito: técnica, decisão, dominação. $3^{\mathrm{a}}$ ed. São Paulo: Atlas, 2001. 
. Estudos de Filosofia do Direito. São Paulo: Atlas, 2003.

. Direito Constitucional: liberdade de fumar, privacidade, Estado, Direitos Humanos e outros temas. São Paulo: Manole, 2007.

FERREIRA, Aurélio Buarque de Holanda. Dicionário Aurélio Básico da Língua Portuguesa. Rio de Janeiro: Nova Fronteira, 1994.

. Novo Aurélio Século XXI: o dicionário da língua portuguesa. $3^{\mathrm{a}}$ ed. Rio de Janeiro:

Nova Fronteira.

FIORI, José Luís. Sobre o poder global. Novos estudos - CEBRAP, São Paulo, n. 73, p. 61-72, 2005. Disponível em <http://www.scielo.br/scielo.php?script=sci_arttext\&pid=S0101-

$33002005000300005 \& \operatorname{lng}=$ pt\&nrm=iso $>$. Acesso em: 24 out. 2009.

FITZMAURICE, Gerald G. Second Report on the Law of Treaties of the Special Rapporteur. Yearbook of the International Law, [s.1.], v. II, 1957. Disponível em

$<$ http://www.un.org/law/ilc/index.htm>. Acesso em: 10 out. 2008. Documento da ONU n. A/CN.4/107.

. Second Third Report on the Law of Treaties of the Special Rapporteur. Yearbook of the International Law, [s.1.], v. II, 1958. Disponível em

<http://www.un.org/law/ilc/index.htm>. Acesso em: 10 out. 2008. Documento da ONU n. A/CN.4/115 and Corr.1.

FLORY, Thiébaut. Le G.A.T.T., droit international et commerce mondial. Paris: Librairie générate de droit et de jurisprudence, 1968.

FOOTER, Mary E. An institutional and normative analysis of the World Trade Organization. Leiden: Martinus Nijhoff Publishers, 2006.

FOUCAULT, Michel. Em defesa da sociedade: curso no Collège de France (1975-1976). Trad. Maria Galvão. São Paulo: Martins Fontes, 1999.

. A verdade e as formas jurídicas. Trad. Roberto Machado e Eduardo Morais. Rio de Janeiro: NAU, 2005.

Vozes, 2007.

. Vigiar e Punir: nascimento da prisão. Trad. Raquel Ramalhete. 34a ed. Petrópolis: . Microfísica do Poder. Trad. Roberto Machado. Rio de Janeiro: Graal, 2008.

FRANKEL, Jeffrey A. Regional trading blocs in the world economic system. Washington: Peterson Institute for International Economics, 1997.

FRIEDEN, Jeffry A. Capitalismo Global: a história econômica e política do século XX. Trad. Vivian Mannheimer. Rio de Janeiro: Zahar, 2008.

FRIEDMANN, Wolfgang G. The changing structure of international law. Nova York: Columbia University Press, 1964.

FUKUYAMA, Francis. Fim da história e o último homem. Trad. Aulyde Rodrigues. Rio de Janeiro: Rocco, 1992. 
FURTADO, Celso. Formação Econômica do Brasil. São Paulo: Companhia Editora Nacional, 2000.

Terra, 2000.

Introdução ao Desenvolvimento: enfoque histórico-estrutural. São Paulo: Paz e

GALVIN, Bridig; LANGENHOVE, Luk Van. Trade in a world of regions. In: SAMPSON, Gary P.; WOOLCOCK, Stephen (Eds.). Regionalism, multilateralism, and economic integration: the recent experience. Tóquio: United Nations University Press, 2003.

GARDNER, Richard N. Sterling-Dollar Diplomacy, The Origins and the Prospects of Our International Economic Order. 2a ed. Nova York: McGraw-Hill, 1969.

. Em busca da Ordem Mundial. Rio de Janeiro: Forense, 1964.

GIANNOTTI, José Arthur. Kant e o Espaço da História Universal. In: KANT, Immanuel. Idéia de uma história universal de um ponto de vista cosmopolita. São Paulo: Brasiliense, 1986.

GIBB, Richard. Regionalism in the World Economy. In: GIBB, Richard; MICHALAK, Wieslaw (Eds.). Continental trading blocs: the growth of regionalism in the world economy. Nova York: John Wiley \& Sons, 1994.

GIDDENS, Anthony. As conseqüências da modernidade. Trad. Raul Filker. São Paulo: UNESP, 1991.

GILPIN, Robert. Global Political Economy: understanding the international economic order. Princeton: Princeton University, 2001.

2002. . A economia política das relações internacionais. Trad. Sérgio Bath. Brasília: UnB, . O Desafio do Capitalismo Global: a economia mundial no século XXI. Trad. Clóvis Marques. Rio de Janeiro: Record, 2004.

GIOVAN, Ileana. Derecho internacional económico y relaciones económicas internacionales. Buenos Aires: Abeledo-Perrot, 1992.

GRAU, Eros Roberto. A ordem econômica na Constituição de 1988: interpretação e crítica. $11^{\mathrm{a}}$ ed. São Paulo: Malheiros, 2006.

HART, Herbert L. A. O Conceito de Direito. Trad. A. Ribeiro Mendes. Lisboa: Fundação Calouste Gulbenkian, 2001.

HAZARD, John N. Commercial Discrimination and International Law. American Journal of International Law, [s.1.], v. 52, n. 3, p. 495-498, 1958.

HILF, Meinhard. Power, Rules and Principles - Which orientation for WTO/GATT Law? Journal of International Economic Law, [s.1.], v. 4, n. 1, p. 111-130, 2001. 
HOBBES, Thomas. Leviatã ou Matéria, Forma e Poder de um Estado Eclesiástico e Civil. Os Pensadores: Thomas Hobbes. Trad. João Paulo Monteiro e Maria Beatriz N. da Silva. São Paulo: Nova Cultural, 2000.

HOBSBAWM, Eric J. A Era do Capital: 1848-1875. Trad. Luciano C. Neto. São Paulo: Paz e Terra, 1982.

. A Era dos Impérios: 1875-1914. Trad. Sieni Maria Campos e Yolanda S. de Toledo. São Paulo: Paz e Terra, 1998.

. Era dos Extremos: O breve século XX: 1914-1991. Trad. Marcos Santarrita. São

Paulo: Companhia das Letras, 2007.

HOEKMAN, Bernard M.; KOSTECKI, Michel M. The Political Economy of the World Trading System: The WTO and Beyond. $2^{\mathrm{a}}$ ed. Oxford: Oxford University Press, 2001. . The WTO: Functions and Basic Principles. In: HOEKMAN, Bernard M.; MATTOO, Aaditya; ENGLISH, Philip (ed.). Development, trade, and the WTO: a handbook. Washington: World Bank Publications, 2002.

HORN, Henrik; MAVROIDIS, Petros C. Economic and legal aspects of the Most-FavoredNation clause. European Journal of Political Economy, [s.1.], v. 17, n. 2, p. 233-279, 2001.

HORNBECK, Stanley K. The Most-Favored-Nation Clause. American Journal of International Law, [s.1.], v. 3, n. 2, p. 619-647, 1909.

HÖLSTI, Kalei J. Governança sem governo: a poliarquia na política internacional européia do século XIX. In: ROSENAU, James N.; CZEMPIEL, Ernst-Otto (Org.). Governança sem governo: ordem e transformação na política internacional. Trad. Sérgio Barth. Brasília: Universidade de Brasília, São Paulo: Imprensa Oficial do Estado de São Paulo, 2000.

HUDEC, Robert E. The GATT legal system and world trade diplomacy. Nova York: Praeger Publishers, 1975.

. Enforcing international trade law: the evolution of the modern GATT Legal System. Salem: Butterworth Legal Publishers, 1993.

. The Gatt Legal System: A Diplomat's Jurisprudence. In: nature of international trade law. Londres: Cameron May, 1999.

. "Like Product": The Differences in Meaning in GATT Articles I and III. In:

COTTIER, Thomas; MAVROIDIS, Petros C. (ed.). Regulatory Barriers and the Principle of Non-discrimination in World Trade Law: Past, Present, and Future. Michigan: University of Michigan, 2000.

HUNT, E. K. História do Pensamento Econômico: uma perspectiva crítica. Trad. José Ricardo B. Azevedo e Maria José C. Monteiro. 2a ed. Rio de Janeiro: Elsevier, 2005.

HURRELL, Andrew. O ressurgimento do regionalismo na política mundial. Contexto Internacional, Rio de Janeiro, v. 17, n. 1, p. 23-59, 1995. 
HVEEM, Helge. Political Regionalism: master or servant of economic internationalization? In: HETTNE, Björn; INOTAI, András; SUNKEL, Osvaldo (Eds.). Globalism and the New Regionalism. Londres: Palgrave Macmillan, 1999.

HYDE, Charles Cheney. Concerning the interpretation of treaties. American Journal of International Law, [s.1.], v. 3, n. 1, p. 46-61, 1909.

ITO, Nomubi. La clause de la nation la plus favorisée. Paris: Les Editions internationales, 1930.

JACKSON, John H. World Trade and the Law of GATT. Indianapolis: Robbs-Merrill, 1969. . The World Trading System: Law and Policy of International Economic Relations. ${ }^{\mathrm{a}}$ ed. Cambridge: MIT, 1997. . The jurisprudence of GATT and the WTO: insights on treaty law and economic relations. Cambridge: Cambridge University Press, 2000 ; DAVEY, William J. Legal problems of international economic relations: cases, materials, and text on the national and international regulation of transnational economic relations. $2^{\mathrm{a}}$ ed. St. Paul: West Pub., 1986.

KANT, Immanuel. Paz perpétua: ensaio filosófico e outros opúsculos. Trad. Raphael Benaion. Rio de Janeiro: Borsoi, 1939. 70, 1997. Fundamentação da Metafísica dos Costumes. Trad. Paulo Quintela. Lisboa: Edições

Crítica da Razão Pura. Os Pensadores: Immanuel Kant. Trad. Valério Rohden e Udo Moosburger. São Paulo: Nova Cultural, 2000.

KECK, Alexander; LOW, Patrick. Special and Differential Treatment in the WTO: Why, When and How? Genebra: WTO, 2004. Disponível em <http://www.wto.org/english/res_e/reser_e/ersd200403_e.doc>. Acesso em: 22 dez. 2009. Economic Research and Statistics Division, Staff Working Paper n. ERSD-2004-03.

KELSEN, Hans. Teoria Geral do Direito e do Estado. São Paulo: Martins Fontes, 1999. . Teoria pura do direito. Trad. João Machado. 6a ed. São Paulo: Martins Fontes, 2000.

KEOHANE, Robert O. After hegemony: cooperation and discord in the world political economy. New Jersey: Princeton, 1984. .; NYE, Joseph S. Introduction. In: NYE, Joseph S.; DONAHUE, John D. (Org.). Governance in a globalizing world. Washington: Brookings Institution Press, 2000.

KEYNES, John Maynard. As conseqüências econômicas da paz. Trad. Sérgio Bath. São Paulo: Imprensa Oficial do Estado, Brasília: Universidade de Brasília, 2002.

KINDLEBERGER, Charles P. The Rise of Free Trade in Western Europe, 1820-1875. The Journal of Economic History, [s.1.], v. 35, n. 1, p. 20-55, 1975.

KOCK, Karin. International trade policy and the GATT 1947-1967. Stockholm: Almqvist \& Wiksell, 1969. 
KRUGMAN, Paul R. What Should Trade Negotiators Negotiate About? Journal of Economic Literature, [s.1.], v. XXXV, n.1, p. 113-120, 1997.

LAFER, Celso. O GATT, a cláusula da nação mais favorecida e a América Latina. Revista de Direito Mercantil, Industrial, Econômico e Financeiro, São Paulo, v. 10, n. 3, p. 41-56, 1971. . Da Reciprocidade no Direito Internacional Econômico - O convênio do Café de 1976. Tese apresentada ao Concurso para Livre-Docente de Direito Internacional Público do Departamento de Direito Internacional da Faculdade de Direito da USP, São Paulo, 1977. . O moderno e o antigo conceito de liberdade. In: Ensaios sobre a liberdade. São

Paulo: Perspectiva, 1980. . A OMC e a regulação do comércio internacional: uma visão brasileira. São Paulo: Forense, 1998.

LAKE, David A. British and American Hegemony Compared: Lessons for the Current Era of Decline. In: FRIEDEN Jeffry A.; LAKE, David A. (ed.). International political economy: perspectives on global power and wealth International Political Economy: Perspectives on Global Power and Wealth. $4^{\mathrm{a}}$ ed. Londres: Routledge, 1999.

LAVIGNE, Marie. International political economy and socialism. Trad. David Lambert. Nova York: Cambridge University, 1991.

LAWRENCE, Robert Z. Crimes \& Punishments: retaliation under the WTO. Washington: Institute for International Economics, 2003.

LONG, Olivier. Law and its limitations in the GATT multilateral trade system. Londres: Graham \& Trotman, Boston: M. Nijhoff: Kluwer Academic Publishers, 1987.

LUZ, Rodrigo. Relações econômicas internacionais: teoria e questões. $2^{\mathrm{a}}$ ed. Rio de Janeiro: Elsevier, 2008.

MAINE, Henry Sumner. Ancient law: its connection with the early history of society, and its relation to modern ideas. Nova York: Charles Scribner, 1867.

MANSFIELD, Edward D.; MILNER, Helen V. The New Wave of Regionalism. International Organization, [s.1.], v. 53, n. 3, p. 589-627, 1999.

MARCEAU, Gabrielle. Um pedido pela coerência no direito internacional. Elogios para a proibição ao "isolamento clínico" na solução de controvérsias na OMC. In: MERCADANTE, Araminta; MAGALHÃES, José Carlos de (Coord.). Solução e prevenção de litígios internacionais. Trad. Adalberto Nader. V. III, Rio de Janeiro: Forense, 2003.

. Balance and coherence by the WTO Appellate Body: who could do better? In:

SACERDOTI, Giorgio; YANOVICH, Alan; BOHANES, Jan (org.). The WTO at Ten: The Contribution of the Dispute Settlement System. Cambridge University Press, 2006.

MCGUIRE, Steven M.; LAWTON, Thomas C. Does the WTO matter? In: VACHANI, Sushil (Org.). Transformations in global governance. Northampton: Edward Elgar Publishing, 2006. 
MCNAIR, Arnold Duncan. The Law of Treaties. Oxford: Clarendon, 1961.

MICHALOPOULOS, Constantine. Trade and Development in the GATT and WTO: the Role of Special and Differential Treatment for Developing Countries. Washington: World Bank, 2000. Disponível em <http://ssrn.com/abstract=630760>. Acesso em: 22 dez. 2009. World Bank Policy Research Working Paper n. 2388.

MILL, John Stuart. Princípios de Economia Política com Algumas de suas Aplicações à Filosofia Social. Os Economistas. Trad. Luiz João Baraúna. V. II, São Paulo: Nova Cultural, 1996.

MILLER, James N. Origins of the GATT - British Resistance to American Multilateralism. Cambridge: Cambridge University, 2000. Disponível em

<http://www.levy.org/pubs/wp318.pdf>. Acesso em: 29 jan. 2009. Jerome Levy Economics Institute Working Paper n. 318.

MONTESQUIEU, Charles Louis de Secondat. Do espírito das Leis. Os Pensadores: Montesquieu. Trad. Leôncio Martins. V. II, São Paulo: Nova Cultural, 2000.

MORA, José Ferrater. Dicionário de Filosofia. Tomo III (K-P). São Paulo: Loyola, 2001.

MOREIRA, Adriano. Teoria das Relações Internacionais. $4^{\mathrm{a}}$ ed. Coimbra: Almedina, 2002.

MURRAY, James A. (ed.). The Oxford English Dictionary. $1^{\mathrm{a}}$ ed. v. VI, Oxford: Clarendon Press, 1933.

. The Oxford English Dictionary. $2^{\mathrm{a}}$ ed. v. X, Oxford: Clarendon Press, 1989.

NASSER, Rabih Ali. A OMC e os países em desenvolvimento. São Paulo: Aduaneiras, 2002.

NGUYEN, Quoc Dinh; DAILLIER, Patrick; PELLET, Alain. Direito internacional público. Trad. Vítor Marques Coelho. Lisboa: Fundação Calouste Gulbenkian, 1999.

NORTH, C. Douglass. Institutions, transaction costs, and the rise of merchant empires. In: TRACY, James D. (ed.). The Political Economy of Merchant Empires. Nova York: Cambridge University Press, 1991.

ORGANIZAÇÃO MUNDIAL DO COMÉRCIO. World Trade Report 2007: Six decades of multilateral trade cooperation: What have we learnt?. Genebra: WTO Publications, 2007. . World Trade Report 2009: Trade Policy Commitments and Contingency Measures. Genebra: WTO Publications, 2009.

OSER, Jacob; BLANCHFIELD, William C. História do pensamento econômico. Trad. Carmem Terezinha dos Santos. São Paulo: Atlas, 1983.

MACHADO, Luiz Toledo. A teoria da dependência na América Latina. Estudos Avançados, [s.l.], v. 13, n. 35, p.199-215, 1999. 
MAVROIDIS, Petros C. If I Don't Do It, Somebody Else Will (Or Won't). Journal of World Trade, [s.1.], v. 40, n. 1, p. 187-214, 2006.

MYERS, Gordon. Banana wars: the price of free trade: a Caribbean perspective. Londres: Zed Books, 2004.

NUNES, António José Avelãs. Uma introdução à Economia Política. São Paulo: Quartier Latin, 2007.

OLIVEIRA, Odete Maria de. Relações Internacionais: estudos de introdução. Curitiba: Juruá, 2001.

PALMETER, David; MAVROIDIS, Petros C. The WTO Legal System: Sources of Law. The American Journal of International Law, [s.1.], v. 92, n. 3, p. 398-413, 1998.

PANAGARIYA, Arvind. Regionalism in trade policy: essays on preferential trading. Singapura: World Scientific, 1999.

PAUL, T. V.; HALL, John A. International Order and the Future of World Politics. Cambridge: Cambridge University Press, 1999.

PAUWELYN, Joost. The nature of WTO obligations. Nova York: New York University School of Law, 2002. Disponível em

<http://www.jeanmonnetprogram.org/papers/02/020101.rtf>. Acesso em: 28 de fevereiro de 2009. Jean Monnet Working Paper 1/02. . A Typology of Multilateral Treaty Obligations: Are WTO Obligations Bilateral or Collective in Nature? European Journal of International Law, [s.1.], v. 14, n. 5, p. 907-951, 2003.

PERELMAN, Chaïm; OLBRECHTS-TYTECA, Lucie. Tratado da argumentação. Trad. Maria Ermantina Galvão. $2^{\text {a }}$ ed. São Paulo: Martins Fontes, 2005.

PETERSMANN, Ernst-Ulrich. The Dispute Settlement System of the World Trade Organization and the Evolution of the GATT Dispute System Since 1948. Common Market Law Review, [s.1.], v. 31, p. 1157-1244, 1994. . The GATT/WTO Dispute Settlement System: International Law, International Organization and Dispute Settlement. Londres: Kluwer Law International, 1997. . Dispute settlement in international economic law - lessons for strengthening international dispute settlement in non-economic areas. Journal of International Economic Law, [s.1.], v. 2, n. 2, p. 189-248, 1999.

PICONE, Paolo; SACERDOTI, Giorgio. Diritto internazionale dell'economia: raccolta sistematica dei principali atti normativi internazionali ed interni con testi introduttivi e note. Milão: Franco Angeli, 1983. 
PIONTEK, Eugeniusz. European integration and international law of economic interdependence. Recueil des Cours, Leiden, v. 236, n. 5, p. 9-126, 1992.

POGREBINSCHI, Thamy. Foucault, para além do poder disciplinar e do biopoder. Revista Lua Nova, [s.1.], v. 63, p. 179-201, 2004.

PRAZERES, Tatiana Lacerda. A OMC e os blocos regionais. São Paulo: Aduaneiras, 2008.

PREBISCH, Raúl. La cooperación internacional en la política de desarrollo latinoamericana. In: GURRIERI, Adolfo. La obra de Prebisch en la CEPAL. México: Fondo de Cultura Económica, 1982.

REALE, Miguel. Horizontes do direito e da História. São Paulo: Saraiva, 1956.

ROSENAU, James N. Governança, ordem e transformação na política mundial. In: ROSENAU, James N.; CZEMPIEL, Ernst-Otto (Org.). Governança sem governo: ordem e transformação na política internacional. Trad. Sérgio Barth. Brasília: Universidade de Brasília, São Paulo: Imprensa Oficial do Estado de São Paulo, 2000.

POWELL, Lindsey. In Defense of Multilateralism. New Haven: Yale Center for Environmental Law and Policy. Disponível em <http://www.yale.edu/gegdialogue/docs/dialogue/oct03/papers/Powell.pdf>. Acesso em: 30 jan. 2009.

RICARDO, David. Princípios de Economia Política e Tributação. Os Economistas. Trad. Paulo Henrique R. Sandroni. São Paulo: Nova Cultural, 1996.

ROSANVALLON, Pierre. O liberalismo econômico: história da idéia de mercado. Trad. Antonio P. Rocha. Bauru: EDUSC, 2002.

RUGGIE, John Gerard. Multilateralism: the Anatomy of an Institution. International Organization, [s.1.], v. 46, n. 3, p. 561-598, 1992.

SARAIVA, José Flávio S. A agonia européia e a gestação da nova ordem internacional (19391947). In: SARAIVA, José Flávio S. (org.). Relações internacionais: Entre a preponderância européia e a emergência americano-soviética (1815-1947). V. 1, Brasília: IBRI, 2001.

SAYRE, Francis B. The Most-Favored-Nation Policy in Relation to Trade Agreement. The American Political Science Review, [s.1.], v. 33, n. 3, p. 411-423, 1939.

SCELLE, Georges. Précis de droit des gens: principes et systematique. V. II, Paris: Sirey, 1934.

SCHACHTER, Oscar. International Law in Theory and Practice. Boston: Martinus Nijhoff, 1991. 
SCHWARTZ, Warren F.; SYKES, Alan O. Toward a Positive Theory of the Most Favored Nation Obligation and Its Exceptions in the WTO/GATT System. International Review of Law and Economics, Nova York, v. 16, n. 1, p. 27-51, 1996.

. The economics of the most favored nation clause. In: BHANDARI, Jagdeep S.;

SYKES, Alan O. (ed.). Economic Dimensions in International Law: comparative and empirical perspectives. Cambridge: Cambridge University Press, 1997.

SCHWARZENBERGER, Georg. The fundamental principles of international law. Recueil des Cours, Leiden, v. 87, n. 1, p. 195-383, 1955.

. The principles and standards of international economic. Recueil des Cours, Leiden,

v. 117, n. 1, p. 1-96, 1966. . International law and order. Londres: Stevens \& Sons, 1971.

SEGRILLO, Ângelo. O declínio da União Soviética. Rio de Janeiro: Record, 2000.

SEIDL-HOHENVELDERN, Ignaz. International Economic Law. $3^{\text {a }}$ ed. [s.1.]: Kluwer Law International, 1999.

SENGUL, Faruk. Essays on the Most Favored Nation Clause and the World Trading System. Tese de Doutorado apresentada à Dedman College, Southern Methodist University, 2006.

SETSER, Vernon G. Did Americans Originate the Conditional Most-Favored-Nation Clause? The Journal of Modern History, [s.1.], v. 5, n.3, p. 319-323, 1933.

SICILIANOS, Linos-Alexander. The Classification of Obligations and the Multilateral Dimension of the Relations of International Responsibility. European Journal of International Law, [s.1.], v. 13, n. 5, p. 1127-1145, 2002.

SILVA, Luís Virgilio Afonso da. O conteúdo essencial dos direitos fundamentais e a eficácia das normas constitucionais. Tese apresentada ao Concurso para provimento do cargo de Professor Titular, junto ao Departamento de Direito do Estado da USP, 2005.

SIMMA, Bruno. From bilateralism to community interest in international law. Recueil des Cours, Leiden, v. 250, n. 6, p. 217-384, 1994.

SMITH, Adam. A Riqueza das Nações: Uma Investigação sobre sua Natureza e suas Causas. Os Economistas. Trad. Luiz João Baraúna. V. I, São Paulo: Nova Cultural, 1996.

SNYDER, Richard. The Most-Favored-Nation Clause: An analysis with particular reference to recent treaty practice and tariffs. Nova York: King's Crown Press, 1948.

SOARES, Guido F. S. A compatibilidade da ALADI e do MERCOSUL com o GATT.

Boletim de Integração Latino-Americana, [s.1.], n. 16, 2005, p. 6. Disponível em <http://ftp.unb.br/pub/UNB/ipr/rel/bila/1995/781.pdf >. Acesso em: 3 fev. 2009. 
SRINIVASAN, Thirukodikaval N. Nondiscrimination in GATT/WTO: was there anything to begin with and is there anything left? World Trade Review, Cambridge, v. 4, n. 1, p. 69-95, 2005.

SUTHERLAND, Peter et al. The Future of the WTO - Addressing institutional challenges in the new millennium. Genebra: WTO, 2004. Relatório apresentado pelo Conselho Consultivo ao Diretor-Geral Supachai Panitchpakdi.

SZAWLOWSKI, Richard. The system of the international organizations of the communist countries. Leiden: Sijthoff, 1976.

TELLES JÚNIOR, Goffredo da Silva. O direito quântico: ensaio sobre o fundamento da ordem jurídica. $5^{\mathrm{a}}$ ed. São Paulo: Max Limonad, 1980.

TERSI, Vinicius Feliciano. Notificação e Acompanhamento dos Acordos Regionais de Comércio pela OMC: o Artigo XXIV do GATT e o Sistema Multilateral de Comércio. Trabalho de Conclusão de Curso apresentado ao Curso de Direito da Universidade de São Paulo, como requisito parcial para a obtenção do grau de Bacharel em Direito, São Paulo, 2006.

TEUBNER, Gunther. How the law thinks: toward a constructivist epistemology of law. Law \& Society Review, [s.1.], v. 23, n. 5, p. 727-757, 1989.

THEMAAT, Pieter Verloren van. The Changing Structure of International Economic Law. Haia: Nijhoff, 1981.

THORSTENSEN, Vera. OMC - Organização Mundial do Comércio: as regras do comércio internacional e a rodada do milênio. São Paulo: Aduaneiras, 1999.

TREBILCOCK, Michael J.; HOWSE, Robert. The regulation of international trade. $2^{\mathrm{a}}$ ed. Londres: Routledge, 2002.

. The Regulation of International Trade. $3^{\mathrm{a}}$ ed. Nova York: Routledge, 2005.

USTOR, Endre. The most-favoured-nation clause in the law of treaties: working paper.

Yearbook of the International Law Commission, [s.1.], v. II, 1968. Disponível em $<$ http://www.un.org/law/ilc/index.htm>. Acesso em: 10 out. 2006. Documento da ONU n. A/CN.4/L.127.

. First report on the most-favoured-nation clause. Yearbook of the International Law Commission, [s.l.], v. II, 1969. Disponível em <http://www.un.org/law/ilc/index.htm>. Acesso em: 10 out. 2006. Documento da ONU n. A/CN.4/213.

. Second Report of the Special Rapporteur. Yearbook of the International Law, [s.1.], v. II, 1970. Disponível em <http://www.un.org/law/ilc/index.htm>. Acesso em: 10 out. 2006. Documento da ONU n. A/CN.4/228 and Add.1.

. Third Report of the Special Rapporteur. Yearbook of the International Law, [s.1.], v. II, 1972. Disponível em <http://www.un.org/law/ilc/index.htm>. Acesso em: 10 out. 2006. Documento da ONU n. A/CN.4/257 and Add.1. 
. Fourth Report of the Special Rapporteur. Yearbook of the International Law, [s.1.], v. II, 1973. Disponível em <http://www.un.org/law/ilc/index.htm>. Acesso em: 10 out. 2006. Documento da ONU n. A/CN.4/266.

. Fifth Report of the Special Rapporteur. Yearbook of the International Law, [s.1.], v. II, 1974. Disponível em <http://www.un.org/law/ilc/index.htm>. Acesso em: 10 out. 2006. Documento da ONU n. A/CN.4/280.

. Sixth Report of the Special Rapporteur. Yearbook of the International Law, [s.1.], v. II, 1975. Disponível em <http://www.un.org/law/ilc/index.htm>. Acesso em: 10 out. 2006. Documento da ONU n. A/CN.4/280.

. Seventh Report of the Special Rapporteur. Yearbook of the International Law, [s.1.], v. II, 1976. Disponível em <http://www.un.org/law/ilc/index.htm>. Acesso em: 10 out. 2006. Documento da ONU n. A/CN.4/293 and Add.1.

VERBIT, Gilbert P. Preferences and the public law of international trade: the end of mostfavoured-nation treatment? In: KOJANEC, Giovanni. International Trade Agreements: workshop 1968/Les Accords de Commerce International: colloque 1968. Recueil des Cours. V. 68, Leiden: Sijthoff, 2002.

VIEIRA, José Luiz Conrado. A integração econômica internacional na era da globalização: aspectos jurídicos, econômicos e políticos sob prismas conceitual e crítico. São Paulo: Letras \& Letras, 2004.

VIGNES, Daniel. La clause de la nation la plus favorisée et la pratique contemporaine: problèmes posés par la Communauté économique européenne. Recueil des cours, Leiden, v. 130, n. 2, p. 207-349, 1970.

VINER, Jacob. The Customs Union Issue. Nova York: Carnegie Endowment for International Peace, 1950. . International Economics. Glencoe: Free Press, 1951.

VIRZO, Roberto. A Sucessão entre Organizações Internacionais e a Transformação do GATT em OMC. In: DAL RI JR., Arno; OLIVEIRA, Odete Maria de (Org.). Direito internacional econômico em expansão: desafios e dilemas. Ijuí: Unijuí, 2003.

VISSCHER, Charles de. Théories et realités en droit international public. Paris: Pedone, 1970.

WEBER, Max. Economia e Sociedade. Trad. Regis Barbosa e Karen Barbosa. V. 1, Brasília: Universidade de Brasília, São Paulo: Imprensa Oficial do Estado de São Paulo, 1999.

WEBSTER, Noah. Webster's New International Dictionary. $2^{\mathrm{a}}$ ed. Londres: G. Bell \& Sons, 1934. . Webster's New International Dictionary. $3^{\mathrm{a}}$ ed. Chicago: G. \& C. Merriam, 1961.

WIGHT, Martin. A Política do Poder. Trad. Carlos Sérgio Duarte. Brasília: Universidade de Brasília, São Paulo: Imprensa Oficial do Estado de São Paulo, 2002. 
WILCOX, Clair. A Charter for World Trade. Nova York: Macmillan, 1949.

WILLIAMSON, Oliver E. The Mechanisms of Governance. Nova York: Oxford University Press, 1996.

WOLFE, Robert. Um passeio pelos "clubes" da OMC. Pontes Bimestral, v. 3, n. 4, ago.-dez. 2007. Disponível em <http://ictsd.net/i/news/12451>. Acesso em: 2 nov. 2009.

WOODS, Thomas E. Cobden on freedom, peace, and trade. Journal Human Rights Review, [s.1.], v. 5, n. 1, p. 77-90, 2003.

ZOELLNER, Carl-Sebastian. Transparency: An Analysis of an Evolving Fundamental Principle In International Economic Law. Michigan Journal of International Law, [s.1.], v. 27, n. 2, p. 579-628, 2006.

\section{b) Legislação da República Federativa do Brasil}

Lei n. 313, 30 jul. 1948. Autoriza o Poder Executivo a aplicar, provisoriamente, o Acordo Geral sobre Tarifas Aduaneiras e Comércio, reajusta a Tarifa das Alfândegas e dá outras providências. Diário Oficial da União, Poder Executivo, Brasília, DF, 3 ago. 1948.

Decreto n. 50.215, 28 jan. 1961. Promulga a Convenção relativa ao Estatuto dos Refugiados, concluída em Genebra, 28 jul. 1951. Diário Oficial da União, Poder Executivo, Brasília, DF, 30 jan. 1961.

Decreto n. 1.355, 30 dez. 1994. Promulga a Ata Final que Incorpora os Resultados da Rodada Uruguai de Negociações Comerciais Multilaterais do GATT. Diário Oficial da União, Poder Executivo, Brasília, DF, 31 dez. 1994.

\section{c) Legislação das Comunidades Europeias}

Regulamento (CE) n. 2820, 21 dez. 1998. Estabelece um sistema plurianual de preferências pautais generalizadas durante o período compreendido entre 1 de julho de 1999 e 31 de dezembro de 2001. L. 357 Jornal Oficial das Comunidades Europeias.

\section{d) Documentos da Liga das Nações}

Committee of Experts for the Progressive Codification of International Law. The MostFavoured-Nation Clause. The American Journal of International Law, [s.1.], v. 22, n. 1, p. 133$156,1928$. 


\section{e) Documentos da Organização das Nações Unidas}

Economic and Social Council. Preparatory Committee of the International Conference on Trade and Employment. Verbatim Report of the Twelfth Meeting of Committee II, 22 nov. 1946. Disponível em: <http://www.wto.org/gatt_docs/English/SULPDF/90220016.pdf>. Acesso em: 28 fev. 2009. Documento da ONU n. E/PC/T/C.II/PV/12.

International Conference on Trade and Employment. Summary Record of the Fifth Meeting, 4 dec. 1947. Disponível em: 〈http://www.wto.org/gatt_docs/English/SULPDF/90190218.pdf〉. Acesso em: 28 fev. 2009. Documento da ONU n. E/CONF.2/C.3/SR.5.

General Assembly. Resolution n. 3.201 (S-VI), 1 may 1974. Declaration on the Establishment of a New International Economic Order. Disponível em:

<http://daccessdds.un.org/doc/RESOLUTION/GEN/NR0/071/94/IMG/NR007194.pdf?OpenE lement>. Acesso em 1 out. 2009.

. Resolution n. 3.202 (S-VI), 1 may 1974. Programme of Action on the

Establishment of a New International Economic Order. Disponível em:

<http://daccessdds.un.org/doc/RESOLUTION/GEN/NR0/071/94/IMG/NR007194.pdf?OpenE lement>. Acesso em 1 out. 2009.

. Resolution n. 3.281 (XXIX), 12 dez. 1974. Charter of Economic Rights and Duties

of States. Disponível em:

$<$ http://daccessdds.un.org/doc/RESOLUTION/GEN/NR0/738/83/IMG/NR073883.pdf?OpenE lement>. Acesso em 1 out. 2009.

ILC Report on the work of its fifty-third session, Official Records, Fifty-fifth

Session, Supplement n. 10. Disponível em:

<http://www.un.org/law/ilc/reports/2001/2001report.htm>. Acesso em: 28 fev. 2009.

Documento da ONU n. A/56/10. . Resolution n. 1995 (XIX), 30 dez. 1964. Establishment of the United Nations

Conference on Trade and Development as an Organ of the General Assembly. Disponível em: < http://www.unctad.org/en/docs/ares1995xix_en.>. Acesso em: 28 fev. 2009.

\section{f) Documentos da Conferência das Nações Unidas para o Comércio e Desenvolvimento}

Secretariat. UNCTAD: a Brief Historical Overview. Disponível em

<http://www.unctad.org/en/docs/gds20061_en.pdf>. Acesso em: 22 mai. 2009. Documento da Unctad n. UNCTAD/GDS/2006/1.

\section{g) Documentos do Acordo Geral sobre Tarifas e Comércio}

Contracting-Parties. Decisão n. L/403, 7 set. 1955, $11^{a}$ sessão. Article XXV - Guiding Principles to be followed by the CONTRACTING PARTIES in considering applications for 
waivers from Part I or other important obligations of the Agreement. Disponível em $<\mathrm{http}: / /$ sul-

derivatives.stanford.edu/derivative?CSNID=90690142\&mediaType=application/pdf $>$. Acesso em: 22 mai. 2009.

Decision n. L/4903, 28 nov. 1979. Differential and more favourable treatment reciprocity and fuller participation of developing countries. Disponível em: <http://sulderivatives. .tanford.edu/derivative?CSNID=90970166\&mediaType $=$ application/pdf $>$. Acesso em: 2 jun. 2009.

GATT Analytical Index. Disponível em <http://www.wto.org/english/res_e/booksp_e/gatt_ai_e/gatt_ai_e.htm>. Acesso em: 10 abr. 2009.

Group of Experts on Anti-Dumping and Countervailing Duties. Second Report, 29 jan. 1960. Disponível em <http://www.wto.org/gatt_docs/English/SULPDF/90730046.pdf>. Acesso em: 11 jun. 2009. Documento do GATT n. L/1141.

\section{h) Documentos da Organização Mundial do Comércio}

Committee on Regional Trade Agreements. Decision n. WT/REG/1, 2 jul. 1996. Disponível em < http://docsonline.wto.org/>. Acesso em: 3 fev. 2009.

General Council. Decision n. WT/L/186, 8 out. 1996. EC - The Fourth ACP-EC Convention of Lomé, Extension of Waiver. Disponível em <http://docsonline.wto.org/DDFDocuments/t/WT/L/186.WPF>. Acesso em: 22 mai. 2009. Decision n. WT/L/127, 7 fev. 1996. Disponível em <http://docsonline.wto.org/>. Acesso em: 3 fev. 2009. Decision n. WT/L/671, 18 dez. 2006. Disponível em <http://docsonline.wto.org/>.

Acesso em: 3 fev. 2009.

\section{i) Documentos do Institut de Droit International}

Resolução n. 2, 23 abr. 1936, Sessão de Bruxelas. Les effets de la clause de la nation la plus favorisée en matière de commerce et de navigation. Rapporteur Boris Nolde. Disponível em <http://www.idi-iil.org/idiF/resolutionsF/1969_edi_02_fr.pdf >. Acesso em: 10 fev. 2009.

Resolução n. 3, 10 set. 1969, Sessão de Edimburgo. The Most Favoured Nation Clause in Multilateral Conventions. Rapporteur Pierre Pescatore. Disponível em <http://www.idiiil.org/idiF/resolutionsF/1936_brux_03_fr.pdf>. Acesso em: 10 fev. 2009.

\section{j) Casos da Corte Permanente de Justiça Internacional}


Oscar Chinn (United Kingdom v. Belgium). Series A./B. of Judgments, orders and advisory opinions, 12 dez. 1934. Fascículo n. 63, Leiden: Sijthoff. Disponível em <http://www.icjcij.org/pcij/serie_AB/AB_63/01_Oscar_Chinn_Arret.pdf>. Acesso em: 10 mar. 2009.

\section{k) Casos da Corte Internacional de Justiça}

Anglo-Iranian Oil Co. (United Kingdom v. Iran). Pleadings, 1952. Disponível em $<$ http://www.icj-cij.org/docket/index.php?p1=3\&p2=3\&code=uki\&case=16\&k=ba>. Acesso em: 10 fev. 2009.

Report of Judgments, advisory opinions and orders, 1952. Disponível em

<http://www.icj-cij.org/docket/files/16/1997.pdf >. Acesso em: 10 fev. 2009.

Rights of Nationals of the United States of America in Morocco (France v. United States of America). Report of Judgments, advisory opinions and orders, 1952. Disponível em <http://www.icj-cij.org/docket/files/11/1927.pdf>. Acesso em: 10 fev. 2009.

\section{l) Casos do Acordo Geral de Tarifas e Comércio}

Cuba - Consular taxes. Ruling by the Chairman, 24 ago. 1948. Disponível em <http://www.wto.org/english/tratop_e/dispu_e/48contax.wpf>. Acesso em: 10 abr. 2009. Documento da OMC n. BISD II/12.

India — Tax rebates on export. Ruling by the Chairman, 24 ago. 1948. Disponível em <http://www.wto.org/english/tratop_e/dispu_e/48taxexp.wpf>. Acesso em: 10 abr. 2009. Documento da OMC n. BISD II/12.

Australia - Subsidy on Ammonium Sulphate. Report adopted by the Contracting Parties, 3 abr. 1950. Disponível em <http://www.wto.org/english/tratop_e/dispu_e/50amosul.wpf>. Acesso em: 10 abr. 2009. Documento da OMC n. GATT/CP.4/39 - BISD II/188.

Germany - Treatment of Imports of Sardines. Report adopted by the Contracting Parties, 31 out. 1952. Disponível em <http://www.wto.org/english/tratop_e/dispu_e/55starch.wpf>. Acesso em: 10 abr. 2009. Documento da OMC n. G/26 - BISD 1S/53.

Belgian - Family Allowances. Report of the Panel, 7 nov. 1952. Disponível em <http://www.wto.org/english/tratop_e/dispu_e/52famalw.wpf>. Acesso em: 10 abr. 2009. Documento da OMC n. G/32 - BISD 1S/59.

Swedish - Anti-Dumping Duties. Report of the Panel, 26 fev. 1955. Disponível em <http://www.wto.org/english/tratop_e/dispu_e/54antidu.wpf>. Acesso em: 10 abr. 2009. Documento da OMC n. L/328 - BISD 3S/81. 
European Economic Community - Programme of Minimum Import Prices, Licences and Surety Deposits for Certain Processed Fruits and Vegetable. Report of the Panel, 18 out. 1978. Disponível em <http://www.wto.org/english/tratop_e/dispu_e/76minimp.wpf>. Acesso em: 7 jul. 2009. Documento OMC n. L/4687 - BISD 25S/68.

Norway - Restrictions on Imports of Certain Textile Products. Report of the Panel, 18 jun. 1980. Disponível em <http://www.wto.org/english/tratop_e/dispu_e/79textil.wpf>. Acesso em: 10 abr. 2009. Documento da OMC n. L/4959 - BISD 27S/119.

European Economic Community - Restrictions on Imports of Apples from Chile. Report of the Panel, 10 nov. 1980. Disponível em <http://www.wto.org/english/tratop_e/dispu_e/79apples.wpf>. Acesso em: 10 abr. 2009. Documento da OMC n. L/5047 - BISD 27S/98.

European Economic Community - Imports of Beef from Canada. Report of the Panel, 10 mar. 1981. Disponível em <http://www.wto.org/english/tratop_e/dispu_e/80beef.wpf>. Acesso em: 7 jul. 2009. Documento OMC n. L/5099 - BISD 28S/92.

Spain - Tariff Treatment of Unroasted Coffee. Report of the Panel, 11 jun. 1981. Disponível em <http://www.wto.org/english/tratop_e/dispu_e/80coffee.wpf>. Acesso em: 10 abr. 2009. Documento da OMC n. L/5135 - BISD 28S/102.

European Economic Community - Tariff Treatment on Imports of Citrus Products from Certain Countries in the Mediterranean Region. Report by the Panel, 7 fev. 1985. Disponível em <http://docsonline.wto.org/GEN_viewerwindow.asp?http://docsonline.wto.org:80/DDFDocum ents/t/JCR/PANELS/82CITRUS.WPF>. >. Acesso em: 10 abr. 2009. Documento da OMC n. $\mathrm{L} / 5776$.

United States - Customs User Fee. Report by the Panel, 2 fev. 1988. Disponível em <http://www.wto.org/english/tratop_e/dispu_e/87usrfee.wpf>. Acesso em: 10 abr. 2009. Documento da OMC n. L/6264 - BISD 35S/245.

European Economic Community - Restrictions on Imports of Dessert Apples. Report of the Panel, 22 jun. 1989. Disponível em <http://www.wto.org/english/tratop_e/dispu_e/88applec.wpf >. Acesso em: 10 abr. 2009. Documento da OMC n. L/6491 - BISD 36S/93.

Japan - Tariff on Imports of Spruce, Pine, Fir (SPF) Dimension Lumber. Report of the Panel, 19 jul. 1989. Disponível em <http://www.wto.org/english/tratop_e/dispu_e/88lumber.wpf>. Acesso em: 10 abr. 2009. Documento da OMC n. L/6470 - BISD 36S/167.

United States - Restrictions on the importation of sugar and sugar containing products applied under the 1955 waiver and under the headnote to the schedule of tariff concessions. Report by the Panel, 7 nov. 1990. Disponível em <http://www.wto.org/english/tratop_e/dispu_e/89sugarc.wpf >. Acesso em: 22 mai. 2009. Documento da OMC n. L/6631 - BISD 37S/228. 
United States - Countervailing Duties on Fresh, Chilled and Frozen Pork from Canada. Report of the Panel, 11 jul. 1991. Disponível em

<http://www.wto.org/english/tratop_e/dispu_e/89pork.wpf>. Acesso em: 11 jun. 2009.

Documento da OMC n. DS7/R - BISD 38S/30.

United States - Restrictions on Imports of Tuna. Report of the Panel, 3 set. 1991. Disponível em <http://docsonline.wto.org/DDFDocuments/t/JCR/PANELS/91TUNA.WPF>. Acesso em: 10 abr. 2009. Documento da OMC n. DS21/R - BISD 39S/155

United States - Definition of Industry Concerning Wine and Grape Product. Report of the Panel, 28 abr. 1992. Disponível em <http://www.wto.org/english/tratop_e/dispu_e/85winegr.wpf>. Acesso em: 11 jun. 2009. Documento da OMC n. SCM/71 - BISD 39S/436.

United States - Denial of Most Favoured Nation Treatment as to Non Rubber Footwear from Brazil. Report by the Panel, 19 jun. 1992. Disponível em <http://www.wto.org/english/tratop_e/dispu_e/91nruber.wpf>. Acesso em: 10 abr. 2009. Documento da OMC n. DS18/R - BISD 39S/128.

EEC - Import Regime for Bananas. Report by the Panel, 11 fev. 1994. Disponível em <http://docsonline.wto.org/DDFDocuments/t/GG/DS/38-R.WPF>. Acesso em: 10 abr. 2009. Documento da OMC n. DS38/R.

\section{m) Casos da Organização Mundial do Comércio}

United States - Standards for Reformulated and Conventional Gasoline. Report of the Appellate Body, 29 abr. 1996. Disponível em

<http://www.wto.org/english/tratop_e/dispu_e/cases_e/ds2_e.htm>. Acesso em: 9 jul. 2009. Documento da OMC n. WT/DS2/AB/R.

Japan - Taxes on Alcoholic Beverages. Report of the Appellate Body, 4 out. 1996. Disponível em <http://docsonline.wto.org/DDFDocuments/t/WT/DS/8ABR.WPF>. Acesso em: 9 jul. 2009. Documento da OMC n. WT/DS8/AB/R, WT/DS10/AB/R, WT/DS11/AB/R.

United States - Restrictions on Imports of Cotton and Man-made Fibre Underwear. Report of the Appellate Body, 10 fev. 1997. Disponível em

$<$ http://docsonline.wto.org/imrd/directdoc.asp?DDFDocuments/t/WT/DS/24ABR.wpf>. Acesso em: 14 mar. 2009. Documento da OMC n. WT/DS24/AB/R.

European Communities - Regime for the Importation, Sale and Distribution of Bananas. Report of the Appellate Body, 9 set. 1997. Disponível em

<http://www.wto.org/english/tratop_e/dispu_e/cases_e/ds27_e.htm>. Acesso em: 10 abr. 2009. Documento da OMC n. WT/DS27/AB/R. 
European Communities - Customs Classification of Certain Computer Equipment. Report of the Appellate Body, 5 jun. 1998. Disponível em <http://www.wto.org/english/tratop_e/dispu_e/cases_e/ds62_e.htm>. Acesso em: 10 abr. 2009. Documento da OMC n. WT/DS62/AB/R, WT/DS67/AB/R, WT/DS68/AB/R.

Indonesia - Certain Measures Affecting the Automobile Industry. Report of the panel, 2 jul. 1998. Disponível em <http://docsonline.wto.org/DDFDocuments/t/WT/DS/54R00.DOC> Acesso em: 14 mar. 2009. Documento da OMC n. WT/DS54/R, WT/DS55/R, WT/DS59/R, WT/DS64/R.

United States - Import Prohibition of Certain Shrimp and Shrimp Products. Report of the Appellate Body, 12 out. 1998. Disponível em <http://docsonline.wto.org/imrd/directdoc.asp?DDFDocuments/t/WT/DS/58ABR.doc> Acesso em: 14 mar. 2009. Documento da OMC n. WT/DS58/AB/R.

Turkey - Restrictions on Imports of Textile and Clothing Products. Report of the Panel, 31 maio 1999. Disponível em <http://docsonline.wto.org/DDFDocuments/t/WT/DS/34R.DOC> Acesso em: 14 mar. 2009. Documento da OMC n. WT/DS34/R. . Report of the Appellate Body, 22 out. 1999. Disponível em <http://docsonline.wto.org/DDFDocuments/t/WT/DS/34ABR.DOC> Acesso em: 14 mar. 2009. Documento da OMC n. WT/DS34/AB/R.

Canada - Certain Measures Affecting the Automotive Industry. Report of the Panel, 11 fev. 2000. Disponível em 〈http://docsonline.wto.org/DDFDocuments/t/WT/DS/139R.DOC〉 Acesso em: 14 mar. 2009. Documento da OMC n. WT/DS139/R, WT/DS142/R.

United States - Tax Treatment for "Foreign Sales Corporations". Report of the Appellate Body, 24 fev. 2000. Disponível em <http://docsonline.wto.org/DDFDocuments/t/WT/DS/108ABR.DOC>. Acesso em: 1 jun. 2009. Documento da OMC n. WT/DS108/AB/R.

United States - Rules of Origin for Textiles and Apparel Products. Report of the Panel, 20 jun. 2003. Disponível em <http://docsonline.wto.org/DDFDocuments/t/WT/DS/243R.doc> Acesso em: 14 mar. 2009. Documento da OMC n. WT/DS243/R.

European Communities - Conditions for the Granting of Tariff Preferences to Developing Countries. Report of the Panel, 1 dez. 2003. Disponível em <http://docsonline.wto.org/DDFDocuments/t/WT/DS/246R-00.doc>. Acesso em: 1 jun. 2009. Documento da OMC n. WT/DS246/R. . Report of the Appellate Body, 7 abr. 2004. Disponível em

<http://docsonline.wto.org/DDFDocuments/t/WT/DS/246ABR.doc>. Acesso em: 1 jun. 2009. Documento da OMC n. WT/DS246/AB/R. 